UNIVERSIDADE DE SÃO PAULO

INSTITUTO DE GEOCIÊNCIAS

\title{
PETROGÊNESE DOS PLÚTONS CABREÚVA E INDAIATUBA, BATÓLITO GRANÍTICO ITU, SP: IDADE, ÁREAS-FONTE E CONDIÇÕES DE CRISTALIZAÇÃO
}

GIOVANNA DE SOUZA PEREIRA

Tese apresentada ao Programa Geociências (Mineralogia e Petrologia) para obtenção do título de Doutora em Ciências

Área de Concentração: Petrologia Ígnea e Metamórfica Orientador: Prof. Dr. Valdecir de Assis Janasi

São Paulo 2019 
Autorizo a reprodução e divulgação total ou parcial deste trabalho, por qualquer meio convencional ou eletrônico, para fins de estudo e pesquisa, desde que citada a fonte.

Serviço de Biblioteca e Documentação do IGc/USP

Ficha catalográfica gerada automaticamente com dados fornecidos pela autora via programa desenvolvido pela Seção Técnica de Informática do ICMC/USP

Bibliotecários responsáveis pela estrutura de catalogação da publicação: Sonia Regina Yole Guerra - CRB-8/4208 | Anderson de Santana - CRB-8/6658




UNIVERSIDADE DE SÃO PAULO

INSTITUTO DE GEOCIÊNCIAS

\title{
PETROGÊNESE DOS PLÚTONS CABREÚVA E INDAIATUBA, BATÓLITO GRANÍTICO ITU, SP: IDADE, ÁREAS-FONTE E CONDIÇÕES DE CRISTALIZAÇÃO
}

\section{GIOVANNA DE SOUZA PEREIRA}

Orientador: Prof. Dr. Valdecir de Assis Janasi

Tese de Doutorado

N. ${ }^{\circ} 608$

\author{
COMISSÃO JULGADORA \\ Dr. Valdecir de Assis Janasi \\ Dra. Ignez de Pinho Guimarães \\ Dr. Leonardo Fadel Cury \\ Dr. Antonio Misson Godoy \\ Dr. Silvio Roberto Farias Vlach
}

São Paulo

2019 
Aos meus pais Giovanni (in memoriam)

e Zilda Maria 


\section{AGRADECIMENTOS}

Em um trabalho de tamanha amplitude de tempo e abrangência de metodologias de estudo, conta-se, inevitavelmente, com o apoio, trabalho e incentivo de diversas pessoas e instituições. Desta maneira, gostaria de expressar meu sincero agradecimento a todos que tornaram possível a sua realização.

À FAPESP e à CAPES, pela bolsa de doutorado (processo 2014/03725-9), à FAPESP pelo apoio financeiro para o desenvolvimento do projeto de pesquisa (processo 2015/01817-6), e ao CNPQ pela bolsa de doutorado (163810/2013-3) no início desta pesquisa.

Ao meu querido orientador professor Valdecir Janasi pela forma como me orientou não só neste trabalho, mas ao longo de mais de 10 anos, dedicando sempre sua atenção, conhecimentos (sem fim!), e disponibilidade com muita paciência, compreensão, integridade e afeto.

Às professoras Adriana Alves e Lucelene Martins, pela companhia e conselhos ao longo desta minha jornada pela academia.

Aos funcionários do IGc-USP que muito contribuíram para que os estudos realizados durante este trabalho tivessem resultados de excelente qualidade e confiabilidade.

Aos colegas de pós-graduação que sempre estiveram me dando força, apoio e ânimo para seguir em frente.

E por fim, aos meus tão queridos pais que foram os maiores precursores deste trabalho, não medindo esforços para que mais esta conquista se realizasse. Esse trabalho é para você pai, que infelizmente já se foi, mas que se faz presente em todos os dias da minha vida. 
“As perdas são outra coisa senão mudanças e as mudanças são o deleite da natureza"

Marco Aurélio 


\section{RESUMO}

PEREIRA, G.S. Petrogênese dos plútons Cabreúva e Indaiatuba, Batólito Granítico Itu, SP: idade, áreas-fonte e condições de cristalização. 2019. 189p. Tese (Doutorado) - Instituto de Geociências, Universidade de São Paulo, São Paulo.

O Batólito Granítico Itu é a mais volumosa ocorrência da Província Granítica Itu, de caráter pós-orogênico à orogênese Brasiliana na Nappe Socorro-Guaxupé ( 660-600 Ma), tendo se originado pela amalgamação de diversas câmaras magmáticas alojadas em níveis rasos da crosta continental, que formaram quatro plútons principais: Cabreúva, Indaiatuba, Itupeva e Salto, dos quais os dois primeiros foram estudados com maior detalhe neste trabalho.

O Plúton Indaiatuba é definido por uma unidade principal de (hornblenda)-biotita granito rapakivi porfirítico grosso, que hospeda enclaves microgranulares de natureza félsica e máfica; variedades de granito hololeucocrático equigranular médio invadem esta fácies principal já em estado sólido, como indicado pela presença de xenólitos angulosos. Manifestações básicas contemporâneas ocorrem registram-se na forma de um monzogabro (localmente portadores de clinopiroxênio) e pequenos corpos híbridos de quartzo monzonito.

O Plúton Cabreúva é caracterizado por uma unidade principal de (hornblenda)-biotita sienogranitos inequigranulares grossos, portadores de enclaves microgranulares máficos e félsicos, e variedades de borda de sienogranitos hololeucocráticos de granulação média cuja composição química indica que se trata de variedades mais diferenciadas $\left(\sim 75-77 \%\right.$ de $\mathrm{SiO}_{2}$, $<0,1 \%$ de $\mathrm{MgO},<0,8 \%$ de $\mathrm{CaO})$. $\mathrm{Na}$ porção central do plúton, formada por granitos porfiríticos, ocorrem pequenos corpos máficos e blocos de rocha quartzo monzodiorítica grossa levemente orientada, cuja composição e textura sugerem origem cumulática.

As idades de cristalização magmáticas obtidas neste trabalho pela datação de sete amostras dos quatro plútons que constituem o batólito por métodos de datação U-Pb in situ de zircão (SHRIMP e LA-MC-ICPMS) são todas semelhantes, e definem o episódio principal de geração de todo o batólito em torno de $578 \pm 4$ Ma. Uma amostra de sienogranito do Plúton Cabreúva

forneceu idade claramente mais jovem que as demais (561 $\pm 6 \mathrm{Ma})$; esta idade, caso não reflita um evento pós-magmático de caráter hidrotermal (sugerido pela química dos cristais de zircão), implicaria que a formação do batólito ocorreu ao longo de um intervalo de tempo de até $20 \mathrm{Ma}$. Cristais herdados de zircão são muito raros nas amostras de Itu, refletindo as temperaturas relativamente altas dos magmas em questão. Apenas em uma amostra do Plúton Itupeva foram identificados núcleos claramente herdados, com idade paleoproterozoica $(\sim 2.2 \mathrm{Ga})$ e neoproterozóica $(\sim 620 \mathrm{Ma})$.

Os granitos do Batólito Itu exibem características de granitos de tipo A da série aluminosa, derivados de magmas pobres em $\mathrm{H}_{2} \mathrm{O}$ e com temperaturas liquidus relativamente altas. Os valores de temperatura obtidos por cálculo de saturação em zircão variam entre 880 e $800^{\circ} \mathrm{C}$ entre os granitos menos e mais evoluídos de Cabreúva (teores de $\mathrm{SiO}_{2}$ variando entre 69 e 77\%); temperaturas um pouco mais baixas (entre 800 e $730^{\circ} \mathrm{C}$ ) são observadas nos granitos equigranulares evoluídos ( $\left.>74 \% \mathrm{SiO}_{2}\right)$, considerados diferenciados de Indaiatuba. As pressões de alojamento estimadas neste trabalho, utilizando calibrações do geobarômetro de $\mathrm{Al}$ em hornblenda, encontram-se na faixa de 2-3 kbar, confirmando um alojamento crustal raso.

No contexto da evolução de câmaras magmáticas rasas, eventos recorrentes de recarga por pulsos de magma de caráter félsico (predominantes) e máfico, são registrados nos plútons Cabreúva e Indaiatuba sob a forma de abundantes enclaves microgranulares. Evidências estruturais e texturais de processos de interação de magmas (mingling e mistura) são frequentes, e, em parte, confirmadas pelos dados geoquímicos e isotópicos. A atuação de processos de separação cristal-líquido ao nível das câmaras rasas é evidenciada por variações composicionais contínuas e, em Cabreúva, pela presença de rocha de caráter cumulático. 
Os dados isotópicos de $\mathrm{Sr}, \mathrm{Nd}$ e $\mathrm{Hf}$ obtidos para os diferentes plútons do Batólito Itu mostram assinatura característica de granitos crustais, com valores fortemente negativos de $\varepsilon \mathrm{Nd}(\mathrm{t})(-10$ a -12$)$ e $\varepsilon \mathrm{Hf}(\mathrm{t})$, mas com razões ${ }^{87} \mathrm{Sr} /{ }^{86} \mathrm{Sr}(\mathrm{t})$ pouco elevadas $(0.706-0.708)$, que sugerem fontes com baixa razão $\mathrm{Rb} / \mathrm{Sr}$. Entre as fontes crustais potenciais para os magmas geradores desses granitos podem ser reconhecidos os ortognaisses ou granulitos do embasamento paleoproterozóico, ou granitos cálcio-alcalinos gerados durante o ciclo orogênico precedente. A presença de um componente do manto é identificada em todos os quatro plútons de Itu (na forma de corpos máficos e enclaves microgranulares máficos); esse componente parece corresponder a um manto enriquecido, similar àquele do qual derivaram as rochas máficas do maciço monzodiorítico Piracaia $\left(\varepsilon N d(t)-7.3\right.$ e -8.5 e $\left.{ }^{87} \mathrm{Sr} /{ }^{86} \mathrm{Sr}(\mathrm{t})=\sim 0.705\right)$, de idade contemporânea à Província Granítica de Itu.

Palavras-chave: magma, magmatismo pós-orogênico, idade de cristalização, crosta continental rasa, interação de magmas. 


\begin{abstract}
PEREIRA, G.S. Petrogenesis of the Cabreúva and Indaiatuba plutons, Itu Granitic Batolith, SP: ages, source areas and conditions of crystallization. 2019. 189p. Thesis (DSc) - Instituto de Geociências, Universidade de São Paulo, São Paulo.
\end{abstract}

The Itu Granitic Batolith is the most voluminous occurrence of the Itu Granitic Province, post-orogenic to the Brasiliano orogenesis ( 660-600 Ma) in the Socorro-Guaxupé Nappe. It is formed by the amalgamation of several magmatic chambers emplaced at the shallow levels of the continental crust, which formed four main plutons: Cabreúva, Indaiatuba, Itupeva and Salto, of which the first two were studied in greater detail in this work.

The Indaiatuba Pluton is defined by a main unit of coarse porphyritic (hornblende)-biotite rapakivi granite, which hosts microgranular enclaves of felsic and mafic nature; mediumgrained equigranular hololeucocratic biotite granite varieties invade this main unit at solid state, as indicated by the presence of angulous xenoliths. Contemporary basic manifestations occur as a monzogabbro (locally clinopyroxene-bearing) and small quartz monzonitic hybrid bodies.

The Cabreúva Pluton is characterized by a main unit of coarse-grained (hornblende)-biotite inequigranular syenogranites, with frequent mafic and felsic microgranular enclaves, and border varieties of medium-grained hololeucocratic biotite syenogranites whose chemical composition indicates that they are more differentiated varieties $\left(\sim 75-77 \% \mathrm{SiO}_{2},<0,1 \% \mathrm{MgO}\right.$, $<0,8 \% \mathrm{CaO}$ ). In the central portion of the pluton, formed by porphyritic granites, occur small mafic bodies and blocks of slightly oriented coarse quartz monzodiorite, whose composition and texture suggest cumulative origin.

The magmatic crystallization ages obtained in this work by dating seven samples of the four plutons that make up the Itu Batholith by U-Pb zircon in situ dating methods (SHRIMP and LA-MC-ICPMS) are all similar, and define the main episode of generation of the whole batholith around $578 \pm 4$ Ma. A sample of syenogranite from Cabreúva provided an age significantly younger than the others $(561 \pm 6 \mathrm{Ma})$; this age, if it does not reflect a hydrothermal post-magmatic event (suggested by the chemistry of zircon crystals), would imply that the formation of the batholith occurred over a period of up to $20 \mathrm{Ma}$. Inherited zircon crystals are very rare in the Itu samples reflecting the relatively high temperatures of these magmas. Clearly inherited nuclei were identified only in one sample of Itupeva, that have paleoproterozoic ( $2.2 \mathrm{Ga})$ and neoproterozoic ( $620 \mathrm{Ma})$ ages.

The Itu Batholith granites exhibit characteristics of aluminous A-type granites derived from $\mathrm{H}_{2} \mathrm{O}$-poor magmas with relatively high liquidus temperatures. The temperature values obtained by zircon saturation calculation vary between 880 and $800^{\circ} \mathrm{C}$ among less and more evolved granites from Cabreúva $\left(\mathrm{SiO}_{2}\right.$ contents between 69 and $\left.77 \mathrm{wt} \%\right)$; slightly lower temperatures (between 800 and $730^{\circ} \mathrm{C}$ ) are observed in the more evolved equigranular granites $(>74 \mathrm{wt} \%$ $\mathrm{SiO}_{2}$ ) considered differentiated from Indaiatuba. The pressures of crystallization estimated in this work using $\mathrm{Al}$ in hornblende geobarometer calibrations are in the 2-3 kbar range, confirming shallow crustal emplacement.

In the context of the evolution of shallow magmatic chambers, recurrent recharge events by felsic (predominant) and mafic magma pulses are recorded in the Cabreúva and Indaiatuba plutons in the form of abundant microgranular enclaves. Structural and textural evidences of magma interaction processes (mingling and mixing) are frequent, and in part confirmed by geochemical and isotopic data. Shallow-chamber crystal-liquid separation processes are evidenced by continuous compositional variations and, in Cabreúva, by the presence of a cumulative rock. 
Whole-rock $\mathrm{Sr}$ and $\mathrm{Nd}$ and zircon $\mathrm{Hf}$ isotopic data obtained for the different plutons of the Itu Batolith show signatures characteristic of crustal granites, with strongly negative values of $\varepsilon \mathrm{Nd}(\mathrm{t})(-10$ to -12$)$ and $\varepsilon \mathrm{Hf}(\mathrm{t})$, but with relatively low ${ }^{87} \mathrm{Sr} /{ }^{86} \mathrm{Sr}(\mathrm{t})(0.706-0.708)$, indicative of sources with low $\mathrm{Rb} / \mathrm{Sr}$ ratio. Among the potential crustal sources for the granite-generating magmas can be recognized orthogneisses or granulites from Paleoproterozoic basement, or calc-alkaline granites generated during the preceding orogenic cycle. The presence of a mantle component is identified in all four Itu plutons (in the form of mafic bodies and mafic microgranular enclaves); this component must correspond to an enriched mantle, similar to that from which the mafic rocks of the monzodioritic Piracaia massif, contemporary to the Itu Province, were derived $\left(\varepsilon N d(t)-7.3\right.$ and -8.5 and $\left.{ }^{87} \mathrm{Sr} /{ }^{86} \mathrm{Sr}(\mathrm{t}) \sim 0.705\right)$.

Keywords: magma, post-orogenic magmatism, crystallization age, shallow continental crust, magma interaction process. 


\section{LISTA DE FIGURAS}

Figura 1 - Localização dos plútons Cabreúva (CB) e Indaiatuba (ID) com relação às cidades da região, no interior do Estado de São Paulo ......................................................... 4

Figura 2 - Exposição do Plúton Cabreúva na forma de "mar de matacões". ......................5

Figura 3 - Imagem aérea de satélite ilustrando uma região de afloramentos de matacões do



Figura 4 - Localização e acessos à área de estudo ...................................................... 6

Figura 5 - Representação esquemática de um ciclo magmático........................................ 7

Figura 6 - Conceito "clássico" de câmaras magmáticas vs. fronts de cristalização ............8

Figura 7 - Representação de uma hot zone................................................................... 10

Figura 8 - Ilustração de um reservatório magmático..................................................... 12



Figura 10 - Tomografia sísmica do reservatório magmático .......................................... 14

Figura 11 - Ilustração esquemática de um dique alimentador...................................... 15

Figura 12 - Sucessão de sills basálticos formando corpo ígneo ..................................... 15

Figura 13 - Desenho esquemático representando a intrusão de um magma de repreenchimento em um magma parcialmente cristalizado com fração cristalina variável ..... 16

Figura 14 - Ilustração esquemática dos vários formatos possíveis de câmaras................. 17

Figura 15 - Ilustração esquemática da formação de uma câmara magmática através de sucessivas injeções de diques/sills alimentadores. Extraída de Gudmundsson (2012)............ 17

Figura 16 - Ilustração esquemática de perfis baseados em modelos conceituais da geometria de corpos ígneos plutônicos.............................................................................. 18

Figura 17 - Ilustração das regiões de um front de cristalização ..................................... 18

Figura 18 - Relações $\mathrm{K}_{2} \mathrm{O}-\mathrm{SiO}_{2}$ em rochas cálcio-alcalinas plutônicas de arco ...............20

Figura 19 - Ilustração esquemática dos processos de condução e convecção................... 22

Figura 20 - Representação de uma câmara magmática em convecção termoquímica. ....22

Figura 21 - Diagrama esquemático de densidades de minerais e rochas .........................23

Figura 22 - Ilustração de uma câmara magmática de composição ácida sendo injetada por



Figura 23 - Ilustração esquemática dos processos dinâmicos atuantes em uma câmara



Figura 24 - Representação esquemática da trajetória de ascensão de um magma ...........25

Figura 25 - Gráfico apresentando a variação teórica da concentração de um elemento em melts residuais com relação ao coeficiente de distribuição e seu magma parental inicial .......26

Figura 26 - Ilustração esquemática do processo de segregação gravitacional .................27

Figura 27 - Ilustração esquemática da evolução da distribuição de cristais durante



Figura 28 - Ilustração esquemática do processo de filter pressing .................................27

Figura 29 - Ilustração esquemática exemplificando a imiscibilidade de melts silicáticos em um basalto. .28

Figura 30 - Representação esquemática da liquid line of descent a partir da qual um magma diferenciado deriva de um magma parental pelo processo de cristalização fracionada. ..........28

Figura 31 - Gráficos ilustrando os efeitos de diferentes processos em sistema aberto ....29

Figura 32 - Ilustração esquemática de processos magmático dinâmicos atuantes em uma câmara magmática .....

Figura 33 - Representação esquemática de uma câmara magmática repreenchida por um magma de natureza composicional diferente do magma hospedeiro 30 
Figura 34 - Desenho esquemático de alguns processos que podem potencialmente gerar gradientes composicionais em sistemas ígneos. ................................................................... 32

Figura 35 - Modelo esquemático do mecanismo de desencadeamento (triggering) de



Figura 36 - Ilustração mostrando a ocorrência de processos de mistura de magmas em diferentes ambientes ígneos e seus respectivos registros geológicos 33

Figura 37 - Desenho ilustrando os efeitos de uma erupção em uma câmara magmática tipo



Figura 38 - Exemplos de estruturas de fluxo em rochas vulcânicas produzidas pelo



Figura 39 - Exemplos de enclaves magmáticos em rochas plutônicas ............................ 35

Figura 40 - Exemplos de texturas de reabsorção e zoneamento em minerais produzidas



Figura 41 - Desenho esquemático ilustrando o desenvolvimento de magmas híbridos e



Figura 42 - Comparações entre razões isotópicas de $\mathrm{Sr}$ em rocha total e suas respectivas



Figura 43 - Ilustração esquemática dos princípios da microanálise ................................ 39

Figura 44 - Ilustração esquemática das formas pelas quais variações químicas e/ou isotópicas em cristais individuais podem refletir processos de evolução magmática.............. 39

Figura 45 - Variação nos teores de K, U e Th nas rochas ígneas com relação à variação no



Figura 46 - Diagrama tipo Tera-Wasseburg exemplificando curvas concórdia e discórdia.



Figura 47 - Configuração geotectônica de crátons e sistemas orogênicos do Gondwana W



Figura 48 - Mapa geológico simplificado da porção centro-leste do Brasil..................... 55

Figura 49 - Mapa tectônico do Cinturão Ribeira Central e a zona de interferência (interference zone) com a porção sul da Faixa Ribeira.......................................................... 56

Figura 50 - Mapa geotectônico com a localização da Nappe Socorro-Guaxupé e o Terreno



Figura 51 - Esquema geológico do embasamento cristalino do sudeste do Brasil com ênfase no Domínio Apiaí-Guaxupé e seus plútons graníticos ............................................... 58









Figura 56 - Localização dos afloramentos visitados com relação à toponímia e o Batólito



Figura 57 - Textura predominante da rocha que define a unidade principal do Plúton



Figura 58 - Textura rapakivi em detalhe na fácies granito rapakivi grosso do Plúton



Figura 59 - Cristal de quartzo manteado em meio ao granito rapakivi do Plúton Indaiatuba.

67

Figura 60 - Enclaves microgranulares félsico e máfico no granito rapakivi ................... 67



Figura 62 - Granito equigranular fino atribuído ao Plúton Itupeva invasor no Granito Indaiatuba. 68 
Figura 63 - Xenólito angular do granito rapakivi (Plúton Indaiatuba) no granito inequigranular fino (Plúton Itupeva)

Figura 64 - Presença de rocha híbrida entre as unidades granítica e máfica do Plúton Indaiatuba

Figura 65 - Variação de granulação da rocha híbrida remetendo às duas rochas que lhe deram origem

Figura 66 - Presença de xenocristais de feldspato alcalino (alguns com textura rapakivi) na rocha híbrida

Figura 67 - Aspecto geral da rocha que define a unidade quartzo-monzonítica do Plúton Indaiatuba

Figura 68 - Aspecto geral da fácies biotita sieno-monzogranito do Plúton Itupeva ........ 72

Figura 69 - Enclave microgranular máfico hospedado na fácies granítica do Plúton Itupeva

Figura 70 - Estrutura de fluxo magmática dada pelos cristais tabulares de feldspato alcalino



Figura 71 - Aspecto geral da fácies sienogranítica do Plúton Cabreúva..........................73

Figura 72 - Porção menos máfica e mais fina do sienogranito do Plúton Cabreúva........ 74

Figura 73 - Aspecto geral da fácies monzogranítica central do Plúton Cabreúva. ........... 74

Figura 74 - Enclaves microgranular félsico com xenocristais da fácies sienogranítica do Plúton Cabreúva em formato oblato e formato tipo augen com alto conteúdo de xenocristais.

Figura 75 - Enclave microgranular máfico com borda de reação na fácies sienogranítica do Plúton Cabreúva .75

Figura 76 - Rocha diorítica grossa de aspecto cumulático encontrada no centro do Plúton Cabreúva



Figura 78 - Distribuição dos pontos de medição gama-espectrométrica, com indicação para as concentrações equivalentes de $\mathrm{K}$

Figura 79 - Distribuição dos pontos de medição gama-espectrométrica, com indicação para as concentrações equivalentes de U.

Figura 80 - Distribuição dos pontos de medição gama-espectrométrica, com indicação para as concentrações equivalentes de Th

Figura 81 - Classificação modal com base no diagrama QAP do corpo de monzogabro



Figura 82 - Classificação modal com base no diagrama QAP da fácies quartzo monzonítica



Figura 83 - Classificação modal com base no diagrama QAP dos emm associados ao Granito Indaiatuba.

Figura 84 - Classificação modal com base no diagrama QAP dos emf associados ao Granito Indaiatuba.

Figura 85 - Classificação modal com base no diagrama QAP da fácies máfica do Granito Itupeva.

Figura 86 - Classificação modal com base no diagrama QAP dos emm do Plúton Cabreúva.

Figura 87 - Classificação modal com base no diagrama QAP da rocha cumulática



Figura 88 - Simbologia utilizada para os diagramas de química mineral. .......................99

Figura 89 - Diagrama dos componentes An-Ab-Or, em proporção molecular, para os plagioclásios dos diferentes plútons do Batólito Itu 101 
Figura 90 - Diagrama QUAD para clinopiroxênios de Ca-Fe-Mg mostrando a composição do clinopiroxênio da amostra monzogabro...

Figura 91 - Diagrama Al x Ti (apfu) para os clinopiroxênios da amostra de monzogabro



Figura 92 - Diagrama de classificação dos anfibólios cálcicos do Batólito Itu analisados com razão $(\mathrm{Na}+\mathrm{K})_{\mathrm{A}} \geq 0,5$..... 103

Figura 93 - Diagrama de classificação dos anfibólios cálcicos do Batólito Itu analisados $\operatorname{com}(\mathrm{Na}+\mathrm{K})_{\mathrm{A}}<0,5 \ldots$ 104

Figura 94 - Diagrama $\mathrm{Al}^{\mathrm{IV}} \times(\mathrm{Na}+\mathrm{K})^{\mathrm{A}}$ destacando a troca edenítica para anfibólios de granitos e enclaves microgranulares do Batólito Itu. ............................................................. 105

Figura 95 - Diagrama $\mathrm{Al}^{\mathrm{IV}}$ x Ti (em apfu) destacando a substituição Ti-tschermakítica para anfibólios de granitos e enclaves microgranulares do Batólito Itu. ..................................... 105

Figura 96 - Diagrama de classificação das biotitas analisadas do Batólito Itu ................ 107

Figura 97 - Diagrama Ti x Al ${ }^{\mathrm{IV}}$ (em apfu) das biotitas do Batólito Itu .......................... 108

Figura 98 - Diagrama R2+Ti x Al ${ }^{\mathrm{IV}}$ (em apfu) das biotitas do Batólito Itu .................. 108

Figura 99 - Diagrama $\mathrm{Fe}^{3+} / \mathrm{Fe}^{2+}$ x mg\# calculados com base em 13-CNK. .................. 109

Figura 100 - Diagrama pressão x mg\# com P calculada................................................. 110

Figura 101 - Variações na razão $\mathrm{Mg} /(\mathrm{Mg}+\mathrm{Fe})$ x Ti das biotitas analisadas do Batólito Itu.

Figura 102 - Diagrama discriminante $\mathrm{FeO}^{\mathrm{T}}-\mathrm{MgO}-\mathrm{Al}_{2} \mathrm{O}_{3}$ para a natureza dos magmas originários das rochas que contêm as biotitas analisadas do Batólito Itu ............................. 113

Figura 103 - Diagrama de variação de Gokhale $\left(\mathrm{FeO}^{\mathrm{T}}-\mathrm{MgO}-\mathrm{Al}_{2} \mathrm{O}_{3}\right)$ para a distinção da natureza das biotitas analisadas do Batólito Itu ................................................................. 113

Figura 104 - Diagrama triangular discriminante conforme a composição química de



Figura 105 - Diagramas de variação utilizando o teor de $\mathrm{SiO}_{2}$ como índice de diferenciação para as amostras do Plúton Cabreúva.

Figura 106 - Diagramas de variação utilizando o teor de $\mathrm{SiO}_{2}$ como índice de diferenciação para as amostras do Plúton Cabreúva.

Figura 107 - Diagramas de variação utilizando o teor de $\mathrm{SiO}_{2}$ como índice de diferenciação para as amostras do Plúton Cabreúva.

Figura 108 - Diagramas de variação utilizando o teor de $\mathrm{SiO}_{2}$ como índice de diferenciação para as amostras do Plúton Cabreúva.

Figura 109 - Diagramas de variação utilizando o teor de $\mathrm{SiO}_{2}$ como índice de diferenciação para as amostras do Plúton Cabreúva.

121

Figura 110 - Diagramas de variação de ETR utilizando o teor de $\mathrm{SiO}_{2}$ como índice de diferenciação para as amostras do Plúton Cabreúva, com exceção do diagrama $\mathrm{Eu} / \mathrm{Eu}^{*} \mathrm{x}$ $(\mathrm{La} / \mathrm{Yb})_{\mathrm{N}}$ 122

Figura 111 - Padrões de fracionamento dos ETR das amostras do Plúton Cabreúva, normalizados 123

Figura 112 - Diagramas de variação utilizando o teor de $\mathrm{SiO}_{2}$ como índice de diferenciação para as amostras dos plútons Cabreúva e Indaiatuba....................................................... 125

Figura 113 - Diagramas de variação utilizando o teor de $\mathrm{SiO}_{2}$ como índice de diferenciação para as amostras dos plútons Cabreúva e Indaiatuba..................................................... 126

Figura 114 - Diagramas de variação utilizando o teor de $\mathrm{SiO}_{2}$ como índice de diferenciação para as amostras dos plútons Cabreúva e Indaiatuba...................................................... 127

Figura 115 - Diagramas de variação utilizando o teor de $\mathrm{SiO}_{2}$ como índice de diferenciação para as amostras dos plútons Cabreúva e Indaiatuba..................................................... 128

Figura 116 - Diagramas de variação utilizando o teor de $\mathrm{SiO}_{2}$ como índice de diferenciação para as amostras dos plútons Cabreúva e Indaiatuba...................................................... 129 
Figura 117 - Diagramas de variação de ETR utilizando o teor de $\mathrm{SiO}_{2}$ como índice de diferenciação para as amostras do Plúton Cabreúva, com exceção do diagrama $\mathrm{Eu} / \mathrm{Eu}$ * $\mathrm{x}$ $(\mathrm{La} / \mathrm{Yb})_{\mathrm{N}}$.

Figura 118 - Padrões de fracionamento dos ETR das amostras do Plúton Indaiatuba, normalizados.

Figura 119 - Diagramas de variação utilizando o teor de $\mathrm{SiO}_{2}$ como índice de diferenciação para as amostras dos plútons que compõem o Batólito Itu.

Figura 120 - Diagramas de variação utilizando o teor de $\mathrm{SiO}_{2}$ como índice de diferenciação para as amostras dos plútons que compõem o Batólito Itu.

Figura 121 - Diagrama $\mathrm{Fe}^{*} \mathrm{x} \mathrm{SiO}_{2}$ mostrando o limite entre granitoides ferroanos e magnesianos

Figura 122 - Diagrama MALI x $\mathrm{SiO}_{2}$, com a distinção das séries alcalina, alcalina-cálcica, cálcio-alcalino e cálcica. 136

Figura 123 - Aproximação da região em destaque na Figura 122. ............................... 136

Figura 124 - Padrões de fracionamento dos elementos terras raras dos cristais de zircão da amostra CAB-16-80A, normalizados pela rocha total. 138

Figura 125 - Diagramas Th e U x Hf para os de cristais de zircão da amostra CAB-16$80 \mathrm{~A}$.

Figura 126 - Diagrama Th/U x Th com ajuste polinomial de $2^{a}$ de ordem (fit) mostrando a tendência dos dados obtidos através dos cristais de zircão da amostra CAB-16-80A..........139

Figura 127 - Diagrama Th x U para os de cristais de zircão da amostra CAB-16-80A. 139

Figura 128 - Diagramas de variação utilizando o Hf como índice de variação para dados químicos obtidos para os cristais de zircão da amostra IGN24A

Figura 129 - Padrões de fracionamento dos elementos terras raras dos cristais de zircão da amostra IGN24A, normalizados pela rocha total

Figura 130 - Diagramas de variação utilizando o Hf como índice de variação para dados químicos obtidos para os cristais de zircão da amostra IGN50B e em comparação com as amostras de Cabreúva.

Figura 131 - Diagrama Th x U para dados químicos obtidos para os cristais de zircão da amostra IGN50B e em comparação com as amostras de Cabreúva. 144

Figura 132 - Padrões de fracionamento dos elementos terras raras dos cristais de zircão da amostra IGN50B, normalizados pela rocha total. 144

Figura 133 - Padrões de fracionamento dos elementos terras raras dos cristais de zircão da amostra IGN56, normalizados pela rocha total 145

Figura 134 - Diagramas Nb e U x Hf para dados químicos obtidos para os cristais de zircão da amostra IGN56 em comparação com as amostras de Cabreúva (CAB-16-80A) e Indaiatuba (IGN-50B). 145

Figura 135 - Diagrama Th x U para dados químicos obtidos para os cristais de zircão da amostra IGN56.

Figura 136 - Padrões de fracionamento dos elementos terras raras dos cristais de zircão da amostra CAB-15-36A, normalizados pela rocha total; quadrados cinzas - raster nos núcleos dos cristais; quadrados brancos - raster nas bordas dos cristais.

Figura 137 - Diagramas Th/U x Th e U para dados químicos obtidos para os cristais de zircão da amostra CAB-15-36A em comparação com as amostras do quartzo monzonito IGN56.

Figura 138 - Padrões de fracionamento dos elementos terras raras dos cristais de zircão da amostra ITU-14X, normalizados pela rocha total. 148

Figura 139 - Diagramas de variação utilizando o Hf como índice de variação para dados químicos obtidos para os cristais de zircão da amostra ITU-14X (Salto) em comparação com as amostras dos outros três plútons. 
Figura 140 - Localização dos spots de datação dos cristais de zircão da amostra IGN56 com suas idades ${ }^{206} \mathrm{~Pb} /{ }^{238} \mathrm{U}$ e erro $1 \sigma$.

Figura 141 - Idade concórdia U-Pb para zircões do quartzo monzonito IGN56 do Plúton Itupeva 150

Figura 142 - Localização dos spots de datação dos cristais de zircão da amostra CAB-15$36 \mathrm{~A}$ com suas idades ${ }^{206} \mathrm{~Pb} /{ }^{238} \mathrm{U}$ e erro $1 \sigma$.

Figura 143 - Idade concórdia U-Pb para zircões do sienogranito CAB-15-36A do Plúton Itupeva.

Figura 144 - Diagrama U-Pb para um cristal de zircão herdado do sienogranito CAB-1536A do Plúton Itupeva.

Figura 145 - Localização dos spots de datação dos cristais de zircão da amostra ITU-2.2.4 com suas idades ${ }^{206} \mathrm{~Pb} /{ }^{238} \mathrm{U}$ e erro $1 \sigma$....

Figura 146 - Idades U-Pb altamente discordantes para zircões do sienogranito rapakivi vermelho ITU-2.2.4 do Plúton Salto. 154

Figura 147 - Localização dos spots de datação dos cristais de zircão da amostra ITU-14X com suas idades ${ }^{206} \mathrm{~Pb} /{ }^{238} \mathrm{U}$ e erro $1 \sigma$. 155

Figura 148 - Idades U-Pb discordantes e a idade concórdia para cristais de zircão do sienogranito rapakivi ITU-14X do Plúton Salto.

Figura 149 - Idade concórdia U-Pb para zircões do sienogranito rapakivi ITU-14X do Plúton Salto. 156

Figura 150 - Localização dos spots de datação dos cristais de zircão da amostra IGN50B com suas idades ${ }^{206} \mathrm{~Pb} /{ }^{238} \mathrm{U}$ e erro $1 \sigma$.

Figura 151 - Idade concórdia U-Pb para zircões do monzogranito rapakivi IGN50B do Plúton Indaiatuba. 158

Figura 152 - Idade concórdia U-Pb para zircões do sienogranito CAB-16-80A do Plúton Cabreúva. 159

Figura 153 - Localização dos spots de datação dos cristais de zircão da amostra IGN24A com suas idades ${ }^{206} \mathrm{~Pb} /{ }^{238} \mathrm{U}$ e erro $1 \sigma$.

Figura 154 - Idade concórdia U-Pb para zircões do sienogranito IGN24A do Plúton Indaiatuba. 160

Figura 155 - Idades U-Pb para os plútons do Batólito Itu 161

Figura 156 - Idades U-Pb para os plútons do Batólito Itu obtidas neste trabalho em comparação com outros dados da Província Granítica Itu e da granitogênese sin-compressional da porção sul da NESG. 162

Figura 157 - Dados isotópicos de $\varepsilon \mathrm{Hf}$ (t) do Batólito Itu em comparação com outros dados da PGI e da granitogênese sin-compressional da porção S da NESG 164

Figura 158 - Dados de isotopia Sr-Nd para as diferentes unidades do Batólito Itu em comparação com outras ocorrências da PGI. 167

Figura 159 - Correlação entre $\varepsilon \mathrm{Nd}_{(t)}$ e $\varepsilon \mathrm{Hf}_{(t)}$ para granitos do Batólito Itu e outras ocorrências da PGI. 168

Figura 160 - Dados de isotopia Sr-Nd para as diferentes unidades do Batólito Itu em comparação com outras ocorrências graníticas associadas a PGI... 169

Figura 161 - Diagrama de temperatura de saturação em zircão x teor de sílica para as amostras de Cabreúva e Indaiatuba. 


\section{LISTA DE TABELAS}

Tabela 1 - Definições e características de materiais e estruturas que compõem os sistemas magmáticos. 13

Tabela 2 - Relação de processos de diferenciação magmática em sistemas fechados e abertos

Tabela 3 - Configurações dos espectrômetros e padrões utilizados durante as medições na microssonda eletrônica 45

Tabela 4 - Limites de detecção para as análises de geoquímica elemental .......................47

Tabela 5 - Resultados da geotermobarometria 111 


\section{SUMÁRIO}











1.5. DINÂMICA DE CÂMARAS MAGMÁTICAS RASAS …......................................... 6



1.5.2. Processos Magmáticos Dinâmicos …………....................................................................... 19

CAPÍTULO 2 - MATERIAIS E MÉTODOS.................................................. 41















CAPÍTULO 3 - SITUAÇÃO GEOLÓGICA _..............................................53

CAPÍTULO 4 - GEOLOGIA DO BATÓLITO ITU .......................................... 65











CAPÍTULO 5 - PETROGRAFIA .......................................................... 82







CAPÍTULO 6 - QUÍMICA MINERAL_..................................................99 






6.5. ESTIMATIVAS DAS CONDIÇÕES DE CRISTALIZAÇÃO BASEADAS NA









6.6. DIAGRAMAS DISCRIMINANTES BASEADOS NA QUÍMICA DE BIOTITA.....112

CAPÍTULO 7 - GEOQUÍMICA DE ROCHA TOTAL............................... 115





7.3. COMPARAÇÃO COM OS DEMAIS PLÚTONS DO BATÓLITO ITU.....................132

7.3.1. Características geoquímicas dos granitos do Batólito Itu .............................................. 134

CAPÍTULO 8-ASSINATURA ISOTÓPICA LU-HF, QUÍMICA DE ZIRCÃO





8.2. GEOCRONOLOGIA POR MÉTODO SHRIMP E LA-MC-ICPMS .......................... 149

8.2.1. Resultados Analíticos .................................................................................................. 149

8.2.2. Discussão: a idade do Batólito Itu e o contexto regional ........................................ 161



CAPÍTULO 9 - GEOQUÍMICA ISOTÓPICA ............................................... 166

9.1. GEOQUÍMICA ISOTÓPICA SR-ND EM ROCHA TOTAL..................................... 166

9.2. CORRELAÇÃO ENTRE OS DADOS ISOTÓPICOS DE ND EM ROCHA TOTAL E



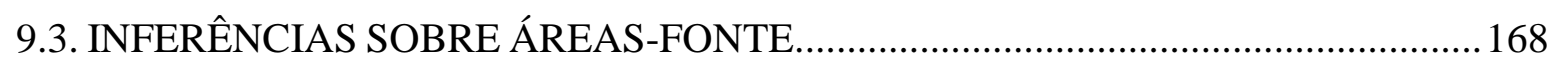

CAPÍTULO 10 - CONSIDERAÇÕES FINAIS..................................... 171



10.2. IDADE E DURAÇÃO DO MAGMATISMO DO BATÓLITO ITU ..........................172

10.3. CONDIÇÕES DE CRISTALIZAÇÃO DO BATÓLITO ITU ...................................174

10.4. PROCESSOS EVOLUTIVOS EM CÂMARAS MAGMÁTICAS ........................... 175 
10.5. AS ÁREAS-FONTE DO MAGMATISMO DO BATÓLITO ITU

REFERÊNCIAS BIBLIOGRÁFICAS .................................................... 179 


\section{CAPÍTULO 1 - INTRODUCÃO}

Os processos magmáticos dinâmicos de ocorrência frequente em câmaras magmáticas graníticas alojadas em níveis de crosta rasa têm sido tema de ampla abordagem na literatura petrológica recente, em razão, principalmente, de sua conexão direta com fenômenos de natureza eruptiva e potenciais riscos associados.

Processos sucessivos de recarga nas câmaras, como pulsos magmáticos de composição, em particular, básica, são admitidos como o principal gatilho para fenômenos vulcânicos associados (e.g., PALLISTER; HOBLITT; REYES, 1992; SIGMARSSON et al., 2011), e podem permanecer registrados na forma de diversas feições estruturais comuns em granitos, como enclaves microgranulares e diques sin-plutônicos (ARVIN; DARGAHI; BABAEI, 2004; BARBARIN; DIDIER, 1992; ELBURG, 1996; HAWKINS; WIEBE, 2004; PEREIRA, 2013; VERNON, 1984; WAIGHT; MAAS; NICHOLLS, 2001; WAIGHT; WIEBE; KROGSTAD, 2007; WIEBE; ADAMS, 1997).

O Batólito Granítico Itu (BGI), de caráter pós-orogênico dentro do contexto da Faixa de Dobramentos ou Orógeno Ribeira, já foi objeto de diversos estudos de campo, petrografia e geoquímica em escala de semi-detalhe, os quais revelaram sua estruturação em quatro plútons principais, com características estruturais e geoquímicas distintas (GALEMBECK, 1997).

Os plútons graníticos Salto, Cabreúva, Indaiatuba e Itupeva, constituintes do BGI ( 50 km a NW da cidade de São Paulo), representam, em conjunto, o resultado final da amalgamação e interação de diversos pulsos magmáticos de composição granítica, alojados em níveis rasos da crosta continental. Neste contexto, compreender a história de formação dessas intrusões significa contribuir para a entendimento de alguns dos diversos processos atuantes em câmaras magmáticas estabelecidas em porção rasa da crosta continental superior.

\subsection{JUSTIFICATIVAS}

A aluna apresentou no ano de 2013 uma Dissertação de Mestrado focada no estudo em detalhe do plúton creditado, naquela época, como o mais jovem do Batólito Itu (Granito Salto); nela ressaltou-se o papel dos processos de recarga na geração de enclaves microgranulares félsicos (emf) e de corpos de granito pórfiro, além de possíveis explanações para a geração da peculiar textura de manteamento de feldspato alcalino por plagioclásio, que faz do Plúton Salto um dos melhores exemplos de granitos tipo rapakivi na América do Sul (cf. RÄMÖ; 
HAAPALA, 1999). Tal pesquisa permitiu chegar à conclusão de que o Granito Salto é o registro da história de uma câmara magmática dinâmica, exposta atualmente em posição inclinada, com sua zona de topo (cúpula) para oeste, tendo sido realimentada por diversos pulsos magmáticos de natureza félsica, identificáveis por suas relações estruturais (e.g., enclaves microgranulares com feições indicativas de injeção em mush cristalino) e de características geoquímicas um pouco mais primitivas que da rocha hospedeira (ALVES, et al., 2015; PEREIRA, 2013).

A extensão desses estudos para os plútons Cabreúva e Indaiatuba, situados imediatamente a leste-nordeste do Granito Salto permitiu a abordagem temática da construção de um batólito, o qual parece corresponder à amalgamação de sucessivas câmaras magmáticas.

O presente trabalho tem como base a elaboração de um modelo geológico-estrutural para os plútons de interesse, utilizando como referência mapas faciológicos prévios, e a compreensão da geometria e relações temporais entre as diferentes variedades de rochas graníticas, definidas a partir de suas relações de contato e disposição de feições como foliação e bandamento magmáticos. Particular atenção foi dada à observação e caracterização de corpos de rocha máfica associados e enclaves microgranulares que, em conjunto, trouxeram informações fundamentais ao entendimento dos processos de recarga e interação de magmas. A diversidade mineralógica e geoquímica de granitos e enclaves foi caraterizada através de análises petrográficas, geoquímica de elementos maiores, menores e traço, e geoquímica isotópica ( $\mathrm{Sr}$, $\mathrm{Nd}$ e Hf), permitindo inferir condições de cristalização, áreas-fonte e relações genéticas entre as diferentes fácies graníticas. Estudos geoquímicos em escala mineral, com identificação de possíveis zoneamentos de elementos traço em cristais de zircão foram ferramentas importantes para a compreensão de processos evolutivos em sistemas fechado (cristalização fracionada) e aberto (contaminação e/ou mistura de magmas).

\subsection{OBJETIVOS}

Este trabalho teve como objetivo principal as caracterizações geológica, geoquímica e isotópica dos plútons Cabreúva e Indaiatuba, com a finalidade de se definir e relacionar diversas faciologias graníticas em câmaras magmáticas rasas; dados do Plúton Salto (PEREIRA, 2013) e Itupeva foram integrados quando necessário. Em uma perspectiva mais ampla, os resultados obtidos permitiram uma melhor compreensão da dinâmica de pequena parte de um amplo sistema magmático em crosta continental rasa, como a formação de um batólito granítico a partir da coalescência de sucessivas câmaras graníticas. Para tanto, foram realizados levantamentos geológico-estruturais em campo em escala de detalhe e semi-detalhe (utilizando 
como base mapas geológico-faciológicos disponíveis na literatura - GALEMBECK, 1997), apoiados por ferramentas geofísicas (medidas em campo da gama-espectrometria e da susceptibilidade magnética total), que juntos permitiram definir a geometria e configurações de idade relativa das diferentes fácies graníticas constituintes dos plútons, podendo assim reconstituir a história dos reservatórios magmáticos. A caracterização da diversidade petrográfica observada em estudos de microscopia óptica, a geoquímica elemental e, em subsequência, isotópica (Sr-Nd-Hf), permitiu inferir sobre fontes e condições de cristalização dos magmas. Estudos em escala de detalhe, como a caracterização da zonalidade na distribuição de elementos traço em cristais de zircão, contribuíram na identificação de processos de evolução e eventual interação entre magmas de diferentes naturezas.

\subsection{ESTRUTURAÇÃO DA TESE}

Este trabalho está estruturado em dez capítulos da seguinte maneira:

- 1. INTRODUÇÃO: apresentação sintética e delimitação da área de estudo e temática destacando sua relevância e justificativas. Apresentação da área de estudo. Revisão bibliográfica sobre câmaras magmáticas e seus principais processos;

- 2. MATERIAIS E MÉTODOS: descrição das técnicas e procedimentos utilizados durante a pesquisa na obtenção de dados;

- 3. SITUAÇÃO GEOLÓGICA: apresentação do contexto geotectônico regional no qual o Batólito Itu encontra-se inserido, e descrição sumária das unidades faciológicas dos plútons Cabreúva, Indaiatuba e Itupeva anteriormente apresentadas (GALEMBECK, 1997);

- 4. GEOLOGIA DO BATÓLITO ITU: definição atual das unidades faciológicas graníticas dos plútons Cabreúva e Indaiatuba baseadas em levantamentos de campo, imagens aéreas e dados de gama-espectrometria;

- 5. PETROgRAFia; 6. QUímica Mineral; 7. GEOQUímiCA DE ROCHA TOTAL; 8. ASSINATURA ISOTÓPICA LU-HF, QUÍMICA DE ZIRCÃO E GEOCRONOLOGIA; 9. GEOQUÍMICA ISOTÓPICA: apresentação e descrição sistemática dos dados analíticos obtidos durante a pesquisa;

- 10. CONSIDERAÇÕES FINAIS: integração das informações apresentadas e discussão de modelo petrogenético que relacione a evolução do Batólito Itu ao conceito atual de dinâmica de câmaras magmáticas graníticas rasas e com a síntese das principais conclusões obtidas para este trabalho. 


\section{4. ÁREA DE ESTUDO}

O BGI situa-se, aproximadamente, entre as latitudes $23^{\circ} 03^{\prime}$ e $23^{\circ} 18^{\prime} \mathrm{S}$ e as longitudes $47^{\circ} 02^{\prime}$ e $47^{\circ} 18^{\prime} \mathrm{W}$. Os afloramentos dos plútons Cabreúva e Indaiatuba situam- se aproximadamente a W-SW da cidade de Itupeva e E-NE da cidade de Itu conforme ilustra a Figura 1.



Figura 1 - Localização dos plútons Cabreúva (CB) e Indaiatuba (ID) com relação às cidades da região, no interior do Estado de São Paulo; coordenadas geográficas em graus e minutos. Modificado de Galembeck (1997).

Os levantamentos de campo foram realizados, em sua maioria, em afloramentos de lajes e matacões, muitos dos quais já previamente cortados para exploração, na forma de paralelepípedos, em pequenas pedreiras nos arredores dos pequenos bairros da região. Uma característica marcante dos diferentes corpos ígneos que compõem o BGI é a forma com que afloram, no formato de matacões com dimensões variando de metros a dezenas de metros, 
caracterizando os denominados "mares de matacões" (Figura 2) que, por vezes, podem ser observados na escala de imagens áreas de satélite de alta resolução (Figura 3).



Figura 2 - Exposição do Plúton Cabreúva na forma de “mar de matacões”.



Figura 3 - Imagem aérea de satélite ilustrando uma região de afloramentos de matacões do Plúton Cabreúva. Extraída do software Google Earth Pro em junho de 2018.

O acesso à área de estudo, partindo-se da cidade de São Paulo, pode ser feito através da Rodovia dos Bandeirantes (SP-348) até a cidade de Jundiaí, a partir daí, o acesso se dá pela 
Rodovia Dom Gabriel Bueno Couto (SP-300) (Figura 4) de onde os afloramentos podem ser acessados através das estradas vicinais da região (Figura 4 - destaque).



Figura 4 - Localização e acessos à área de estudo. Extraídos de maps.google.com.br em junho de 2018.

\subsection{DINÂMICA DE CÂMARAS MAGMÁTICAS RASAS}

Fenômenos de origem magmática são os principais responsáveis pela formação dos continentes e da crosta oceânica. Além disso, são também os principais agentes de transporte de calor e massa a partir do manto para a crosta, para a hidrosfera (hidrotermalismos continental e oceânico) e para a atmosfera (emissão de gases e cinzas vulcânicas). As maiores expressões 
desses fenômenos são a cristalização de corpos plutônicos e a formação de produtos vulcânicos (MENAND; DE SAINT-BLANQUAT; ANNEN, 2011).

Câmaras magmáticas são grandes reservatórios subterrâneos que contêm material silicático (tipos carbonático e sulfetado são raros) parcialmente a totalmente fundido. Algumas se comportam como áreas de armazenamento provisório para erupções de natureza vulcânica, enquanto outras não possuem conexão direta com a superfície terrestre, e ao resfriarem, acabam por se solidificar, formando assim, corpos ígneos intrusivos de granulação mais grossa, os plútons. Estes reservatórios existem, sem dúvida, em todos os níveis da Terra, sendo que a crosta se comporta como um repositório de câmaras magmáticas, repleta de evidências de câmaras pretéritas - sills, lacólitos, plútons, intrusões acamadadas, entre outras. O manto, em si, contém inúmeras câmaras magmáticas, entretanto, sua constante dinâmica e inacessibilidade impedem constatações diretas (MARSH, 1989; BACHMANN; HUBER, 2016).

Conceitos intrínsecos aos processos magmáticos, a partir dos quais os magmas são formados, ascendem, são armazenados e, eventualmente, entram em erupção (Figura 5) são objetos de interesse constante em câmaras magmáticas. O magma tem sua composição química determinada na fonte com subsequente modificação na câmara magmática. Desta maneira, a evolução magmática é caracterizada por processos magmáticos da fonte e da própria câmara (MARSH, 1989).



Figura 5 - Representação esquemática de um ciclo magmático. Extraída de Gudmundsson (2012).

Se grandes volumes de magma em câmaras magmáticas geram erupções vulcânicas de grande expressão, cujo volume e duração podem acarretar em consequências globais para a humanidade, ou se solidificam lentamente dentro da crosta para formar plútons, depende do 
que ocorre principalmente em reservatórios magmáticos localizados nos primeiros $10-15 \mathrm{~km}$ da crosta terrestre (BACHMANN; BERGANTZ, 2008).

O crescimento de plútons é um processo de grande escala de tempo com grandes câmaras magmáticas se desenvolvendo durante episódios com maiores fluxos de magmas. Muitos plútons e batólitos se formam pela aglomeração de pulsos discretos que comumente têm o formato de sills (ANNEN, 2009). Entretanto, a noção "clássica" de que, dentro da câmara magmática, cristais nucleiam, crescem e se depositam ad infinitum no interior de grandes pools de magma para, eventualmente, formarem rochas, está em desuso. Majoritariamente, os processos magmáticos em câmara magmática parecem operar, a pequenas escalas, dentro de fronts de solidificação marginais (Figura 6 - MARSH, 2006).



Figura 6 - Conceito “clássico" de câmaras magmáticas (A - classical) vs. fronts de cristalização (B solidification front). Extraída de Marsh (2006).

O motor fundamental para o magmatismo crustal é o poder de entrada do manto na crosta, e os magmas silicáticos podem ser originados a partir de três fontes principais: crosta superior, crosta inferior e subducting slab. Para sistemas relativamente pequenos, as escalas de tempo variam entre $10^{3}$ e $10^{4}$ anos, ficando entre $10^{5}$ e $10^{6}$ para sistemas magmáticos de maior expressão em tamanho (DE SILVA et al., 2007).

Um modelo amplamente admitido atualmente para a geração de magmas félsicos a intermediários é a fusão parcial em zonas quentes (hot zones) na crosta profunda, próximo a Moho. O modelo é diretamente relacionado ao magmatismo de subducção, mas também é aplicável a magmas gerados em outros contextos tectônicos (ANNEN; BLUNDY; SPARKS, 
2006). Nele, assume-se que magmas basálticos hidratados (com fluidos provenientes do manto fértil) intrudem a crosta inferior numa sucessão de sills, dando origem às hot zones crustais profundas (Figura 7), onde os líquidos são gerados a partir de duas fontes distintas: da cristalização parcial dos basaltos produzindo líquidos residuais ricos em $\mathrm{H}_{2} \mathrm{O}$; e da fusão parcial das rochas crustais pré-existentes (ANNEN; BLUNDY; SPARKS, 2006). Consequentemente, a transferência de calor e $\mathrm{H}_{2} \mathrm{O}$, associada à interação de magmas, resulta em processos como assimilação e cristalização fracionada (AFC; cf. DEPAOLO, 1981) ou mistura, assimilação, armazenamento e hibridização (MASH; cf. HILDRETH; MOORBATH, 1988), que podem levar, dependendo do grau de interação, à formação de câmaras magmáticas zonadas ou homogêneas. Devido ao alto conteúdo de fluidos e voláteis, estes magmas podem ter baixa viscosidade e densidade, e assim podem ascender rapidamente (ANNEN; BLUNDY; SPARKS, 2006). Fatores como perda de pressão e de voláteis são determinantes na cristalização desses magmas, ocorrendo a pequenas profundidades, e formando assim câmaras magmáticas conectadas a vulcões ou plútons rasos. 




Figura 7 - Representação de uma hot zone em perfil na crosta continental superior-inferior. Sills de basaltos intrudem a descontinuidade de Mohorovičić (entre o manto e a crosta) e melts resultantes ascendem na forma de diques, intrudindo as crostas inferior e superior; (1) descontinuidade de Mohorovičić, (2) crosta inferior, (3) descontinuidade de Conrad. Extraída de Annen, Blundy e Sparks (2006).

Entretanto, é correto afirmar que um plúton representa uma câmara magmática? Se as rochas foram algum dia um magma amplamente fundido e móvel, pode ser que um dia elas foram uma câmara magmática (BACH et al., 2001). Todavia, alguma diferenciação por 
cristalização é provável, em contraste com a formação de rochas mais homogêneas nas margens da câmara onde ocorre "congelamento", não sofrendo, assim, contaminação pela encaixante.

Tem sido amplamente reconhecido que corpos ígneos resultam de uma interação complexa entre vários processos petrogenéticos, como cristalização fracionada, diferenciação termogravitacional, imiscibilidade de líquidos, contaminação e/ou assimilação das encaixantes e processos de interação de magmas (magma mixing e magma mingling). Muitos maciços ígneos contêm rochas híbridas, apontando para a coexistência de dois ou mais magmas composicionalmente contrastados. Tais rochas híbridas fornecem evidências do importante papel dos magmas máficos na geração e evolução de magmas granitoides cálcio-alcalinos. Uma abordagem pelo ponto de vista da geoquímica de rocha total, por si só, não fornece um modelo petrogenético inequívoco, pois suas tendências lineares em diagramas binários podem resultar de processos de mistura como também de pequenos graus de cristalização fracionada. Similarmente, pequenos corpos de magmas híbridos podem se reequilibrar quimicamente com seu magma hospedeiro e, consequentemente, não mais refletirem suas químicas magmáticas iniciais. Existem numerosos processos que podem tornar difícil estabelecer claramente cronologias para diferentes eventos de mistura de magmas (SŁABY; MARTIN, 2008).

São muitos os modelos para os mecanismos de mistura em ambiente plutônico (BATEMAN, 1995): (1) uma única fase entre intrusão de um magma máfico em uma câmara félsica e hibridização in situ ao longo da interface; (2) a hibridização ocorre antes da ascensão do magma, no local da fusão parcial onde o calor do magma máfico contribuiu para o evento de fusão crustal; (3) magmas podem se tornar hibridizados através do processo de captura de cristais; (4) difusão seletiva de alguns componentes, ou mistura mecânica de líquidos intersticiais. Além disso, existem também várias inibições do tipo cinéticas e/ou dinâmicas para a completa mistura entre magmas máficos e quentes e magmas félsicos e, consequentemente, mais frios, através de uma estratificação estável devido ao contraste de densidades entre estes líquidos.

Além de serem identificadas na química dos magmas, variações na composição de minerais magmáticos registram mudanças químicas e físicas no magma a partir do qual eles cresceram (GINIBRE; WÖRNER; KRONZ, 2007). Com novas técnicas analíticas para o estudo da composição de elementos maiores, menores e traços (alta resolução espacial), processos magmáticos como cristalização, recarga em uma câmara magmática, descompressão durante ascensão, e convecção dentro da própria câmara podem ser identificados, e a história dos sistemas magmáticos antes da erupção pode ser reconstruída. 


\subsubsection{Conceituação Adotada}

\section{Nomenclatura e Definições}

Magmas são misturas de cristais e líquido (em geral, de composição silicática); a proporção de cristais, em determinado momento, dependerá de fatores como composição, temperatura, pressão, atividade de fluidos, entre outros. A capacidade desses magmas fluírem depende fundamentalmente de suas viscosidades e estas, por sua vez, da proporção de cristais em seus melts. Quando esta proporção se encontra entre 0 e $50 \%$, os magmas podem fluir (um limiar mecânico crítico de fluidez é atingido quando há cerca de 50-60 \% de cristais - BACHMANN; BERGANTZ, 2008). Definições modernas consideram que uma câmara magmática corresponde a uma região contínua, onde magmas capazes de se mover e, portanto, factíveis de entrar em erupção (com fração cristalina <50 \%), são armazenados (cf. Figura 8). Em contrapartida, o mush cristalino corresponde a um arranjo de cristais em contato e líquido intersticial, o qual se comporta de modo rígido/semirrígido. Câmara magmática e mush, juntos, formam o reservatório magmático (BACHMANN; BERGANTZ, 2008).



Figura 8 - Ilustração de um reservatório magmático formado pela câmara magmática (área laranja, contendo o eruptible magma) e pelo crystal mush (área vermelha). Extraída de Bachmann e Bergantz (2008).

Miller et al. (2011) também definiram e ilustraram a terminologia mais moderna para materiais em sistemas magmáticos de crosta rasa segundo a Tabela 1 e a Figura 9. 
Tabela 1 - Definições e características de materiais e estruturas que compõem os sistemas magmáticos.

\begin{tabular}{|c|c|c|c|}
\hline \multicolumn{4}{|r|}{ DEFINIÇÕES } \\
\hline Magma & \multicolumn{3}{|c|}{$\begin{array}{l}\text { Material com alta proporção de melt (40-50\%), sendo assim móvel e, potencialmente factível } \\
\text { de entrar em erupção; normalmente contém cristais e pode, também, conter vesículas com } \\
\text { fluidos. }\end{array}$} \\
\hline Dique & \multicolumn{3}{|c|}{$\begin{array}{l}\text { Estrutura magmática, ativa ou não, que transporta magma para cima (não necessariamente na } \\
\text { vertical); normalmente corta limites litológicos. }\end{array}$} \\
\hline Sill & \multicolumn{3}{|c|}{$\begin{array}{l}\text { Estrutura magmática, ativa ou não, que transporta magma lateralmente (não necessariamente na } \\
\text { horizontal); normalmente concordante com limites litológicos. }\end{array}$} \\
\hline Plúton & \multicolumn{3}{|c|}{$\begin{array}{l}\text { Massa intrusiva exposta, de dimensões consideráveis (> } \mathrm{km}^{2} \text { em exposição), solidificada } \\
\text { durante um tempo geológico relativamente breve (não mais do que poucos milhões de anos); } \\
\text { infere-se que tenha sido construída a partir de produtos de um mesmo sistema magmático. }\end{array}$} \\
\hline Batólito & \multicolumn{3}{|c|}{$\begin{array}{l}\text { Exposição contínua a semi-contínua }>100 \mathrm{~km}^{2} \text { (ao nível de exposição, ou abaixo deste, de } \\
\text { maneira inferida, ou mesmo, previamente acima do nível presente de exposição); pode abranger } \\
\text { um intervalo de tempo muito maior do que o plausível para o armazenamento de magmas, } \\
\text { correspondendo a dezenas ou mesmo centenas de milhares de anos, e provavelmente } \\
\text { relacionados a processos tectonomagmáticos prolongados. }\end{array}$} \\
\hline $\begin{array}{c}\text { Sistema } \\
\text { magmático: }\end{array}$ & \multirow{2}{*}{\multicolumn{3}{|c|}{$\begin{array}{l}\text { Materiais que variam de fundidos a parcialmente fundidos, até solidifi } \\
\text { uma zona ativa de transferência e armazenamento de magmas. } \\
\text { MATERIAIS DENTRO DO SISTEMA (cf. Figura 9) }\end{array}$}} \\
\hline MATERIAIS DENTRO DO SISTEMA (cf. Figura 9) & & & \\
\hline \multicolumn{2}{|c|}{ MATERIAL } & $\begin{array}{c}\text { \% DE } \\
\text { CRISTAIS }\end{array}$ & COMPORTAMENTO REOLÓGICO \\
\hline \multicolumn{2}{|c|}{ Magma pobre em cristais } & $<\sim 15$ & $\begin{array}{l}\text { Baixa viscosidade, altamente móvel e susceptível a entrar em } \\
\text { erupção; }\end{array}$ \\
\hline \multicolumn{2}{|c|}{ Magma rico em cristais } & $\sim 15-45$ & $\begin{array}{l}\text { Viscosidade mais alta, ainda móvel; cristais podem se depositar } \\
\text { e/ou serem transportados por convecção; }\end{array}$ \\
\hline \multicolumn{2}{|l|}{ Mush } & $\sim 45$ a $\sim 60$ & $\begin{array}{l}\text { Muito mais resistente, muito pouco móvel e ainda factível de } \\
\text { entrar em erupção; extração de melt pelo processo de } \\
\text { compactação efetiva; }\end{array}$ \\
\hline \multicolumn{2}{|l|}{ Rigid sponge } & $>\sim 60$ & $\begin{array}{l}\text { Próximo à resistência/viscosidade de rocha, imóvel, impossível } \\
\text { de entrar em erupção; extração de melt não efetiva pelo } \\
\text { processo de compactação lenta; }\end{array}$ \\
\hline \multicolumn{2}{|l|}{ Rocha sólida } & 100 & $\begin{array}{l}\text { Sem melt, sem extração de melt; viscosidade/resistência } \\
\text { extremamente alta. }\end{array}$ \\
\hline
\end{tabular}

Fonte: MILLER et al. (2011)



Figura 9 - Estruturação da parte superior de um sistema magmático. Extraída de Miller et al. (2011). 
Câmaras magmáticas e reservatórios não podem ser diretamente observados devido ao fato de se formarem na crosta terrestre (ou manto superior), entretanto, suas existências podem ser estabelecidas por pelo menos três linhas de evidências (BACHMANN; BERGANT, 2008):

(1) detecções indiretas através de métodos geofísicos, utilizando-se principalmente a tomografia sísmica (Figura 10);

(2) corpos plutônicos expostos (principalmente aqueles cristalizados nos primeiros $5-15 \mathrm{~km}$ da crosta terrestre), os quais são creditados como câmaras magmáticas "fósseis" exumadas;

(3) erupções vulcânicas de grande volume, as quais necessitam de grandes reservatórios de magma susceptível a entrar em erupção (predominantemente em estado líquido), e que estejam periodicamente disponíveis na crosta.



Figura 10 - Tomografia sísmica do reservatório magmático da área do complexo de caldeiras de Yellowstone, WY, EUA. Extraída de Bachmann e Bergantz (2008).

Plútons são construídos de maneira incremental (MILLER et al., 2011; GUDMUNDSSON, 2012; ANNEN, 2009). O número e dimensões dos incrementos, entretanto, permanecem como questões em aberto, e a duração da construção dos plútons parece atingir um grande range: de dezenas de milhares a milhões de anos. Repreenchimentos via diques/sills têm sido uma hipótese bem aceita (Figura 11), em parte por causa das relações observadas em campo (Figura 12), com pequenos e discretos incrementos ao longo de períodos prolongados; cálculos teóricos 
sugerem que plútons formados por rápido suprimento via diques/sills são também plausíveis (MILLER et al., 2011).



Figura 11 - Ilustração esquemática de um dique alimentador se tornando um sill ao encontrar uma barreira de maior rigidez. $\mathrm{O}$ incremento via sills alimentadores pode criar uma câmara magmática e, consequentemente, um plúton. Extraída de Miller et al. (2011).



Figura 12 - Sucessão de sills basálticos formando corpo ígneo. Extraída de Gudmundsson (2012).

Os processos físicos pelos quais os magmas se colocam em crosta continental superior remetem à questão o modo como o espaço físico é criado para tal. Modelos recentes envolvem teorias onde seções de crosta que descendem em uma zona de armazenamento profunda a partir da qual o magma ascende (piston-like emplacement), intrusões tipo dike-on-dike ou sill-on-sill, entre outros. Independentemente de qual interpretação seja utilizada, é possível afirmar que se 
plútons são repreenchidos em pequenas parcelas e durante intervalos de tempo prolongados, estes são simplesmente resultado da amalgamação de diques e/ou sills sucessivamente intrudidos e solidificados (Figura 13). Adicionais evidências de múltiplos repreenchimentos extensos de câmaras são os processos de cristalização fracionada em crosta superior, as evidências físicas e químicas que remetem à mistura e à coexistência de magmas contrastados, e as populações de cristais misturados, as quais diferem, de maneira considerável, isotópica e cronologicamente (MILLER et al., 2011).



Figura 13 - Desenho esquemático representando a intrusão de um magma de repreenchimento em um magma parcialmente cristalizado com fração cristalina variável (A). Dique ascende no mush até encontrar um horizonte com maior fração cristalina (mais rígido) (B). Em C, a ascensão do dique é interrompida, e este se espalha lateralmente abaixo do horizonte rígido, formando assim um sill. Extraída de Miller et al. (2011). 
A evolução geométrica de uma câmara magmática após o posicionamento do primeiro sill varia consideravelmente, e depende de muitos fatores. Talvez o tipo mais comum de câmara magmática seja, entretanto, em forma de sill (sill-like) (Figuras 14d, 15 e 16d). Este é o formato que normalmente é registrado em estudos sísmicos de vulcões e zonas de rifts, como nas cristas meso-oceânicas. Esta hipótese também é sustentada pela ocorrência comum de sills em áreas vulcânicas e formação de colapsos de caldeiras (CASHMAN; GIORDANO, 2014). Geralmente, esta é a geometria mais favorável para a geração das ring-faults ao longo das quais a subsidência do tipo piston-like ocorre (GUDMUNDSSON, 2012).



Figura 14 - Ilustração esquemática dos vários formatos possíveis de câmaras magmáticas; câmaras de formato sill-like ou elipsoildal-oblato (letra d) são, presumivelmente, o tipo mais comum de geometria de câmara magmática. Extraída de Gudmundsson (2012).



Figura 15 - Ilustração esquemática da formação de uma câmara magmática através de sucessivas injeções de diques/sills alimentadores. Extraída de Gudmundsson (2012). 




Figura 16 - Ilustração esquemática de perfis baseados em modelos conceituais da geometria de corpos ígneos plutônicos, produtos da cristalização de câmaras magmáticas. Extraída de Annen et al. (2015).

\section{Fronts de cristalização}

A relação espacial entre a posição das curvas liquidus e solidus define um front de solidificação, ou cristalização, em qualquer corpo magmático (Figura 17). Atravessando esta região, o magma varia de inteiramente líquido a inteiramente sólido. Idealmente, com o resfriamento, este arranjo de isotermas se propaga em direção ao interior do corpo, se encontrando em seu centro no final da solidificação. Embora fino no início do magmatismo, o front de cristalização vai espessando com o tempo em proporção com a raiz quadrada do tempo, como observado experimentalmente (MARSH, 2002).



Figura 17 - Ilustração das regiões de um front de cristalização. Extraída de Marsh (2002). 
Com base no comportamento reológico, o front de cristalização pode ser subdividido em quatro regiões (MARSH, 2002; cf. Figura 17):

1. Crosta rígida - Delimitada pela curva solidus (cristalinidade $\mathrm{N}=100 \%$ ) e o ponto crítico de cristalinidade ( $\mathrm{N}$ variando entre $50-55 \%$ );

2. Zona de mush - Delimitada pelo front de captura $(\mathrm{N}=25 \%)$ e a região de cristalinidade crítica com empacotamento máximo de sólidos, onde $\mathrm{N}$ varia de 50 a $55 \%$; a migração dos cristais é dificultada pois estes atuam como obstáculos mútuos;

3. Front de captura - Delimitada pelo limite exterior que marca a zona de suspensão, a partir da qual é improvável que os cristais depositados "escapem" do front de cristalização e a zona de mush;

4. Zona de suspensão - Região entre o início da curva liquidus, abaixo da qual $\mathrm{N}=0$, e o fim do front de captura, a uma cristalinidade de cerca de $25 \%$ onde cristais pequenos e esparsos podem se mover livremente.

\subsubsection{Processos Magmáticos Dinâmicos}

A enorme gama de composições e condições de áreas-fonte permitem a geração de diversos magmas primários, entretanto, estes estão aquém de todo espectro do qual se tem registro. Esse material é produto da diferenciação magmática desses magmas primários ao deixarem suas áreas-fonte. Rochas indiferenciadas representando magmas primários solidificados são a exceção, e não a regra (BEST, 2003). Supõe-se, em sua maioria, que processos de diferenciação produzam rochas de natureza comagmática ou cogenética, visto que é comum a ocorrência de suítes de rochas composicionalmente variadas e, restritamente, associadas no espaço e no tempo (Figura 18). Entretanto, magmas de diferentes fontes ou pulsos com diferentes graus de diferenciação podem, coincidentemente, formar uma única intrusão (composite intrusion) ou uma estrutura ígnea vulcânica (composite volcano ou stratovolcano). Dados químicos, isotópicos, mineralógicos e de composições modais podem ser usados para testar a hipótese de um magma parental, a partir do qual outras composições mais evoluídas, observadas em suítes rochosas, podem ser obtidas através de processos de diferenciação magmática. Magmas parentais, em sua maioria, não são primários, ou completamente preservados após gerados na fonte, porém apresentam composições primitivas com relação a outros magmas que formam suítes comagmáticas (BEST, 2003). De maneira simplificada, alguns processos de diferenciação encontram-se destacados na Tabela 2. 




Figura 18 - Relações $\mathrm{K}_{2} \mathrm{O}-\mathrm{SiO}_{2}$ em rochas cálcio-alcalinas plutônicas de arco. Composições de rochas do Batólito de Sierra Nevada, Califórnia (círculos são dados químicos referenciados em Bateman, 1992) e do Batólito Costeiro do Peru (área sombreada - dados de Atherton e Sanderson, 1987). Extraída de Best (2003).

Tabela 2 - Relação de processos de diferenciação magmática em sistemas fechados e abertos.



Fonte: BEST (2003). 
De modo habitual, esses processos tendem a operam simultaneamente, ou em conjunto. Segundo Wilson (1989), de uma maneira geral, a cristalização fracionada combinada à assimilação das rochas encaixantes em diferentes proporções, atuando tanto na crosta quanto no manto, parece ser o processo dominante na diferenciação de magmas primários. Entretanto, nos anos recentes, o processo de mistura de magmas tem sido muito utilizado na elaboração de modelos petrogenéticos de suítes de rochas ígneas cogenéticas em diversos ambientes tectônicos.

\section{Convecção}

A convecção é um processo físico de transferência de energia através do movimento de fluidos de diferentes densidades, sendo mais eficiente, em uma ou duas ordens de magnitude, que o processo de condução em corpos magmáticos em resfriamento (Figura 19). Processos convectivos atuantes em uma câmara magmática preenchida são controlados por sua forma e tamanho, pela viscosidade do magma e por processos atuantes na borda da câmara (TURNER; CAMPBELL, 1986). A convecção puramente térmica é considerada por atuar somente nos estágios iniciais após a entrada do(s) melt(s) na câmara, passando a uma convecção termoquímica, ou double-diffusive convection retroalimentada (Figura 20), dependente das variações na temperatura e composição dos líquidos magmáticos (BEST, 2003). 




Figura 19 - Ilustração esquemática dos processos de condução (b) e convecção (c) após a entrada de um melt (a) em uma câmara magmática. Modificada de Best (2003).



Figura 20 - Representação de uma câmara magmática em convecção termoquímica. A estratificação composicional representada na figura e gráficos esquemáticos $\left(\mathrm{T}, \mathrm{XH}_{2} \mathrm{O}\right.$ e $\rho$ ) pode ser produzida por um input de magma inicialmente homogêneo. Extraída de Best (2003). 
Desde os estudos pioneiros de Shaw (1965), numerosas teorias e experimentos têm demonstrado que o fracionamento composicional é um "motor" com um papel muito mais significativo na convecção magmática que os gradientes térmicos dentro da câmara (e.g., MCBIRNEY, 1980; SPARKS et al., 1984). Enquanto a variação da densidade de dado melt, em particular, de 800 a $1200{ }^{\circ} \mathrm{C}$, é de cerca de $0,1 \mathrm{~g} / \mathrm{cm}^{3}$ ou menos, as densidades de melts livres de voláteis, a pressão de $1 \mathrm{~atm}$ e temperatura de $1000{ }^{\circ} \mathrm{C}$, variam entre 2,2 e $2,8 \mathrm{~g} / \mathrm{cm}^{3}$, a depender de suas composições (Figura 21). As variações de densidade em magmas com alto conteúdo de voláteis podem ser muito maiores (BEST, 2003).



Figura 21 - Diagrama esquemático de densidades de minerais e rochas mais comuns. À direita no diagrama, variação da densidade de diferentes composições de melts em função da variação de $\mathrm{T}(\mathrm{P}=1 \mathrm{~atm})$. Extraída de Best (2003).

\section{Replenishment}

O tempo de duração de uma câmara magmática ativa é frequentemente estendido por episódios recorrentes de "repreenchimento" (replenishment), na forma de novos pulsos de magma, geralmente mais quente, e consequentemente menos viscoso que o material encaixante (Figura 22). Consequentemente, ao ascender, este novo líquido pode tanto se misturar, ou 
hibridizar dentro da câmara, dependendo das composições dos magmas envolvidos no processo (magma mixing, magma mingling e hybridization).



Figura 22 - Ilustração de uma câmara magmática de composição ácida sendo injetada por um pulso de magma máfico, via dique alimentador. Modificada de Best (2003).

\section{Stoping}

O fenômeno de stoping consiste em um processo de emplacement passivo típico de plútons félsicos onde fragmentos de rocha (granulometria variada) se desprendem das encaixantes e são fisicamente incorporados no magma invasor (Figura 23); estes xenólitos podem ser quimicamente assimilados (“digeridos”) em diferentes graus (BEST, 2003).



Figura 23 - Ilustração esquemática dos processos dinâmicos atuantes em uma câmara magmática; destaque em vermelho para o mecanismo de stoping. Extraída de Glazner et al. (2004). 


\section{Fracionamento cristais-melt}

O mecanismo de fracionamento cristais-melt ocupa um papel proeminente dentre os processos de diferenciação magmática e rege os sistemas dito fechados. O processo de solidificação de um magma ocorre dentro de um intervalo de temperatura, e não em uma temperatura específica. Sua cristalização se inicia a uma temperatura liquidus, tornando-se completa a uma temperatura solidus; ambas as curvas solidus e liquidus dependem da pressão e são subparalelas no espaço P-T (WILSON, 1989; cf. Figura 24).



Figura 24 - Representação esquemática da trajetória de ascensão de um magma com relação a seu intervalo de cristalização em função das variações de temperatura e pressão. Extraída de Wilson (1989).

Bowen $(1928,1941)$ distinguiu dois tipos de cristalização. Durante a cristalização em equilíbrio, cristais se formam com a remoção do calor, continuamente reagindo, e se reequilibrando com o líquido. Já durante a cristalização fracionada, os cristais são imediatamente isolados do sistema assim que eles são formados, e, desta maneira, são impedidos de reagir com o líquido residual (YODER, 1979). A principal exigência para a diferenciação durante a cristalização é a atuação de um mecanismo que remova os cristais do magma.

Devido ao contraste composicional entre o melt e seus cristais recém-formados, a segregação pelo processo de cristalização fracionada é um mecanismo muito eficiente em 
diferenciar o magma parental de seus produtos composicionalmente contrastados. Em magmas evoluídos, os efeitos da cristalização fracionada são melhor observados em variações composicionais nos elementos traço do que nos maiores e menores, pois os elementos compatíveis tendem a se concentram nas fases sólidas, enquanto a fase líquida enriquece em elementos incompatíveis com relação a sua composição inicial (Figura 25).



Figura 25 - Gráfico apresentando a variação teórica da concentração de um elemento em melts residuais $\left(\mathrm{C}_{\mathrm{m}}\right)$ com relação ao coeficiente de distribuição D e seu magma parental inicial C $C_{p}$. Extraída de Best (2003).

Os mecanismos de separação mais relevantes são: (1) deposição gravitacional dos cristais mais pesados, ou flotação dos cristais mais leves (Figura 26); (2) diferenciação por fluxo (Figura 27); (3) filter pressing (Figura 28); (4) nucleação seletiva; (5) imiscibilidade de líquidos (Figura 29); e (6) transmissão de fluidos-gases (HALL, 1996; WILSON, 1989; BEST, 2003). Esses mecanismos podem resultar na separação de todos os cristais formados previamente do líquido residual, ou somente alguns deles, ou podem envolver separação entre os próprios cristais. 


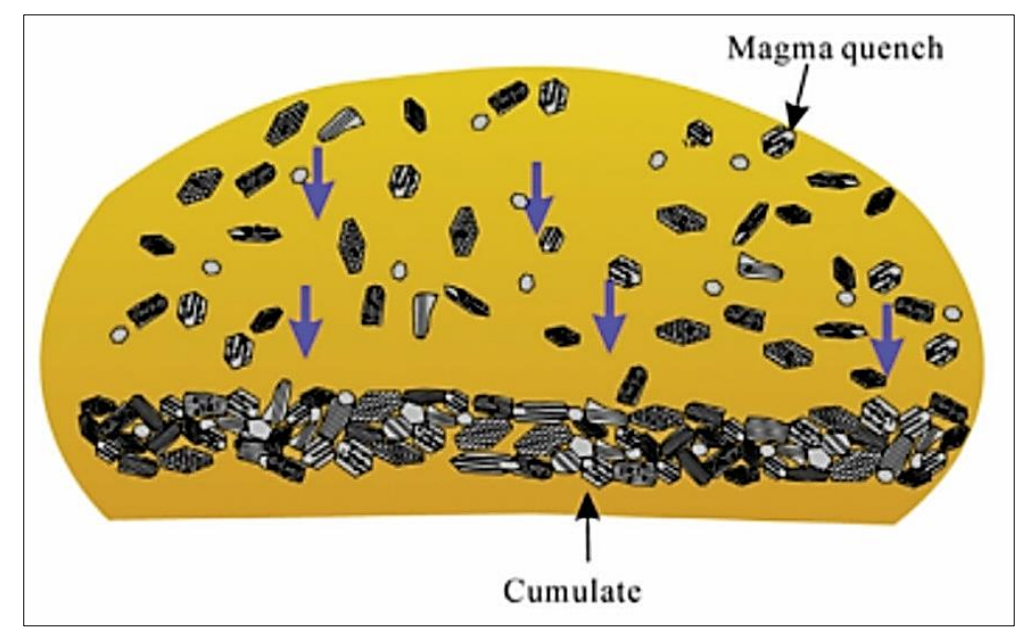

Figura 26 - Ilustração esquemática do processo de segregação gravitacional pela deposição de cristais mais densos e, consequentemente, formação de rochas de origem cumulática. Extraída de Chen et al. (2016).



Figura 27 - Ilustração esquemática da evolução (sentido da esquerda para a direita) da distribuição de cristais durante emplacement e resfriamento de diques, com atuação do processo de diferenciação por fluxo. Extraída de Nkono et al. (2006).



Figura 28 - Ilustração esquemática do processo de filter pressing, onde melts residuais de magmas parcialmente cristalizados podem ser filtrados através do arranjo de cristais interligados devido a gradientes de pressão locais; fases fluidas e gases também podem influenciar no filter pressing. Extraída de Pohl (2011). 




Figura 29 - Ilustração esquemática exemplificando a imiscibilidade de melts silicáticos em um basalto. Os espaços intersticiais entre os cristais de plagioclásio e piroxênio são preenchidos por glóbulos (micrométricos) de vidro rico em ferro exsolvidos em vidro silicático pelo processo de imiscibilidade. Extraída de Best (2003).

O papel da cristalização fracionada na geração de magmas derivados foi defendido por Bowen de modo muito enfático (1928 - liquid line of descent), tanto que durante muitos anos foi quase tido como assertivo que todas as rochas ígneas se relacionavam por esse processo (cf. Figura 6[A] classical). Era assumido que para qualquer suíte de rochas ígneas, havia um tipo de magma parental a partir do qual os outros eram derivados por diferenciação magmática (Figura 30). Este pressuposto não é mais razoável, visto que estudos experimentais dos últimos anos têm demonstrado que quase todas as composições magmáticas comuns podem igualmente serem produzidas diretamente via fusão parcial de materiais fonte adequados, sob condições apropriadas de fusão (HALL, 1996). Por esta razão, embora a cristalização fracionada de fato ocorra, não é certo que ela desempenhe um papel exclusivo no desenvolvimento dos tipos mais volumosos de magmas (Figura 31).



Figura 30 - Representação esquemática da liquid line of descent a partir da qual um magma diferenciado deriva de um magma parental pelo processo de cristalização fracionada. Modificada de Wilson (1989). 




Figura 31 - Gráficos ilustrando os efeitos de processos em sistema aberto ( $a$ - assimilação; b - mistura) sobre curvas composicionais de cristalização fracionada. (a) Extraída de Tegner et al. (1999) e (b) extraída de Namur, Charlier e Holness (2012).

\section{Assimilação}

Magmas normalmente fundem, reagem com, ou incorporam mecanicamente material proveniente das rochas encaixantes e xenólitos (Figura 32). O magma que sofre este processo é dito como contaminado, enquanto as encaixantes são denominadas assimiladas; alguns autores divergem se o material incorporado deve ter sido completamente liquefeito para ser considerado assimilado.



Figura 32 - Ilustração esquemática de processos magmático dinâmicos atuantes em uma câmara magmática, incluindo contaminação pelas rochas encaixantes em sua borda (assimilation). Disponível em:

https://earthobservatory.sg/project/magma-degassing-and-controls-eruption-style. Acesso em: 26 nov. 2018. 
Existem dois tipos de mecanismos diferentes pelos quais o material contaminante pode ser incorporado em um corpo ígneo. O primeiro é por fusão de parte da encaixante e, consequente mistura da fração melt com o corpo principal de magma. O segundo consta de reação química e incorporação mecânica da encaixante, não envolvendo processos de fusão; este é de longe o processo mais importante no que concerne aos processos de assimilação magmática (HALL, 1996).

\section{Mistura e Hibridização}

Magmas de composições diferentes podem, ocasionalmente, se intrudir (Figura 33), então, frequentemente, há a possibilidade de uma eventual mistura. Por outro lado, diferenças entre densidade e viscosidade são susceptíveis a inibir esse processo quando magmas de diferentes composições são postos justos, e evidências de vasta mistura são, desta maneira, difíceis de encontrar; a assinatura geoquímica é normalmente ambígua. Por exemplo, estudos isotópicos têm determinado alguns elementos isótopos presentes em muitos magmas que derivam de mais de uma fonte, mas é normalmente difícil indicar se estes resultados representam mistura de magmas ou fusão de uma fonte que tenha sido, previamente, submetida a processos de mistura.



Figura 33 - Representação esquemática de uma câmara magmática repreenchida por um magma de natureza composicional diferente do magma hospedeiro. Extraída de Best (2003). 
Debates sobre mistura de magmas focaram, no passado, em mistura de magmas contrastados, como líquidos graníticos e basálticos. Mais atualmente, tem sido dado um maior foco na mistura de magmas similares como, por exemplo, batches de magma basáltico se intrudindo mutuamente, ou a mistura de dois magmas graníticos de diferentes origens (HALL, 1996; cf. item 1.1. JUSTIFICATIVAS).

A mistura de magmas é um processo que pode virtualmente ocorrer em qualquer estágio do tempo de vida de um sistema magmático e, não necessariamente requer a presença de membros finais gerados a partir de diferentes fontes (Figura 34a). De fato, processos de mistura podem ocorrer sempre que gradientes químicos estejam presentes no sistema magmático; isto implica que esses processos podem afetar processos petrológicos, prévios e/ou concomitantes, tais como cristalização fracionada, assimilação e fusão parcial (Figuras 34b, c e d). Tais gradientes composicionais são o pré-requisito para desencadear processos de mistura. Na verdade, em qualquer configuração petrológica na qual melts com diferentes composições possam ser gerados, é muito provável que esses magmas sejam transportados para diferentes níveis crustais. Durante este processo, os variados melts formados podem atravessar suas trajetórias mútuas em direção à superfície e, assim, sofrerem mistura (Figura 34e). É possível que todos os processos acima citados ocorram juntos, ampliando desta maneira, o efeito da mistura e induzindo a uma considerável heterogeneidade nos sistemas magmáticos (PERUGINI; POLI, 2012). 




Figura 34 - Desenho esquemático de alguns processos que podem potencialmente gerar gradientes composicionais em sistemas ígneos e, assim, induzir ao desenvolvimento de processos de mistura entre diferentes melts. Extraída de Perugini e Poli (2012).

Processos de mistura de magmas podem ocorrer potencialmente em qualquer ambiente geológico, desde em câmaras magmáticas crustais profundas a condutos vulcânicos, bem como desencadeando erupções (SPARKS; SIGURDSSON; WILSON, 1977; SNYDER, 2000 Figura 35) e produzir diversas evidências de sua ocorrência (Figura 36). Estudos atuais apontam que o inverso também pode ocorrer, onde episódios de erupções vulcânicas provocam, em consequência, a mistura (WOODS; COWAN, 2009 - Figura 37). 




Figura 35 - Modelo esquemático do mecanismo de desencadeamento (triggering) de erupções vulcânicas explosivas via mistura de magmas em subsuperfície. Extraída de Sparks, Sigurdsson e Wilson (1977).



Figura 36 - Ilustração mostrando a ocorrência de processos de mistura de magmas em diferentes ambientes ígneos e seus respectivos registros geológicos, desde câmaras magmáticas a produtos vulcânicos. Extraída de Perugini e Poli (2012). 




Figura 37 - Desenho ilustrando os efeitos de uma erupção em uma câmara magmática tipo two layer. Extraído de Woods e Cowan (2009).

A partir de um ponto de vista estrutural, os produtos de processos de mistura de magma podem ser agrupados em três classes principais (PERUGINI; POLI, 2012):

(1) estruturas de fluxo (Figura 38);

(2) enclaves magmáticos (produtos do processo de magma mingling) (Figura 39);

(3) desequilíbrio físico-químico em cristais (Figura 40).

Vale a pena notar que enquanto as classes (1) e (2) são exclusivas de processos de mistura de magmas, a presença de estruturas da classe (3) em rochas ígneas não necessariamente implica em gradientes composicionais. De fato, tem sido documentado, por exemplo, que especialmente em rochas vulcânicas, desequilíbrio físico e/ou químico em minerais pode ser induzido por descompressão durante ascensão do magma em direção à superfície.



Figura 38 - Exemplos de estruturas de fluxo em rochas vulcânicas produzidas pelo processo de mistura de magmas. Extraída de Perugini e Poli (2012). 



Figura 39 - Exemplos de enclaves magmáticos em rochas plutônicas. Extraída de Perugini e Poli (2012).


Figura 40 - Exemplos de texturas de reabsorção e zoneamento em minerais produzidas durante processo de mistura de magmas. (a) cristal de plagioclásio mostrando várias zonas de reabsorção e crescimento; (b) imagem BSE de cristal de diopsídio mostrando núcleo reabsorvido; (c) imagem BSE de cristal de plagioclásio com zoneamento oscilatório e núcleo reabsorvido. Extraídas de Perugini e Poli (2012). 
Tanto contrastes de densidade quanto de viscosidade exercem um controle decisivo no processo de interação de magmas. Exceto sob condições favoráveis, um magma basáltico injetado via dique sin-plutônico em uma câmara magmática granítica poderá se misturar de maneira eficiente com o hospedeiro para produzir um magma híbrido homogêneo (Figura 41). Somente magmas com aproximadamente temperaturas, viscosidades, composições e densidades similares podem misturar para produzir híbridos (BATEMAN, 1995).



Figura 41 - Desenho esquemático ilustrando o desenvolvimento de magmas híbridos e enclaves em uma câmara magmática. Extraída de Bateman (1995).

A distribuição de elementos traço e isótopos como ferramenta de investigação de processos magmáticos

Rochas magmáticas têm sido tradicionalmente utilizadas como a principal ferramenta na avaliação da composição do manto e da crosta continental, bem como dos processos pelos quais magmas são gerados e, subsequentemente, diferenciados. Mais recentemente, as escalas de 
tempo pelas quais estes processos se desenvolvem também têm sido objeto de investigação (DAVIDSON; MORGAN; CHARLIER, 2007).

Ao longo das últimas décadas, os avanços em técnicas analíticas têm contribuído não só para o progresso do conhecimento petrológico, bem como na determinação do foco da problemática em questão. Particularmente, desde o trabalho de Bowen (1928), estudos petrológicos focaram-se em caminhos P-T-cristalização de magmas de diferentes composições. A partir da década de 50, o campo da pesquisa petrológica voltou-se para a petrologia experimental, estimulando o surgimento da microssonda eletrônica, capaz de determinar a composição de diferentes materiais (incluindo minerais e vidro) em pequena escala. Desde os anos 1970, desenvolvimentos analíticos mudaram o foco dos estudos em direção ao estudo da composição de elementos traço e isótopos das rochas, mesmo sendo utilizados para determinar a composição da rocha total (bulk composition). O desenvolvimento de tecnologias, como o laser ablation ICP-MS, nos anos 80, permitiu que concentrações de elementos traço fossem determinadas na mesma escala espacial que a dos elementos maiores e menores. A vantagem de se determinar composições de maiores, menores, traços e isótopos in situ é a de que a distribuição desses elementos dentre e dentro dos próprios minerais pode ser utilizada para avaliar e modelar os efeitos de diferentes processos petrogenéticos (DAVIDSON; MORGAN; CHARLIER, 2007; BELOUSOVA; GRIFFIN; O’REILLY, 2005).

Conforme se examinam rochas plutônicas e vulcânicas em maior detalhe, torna-se cada vez mais claro que magmas passam por modificações em diferentes estágios conforme ascendem pela litosfera, via processos como cristalização fracionada, mistura de magmas e contaminação das encaixantes. Estudos petrológicos têm normalmente demonstrado que evidências texturais e composicionais sugerindo desequilíbrio composicional apontam para o fato de que tais processos sejam a regra e não a exceção, e que os cristais não parecem ter crescido originalmente na rocha que constituem. Composições isotópicas são utilizadas para inferir processos petrogenéticos em sistemas tanto fechados (de maneira idealizada) quanto abertos, uma vez que podem ser consideradas uma forma de identidade petrológica, a qual permite identificar componentes e possíveis fontes envolvidas. Normalmente, esta identificação isotópica é feita para rochas totais, assumindo-se que todas as fases estejam em equilíbrio isotópico. Entretanto, exemplos têm sido identificados onde cristais e rocha não compartilham as mesmas composições (razões isotópicas iniciais) (Figura 42). Em tais casos, a composição da rocha total representa um instantâneo em tempo, com mistura mecânica de diferentes fases, as quais experimentaram variadas condições de crescimento (DAVIDSON et al., 2001). 




Figura 42 - Comparações entre razões isotópicas de $\mathrm{Sr}$ em rocha total (barras cinzas) e suas respectivas fases minerais (barras pretas) em rochas vulcânicas. $\Delta{ }^{87} \mathrm{Sr} /{ }^{86} \mathrm{Sr}=$ razão ${ }^{87} \mathrm{Sr} /{ }^{86} \mathrm{Sr}$ medida menos a menor razão obtida sob consideração, multiplicada por $10^{4}$. Extraída de Davidson et al. (2001).

Análises químicas e isotópicas em escala mineral têm se mostrado como uma importante ferramenta no estudo de processos de maior escala, como em câmaras magmáticas, auxiliando na compreensão da evolução de sistemas magmáticos bem como na identificação e quantificação de processos dinâmicos em câmaras magmáticas (e.g., cristalização fracionada, assimilação, mistura de magmas). Davidson, Morgan e Charlier (2007) demonstraram a importância da amostragem e análises em escala mineral, uma vez que os efeitos desses processos podem ficar registrados na assinatura isotópica e/ou na variação de elementos traço durante a cristalização dos minerais (Figuras 43 e 44). 




Figura 43 - Ilustração esquemática dos princípios da microanálise (no caso, isotópica). Um cristal crescendo em um magma de composição isotópica Rc registra esta composição durante sua cristalização. Em um determinado tempo $\left(\mathrm{t}_{2}\right)$, a entrada de um magma contaminante de composição isotópica distinta $(\mathrm{Rr})$, causa desequilíbrio no sistema, o que é ilustrado pela dissolução parcial do cristal; o magma em processo de cristalização se hibridizará com o contaminante formando um novo líquido de composição isotópica ( $R$ h). A cristalização contínua do mineral registrará estes diferentes eventos. Extraída de Davidson, Morgan e Charlier (2007).



Figura 44 - Ilustração esquemática das formas pelas quais variações químicas e/ou isotópicas em cristais individuais podem refletir processos de evolução magmática. (A) Entrada de um novo pulso magmático mais primitivo na câmara magmática, causando dissolução parcial dos cristais, e novo crescimento em equilíbrio com

o contaminante; (B) Variações progressivas na composição magmática para membros mais primitivos são registradas na forma de zoneamento composicional dos cristais; (C) $\mathrm{O}$ magma muda de composição conforme um contaminante crustal é adicionado, desta forma os cristais desenvolvem zoneamento (de maneira inversa ao caso b); (D) Transferência de cristais ao longo de pequenas câmaras magmáticas interconectadas com diferentes composições isotópicas/químicas; (E) Similar ao caso D, entretanto, aqui a variação composicional se dá dentro

da própria câmara magmática; (F) Cristalização na borda da câmara magmática com diferentes níveis de contaminação pela rocha encaixante; este processo pode ocorrer concomitante com os anteriormente descritos. Extraída de Davidson, Morgan e Charlier (2007). 
Comparações de perfis núcleo-borda de diversos cristais de uma mesma rocha, em princípio, têm permitido reconstruir a evolução químico-isotópica do sistema magmático a partir dos quais os cristais são derivados (cf. Figura 43). 


\section{CAPÍTULO 2 - MATERIAIS E MÉTODOS}

Este trabalho foi realizado ao longo de várias etapas que contaram com diferentes metodologias: levantamentos de campo, descrições petrográficas, análises de química mineral, geoquímica de rocha total e isotópica, além de cálculos geocronológicos.

\subsection{LEVANTAMENTOS DE CAMPO}

A existência de um mapa geológico-faciológico de semi-detalhe prévio para os quatro plútons componentes do BGI (GALEMBECK, 1997) facilitou a investigação, neste estudo, dos processos petrológicos responsáveis pela diversidade e zonalidade de rochas observadas nos diferentes plútons. Entretanto, a inspeção mais detalhada do mapa apontou para a necessidade de revisar alguns critérios de agrupamento das unidades (ULBRICH; VLACH; JANASI, 2001), a partir de um conceito de zonalidade de câmaras magmáticas (PEREIRA, 2013). Além disso, medidas estruturais, especialmente de foliação e bandamento magmáticos, foram determinadas (quando possível, visto que os corpos são, em sua maioria, maciços) de forma sistemática, de modo a auxiliar na identificação da geometria tridimensional dos corpos ígneos. Os levantamentos de campo tiveram como objetivo revisar o mapa proposto por Galembeck (op. cit.), e dar ênfase na identificação da zonalidade da câmara magmática pretérita (identificação de margens e topo, bem como orientações paleoverticais), na determinação da geometria dos corpos, em especial a unidade rapakivi constituinte do Plúton Indaiatuba e, na distribuição dos enclaves e corpos máficos nas diferentes porções dos plútons.

Foram visitados 136 afloramentos durante este trabalho; incluem-se aqui levantamentos nas encaixantes e em determinados pontos dos granitos Salto e Itupeva, onde foram realizadas medidas de gamaespectrometria e susceptibilidade magnética. Como consequência, obteve-se um acervo de 197 amostras representativas dos litotipos descritos.

Ferramentas de mapeamento e descrição das diferentes variedades de granito foram utilizadas na obtenção de medidas de gama-espectrometria in situ e os valores absolutos de susceptibilidade magnética. Esses dados foram integrados com dados de levantamentos aerogeofísicos e de campo, realizados na região, e disponíveis na literatura (FERREIRA, 1991; PASCHOLATI, 1990). Quando possível, tais dados foram integrados com imagens tipo SRTM disponibilizados pela NASA e pelo Embrapa afim de se melhor observar/individualizar as unidades faciológicas em associação com aspectos geomorfológicos e fisiográficos. 
Durante estes trabalhos de campo, se fez uso de aparelho tipo GPS Garmin modelo eTrex Legend H para uma localização mais precisa de afloramentos e obtenção de coordenadas UTM para plotagem em mapas digitais, além da utilização dos softwares Google Maps e Avenza Maps, disponíveis para aparelhos do tipo celular e tablet, e úteis na localização de pequenas estradas de acesso locais.

Para uma melhor sistematização e tratamento espacial dos dados obtidos em campo, estes foram lançados em bancos de dados georreferenciados, utilizando os softwares ArcMap 10.5 e Global Mapper 18; para os trabalhos de edição gráfica de mapas digitais, fotos e figuras utilizou-se o software Corel Draw e Corel Photo-Paint, ambos na versão 2018. Para diagramas e gráficos foram utilizados os softwares Origin Pro 8, Grapher 12 e Surfer 13, ambos da Golden Software, além do programa Microsoft Excel 2016.

\section{Gamaespectrometria de campo}

O levantamento do tipo radiométrico utilizando raios gama foi uma ferramenta de grande utilidade na distinção de litotipos durante este trabalho (Figura 45). Este tipo de estudo deveria sempre começar com o levantamento do tipo aéreo, o qual permite determinar grandes anomalias radiométricas. Desta maneira, foram integrados a este trabalho os dados disponíveis em Ferreira (1991), úteis na escolha das campanhas de levantamentos de medidas radiométricas; também foram utilizados os dados de campo de Pascholati (1990). A espectrometria gama ou radiometria gama é um método analítico que permite a medição e quantificação de isótopos emissores de raios gama em uma determinada amostra; no caso, isótopos radioativos naturais de urânio, tório e potássio. 




Figura 45 - Variação nos teores de K, U e Th nas rochas ígneas com relação à variação no teor de sílica. Extraído de Ribeiro, Mantovani e Louro (2013).

A execução dos levantamentos superficiais in situ foi feita utilizando-se um gamaespectrômetro portátil Satisgeo modelo GS-512, dotado de espectrômetro com três sondas (GSP-2, GSP-3 e GSP-4) e cintilômetro NaI(Tl) e, de display gráfico LCD, para acompanhamento das medidas. Como padronização, procurou-se fazer medições em superfícies planas e frescas e em modo de estabilização (stab mode). Após 5 minutos de leitura, os dados de radiação cósmica, urânio equivalente (eU - ppm), tório equivalente (eTh - ppm) e potássio $(\mathrm{K}-\%)$.

\subsection{MICROSCOPIA ÓPTICA}

Após a descrição macroscópica sistemática das amostras coletadas, foi realizada uma seleção de variedades representativas para fins de estudos de microscopia. As análises petrográficas tiveram como objetivo a caracterização das principais feições das fácies descritas utilizando-se padrões como texturas, estruturas, índice de cor, granulação, granularidade e as proporções entre a mineralogia principal, além da descrição dos minerais máficos e fases acessório.

As descrições petrográficas foram realizadas com o auxílio de um microscópio Zeiss Axioplan de luz transmitida e refletida, com objetivas de aumento de 2,5, 10, 20 e 40 vezes, em 97 seções delgadas convencionais (espessura de $30 \mu \mathrm{m}$ e recobertas por bálsamo do Canadá e 
lamínula). Foram obtidas fotomicrografias das feições texturais, estruturais e mineralógicas de maior interesse utilizando o microscópio Olympus BX50 acoplado a uma câmera Infinity 1, e extraídas através do programa analySIS Starter. Imagens para mosaicos das seções delgadas foram obtidas utilizando-se o microscópio Zeiss AxioImager A2m acoplado a uma câmera AxioCam MR3, e extraídas através do software ZEN 2.3; todos os equipamentos pertencem ao Laboratório de Microscopia Petrográfica (LMP) do NAP Geoanalítica do Instituto de Geociências. Posteriormente, as imagens foram tratadas nos softwares Corel Draw 2018 e Image Composite Editor da Microsoft.

Com o objetivo de obter uma estimativa mais precisa das porcentagens dos minerais nas seções delgadas, foram obtidas análises modais de lâminas selecionadas, com o auxílio de um charriot acoplado ao microscópio petrográfico, além de um contador de pontos, ambos pertencentes ao LMP. Este método de contagem permite que seja obtida uma estimativa das proporções volumétricas entre os minerais da rocha analisada a partir de suas proporções relativas, medidas em uma determinada área. A classificação modal das amostras com estimativas foi baseada nas recomendações de Le Maitre (2002) e ilustradas em diagramas ternários elaboradas no software Grapher 12.

\subsection{QUÍMICA MINERAL}

As análises químicas pontuais de feldspatos, anfibólios, biotitas e piroxênios foram realizadas em 14 amostras consideradas representativas das unidades principais de cada plúton, a partir das quais foram confeccionadas lâminas polidas (com espessura de $45 \mu \mathrm{m}$ ). As análises quantitativas foram obtidas por WDS, e em casos onde os aspectos texturais das biotitas e anfibólios se assemelhavam, recorreu-se às análises por EDS. Tais atividades foram desenvolvidas no Laboratório de Microssonda Eletrônica do NAP Geonalitíca do Instituto de Geociências, em equipamento JEOL JXA-FE-8530F com canhão eletrônico suportado por Field Emission (FE), provido de cinco espectrômetros de dispersão de comprimento de onda (WDS), cada qual com dois cristais analisadores intercambiáveis e um espectrômetro por energia dispersiva (EDS). Encontram-se também disponíveis no equipamento, cristais analisadores de grande área para elementos leves, bem como detector para imageamento CL. As análises foram realizadas em padrão com potencial de aceleração de $15 \mathrm{kV}$, feixe eletrônico com corrente de $20 \mathrm{nA}$ e diâmetro de $5 \mu \mathrm{m}$, com exceção dos feldspatos, nos quais o padrão do diâmetro do feixe para as análises foi de $10 \mu \mathrm{m}$. Os dados obtidos corrigidos pela rotina CITZAF versão 3.5 (ARMSTRONG, 1995), licenciada pela JEOL e baseada em Armstrong 
(1991). As configurações dos espectrômetros e padrões utilizados durante as medições se encontram na Tabela 3.

Tabela 3 - Configurações dos espectrômetros e padrões utilizados durante as medições na microssonda eletrônica JEOL JXA-FE-8530F. Os padrões utilizados são procedentes tanto dos Smithsonian Microbeam Standars (JAROSEWICH, 2002) quanto do Geller MicroÅnalitycal Laboratory. *Fe medido como $\mathrm{Fe}_{2} \mathrm{O}_{3}$.

\begin{tabular}{|c|c|c|c|c|c|c|c|}
\hline \multirow[t]{2}{*}{ Elemento } & \multirow[t]{2}{*}{ Linha } & \multirow[t]{2}{*}{ Cristal } & \multicolumn{4}{|c|}{ Padrão } & \multirow[t]{2}{*}{ Procedência } \\
\hline & & & Feldspato & Biotita & Anfibólio & Piroxênio & \\
\hline $\mathrm{Si}$ & $\mathrm{K} \alpha$ & TAP & anorthoclase & diopside & diopside & diopside & SMS \\
\hline $\mathrm{Al}$ & $\mathrm{K} \alpha$ & TAP & anorthite & anorthoclase & anorthite & anorthite & SMS \\
\hline $\mathrm{Fe}$ & $\mathrm{K} \alpha$ & LIFL & fayalite* & fayalite & fayalite & fayalite & SMS \\
\hline $\mathrm{Mn}$ & $\mathrm{K} \alpha$ & LIFL & fayalite & fayalite & fayalite & fayalite & SMS \\
\hline $\mathrm{Zn}$ & $\mathrm{K} \alpha$ & LIFL & & willemite & willemite & & GML \\
\hline $\mathrm{Cl}$ & $\mathrm{K} \alpha$ & PETJ & & sodalite & sodalite & & GML \\
\hline $\mathrm{K}$ & $\mathrm{K} \alpha$ & PETJ & ortoclase & ortoclase & ortoclase & ortoclase & GML \\
\hline $\mathrm{Ca}$ & $\mathrm{K} \alpha$ & PETJ & wollastonite & wollastonite & wollastonite & wollastonite & GML \\
\hline $\mathrm{Zr}$ & $\mathrm{L} \alpha$ & PETJ & & zircon & zircon & & GML \\
\hline $\mathrm{Sr}$ & $\mathrm{L} \alpha$ & PETJ & strontianite & & & & SMS \\
\hline $\mathrm{Ti}$ & $\mathrm{K} \alpha$ & LIFL & rutile & rutile & rutile & rutile & GML \\
\hline $\mathrm{Cr}$ & $\mathrm{K} \alpha$ & LIFL & & & chromite & chromite & SMS \\
\hline $\mathrm{Ba}$ & $\mathrm{L} \alpha$ & LIFL & benitoite & benitoite & & & SMS \\
\hline $\mathrm{F}$ & $\mathrm{K} \alpha$ & TAPH & & fluorapatite & fluorapatite & & GML \\
\hline $\mathrm{Na}$ & $\mathrm{K} \alpha$ & TAPH & albite & albite & albite & albite & GML \\
\hline $\mathrm{Mg}$ & $\mathrm{K} \alpha$ & TAPH & diopside & diopside & olivine & diopside & SMS \\
\hline
\end{tabular}

Fonte: Laboratório de Microssonda Eletrônica do NAP Geonalitíca do IGc - USP.

As fórmulas estruturais para feldspatos e piroxênios foram calculadas segundo Deer, Howie e Zussman (1992). Para as biotitas, foi utilizada uma planilha de cálculo de fórmula estrutural segundo Tindle e Webb (1990) e com estimativas de temperaturas de Luhr, Carmichael e Varekamp (1984). Para os anfibólios, utilizou-se a planilha de Locock (2014). Para o cálculo dos parâmetros intensivos, foram utilizadas planilhas de cálculo de iterações baseadas nos modelos termométricos de Anderson (1996) e barométricos de Mutch et al. (2016).

Os dados foram tratados em planilhas do programa Microsoft Excel 2016 segundo normas da IMA (International Mineralogical Association). Além disso, diversos diagramas classificatórios e de variações composicionais foram elaborados com o auxílio dos programas Grapher 12 e Origin Pro 8 e, posteriormente, editados no Corel Draw 2018. 


\subsection{GEOQUÍMICA DE ROCHA TOTAL}

Análises geoquímicas de rocha total utilizam como métodos a fluorescência de raios $\mathrm{X}$ (FRX) e a espectrometria de massa com fonte de plasma induzido (ICP-MS).

O material de interesse coletado em levantamentos de campo é tratado no Laboratório de Tratamento de Amostras (LTA), do Instituto de Geociências, antes de ser encaminhado para análise química. Este tratamento abrange as seguintes etapas:

- Escolha de amostras representativas (10 vezes maior que o maior grão da amostra);

- Retirada de porções alteradas da amostra (quando presentes) por meio da prensa hidráulica;

- Britagem das amostras em britador de mandíbulas de aço;

- Prensagem em prensa hidráulica;

- Quarteamento e homogeneização manual do material prensado;

- Moagem da amostra quarteada em moinho de ágata do tipo planetário até granulometria menor que 200 mesh;

- Micronização do pó por cerca de 15 minutos em solução com etanol (somente na preparação de pastilhas de pó prensado);

- Secagem da solução em estufa por cerca de 48 horas;

Para a obtenção de pastilhas de pó prensado, são separados cerca de $7 \mathrm{~g}$ do pó obtido pela micronização, o qual foi misturado de maneira manual com cera ligante $\left(\mathrm{C}_{6} \mathrm{H}_{8} \mathrm{O}_{3} \mathrm{~N}_{2}\right)$ na proporção de $20 \%$ da massa de pó total $(\sim 1,4 \mathrm{~g})$. A mistura resultante é levada a uma prensa de carbeto de tungstênio, que produz pastilhas do material com $40 \mathrm{~mm}$ de diâmetro a uma pressão de $30 \mathrm{kPa}$.

A preparação de pastilhas de material fundido é realizada primeiramente com a mistura de $1 \mathrm{~g}$ do pó da amostra moída com nove partes de fundente (metaborato de lítio - $\mathrm{LiBO}_{2}-\mathrm{com}$ tetraborato de lítio - $\mathrm{Li}_{2} \mathrm{~B}_{4} \mathrm{O}_{7}$ ); posteriormente esta mistura é encaminhada para fusão em um forno específico a fim de se obter as pastilhas fundidas.

Vale aqui ressaltar que a escolha de uma amostra não adequada para análise química pode ser uma grande fonte de erro. A diminuição granulométrica das amostras pretendida $(<200$ mesh) tem a necessidade de ser feita de maneira correta, visto que esta compromete na qualidade do material preparado (e.g., trincagem de pastilha fundida por função de grãos maiores). 
As pastilhas fundidas são analisadas no Laboratório de Fluorescência de Raios X do NAP Geoanalítica do Instituto de Geociências, utilizando um espectrômetro de massa automático Philips, modelo PW2400, capaz de medir quantitativamente elementos de número atômico maior que 8, e com limites de detecção da ordem de 1-10 ppm para elementos traço; detalhes adicionais da metodologia utilizada neste laboratório são descritos por Mori et al. (1999). Os elementos terras raras e outros elementos traço presentes em teores mais baixos (elementos terras raras, Th, U, Ta, Hf, etc.) são analisados no Laboratório de Química e ICP do Núcleo NAP Geoanalítica do Instituto de Geociências, pelo método de ICP-MS através do equipamento ELAN 6100DRC da Perkin Elmer/Sciex (NAVARRO, 2004). Na metodologia adotada no laboratório, as amostras são solubilizadas por ataque ácido $\left(\mathrm{HF}+\mathrm{HNO}_{3}\right)$ em bomba de teflon (bomba Parr) com pressão e temperatura controladas.

Os limites de detecção dos diferentes elementos analisados encontram-se na Tabela 4.

Tabela 4 - Limites de detecção para as análises de geoquímica elemental dos Laboratório de Fluorescência de Raios X e Laboratório de Química e ICP-AES/MS do NAP Geoanalítica do IGc-USP; óxidos analisados via FRX, traços via ICP-MS. (*) elementos analisados via FRX.

\begin{tabular}{|c|c|c|c|}
\hline & $\%$ - ppm & & ppm \\
\hline $\mathrm{SiO}_{2}$ & 0.030 & $\mathrm{Ni}$ & $5^{*}$ \\
\hline $\mathrm{TiO}_{2}$ & 0.003 & Sn & - \\
\hline$\overline{\mathrm{Al}_{2} \mathrm{O}_{3}}$ & 0.020 & Co & $6^{*}$ \\
\hline $\mathrm{Fe}_{2} \mathrm{O}_{3}$ & 0.010 & $\mathbf{V}$ & 9* \\
\hline MnO & 0.002 & $\mathbf{W}$ & - \\
\hline MgO & 0.010 & Ga & $9 *$ \\
\hline $\mathrm{CaO}$ & 0.010 & $\mathbf{Z n}$ & $2 *$ \\
\hline $\mathrm{Na}_{2} \mathrm{O}$ & 0.020 & $\mathbf{C u}$ & $5^{*}$ \\
\hline $\mathbf{K}_{2} \mathbf{O}$ & 0.010 & Ag & - \\
\hline $\mathrm{P}_{2} \mathrm{O}_{5}$ & 0.003 & As & - \\
\hline $\mathrm{SO}_{3}$ & 0.010 & Se & - \\
\hline \multirow[t]{2}{*}{ LOI } & 0.010 & Mo & - \\
\hline & - & $\mathbf{B i}$ & - \\
\hline $\mathbf{L i}$ & - & $\mathbf{C d}$ & - \\
\hline Cs & 0.01 & $\mathbf{S b}$ & \\
\hline $\mathbf{R b}$ & 0.01 & La & \\
\hline $\mathbf{B a}$ & 0.50 & $\mathrm{Ce}$ & 0.01 \\
\hline $\mathbf{B e}$ & - & Pr & 0.01 \\
\hline $\mathrm{Sr}$ & 0.01 & Nd & 0.01 \\
\hline $\mathbf{P b}$ & 0.02 & Sm & 0.08 \\
\hline
\end{tabular}




\begin{tabular}{|c|c|c|c|}
\hline Th & 0.01 & Eu & 0.01 \\
\hline $\mathbf{U}$ & 0.01 & $\mathbf{G d}$ & 0.01 \\
\hline $\mathbf{Z r}$ & 0.03 & $\mathbf{T b}$ & 0.01 \\
\hline $\mathbf{H f}$ & 0.01 & $\mathbf{D y}$ & 0.01 \\
\hline $\mathbf{T a}$ & - & $\mathbf{H o}$ & 0.01 \\
\hline $\mathbf{Y}$ & 0.01 & $\mathbf{E r}$ & 0.01 \\
\hline $\mathbf{N b}$ & 0.01 & $\mathbf{T m}$ & 0.01 \\
\hline $\mathbf{S c}$ & $14^{*}$ & $\mathbf{Y b}$ & 0.01 \\
\hline $\mathbf{C r}$ & $13^{*}$ & $\mathbf{L u}$ & 0.01 \\
\hline
\end{tabular}

Fonte: Laboratório de Fluorescência de Raios X e Laboratório de Química e ICP do NAP Geoanalítica do IGcUSP.

\subsection{ISOTOPIA RB-SR E SM-ND EM ROCHA TOTAL}

Dados de isotopia em rocha total (métodos $\mathrm{Rb}-\mathrm{Sr}$ e $\mathrm{Sm}-\mathrm{Nd}$ ) foram obtidos no Centro de Pesquisas Geocronológicas (CPGeo) do Instituto de Geociências para um conjunto de onze amostras previamente analisadas para elementos traço. Estes dados auxiliaram na determinação de possíveis vinculações entre diferentes pulsos magmáticos formadores dos plútons e na identificação das áreas-fonte dos magmas.

A metodologia laboratorial básica de tratamento de amostra para análise de ambos os sistemas radiométricos consiste na pesagem da amostra, e sua dissolução total (abertura da amostra) por via ácida, com separação dos elementos de interesse em colunas de troca iônica, para posterior determinação das razões isotópicas em espectrômetros de massa específicos. A diluição das amostras foi realizada por digestão ácida, utilizando-se dos ácidos $\mathrm{HNO}_{3}+\mathrm{HF}$ e $\mathrm{HCl}$ em diferentes etapas em recipiente específico de teflon, tipo Savillex, em chapa à $100^{\circ} \mathrm{C}$ em uma "clean box".

As análises de $\mathrm{Sr}$ foram feitas por espectrometria de massa por ionização térmica (TIMS) em espectrômetro Thermo Triton da Thermo Scientific e os isótopos de Nd foram detectados em espectrômetro de massa com plasma indutivo acoplado modelo Neptune, também da Thermo Scientific; maiores detalhes são fornecidos em Sato et al. (1995).

\subsection{QUÍMICA DE ZIRCÃO - LA-Q-ICP-MS}

O estudo de processos petrológicos em sistema aberto (e.g., contaminação, mistura de magmas) ganhou importante impulso com a possibilidade de análises pontuais em minerais 
zonados, o que tem revelado, em muitos casos, complexas histórias registradas em fases minerais principais (e.g., plagioclásio, feldspato alcalino, quartzo) ou acessórias (e.g., zircão).

Análises pontuais em zircão têm mostrado importantes zonalidades na distribuição de elementos traço, e também nas razões isotópicas de Hf, que são bastante sensíveis à contribuição de diferentes fontes para o magmatismo granítico (BELOUSOVA; GRIFFIN; O’REILLY, 2006; SHAW; FLOOD, 2009).

As análises pontuais de elementos traço e terras raras por LA-Q-ICPMS foram realizadas no Laboratório de Química e ICP-AES/MS do NAP Geoanalítica do Instituto de Geociências.

As microanálises foram obtidas em amostrador tipo laser ablation modelo New Wave 213 A/F (para o Nd, YAG deep UV - $213 \mathrm{~nm}$ ) acoplado a um espectrômetro de massa quadrupolo Thermo Scientific iCAP, controlado pelo software Qtegra. A amostragem foi realizada em modo raster a $60 \mu \mathrm{m}$, com spot de $30 \mu \mathrm{m}$ e passo de $1 \mu \mathrm{m} / \mathrm{s}$.

Os resultados obtidos foram tratados posteriormente pelo software Glitter ${ }^{\circledR}$. Foram utilizados o $\mathrm{ZrO}_{2}$ obtido por WDS como padrão interno e o vidro de composição silicática NIST SRM-610 na correção do drift instrumental (HINTON, 1999); para a conferência da qualidade das análises foi utilizado o padrão de referência internacional Zr91500 (WIEDENBECK et al., 1995).

\subsection{DATAÇÃO U-PB (MÉTODO SHRIMP)}

Determinações das idades U-Pb em cristais de zircão dos diferentes plútons do Batólito Itu foram obtidas pelo método SHRIMP (Sensitive High Resolution Ion Microprobe - SHRIMP IIe/MC) para sete amostras. O Laboratório SHRIMP do CPGeo, localizado no Instituto de Geociências da USP, inaugurado em 2010, é o único existente na América Latina, e sua implantação tem permitido uma evolução notável nas pesquisas geocronológicas no Brasil. As condições de análise são descritas em Sato et al. (2014).

Para que a datação pelo método U-Pb forneça resultados adequados, devem ser utilizados sistemas (minerais), que não contenham $\mathrm{Pb}$ inicial em sua composição, ou seja, todo o $\mathrm{Pb}$ presente deve ser derivado do decaimento do U. O zircão, seguido da monazita e, posteriormente, pela titanita são os sistemas mais utilizados na datação pelo método U-Pb. Todo urânio de ocorrência natural contém os isótopos ${ }^{238} \mathrm{U}$ e ${ }^{235} \mathrm{U}$ que decaem, respectivamente, para ${ }^{206} \mathrm{~Pb}$ e ${ }^{207} \mathrm{~Pb}$. As duas razões isotópicas são utilizadas para compor o diagrama concórdia, onde as idades calculadas pelos sistemas isotópicos são coincidentes ou concordantes. Quando os minerais analisados não plotam na curva concórdia, o sistema U-Pb se mostra perturbado, por 
exemplo, devido à perda de ${ }^{206} \mathrm{~Pb}$ e/ou ${ }^{207} \mathrm{~Pb}$. Mesmo nesse caso, é possível que diversas frações de minerais se alinhem ao longo de uma reta denominada discórdia, indicando um episódio comum, responsável pela perda de $\mathrm{Pb}$; deste modo, a discórdia une a idade de perda de $\mathrm{Pb}$ (intercepto inferior com a concórdia) e a idade da rocha (Figura 46).



Figura 46 - Diagrama tipo Tera-Wasseburg exemplificando curvas concórdia e discórdia. Extraído de Sato et al. (2008).

A datação pelo método SHRIMP consiste de análises pontuais dos cristais de zircão por microssonda iônica através de um feixe de elétrons de $\mathrm{O}$ de alta energia com diâmetro variando entre 20 e $40 \mu \mathrm{m}$, e profundidade de abrasão na amostra entre 2 e $3 \mu \mathrm{m}$. A alta resolução espacial (em escala de $\mu \mathrm{m}$ ) possibilita uma boa seleção de domínios nos cristais para análise, permitindo a escolha de porções preservadas de processos de perda de $\mathrm{Pb}$, e a identificação de domínios com idades distintas (e.g., separando núcleos herdados, porções com sobrecrescimentos e/ou afetadas por processos hidrotermais de dissolução e reprecipitação), escolhidos a partir de estudos prévios da morfologia e zonalidade interna dos cristais em imagens de catodoluminescência. Desse modo, tipicamente se obtêm resultados concordantes, que oferecem segurança para o significado da idade obtida (IRELAND; WILLIAMS, 2003; WILLIAMS, 1998). 
Foram preparados concentrados de zircão no Laboratório de Separação do CPGeo seguindo o procedimento de Loios (2009):

- Fragmentação das amostras em britador de mandíbulas de aço até a granulometria $1 \mathrm{~cm}$;

- Moagem em moinho de disco com redução gradual até a fração próxima à areia fina;

- Passagem do material em peneira vibratória com abertura maior que 0,250 mm;

- Passagem do material em peneira vibratória com abertura entre 0,250 e 0,100 mm;

- Peneiração do material em peneira vibratória com abertura menor que $0,100 \mathrm{~mm}$;

Frações menores que 0,250 $\mathrm{mm}$ foram separadas por densidade em meio aquoso em mesa vibratória de Wiffley resultando em dois separados:

- Caneca 1: pesados, concentrados na caneca;

- Caneca 2: leves e carreados pela água, que se depositam na caneca;

O material da caneca 1 é secado sob o calor de lâmpadas térmicas e passado por ímã de mão para a extração de minerais fortemente magnéticos como magnetita e ilmenita. Posteriormente, procede-se com:

- Separação em separador eletromagnético tipo FRANTZ, com inclinação de $10^{\circ}$ e campo elétrico a $0.5 \mathrm{~A}$, separando material magnético de não magnético;

- Separação por líquidos densos (primeiro, bromofórmio $\left(\rho=2.89 \mathrm{~g} / \mathrm{cm}^{3}\right)$ e depois, iodeto de metileno $\left.\left(\rho=3.325 \mathrm{~g} / \mathrm{cm}^{3}\right)\right)$ da fração não magnética;

- Separação da fração densa (que afundou nos líquidos do processo anterior) no FRANTZ com intensidades $0.75 \mathrm{~A}$ e $1.0 \mathrm{~A}$.

A partir da porção não magnética, separada a 1.0 A no FRANTZ, o mineral zircão foi separado pelo processo de catação com o auxílio de lupa e pinça; é dada preferência aos cristais límpidos, sem fraturas e inclusões. O arranjo de cristais (mount) é preparado em resina de epóxi onde os cristais são lixados e polidos até estarem com espessura específica. Em seguida, são recobertos com película de ouro $(6.4 \mathrm{~nm})$, estando assim adequados para análise isotópica em microssonda iônica. Previamente, foram realizados com imagens de catoluminescência (CL) para a determinação adequada da localização dos spots de análise devido a presença de zoneamentos, núcleos herdados e cristais que sofreram perda de $\mathrm{Pb}$ comum. Essas imagens foram obtidas no espectrômetro FEI Quanta 250 SEM e XMAX detector de CL da Oxford Instruments, com voltagem de $15 \mathrm{kV}$, distância de 16.9 - $17 \mathrm{~mm}$, corrente no filamento do 
detector PMD (filamento de emissão = $100 \mu \mathrm{A}$ ) e intervalo de magnificação de 100 a 250 vezes. Assim, como a microssonda iônica, o espectrômetro encontra-se no Laboratório de Geocronologia de Alta Resolução (GEOLAB) do CPGeo do Instituto de Geociências da USP. 


\section{CAPÍTULO 3 - SITUACÃO GEOLÓGICA}

A Província Granítica Itu (IGP) caracteriza-se como um cinturão, grosso modo linear, de plútons granitóides pós-orogênicos, que abrangem uma área de cerca $\sim 60 \mathrm{~km}$ de largura por $350 \mathrm{~km}$ de comprimento, formada durante o Neoproterozóico ao longo da borda sul da Nappe de Empurrões Socorro-Guaxupé, e relacionada à porção central da província Mantiqueira (cinturão Ribeira) (ALVES et al., 2013; JANASI et al., 2009).

\section{Província Mantiqueira}

A Província Mantiqueira representa uma província estrutural altamente complexa do Neoproterozóico/Eopaleozóico (900-480 Ma -SILVA et al., 2005) situada nas porções sul e sudeste do atual território brasileiro, englobando orógenos como as faixas Brasília Sul, Araçuaí, Ribeira, Dom Feliciano, entre outros (HEILBRON et al., 2004). Ela reflete uma interação múltipla entre placas e terrenos (microplacas), tardiamente agregadas à borda leste das placas Paranapanema e São Franciscana (borda leste do Gondwana W), já aglutinadas em um protocontinente (Figura 47).



Figura 47 - Configuração geotectônica de crátons e sistemas orogênicos do Gondwana W ao final do Neoproterozóico. Extraído de Heilbron, Cordani e Alkmim (2017). 
A evolução altamente complexa da Província Mantiqueira compreende três sistemas sucessivos de orógenos: Brasiliano I (clímaces colisionais em 790 Ma - Domínio Embu e 730$700 \mathrm{Ma}$ - Orógeno São Gabriel), II (clímaces colisionais em 640-620 Ma - Orógeno Dom Feliciano e $600 \mathrm{Ma}$ - orógenos Paranapiacaba e Rio Piên) e III (clímaces agrupados entre 590560Ma - Orógeno Araçuaí e 520-500 Ma - Orógeno Búzios) (SILVA et al., 2005); também preserva remanescentes de unidades paleotectônicas arqueanas, paleoproterozóicas e mesoproterozóicas.

\section{Cinturões Ribeira e Brasília Sul}

O Cinturão Ribeira representa a porção central da Província Mantiqueira e é constituído por inúmeros domínios/terrenos amalgamados durante a convergência dos crátons São Francisco e Congo Sudoeste (cf. Figura 47). As relações de alguns terrenos com seus orógenos de procedência são dúbias: os terrenos Apiaí, São Roque e Embu integram a parte central da Província Mantiqueira (Figura 48) e suas relações com os terrenos da extremidade sul do Orógeno Brasília são objeto de muita especulação (HEILBRON et al., 2004). O Cinturão Ribeira é formado por dois terrenos, os terrenos Ocidental e Oriental, subdivididos em diferentes domínios identificados por seus contrastes litológicos, geoquímicos e geocronológicos. Ambos consistem, em sua maioria, de rochas gnáissicas de fácies granulítica, e charnockitos que diferem distintamente das rochas da fácies anfibolito do Orógeno Araçuaí adjacente. As diferentes unidades foram justapostas há 595 Ma na porção NW, e em 500 Ma em sua porção SE, durante os vários períodos sucessivos da orogenia neoproterozóica (KÜHN; STÜWE; TROUW, 2004). 




Figura 48 - Mapa geológico simplificado da porção centro-leste do Brasil; destaque para a região central do Cinturão Ribeira com a configuração regional dos terrenos Embu, Apiaí e São Roque (SR). Modificado de Henrique-Pinto et al. (2015).

Neste mesmo contexto, o Cinturão Brasília orienta-se aproximadamente de NW para SE, e representa o resultado final da convergência e colisão dos crátons Paranapanema e São Francisco durante o final do Neoproterozóico. Existe uma zona de interferência que ocorre no contato entre as porções sul do Cinturão Brasília e central do Ribeira (Figura 49), e esta permanece registrada na forma de duas unidades geotectônicas principais: a nappe SocorroGuaxupé, integrante da Faixa Brasília Sul, e o Terreno Embu, parte do Cinturão Ribeira Central (VINAGRE et al. 2016). O contato entre estas unidades é interpretado como uma zona de cisalhamento principal - zona de cisalhamento Buquira-Jundiuvira - separando os dois 
cinturões de dobramentos (CAMPOS NETO; CABY, 1999, 2000). Uma interpretação alternativa considera este contato como gradacional e a existência de uma zona de cisalhamento de menor importância (TROUW et al., 2013).



Figura 49 - Mapa tectônico do Cinturão Ribeira Central e a zona de interferência (interference zone) com a porção sul da Faixa Ribeira. Extraída de Heilbron et al. (2008).

Nappe de Empurrões Socorro-Guaxupé

A Nappe de Empurrões Socorro-Guaxupé (NESG) é uma espessa lasca pilha alóctone (ca. $15 \mathrm{~km}$ ) neoproterozóica, composta de lóbulos: o lóbulo Guaxupé ao norte, e o lóbulo Socorro ao sul, separados por uma estrutural do tipo antiforme do Sistema de Nappes Andrelândia (ANS) subjacente (VINAGRE et al., 2016 - cf. Figura 50). Constuituem-se de três unidades que correspondem a níveis distintos da crosta continental: a Unidade Granulítica Inferior, a Unidade Diatexítica Intermediária e a Unidade Migmatítica Superior (Complexo Migmatítico Varginha-Guaxupé), onde encontra-se intrudida a IGP (Figura 51). Predominam paragnaisses bandados com leucossomas graníticos; ortognaisses configuram corpos mapeáveis (HEILBRON et al., 2004). 




Figura 50 - Mapa geotectônico com a localização da Nappe Socorro-Guaxupé (7) e o Terreno Embu (8). Extraído de Vinagre et al. (2016). 




Figura 51 - Esquema geológico do embasamento cristalino do sudeste do Brasil com ênfase no Domínio Apiaí-Guaxupé e seus plútons graníticos. Extraído de Janasi et al. (2009). 
Os segmentos central e norte da Província Mantiqueira exibem um cinturão de tendência $\mathrm{N}-\mathrm{NE}$ de $900 \mathrm{~km}$ de rochas granitóides sin-orogênicos dominado por granitos cálcio-alcalinos de alto K com plútons charnockíticos peraluminosos tipo S. Esse magmatismo é contemporâneo com um metamorfismo de baixa $\mathrm{P}$ e alta $\mathrm{T}$, ocorrido há 580-560 Ma e representa uma margem continental ativa relacionada à subducção para leste do Placa São Francisco (Orógeno Araçuaí) (JANASI et al., 2009).

Eventos magmáticos mais antigos são observados em outros terrenos (Complexo de Arco Rio Negro - cinturão parcialmente juvenil de ortognaisses tonalíticos datados de $630 \mathrm{Ma}$ ). Segundo Alves et al. (2015), os eventos magmáticos do Terreno Embu podem ser divididos em 3 grupos principais: ortognaisses tonianos (810-770 Ma), granitos criogenianos a ediacaranos (680-630 Ma) e granitos ediacaranos (595-580 Ma). A acreção dextral do Terreno Embu ao Terreno Apiaí Guaxupé ocorreu em 590 Ma, concomitante com o desenvolvimento da IGP no Terreno Apiaí Guaxupé (JANASI et al., 2009).

\section{O Batólito Itu}

O Batólito Granítico Itu é integrante da Província Granítica Itu (IGP), de caráter pósorogênico (VLACH; JANASI; VASCONCELLOS, 1990; WERNICK et al., 1997; JANASI et al., 2009), que se instalou no extremo sul da borda retrabalhada do Cráton Paranapanema (CAMPOS NETO, 2000), junto ao contato com a Faixa de Dobramentos Ribeira (JANASI et al., 2009) ao final do Neoproterozóico ( 580-560 Ma). Situa-se na porção meridional da Nappe Socorro-Guaxupé (CAMPOS NETO; CABY, 1999), que localmente expõe ortognaisses migmatíticos atribuídos ao Complexo Migmatítico Varginha-Guaxupé. É parcialmente recoberto, a oeste, por sedimentos permo-carboníferos do Subgrupo Itararé, inserido na estratigrafia da Bacia do Paraná. Uma série de falhas transcorrentes que ocorrem na região (da Cachoeira, da Fonte, de Cururu, de Piraí e de Itaguá) estão associadas ao splitting off da Zona de Cisalhamento Itu, esta por sua vez vinculada à Zona de Cisalhamento de Taxaquara (Figura $52)$. 




Figura 52 - Mapa geológico simplificado do Batólito Granítico Itu. Modificado de Galembeck (1997).

Galembeck (1997), a partir de um mapeamento faciológico envolvendo estudos petrográficos, geoquímica de rocha total e tipologia de zircão, compartimentou o Batólito Granítico Itu em quatro intrusões distintas: os granitos Itupeva, Cabreúva, Indaiatuba e Salto (Figura 52). Todas as quatro intrusões são dominadas por granitos do tipo A da série aluminosa, mas existem diferenças sistemáticas entre elas.

A distribuição das diferentes fácies petrográficas que constituem o Plúton Cabreúva, conforme mapeado por Galembeck (1997), é mostrada na Figura 53. O plúton é descrito como 
três intrusões segmentadas, separadas entre si pelos granitoides do Plúton Indaiatuba (Figura 54).



Figura 53 - Mapa faciológico do Plúton Cabreúva. Modificado de Galembeck (1997). 
O corpo principal, a sul, tem forma subcircular em planta, amplamente dominada por sienogranitos grossos inequigranulares hololeucocráticos (unidade CB-6 de Galembeck) com bordas também hololeucocráticas, mas de granulação média (fácies CB-7 e CB-8), refletindo, aparentemente, um resfriamento mais rápido. A porção central do plúton é formada por uma associação de granitos com índice de cor e granulação variados, em parte com textura rapakivi, associados a corpos dioríticos, e parece registrar um segundo pulso invasor da câmara, aparentemente de caráter híbrido, refletindo desta maneira interação in situ entre magmas máfico e félsico.

A norte, o corpo principal de Cabreúva é truncado pelo Plúton Indaiatuba (unidade ID), que possuiria, em planta, uma geometria elipsoidal alongada N70E (Figura 52). O Plúton Indaiatuba foi definido por Galembeck (1997) como sendo constituído por um único tipo litológico, dado por sienogranitos porfiróides com textura rapakivi e de granulação grossa (fácies ID-1). Em seu interior, ocorre um pequeno corpo de monzogranitos porfiríticos atribuído à fácies CB-9 do Plúton Cabreúva (Figura 54). 




Figura 54 - Mapa faciológico do Plúton Indaiatuba. Modificado de Galembeck (1997).

As bordas do Plúton Indaiatuba foram mapeadas como fácies do Plúton Cabreúva (cf. Figura 54; fácies CB-7 e CB-6 e faixas de granitos ricos em xenólitos (fácies tipo associação xenolítica do Plúton Cabreúva)) e enclaves microgranulares máficos marcam a borda do Plúton Indaiatuba em sua metade ocidental.

Cabe aqui comentar sobre a geologia do Plúton Itupeva (Figura 55) que, por vezes, parece ter uma associação de fácies com a borda do Plúton Indaiatuba. Apresenta uma ampla variedade composicional e textural, com um zoneamento composicional do tipo inverso definido por biotita leucogranitos de borda, e biotita monzogranitos porfiríticos no centro associados com rochas híbridas, máficas a intermediárias, na forma de pequenos corpos intrusivos e enclaves microgranulares (fácies IP-1). 




Figura 55 - Mapa faciológico do Plúton Itupeva. Modificado de Galembeck (1997). 


\section{CAPÍTULO 4-GEOLOGIA DO BATÓLITTO ITU}

Visitas de campo à região de Itupeva, Cabreúva, Itu e seus arredores (cf. Figura 1), permitiram uma melhor observação das relações entre os plútons Cabreúva e Indaiatuba e suas diferentes fácies constituintes, além de diferentes feições petrográficas. Com base no mapeamento faciológico do Batólito Itu de Galembeck (1997 - cf. Figuras 53, 54 e 55), foram visitados afloramentos (Figura 56) das diversas fácies graníticas constituintes do Plúton Cabreúva, da fácies granito rapakivi do Plúton Indaiatuba, além de algumas fácies graníticas pertencentes ao Plúton Itupeva, por estas parecerem vinculadas ao Plúton Indaiatuba, bem como alguns afloramentos pertencentes às encaixantes granítico-gnáissicas do batólito.



Figura 56 - Localização dos afloramentos visitados com relação à toponímia e o Batólito Itu. Mapa topográfico base: SF-23-Y-C em escala 1:250000 (IBGE, 1983); mapa geológico esquematizado com base no mapa de Galembeck (1997). 
Apresentam-se a seguir de modo sintético as principais características de campo das variedades faciológicas mais importantes dos plútons Indaiatuba, Cabreúva e Itupeva, destacando aspectos estruturais, como a presença de enclaves, aspecto menos enfatizado no trabalho de Galembeck (1997).

\subsection{LEVANTAMENTOS DE CAMPO}

\subsubsection{Plúton Indaiatuba}

O litotipo que define a unidade principal do Granito Indaiatuba é uma rocha com matriz de granulação média a grossa variando em textura de inequigranular porfirítica (Figura 57), composta predominantemente por quartzo, feldspato alcalino e plagioclásio, além de biotita, anfibólio (mais raramente) e minerais opacos, com IC $\sim 5$. Os cristais de feldspato alcalino são frequentemente tabulares (tamanho do maior eixo $\sim 2 \mathrm{~cm}-$ por vezes, fenocristais), enquanto os de quartzo variam em forma de irregulares a levemente arredondados (tamanho $\sim 1,5 \mathrm{~cm}$ ). A textura rapakivi é predominante (Figuras 58a e 58b), e ocasionalmente ocorrem cristais de quartzo manteados por biotita (Figura 59). É comum a presença de enclaves microgranulares tanto félsicos e máficos de formas e tamanhos variados (Figuras 60a, 60b, e 61).



Figura 57 - Textura predominante da rocha que define a unidade principal do Plúton Indaiatuba. Afloramento CAB-17-38. 




Figura 58 - Textura rapakivi em detalhe na fácies granito rapakivi grosso do Plúton Indaiatuba. Afloramento CAB-17-38.



Figura 59 - Cristal de quartzo manteado em meio ao granito rapakivi do Plúton Indaiatuba. Afloramento CAB14-06.



Figura 60 - Enclaves microgranulares félsico (a) e máfico no granito rapakivi (b). Afloramento CAB-14-06. 




Figura 61 - Enclaves microgranulares máficos no granito rapakivi. Afloramento CAB-15-34.

Conforme se segue para a porção norte-nordeste do Plúton Indaiatuba, o granito rapakivi é invadido por um granito hololeucocrático equigranular fino a médio (Figura 62), o qual se acredita pertencer a uma fácies granítica do Plúton Itupeva. A presença de xenólitos do granito rapakivi no granito fino, por vezes com bordas regulares, indica invasão em estado sólido (Figura 63). É observada a ocorrência de enclaves microgranulares máficos de granulometria muito fina (Figura 64).



Figura 62 - Granito equigranular fino atribuído ao Plúton Itupeva invasor no Granito Indaiatuba. Afloramento CAB-14-04. 




Figura 63 - Xenólito angular do granito rapakivi (Plúton Indaiatuba) no granito inequigranular fino (Plúton Itupeva). Afloramento CAB-15-33.

Em alguns afloramentos é registrada a presença de corpos híbridos no contato entre o granito e corpos mais máficos, classificados como quartzo-monzonitos (Figura 64). A rocha híbrida tem granulação heterogênea (Figura 65), parte mais grossa como granito, parte mais fina como granodiorito, e apresenta feições de reação como a textura rapakivi (rara no Plúton Itupeva) e quartzo manteado por minerais máficos (Figura 66) como resultado da interação. Corpos arredondados de dimensões métricas do granodiorito ocorrem dentro do híbrido.



Figura 64 - Presença de rocha híbrida entre as unidades granítica e máfica do Plúton Indaiatuba. Afloramento CAB-15-50. 




Figura 65 - Variação de granulação da rocha híbrida remetendo às duas rochas que lhe deram origem. Afloramento CAB-15-50.



Figura 66 - Presença de xenocristais de feldspato alcalino (alguns com textura rapakivi) na rocha híbrida. Afloramento CAB-15-50. 
A fácies quartzo-monzonítica forma corpos de dimensões relativamente pequena, raramente mapeáveis na escala 1:50.000. Corpos menores são intrusivos nos granitos, e estes constituem uma rocha equigranular fina composta basicamente por plagioclásio (matriz predominante, e por vezes como fenocristais), feldspato alcalino, quartzo e minerais máficos (biotita, hornblenda e titanita), muito finos (Figura 67). Em corpos de maior dimensão (e.g., amostra IGN-56), tem granulação média.



Figura 67 - Aspecto geral da rocha que define a unidade quartzo-monzonítica do Plúton Indaiatuba. Afloramento CAB-15-57.

\subsubsection{Plúton Itupeva}

O Plúton Itupeva é a mais complexa das quatro unidades graníticas do batólito, compreendendo inúmeras variedades texturais desde granodioritos equigranulares a biotita monzo e sienogranito porfiríticos a inequigranulares, as quais podem hospedar pequenos corpos de rochas máficas híbridas e enclaves microgranulares máficos associados. Cabe aqui ressaltar que o Granito Itupeva não foi alvo de estudo de detalhe neste trabalho, sendo somente definidas as suas relações de contato com Indaiatuba e Cabreúva, e suas implicações petrológicas no contexto do batólito.

O litotipo que define esta fácies caracteriza-se como uma rocha predominantemente inequigranular a equigranular média (Figura 68), composta de feldspato alcalino ( 45\%), plagioclásio $(\sim 22 \%)$ e quartzo $(\sim 30 \%)$, além de máficos (IC 3-6). Por vezes, a rocha se 
apresenta como porfirítica, tipicamente com fenocristais de feldspato alcalino tabular. É comum a ocorrência de diques aplíticos bem como de enclaves microgranulares de natureza máfica, em sua maioria, de tamanhos centimétricos a decimétricos (Figura 69). Estruturas indicando fluxo magmático bem como deformacionais são raras (Figura 70).

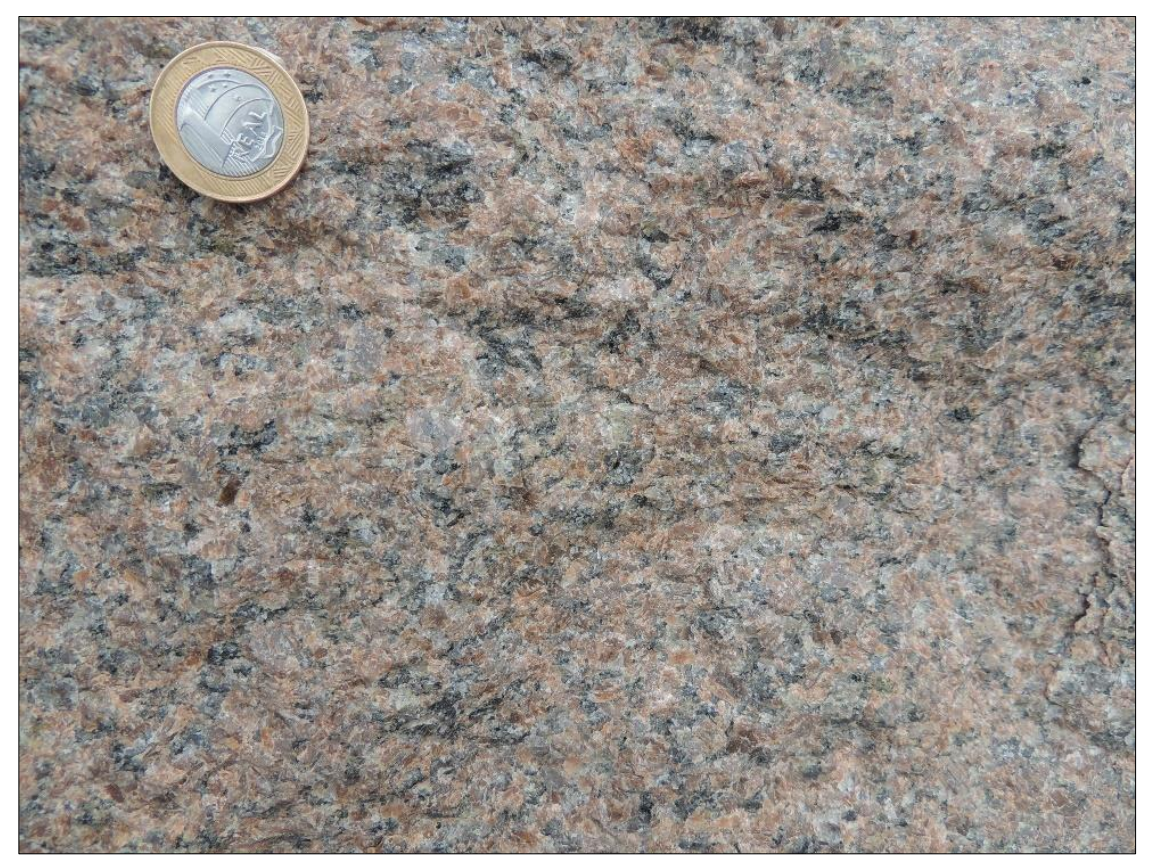

Figura 68 - Aspecto geral da fácies biotita sieno-monzogranito do Plúton Itupeva. Afloramento CAB-16-92.



Figura 69 - Enclave microgranular máfico hospedado na fácies granítica do Plúton Itupeva. Afloramento CAB15-19. 


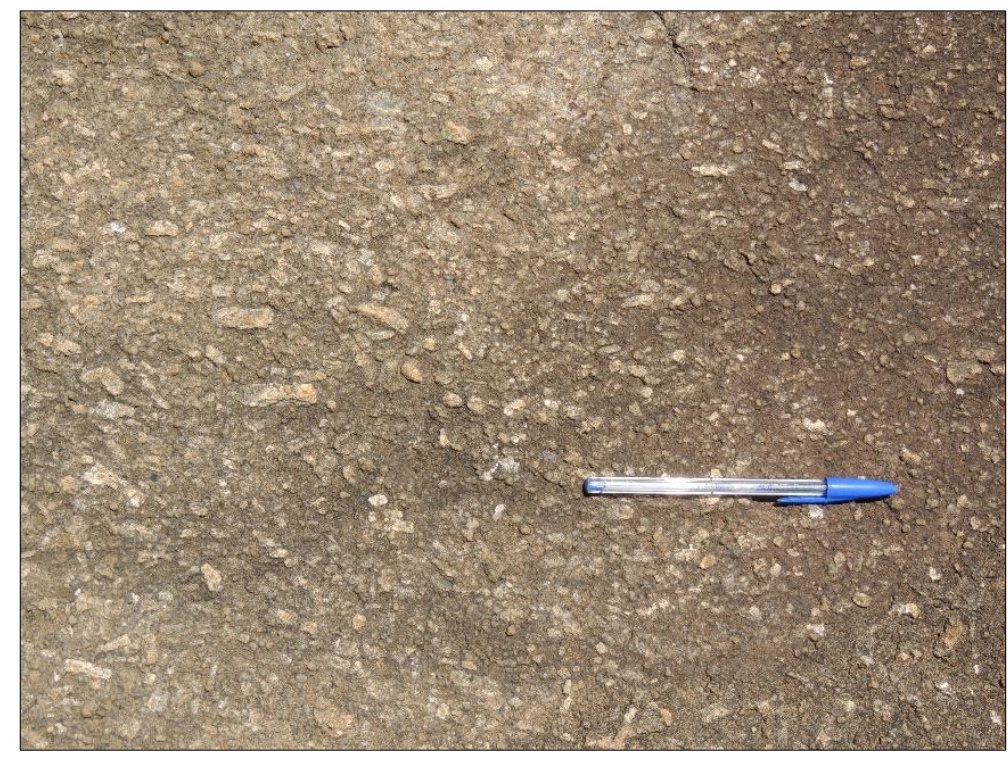

Figura 70 - Estrutura de fluxo magmática dada pelos cristais tabulares de feldspato alcalino (por vezes fenocristais). Afloramento CAB-16-101.

\subsubsection{Plúton Cabreúva}

A maior parte da área de exposição do Plúton Cabreúva é constituída por um equi a inequigranular grossa de composição sienogranítica e IC 3-5, no qual os cristais de feldspato alcalino se destacam, alcançando até $2 \mathrm{~cm}$. Os demais minerais principais (plagioclásio, quartzo e biotita) acompanham o feldspato alcalino na matriz, que caracteristicamente tem granulação grossa (Figura 71). Por vezes, a rocha apresenta-se menos máfica e menos grossa do que a fácies típica (Figura 72).



Figura 71 - Aspecto geral da fácies sienogranítica do Plúton Cabreúva. Afloramento CAB-15-31. 




Figura 72 - Porção menos máfica e mais fina do sienogranito do Plúton Cabreúva. Afloramento CAB-15-45.

$\mathrm{Na}$ porção central do plúton ocorre um biotita monzogranito inequigranular a porfirítico mais máfico (IC 6-8), no qual os cristais de feldspato alcalino se destacam mais da matriz de granulação média (Figura 73). Enclaves microgranulares félsicos de contornos arredondados são abundantes, e podem alcançar até 1-2 m; xenocristais de tamanho equivalente ao dos cristais do granito hospedeiro estão presentes frequentemente, outros formatos achatados também ocorrem (Figuras 74a e 74b). Enclaves microgranulares máficos são menos abundantes e de menor tamanho (até decimétricos), e podem ter auréola de concentração de minerais máficos (Figura 75).



Figura 73 - Aspecto geral da fácies monzogranítica central do Plúton Cabreúva. Afloramento CAB-16-90. 




Figura 74 - Enclaves microgranular félsico com xenocristais da fácies sienogranítica do Plúton Cabreúva em formato oblato (a) e formato tipo augen com alto conteúdo de xenocristais (b). Afloramento CAB-16-80.



Figura 75 - Enclave microgranular máfico com borda de reação na fácies sienogranítica do Plúton Cabreúva. Afloramento CAB-16-80.

Na porção central do Plúton Cabreúva, associados aos monzogranitos inequigranulares, ocorrem blocos de uma rocha diorítica grossa levemente orientada, com IC relativamente baixo $(\sim 15)$ cuja textura sugere origem cumulática (Figura 76). 




Figura 76 - Rocha diorítica grossa de aspecto cumulático encontrada no centro do Plúton Cabreúva. Afloramento CAB-16-91.

\subsection{RADIOMETRIA DE CAMPO}

Levantamentos aerogeofísicos (e.g., FERREIRA, 1991) e estudos de radiometria de campo no Batólito Itu (PASCHOLATI, 1990) registram elevados teores dos elementos radioativos Th, $\mathrm{U}$ e K, e variações internas importantes que sugerem, em alguns casos, a individualização de corpos com características específicas.

Segundo Pascholati (1990), a Suíte Granítica Itu (lá denominada) apresenta os seguintes valores médios de concentração dos isótopos: 4,2\% de K, 5,0 ppm de eU (urânio equivalente) e 31,3 ppm de eTh (tório equivalente). As determinações são obtidas em unidades “equivalentes" quando não são efetuados testes apropriados para ser ter certeza que o elemento se encontra em equilíbrio, isto é, se as condições de equilíbrio fossem aplicáveis, uma certa determinação radiométrica seria equivalente (PASCHOLATI, 1990). O mapa áereo de Ferreira para o contorno da contagem total é apresentado na Figura 77 abaixo, destacando em geral, o padrão mais radioativo dos granitos Salto e Itupeva, e região central do Plúton Indaiatuba. 




Figura 77 - Mapa de contorno da contagem total. Base aerogeofísica de Ferreira (1991) e contorno faciológico de Galembeck (1997).

As figuras 78, 79 e 80 a seguir apresentam a distribuição dos teores de $\mathrm{K}$, U e Th equivalentes nos pontos de amostragem do Batólito Itu utilizando como base o mapa geológico de Galembeck (1997) e os mapas de radiometria de campo obtidos para tais elementos por Pascholati (1990). 




Figura 78 - Distribuição dos pontos de medição gama-espectrométrica, com indicação para as concentrações equivalentes de K. Mapas-base: contorno faciológico segundo Galembeck (1997); isolinhas para o sinal de K a partir de dados de radiometria de campo de Pascholati (1990). 




Figura 79 - Distribuição dos pontos de medição gama-espectrométrica, com indicação para as concentrações equivalentes de U. Mapas-base: contorno faciológico segundo Galembeck (1997); isolinhas para o sinal de U a partir de dados de radiometria de campo de Pascholati (1990). 




Th (ppm)

- 0 - 10

- $11-20$

- $21-30$

- $31-40$

- $41-50$

- $51-60$

- $61-67.8$

Figura 80 - Distribuição dos pontos de medição gama-espectrométrica, com indicação para as concentrações equivalentes de Th. Mapas-base: contorno faciológico segundo Galembeck (1997); isolinhas para o sinal de Th a partir de dados de radiometria de campo de Pascholati (1990).

Os resultados mostram padrões característicos para cada plúton, e constituem, portanto, ferramentas de campo úteis na sua individualização, bem como na identificação de regiões 
caracterizadas por enriquecimentos anômalos (em geral, correspondentes a granitos especializados) e das rochas encaixantes (em geral com teores mais baixos desses elementos).

Os dados gama-espectrométricos obtidos em campo determinam que teores mais elevados de U diferenciam os plútons Salto e Itupeva de Cabreúva e Indaiatuba (cf. Figura 79). O Granito Nhandeara, não separado do Granito Itupeva em mapas prévios do Batólito Itu, se destaca por teores elevados de Th (40-67 ppm) e U, claramente se distingue do Granito Salto pelas razões Th/U mais altas. Outra característica definidora de contrastes entre os granitos Cabreúva e Indaiatuba é que o primeiro se caracteriza por granitos com teores mais baixos de Th e $\mathrm{U}$ (Figuras 79 e 80). Um conjunto de granitos previamente mapeado como Cabreúva (GALEMBECK, 1997), mas situado a norte do plúton, formando um anel externo ao Granito Indaiatuba (pontos CAB-15-32, CAB-15-43 CAB-15-45), se destaca do campo de Cabreúva (devido a teores mais altos de U), uma indicação de que provavelmente não há vínculo genético com este.

Os levantamentos de campo e os dados petrográficos e geoquímicos demonstram que o Granito Itupeva é, na realidade, um plúton muito heterogêneo, e deve se resultado da coalescência de diferentes intrusões em parte independentes, entre elas o Granito Inhandjara (GAMA, 1946; ARAÚJO, 2018) individualizado um corpo de granito especializado (ver também geoquímica), e suas relações com a mineralização de wolframita encaixada em rochas gnáissicas na sua borda leste.

Os dados obtidos em levantamento radiométrico de campo podem ser consultados, na íntegra, na Tabela A1 do Apêndice A. 


\section{CAPÍTULO 5-PETROGRAFIA}

Existe uma extensa documentação petrográfica para os granitos do Batólito Itu, incluindo análises modais das principais faciologias graníticas (GALEMBECK, 1997) e determinações químicas de minerais principais, especialmente os máficos, por microssonda eletrônica (GALEMBECK; WERNICK; HÖRMANN, 1997). Deste modo, a caracterização petrográfica desta tese focalizou-se na caracterização da mineralogia e textura das amostras escolhidas para determinações geoquímicas, isotópicas e geocronológicas. Adicionalmente, foi dada ênfase a enclaves microgranulares máficos e félsicos, os quais não foram descritos nos trabalhos anteriores.

Aqui são apresentadas as principais características petrográficas dos litotipos definidos neste trabalho, ilustradas por fotomicrografias. Como etapa adicional, a petrografia foi reavaliada com ênfase na observação das principais características dos feldspatos, biotitas e anfibólios (quando presentes), utilizando a microscopia eletrônica como ferramenta auxiliar na caracterização mineralógica via microssonda eletrônica (Capítulo 6).

\subsection{PLÚTON INDAIATUBA}

\section{Granito}

A fácies predominante do Granito Indaiatuba caracteriza-se como uma rocha granítica rapakivi caracterizada por textura inequigranular porfirítica hipidiomórfica com fenocristais de feldspato alcalino, de quartzo arredondado (alguns apresentando extinção do tipo ondulante) e subordinadamente plagioclásio. A matriz é caracterizada por textura inequigranular seriada, com predominância de granulação fina a média.

Mineralogicamente, o granito é composto por quartzo, microclínio, oligoclásio/andesina, anfibólio, biotita/clorita, ilmenita e outros minerais opacos (Fotomicrografia 1). Os minerais acessórios titanita, allanita, apatita e zircão perfazem juntos menos de $1 \%$ da rocha.

Os feldspatos apresentam-se fortemente alterados, com o plagioclásio apresentando alteração mais pronunciada no núcleo dos cristais, refletindo o zoneamento do tipo normal, e o feldspato alcalino apresentando alteração para coloração amarronzada, provavelmente devido à formação de argilominerais (sericitização). A textura rapakivi se torna visível, principalmente, 
por essa diferença no padrão de alteração dos feldspatos (Fotomicrografia 2). Este tipo de alteração é característica de todos os granitóides constituintes do Batólito Itu.

O litotipo da fácies granito hololeucocrático equigranular fino a médio (cf. Figuras 62 e 63) caracteriza-se como uma rocha de textura equigranular alotriomórfica (Fotomicrografia 3 ) em contato reto com o granito rapakivi (Fotomicrografia 4), e de composição muito similar a ela.


Fotomicrografias 1 a 4 - Concentrado de minerais máficos no granito rapakivi - amostra CAB-14-06A1 (1); textura rapakivi no granito rapakivi e padrão de alteração dos feldspatos - amostra CAB-14-06A1 (2); aspecto geral do granito hololeucocrático equigranular - amostra CAB-14-01B (3); contato entre granito rapakivi e granito equigranular - amostra CAB-14-01B (4).

\section{Monzogabro}

O corpo de monzogabro (CAB-15-57 - Figura 81) associado ao Plúton Indaiatuba caracteriza-se como uma rocha inequigranular fina a média com cristais maiores de plagioclásio (por vezes fenocristais; Fotomicrografia 5), e matriz definida por plagioclásio e minerais máficos; a ocorrência é quartzo é rara. Cabe aqui ressaltar a única ocorrência de piroxênio em 
todo o batólito, por vezes em textura subofítica com ripas de cristais de plagioclásio (Fotomicrografia 6).



Figura 81 - Classificação modal com base no diagrama QAP de Streckeisen (1976) do corpo de monzogabro associado ao Granito Indaiatuba.


Fotomicrografias 5 e 6 - Aspecto geral do monzograbro do Plúton Idaiatuba (5) e detalhe para textura subofítica com ripa de plagioclásio parcialmente englobada por cristal de piroxênio (6) - amostra CAB-15-57.

Ocorre uma rocha híbrida entre a fácies granítica e a fácies quartzo monzonítica (Capítulo 4 - Figura 82) do Plúton Indaiatuba (cf. Figuras 64, 65 e 66), observada em campo, que se caracteriza como uma rocha inequigranular média a fina, alotriomórfica (Fotomicrografia 7), rica em xenocristais e xenólitos capturados da rocha granítica (Fotomicrografias 8 a 10). 
Texturas de intercrescimento, tipo granófiros, são abundantes tanto na rocha híbrida quanto na rocha granítica (Fotomicrografia 11).



Fotomicrografias 7 a 12 - Textura alotriomófica da rocha híbrida - amostra CAB-15-50B2 (7); xenocristais rapakivi na rocha híbrida - amostras $\mathrm{CAB}-15-50 \mathrm{~A}$ e $\mathrm{CAB}-15-50 \mathrm{C} 2$ (8 e 9); xenocristrais em rocha híbrida amostra $\mathrm{CAB}-15-50 \mathrm{C1}$ (10); granófiros na rocha híbrida, principalmente entre os xenocristais - amostras CAB15-50B1 e CAB-15-50C4 (11 e 12). 




Figura 82 - Classificação modal com base no diagrama QAP de Streckeisen (1976) da fácies quartzo monzonítica do Granito Indaiatuba, descrita em campo.

\section{Enclave Microgranular Máfico (EMM)}

Microscopicamente, os enclaves microgranulares máficos caracterizam-se como rochas equigranulares hipidiomórficas (Fotomicrografia 13). Alguns enclaves apresentam xenocristais de quartzo e de feldspato (Fotomicrografia 14) com contatos irregulares e reentrantes, bordas arredondadas e zoneamento do tipo inverso. Quando em contato com o granito hospedeiro, ocorre uma concentração de cristais de quartzo e plagioclásio no enclave, próxima ao contato, caracteristicamente de maneira abrupta. A relação entre ambos os enclaves denota um contraste de reologia onde por vezes é possível observar "gotas" e reentrâncias do enclave máfico no enclave mais félsico (Fotomicrografias 15 e 16).

O enclave é composto por quartzo, oligoclásio, biotita/clorita, anfibólio (formando agregados - Fotomicrografias 17 e 18), titanita, ilmenita e outros minerais opacos. Minerais acessórios, principalmente apatita e zircão, perfazem cada qual menos de $1 \%$ do enclave. Por vezes, epídoto e muscovita ocorrem em pequenas proporções como minerais de alteração do plagioclásio. Dada a proporção dos minerais félsicos, os enclaves máficos caracterizam-se como rochas de composição monzonítica e quartzo monzodiorítica (Figura 83). 



Fotomicrografias 13 a 18 - Aspecto do emm do Plúton Indaiatuba levemente orientado - amostra CAB-1406A2 (13); xenocristal rapakivi no emm - amostra CAB-15-50A2 (14); "lentes" entre emm e emf - amostra CAB-15-34.1 (15 e 16); agregados de anfibólio - amostras CAB-14-06A2 e CAB-15-34.2 (17 e 18). 




Figura 83 - Classificação modal com base no diagrama QAP de Streckeisen (1976) dos emm associados ao Granito Indaiatuba.

\section{Enclave Microgranular Félsico (EMF)}

Os enclaves microgranulares félsicos caracterizam-se como rochas equi a inequigranulares alotriomórficas (salvo alguns cristais idiomórficos pequenos de minerais acessórios e alguns poucos cristais de plagioclásio, biotita e anfibólio tabulares). Podem apresentar xenocristais de quartzo, microclínio, plagioclásio (em sua maioria) de bordas arredondadas, e por vezes corroídas; o contato entre o enclave e a rocha hospedeira é abrupto (Fotomicrografia 19).

Em análise microscópica, a composição mineralógica do enclave é dada basicamente por quartzo, microclínio, oligoclásio, biotita, clorita, anfibólio, titanita, ilmenita, além de minerais como apatita, zircão e epídoto, perfazendo juntos menos de $1 \%$ da rocha. A proporção entre os minerais félsicos indica uma composição monzogranítica para os enclaves (Figura 84). 


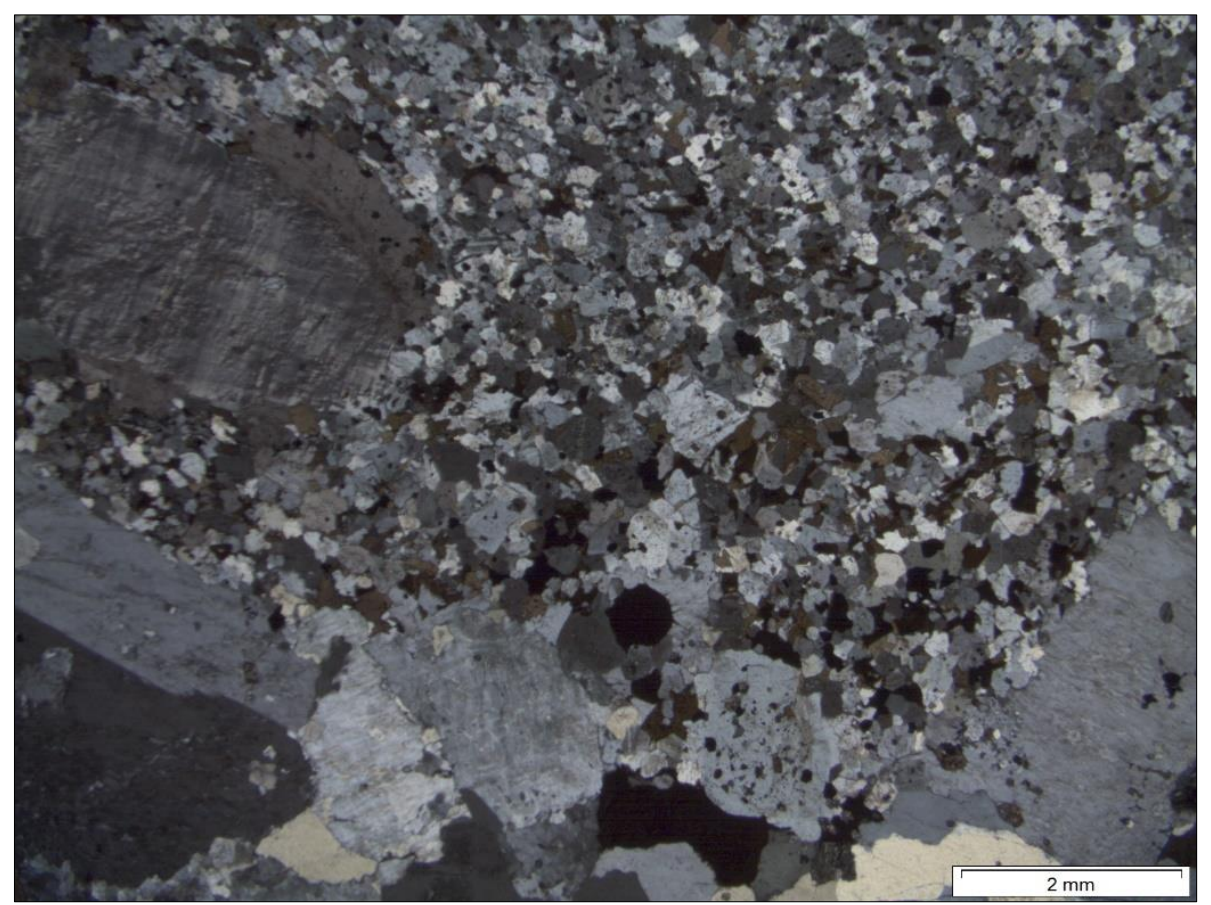

Fotomicrografia 19 - Contato entre granito rapakivi e emf do Plúton Indaiatuba - amostra CAB-15-36F.



Figura 84 - Classificação modal com base no diagrama QAP de Streckeisen (1976) dos emf associados ao Granito Indaiatuba.

\subsection{PLÚTON ITUPEVA}

O granito que define a fácies granítica principal do Plúton Itupeva caracteriza-se como uma rocha inequigranular a porfirítica, com matriz apresentando pouca variação granulométrica 
(equigranular média), e que contém cristais maiores de feldspato alcalino, plagioclásio e quartzo arredondado (Fotomicrografia 20). Em algumas porções do granito ocorrem cristais de quartzo e feldspatos com hábito xenomórfico.

Mineralogicamente, o granito é composto por microclínio, quartzo, plagioclásio, biotita/clorita e outros minerais máficos e acessórios, cada qual perfazendo menos de $1 \%$ da rocha, como ilmenita e outros minerais opacos, titanita, apatita, zircão e allanita (Fotomicrografia 21). Ocorrem também alguns minerais de alteração dos feldspatos como a sericita e o carbonato.



Fotomicrografias 20 e 21 - Aspecto geral da rocha que define a fácies granítica principal do Granito Itupeva amostra CAB-15-27 (20); cristal de allanita metamítica no granito Itupeva - amostra CAB-15-30 (21).

Ocorrem corpos locais de rocha máfica associados, os quais caracterizam-se como rochas inequigranulares hipidiomórdicas a alotriomórficas com matriz variando de fina a média (Fotomicrografia 22), definida por cristais de plagioclásio e máficos (principalmente biotita e anfibólio - Fotomicrografias 23 e 24), enquanto os cristais de feldspato alcalino só são observáveis quando de maior tamanho; a presença de quartzo é rara. Sua composição varia entre quartzo monzonito e quartzo monzodiorito (Figura 85). 




Fotomicrografias 22 a 24 - Aspecto geral da rocha mais máfica do Plúton Itupeva - amostra CAB-16-95 (22); cristais máficos de biotita e anfibólio em destaque - amostras CAB-16-95 e CAB-16-98 (23 e 24).



Figura 85 - Classificação modal com base no diagrama QAP de Streckeisen (1976) da fácies máfica do Granito Itupeva. 
Os litotipos atribuídos por Araújo (2018) ao Granito Nhandeara (não distinguido por Galembeck, 1997) são caracteristicamente granitos hololeucocráticos (1-3\% de máficos Fotomicrografias 25 e 26), com granulação variando de fina a média, fortes efeitos cataclásticos, associados a mineralogia secundária produzida por hidrotermalismo (e.g., presença de fluorita, epídoto, sulfetos e topázio).


Fotomicrografias 25 e 26 - Aspecto geral do granito hololeucocrático que define a fácies principal do Granito Nhandeara dentro da área de estudo - amostras CAB-15-41 e CAB-15-42 (25 e 26).

\subsection{PLÚTON CABREÚVA}

\section{Granito}

O litotipo que caracteriza a fácies granítica do Plúton Cabreúva é similar, ao microscópio, aos granitos do Plúton Indaiatuba, dos quais se distingue pela ausência da textura rapakivi e pelo caráter caracteristicamente mais equigranular, com sua textura variando de inequi a equigranular, e matriz média a grossa (Fotomicrografias 27 e 28). 




Fotomicrografias 27 e 28 - Aspecto geral da rocha que caracteriza a fácies principal do Plúton Cabreúva amostras CAB-14-18 e CAB-16-80A (27 e 28).

\section{Granito Porfirítico}

O granito porfirítico da porção central do Plúton Cabreúva caracteriza-se como uma rocha inequigranular porfirítica, com matriz equigranular fina (Fotomicrografia 29), e que contém fenocristais de feldspato alcalino, plagioclásio e quartzo arredondado, por vezes apresentando aspecto xenocristalino.

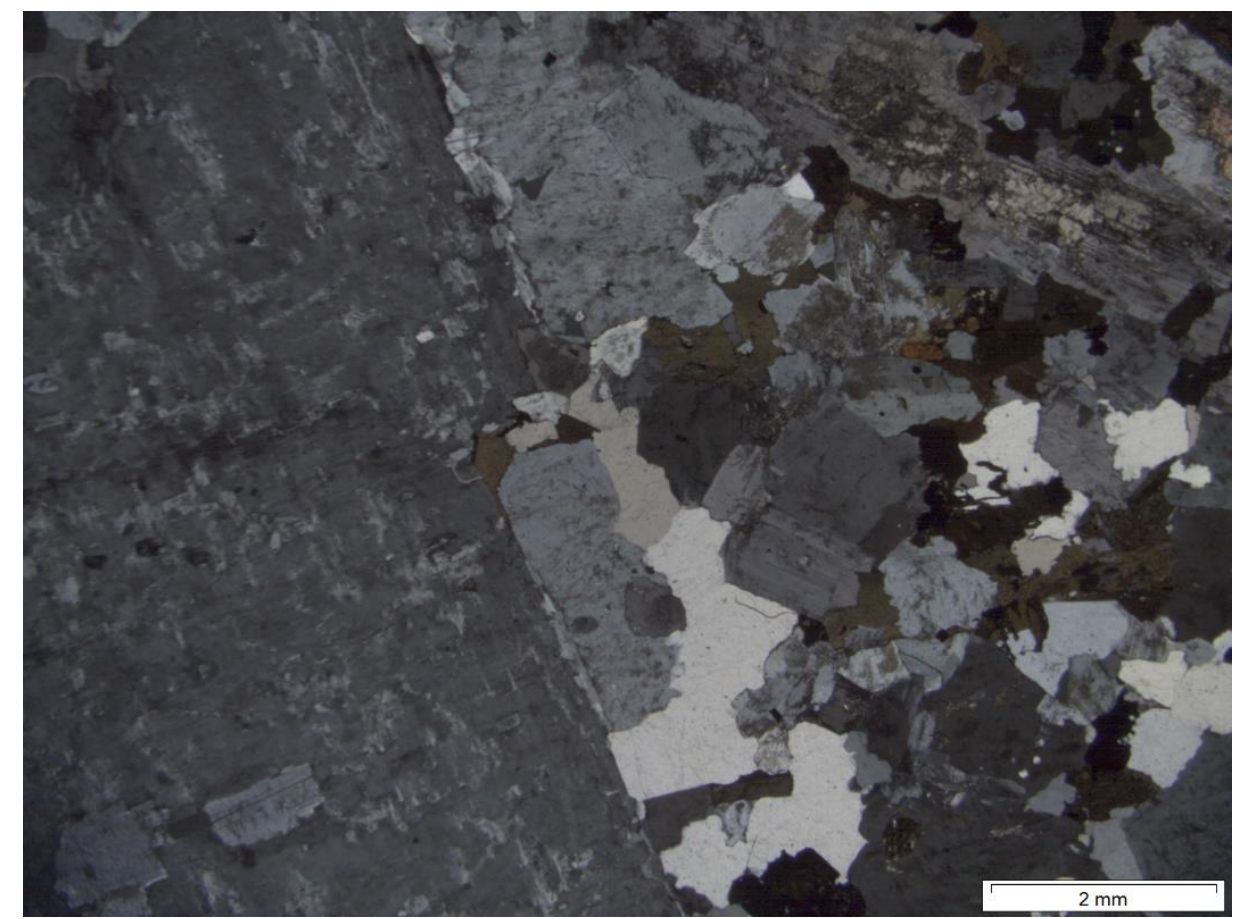

Fotomicrografia 29 - Aspecto geral do granito da fácies pórfiro do Plúton Cabreúva - amostra CAB-16-90. 
Os enclaves microgranulares félsicos caracterizam-se como rochas equi a inequigranulares hipidiomórficas a alotriomórficas (Fotomicrografias 30 e 31). Apresentam conteúdo variável de xenocristais de quartzo, feldspato alcalino e plagioclásio de bordas arredondadas, e por vezes corroídas (Fotomicrografias 32, 33, 34, 35 e 36). O contato entre o enclave e a rocha hospedeira é abrupto, e não parece ter havido qualquer tipo de reação entre eles (Fotomicrografia 37).

A composição mineralógica dos enclaves é dada basicamente por quartzo, feldspato alcalino e plagioclásio, além de biotita/clorita, titanita/ilmenita. Minerais como apatita, zircão e epídoto, perfazem juntos menos de $1 \%$ da rocha. 



Fotomicrografias 30 a 37 - Imagens de granitos e enclaves microgranulares félsicos do Plúton Cabreúva com texturas variando de hipidiomórfica (30) a alotriomórfica (31) - amostras CAB-16-76E2 e CAB-16-76B; conteúdo variável de xenocristais, incluindo rapakivi (34) no emf - amostras CAB-16-76E1 (32), CAB-16-78A (33 e 34), CAB-16-76B (35), CAB-16-76D (36) e CAB-16-76C (37). 


\section{Enclave Microgranular Máfico (EMM)}

Microscopicamente, os enclaves microgranulares máficos caracterizam-se como rochas equigranulares hipidiomórficas a alotriomórficas. Alguns enclaves apresentam xenocristais de quartzo e de feldspatos (Fotomicrografias 38 e 39), por vezes com textura rapakivi (Fotomicrografia 40), com contatos irregulares e reentrantes, e bordas arredondadas. Aparentemente, o enclave apresenta um aspecto bem alterado, dado pela formação de material muito fino sobre os cristais do enclave.


Fotomicrografias 38 a 40 - Conteúdo variável de xenocristais no emm do Plúton Cabreúva; xenocristal rapakivi (40) - amostra ITU-10-36C (38 e 39), ITU-10-36B2 (40).

Dada a proporção dos minerais félsicos, os enclaves máficos do Plúton Cabreúva caracterizam-se como rochas de composição quartzo monzonítica a quartzo monzodiorítica conforme a figura a seguir: 




Figura 86 - Classificação modal com base no diagrama QAP de Streckeisen (1976) dos emm do Plúton Cabreúva.

\section{Cumulato}

O litotipo pertencente ao Plúton Cabreúva, classificado como cumulático em campo (cf. Figura 76), é caracterizado como uma rocha inequigranular média a grossa (Fotomicrografia 41), rica em plagioclásio com relação ao feldspato alcalino, e com pouco quartzo. O conteúdo de minerais máficos é dado em sua maioria por biotita, anfibólio (perfazendo cerca de $20 \%$ da rocha), minerais opacos, além de minerais acessórios como zircão e apatita. Dada a proporção dos minerais félsicos, esta rocha classifica-se como um quartzo monzodiorito (Figura 87).



Fotomicrografia 41 - Aspecto geral da textura da rocha cumulática pertencente ao Plúton Cabreúva - amostra CAB-16-91B. 




Figura 87 - Classificação modal com base no diagrama QAP de Streckeisen (1976) da rocha cumulática pertencente ao Plúton Cabreúva. 


\section{CAPÍTULO 6 - QUÍMICA MINERAL}

Neste capítulo são apresentados dados de química mineral de plagioclásios, anfibólios, biotitas e piroxênios obtidos para amostras dos diferentes plútons, com a finalidade de caracterizar os principais litotipos e as variações composicionais dentre eles, além de definir condições de cristalização: $\mathrm{P}, \mathrm{T}$ e $f \mathrm{O}_{2}$. Análises químicas de anfibólios e biotitas de variedades de granitos do batólito Itu foram apresentadas anteriormente por Galembeck (1997), e Galembeck, Wernick e Hörmann (1997) publicaram artigo específico comparando as biotitas dos plútons Salto e Cabreúva. Os resultados e imagens de todas as análises in situ obtidas pelo método de microssonda eletrônica são apresentados no Apêndice B.

A simbologia utilizada para as amostras analisadas pela metodologia de microssonda eletrônica é utilizada conforme a legenda apresentada na figura a seguir:

\begin{tabular}{|c|c|}
\hline CABREÚVA & INDAIATUBA \\
\hline O CAB-16-80A & $\triangle \mathrm{CAB}-15-34.2$ \\
\hline - CAB-14-09 & $\triangle \mathrm{CAB}-14-06 \mathrm{~A} / \mathrm{CAB}-14-06 \mathrm{~B}$ \\
\hline O CAB-16-90 & $\Delta \mathrm{CAB}-15-34.1$ \\
\hline O CAB-16-91 & \& CAB-15-57 \\
\hline ITUPEVA & SALTO \\
\hline$\square$ CAB-15-36A & $\diamond 2008-\mathrm{ITU}-2.1 \mathrm{C}$ \\
\hline$\square$ CAB-16-98 & $\diamond$ FME3_7 / FME3_3 \\
\hline$\square$ CAB-16-101 & $\diamond 2008-\mathrm{IT} U-2.1 \mathrm{~A} 1$ \\
\hline
\end{tabular}

Figura 88 - Simbologia utilizada para os diagramas de química mineral.

\subsection{PLAGIOCLÁSIO}

Foram obtidas composições de plagioclásio em todas as amostras em que foram analisados minerais máficos. Os resultados são apresentados na Tabela B1 do Apêndice B, e as imagens de elétrons retroespalhados indicando a situação textural dos cristais analisados, e os pontos analíticos em seu interior são apresentadas na Prancha B1 do mesmo documento.

O plagioclásio original dos granitos do Plúton Cabreúva é um oligoclásio, mas sua composição é variável em função da unidade. No sienogranito inequigranular grosso, que constitui a maior parte do plúton (amostra CAB-16-80), trata-se de oligoclásio sódico no limite com albita $\left(\mathrm{An}_{11-9}\right)$; finas bordas albíticas ocorrem em parte dos cristais, em especial no contato 
com o feldspato alcalino. Em contrapartida, nas variedades menos evoluídas, a composição é um pouco mais cálcica: $\mathrm{An}_{17-15}$ na amostra $\mathrm{CAB}-15-09$; máximo de $\mathrm{An}_{21}$ em núcleo subidiomórfico, passando a $\mathrm{An}_{18-16}$ nas bordas e em cristais intersticiais na variedade porfirítica (amostra CAB-16-90), variação semelhante à observada na rocha de aspecto "cumulático" a ela associada (amostra CAB-16-91 - An 20-15) (Figura 89). Composições albíticas praticamente puras se associam a bordas finas no contato com feldspato alcalino, ou com manchas de alteração no interior de alguns cristais.

$\mathrm{Na}$ amostra de granito do Plúton Itupeva, o plagioclásio original é também um oligoclásio, de composição similar ao das variedades menos evoluídas de Cabreúva, variando entre $\mathrm{An}_{22} \mathrm{e}$ $\mathrm{An}_{16}$ e com zoneamento normal (Prancha B1). Bordas albíticas se restringem a estreitas projeções irregulares, em contato com o feldspato alcalino.

Os plagioclásios mais cálcicos encontrados no Batólito Itu ocorrem no monzogabro portador de clinopiroxênio (amostra CAB-15-57 do Plúton Indaiatuba). Os cristais idiomórficos melhor desenvolvidos são labradoritas não zonadas, com composição média $\mathrm{An}_{55} \mathrm{Ab}_{42} \mathrm{Or}_{3}$ (Figura 89).

No enclave máfico de Indaiatuba (amostra CAB-15-34.1), os núcleos mais cálcicos são de andesina $A_{33-31}$, e são sobrecrescidos, após zona de reabsorção, por bordas sensivelmente mais sódicas, $\mathrm{An}_{12}$. Plagioclásio idiomórfico incluído em feldspato alcalino tem zoneamento entre $\mathrm{An}_{19}$ e $\mathrm{An}_{14}$, e fina borda de albita $\mathrm{An}_{3}$.

O enclave máfico de Itupeva da amostra CAB-16-98 tem núcleos de andesina cálcica (An 43 45 em um cristal; $\mathrm{An}_{35}$ em outro), com passagem abrupta a bordas largas, homogêneas, com poucas inclusões, de composição $\mathrm{An}_{25-27}$. $\mathrm{Na}$ interface de reabsorção, ocorrem manchas de albita $\mathrm{An}_{12-6 .}$

No enclave microgranular félsico de Salto (amostra 2008-ITU-2.1A1), o plagioclásio tem alguns núcleos com aspecto alterado de composição andesina $\left(\mathrm{An}_{39-38}\right)$ que passam a bordas de oligoclásio cálcico, que também é a composição do plagioclásio homogêneo da matriz ( $\mathrm{An}_{27}$ 24). Albita ocorre restritamente em núcleo afetado por alteração. Alves et al. (submetido) apresentaram um estudo sistemático do plagioclásio do Plúton Salto, e reportam composições de oligoclásio, variáveis em função da amostra, entre An31-29 (amostra ITU-67H) e An 18-14 (amostra ITU-36B), com valores intermediários $\left(\mathrm{An}_{25-23}\right)$ na amostra ITU-67B. Nos sienogranitos do Plúton Salto hospedeiros dos enclaves, inclusive nos mantos dos cristais rapakivi, o plagioclásio é um oligoclásio cálcico $\mathrm{An}_{29-21}$. 




Figura 89 - Diagrama dos componentes An-Ab-Or, em proporção molecular, para os plagioclásios dos diferentes plútons do Batólito Itu. Modificado de Smith e Brown (1988).

O mineral piroxênio ocorre exclusivamente em uma amostra de rocha máfica do Plúton Indaiatuba (amostra CAB-15-57 - cf. Fotomicrografias 5 e 6). Não há registro prévio da ocorrência deste mineral em rochas do Batólito Itu.

Foram realizadas análises em diversas porções dos cristais (núcleo, borda, zonas intermediárias); imagens de elétrons retroespalhados mostrando a localização dos pontos analisados são apresentadas no Prancha B2 do Apêndice B.

A fórmula estrutural do clinopiroxênio, calculada na base de 4 cátions e 6 oxigênios, é apresentada na Tabela B2. Na nomenclatura de Morimoto (1988), situam-se no campo da augita, com composição média $\mathrm{Wo}_{45} \mathrm{En}_{42} \mathrm{Fs}_{14}$ (Figura 90); o mg\# (calculado pela razão $\mathrm{En} /(\mathrm{En}+\mathrm{Fs}))$ é 0,76 e a razão $\mathrm{Fe}^{3+} / \mathrm{Fe}_{\mathrm{t}}$ estimada é 0,16 .

Existe uma correlação negativa entre o $\mathrm{Ti}$ e $\mathrm{Al}$ onde os teores mais baixos correspondem em geral a regiões mais próximas das bordas dos cristais (Figura 91). 




Figura 90 - Diagrama QUAD para clinopiroxênios de Ca-Fe-Mg mostrando a composição do clinopiroxênio da amostra CAB-15-57 (corpo máfico de monzogabro do Plúton Indaiatuba). Modificado de Morimoto (1988).



Figura 91 - Diagrama Al x Ti (apfu) para os clinopiroxênios da amostra de monzogabro (CAB-15-57 - corpo máfico do Plúton Indaiatuba).

\subsection{ANFIBÓLIO}

Foram analisados anfibólios de amostras dos plútons Cabreúva e Indaiatuba; para comparação, procurou-se analisar anfibólios dos plútons Salto e Itupeva, mas poucas amostras desses plútons são portadoras de anfibólio; em Itupeva este é restrito às variedades mais máficas e em Salto encontra-se quase que invariavelmente alterado a biotita e clorita. No caso de Salto, uma amostra de enclave microgranular félsico preserva a mineralogia original, o que permitiu a obtenção de diversas análises em anfibólio. 
Pranchas com imagens de elétron retroespalhados indicando a situação textural dos cristais de anfibólio analisados e os pontos analíticos em seu interior são apresentadas na Prancha B3 do Apêndice B.

Os resultados das análises químicas e as fórmulas estruturais calculadas para 13 cátions exceto $\mathrm{Ca}$, Na e K (13-CNK) são apresentados na Tabela B3 do mesmo documento. Os anfibólios foram classificados segundos os parâmetros recomendados pelo IMA (HAWTHORNE; OBERTI, 2007) para anfibólios cálcicos (Figuras 92 e 93). Todos têm Si > 6,5 apfu; os anfibólios dos granitos dos plútons Cabreúva e Indaiatuba têm $(\mathrm{Na}+\mathrm{K})_{\mathrm{A}}$ superior a 0,5, e se classificam como ferro-edenitas (Figura 92). Os anfibólios de enclaves máficos do plúton Indaiatuba têm $(\mathrm{Na}+\mathrm{K})_{\mathrm{A}}<0,5$, e são classificados como hornblenda, no limite entre os campos ferroso e magnesiano (Figura 93); existe uma variação para composições mais ricas em Mg e Si (em direção ao campo da actinolita), que correspondem a porções mais claras dos cristais. Os anfibólios dos enclaves máficos do Plúton Itupeva e do Plúton Salto têm composição semelhante, no campo da magnésio-hornblenda, embora parte das análises do anfibólio de Salto tenha $(\mathrm{Na}+\mathrm{K})_{\mathrm{A}}>0,5$, e corresponda portanto a edenita. O anfibólio do enclave microgranular fino de Salto (amostra 2008-ITU-2.1A1) tem composição semelhante à dos enclaves dos granitos do Plúton Indaiatuba, no campo da ferro-edenita.



Figura 92 - Diagrama de classificação dos anfibólios cálcicos do Batólito Itu analisados com razão $(\mathrm{Na}+\mathrm{K})_{\mathrm{A}} \geq$ 0,5; componentes expressos em apfu. Modificado de Hawthorne e Oberti (2007). 




Figura 93 - Diagrama de classificação dos anfibólios cálcicos do Batólito Itu analisados com $(\mathrm{Na}+\mathrm{K})_{\mathrm{A}}<0,5$; componentes expressos em apfu. Modificado de Hawthorne e Oberti (2007).

A correlação $(\mathrm{Na}+\mathrm{K})_{\mathrm{A}} \times \mathrm{Al}^{\mathrm{IV}}$ mostrada na Figura 94 mostra como a maior proporção do membro-final edenita ou K-edenita distingue os anfibólios dos granitos dos plútons Cabreúva e Indaiatuba. Essa troca, dada pelo vetor $\mathrm{Na}(\mathrm{K}){ }^{\mathrm{A}} \mathrm{Al}^{\mathrm{IV}}=\square^{\mathrm{A}} \mathrm{Si}^{\mathrm{IV}}$, é favorecida pelo aumento de temperatura (BLUNDY; HOLLAND, 1990), sugerindo assim que os anfibólios de Cabreúva e Indaiatuba cristalizaram a temperaturas mais altas. Por outro lado, observa-se uma ampla variação desses componentes nos enclaves máficos estudados dos plútons Itupeva e Indaiatuba, até valores muito baixos (alcançando composições de actinolita), que podem estar relacionados a recristalização a temperaturas submagmáticas, ou a desequilíbrios locais associados à geração do anfibólio a partir de um piroxênio cálcico original. Um aspecto a ser destacado nesta mesma figura é o comportamento distinto das amostras de Indaiatuba (enclaves e granito), que seguem uma tendência paralela às de Cabreúva (e Itupeva), mais rica em $\mathrm{Na}+\mathrm{K}$ para uma mesma proporção de $\mathrm{Al}^{\mathrm{IV}}$. Esse comportamento também é observado, de modo ainda um pouco mais destacado, pelo anfibólio do enclave microgranular félsico de Salto. 




Figura 94 - Diagrama $\mathrm{Al}^{\mathrm{IV}} \times(\mathrm{Na}+\mathrm{K})^{\mathrm{A}}$ destacando a troca edenítica para anfibólios de granitos e enclaves microgranulares do Batólito Itu.

A Figura 95 mostra a covariação de $\mathrm{Ti}$ e $\mathrm{Al}^{\mathrm{IV}}$. Os anfibólios dos granitos Cabreúva e Indaiatuba mostram teores mais altos de Ti se comparados aos anfibólios dos enclaves máficos e félsicos; não existe, contudo, correlação entre esses cátions, exceto no enclave máfico de Indaiatuba, onde ambos diminuem nas porções actinolíticas.



Figura 95 - Diagrama $\mathrm{Al}^{\mathrm{IV}}$ x Ti (em apfu) destacando a substituição Ti-tschermakítica para anfibólios de granitos e enclaves microgranulares do Batólito Itu. 


\subsection{BIOTITA}

Um estudo comparativo detalhado entre as biotitas dos plútons Cabreúva e Salto foi apresentado por Galembeck, Wernick e Hörmann em 1997; análises de biotitas de granitos dos plútons Indaiatuba e Itupeva também foram apresentadas por Galembeck (1997).

Os resultados analíticos de biotitas do Batólito Itu e respectivas imagens de microscopia eletrônica são apresentados na Tabela B4 e Prancha B4, ambas do Apêndice B.

Uma ampla variação de $\mathrm{Fe}^{\mathrm{T}} /\left(\mathrm{Fe}^{\mathrm{T}}+\mathrm{Mg}\right.$ ), entre 0,42 e 0,81 , é observada (Figura 96 ), com as biotitas dos granitos Cabreúva se distinguindo das demais por suas razões mais elevadas $(0,65$ 0,81); entre as diferentes amostras de Cabreúva, a variação é paralela à observada nos anfibólios. A amostra de granito Indaiatuba tem biotita com $\mathrm{Fe}^{\mathrm{T}} /\left(\mathrm{Fe}^{\mathrm{T}}+\mathrm{Mg}\right)$ mais baixo $(0,57-$ 0,61), idêntico ao do enclave microgranular máfico do mesmo plúton (amostra CAB-15-34.1; 0,55-0,62), mas ligeiramente superior ao granito do Plúton Itupeva CAB-15-36 (0,53-0,55).

As biotitas dos enclaves microgranulares máficos de Itupeva mostram $\mathrm{Fe}^{\mathrm{T}} /\left(\mathrm{Fe}^{\mathrm{T}}+\mathrm{Mg}\right)=$ 0,48-0,53 (amostra CAB-16-98) e 0,46-0,49 (amostra CAB-16-101), enquanto no emm de Salto a biotita tem $\mathrm{Fe}^{\mathrm{T}} /\left(\mathrm{Fe}^{\mathrm{T}}+\mathrm{Mg}\right)=0,41-0,45$, o mais baixo identificado no Batólito Itu. A biotita dos

emf de Salto tem $\mathrm{Fe}^{\mathrm{T}} /\left(\mathrm{Fe}^{\mathrm{T}}+\mathrm{Mg}\right)=(0,52-0,60)$, semelhantes aos do granito Itupeva, mas na amostra 2008-ITU-2.1A1 se estendem para maiores proporções de $\mathrm{Al}^{\mathrm{T}}$ (Figura 96). 




Figura 96 - Diagrama de classificação das biotitas analisadas do Batólito Itu segundo Anderson (2008).

Diversas trocas catiônicas podem ocorrer na biotita, e trocas envolvendo Ti e Al foram sumarizadas por Dymek (1983). A Figura 97 mostra uma diferença notável entre as biotitas dos granitos e as dos enclaves microgranulares máficos. $\mathrm{O}$ conteúdo de $\mathrm{Al}$ octaédrico dos granitos é sempre inferior a 0,1 apfu, chegando a valores próximos a zero em algumas amostras, enquanto os totais de Ti são sempre elevados (0,35-0,40 apfu). Já nos emm o $\mathrm{Al}^{\mathrm{VI}}$ varia entre 0,2 e 0,4 apfu, e uma clara correlação negativa entre $\mathrm{Al}^{\mathrm{VI}}$ e Ti é evidente entre as diferentes amostras de emm internamente a elas (Figura 97).

A correlação negativa entre $\mathrm{Ti}$ e $\mathrm{Al}^{\mathrm{VI}}$ reflete uma troca acoplada envolvendo exclusivamente o sítio octaédrico: $2\left(\mathrm{Al}^{3+}\right)^{\mathrm{VI}}=\left(\mathrm{Ti}^{4+}\right)^{\mathrm{VI}}+\left(\mathrm{R}^{2+}\right)^{\mathrm{VI}}$ (troca do Ti-espinélio; DYMEK, 1983), como demonstrado pela excelente correlação entre esses componentes dentro do conjunto dos granitos e entre estes e os enclaves microgranulares (Figura 98). 




Figura 97 - Diagrama Ti x Al ${ }^{\mathrm{IV}}$ (em apfu) das biotitas do Batólito Itu em correlação negativa.

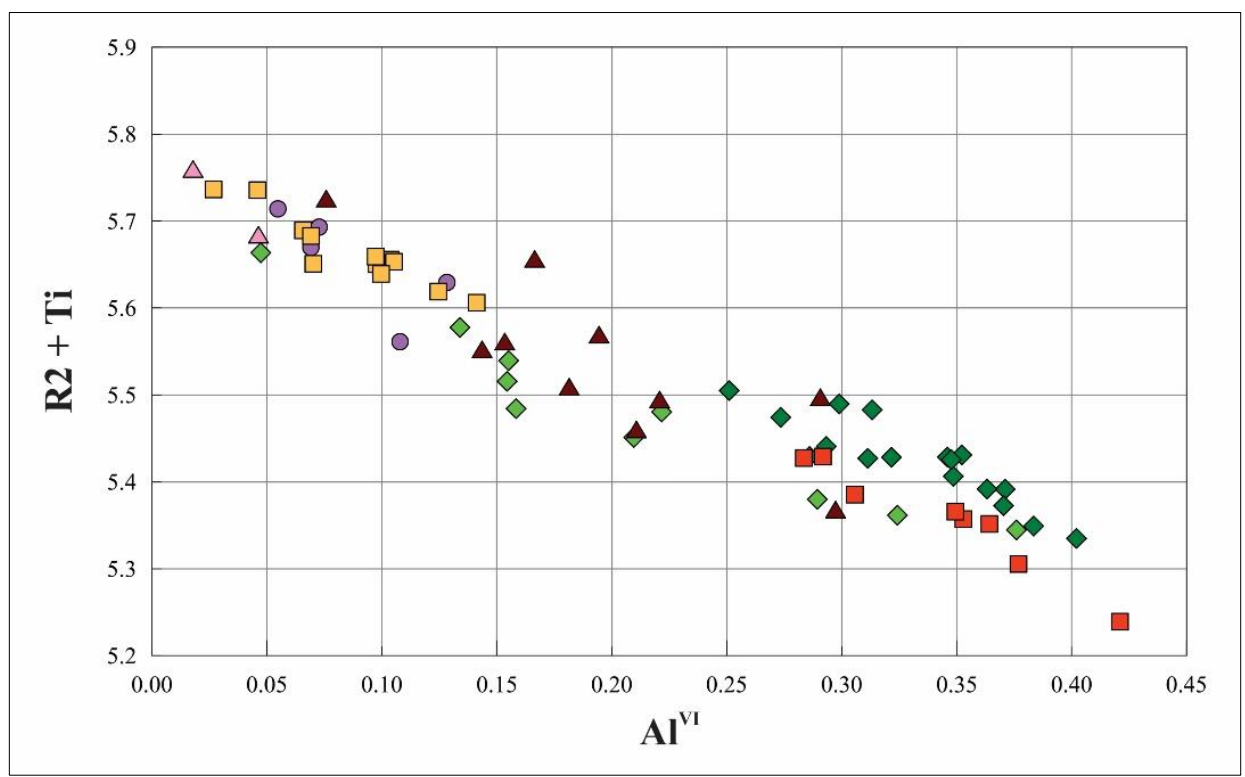

Figura 98 - Diagrama R2+Ti x Al ${ }^{\mathrm{IV}}$ (em apfu) das biotitas do Batólito Itu mostrando correlação negativa associada a troca Ti-espinélio (DYMEK, 1983). 


\subsection{ESTIMATIVAS DAS CONDIÇÕES DE CRISTALIZAÇÃO BASEADAS NA QUÍMICA MINERAL}

\subsubsection{Condições Redox}

A razão $\mathrm{Fe}^{3+} / \mathrm{Fe}^{2+}$ dos anfibólios é reflexo das condições redox $\left(f \mathrm{O}_{2}\right)$, mas não é medida diretamente na microssonda eletrônica. A adoção do cálculo da fórmula estrutural pelo método 13 cátions menos $\mathrm{Ca}, \mathrm{Na}, \mathrm{K}$ (13-CNK) é a mais recomendada para anfibólios cálcicos, e a razão $\mathrm{Fe}^{3+} / \mathrm{Fe}^{2+}$ calculada por esse método mostra boa correlação com o mg\#. Claramente, os anfibólios dos plútons Indaiatuba e Cabreúva refletem cristalização sob condições reduzidas, com valores típicos de $\mathrm{Fe}^{3+} / \mathrm{Fe}^{2+}=0,2-0,3$; conforme mostra mais claramente o mg\#, Indaiatuba tende a ser um pouco menos reduzido que Cabreúva (Figura 99). Análises realizadas em amostras dos plútons Salto e Itupeva mostram que em geral os anfibólios de suas rochas têm razões $\mathrm{Fe}^{3+} / \mathrm{Fe}^{2+}$ mais altas $(0,4-0,6)$, indicando cristalização sob condições mais oxidantes. No entanto, o emf da amostra 2008-ITU-2.1A1 do Plúton Salto tem baixa razão $\mathrm{Fe}^{3+} / \mathrm{Fe}^{2+}$ e mg\# equivalente ao do granito Indaiatuba, sugerindo variações importantes de $f \mathrm{O}_{2}$ naquele plúton.

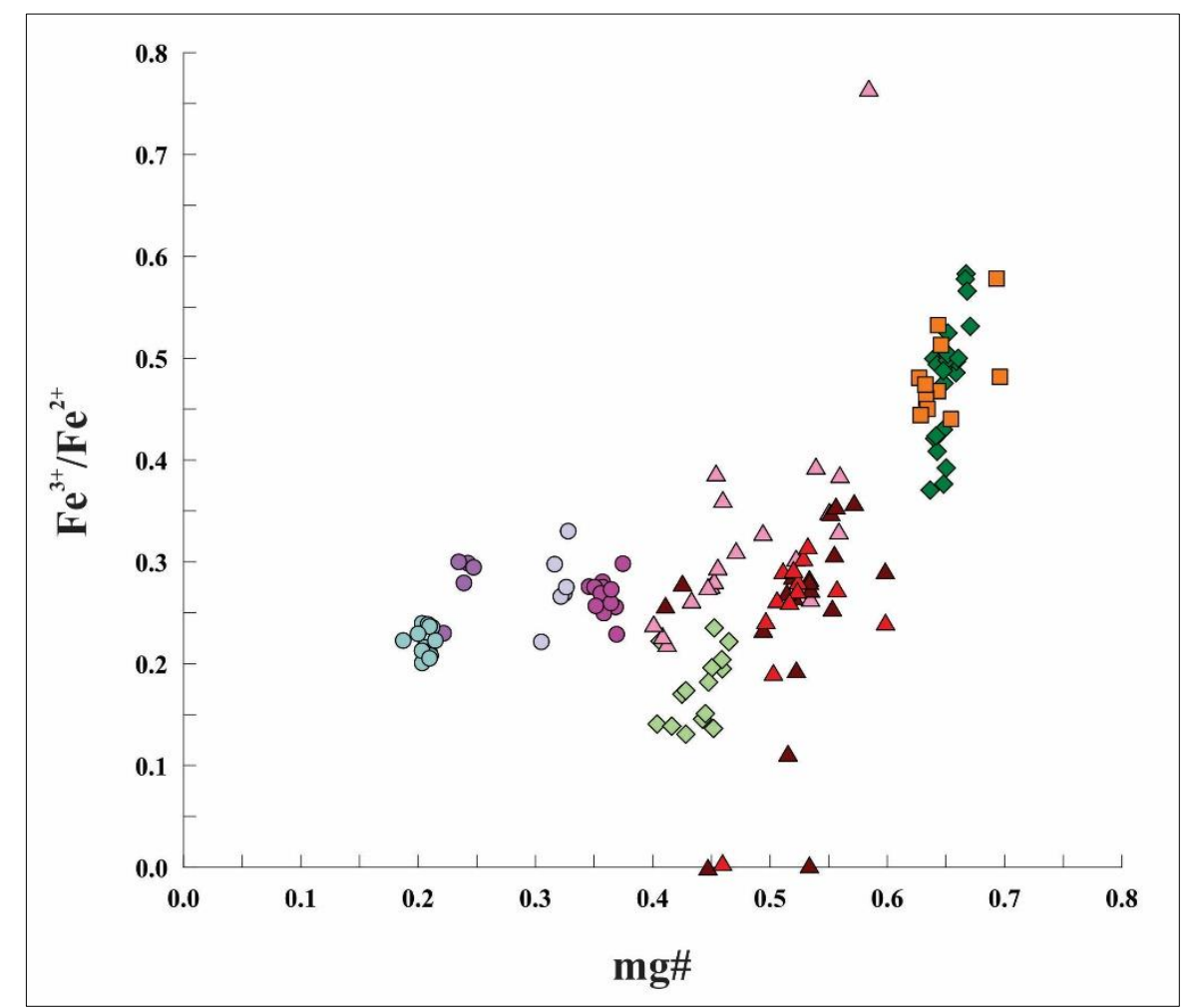

Figura 99 - Diagrama $\mathrm{Fe}^{3+} / \mathrm{Fe}^{2+} \mathrm{x}$ mg\# calculados com base em 13-CNK da fórmula estrutural dos anfibólios do Batólito Itu. 


\subsubsection{Pressão}

Conforme indicado na literatura, a estimativa de pressão idealmente deve ser realizada em hornblenda que coexiste com plagioclásio e tem mg\# < 0,65 (ANDERSON; SMITH, 1995). As amostras mais reduzidas (e com mg\# fora do intervalo recomendado) são a maioria do acervo obtido; apenas as amostras de Salto e Itupeva se encontram nessa faixa, e fornecem valores de pressão semelhantes, de 2,5-3,0 kbar (calibração de Mutch et al. (2016)), compatíveis com a situação geológica desses plútons (cf. Figura 100). Embora com mg\# um pouco mais alto que o da faixa recomendada, a amostra do Granito Indaiatuba indica valores de pressão na mesma faixa. As amostras de Cabreúva têm hornblenda muito rica em $\mathrm{Fe}$, e os valores de $\mathrm{P}$ mais elevados obtidos devem estar falseados, em função do maior componente Fe-edenítico nessas amostras.

Os valores de pressão obtidos com outras calibrações da literatura são apresentados na Tabela 5.



Figura 100 - Diagrama pressão x mg\# com P calculada pelo método de Mutch et al. (2016). 


\subsubsection{Temperatura}

A temperatura de cristalização de pares anfibólio-plagioclásio pode ser estimada com base na formulação de Blundy e Holland (1990) e Holland e Blundy (1994), os quais requerem estimativas independentes de pressão. Utilizando as pressões obtidas pela calibração de Mutch et al. (2016), as temperaturas obtidas são apresentadas na Tabela 5. Os valores mais consistentes são mostrados pela formulação baseada na troca edenita-richterita $\left(\mathrm{T}^{2}\right)$, que se situam entre 630 e $760^{\circ} \mathrm{C}$, e são sistematicamente mais baixos (entre 30 e $100^{\circ} \mathrm{C}$ ) que aqueles obtidos pela troca edenita-tremolita. A temperatura mais alta é obtida para o emf de Salto (2008-ITU-2.1A1), refletindo o rápido congelamento da rocha; em contraposição, os valores baixos $\left(\sim 630^{\circ} \mathrm{C}\right)$ no emm de Indaiatuba (CAB-15-34.2) sugerem reequilíbrio sob condições submagmáticas. As temperaturas obtidas para as amostras de granitos do Plúton Cabreúva refletem as condições de solidus, com destaque para o valor mais baixo $\left(\sim 677^{\circ} \mathrm{C}\right)$ para o granito mais diferenciado (CAB-16-80A), como esperado.

Tabela 5 - Resultados da geotermobarometria. Ab (plag) - teor de albita do plagiclásio do par Plag-Amph; Al ${ }^{\mathbf{T}}$ (amph) - Al total calculado da fórmula estrutural do anfibólio do par Plag-Amph; $\mathbf{T}^{\mathbf{1}}-\mathrm{T}$ calculada usando o geotermômetro Plag-Amph $\left(E d-\operatorname{Tr}^{1}\right) ; \mathbf{T}^{\mathbf{2}}-\mathrm{T}$ calculada usando o geotermômetro Plag-Amph $\left(\mathrm{Ed}-\mathrm{Ri}^{1}\right) ; \mathbf{P}^{\mathbf{1}}, \mathbf{P}^{\mathbf{2}}, \mathbf{P}^{\mathbf{3}} \mathrm{e}$ $\mathbf{P}^{4}$ - pressões calculadas utilizando diferentes geobarômetros.

\begin{tabular}{|l|c|c|c|c|c|c|c|c|}
\hline \multicolumn{1}{|c|}{ Amostra } & $\begin{array}{c}\mathbf{A b} \\
(\mathbf{p l a g})\end{array}$ & $\begin{array}{c}\mathbf{A l}^{\mathbf{T}} \\
(\mathbf{a m p h})\end{array}$ & $\begin{array}{c}\mathbf{T}^{\mathbf{1}}\left({ }^{\mathbf{0}} \mathbf{C}\right) \\
(\mathbf{e d - t r})\end{array}$ & $\begin{array}{c}\mathbf{T}^{\mathbf{2}}\left({ }^{\mathbf{0}} \mathbf{C}\right) \\
(\mathbf{e d - r i})\end{array}$ & $\begin{array}{c}\mathbf{P}^{\mathbf{1}} \\
(\mathbf{k b a r})\end{array}$ & $\begin{array}{c}\mathbf{P}^{\mathbf{2}} \\
(\mathbf{k b a r})\end{array}$ & $\begin{array}{c}\mathbf{P}^{\mathbf{3}} \\
(\mathbf{k b a r})\end{array}$ & $\begin{array}{c}\mathbf{P}^{\mathbf{4}} \\
(\mathbf{k b a r})\end{array}$ \\
\hline $\mathbf{2 0 0 8 - I T U - 2 . 1 A 1}$ & 0.74 & 1.259 & 818.6 & $\mathbf{7 6 3 . 9}$ & 1.55 & 2.85 & 4.18 & $\mathbf{2 . 4 9}$ \\
\hline CAB-15-34.1 & 0.85 & 0.889 & 660.3 & $\mathbf{6 3 3 . 3}$ & 1.30 & 1.36 & 1.24 & $\mathbf{1 . 5 8}$ \\
\hline CAB-15-34.2 & 0.87 & 1.013 & 682.5 & $\mathbf{6 3 0 . 0}$ & 1.78 & 1.98 & 1.83 & $\mathbf{1 . 8 6}$ \\
\hline CAB-14-09 & 0.81 & 1.314 & 749.5 & $\mathbf{7 1 3 . 8}$ & 2.32 & 2.86 & 3.28 & $\mathbf{2 . 6 5}$ \\
\hline CAB-16-80A & 0.89 & 1.501 & 744.9 & $\mathbf{6 7 6 . 6}$ & 3.22 & 4.17 & 4.18 & $\mathbf{3 . 2 4}$ \\
\hline CAB-16-90 & 0.81 & 1.664 & 845.6 & $\mathbf{7 4 5 . 8}$ & 1.35 & 3.89 & 4.94 & $\mathbf{3 . 8 1}$ \\
\hline CAB-16-91B & 0.81 & 1.503 & 793.0 & $\mathbf{7 1 7 . 9}$ & 2.20 & 3.66 & 4.18 & $\mathbf{3 . 2 5}$ \\
\hline
\end{tabular}

Fonte: $\mathbf{T}^{\mathbf{1}}$ e $\mathbf{T}^{\mathbf{2}}$ - HOLLAND; BLUNDY (1994); $\mathbf{P}^{1}$ - ANDERSON; SMITH (1995); $\mathbf{P}^{2}$ - ANDERSON (1996); $\mathbf{P}^{3}$ - SCHMIDT (1992); $\mathbf{P}^{4}-$ MUTCH et al. (2016).

Também foram calculadas temperaturas baseadas nos teores Ti das biotitas do Batólito Itu, conforme mostra a Figura 101. Os maiores valores médios de temperatura $\left(\sim 780^{\circ} \mathrm{C}\right)$ são uma vez mais obtidos para emf do Plúton Salto e os menores $\left(\sim 610^{\circ} \mathrm{C}\right)$ para um enclave microgranular máfico do Plúton Itupeva. As maiores dispersões de valores ocorrem nos emm, refletindo processos de recristalização a temperaturas variadas. 




Figura 101 - Variações na razão $\mathrm{Mg} /(\mathrm{Mg}+\mathrm{Fe})$ x Ti das biotitas analisadas do Batólito Itu. Modificado de Henry, Guidotti e Thomson (2005).

\subsection{DIAGRAMAS DISCRIMINANTES BASEADOS NA QUÍMICA DE BIOTITA}

Abdel-Rahman (1994) sugeriu diagramas baseados na química de biotitas para discriminar entre a natureza de magmas alcalinos $(\mathrm{A})$, peraluminosos ( $\mathrm{P}$ - incluindo magmas de tipo $\mathrm{S}) \mathrm{e}$ cálcio-alcalinos (C) (Figura 102). Nesse diagrama, as biotitas dos granitos Cabreúva e Indaiatuba caem no campo alcalino, enquanto as biotitas dos enclaves microgranulares máficos se situam no cálcio-alcalino. A amostra do granito Itupeva, por sua vez, se situa no limite entre os campos. 




Figura 102 - Diagrama discriminante $\mathrm{FeO}^{\mathrm{T}}-\mathrm{MgO}-\mathrm{Al}_{2} \mathrm{O}_{3}$ para a natureza dos magmas originários das rochas que contêm as biotitas analisadas do Batólito Itu. Modificado de Abdel-Rahman (1994).

Petrograficamente, os cristais de biotita são, por vezes, reconhecidos como secundários, o que é justificado nas figuras 103 e 104, onde são discriminadas biotitas magmáticas, hidrotermais e neoformadas; é comum a ocorrência de clorita associada em estágios hidrotermais, principalmente nos emm dos plútons Salto e Indaiatuba (amostras 2008-ITU2.1C, CAB-15-34.1 e CAB-15-34.2).



Figura 103 - Diagrama de variação de Gokhale $\left(\mathrm{FeO}^{\mathrm{T}}-\mathrm{MgO}-\mathrm{Al}_{2} \mathrm{O}_{3}\right)$ para a distinção da natureza das biotitas analisadas do Batólito Itu. Modificado de Gokhale (1968). 


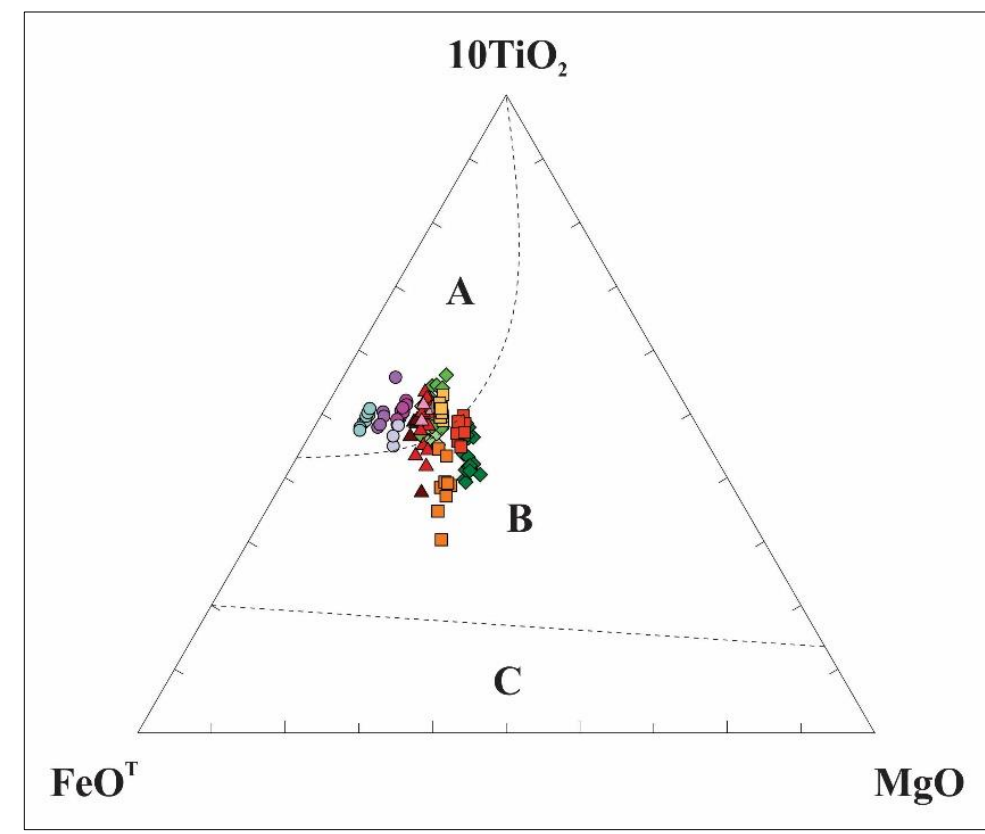

Figura 104 - Diagrama triangular discriminante conforme a composição química de biotitas de diferentes origens. (A) Domínio das biotitas magmáticas primárias; (B) Domínio das biotitas reequilibradas; (C) Domínio das biotitas neoformadas. Limites do diagrama segundo Nachit et al. (2005). 


\section{CAPÍTULO 7 - GEOOUÍMICA DE ROCHA TOTAL}

Existe na literatura prévia um importante acervo de dados geoquímicos para todo o batólito (GALEMBECK, 1997) e para o Plúton Cabreúva (9 amostras apresentadas por Töpfner, 1996). Esses dados foram tabulados e utilizados ao longo do desenvolvimento desta tese para comparação e orientação de sítios afim de novas determinações. No entanto, eles não estão sendo considerados em diagramas de variação química em conjunto com os dados aqui obtidos, em vista de terem sido obtidos em laboratórios e épocas muito distintos. Em particular, a avaliação dos resultados apresentados por Galembeck (1997) mostra um acervo numeroso, mas de qualidade heterogênea. Deste modo, para o banco de dados de referência montado durante esta tese, se fez uma filtragem daqueles resultados, mantendo-se aqueles avaliados como de melhor qualidade. Estes resultados filtrados são, em linhas gerais, consistentes com os de Töpfner (1996) e com os aqui obtidos, mas em vista do caráter fracionado da maior parte dos granitos, em que sutis diferenças em alguns elementos podem ser significativas, optou-se, por considerar, nos diagramas discriminantes utilizados, apenas as amostras obtidas neste projeto, que são suficientes para caracterizar adequadamente as variações observadas nos plútons estudados.

\subsection{PLÚTON CABREÚVA}

Foram obtidas análises químicas de 17 amostras de rochas do Plúton Cabreúva. Os resultados são apresentados nas Tabelas $\mathrm{C} 1$ e C2 do Apêndice C; foram elaborados diagramas de variação usando $\mathrm{SiO}_{2}$ como índice de diferenciação os quais são apresentados nas Figuras 105 a 109 (elementos maiores menores e traço).

Cinco conjuntos de rochas foram considerados:

(1) sienogranito grossos que constituem a porção principal do plúton (equivalentes à fácies CB-6 de Galembeck, 1997) - CAB-sgr;

(2) granitos porfiríticos da porção central do plúton (fácies CB-5; uma única amostra, CAB16-90), aos quais se associam uma rocha cumulática equivalente à fácies CB-1 ("quartzo monzodiorito esbranquiçado", amostra CAB-16-91B) e um leucogranito equigranular fino a médio (CAB-14-15) - CAB-grp;

(3) enclaves microgranulares félsicos, todos eles encontrados dentro dos sienogranito grossos - CAB-emf; 
(4) e (5), respectivamente granitos hololeucocráticos das bordas oeste (amostras IGN-24 e IGN-28) e leste (amostras CAB-14-18 e CAB-15-82) - CAB-bW e CAB-bE.

Os sienogranitos grossos típicos são bastante diferenciados, com teores de $\mathrm{SiO}_{2}$ entre 72 e $75 \%$; exceção é a amostra CAB-14-09, da borda norte do plúton, com $\sim 70 \%$ de $\mathrm{SiO}_{2}$. Os enclaves microgranulares félsicos (emf) hospedados nesses sienogranitos são

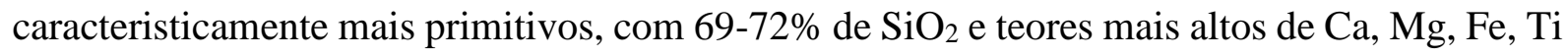
e P (Figuras 105 e 106). Os elementos traço mostram outras diferenças importantes entre os emf e os sienogranitos; os emf são mais ricos em $\mathrm{Zr}$, Nb e $\mathrm{Sr}$, mas têm teores mais baixos de $\mathrm{Ba}$, Sr e Ce do que a tendência dos sienogranitos. Os emf também se distinguem por teores mais altos de U, mas não de Th (Figura 109), de modo que a razão Th/U os separa claramente dos sienogranitos, exceto a amostra CAB-16-79, que segue a mesma tendência dos emf.

A única amostra de granito porfirítico analisada da unidade CB-5 de Galembeck (1997) mostra um comportamento distinto, em todos os diagramas, semelhante ao do granito CAB-1409, amostra menos diferenciada do grupo dos sienogranitos grossos. O leucogranito equigranular associado a esta unidade tem comportamento semelhante às amostras mais diferenciadas do grupo dos sienogranitos grossos, exceto por teores notavelmente mais altos de Rb, F, Th e U (Figuras 107 e 109). O quartzo monzodiorito cumulático distingue-se por seu caráter mais primitivo, destacado não apenas pelo teor muito mais baixo de $\mathrm{SiO}_{2}(\sim 61 \%)$, mas por teores mais altos dos óxidos presentes no plagioclásio $(\mathrm{Ca}, \mathrm{Na}, \mathrm{Al})$, minerais máficos $(\mathrm{Ca}$, $\mathrm{Fe}, \mathrm{Mg}$ ), e minerais acessórios comuns (Ti, P, Zr, Nb); no entanto, os teores de Ce, Y, Th e U são relativamente baixos (Figuras 108 e 109), e o teor de K é muito mais baixo ( 2,5\%), refletindo a pouca abundância de feldspato alcalino.

Os granitos hololeucocráticos das duas bordas do plúton apresentam, como esperado, os mais altos teores de $\mathrm{SiO}_{2}$ (75-77\%), mas mostram comportamento contrastante entre si. Os granitos da borda oeste, que se assemelham texturalmente aos sienogranitos grossos, se comportam como parte da tendência evolutiva da unidade principal. Em contraposição, os granitos da borda leste, embora algo diferentes entre si, diferem dos da borda oeste (e deste modo se deslocam da tendência geral do Plúton Cabreúva) em alguns aspectos importantes, como teores mais baixos de Rb, F, Nb, Y, Th e U (Figuras 107, 108 e 109). É provável, portanto, que não sejam comagmáticos com a unidade principal.

A tendência geral de evolução geoquímica do Plúton Cabreúva, consideradas as unidades de sienogranitos grossos e granitos hololeucocráticos da borda oeste, fica bem definida com empobrecimento progressivo dos óxidos de $\mathrm{Mg}$, Fe, Ca, Al, Ti e P, e também de K a partir de 
$74 \%$ de $\mathrm{SiO}_{2}$ (Figuras 105 e 106). Entre os elementos traço, observa-se o empobrecimento de $\mathrm{Ba}, \mathrm{Sr}, \mathrm{Zr}$ e Ce, e enriquecimento de Rb, Nb, Th e F (Figuras 107, 108 e 109).


\section{- CAB-sgr \\ - CAB-gpr \\ - CAB-emf \\ - CAB-bW \\ O CAB-bE}

CABREÚVA

Figura 105 - Diagramas de variação utilizando o teor de $\mathrm{SiO}_{2}$ como índice de diferenciação para as amostras do Plúton Cabreúva. 



\section{CABREÚVA}

- CAB-sgr

- CAB-gpr

- CAB-emf

- CAB-bW

O CAB-bE

Figura 106 - Diagramas de variação utilizando o teor de $\mathrm{SiO}_{2}$ como índice de diferenciação para as amostras do Plúton Cabreúva. 



\section{- CAB-sgr \\ - CAB-gpr \\ - $\mathrm{CAB}-\mathrm{emf}$ \\ - CAB-bW \\ O CAB-bE}

CABREÚVA

Figura 107 - Diagramas de variação utilizando o teor de $\mathrm{SiO}_{2}$ como índice de diferenciação para as amostras do Plúton Cabreúva. 



\section{CABREÚVA}



Figura 108 - Diagramas de variação utilizando o teor de $\mathrm{SiO}_{2}$ como índice de diferenciação para as amostras do Plúton Cabreúva. 



\section{CABREÚVA}

- CAB-sgr

- CAB-gpr

- CAB-emf

- CAB-bW

O CAB-bE

Figura 109 - Diagramas de variação utilizando o teor de $\mathrm{SiO}_{2}$ como índice de diferenciação para as amostras do Plúton Cabreúva.

Os padrões de ETR dos diferentes conjuntos de granitos do Plúton Cabreúva são apresentados nas Figuras 110 e 111.

De um modo geral, os padrões são pouco fracionados, com fortes anomalias negativas de Eu (Figura 111). Entre os sienogranitos grossos, o fracionamento dos ETR, medido pela razão $(\mathrm{La} / \mathrm{Yb})_{\mathrm{N}}$, diminui com o aumento de $\mathrm{SiO}_{2}$ (de 20-25 para 10-11 - Figura 110), enquanto a anomalia negativa de $\mathrm{Eu}\left(\mathrm{Eu} / \mathrm{Eu}^{*}\right)_{\mathrm{N}}$ se torna mais acentuada (de 0,50 para 0,18). Como nos demais elementos traço, o granito porfirítico da unidade CB-5 de Galembeck (1997) tem comportamento semelhante ao dos sienogranitos grossos menos diferenciados, e os granitos hololeucocráticos da borda oeste se comportam como membros mais fracionados, alcançando as mais baixas razões $(\mathrm{La} / \mathrm{Yb})_{\mathrm{N}}(7)$ e $\left(\mathrm{Eu} / \mathrm{Eu}^{*}\right)_{\mathrm{N}}(0,08)$. Os granitos hololeucocráticos da borda 
leste uma vez mais destoam do conjunto, por apresentarem padrões de ETR fracionados (Figuras 110 e 111), com razões $(\mathrm{La} / \mathrm{Yb})_{\mathrm{N}}=30-35$.
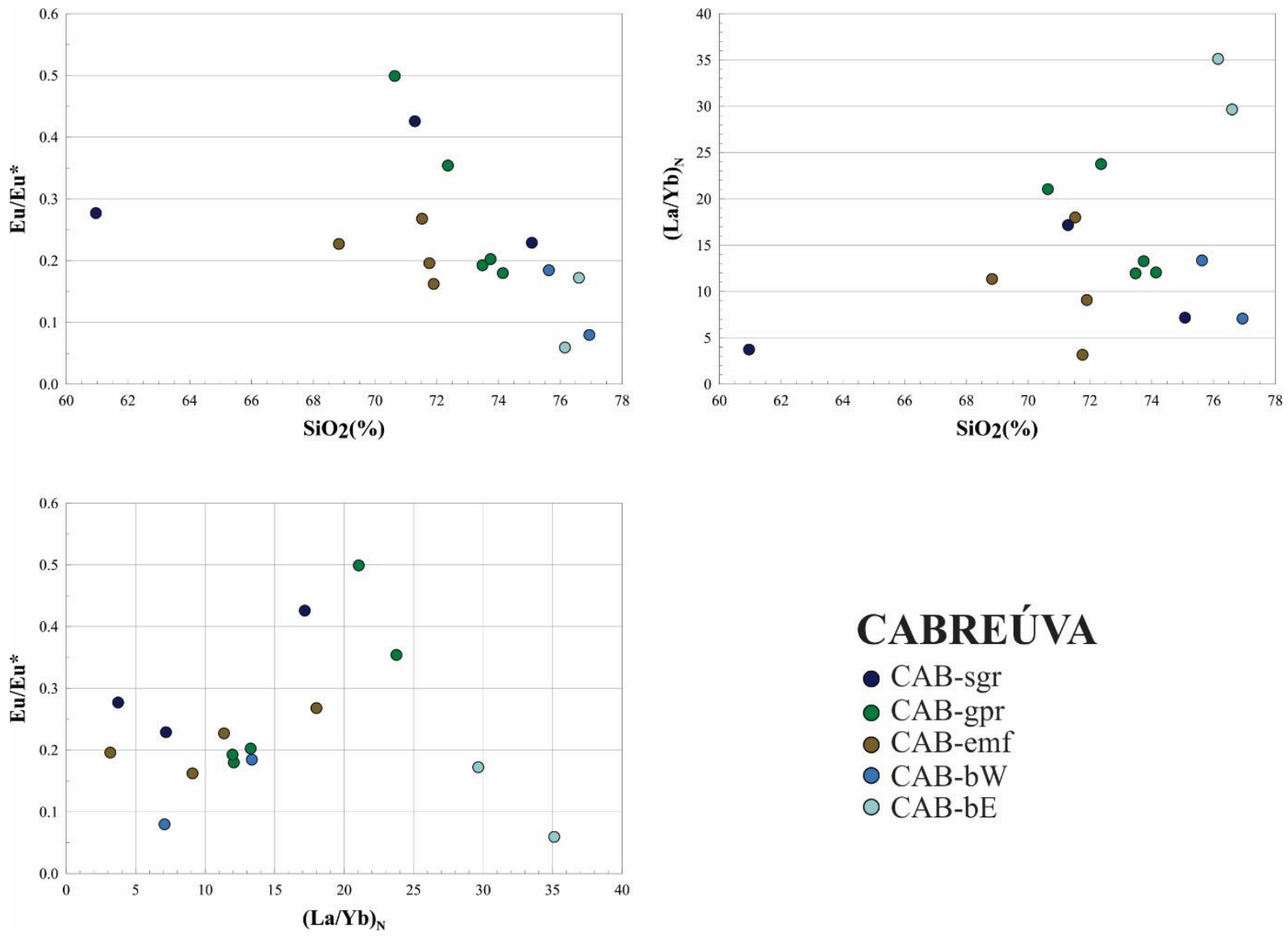

\section{CABREÚVA}

- $\mathrm{CAB}-\mathrm{sgr}$

- CAB-gpr

- CAB-emf

- CAB-bW

O CAB-bE

Figura 110 - Diagramas de variação de ETR utilizando o teor de $\mathrm{SiO}_{2}$ como índice de diferenciação para as amostras do Plúton Cabreúva, com exceção do diagrama Eu/Eu* x $(\mathrm{La} / \mathrm{Yb})_{\mathrm{N}}$. 



Figura 111 - Padrões de fracionamento dos ETR das amostras do Plúton Cabreúva, normalizados segundo Boynton (1984).

\subsection{PLÚTON INDAIATUBA}

Galembeck (1997) descreveu o Plúton Indaiatuba como formado por uma única unidade, um sienogranito porfiróide rapakivi (ID-1), cuja geometria irregular sugere tratar-se de partes de um corpo que foi recortado por intrusões posteriores. As observações de campo, no entanto, 
mostram a ocorrência de outras variedades petrográficas associadas, em especial, granitos equigranulares finos, os quais em vários afloramentos são vistos intrudindo os granitos rapakivi, e corpos máficos, na forma de enclaves microgranulares máficos ou corpos isolados (cf. Capítulo 4). Uma variedade de granito inequigranular grosso (amostra CAB-15-44), aflorante a oeste da cidade de Itupeva e claramente associada aos granitos rapakivi, atribuída por Galembeck (1997) ao Plúton Cabreúva, foi aqui considerada parte do Plúton Indaiatuba.

Foram considerados quatro conjuntos de rochas para o Plúton Indaiatuba cujos resultados das análises químicas são apresentados nas Tabelas C3 e C4 do Apêndice C:

(1) granitos inequigranulares rapakivi grossos que constituem a unidade principal do plúton (amostras IGN-50B, CAB-14-01B, CAB-14-06A e CAB-15-36B) - IND-rap;

(2) granitos equigranulares finos (amostras CAB-15-35 e CAB-15-50A) a médios (amostra CAB-14-04) intrusivos no granito rapakivi grosso, além de corpos aplíticos associados (amostra CAB-15-50E) - IND-eq;

(3) enclaves microgranulares máficos (amostras CAB-14-06C e CAB-15-34) e corpos máficos associados (quartzo monzonito - amostra $\mathrm{CAB}-15-50 \mathrm{~B}$; monzogabro - amostra CAB15-57) - IND-maf.

(4) granito inequigranular grosso aflorante a W da cidade de Itupeva e associado aos INDrap (amostra CAB-15-44) - IND-sgr.

As Figuras 112 a 116 mostram a variação química das rochas do Plúton Indaiatuba para elementos maiores, menores e traço, comparando-as com rochas do Plúton Cabreúva, já descritas acima.

Os sienogranitos rapakivi têm intervalo composicional restrito, entre 70 e $72 \% \mathrm{SiO}_{2}$, enquanto os granitos equigranulares finos que os invadem são mais diferenciados, com 74 a $76 \%$ de $\mathrm{SiO}_{2}$. Existe uma tendência geral de variação definida pelos dois conjuntos, com diminuição de todos os óxidos, inclusive o $\mathrm{K}$, com o aumento de $\mathrm{SiO}_{2}$; exceção é o $\mathrm{Na}$, que não mostra tendência evidente, e chega a ser ligeiramente mais elevado em algumas amostras de granito equigranular (Figuras 112 e 113). Diversos elementos traço também mostram teores mais baixos nos granitos equigranulares, notavelmente Ba, Sr, Zr, Zn e Ce (Figuras 114 e 115). Aumento de concentração é observada para Rb e, nas amostras CAB-14-04 e CAB-15-50E, também para Th, U e Nb (Figuras 114, 115 e 115).

As quatro amostras de rochas máficas do Plúton Indaiatuba têm teores de $\mathrm{SiO}_{2}$ entre 50 e $58 \%$, caracterizando-se um hiato composicional de cerca de $10 \%$ de $\mathrm{SiO}_{2}$ entre elas e os granitos mais primitivos. Trata-se de um conjunto heterogêneo. A amostra CAB-15-57, que ocorre como blocos isolados, e distingue-se petrograficamente pela presença de clinopiroxênio e plagioclásio 
de composição labradorita, corresponde quimicamente a um monzogabro com $50 \% \mathrm{SiO}_{2} \mathrm{e}$ conteúdo relativamente alto de $\mathrm{MgO}(5,6 \%), \mathrm{CaO}(8,4 \%)$; a rocha tem $0,57 \% \mathrm{P}_{2} \mathrm{O}_{5}, 1,9 \% \mathrm{TiO}_{2}$, 1070 ppm Ba e 680 ppm Sr. As amostras CAB-15-34 e CAB-15-50B têm $\mathrm{SiO}_{2}$ entre 54 e 57\% e compartilham algumas características significativas, como teores elevados de $\mathrm{TiO}_{2}(2-2,2 \%)$, $\mathrm{P}_{2} \mathrm{O}_{5}(0,9-1 \%), \mathrm{Ba}(2300$ - 2400 ppm) e Sr (500 - 800 ppm). A amostra CAB-15-06C tem o mais alto teor de $\mathrm{SiO}_{2}$ do grupo - 58\%) e se distingue por teores elevados de $\mathrm{Nb}, \mathrm{Zr}, \mathrm{Y}$ e Th (Figuras 115 e 116).


\section{CABREÚVA}



INDAIATUBA
$\triangle$ IND-rap
$\triangle$ IND-eq
$\triangle$ IND-maf
$\Delta$ IND-sgr

Figura 112 - Diagramas de variação utilizando o teor de $\mathrm{SiO}_{2}$ como índice de diferenciação para as amostras dos plútons Cabreúva e Indaiatuba. 



CABREÚVA

- CAB-sgr

- CAB-gpr

- CAB-emf

- CAB-bW

O CAB-bE

\section{INDAIATUBA}
$\triangle$ IND-rap
$\triangle \mathrm{IND}$-eq
$\triangle$ IND-maf
$\Delta$ IND-sgr

Figura 113 - Diagramas de variação utilizando o teor de $\mathrm{SiO}_{2}$ como índice de diferenciação para as amostras dos plútons Cabreúva e Indaiatuba. 



\section{CABREÚVA}

- CAB-sgr

- CAB-gpr

- CAB-emf

- CAB-bW

O CAB-bE

\section{INDAIATUBA}
$\triangle$ IND-rap
$\triangle$ IND-eq
$\triangle$ IND-maf
$\Delta$ IND-sgr

Figura 114 - Diagramas de variação utilizando o teor de $\mathrm{SiO}_{2}$ como índice de diferenciação para as amostras dos plútons Cabreúva e Indaiatuba. 



CABREÚVA

- CAB-sgr

- CAB-gpr

- CAB-emf

- CAB-bW

O CAB-bE

\section{INDAIATUBA}
$\triangle$ IND-rap
$\triangle$ IND-eq
$\triangle$ IND-maf
$\Delta$ IND-sgr

Figura 115 - Diagramas de variação utilizando o teor de $\mathrm{SiO}_{2}$ como índice de diferenciação para as amostras dos plútons Cabreúva e Indaiatuba. 



\section{CABREÚVA}

- CAB-sgr

- CAB-gpr

- CAB-emf

- CAB-bW

o CAB-bE

\section{INDAIATUBA}

$\triangle$ IND-rap

$\triangle$ IND-eq

$\triangle$ IND-maf

$\Delta$ IND-sgr

Figura 116 - Diagramas de variação utilizando o teor de $\mathrm{SiO}_{2}$ como índice de diferenciação para as amostras dos plútons Cabreúva e Indaiatuba.

Os padrões de ETR dos diferentes conjuntos de rochas do Plúton Indaiatuba são mostrados nas Figuras 117 e 118.

Observa-se uma tendência de diminuição do fracionamento dos ETR $\left((\mathrm{La} / \mathrm{Yb})_{\mathrm{N}}\right.$ de 26 até 9) e aumento da anomalia negativa de $\mathrm{Eu}\left(\left(\mathrm{Eu} / \mathrm{Eu}^{*}\right)_{\mathrm{N}}\right.$ de 0,56 a 0,21$)$ com o aumento de $\mathrm{SiO}_{2}$ (Figura 117), análoga ao observado em Cabreúva. As rochas máficas têm padrões de ETR moderadamente fracionados $\left((\mathrm{La} / \mathrm{Yb})_{\mathrm{N}}\right.$ em torno de 10; exceto na amostra CAB-15-34, chegando a 18) com fracas anomalias negativas de $\mathrm{Eu}\left(\left(\mathrm{Eu} / \mathrm{Eu}^{*}\right)_{\mathrm{N}}=0,92-0,95\right)$, exceto na amostra mais diferenciada (CAB-14-06C), onde a anomalia é acentuada $(0,42)$. 

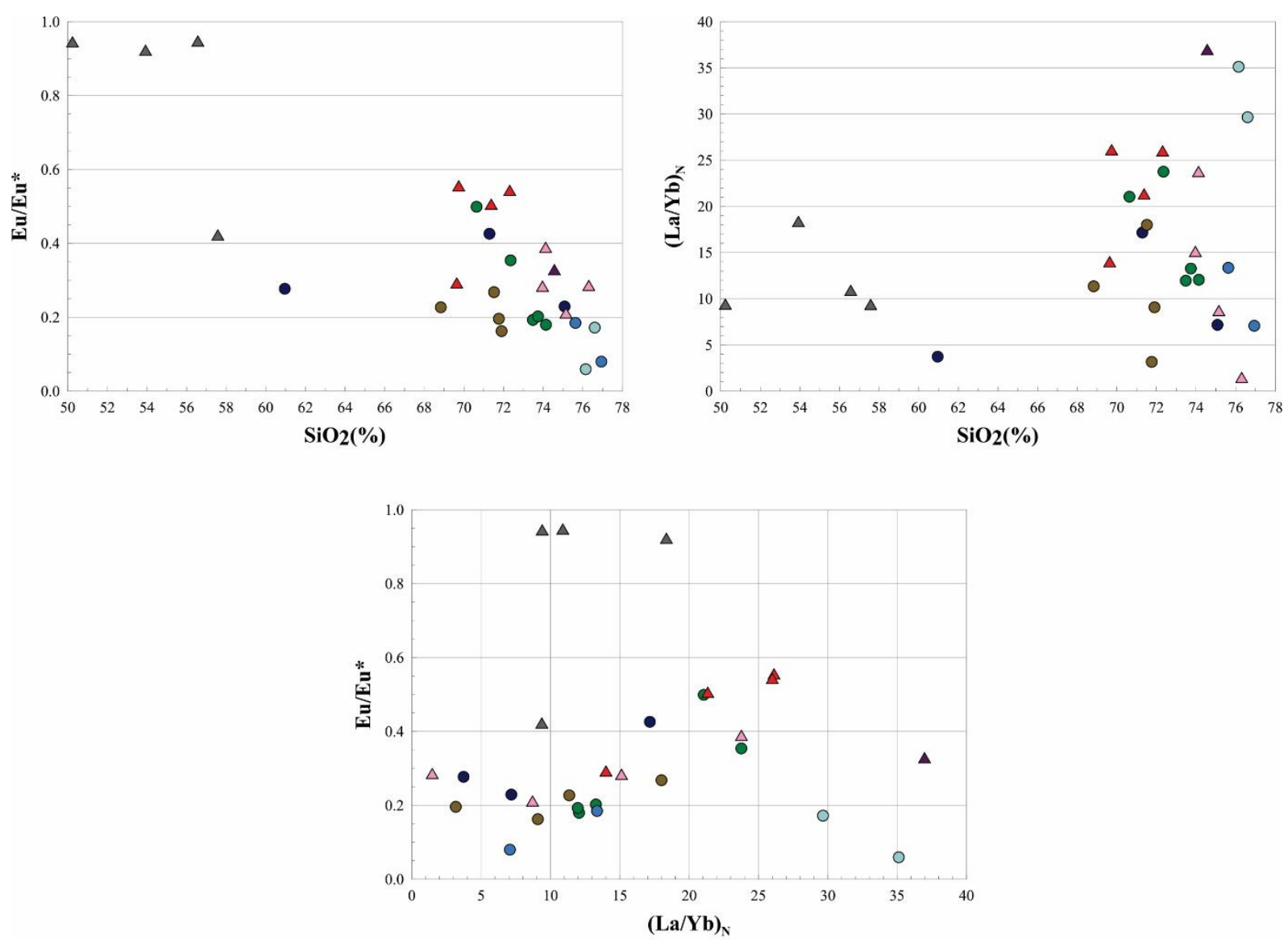

\section{CABREÚVA}

- CAB-sgr

- CAB-gpr

- CAB-emf

- CAB-bW

O CAB-bE

\section{INDAIATUBA}
$\triangle$ IND-rap
$\triangle$ IND-eq
$\triangle$ IND-maf
$\Delta$ IND-sgr

Figura 117 - Diagramas de variação de ETR utilizando o teor de $\mathrm{SiO}_{2}$ como índice de diferenciação para as amostras do Plúton Cabreúva, com exceção do diagrama Eu/Eu* x $(\mathrm{La} / \mathrm{Yb})_{\mathrm{N}}$. 

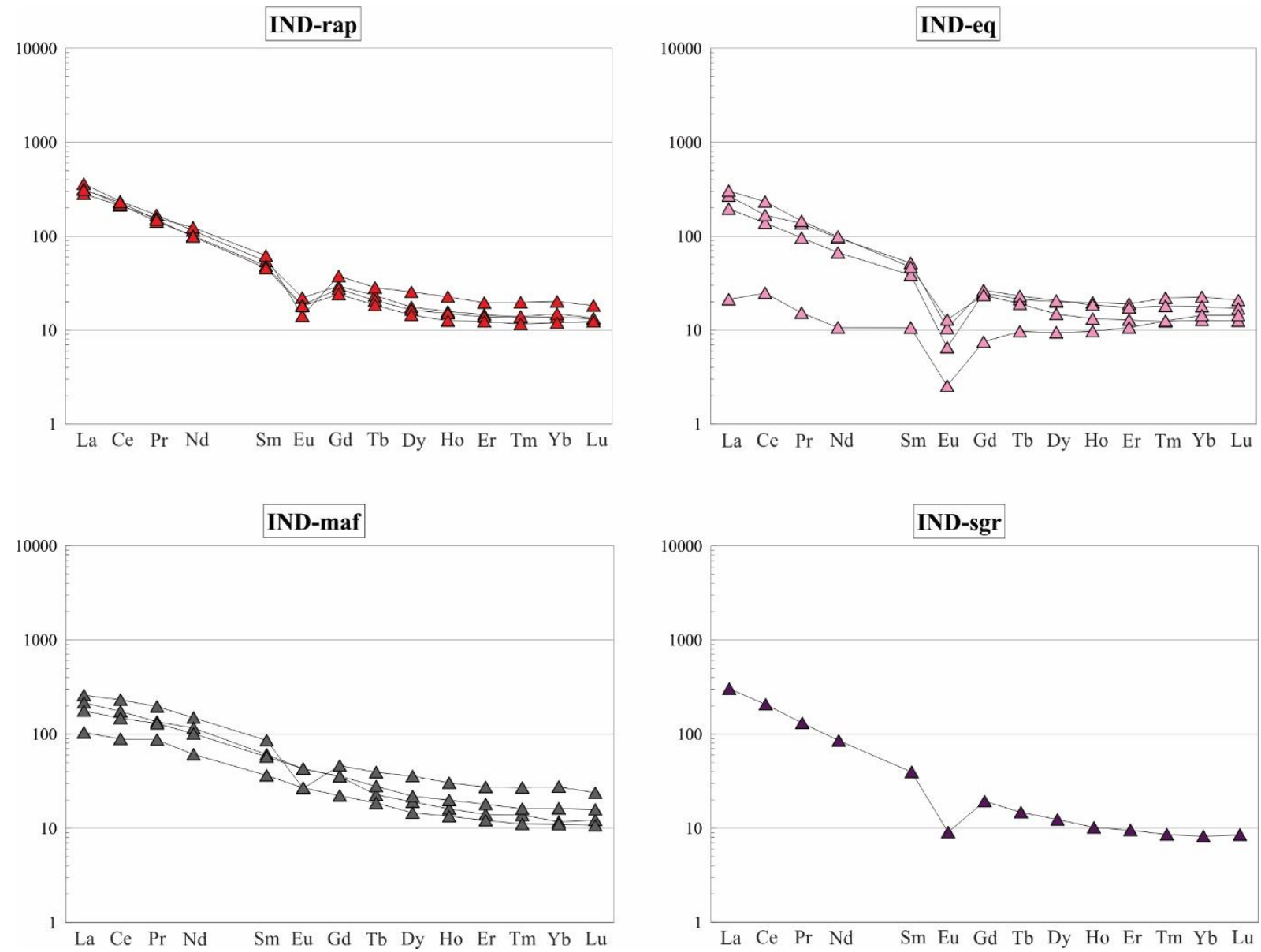

Figura 118 - Padrões de fracionamento dos ETR das amostras do Plúton Indaiatuba, normalizados segundo Boynton (1984).

As Figuras 112 a 117 também permitem a comparação entre os granitos do Plúton Indaiatuba com as variedades encontradas no Plúton Cabreúva. Considerando as unidades principais dos dois plútons, os sienogranitos rapakivi de Indaiatuba se comportam como rochas mais primitivas em relação aos sienogranitos grossos de Cabreúva. Para praticamente todos os elementos, existe superposição de teores entre os sienogranitos rapakivi e os granitos de Cabreúva com teores de $\mathrm{SiO}_{2}$ similar (mas não com os emf de Cabreúva, os quais se distinguem dos granitos hospedeiros, como descrito anteriormente). Uma exceção notável é o Th, que é sistematicamente mais alto em Indaiatuba, e também nos granitos equigranulares associados a eles (Figura 116). Um detalhe do comportamento do $\mathrm{MgO}$ para os granitos mostra que os granitos equigranulares de Indaiatuba (com uma exceção da amostra CAB-15-50A, que se associa diretamente com rocha máfica) têm teores de $\mathrm{MgO}$ muito baixos $(0,02-0,05 \%)$, claramente distintos dos sienogranitos Cabreúva com teores equivalentes de $\mathrm{SiO}_{2}$, no que são acompanhados pelo granito inequigranular grosso CAB-15-44 e pelo leucogranito equigranular fino a médio associado à unidade central de Cabreúva (Figura 112). 


\subsection{COMPARAÇÃO COM OS DEMAIS PLÚTONS DO BATÓLITO ITU}

Os diagramas de variação das Figuras 129 e 120 foram elaborados para fins de comparação geoquímica entre os Plútons Cabreúva e Indaiatuba e os outros dois plútons que constituem o Batólito Itu (aqui, outliers foram desconsiderados). As análises do Plúton Salto (granitos rapakivi) foram retiradas do trabalho de mestrado da autora (PEREIRA, 2013), e as análises do Plúton Itupeva (somente amostras de granitos) são provenientes da Dissertação de Mestrado de Viviana M. Monsálvez (em elaboração) - Tabelas C5 a C8 do Apêndice C.

Para facilitar a comparação, foram traçadas linhas de tendência para as variações observadas no Plúton Salto e para a unidade principal de sienogranitos grossos do Plúton Cabreúva (CABsgr), utilizando o ajuste polinomial (fit) de $2^{\mathrm{a}}$ ordem do programa Grapher. Os diagramas mostram que, para teores equivalentes de $\mathrm{SiO}_{2}$, os granitos do Plúton Salto apresentam teores mais elevados de $\mathrm{Al}, \mathrm{Mg}, \mathrm{P}, \mathrm{Ba}$ e $\mathrm{Sr}$ se comparados aos granitos dos plútons Cabreúva e Indaiatuba. Os granitos do Plúton Itupeva mostram diferenças semelhantes a Salto, com teores ainda mais elevados de $\mathrm{P}, \mathrm{Ba}$ e $\mathrm{Sr}$; além disto, mostram ainda teores mais elevados de $\mathrm{Ca}$ e mais baixos de Zr. No Plúton Itupeva, o enriquecimento em P, Ba e Sr é também observado nas rochas mais máficas que, deste modo, parecem equivalentes um pouco mais ricos em $\mathrm{SiO}_{2}$ das amostras de rochas máficas, como CAB-15-34 e CAB-15-50B, do Plúton Indaiatuba. 

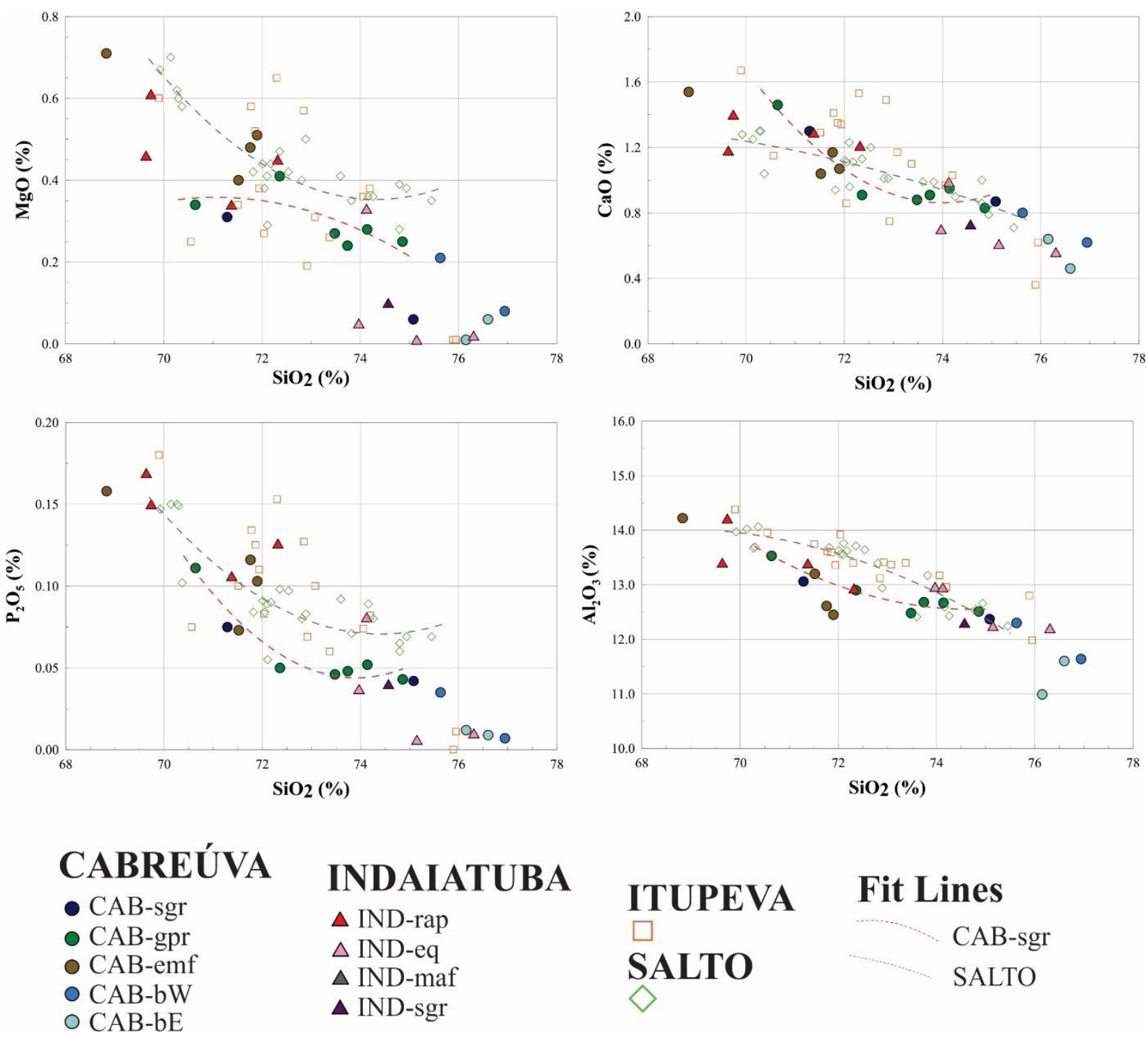

ITUPEVA Fit Lines

SALTO

CAB-sgr

SALTO

Figura 119 - Diagramas de variação utilizando o teor de $\mathrm{SiO}_{2}$ como índice de diferenciação para as amostras dos plútons que compõem o Batólito Itu. 



\section{CABREÚVA}

- CAB-sgr

- CAB-gpr

- CAB-emf

- CAB-bW

o CAB-bE
INDAIATUBA

$\triangle$ IND-rap

$\triangle$ IND-eq

$\triangle$ IND-maf

$\Delta$ IND-sgr

\section{ITUPEVA Fit Lines}

SALTO

CAB-sgr

SALTO

Figura 120 - Diagramas de variação utilizando o teor de $\mathrm{SiO}_{2}$ como índice de diferenciação para as amostras dos plútons que compõem o Batólito Itu.

\subsubsection{Características geoquímicas dos granitos do Batólito Itu}

Frost et al. (2001) propuseram uma classificação para rochas graníticas baseada no número de número de $\mathrm{Fe}$ ou $\mathrm{Fe}^{*}$, fator pelas quais podem ser divididas em dois grupos: ferroanos ou magnesianos. Essa razão é um indicador sensível da região fonte de magmas graníticos e das sequências de cristalização subsequentes. Enquanto melts enriquecidos em $\mathrm{Fe}$ derivados de fontes basálticas (tanto toleíticas como moderadamente alcalinas) contribuem para granitoides ferroanos, granitoides magnesianos, em contraste, são provavelmente derivados de magmatismo de arco de ilhas, o qual se que sequencias de diferenciação relativamente oxidantes (FROST; FROST, 2007). 
O conjunto de amostras de granitos do Batólito Itu cai, em sua maioria, no campo ferroano do diagrama de Frost (Figura 121), corroborando o modelo proposto para os granitos tipo A, de suíte mais enriquecida em Fe. A amostra que cai no campo magnesiano trata-se do exemplar do corpo de monzogabro pertencente ao Plúton Indaiatuba.

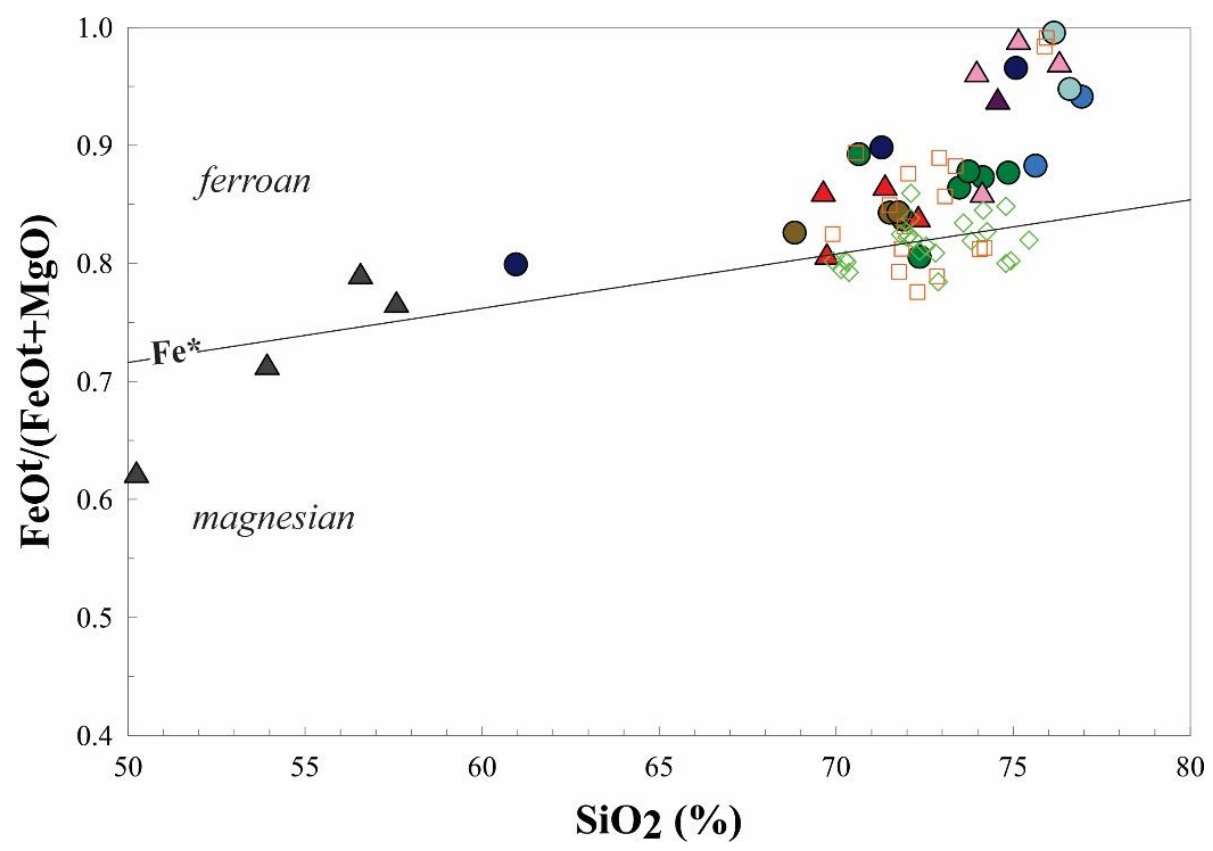

Figura 121 - Diagrama $\mathrm{Fe}^{*} \mathrm{x} \mathrm{SiO}_{2}$ mostrando o limite entre granitoides ferroanos e magnesianos. Modificado de Frost et al. (2001).

Com base na alcalinidade, Frost et al. (2001) também propuseram um índice denominado MALI (modified alkali-lime index), que consiste no conteúdo $\mathrm{Na}_{2} \mathrm{O}+\mathrm{K}_{2} \mathrm{O}-\mathrm{CaO}$. Para qualquer suíte magmática, o MALI cresce com o aumento de $\mathrm{SiO}_{2}$; variações no índice podem ocorrer tanto por mudanças na fonte quanto pela história de diferenciação magmática (FROST et al., 2001).

Como plútons e como corpos graníticos individuais, as amostras analisadas do batólito de espalham por composições desde alcalinas a cálcio-alcalinas (Figuras 122 e 123). 


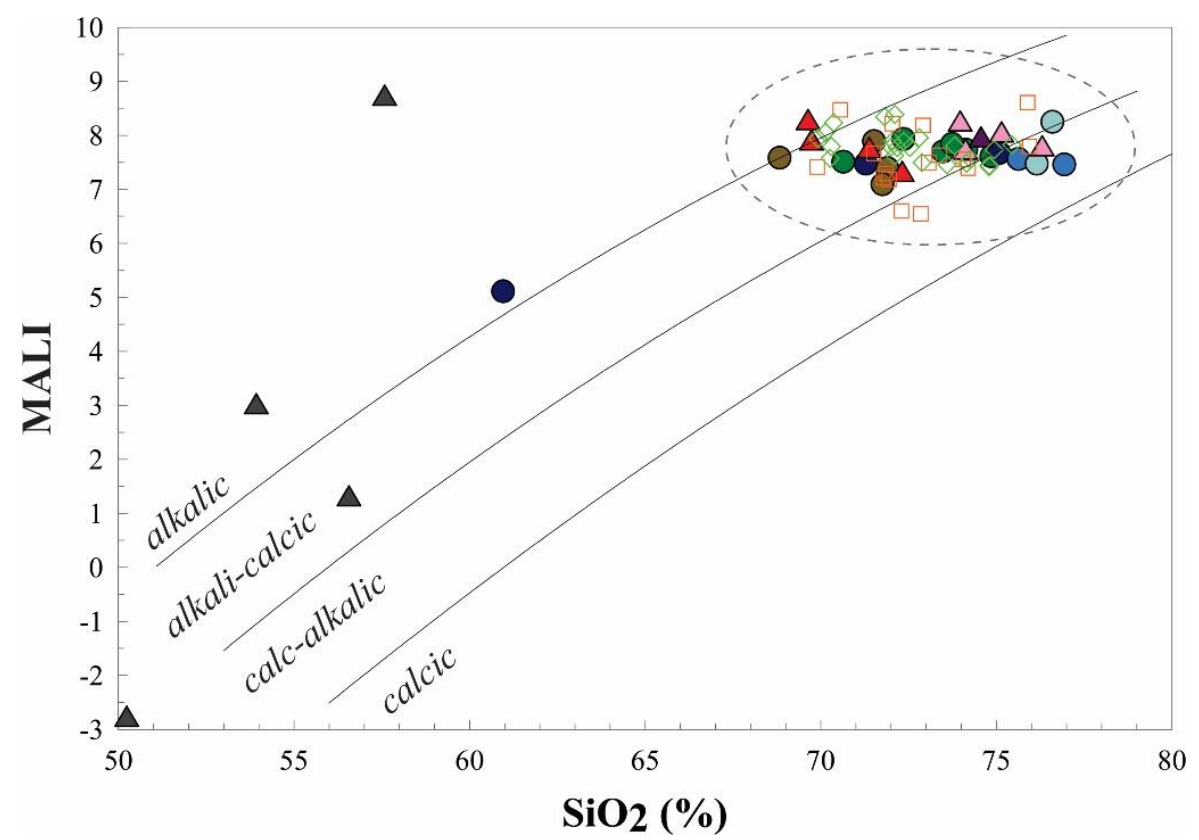

Figura 122 - Diagrama MALI x $\mathrm{SiO}_{2}$, com a distinção das séries alcalina, alcalina-cálcica, cálcio-alcalino e cálcica. Modificado de Frost et. al (2001).



Figura 123 - Aproximação da região em destaque na Figura 131. 


\section{CAPÍTULO 8-ASSINATURA ISOTÓPICA LU-HF,.QUÍMICA DE ZIRCÃOE GEOCRONOLOGIA}

Foram separados cristais de zircão em amostras representativas das diversas unidades do Batólito Itu: duas do plúton Cabreúva, uma de Indaiatuba, duas de Itupeva e duas de Salto. O objetivo principal foi a determinação da idade dos diferentes plútons, a qual foi realizada através de metodologias de análise in situ (SHRIMP e LA-MC-ICPMS); de modo complementar, foram obtidos dados de química de zircão pela técnica de LA-Q-ICPMS e de isotopia de Hf por LAMC-ICPMS nas mesmas amostras.

\subsection{MORFOLOGIA E QUÍMICA DE ZIRCÃO}

Imagens de catodoluminescência de cristais de zircão selecionados são apresentadas na Prancha D1 do Apêndice D. Análises químicas de porções destes cristais foram realizadas por LA-Q-ICPMS no modo raster, procurando-se seguir zonas homogêneas dentro dos cristais. Os resultados são mostrados na Tabela D1 do Apêndice D, e a localização dos rasters é apresentada nas imagens da Prancha D2 do mesmo documento.

Um estudo detalhado da tipologia (morfologia) do zircão dos diversos plútons do Batólito Itu foi apresentado por Galembeck (1997), que descreveu os zircões do Plúton Itupeva como típicos de granitos "híbridos, cálcicos-alcalinos de alta temperatura", enquanto que os dos outros plútons indicariam um incremento progressivo na alcalinidade desde Indaiatuba a Salto e então Cabreúva, com algumas amostras do último plúton se situando no campo alcalino. Imagens de cristais típicos ilustradas naquele trabalho indicam que faces prismáticas curtas (resultando em relações de aspecto de 2:1 ou menos) são características dos plútons Itupeva e Salto, enquanto em Cabreúva e Indaiatuba elas são geralmente maiores, e as proporções são 3:1 a $2: 1$.

Foram obtidas análises químicas de zircões de duas amostras de sienogranitos do Plúton Cabreúva.

Os zircões da amostra CAB-16-80A têm razões comprimento:largura típicas da ordem de 2:1 a 3:1. Imagens de catodoluminescência mostram que a maior parte dos grãos é zonada, com núcleos homogêneos e porções externas com zoneamento oscilatório (Prancha D1). Os núcleos mostram uma ampla variedade de tons cinza nas imagens, refletindo diferenças químicas importantes e assim, provavelmente, cristalização a partir de magmas distintos. Núcleos escuros 
(ricos em U) são levemente dominantes sobre os núcleos claros que, por sua vez, normalmente têm bordas com zoneamento oscilatório menos desenvolvidas. Ocasionalmente, núcleos de tom cinza médio, que podem ou não mostrar zoneamentos oscilatórios, são encontrados no centro de cristais claros homogêneos.

A Figura 124 mostra os padrões de ETR normalizados pela rocha total; esses padrões são semelhantes aos padrões normalizados pelo condrito, porém com valores absolutos $\sim 20 \mathrm{x}$ mais baixos. São padrões típicos de zircão, com forte enriquecimento de ETRP, com mediana de Lu $=3600 \times$ condrito e $(\mathrm{Gd} / \mathrm{Yb})_{\mathrm{N}}=0,045$; a anomalia negativa de Eu após normalização pela rocha total é pronunciada (mediana $\left.\left(\mathrm{Eu} / \mathrm{Eu}^{*}\right)_{\mathrm{N}}=0,22\right)$. Existe uma grande variação nos teores de ETRL; apenas os padrões mais pobres em La e Pr têm anomalias positivas de Ce. Os teores de Hf podem ser um proxy da evolução magmática, e mostram correlação positiva para Th e U (Figura 125), que se comportam, portanto, como elementos incompatíveis; a razão $\mathrm{Th} / \mathrm{U}$ mostra tendência a crescer com o aumento de Th (Figura 126). Em linhas gerais, a correlação entre Th e U é boa (Figura 127), e as razões Th/ U são inferiores a 1 (mediana=0,83).

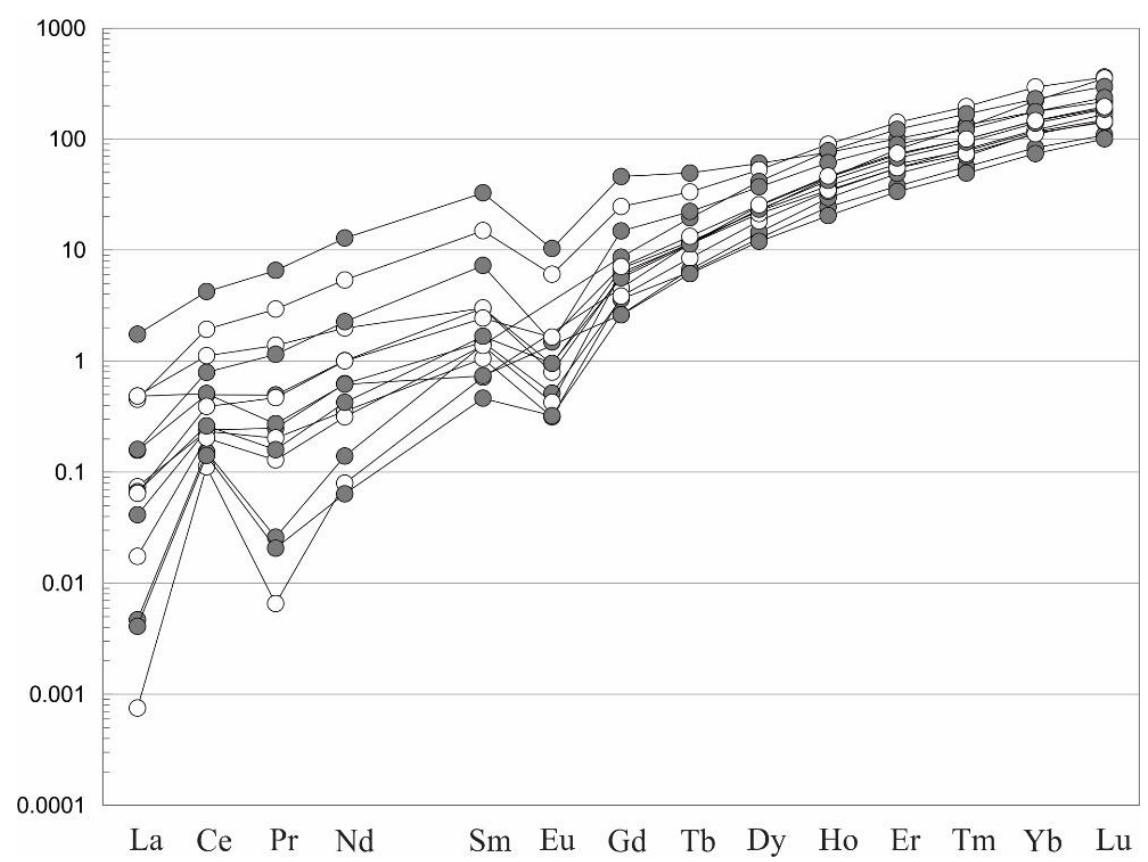

Figura 124 - Padrões de fracionamento dos elementos terras raras dos cristais de zircão da amostra CAB-1680A, normalizados pela rocha total; círculos cinzas - raster nos núcleos dos cristais; círculos brancos - raster nas bordas dos cristais. 



Figura 125 - Diagramas Th e U x Hf para os de cristais de zircão da amostra CAB-16-80A.



Figura 126 - Diagrama Th/U x Th com ajuste polinomial de $2^{a}$ de ordem (fit) mostrando a tendência dos dados obtidos através dos cristais de zircão da amostra CAB-16-80A.

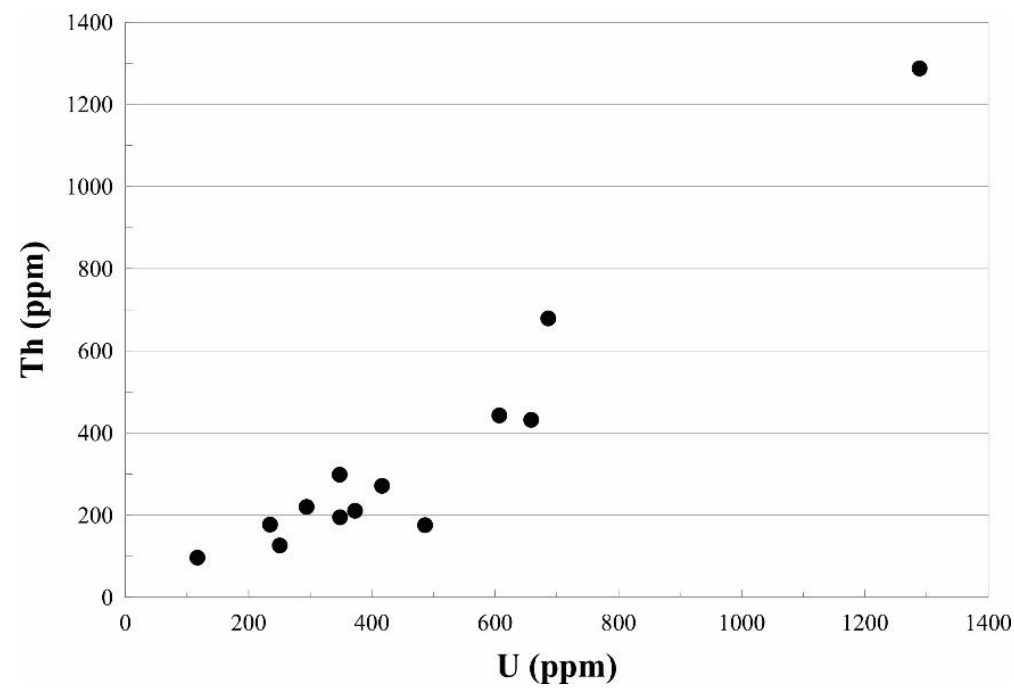

Figura 127 - Diagrama Th x U para os de cristais de zircão da amostra CAB-16-80A. 
Os zircões da amostra IGN24A são muito distintos; a maior parte dos cristais é totalmente escura nas imagens de catodoluminescência (Prancha D1). Uma segunda população é muito mais clara na CL, e tem zoneamento oscilatório. Embora raros, existem cristais CL-escuros com núcleo de cristal claro e zoneamento oscilatório, além de zoneamento oposto, com cristal CLescuro com borda com zoneamento oscilatório.

Em diagramas de variação utilizado Hf como índice de evolução, as quatro análises de zircão com zoneamento oscilatório (rasters 1n, 3, 7 e 12b - Tabela D1) se destacam das demais pelo caráter mais pobre em Hf, e tendem a superpor com as composições dos zircões de CAB16-80A. Os zircões CL-escuros predominantes são os mais ricos em Hf de todo o conjunto analisado neste trabalho, e mostram notável enriquecimento em diversos elementos (Y, ETRP, Th, U, Nb) (Figura 128). O padrão de ETR dos dois conjuntos é notavelmente diferente (Figura 129): os cristais com zoneamento oscilatório têm mediana de $\mathrm{Lu}=2900 \mathrm{x}$ o condrito, enquanto os cristais CL-escuros têm 12000x; a razão $(\mathrm{Gd} / \mathrm{Yb})_{\mathrm{N}}$ tem valores, respectivamente, 0,063 e 0,040, mostrando o maior fracionamento entre ETRM e ETRP nos cristais CL-escuros. A anomalia negativa de Eu após normalização pela rocha total é forte nas porções CL-escuras $\left(\mathrm{Eu} / \mathrm{Eu}^{*}=0,19\right)$ e variável nas porções com zoneamento oscilatório. 



\section{Hf (ppm)}

Figura 128 - Diagramas de variação utilizando o Hf como índice de variação para dados químicos obtidos para os cristais de zircão da amostra IGN24A. 




Figura 129 - Padrões de fracionamento dos elementos terras raras dos cristais de zircão da amostra IGN24A, normalizados pela rocha total; círculos cinzas - raster nos núcleos dos cristais; círculos brancos - raster nas bordas dos cristais. $\mathrm{O}$ traçado vermelho foi utilizado para diferenciar o conjunto de amostras que apresentam zoneamento oscilatório.

As imagens de CL de cristais de zircão da amostra do Granito Indaiatuba analisada (IGN50B) (razão comprimento:largura 2:1 a 3:1; comprimento máximo $300 \mu$ ) mostram típicos zoneamentos oscilatórios na ampla maioria dos cristais; pequenas inclusões de mineral branco na CL são características (Prancha D1). Uma pequena parcela dos cristais mostra núcleos distintamente mais claros, que podem ter zoneamento oscilatório discreto, e têm sempre bordas com o padrão oscilatório normal. Pequenos núcleos CL-escuros ocorrem em alguns desses núcleos mais claros. Ainda menos frequentes são núcleos CL-escuros, também manteados por zoneamento do tipo oscilatório normal.

Comparado aos zircões das duas amostras de Cabreúva, os zircões do Granito Indaiatuba têm em média teores mais baixos de Hf, indicativos de caráter menos evoluído do magma. A despeito disto, mostram teores de Th, $\mathrm{U}$ e Nb similares aos da amostra CAB-16-80A (Figura 130). No diagrama Th $x$ U, pode se distinguir a maior proporção de Th a um mesmo teor de U em relação a Cabreúva, reproduzindo característica observada na geoquímica de rocha total (Figura 131 - cf. Diagramas C7 - Apêndice C). A anomalia negativa de Eu após normalização pela rocha total $\left(\mathrm{Eu} / \mathrm{Eu}^{*}=0,36\right)$ é em geral menos acentuada que a observada nas amostras de Cabreúva (Figura 132). A mediana de Lu (2600 ppm) reflete menor enriquecimento em ETRP; a mediana da razão $(\mathrm{Gd} / \mathrm{Yb})_{\mathrm{N}}$ é de 0,056 . 



Hf (ppm)

$\triangle$ IGN50B • CAB-16-80A $\bigcirc$ IGN24A

Figura 130 - Diagramas de variação utilizando o Hf como índice de variação para dados químicos obtidos para os cristais de zircão da amostra IGN50B (à direita) e em comparação com as amostras de Cabreúva (à esquerda). 



$\triangle$ IGN50B

CAB-16-80A

IGN24A

Figura 131 - Diagrama Th x U para dados químicos obtidos para os cristais de zircão da amostra IGN50B (à direita) e em comparação com as amostras de Cabreúva (à esquerda).

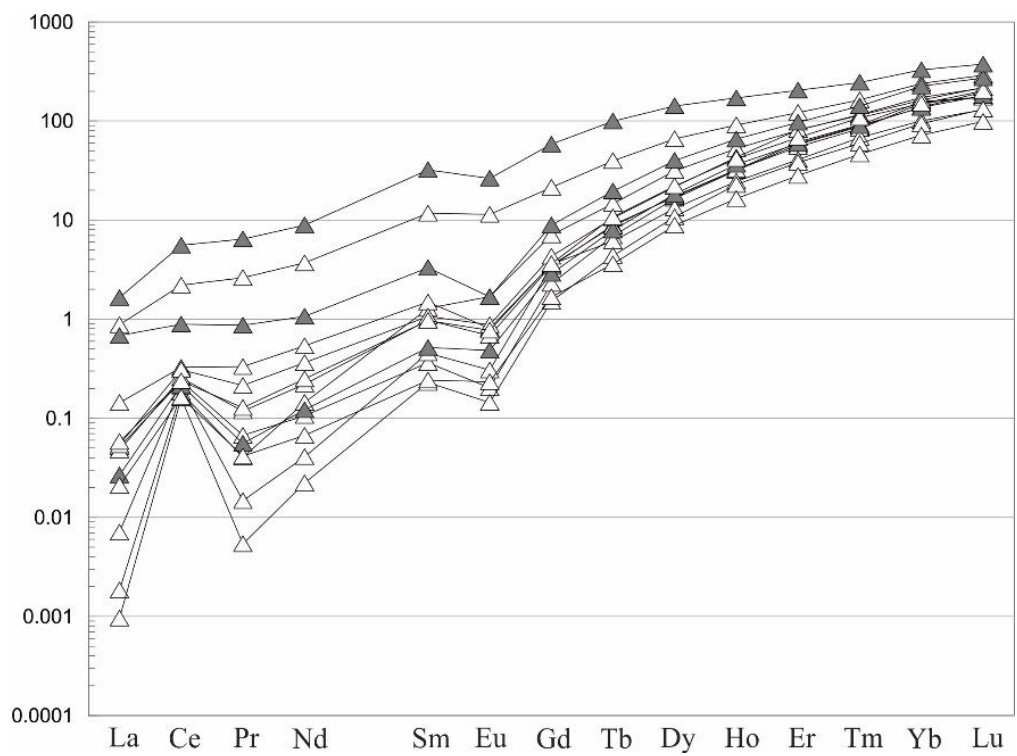

Figura 132 - Padrões de fracionamento dos elementos terras raras dos cristais de zircão da amostra IGN50B, normalizados pela rocha total; triângulos cinzas - raster nos núcleos dos cristais; triângulos brancos - raster nas bordas dos cristais.

Foram analisados zircões de duas amostras do Plúton Itupeva.

Os zircões do quartzo monzonito IGN56 têm razões de aspecto tipicamente superiores a 3:1 (embora a estimativa seja prejudicada pela quebra dos extremos durante a preparação), e são, portanto, diferentes da morfologia mais comum citada por Galembeck (1997) para este plúton, que é baseada em rochas com composições mais félsicas. O zoneamento oscilatório e relativamente espaçado de maneira paralela às faces prismáticas é típico de todos os cristais; existe uma tendência à passagem gradual para bordas CL-escuras quando estas são preservadas. Um único cristal mostra uma borda escura com contato abrupto com um núcleo reabsorvido mais claro (Prancha D1). 
Os padrões de ETR de todos os rasters analisados são semelhantes, com mediana de Lu= 4100x condrito e $(\mathrm{Gd} / \mathrm{Yb})_{\mathrm{N}}=0,083$; o fracionamento ETRM/ETRP é o mais baixo do conjunto analisado. A anomalia negativa de Eu após normalização pela rocha total é a menos acentuada de todo o conjunto analisado (mediana $\left(\mathrm{Eu} / \mathrm{Eu}^{*}\right)=0,61$; Figura 133$)$. Os teores muito baixos de LREE permitem medir com maior precisão a anomalia positiva de Ce, com valores típicos de $\left(\mathrm{Ce} / \mathrm{Ce}^{*}\right)_{\mathrm{N}}$ variando de 12 a 24 . Os zircões de IGN56 têm teores relativamente baixos de Hf, e se diferenciam dos zircões de outras amostras analisadas com mesmos teores de Hf pelo $\mathrm{Nb}$ e U mais baixos (Figura 134); existe uma boa correlação positiva entre Th e U (Figura 135); as razões $\mathrm{Th} / \mathrm{U}$ sistematicamente superiores a 1 (mediana=1,75).



Figura 133 - Padrões de fracionamento dos elementos terras raras dos cristais de zircão da amostra IGN56, normalizados pela rocha total; quadrados cinzas - raster nos núcleos dos cristais; quadrados brancos - raster nas bordas dos cristais.


IGN56 $\triangle$ IGN50B

CAB-16-80A

Figura 134 - Diagramas Nb e U x Hf para dados químicos obtidos para os cristais de zircão da amostra IGN56 em comparação com as amostras de Cabreúva (CAB-16-80A) e Indaiatuba (IGN-50B). 




Figura 135 - Diagrama Th x U para dados químicos obtidos para os cristais de zircão da amostra IGN56.

Os zircões do biotita sienogranito Itupeva CAB-15-36A são, com poucas exceções, curtos, com razões comprimento:largura de $\sim 2: 1$, e possuem zoneamento oscilatório típico. Ocasionalmente, ocorrem núcleos não zonados que podem ser CL-escuros, cinzentos ou mais raramente claros. Uma borda padrão CL-escura está presente em alguns cristais (Prancha D1).

Os padrões de REE de núcleos não zonados são tipicamente menos fracionados com $(\mathrm{Gd} / \mathrm{Yb})_{\mathrm{N}}=0,10-0,14$, contrastando com porções de zoneamento oscilatório, que têm $(\mathrm{Gd} / \mathrm{Yb})_{\mathrm{N}}=0,03-0,07$. As anomalias negativas de $\mathrm{Eu}$ (normalizadas pela rocha total) são pronunciadas, e da mesma ordem de magnitude dos granitos Cabreúva e Indaiatuba (mediana de $\left.\left(\mathrm{Eu} / \mathrm{Eu}^{*}\right)=0.34\right)$ (Figura 136). Um núcleo CL-claro tem padrão de ETR distinto, com anomalia de Eu pouco pronunciada $\left(\left(\mathrm{Eu} / \mathrm{Eu}^{*}\right)=0,77\right)$; este núcleo se destaca do padrão geral da amostra para vários elementos, notavelmente os teores mais baixos de $\mathrm{Nb}, \mathrm{Y}, \mathrm{U}$ e Th (raster 8 - Tabela D1). Em contraste com o quartzo monzonito IGN56, as relações Th/U são baixas na maioria dos cristais da amostra CAB-15-36A (0,4-0,7), exceto nos núcleos CL-escuro e CLclaro (1,2-2,7), que contrastam entre si no conteúdo absoluto desses elementos (p.ex., Th=650700 e 150 ppm, respectivamente - Figura 137). Os conteúdos Hf são maiores e mais variados do que em IGN56 (mediana 14.800 ppm vs. 11.700 ppm); os teores mais altos se associam às porções com zoneamento oscilatório (Tabela D1). 


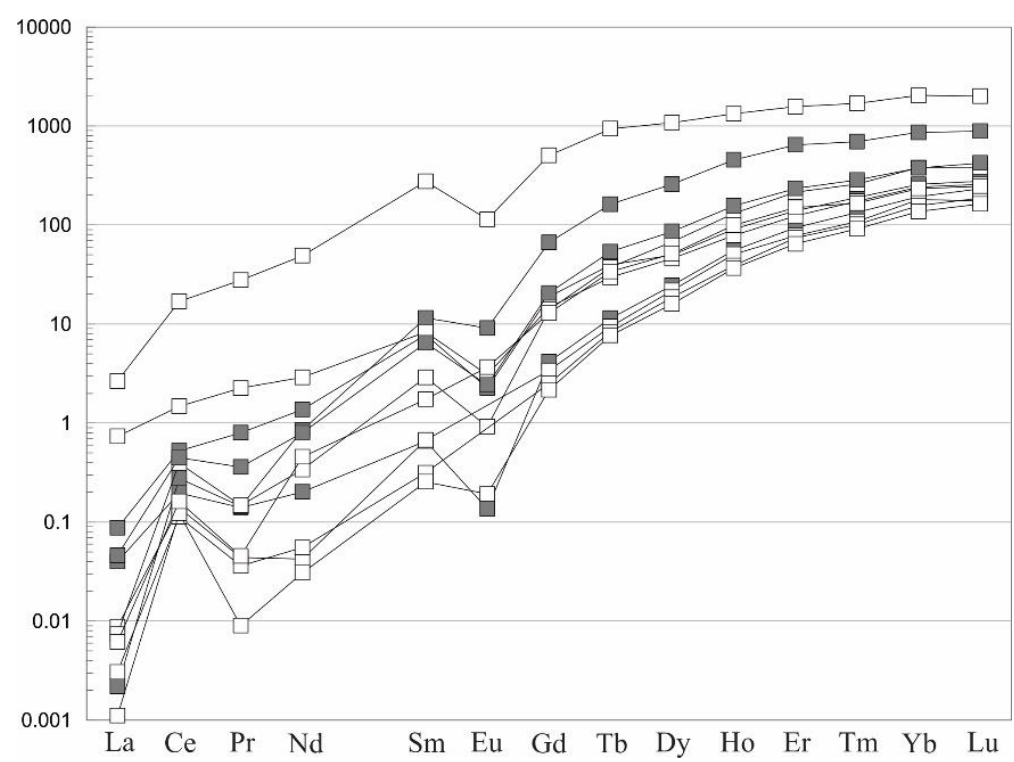

Figura 136 - Padrões de fracionamento dos elementos terras raras dos cristais de zircão da amostra CAB-1536A, normalizados pela rocha total; quadrados cinzas - raster nos núcleos dos cristais; quadrados brancos raster nas bordas dos cristais.


CAB-15-36A

IGN56

Figura 137 - Diagramas Th/U x Th e U para dados químicos obtidos para os cristais de zircão da amostra CAB15-36A em comparação com as amostras do quartzo monzonito IGN-56.

Na amostra de Salto ITU-14X, morfologia e zoneamento interno do zircão são semelhantes a CAB-15-36A, com zoneamento oscilatório, e contatos abruptos frequentes, e núcleos que podem ser CL-claros ou CL-escuros. Os núcleos CL-claros, em sua maioria, têm padrões de ETR íngremes de inclinação negativa, similares $(\mathrm{Gd} / \mathrm{Yb})_{\mathrm{N}} \sim 0,08$, enquanto os núcleos CLescuros (rasters 11.2 e 12.1) têm composições modificadas por processos hidrotermais, como mostrado por teores anomalamente altos de Fe, Ti (Tabela D1) exibem fracionamento bem menor, $(\mathrm{Gd} / \mathrm{Yb})_{\mathrm{N}} \sim$ 0,21-0,27 (Figura 138). Todas as porções com zoneamento oscilatório mostram padrões enriquecidos em LREE, que em alguns casos resultam na supressão da 
anomalia positiva de Ce. A anomalia negativa de Eu é discreta mesmo em núcleos CL-claros mais pobres em ETRL (mediana de $\left(\mathrm{Eu} / \mathrm{Eu}^{*}\right)=0,74$, normalizada pela rocha total. Os teores totais de Nb, U e Th são elevados na maior parte das análises (Figura 139).



Figura 138 - Padrões de fracionamento dos elementos terras raras dos cristais de zircão da amostra ITU-14X, normalizados pela rocha total; losangos cinzas - raster nos núcleos dos cristais; losangos brancos - raster nas bordas dos cristais.
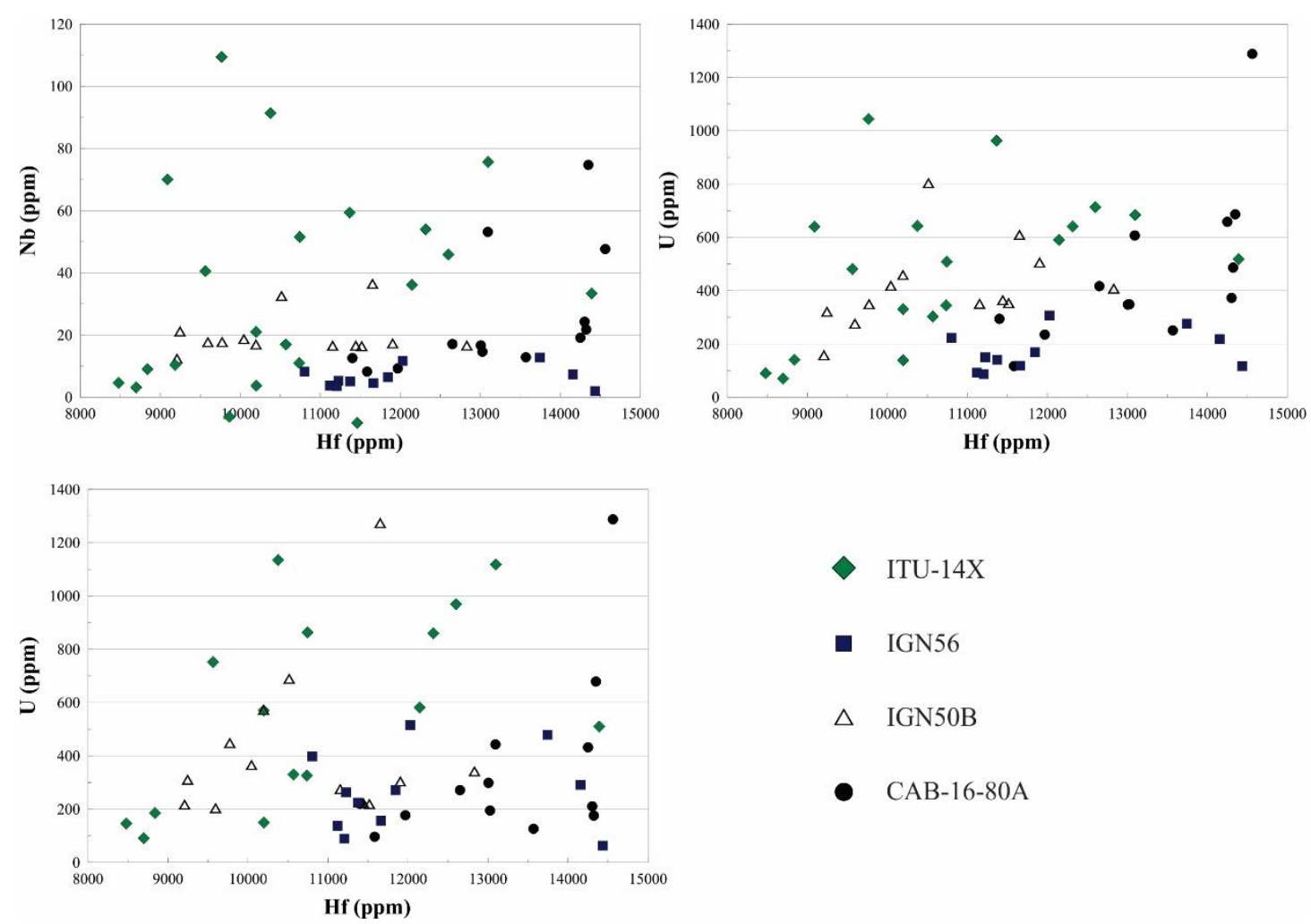

ITU-14X

- IGN56

$\triangle$ IGN50B

- $\mathrm{CAB}-16-80 \mathrm{~A}$

Figura 139 - Diagramas de variação utilizando o Hf como índice de variação para dados químicos obtidos para os cristais de zircão da amostra ITU-14X (Salto) em comparação com as amostras dos outros três plútons. 


\subsection{GEOCRONOLOGIA POR MÉTODO SHRIMP E LA-MC-ICPMS}

\subsubsection{Resultados Analíticos}

Determinações anteriores de idades de rochas do Batólito Itu referem-se a dados $\mathrm{Rb}$-Sr apresentados por Tassinari (1988), que obteve uma isócrona baseada em 7 amostras do Plúton Cabreúva, com uma idade de $586 \pm 10 \mathrm{Ma}$ e razão ${ }^{87} \mathrm{Sr} /{ }^{86} \mathrm{Sr}$ inicial de 0.7066 . Töpfner (1996) obteve uma idade U-Pb em zircão por TIMS para uma amostra do mesmo plúton, com base em 8 frações de zircão multigrão de tamanhos diferentes; o resultado obtido (582.6 $\pm 6.4 \mathrm{Ma}$ ) está dentro do erro da idade isocrônica $\mathrm{Rb}-\mathrm{Sr}$ anterior. Uma nova idade $\mathrm{Rb}$-Sr também foi obtida, com erro maior $(583 \pm 20 \mathrm{Ma})$ e razão inicial de 0.7081 .

Uma datação sistemática de U-Pb de todos os plútons do Batólito de Itu foi realizada neste trabalho, utilizando técnicas in situ (SHRIMP e, em uma amostra, LA-ICPMS), que na maioria dos casos logrou superar problemas com modificações pós-magmáticas e perda de $\mathrm{Pb}$, que são evidentes em porções de cristais de zircão de muitas amostras do batólito.

Duas amostras do Plúton Itupeva foram datadas por SHRIMP: hornblenda-biotita quartzo monzonito equigranular médio IGN-56, de um pequeno corpo intrusivo nos biotita granitos porfiríticos hospedeiros, e biotita granito inequigranular róseo $\mathrm{CAB}-15-36 \mathrm{~A}$, localizado na região sul do Plúton Itupeva, em contato com o Plúton Indaiatuba.

O quartzo monzonito IGN-56 forneceu uma idade concórdia bem definida de $\mathbf{5 8 4 . 3} \pm \mathbf{5 . 2}$ Ma $(2 \sigma)$ com baixo MSWD e probabilidade de concordância de 0,53, a partir de 12 pontos analíticos (Figuras 140 e 141 - Tabela D2 do Apêndice D). 




Figura 140 - Localização dos spots de datação dos cristais de zircão da amostra IGN56 com suas idades ${ }^{206} \mathrm{~Pb} /{ }^{238} \mathrm{U}$ e erro $1 \sigma$.



Figura 141 - Idade concórdia U-Pb para zircões do quartzo monzonito IGN56 do Plúton Itupeva. 
O sienogranito inequigranular róseo $\mathbf{C A B}-15-36 \mathrm{~A}$ também forneceu uma idade concórdia bem definida, com 576.6 + 5.2 Ma, baixo MSWD e probabilidade de concordância de 0,97, a partir de 13 pontos analíticos (Figuras 142 e 143). Um único núcleo herdado de idade paleoproterozóica (ponto de análise $6.1 \rightarrow$ Tabela D2 - Apêndice D; idade ${ }^{207} \mathrm{~Pb} /{ }^{206} \mathrm{~Pb}$ de $2189 \pm 23 \mathrm{Ma}$ ) foi identificado (Figura 144); outro núcleo herdado tem idade um pouco mais antiga que o granito ( $602 \mathrm{Ma})$, possivelmente refletindo a incorporação de zircão de rochas graníticas do período sin-compressional.



Figura 142 - Localização dos spots de datação dos cristais de zircão da amostra CAB-15-36A com suas idades ${ }^{206} \mathrm{~Pb} /{ }^{238} \mathrm{U}$ e erro $1 \sigma$. 




Figura 143 - Idade concórdia U-Pb para zircões do sienogranito CAB-15-36A do Plúton Itupeva.



Figura 144 - Diagrama U-Pb para um cristal de zircão herdado do sienogranito CAB-15-36A do Plúton Itupeva. 
A datação dos granitos do Plúton Salto foi menos direta. Os zircões da amostra ITU-2.2.4, um sienogranito rapakivi vermelho, são fortemente afetados por modificações pósmagmáticas, que resultaram em altos conteúdos de $\mathrm{Pb}$ comum e idades $\mathrm{U}-\mathrm{Pb}$ fortemente discordantes (Figuras 145 e 146 - Tabela D2 do Apêndice D) nas análises por SHRIMP.



Figura 145 - Localização dos spots de datação dos cristais de zircão da amostra ITU-2.2.4 com suas idades ${ }^{206} \mathrm{~Pb} /{ }^{238} \mathrm{U}$ e erro $1 \sigma$. Notar a CL-escura dos cristais de zircão, resultado do alto conteúdo de $\mathrm{Pb}$ comum. 




Figura 146 - Idades U-Pb altamente discordantes para zircões do sienogranito rapakivi vermelho ITU-2.2.4 do Plúton Salto.

Uma segunda amostra foi escolhida para a datação por SHRIMP: ITU-14X, um granito rapakivi com cristais de plagioclásio de coloração branca, indicativo de que a rocha foi menos afetada por processos hidrotermais pós-magmáticos. Mesmo nesta amostra, várias análises pontuais atingiram porções danificadas dos cristais de zircão, resultando em comportamento discordante, e as idades ${ }^{206} \mathrm{~Pb} /{ }^{238} \mathrm{U}$ na faixa de 440-540 Ma. Um conjunto de 5 pontos (entre 12 analisados - Tabela D2 do Apêndice D) é concordante, e uma idade concórdia baseada nesses resultados fornece 576.6 \pm 7.6 Ma, considerada a melhor estimativa para a cristalização magmática deste granito (Figuras 147, 148 e 149). 




Figura 147 - Localização dos spots de datação dos cristais de zircão da amostra ITU-14X com suas idades ${ }^{206} \mathrm{~Pb} /{ }^{238} \mathrm{U}$ e erro $1 \sigma$.

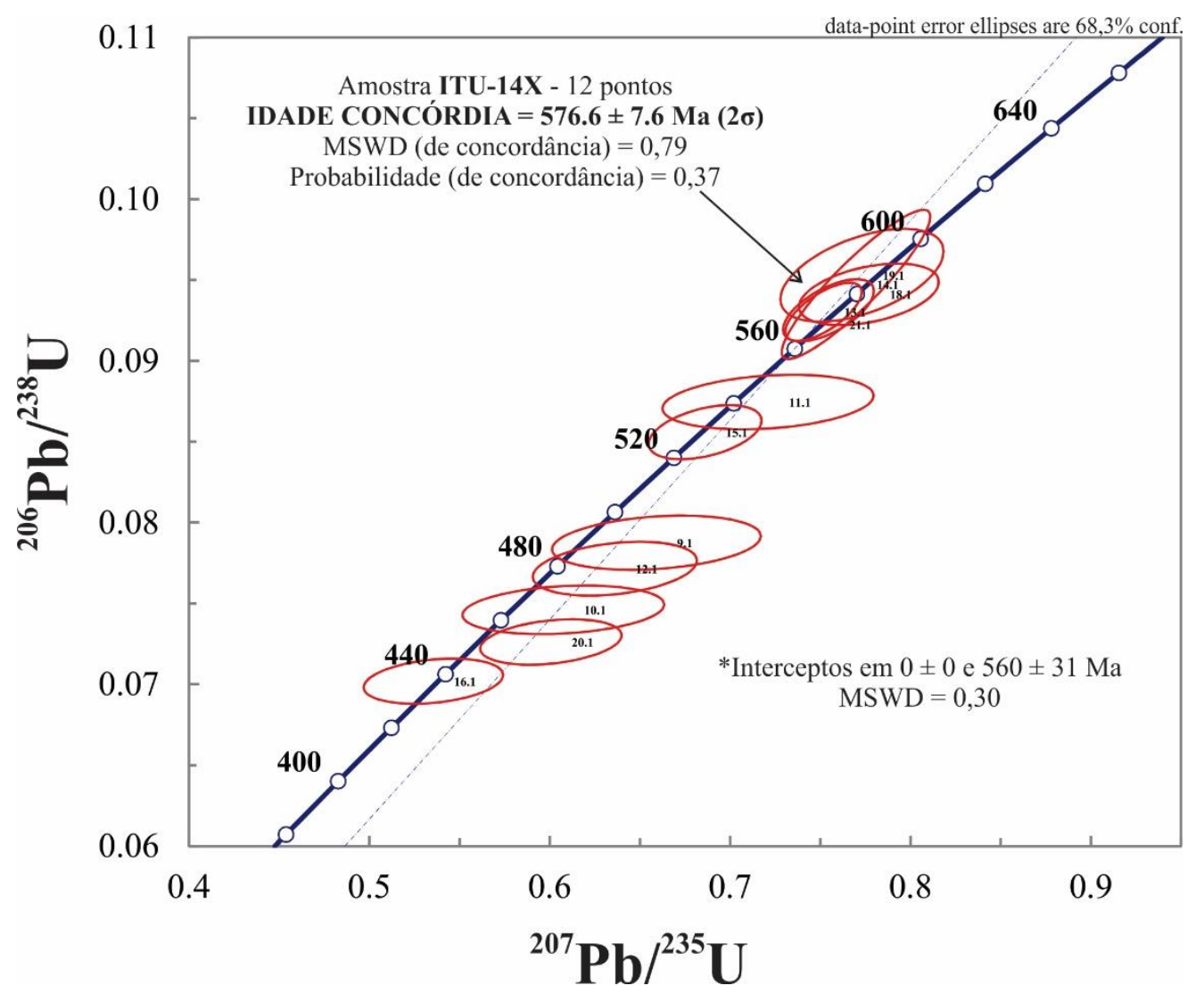

Figura 148 - Idades U-Pb discordantes e a idade concórdia (ver Figura 149) para cristais de zircão do sienogranito rapakivi ITU-14X do Plúton Salto. 


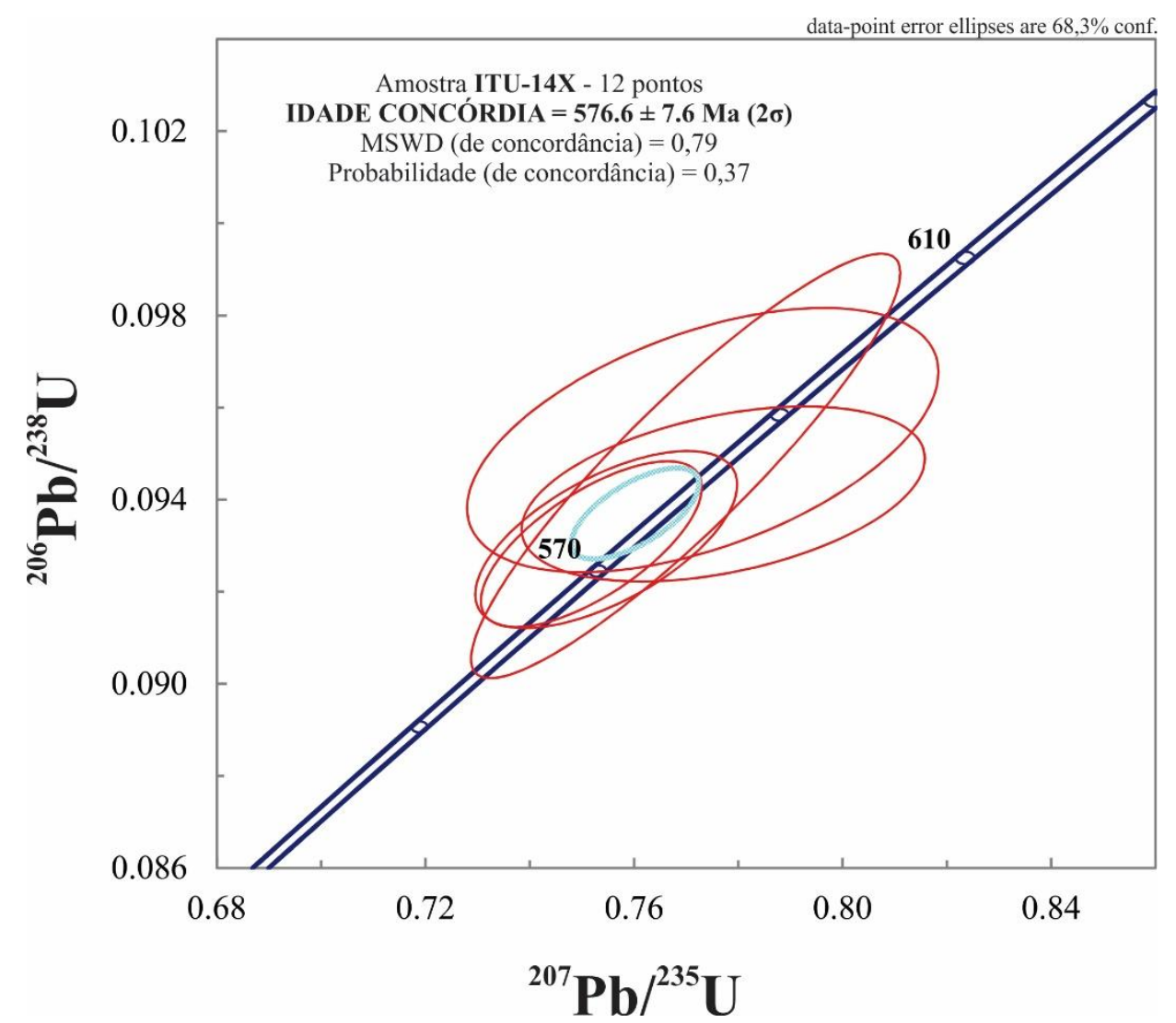

Figura 149 - Idade concórdia U-Pb para zircões do sienogranito rapakivi ITU-14X do Plúton Salto.

A idade do Plúton Indaiatuba foi obtida pela datação de zircão de um granito rapakivi de granulação grossa típico (IGN50B) com grandes cristais ovóides de K-feldspato manteados por plagioclásio branco, fracamente a não afetados por processo pós-magmáticos. Vinte e cinco pontos foram analisados pelo método LA-MC-ICPMS (Tabela D2 - Apêndice D, e resultaram em idade concórdia a 579.1 \pm 3.8 Ma, com baixo MSWD e probabilidade de concordância de 0,63 (Figuras 150 e 151). 




Figura 150 - Localização dos spots de datação dos cristais de zircão da amostra IGN50B com suas idades ${ }^{206} \mathrm{~Pb} /{ }^{238} \mathrm{U}$ e erro $1 \sigma$. 




Figura 151 - Idade concórdia U-Pb para zircões do monzogranito rapakivi IGN50B do Plúton Indaiatuba.

Duas amostras do Plúton Cabreúva, considerado por critérios geológicos mais novo que os plútons anteriores, foram datadas pelo método SHRIMP; IGN24A, um biotita sienogranito da borda oeste do plúton, e CAB-16-80A, um biotita sienogranito de granulação grossa de sua porção central.

Foram analisados 12 pontos em cristais de zircão da amostra CAB-16-80A; todos produziram resultados próximos à concordância, exceto o ponto 1.1, 18\% discordante (Tabela D2 - Apêndice D). Uma idade concórdia de 573.4 + 5.8 Ma com MSWD = 0,44 e probabilidade de concordância $=0,51$ é obtida para um aglomerado principal de 8 pontos, excluindo o ponto 1.1 e outros dois pontos com idade ${ }^{206} \mathrm{~Pb} /{ }^{238} \mathrm{U}$ um pouco mais alta (Figura 152). 


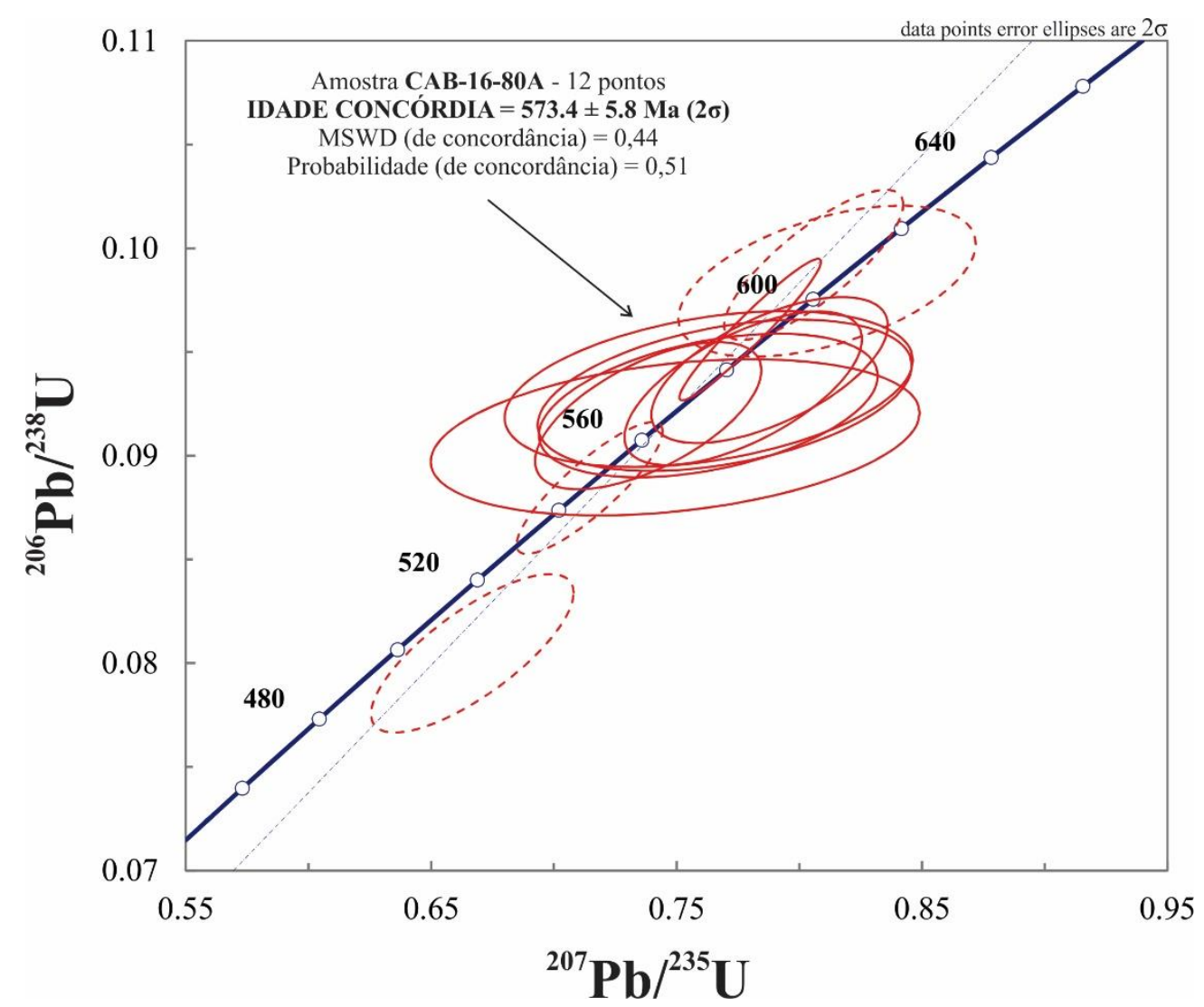

Figura 152 - Idade concórdia U-Pb para zircões do sienogranito CAB-16-80A do Plúton Cabreúva.

A amostra IGN24A produziu resultados concordantes, com exceção de duas frações (Tabela D2). As outras nove frações forneceram uma idade concórdia bem definida de $\mathbf{5 6 0 . 9} \pm$ 6.2 Ma (Figuras 153 e 154).

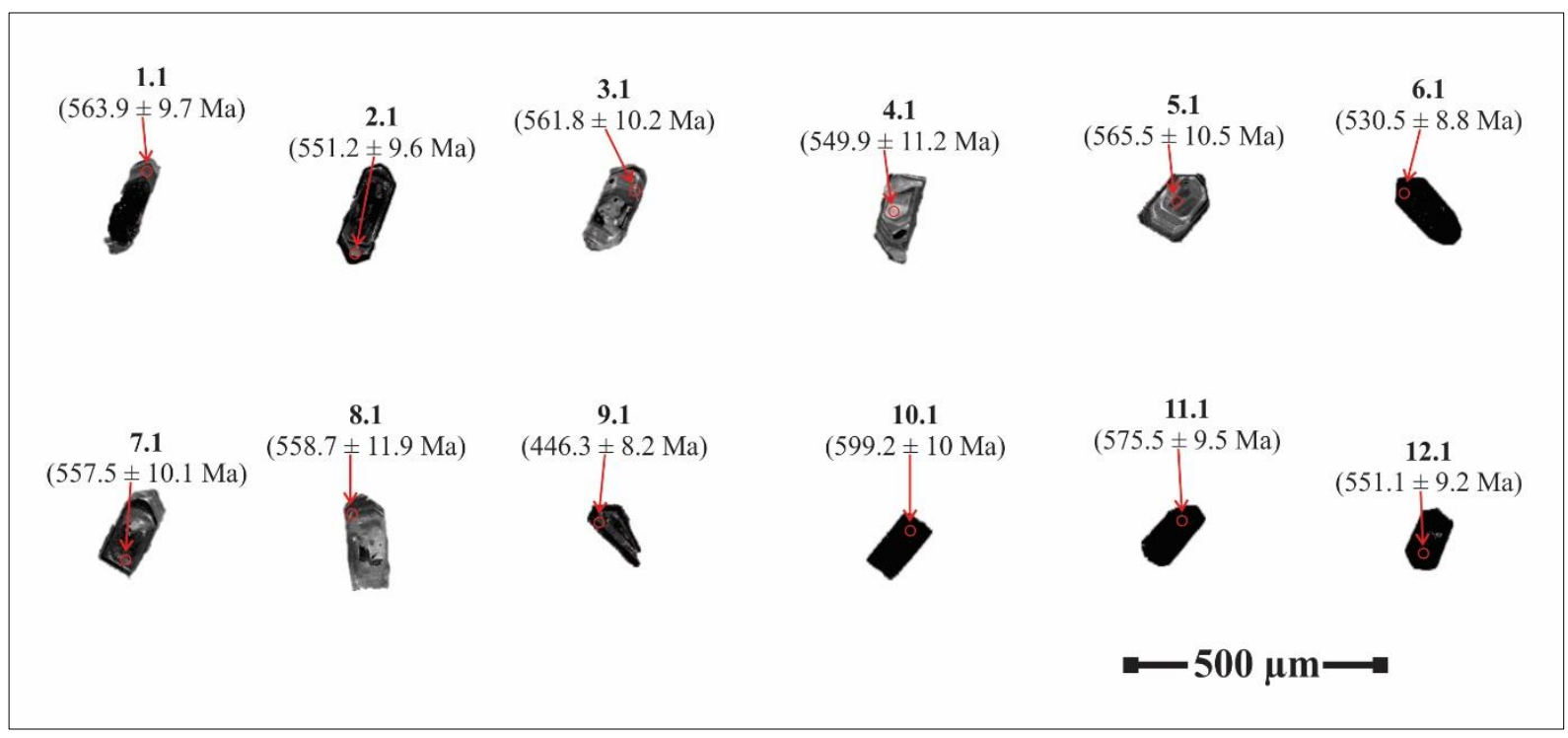

Figura 153 - Localização dos spots de datação dos cristais de zircão da amostra IGN24A com suas idades ${ }^{206} \mathrm{~Pb} /{ }^{238} \mathrm{U}$ e erro $1 \sigma$. 


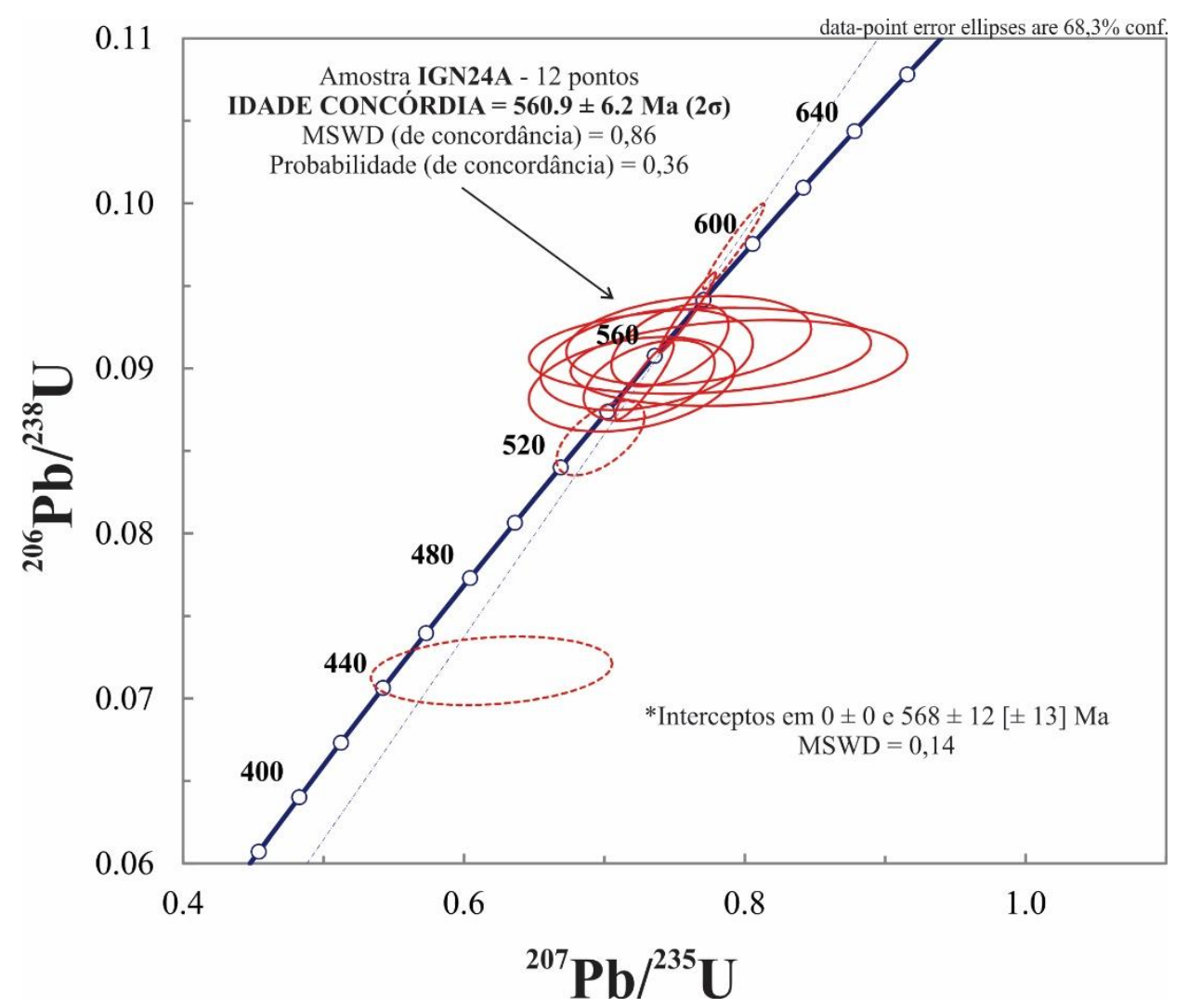

Figura 154 - Idade concórdia U-Pb para zircões do sienogranito IGN24A do Plúton Indaiatuba.

Esta idade é até 20 Ma mais jovem do que as idades obtidas para os outros plútons do Batólito Itu, apontando para uma evolução mais longa para o batólito e para o magmatismo pós-orogênico da província, um resultado um tanto surpreendente.

A incerteza de \pm 6 Ma nessas duas idades obtidas para Itu permite que se considere que elas se sobrepõem marginalmente, mas o espalhamento de $\sim 12$ Ma mostrado pelos valores centrais é notável. Esse intervalo de tempo seria substancial para a construção de um único plúton (unidade estrutural), mas pode ser real, já que as duas idades parecem de boa qualidade e igualmente confiáveis.

Em paralelo às idades obtidas nesta tese, duas idades U-Pb em zircão por SHRIMP foram obtidas na dissertação de mestrado de ARAÚJO (2018) para o stock satélite Inhandjara, que consiste em granitos especializados, em parte portadores de topázio, e que podem ter conexões genéticas com o Plúton Cabreúva. É interessante notar que as idades obtidas mostram uma faixa similar (amostra IPV-14, 564.9 — 6.8 Ma; amostra IPV- 30, 575.7 + 5.6 Ma) (Araújo, 2018), reforçando a indicação de um longo período de tempo para a geração do Batólito de Itu. 


\subsubsection{Discussão: a idade do Batólito Itu e o contexto regional}

A Figura 155 sintetiza as idades obtidas para as amostras do Batólito Itu neste trabalho, e inclui as idades obtidas para o stock Inhandjara por ARAÚJO (2018) em sua dissertação de mestrado. Considerada a incerteza média de $5 \mathrm{Ma}$, amostras de todos os plútons, incluída a amostra IPV-14 de Inhandjara, têm idades idênticas; a idade média dessas 6 amostras é de 575 Ma, com desvio-padrão de 8 Ma. As exceções são as amostras IGN24A (Cabreúva) e IPV-30 (Inhandjara), que sugerem que a construção do batólito se estendeu por um intervalo maior do que até então admitido, com idades de geração de granitos até 560 Ma. A intensidade de processos de alteração pós-magmática em praticamente todas as amostras do batólito (como especialmente evidente na amostra de granito rapakivi vermelho do Plúton Salto), também refletida na existência de idades concordantes excepcionalmente jovens em cristais de zircão de algumas das amostras datadas, sugere uma nota de cautela na interpretação desses valores mais jovens.



Figura 155 - Idades U-Pb para os plútons do Batólito Itu obtidas neste trabalho incluindo dados de Araújo (2018) para o stock de Inhandjra.

O uso de abração química nos zircões previamente à metodologia para datação e, eventualmente, o emprego do método TIMS em cristais únicos selecionados, poderá confirmar ou não a extensão do magmatismo no batólito até 560 Ma. O emprego da metodologia TIMS em monocristais no futuro poderá ser particularmente útil para identificar e quantificar 
diferenças mais sutis na idade dos diferentes plútons, por permitir alcançar incertezas sensivelmente menores que as alcançadas pelos métodos in situ aqui empregados.

A Figura 156 compara as idades obtidas para o Batólito Itu com outras idades U-Pb obtidas para outras ocorrências da PGI e granitos gerados no período sin-compressional na porção sul da Nappe Socorro-Guaxupé.



Figura 156 - Idades U-Pb para os plútons do Batólito Itu obtidas neste trabalho em comparação com outros dados da Província Granítica Itu e da granitogênese sin-compressional da porção sul da NESG.

O metamorfismo principal, identificado por muitos autores como "sin-colisional", está datado no intervalo de 625 a 600 Ma (MARTINS; VLACH; MARTINS, 2009; ROCHA et al., 2017). Esse período coincide com o intervalo de geração de granitos anatéticos, como o granito Nazaré Paulista (JANASI, 1999; MARTINS, 2006; A. Virmond, dissertação de mestrado em andamento). A longa história de formação do Batólito Socorro (TOLEDO; JANASI; SILVA, 2018; B. Toledo, dissertação de mestrado em andamento) inclui desde charnockitos/ortognaisses gerados no período "pré-colisional” (640-630 Ma) até o magmatismo cálcio-alcalino de alto potássio (HKCA), que corresponde aos hornblenda-biotita granitos "tipo Bragança Paulista”, datados em 610 Ma (EBERT et al., 1996; TOLEDO; JANASI; SILVA, 
2018) e, portanto, contemporâneos ao metamorfismo regional e à geração de granitos anatéticos.

A geração do batólito de Itu claramente ocorreu cerca de 20 Ma após o final do metamorfismo regional e, a geração dos granitos anatéticos e do Batólito Socorro. Outras ocorrências importantes da PGI, como o Monzodiorito Piracaia e, ao menos em parte, o Batólito Morungaba, têm idades semelhantes (JANASI et al., 2009; JANASI et al., 2019). Observa-se, no entanto, que algumas ocorrências de granitos com afinidades de tipo A, associadas à PGI (Sienogranito Atibaia e Sienogranito Terra Nova), têm revelado idades mais antigas, que se situam dentro do intervalo entre os dois grupos, sugerindo o início da geração de granitos "pósorogênicos" imediatamente após o final do evento compressional (JANASI et al., 2019).

\subsection{ISOTOPIA DE HF EM ZIRCÃO}

Foram obtidos dados isotópicos de Hf em zircão de três das amostras datadas neste trabalho. Análises das outras amostras datadas não foram obtidas em tempo por problemas analíticos no laboratório do CPGeo, mas encontram-se em curso para a publicação de artigo. A Tabela D3 do Apêndice D apresenta os resultados analíticos, e a Figura 157 sumariza os resultados. Para comparação, foram obtidas análises em zircão de outras ocorrências associadas à Província Granítica Itu: Monzodiorito Piracaia, Sienogranito Atibaia e Sienogranito Piracaia, todas datadas por Janasi et al. (2019). 



Figura 157 - Dados isotópicos de $\varepsilon \mathrm{Hf}(\mathrm{t})$ de três amostras do Batólito Itu datadas neste trabalho. Para comparação foram utilizadas análises dos granitos Piracaia, Atibaia e Terra Nova associados à PGI (JANASI et al., 2019).

Os resultados de $\varepsilon \mathrm{Hf}_{\mathrm{t}}$ para as amostras dos plútons Indaiatuba e Cabreúva são semelhantes, com pequena dispersão e valores médios fortemente negativos: -14,8 para Cabreúva (amostra IGN24A) e -17,8 para Indaiatuba (Figura 157). A amostra de Salto apresenta dispersão de valores muito maior, embora seja clara a concentração de resultados para valores intermediários; o valor médio de -11,6 é claramente menos negativo que o das outras duas amostras.

Os dois sienogranitos analisados para comparação mostram os seguintes padrões: Atibaia tem valores uniformes, e valor médio um pouco menos negativo que o da amostra de Cabreúva (-14), e Terra Nova mostra dispersão significativa, mas contínua entre -17 e -8; o valor médio (-11) é semelhante ao da amostra de Salto. 
O monzodiorito de Piracaia apresenta o valor de $\varepsilon \mathrm{Hf}_{\mathrm{t}}$ mais baixo do conjunto, mas ainda bastante negativo (-10); o valor é semelhante ao da amostra de Terra Nova, com dispersão um pouco menor. Em vista da composição básica da amostra, trata-se de uma referência para a assinatura isotópica de $\mathrm{Hf}$ de rochas mais primitivas da PGI, com derivação do manto. Nesse sentido, é notável a semelhança entre a assinatura isotópica de Hf dessa amostra com a amostra de Salto, e o caráter mais negativo das amostras de Cabreúva e Indaiatuba.

Uma discussão sobre o significado dos dados isotópicos de Hf será feita de modo integrado com os isótopos de $\mathrm{Sr}$ e $\mathrm{Nd}$ no capítulo 9 a seguir. 


\section{CAPÍTULO 9- GEOOUÍMICA ISOTÓPICA}

Estudos prévios sobre o Batólito Itu não se utilizaram da geoquímica isotópica para estudos petrogenéticos. Apenas dados para o sistema Rb-Sr foram apresentados por Tassinari (1988) e Töpfner (1996), que obtiveram razões iniciais ${ }^{87} \mathrm{Sr} /{ }^{86} \mathrm{Sr}(\mathrm{i})$ em isócronas $\mathrm{Rb}-\mathrm{Sr}$ do Plúton Cabreúva. Nesta tese, foram obtidas análises isotópicas para os sistemas $\mathrm{Rb}-\mathrm{Sr}$ e $\mathrm{Sm}-\mathrm{Nd}$ (em rocha total) e Lu-Hf (em zircão) de amostras representativas de todos os plútons que constituem o batólito.

\subsection{GEOQUÍMICA ISOTÓPICA SR-ND EM ROCHA TOTAL}

Os dados de isotopia Sr-Nd são apresentados nas Tabelas E1 e E2 do Apêndice E e plotados na Figura 158. Embora a variação total seja pequena $\left(\varepsilon N d(t)=-10\right.$ a $-13 ;{ }^{87} \mathrm{Sr} /{ }^{86} \mathrm{Sr}(\mathrm{i})=0,704-$ 0,711), existem diferenças sistemáticas entre os plútons e entre os termos graníticos e máficos de cada plúton. É notável que os termos máficos exibem variação ainda menor, e confinada ao intervalo mais "primitivo" com variação praticamente nula de ${ }^{87} \mathrm{Sr} /{ }^{86} \mathrm{Sr}$ (i) $(0,7056$ - 0,7062; ligeiramente maior no enclave de Salto, que é um enclave bastante transformado por interação com o granito hospedeiro) e de $\varepsilon \mathrm{Nd}(\mathrm{t})(-10,3 \mathrm{a}-11,3)$.

Entre as rochas graníticas, Cabreúva se destaca por valores mais altos de ${ }^{87} \mathrm{Sr} /{ }^{86} \mathrm{Sr}(\mathrm{i})$ e mais negativos de $\varepsilon N d(t)$. Itupeva tem valores de $\varepsilon N d(t)$ semelhantes, mas as duas amostras têm ${ }^{87} \mathrm{Sr} /{ }^{86} \mathrm{Sr}(\mathrm{i})$ mais baixo que Cabreúva. Salto tem $\varepsilon \mathrm{Nd}(\mathrm{t})$ menos negativo entre todos os granitos (da ordem de -10,0 a -10,6, igual às rochas máficas de Itupeva). Uma amostra de granito do Stock Inhandjara (ARAÚJO, 2018), é representada, e tem o valor de $\varepsilon \mathrm{Nd}(\mathrm{t})$ mais negativo de todo o batólito $(-13,1)$. Esta tendência é confirmada pela análise de outras três amostras, cujos $\varepsilon N d(t)$ variam de -11,6 a -12,7 (ARAÚJO, 2018); os valores de ${ }^{87} \mathrm{Sr} /{ }^{86} \mathrm{Sr}$ (i) em rocha total dessa amostra não foram calculados pois, assim como na amostra lançada no diagrama, os valores da razão $\mathrm{Rb} / \mathrm{Sr}$ são muito altos, tornando imprecisa a extrapolação da razão ${ }^{87} \mathrm{Sr} /{ }^{86} \mathrm{Sr}$ para a idade da rocha. Estimativas precisas das razões ${ }^{87} \mathrm{Sr} /{ }^{86} \mathrm{Sr}(\mathrm{i})$ podem ser feitas em plagioclásio, mineral praticamente isento de Rb e rico em Sr (DAVIDSON et al., 2007) que, portanto, mantém ao longo do tempo suas razões originais. O estudo já completado no Plúton Salto, utilizando análises in situ por LA-MC-ICPMS, está sendo submetido em artigo no qual a autora participa (ALVES; JANASI; PEREIRA, 2019), e mostra razões iniciais de 0,7068 para os granitos, valor esse um pouco superior ao dos enclaves microgranulares félsicos $(0,7060$ e 0,7063$)$, 
enquanto os enclaves microgranulares máficos, todos de tamanho reduzido neste plúton $(<4$ cm; PEREIRA, 2013), preservam razões iniciais de $\mathrm{Sr}$ ainda mais primitivas (0,7055 a 0,7058). Resultados desse tipo colocam dúvida sobre o valor superior a 0,708 calculado para rocha total de uma das amostras de Salto, e devem ser obtidos para os demais plútons do Batólito Itu em trabalhos futuros.



Figura 158 - Dados de isotopia Sr-Nd para as diferentes unidades do Batólito Itu.

\subsection{CORRELAÇÃO ENTRE OS DADOS ISOTÓPICOS DE ND EM ROCHA TOTAL E HF EM ZIRCÃO}

Os dados de isotopia de Hf em cristais de zircão previamente datados por SHRIMP ou LAQ-ICPMS de três amostras do Batólito Itu foram apresentados no capítulo 8. Os resultados (cf. Figura 157) apresentam valores médios de $\varepsilon \mathrm{Hf}(\mathrm{t})$ distintos, progressivamente mais negativos na sequência Salto $(-11,6) \rightarrow$ Cabreúva $(-14,8) \rightarrow$ Indaiatuba $(-17,8)$. Como foi informado no capítulo 8, dados para as outras amostras do Batólito Itu datadas pelo método U-Pb serão obtidos para publicação futura.

Os valores médios de $\varepsilon \mathrm{Hf}(\mathrm{t})$ em zircão são consistentes com os valores de $\varepsilon \mathrm{Nd}(\mathrm{t})$ obtidos em rocha total para as mesmas amostras, mostrando uma correlação positiva bem evidente (Figura 159). Combinados, esses dados indicam uma contribuição de fonte mais primitiva (com 
menor vida crustal) menor em Salto, que se aproxima dos valores apresentados pela amostra do Monzodiorito Piracaia (JANASI et al., 2019), interpretados como próximos ao componente de manto enriquecido regional (JANASI; VLACH; ULBRICH, 1993).



Figura 159 - Correlação entre $\varepsilon \mathrm{Nd}_{(\mathrm{t})}$ e $\varepsilon \mathrm{Hf}_{(\mathrm{t})}$ para granitos do Batólito Itu e outras ocorrências da PGI.

\subsection{INFERÊNCIAS SOBRE ÁREAS-FONTE}

A Figura 160 compara a isotopia $\mathrm{Sr}-\mathrm{Nd}$ das diferentes variedades de granitos do Batólito Itu com outras ocorrências da BPI (Monzodiorito Piracaia, Sienogranito Atibaia, Batólito Morungaba; dados de Janasi et al., 2009) e com granitos "sin-orogênicos" da porção sul da Nappe Socorro-Guaxupé (MARTINS, 2011 e dados inéditos de B. Toledo, dissertação de mestrado em andamento). 


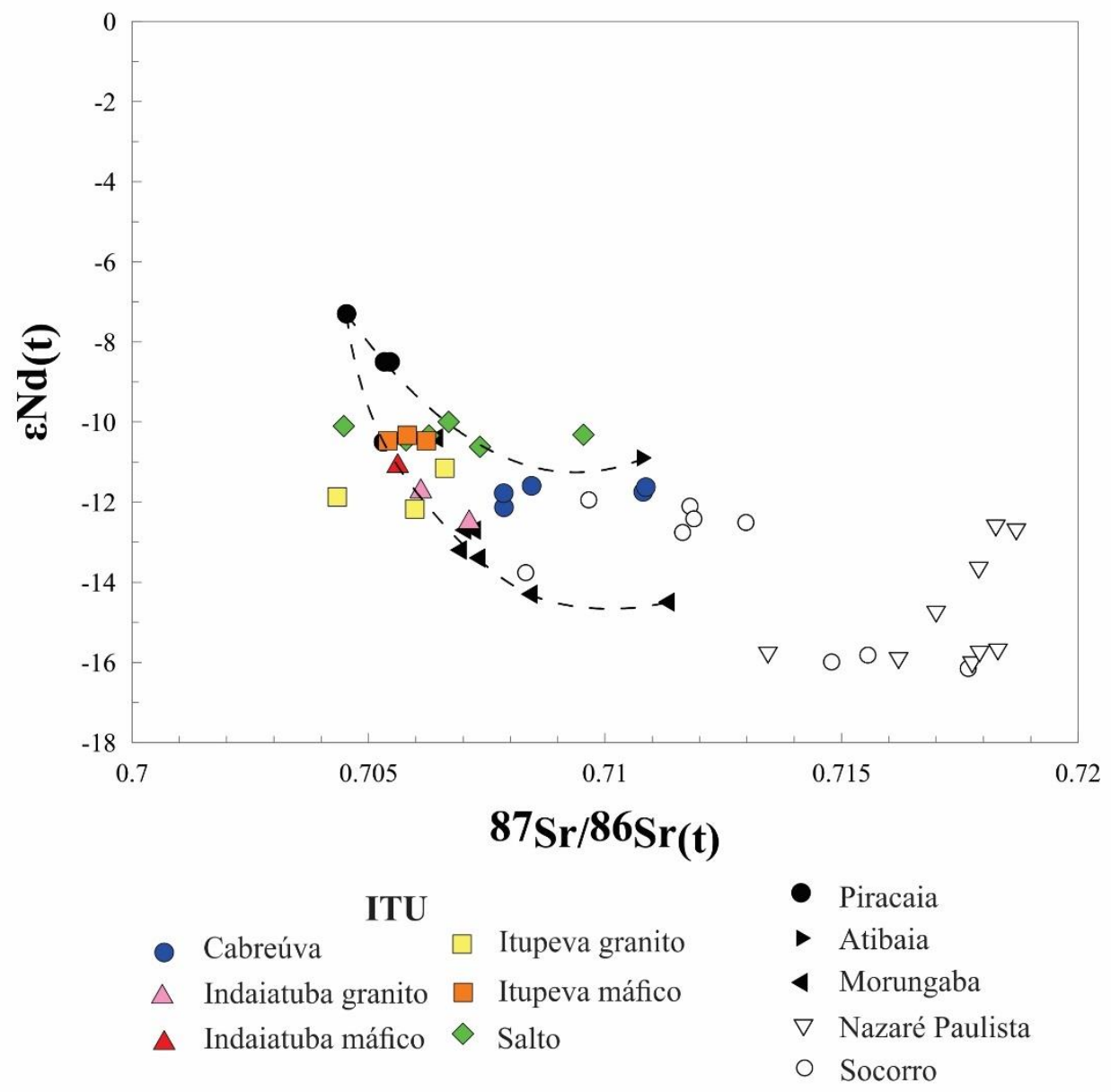

Figura 160 - Dados de isotopia Sr-Nd para as diferentes unidades do Batólito Itu em comparação com outras ocorrências graníticas associadas a PGI. As linhas tracejadas são envoltórias aproximadas que abrangem as rochas do batólito.

Todas as rochas do Batólito Itu se situam em um campo entre os monzodioritos Piracaia (amostras mais primitivas, representando aqui fontes no manto enriquecido), o sienogranito Atibaia $\left({ }^{87} \mathrm{Sr} /{ }^{86} \mathrm{Sr}(\mathrm{i})=0,711\right.$ e $\left.\varepsilon \mathrm{Nd}(\mathrm{t})=-11\right)$ e os granitos do Batólito Morungaba, cuja variação se estende em uma linha de mistura entre o monzodiorito Piracaia e uma amostra com ${ }^{87} \mathrm{Sr} /{ }^{86} \mathrm{Sr}(\mathrm{i})=0,711$ e $\varepsilon \mathrm{Nd}(\mathrm{t})=-14,5$ (Figura 160). As três amostras de Indaiatuba se alinham na mesma linha de mistura entre Piracaia e Morungaba, com o enclave máfico mais próximo de Piracaia. Cabreúva se distingue por se estender para razões iniciais mais altas que Indaiatuba, mantendo $\varepsilon \mathrm{Nd}(\mathrm{t})$ constante, em torno de -12. Salto e as variedades máficas de Itupeva mostram valores ligeiramente mais primitivos, se aproximando de Piracaia.

Comparados aos granitos "sin-orogênicos", os granitos do BPI são claramente mais primitivos em termos dos isótopos de $\mathrm{Sr}$ e $\mathrm{Nd}$. Os granitos anatéticos de Nazaré Paulista, produzidos via fusão de fontes predominantemente metassedimentares, têm razões ${ }^{87} \mathrm{Sr} /{ }^{86} \mathrm{Sr}(\mathrm{i})$ caracteristicamente mais altas $(>0,716)$ e $\varepsilon N d(t)$ variável, mas em geral mais negativos $(-12$ a 
-16). Os granitos do Batólito Socorro têm variação de $\varepsilon N d(t)$ semelhante, e ${ }^{87} \mathrm{Sr} /{ }^{86} \mathrm{Sr}(\mathrm{i})$ tipicamente mais altos que os granitos da PGI $(>0,710)$, embora não tão elevados como os granitos Nazaré Paulista; os valores mais negativos e com maiores razões ${ }^{87} \mathrm{Sr} /{ }^{86} \mathrm{Sr}(\mathrm{i})$ correspondem a algumas variedades de granitos hololeucocáticos, cuja assinatura $\mathrm{Sr}-\mathrm{Nd}$ se assemelha à dos granitos anatéticos (B. Toledo, dissertação de mestrado em andamento).

Os dados isotópicos $\mathrm{Sr}-\mathrm{Nd}-\mathrm{Hf}$ sugerem que as fontes dos granitos do Batólito Itu incluem um componente de manto enriquecido, mais evidente nos enclaves e pequenos corpos máficos, e nos granitos rapakivi do Plúton Salto. O componente crustal poderia corresponder a rochas semelhantes às fontes do magmatismo sin-orogênico, mas é notável a assinatura isotópica de Sr mais primitiva; de fato, razões iniciais de $\mathrm{Sr}$ tão baixas como as observadas em granitos do Plúton Salto (0,706 - 0,707; ALVES; JANASI; PEREIRA, 2019) não foram detectadas nos granitos "sin-orogênicos", e sugerem fontes crustais com baixa razão $\mathrm{Rb} / \mathrm{Sr}$ (granulíticas?). 


\section{CAPÍTULO 10 - CONSIDERACÕES FINAIS}

\subsection{GEOLOGIA DO BATÓLITO ITU}

Um trabalho extensivo de mapeamento faciológico de toda a área do Batólito Itu foi apresentado por Galembeck (1997). Este notável trabalho tem dado importante suporte a toda a pesquisa realizada desde então no batólito, como a presente tese. A revisita ao batólito, seja em trabalhos de campo, seja na avaliação de levantamentos aerogeofísicos e de novos dados petrográficos e geoquímicos, não teve como propósito propor alterações no mapa já existente. Foi constatado, no entanto, que algumas alterações são requeridas no mapa do batólito, para melhor exprimir a sua geologia.

O trabalho de mestrado da autora focalizou a origem dos enclaves microgranulares do Plúton Salto, e foi apresentado um mapa geológico que modificou o mapa original de Galembeck (1997), redimensionando a disposição das unidades, em especial a unidade de granitos pórfiros.

No presente trabalho, que enfocou os plútons Cabreúva e Indaiatuba, consideramos necessárias algumas alterações na definição desses plútons e suas relações mútuas e com o Plúton Itupeva.

O conceito amplamente utilizado na literatura geológica para definição de um plúton referese a uma unidade estrutural coerente, definida por contatos externos bem definidos. O "Plúton Cabreúva", como definido por Galembeck (1997), obedece apenas parcialmente a esta definição. Em nosso entendimento, a designação Plúton Cabreúva deve se restringir ao corpo constituinte da porção SE do Batólito Itu, de formato subcircular, e definido, em praticamente toda a sua borda oeste, sul e leste, por uma borda de leucogranito de granulação menos grossa que a fácies interna, e que tem na sua porção central um corpo de granito porfirítico associado a ocorrências menores de rocha máfica. Este corpo é limitado, a norte, por uma "fácies xenolítica" (nomenclatura de Galembeck, 1997) e granitos equigranulares que foram visitados durante a realização deste trabalho, e correspondem a rochas mais antigas, invadidas pelos granitos do plúton. Deste modo, as ocorrências isoladas de rochas texturalmente semelhantes às fácies do Plúton Cabreúva situadas a norte, em contato com rochas atribuídas aos plútons Indaiatuba e Itupeva (cf. Figura 53), não fazem parte dele.

Contrariamente aos outros três plútons definidos por Galembeck (1997), o Plúton Indaiatuba foi descrito como formado por uma única fácies (granito rapakivi grosso), que ocorre 
com formato irregular (cf. Figura 54), aparentemente recortada por granitos atribuídos aos plútons Cabreúva e Itupeva. Ao nosso ver, os granitos que se associam espacialmente ao granito rapakivi ID-1 de Galembeck não mostram relação estrutural com nenhum desses outros dois plútons, e deveriam ser agrupados, ao menos tentativamente, como parte do mesmo Plúton Indaiatuba. Os dados geoquímicos obtidos neste trabalho confirmam esta possibilidade.

O Plúton Itupeva também foi estudado neste trabalho, embora apenas em escala de reconhecimento; trabalho de detalhe sobre a sua petrologia está sendo realizado como Dissertação de Mestrado de Viviana Hernández. Desde o início dos trabalhos, no entanto, consideramos inconsistente atribuir ocorrências de rochas plutônicas máficas ("dioritos") situadas dentro das estruturas dos plútons Cabreúva e Indaiatuba ao Plúton Itupeva, como proposto no mapa de Galembeck. Deste modo, os diferentes corpos máficos foram associados, nesta tese, aos plútons dentro dos quais são encontrados. Adicionalmente, tornou-se evidente que os granitos que constituem o extremo nordeste do Batólito Itu correspondem a uma pequena intrusão independente, estrutural e morfologicamente, formada por granitos altamente fracionados, que mostram vinculação com mineralizações de metais raros (Nb-Sn-W). Esta intrusão foi individualizada como "Stock Inhandjara", e foi tema de uma Dissertação de Mestrado (ARAÚJO, 2018)

\subsection{IDADE E DURAÇÃO DO MAGMATISMO DO BATÓLITO ITU}

Um total de sete amostras do Batólito Itu foi alvo de datação U-Pb em zircão (6 pelo método SHRIMP e 1 por LA-MC-ICPMS). O objetivo foi determinar com maior precisão a idade e duração do magmatismo que formou o batólito. Adicionalmente, a presença de cristais herdados poderia trazer informação importante sobre as fontes do magmatismo. A datação U-Pb é também requisito para a obtenção de dados de isotopia de Hf, importante ferramenta para estudos petrogenéticos.

As idades de cristalização magmáticas obtidas neste trabalho são consistentes e marcam episódio principal em $578 \pm 4 \mathrm{Ma}$, indicando a formação de todos os plútons que constituem o batólito dentro da margem de erro. A imprecisão dos métodos não possibilita identificar com clareza a sucessão de eventos. Além disto, muitos cristais de zircão refletem processos hidrotermais que afetaram as rochas do batólito, em especial os granitos mais diferenciados de coloração avermelhada. Em alguns pontos, são obtidas idades discordantes ou, embora concordantes, claramente mais jovens que o intervalo principal identificado como marcador da idade magmática. A amostra de sienogranito Cabreúva IGN24A, situada na borda oeste do 
plúton, forneceu idade claramente mais jovem que as demais (561 $\pm 6 \mathrm{Ma})$. Caso admitida como idade de cristalização magmática, ela implica na formação do batólito (e do Plúton Cabreúva, em particular) ao longo de intervalo de tempo de até $20 \mathrm{Ma}$. A extensão do magmatismo Itu até idades desta ordem é também sugerida por uma das idades obtidas para o Stock Inhandjara por Araújo (2018). Uma interpretação alternativa, em parte suportada pela química notavelmente rica em elementos não típicos do mineral zircão nas duas amostras com idades mais jovens, admitiria esta idade como reflexo de um evento pós-magmático, de caráter hidrotermal.

Cristais herdados são muito raros nas amostras de Itu, refletindo as temperaturas relativamente altas dos magmas (Figura 161). Apenas a amostra de Itupeva CAB-15-36A apresentou núcleo de zircão claramente herdado, com idade paleoproterozoica ( 2.2 Ga). Um cristal de zircão com idade equivalente ao magmatismo neoproterozoico sin-orogênico ( 620 Ma) foi também identificado nesta amostra.


INDAIATUBA

$\triangle$ IND-rap

$\triangle$ IND-eq

$\triangle$ IND-maf

$\Delta$ IND-sgr

Figura 161 - Diagrama de temperatura de saturação em zircão x teor de sílica para as amostras de Cabreúva e Indaiatuba. 


\subsection{CONDIÇÕES DE CRISTALIZAÇÃO DO BATÓLITO ITU}

Evidências geológicas mostram claramente que o Batólito Itu, embora intrusivo em rochas afetadas por metamorfismo de alto grau na orogênese brasiliana (com idades na faixa de 630$605 \mathrm{Ma}$ ), alojou-se em níveis relativamente rasos da crosta. A profusa alteração hidrotermal, associada localmente (no Stock Inhandjara) com processos de greisenização e geração de jazimento de metais raros (ARAÚJO, 2018) e a presença de cavidades miarolíticas na facies petrográfica interpretada como zona de cúpula do Plúton Salto (PEREIRA, 2013) são evidências geológicas de alojamento raso.

Neste trabalho, foi realizada a estimativa da pressão de alojamento dos vários plútons que constituem o Batólito Itu, utilizando calibrações recentes do geobarômetro de Al em hornblenda (MUTCH et al., 2016). Os resultados mais robustos foram obtidos para os plútons Salto e Itupeva, nos quais o anfibólio, embora raro, tem mg\# mais alto, dentro da faixa admitida como adequada para aplicação do geobarômetro (entre 35 e 65; ANDERSON; SMITH, 1995). As pressões estimadas encontram-se na faixa de 2 - $3 \mathrm{kbar}$, confirmando alojamento raso. A amostra de granito rapakivi do Plúton Indaiatuba fornece resultado semelhante, embora o anfibólio tenha mg\# um pouco mais baixo que o limite inferior sugerido. Os anfibólios das quatro amostras de granito Cabreúva analisadas têm mg\# ainda mais baixo, e fornecem valores de pressão mais altos, uma vez que sob as condições em que se formaram o aumento do Al está relacionado à troca edenítica, que reflete o aumento da temperatura, e não da pressão. Em contrapartida, o anfibólio do enclave máfico de Indaiatuba mostra ampla variação composicional devido a reequilíbrio a baixas temperaturas, que resulta em espalhamento dos valores de pressão; os valores mais elevados são derivados das porções não transformadas, e se situam na faixa de 2 - 3 kbar.

Os granitos do Batólito Itu exibem características de granitos de tipo A da série aluminosa (JANASI et al., 2009), e como tal derivam de magmas relativamente pobres em $\mathrm{H}_{2} \mathrm{O}$ (refletidas na ausência ou pequena abundância de pegmatitos e no caráter tardio da cristalização da biotita na maioria das rochas) e com temperaturas liquidus relativamente altas. São em geral saturados em zircão e livres de herança, de modo que as temperaturas de saturação em zircão são boas estimativas das temperaturas liquidus (Figura 161). Os valores obtidos variam entre 880 e $800^{\circ} \mathrm{C}$ entre os granitos menos e mais evoluídos de Cabreúva (teores de $\mathrm{SiO}_{2}$ entre 69 e 77\%); temperaturas um pouco mais baixas (entre 800 e $730^{\circ} \mathrm{C}$ ) são observadas em granitos equigranulares evoluídos (> 74\% $\mathrm{SiO}_{2}$ ) considerados diferenciados de Indaiatuba. 
As temperaturas solidus foram estimadas pelo geotermômetro hornblenda-plagioclásio nas rochas portadoras de anfibólio (cf. Tabela 5), e se situam no intervalo 740 - $670^{\circ} \mathrm{C}$ no plúton Cabreúva; o valor mais baixo é mostrado pelo granito mais diferenciado. O enclave máfico de Indaiatuba mostra os valores mais baixos, considerados subsolidus $\left(630^{\circ} \mathrm{C}\right)$.

As composições da biotita são também sensíveis à temperatura, e em particular os teores de $\mathrm{Ti}$ aumentam com a temperatura. Observa-se que em muitos casos a troca $\mathrm{TiR}^{2+}=2 \mathrm{Al}^{\mathrm{VI}}$ reflete transformações subsolidus, e associa-se à perda do pleocroísmo tipicamente marrom das biotitas primárias e à presença de inclusões xenomórficas de minerais de Ti (ilmenita, rutilo) ou mesmo transformação parcial a clorita. Os valores obtidos se situam entre 650 e $750^{\circ} \mathrm{C}$.

Uma importante variação no estado de oxidação é observada entre os granitos do Batólito Itu, refletida claramente na química dos minerais máficos. A razão $\mathrm{Fe}^{3+} / \mathrm{Fe}^{2+}$ dos anfibólios, embora obtida de modo indireto, por estimativa baseada nas fórmulas estruturais dos anfibólios baseadas em 13 cátions exceto $\mathrm{Ca}, \mathrm{Na}$ e $\mathrm{K}$, mostra claramente o caráter mais reduzido dos granitos do Plúton Cabreúva, o que também é indicado pelo mg\# mais baixo de anfibólios e biotitas. Em contraposição, os Plútons Salto e Itupeva têm biotitas e, quando presentes, anfibólios, com mg\# claramente mais altos; a biotita é compatível com condições oxidantes, da ordem de FMQ+2, por comparação com as composições de granitos de tipo A de Anderson (2008) (cf. Figura 96). Embora com poucos dados, as condições de oxidação dos granitos do Plúton Indaiatuba se aproximam das observadas em Cabreúva.

\subsection{PROCESSOS EVOLUTIVOS EM CÂMARAS MAGMÁTICAS}

Os diferentes plútons que constituem o batólito Itu são interpretados como produtos da cristalização de câmaras magmáticas formadas na porção superior da crosta. Uma visão atual integrada dos processos ígneos propõe que as câmaras magmáticas correspondem ao topo de um sistema magmático transcrustal muito maior onde interagem fusões, cristais, e voláteis exsolvidos, distribuídos de maneira heterogênea no espaço e no tempo (CASHMAN; SPARKS; BLUNDY, 2017). Nesse sentido, as câmaras magmáticas são visualizadas como sistemas abertos, nos quais podem ocorrer processos de assimilação e sucessiva recarga por magmas gerados em profundidade, resultando em fenômenos relacionados a mistura. Nesse conceito, a crosta inferior seria o local onde as condições termais e reológicas são mais favoráveis processos extensivos e rápidos de segregação e fracionamento de fusões. Em contrapartida, na crosta superior seriam necessárias altas taxas de transferência de fusão para manter corpos magmáticos dominados por magmas, de maneira que mushes cristalinos mais frios, de longa 
vida, podem facilmente se desenvolver. Desta maneira, transferências de fusão por percolação parecem ser o mecanismo principal de criação de regiões ricas em líquidos e, consequente, evolução química de um sistema magmático (CASHMAN; SPARKS; BLUNDY, 2017). Modelos termais sugerem, portanto, que a crosta inferior é o local mais favorável para os estágios iniciais de fracionamento e segregação de produtos líquidos, e seções crustais expostas mostram um contínuo desde cumulatos máficos na crosta inferior até intrusivas graníticos na crosta superior.

Neste trabalho, e também em Galembeck (1997), foram identificadas localmente rochas graníticas de caráter cumulático no Plúton Cabreúva (quartzo monzodiorito CAB-16-91), o que é considerado um indicador da atuação de processos de cristalização fracionada a nível de câmara magmática. O comportamento geoquímico desta amostra em diagramas de variação é, em linhas gerais, compatível com o esperado para a geração líquidos residuais fortemente diferenciados, como os granitos equi- a inequigranulares da borda do plúton com $\sim 76-77 \%$, por cristalização fracionada a partir de magmas de composição equivalente à dos sienogranitos predominantes. A correlação entre índice de diferenciação (teor de $\mathrm{SiO}_{2}$ ) e temperaturas de saturação em zircão (Figura 161) é outro fator consistente com processos de fracionamento magmático. No caso do Plúton Indaiatuba, não foram identificadas rochas claramente cumuláticas, embora uma relação de diferenciação magmática entre os sienogranitos rapakivi (fácies ID-1 de Galembeck, 1997) e granitos equigranulares finos e médios que os intrudem seja permitida pelos dados geoquímicos. Como já destacado, a dinâmica de processos de fracionamento magmático em crosta rasa é regida principalmente pela mecânica de segregação por compactação de fusões e fluidos da matriz cristalina (filter pressing), o que pode causar variações geoquímicas que podem não ser descritas matematicamente como fracionamento em membros finais, ou cristalização em equilíbrio (CASHMAN; SPARKS; BLUNDY, 2017).

Evidências de campo mostram que a dinâmica evolutiva de todos os plútons que constituem o Batólito Itu envolveu contínuos episódios de recarga, envolvendo pulsos félsicos e máficos. Alves et al. (2015) mostraram que enclaves microgranulares félsicos registram processos de injeção de novos pulsos de magma félsico em mushes no Plúton Salto; neste plúton, enclaves microgranulares máficos são restritos em abundância e tamanho $(<4 \mathrm{~cm})$, o que é explicado pelo fato de que injeções máficas não alcançaram o nível atual de exposição da câmara magmática pretérita. Em contrapartida, nos plútons Cabreúva e Indaiatuba, tanto enclaves microgranulares félsicos como máficos são identificados, muitas vezes em associação. De modo similar ao observado em Salto (PEREIRA, 2013), foi demonstrado neste trabalho que os enclaves microgranulares félsicos de Cabreúva são caracteristicamente mais primitivos que os 
granitos que eles invadem, o que implica derivarem de magmas mais quentes e, portanto, com maior potencial de congelamento quando em contato com o mush. Evidências de mistura são abundantes nos enclaves microgranulares máficos e félsicos em todos os quatro plútons do batólito, gerando rochas híbridas, que muitas vezes incluem e assimilam parcialmente cristais e, possivelmente líquidos derivados do mush hospedeiro.

Ocorrências mais expressivas de rochas máficas foram descritas e individualizadas por Galembeck (1997) no Plúton Itupeva, que também é notável pela ausência de enclaves microgranulares máficos; os processos de coexistência e mistura de magmas nesse plúton são atualmente abordados em detalhe no mestrado de Viviana Hernandez. Corpos individualizados de rocha máfica foram também mapeados por Galembeck (1997) em Cabreúva, embora trabalhos de campo realizados nesta tese não tenham logrado amostrar essas rochas. Por outro lado, um corpo de monzogabro foi identificado no Plúton Indaiatuba (amostra CAB-15-57), e constitui a ocorrência de rocha máfica melhor preservada, e a única portadora de clinopiroxênio em todo o batólito.

Os contínuos inputs de magma máfico em níveis mais rasos da crosta devem ter sido responsáveis pela manutenção das temperaturas acima do solidus e sobrevivência das câmaras magmáticas que deram origem aos plútons do Batólito Itu por um longo período de tempo, considerando que as taxas de intrusão tenham sido suficientemente altas e/ou os volumes tenham sido suficientemente grandes.

\subsection{AS ÁREAS-FONTE DO MAGMATISMO DO BATÓLITO ITU}

Os granitos que constituem o Batólito Itu podem ser classificados como de tipo A (e.g., GALEMBECK, 1997) da série aluminosa (grupo A2 de Eby, 1992), com variações entre tipos reduzidos (Cabreúva) e oxidados (Salto, Itupeva). Admite-se, em geral, uma origem por fusão de crosta pobre em água e, portanto, a temperaturas elevadas (cf. Figura 161) para esses granitos (EBY, 1992; CREASER et al., 1991).

Os dados isotópicos de $\mathrm{Sr}, \mathrm{Nd}$ e $\mathrm{Hf}$ obtidos para os diferentes plútons do Batólito Itu mostram assinatura característica de granitos crustais, com valores fortemente negativos de $\varepsilon N d(t)(-10$ a -12$)$ e $\varepsilon H f(t)$, mas com razões ${ }^{87} \mathrm{Sr} /{ }^{86} \mathrm{Sr}(\mathrm{t})$ pouco elevadas $(0,706-0,708)$, que sugerem fontes com baixa razão Rb/Sr. A contribuição de fonte crustal antiga, não juvenil, é também sugerida pela presença de cristal de zircão herdado com idade paleoproterozóica em Itupeva (amostra CAB-15-36A). 
Uma fonte potencial para granitos de tipo A são granitos cálcio-alcalinos gerados durante o ciclo orogênico precedente. Em linhas gerais, a assinatura isotópica de $\mathrm{Nd}$ dos granitos do batólito, em especial do Plúton Cabreúva, são semelhantes à do magmatismo "sin-orogênico" tipo Socorro/Bragança Paulista (cf. Figura 160), o que levou à realização de estudos experimentais (SALAZAR, 2016) de fusão-desidratação dessas rochas em condições de alta temperatura e baixa pressão $\left(950^{\circ} \mathrm{C}\right.$ e $\left.400 \mathrm{MPa}\right)$, nos quais foram produzidos cerca de $35 \%$ de um fundido granítico pobre em $\mathrm{Ca}$, ferroano e peraluminoso e $65 \%$ em volume de fases residuais (reequilibradas) e neoformadas. A conclusão desse trabalho foi que o processo de desidratação-fusão de tais rochas sob condições de baixas pressões e altas temperaturas poderia gerar magmas de tipo A, como o caso de Itu, muito embora os produtos obtidos sejam peraluminosos, e não metaluminosos.

Uma característica isotópica importante dos granitos do batólito Itu, entretanto, são as razões ${ }^{87} \mathrm{Sr} /{ }^{86} \mathrm{Sr}(\mathrm{t})$, mais baixas que as do magmatismo sin-orogênico. Esta assinatura é compartilhada por outros plútons da PGI (cf. Figura 160), e pode estar relacionada não apenas a uma fonte crustal com baixa razão $\mathrm{Rb} / \mathrm{Sr}$, mas também ao componente máfico derivado do manto presente em todos os quatro plútons de Itu (na forma de corpos máficos, enclaves microgranulares félsicos e máficos e híbridos). As assinaturas isotópicas dos monzodioritos e rochas associadas do Plúton Piracaia $\left(\varepsilon N d(t)-7,3\right.$ e -8.5 e ${ }^{87} \mathrm{Sr} /{ }^{86} \mathrm{Sr}(\mathrm{t})=\sim 0.705$; JANASI et al., 1993) são típicas de magmas derivados de manto que foi enriquecido em processo prévio de subducção e se adequam bem a esta composição. 


\section{REFERÊNCIAS BIBLIOGRÁFICAS}

ABDEL-RAHMAN, A.F.M., 1994. Nature of biotites from alkaline, calc-alkaline, and peraluminous magmas. Journal of Petrology, 35(2): 525-541.

ALVES A., JANASI V.A., CAMPOS NETO M.C., HEAMAN L., SIMONETTI A., 2013. U-Pb geochronology of the granite magmatism in the Embu Terrane: Implications for the evolution of the Central Ribeira Belt, SE Brazil. Precambrian Research, 230: 1-12.

ALVES A., PEREIRA G.S., JANASI V.A., HIGGINS M., POLO L.A., JURIAANS O.S., RIBEIRO B.V., 2015. The origin of felsic microgranitoid enclaves: Insights from plagioclase crystal size distributions and thermodynamic models. Lithos, 239: 33-44.

ALVES, A., JANASI, V.A., PEREIRA, G.S., 2019. Unveiling the hidden evidences of magma mixing processes via combination of in situ $\mathrm{Sr}$ isotopes and trace elements analyses on plagioclase crystals. Lithos: submitted.

ANDERSON, J.L., SMITH, D.R., 1995. The effects of temperature and $f \mathrm{O}_{2}$ on the Alin-hornblende barometer. American Mineralogist, 80(5-6): 549-559.

ANDERSON, J.L., 1996. Status of thermobarometry in granitic batholiths. Transactions of Royal Society of Edinburgh Earth Sciences, 87:125-138.

ANDERSON J.L., BARTH A.P., WOODEN J.L., MAZDAB F. 2008. Thermometers and thermobarometers in granitic systems. Reviews in Mineralogy and Geochemistry, 69:121142.

ANDRADE, S., 2016. Análises por LA-ICPMS em zircões de rochas graníticas da Faixa Ribeira no Estado de São Paulo - SE do Brasil: implicações genéticas e geocronológicas: USP. Tese de Doutorado, Instituto de Geociências, $121 \mathrm{p}$.

ANNEN, C., BLUNDY, J.D., SPARKS, R.S.J., 2006. The Genesis of Intermediate and Silicic Magmas in Deep Crustal Hot Zones. Journal of Petrology, 47(3): 505-539.

ANNEN C. 2009. From plutons to magma chambers: Thermal constraints on the accumulation of eruptible silicic magma in the upper crust, Earth and Planetary Science Letters, 284: 409-416.

ANNEN C., BLUNDY J.D., LEUTHOLD J., SPARKS R.S.J., 2015. Construction and evolution of igneous bodies: Towards an integrated perspective of crustal magmatism. Lithos, 230: 206-221. 
ARAÚJO, F.P., 2018. O Leucogranito Inhandjara: um exemplo de diferenciação magmato-hidrotermal na província granítica Itu, SP: USP. Dissertação de Mestrado, Instituto de Geociências, 201 p.

ARMSTRONG J., 1991. Quantitative elemental analysis of individual microparticales with electron beam instruments. Electron Probe Quantization: 261-285.

ARVIN, M., DARGAHI, S., BABAEI, A.A., 2004. Mafic microgranular enclave swarms in the Chenar granitoid stock, NW of Kerman, Iran: evidence for magma mingling. Journal of Asian Earth Sciences, 24(1): 105-113.

ATHERTON P., SANDERSON M., 1987. The Cordillera Blanca Batholith: A study of granite intrusion and the relation of crustal thickening to peraluminosity. Geologische Rundschau, 76.

BACHL C.A., MILLER C.F., MILLER J.S., FAULDS J.E. 2001. Construction of a pluton: Evidence from an exposed cross section of the Searchlight pluton, Eldorado Mountains, Nevada. Geological Society of America Bulletin, 113(9): 1213-1228.

BACHMANN, O., BERGANTZ, G., 2008. The Magma Reservoirs That Feed Supereruptions. Elements, 4: 17-21.

BACHMANN O., HUBER C., 2016. Silicic magma reservoirs in the Earth's crust. American Mineralogist: 101(11): 2377-2404.

BARBARIN, B., DIDIER, J., 1992. Genesis and evolution of mafic microgranular enclaves through various types of interaction between coexisting felsic and mafic magmas. Transactions of Royal Society of Edinburgh: Earth Sciences, 83(1-2): 145-153.

BATEMAN P.C., 1992. Plutonism in the central part of the Sierra Nevada Batholith, California. USGS Professional Paper.

BATEMAN R. 1995. The interplay between crystallization, replenishment and hybridization in large felsic magma chambers. Earth-Science Reviews, 39: 91-106.

BELOUSOVA E.A., GRIFFIN W.L., O'REILLY S.Y., 2005. Zircon Crystal Morphology, Trace Element Signatures and Hf Isotope Composition as a Tool for Petrogenetic Modelling: Examples From Eastern Australian Granitoids. Journal of Petrology, 47(2): 329353.

BEST M.G. 1982. Igneous and metamorphic geology. San Francisco, Freeman, 729p.

BLUNDY, J.D., HOLLAND., T.J.B., 1990. Calcic amphibole equilibria and a new amphibole-plagioclase geothermometer. Contributions to Mineralogy and Petrology, 104(2): 208-224. 
BOWEN N.L. 1928. The Evolution of the Igneous Rocks. New Jersey, Princeton University Press, 334p.

BOWEN N.L. 1941 Certain singular points on crystallization curves of solid solutions. Proceedings of the National Academy of Sciences of the United States of America, 27(6): 301309.

BOYNTON, W.V. 1984. Geochemistry of the rare earth elements: meteorite studies. In: Henderson P. (ed.), Rare earth element geochemistry. Elsevier, pp. 63-114.

CAMPOS NETO, M.C., 2000. Orogenic systems from Southwestern Gondwana: An approach to Brasiliano-Pan-African cycle and orogenic collage in Southeastern Brazil. In: CORDANI, U.G.; MILANI, E.J.; THOMAZ FILHO, A.; CAMPOS, D.A. (Org.). Tectonic Evolution of South America. Rio de Janeiro: 31st International Geological Congress, 335-365.

CAMPOS NETO, M.C., CABY, R., 1999. Terrane accretion and upward extrusion of high-pressure granulites in the Neoproterozoic nappes of southeast Brazil: Petrologic and structural constraints. Tectonics, 19(4): 669-687.

CASHMAN K.D., GIORDANO G. 2014. Calderas and magmas reservoirs. Journal of Volcanology and Geothermal Research, 288: 28-45.

CHEN S., NIU Y., LI J., SUN W., ZHANG Y., HU Y., SHAO F., 2016. Syn-collisional adakitic granodiorites formed by fractional crystallization: Insights from their enclosed mafic magmatic enclaves (MMEs) in the Qumushan pluton, North Qilian Orogen at the northern margin of the Tibetan Plateau. Lithos, 248: 455-468.

DAVIDSON J., TEPLEY III F., PALACZ Z., MEFFAN-MAIN S. 2001. Magma recharge, contamination and residence times revealed by in situ laser ablation isotopic analysis of feldspar in volcanic rocks, Earth and Planetary Science Letters, 184: 427-442.

DAVIDSON, J.P., MORGAN, D.J., CHARLIER, B.L.A., 2007. Isotopic Microsampling of Magmatic Rocks. Elements, 3: 253-259.

DAVIDSON, J.P., MORGAN, D.J., CHARLIER, B.L.A., HARLOU, R., HORA, J.M., 2007. Microsampling and Isotopic Analysis of Igneous Rocks: Implications for the Study of Magmatic Systems. Annual Review of Earth and Planetary Sciences, 35(1): 273-311.

DEER, W.A., HOWIE, R.A., ZUSSMAN, J., 1992. An Introduction to the RockForming Minerals, Prentice Hall, Harlow, 2nd edition, 696p.

DEPAOLO, D.J., 1981. Trace-element and isotopic effects of combined wallrock assimilation and fractional crystallization. Earth and Planetary Science Letters, 53: 189-202.

DE SILVA, S., MILLER, C., BACHMANN, O., YOSHIDA, T., KNESEL, K., 2007. Large silicic magma systems. Journal of Volcanology and Geothermal Research, 167(Preface). 
DYMEK, R.F., 1983. Titanium, aluminum and interlayer cation substitutions in biotite from high-grade gneisses, West Greenland. American Mineralogist, 68(9-10): 880-899.

EBERT, H.D., CHEMALE, J.F., BABINSKI, M., ARTUR, A.C., VAN SCHMUS, W.R., 1996. Tectonic setting and U/Pb zircon dating of the plutonic Socorro Complex in the Transpressive Rio Paraíba do Sul Shear Belt, SE Brazil. Tectonics, 15(3): 688-699.

ELBURG, M.A., 1996. Evidence of isotopic equilibration between microgranitoid enclaves and host granodiorite, Warburton Granodiorite, Lachlan Fold Belt, Australia. Lithos, 38: $1-22$.

FERREIRA, F.J.F.,1991. Aerogamaespectometria e aeromagnetometria de um trato ocidental do Pré-Cambriano Paulista. São Paulo, SP: USP. Tese de Doutorado, Instituto de Geociências, 150 p.

FROST, R.B., BARNES, C.G, COLlinS, W.J., ARCULUS, R.J., ELliS, D.J., FROST, C.D., 2001. A Geochemical Classification for Granitic Rocks. Journal of Petrology, 42(11): 2033-2048.

FROST, C.D., FROST, R.B., 2007. On Ferroan (A-type) Granitoids: their Compositional Variability and Modes of Origin. Journal of Petrology, 52(1): 39-53.

GALEMBECK, T.M.B., 1997. O complexo múltiplo, centrado, plurisserial Itu-SP. Rio Claro, SP: UNESP. Tese de Doutorado, Instituto de Geociências e Ciências Exatas, 374 p.

GALEMBECK, T.M.B., WERNICK, E., HÜRMANN, P.K. 1997. Chemistry of Biotites and Whole Rocks from Rapakivi Itu Complex (Late Precambrian), State of São Paulo, SE Brazil. Anais da Academia Brasileira de Ciências, 63(9): 415-429.

GAMA, R.R.S. Estudo da jazida de wolframita de Inhandjara. São Paulo, 1946. Tese (Provimento de Cátedra), 95 p.

GINIBRE C., WÖRNER G., KRONZ A. 2007. Crystal Zoning as an Archive for Magma Evolution. Elements, 3: 261-266.

GLAZNER A., BARTLEY J.M., COLEMAN D., GRAY W., RYAN Z.T., 2004. Are plutons assembled over millions of years by amalgamation from small magma chambers? GSA Today, 14.

GOKHALE, N.W., 1968 Chemical composition of biotites as a guide to ascertain the origin of granites. Bulletin of Geological Society of Finland, 40: 107-111.

GUDMUNDSSON A. 2012. Magma chambers: Formation, local stresses, excess of pressures, and compartments. Journal of Volcanology and Geothermal Research, 237-238: 1941.

HALL A. 1996. Igneous Petrology. Harlow, Pearson Education Limited (2nd ed.), 551p. 
HAWTHORNE, F.C., OBERTI, R., 2007. Amphiboles: Crystal Chemistry. Reviews in Mineralogy and Geochemistry, 67(1): 1-57.

HAWKINS, D.P., WIEBE, R.A., 2004. Discrete stoping events in granite plutons: A signature of eruptions from silicic magma chambers? Geology, 32(12): 10211024.

HEILBRON M., PEDROSA-SOARES A.C., CAMPOS NETO M.C., SILVA L.C., TROUW R.A.J., JANASI V.A., 2004. Província Mantiqueira. In: MANTESSO-NETO V. et al. (orgs.) Geologia do Continente Sul-Americano: Evolução da Obra de Fernando Flávio Marques de Almeida, p. 203-235.

HENRIQUE-PINTO, R., JANASI, V.A., VASCONCELLOS, A.C.B.C., SAWYER, E. W., BARNES, S.J., BASEI, M. A. S., TASSINARI, C. C. G., 2015. Zircon provenance in metasandstones of the São Roque Domain: Implications for the Proterozoic evolution of the Ribeira Belt, SE Brazil. Precambrian Research, 256: 271-288.

HENRY, D.J., GUIDOTTI, C.V., THOMSON, J.A., 2005. The Ti-saturation surface for low-to-medium pressure metapelitic biotites: Implications for geothermometry and $\mathrm{Ti}$ substitution mechanisms. American Mineralogist, 90: 316-328.

HILDRETH, W., MOORBARTH, S., 1988. Crustal contribution to arc magmatism in the Andes of Central Chile. Contributions to Mineralogy and Petrology, 98: 455-489.

HINTO R., 1999. NIST SRM 610, 611 and SRM 612, 613 Multi-Element Glasses: Constraints from Element Abundance Ratios Measured by Microprobe Techniques. Geostandards Newsletter, 23(2): 197-207.

HOLLAND, T., BLUNDY, J., 1994. Non-ideal interactions in calcic amphiboles and their bearings on amphibole-plagioclase thermometry. Contributions to Mineralogy and Petrology, 116: 433-447.

IRELAND, T.R., WILLIAMS, I.S., 2003. Considerations in zircon geochronology by SIMS. Reviews in Mineralogy and Geochemistry, 53(1):215-241.

JANASI, V.A., VLACH, S.R.F., ULBRICH, H.H.G.J., 1993. Enriched-mantle contributions to the Itu granitoid belt, southeastern Brazil: evidence from K-rich diorites and syenites. Anais da Academia Brasileira de Ciências, 65(supl.): 107-118.

JANASI, V.A., 1999. Petrogênese de granitos crustais na Nappe de Empurrão SocorroGuaxupé (SP-MG): uma contribuição da geoquímica elemental e isotópica. Post-Doctoral Thesis, Universidade de São Paulo, São Paulo, Brazil, 304 pp.

JANASI, V.A., VLACH, S.R.F., CAMPOS NETO, M.C., ULBRICH, H.H.G.J., 2009. Associated A-type subalkaline and high-K calc-alkaline granites in the Itu Granite Province, 
southeastern Brazil: petrological and tectonic significance. Canadian Mineralogist, 47(6): 15051526.

JANASI, V.A., PEREIRA, G.S., MONSALVE, V.M., TOLEDO, B.B., ALVES, A., MARTINS, L., 2019. From post-collisional to post-orogenic Neoproterozoic magmatism in SE Brazil: ages and sources of the Itu Granitic Province, 9th Symposium on the Origin of Granites and Related Rocks, Nanjing, China.

JAROSEWICH E., 2002. Smithsonian Microbeam Standards. Journal of research of the National Institute of Standards and Technology, 107(6): 681-685.

KÜHN A., STÜWE K., TROUW R.A.J., 2004. Metamorphic Evolution of the Ribeira Belt: Evidence from Outcrops in the Rio de Janeiro Area, Brazil. Journal of Petrology, 45(11): 2303-2323.

LE MAITRE R. W., 2002. Igneous Rocks: a Classification and Glossary of Terms Recommendations of the International Union of Geological Sciences, Sub-Commission on the Systematics of Igneous Rocks, Cambridge University Press, 236p.

LOCOCK A., 2014. An Excel spreadsheet to classify chemical analyses of amphiboles following the IMA 2012 recommendations. Computers \& Geosciences, 62: 1-11.

LOIOS V.A.P., 2009. Métodos de preparação e separação de minerais no CPGeo do IGC-USP. In: Boletim de Resumos Expandidos do Simpósio 45 Anos de Geocronologia no Brasil, 10: 107-109.

LUHR J.F., CARMICHARL I.S.E., VAREKAMP J.C., 1984. The 1982 eruptions of El Chichón Volcano, Chiapas, Mexico: mineralogy and petrology of the anhydrite-bearing pumices. Journal of Volcanology and Geothermal Research, 23: 69-108.

MARSH, B.D., 1989. Magma Chambers. Annual Review of Earth and Planetary Sciences, 17: 439-474.

MARSH B.D. 2002. On bimodal differentiation by solidification front instability in basaltic magmas, part 1: Basic mechanics. Geochimica et Cosmochimica Acta, 66(12): 22112229.

MARSH B.D. 2006. Dynamics of Magmatic Systems. Elements, 2: 287-292.

MARTINS, L., 2006. Geração e migração de magmas graníticos na crosta continental: estudos de detalhe em granitos e migmatitos da região de Nazaré Paulista (SP). Doctorate Thesis, Universidade de São Paulo, São Paulo, 159 pp.

MARTINS, L., VLACH, S.R.F., JANASI, V.A., 2009. Reaction microtextures of monazite: Correlation between chemical and age domains in the Nazaré Paulista migmatite, SE Brazil. Chemical Geology, 261(3-4): 271-285. 
MCBIRNEY A., 1980. Mixing and unmixing of magmas. Journal of Volcanology and Geothermal Research. 7(3): 357-371.

MENAND T., SAINT-BLANQUAT M., ANNEN C., 2010. Emplacement of magma pulses and growth of magma bodies. Tectonophysics, 500(1-2): preface.

MILLER C.F., FURBISH D.J., WALKER B.A., CLAIBORNE L.L., KOTEAS G.C., BLEICK H.A., MILLER J.S. 2011. Growth of plutons by incremental emplacement of sheets in crystal-rich host: Evidence from Miocene intrusions of the Colorado River region, Nevada, USA. Tectonophysics, 500: 65-77.

MOREL M.L.A., NEBEL O., BEL-JACOBSEN Y.J., MILLER J.S., VROON P.S., 2008. Hafnium isotope characterization of the GJ-1 zircon reference material by solution and laser-ablation MC-ICPMS. Chemical Geology. 255(1): 231-235.

MORI, P.E., REEVES, S., CORREIA, C.T., HAUKKA, M., 1999. Development of a fused glass disc XRF facility and comparison with the pressed powder pellet technique at Instituto de Geociências, Universidade de São Paulo. Revista Brasileira de Geociências, 29: 441-446.

MORIMOTO, N., 1988. Nomenclature of pyroxenes. American Mineralogist, 73: 1123 1133.

MUTCH E.J.F., BLUNDY J.D., TATTICH B.C., COOPER F.J., BROOKER R.A., 2016. An experimental study of amphibole stability in low-pressure granitic magmas and a revised Al-in-hornblende geobarometer. Contributions to Mineralogy and Petrology, 171: 85.

NACHIT, H., IBHI, N., ABIA, E.H., OHOUD, M.B., Discrimination between primary magmatic biotites, reequilibrated biotites and neoformed biotites. Comptes Rendus Geoscience, 337: 1415-1420.

NAMUR O., CHARLIER B., HOLNESS M. B., 2012. Dual origin of Fe-Ti-P gabbros by immiscibility and fractional crystallization of evolved tholeiitic basalts in the Sept Iles layered intrusion. Lithos, 154: 100-114.

NAVARRO, M.S., 2004. A Implantação de Rotina, e seu Refinamento, para a Determinação de Elementos Terras Raras em Materiais Geológicos por ICP-OES e ICP-MS: aplicação ao caso dos granitóides de Piedade-Ibiúna (SP) e Cunhaporanga (PR). São Paulo, SP: USP. Dissertação de Mestrado, Instituto de Geociências, 132 p.

NKONO C., FÉMÉNIAS O., DIOT H., BERZA T., DEMAIFFE D., 2006. Flowage differentiation in an andesitic dyke of the Motru Dyke Swarm (Southern Carpathians, Romania) inferred from AMS, CSD and geochemistry. Journal of Volcanology and Geothermal Research, 154(3): 201-221. 
PALLISTER, J.S., HOBLITT, R.P., REYES, A.G., 1992. A basalt trigger for the 1991 eruptions of Pinatubo volcano? Nature, 356: 426-428.

PASCHOLATI, E.M. Caracterização Geofísica da Suíte Intrusiva de Itu. São Paulo, SP: USP, 1990. Tese de doutorado, Instituto Astronônico e Geofísico, 135 p.

PEREIRA, G.S., 2013. O significado dos enclaves microgranulares félsicos na evolução de magmas graníticos: petrologia dos enclaves do Granito Salto, Batólito Itu, SP. São Paulo, SP: USP. Dissertação de Mestrado, Instituto de Geociências, 109p.

PERUGINI D., POLI G. 2012. The mixing of magmas in plutonic and volcanic environments: Analogies and differences. Lithos, 153: 261-277.

PIMENTEL, M., 2016. The tectonic evolution of the Neoproterozoic Brasília Belt, central Brazil: a geochronological and isotopic approach. Brasilian Journal of Geology, 46: 6782.

RÄMÖ O.T., HAAPALA I. 1995. One hundred years of rapakivi granite. Mineralogy and Petrology, 52 (3-4), 129-185.

RIBEIRO V.B., MANTOVANI M.S.M., LOURO V.H.A., 2013. Aerogamaespectrometria e suas aplicações no mapeamento geológico. Terrae Didática, 10: 2951.

ROCHA, B.C., MORAES, R., MÖLLER, A., CIOFFI, C.R., JERCINOVIC, M.J., 2017. Timing of anatexis and melt crystallization in the Socorro-Guaxupé Nappe, SE Brazil: Insights from trace element composition of zircon, monazite and garnet coupled to U-Pb geochronology. Lithos, 277: 337-355.

SATO, K., TASSINARI, C.C.G., KAWASHITA, K., PETRONILHO, L., 1995. O método geocronológico Sm-Nd no IG/USP e suas aplicações. Anais da Academia Brasileira de Ciências, 67: 315-336.

SATO K., BASEI M.A.S., SIGA JÚNIOR O., SPROESSER W.M., PASSARELLI C., 2008. Novas técnicas aplicadas ao método U-Pb no CPGeo - IGc/USP: avanços na digestão química, espectrometria de massa (TIMS) e exemplos de aplicação integrada com SHRIMP. Geologia USP. Série Científica, 8: 76-99.

SATO K., TASSINARI C., BASEI M.A.S., SIGA JÚNIOR O., ONOE A.T., SOUZA M.D., 2014. Sensitive High Resolution Ion Microprobe (SHRIMP IIe/MC) of the Institute of Geosciences of the University of São Paulo, Brazil: Analytical method and first results. Geologia USP. Série Científica, 14: 3-18. 
SCHMIDT, M.W., 1992. Amphibole composition in tonalite as a function of pressure: an experimental calibration of the Al-in-hornblende barometer. Contributions to Mineralogy and Petrology, 110(2-3): 304-310.

SHAW H., 1965. Comments on viscosity, crystal settling, and convection in granitic magmas. American Journal of Science, 263(2): 120-152.

SHAW, S.E., FLOOD, R.H., 2009. Zircon Hf Isotopic Evidence for Mixing of Crustal and Silicic Mantle-derived Magmas in a Zoned Granite Pluton, Eastern Australia. Journal of Petrology, 5(1): 147-168.

SIGMARSSON, O., VLASTELIC, I., ANDREASEN, R., BINDEMAN, I., DEVIDA, J.L., MOUNE, S., KEIDING, J.K., LARSEN, G., HÖSKULDSSON, A., THORDARSON, T., 2011. Remobilization of silicic intrusion by mafic magmas during the 2010 Eyjafjallajokull eruption. Solid Earth, 2: 271-281.

SILVA L.C., MCNAUGHTON N.J., ARMSTRONG R., HARTMANN L.A., FLETCHER I.R., 2005. The neoproterozoic Mantiqueira Province and its African connections: a zircon-based $\mathrm{U}-\mathrm{Pb}$ geochronologic subdivision for the Brasiliano/Pan-African systems of orogens. Precambrian Research, 136: 203-240.

SŁABY E., MARTIN H. 2008. Mafic and Felsic Magma Interaction in Granites: the Hercynian Karkonosze Pluton (Sudetes, Bohemian Massif). Journal of Petrology, 49(2): 353391.

SMITH J.V., BROWN, W.L., 1998. Feldspar minerals. Crystal Structures, Physical, Chemical, and Microtextural Properties (volume 1). Springer-Verlag Berlin Heidelberg, 2nd edition, 828p.

SNYDER D. 2000. Thermal effects of the intrusion of basaltic magma into a more silicic magma chamber and implications for eruption triggering. Earth and Planetary Science, 175: 257-273.

SPARKS S., SIGURDSSON H., WILSON L., 1977. Magma mixing: a mechanism for triggering acid explosive eruptions. Nature, 267(5609): 315-318.

SPARKS R.S.J., HUPPERT H.E., TURNER J.S., SAKUYAMA M., O’HARA M.J., MOORBATH S.E., THOMPSON R.N., OXBURGH E.R., 1984. Philosophical Transactions of the Royal Society of London. Series A, Mathematical and Physical Sciences. 310(1514):511534.

STREICKEISEN, A., 1976. Classification of Common Igneous Rocks by Mean of Their Chemical Composition. A Provisional Attempt. Neues Jahrbuch für Mineralogie, Monatshefte, 1: $1-15$. 
TASSINARI, C., 1988. As idades das rochas e dos eventos metamórficos da porção sudeste do Estado de São Paulo e sua evolução crustal. Doctoral Thesis, Universidade de São Paulo, São Paulo, Brazil, 236 pp.

TEGNER C., ROBINS B., REGINIUSSEN H., GRUNDVIG S., 1999. Assimilation of Crustal Xenoliths in a Basaltic Magma Chamber: $\mathrm{Sr}$ and $\mathrm{Nd}$ Isotopic Constraints from the Hasvik Layered Intrusion, Norway. Journal of Petrology, 40(3): 363-380.

TINDLE A., WEBB P., 1990. Estimation of lithium contents in trioctahedral micas using microprobe data: application to micas from granitic rocks. European Journal of Mineralogy, 2(5): 595-610.

TOLEDO, B.B., JANASI, V.A., SILVA, L.G.R., 2018. SHRIMP U-Pb Geochronology of the Socorro Batholith and implications for the Neoproterozoic evolution in SE Brazil. Brazilian Journal of Geology, 48: 761-782.

TÖPFNER, C. Brasiliano-granitoide in den Bundesstaaten São Paulo und Minas Gerais, Brasilien-eine Vergleichende studie. Münchner Geol. Hefte, A17, 1996.

TROUW, R.A.J., PETERNEL, R., RIBEIRO, A., HEILBRON, M., VINAGRE, R., DUFFLES, P., TROUW, C.C., FONTAINHA, M., KUSSAMA, H.H., 2013. A new interpretation for the interference zone between the southern Brasília belt and the central Ribeira belt, SE Brazil. Journal of South American Earth Sciences. 48: 43-57.

TURNER J., CAMPBELL I., 1986. Convection and mixing in magma chambers. EarthScience Reviews, 23(4): 255-352.

ULBRICH, H.H.G.J., VLACH, S.R.F., JANASI, V.A., 2001. O mapeamento faciológico em rochas ígneas plutônicas. Revista Brasileira de Geociências, 31: 163-172.

VERNON, R.H., 1984. Microgranitoid enclaves in granites - globules of hybrid magma quenched in a plutonic environment. Nature, 309: 438-439.

VINAGRE, R., TROUW, R. A. J., KUSSAMA, H., PETERNEL, R., MENDES, J.C., DUFFLES, P., 2017. Superposition of structures in the interference zone between the southern Brasília belt and the central Ribeira belt in the region SW of Itajubá (MG), SE Brazil. Brazilian Journal of Geology, 46(4), 547-566.

VLACH, S.R.F., JANASI, V.A., VASCONCELLOS, A.C.B.C., 1990. The Itu belt: associated calc-alkaline and aluminous A-type late Brasiliano granitoids in the States of São Paulo and Paraná, Southern Brazil. In: SBG, XXXVI Congresso Brasileiro de Geologia, Natal, RN, Anais: 1700-1711. 
WAIGHT, T.E., MAAS, R., NICHOLLS, I.A., 2001. Geochemical investigations of microgranitoid enclaves in the S-type Cowra Granodiorite, Lachlan Fold Belt, SE Australia. Lithos, 56: 165-185.

WAIGHT, T.E., WIEBE, R.A., KROGSTAD, E.J., 2007. Isotopic evidence for multiple contributions to felsic magma chambers: Gouldsboro Granite, Coastal Maine. Lithos, 93(3-4): 234-247.

WERNICK, E., GALEMBECK, T.M.B., GODOY, A.M., HÖRMANN, P.K., 1997. Geochemical variability of the Rapakivi Itu Province, State of São Paulo, SE Brazil. Anais da Academia Brasileira de Ciências, 69(3): 395-413.

WIEBE, R.A., ADAMS, S.D., 1997. Felsic enclave swarms in the Gouldsboro Granite, Coastal Maine: a record of eruption through the roof of a silicic magma chamber. The Journal of Geology, 105: 617-627.

WIEDENBECK M., ALLÉ P., CORFU F., GRIFFIN W.L., MEIER M., OBERLI F., QUADT A.V.O.N., RODDICK J.C., SPIEGEL W., 1995. Three natural zircon standards Ffor U-TH-PB, LU-HF, trace element and REE analyses. Geostandards Newsletter, 19(1): 1-23.

WILLIAMS, I.S., 1998. U-Th-Pb geochronology by ion microprobe. In: MCKIBBEN, M.A.; SHANKS III, W.C.; RIDLEY, W.I. (Eds). Applications of Microanalytical Techniques to Understanding Mineralizing Processes. Reviews in Economic Geology, 7: 1-35.

WILSON M., 1989. Igneous Petrogenesis. A Global Tectonic Approach. London, Unwin Hyman, 466p.

WOODS A., COWAN A., 2009. Magma mixing triggered during volcanic eruptions. Earth and Planetary Science Letters, 288(1): 132-137.

YODER JR. H.S. (Editor) 1979. The evolution of the igneous rocks - Fiftieth anniversary perspectives. New Jersey, Princeton University Press, 588p. 


\section{APÊNDICE A - DADOS DE RADIOMETRIA DE CAMPO}


Tabela A1 - Relação dos dados obtidos em levantamentos de campo, incluindo levantamento radiométrico, dados de localização na base UTM datum WGS-84.

\begin{tabular}{|c|c|c|c|c|c|c|c|c|}
\hline Ponto & Lat & Long & Plúton & Litotipo & TC & $\mathbf{K}(\%)$ & $\mathbf{U}(\mathbf{p p m})$ & Th(ppm) \\
\hline CAB-15-50 & 7435680 & 285526 & Indaiatuba & granodiorito & 21.4 & 3.2 & 2.9 & 14.2 \\
\hline CAB-15-50 & 7435680 & 285526 & Indaiatuba & granito & 52.9 & 7.1 & 6.4 & 39.8 \\
\hline CAB-15-50 & 7435680 & 285526 & Indaiatuba & granito & 45.9 & 6.5 & 5.9 & 32.2 \\
\hline CAB-15-50 & 7435680 & 285526 & Indaiatuba & granito & 31.1 & 4.4 & 3.7 & 22.5 \\
\hline CAB-15-50 & 7435680 & 285526 & Indaiatuba & granito & 35.0 & 4.5 & 3.9 & 27.3 \\
\hline CAB-15-51 & 7435000 & 285438 & Indaiatuba & granito pórfiro & 32.4 & 4.4 & 3.3 & 25.4 \\
\hline CAB-15-51 & 7435000 & 285438 & Indaiatuba & granito & 34.8 & 5.0 & 3.7 & 25.4 \\
\hline CAB-15-51 & 7435000 & 285438 & Indaiatuba & granito & 36.4 & 5.4 & 3.9 & 25.9 \\
\hline CAB-15-57 & 7435899 & 284063 & Indaiatuba & diorito & 20.8 & 2.9 & 3.4 & 13.2 \\
\hline CAB-16-73 & 7426340 & 270712 & Cabreúva & & 43.2 & 4.4 & 6.3 & 36.4 \\
\hline CAB-16-73 & 7426340 & 270712 & Cabreúva & & 50.4 & 5.0 & 8.7 & 39.2 \\
\hline CAB-16-73 & 7426340 & 270712 & Cabreúva & "casca" & 44.2 & 4.9 & 5.5 & 36.8 \\
\hline CAB-16-74 & 7426831 & 271899 & Cabreúva & & 33.0 & 4.1 & 4.7 & 17.6 \\
\hline CAB-16-74 & 7426831 & 271899 & Cabreúva & & 32.7 & 4.2 & 4.8 & 17.1 \\
\hline CAB-16-74 & 7426831 & 271899 & Cabreúva & & 35.7 & 8.0 & 5.1 & 20.1 \\
\hline CAB-16-79 & 7426265 & 274477 & Cabreúva & & 35.3 & 3.8 & 6.2 & 19.2 \\
\hline CAB-16-79 & 7426265 & 274477 & Cabreúva & & 32.9 & 3.5 & 5.7 & 19.1 \\
\hline CAB-16-80/IGN29 & 7425833 & 275847 & Cabreúva & & 33.7 & 4.1 & 5.1 & 18.2 \\
\hline CAB-16-80/IGN29 & 7425833 & 275847 & Cabreúva & & 35.8 & 4.4 & 5.4 & 18.3 \\
\hline CAB-16-80/IGN29 & 7425833 & 275847 & Cabreúva & & 44.8 & 5.2 & 7.4 & 21.1 \\
\hline CAB-16-83 & 7425654 & 276239 & Cabreúva & & 39.6 & 4.0 & 5.8 & 20.5 \\
\hline CAB-16-84 & 7426452 & 279835 & Cabreúva & & 29.7 & 3.7 & 4.4 & 14.6 \\
\hline CAB-16-84 & 7426452 & 279835 & Cabreúva & & 30.1 & 3.9 & 3.9 & 15.4 \\
\hline CAB-16-85 & 7426499 & 280494 & Cabreúva & & 31.7 & 4.2 & 3.8 & 14.6 \\
\hline CAB-16-85 & 7426499 & 280494 & Cabreúva & & 25.0 & 3.5 & 3.4 & 11.1 \\
\hline
\end{tabular}


Tabela A1 - continuação

\begin{tabular}{|c|c|c|c|c|c|c|c|}
\hline CAB-16-86 & 7426500 & 281335 & Cabreúva & 28.4 & 3.6 & 3.8 & 12.9 \\
\hline CAB-16-86 & 7426500 & 281335 & Cabreúva & 28.5 & 3.5 & 4.0 & 9.5 \\
\hline CAB-16-87 & 7425918 & 282992 & Cabreúva & 20.1 & 1.9 & 2.8 & 3.3 \\
\hline CAB-16-87 & 7425918 & 282992 & Cabreúva & 22.7 & 2.7 & 3.4 & 3.9 \\
\hline CAB-16-87 & 7425918 & 282992 & Cabreúva & 18.6 & 2.0 & 2.7 & 4.6 \\
\hline CAB-16-88 & 7428415 & 282543 & Cabreúva & 39.4 & 4.0 & 6.2 & 16.1 \\
\hline CAB-16-88 & 7428415 & 282543 & Cabreúva & 36.5 & 3.7 & 7.0 & 12.5 \\
\hline CAB-16-88 & 7428415 & 282543 & Cabreúva & 25.3 & 2.9 & 3.9 & 8.6 \\
\hline CAB-16-88 & 7428415 & 282543 & Cabreúva & 40.0 & 4.1 & 6.3 & 14.5 \\
\hline CAB-16-89 & 7429516 & 280401 & Cabreúva & 28.8 & 3.6 & 3.6 & 14.4 \\
\hline CAB-16-89 & 7429516 & 280401 & Cabreúva & 28.7 & 3.7 & 3.8 & 14.6 \\
\hline CAB-16-90 & 7429377 & 278973 & Cabreúva & 41.4 & 5.3 & 5.0 & 20.5 \\
\hline CAB-16-90 & 7429377 & 278973 & Cabreúva & 27.2 & 3.7 & 2.7 & 13.2 \\
\hline CAB-16-90 & 7429377 & 278973 & Cabreúva & 29.7 & 3.8 & 3.5 & 16.0 \\
\hline CAB-16-91 & 7429859 & 277844 & Cabreúva & 34.1 & 3.9 & 5.0 & 23.0 \\
\hline CAB-16-91 & 7429859 & 277844 & Cabreúva & 31.6 & 3.8 & 4.4 & 19.9 \\
\hline CAB-16-92 & 7445744 & 279397 & Itupeva & 25.1 & 3.8 & 2.8 & 12.3 \\
\hline CAB-16-92 & 7445744 & 279397 & Itupeva & 24.9 & 3.7 & 3.2 & 12.0 \\
\hline CAB-16-92 & 7445744 & 279397 & Itupeva & 25.7 & 3.8 & 3.6 & 13.3 \\
\hline CAB-16-93 & 7445057 & 280059 & Itupeva & 33.3 & 3.8 & 3.7 & 25.8 \\
\hline CAB-16-93 & 7445057 & 280059 & Itupeva & 29.2 & 3.3 & 3.9 & 20.6 \\
\hline CAB-16-94 & 7444657 & 281892 & Itupeva & 52.4 & 3.8 & 12.2 & 39.1 \\
\hline CAB-16-94 & 7444657 & 281892 & Itupeva & 61.8 & 5.1 & 12.3 & 47.1 \\
\hline CAB-16-94 & 7444657 & 281892 & Itupeva & 72.7 & 5.9 & 12.2 & 48.5 \\
\hline CAB-16-94 & 7444657 & 281892 & Itupeva & 69.1 & 5.6 & 12.7 & 50.9 \\
\hline CAB-16-94 & 7444657 & 281892 & Itupeva & 66.0 & 5.4 & 16.7 & 38.8 \\
\hline
\end{tabular}


Tabela A1 - continuação

\begin{tabular}{|c|c|c|c|c|c|c|c|c|}
\hline CAB-16-95 & 7444497 & 282488 & Itupeva & granito cinza com enclaves & 39.7 & 3.3 & 9.9 & 18.6 \\
\hline CAB-16-95 & 7444497 & 282488 & Itupeva & granito cinza com enclaves & 41.5 & 3.2 & 9.7 & 21.8 \\
\hline CAB-16-95 & 7444497 & 282488 & Itupeva & $\begin{array}{l}\text { granodiorito/diorito enclaves } \\
\text { grandes }\end{array}$ & 24.9 & 2.6 & 4.6 & 12.6 \\
\hline CAB-16-95 & 7444497 & 282488 & Itupeva & $\begin{array}{l}\text { granodiorito/diorito enclaves } \\
\text { grandes }\end{array}$ & 25.2 & 2.4 & 5.3 & 11.9 \\
\hline CAB-16-96 & 7444073 & 282760 & Itupeva & bt granito róseo & 44.9 & 3.2 & 13.3 & 19.4 \\
\hline CAB-16-96 & 7444073 & 282760 & Itupeva & & 41.9 & 3.0 & 12.5 & 17.9 \\
\hline CAB-16-97 & 7442851 & 282850 & Itupeva & & 34.1 & 3.0 & 7.5 & 14.5 \\
\hline CAB-16-97 & 7442851 & 282850 & Itupeva & & 36.1 & 2.7 & 9.5 & 10.4 \\
\hline CAB-16-97 & 7442851 & 282850 & Itupeva & & 43.1 & 3.2 & 11.1 & 12.6 \\
\hline CAB-16-97 & 7442851 & 282850 & Itupeva & & $\begin{array}{r}42 . \\
8\end{array}$ & 3.1 & 11.4 & 11.8 \\
\hline CAB-16-98 & 7442048 & 283621 & Itupeva & granito pórfiro & 35.9 & 2.6 & 9.1 & 10.9 \\
\hline CAB-16-98 & 7442048 & 283621 & Itupeva & granito pórfiro & 39.5 & 2.3 & 11.6 & 9.3 \\
\hline CAB-16-98 & 7442048 & 283621 & Itupeva & granito pórfiro & 31.6 & 2.4 & 7.5 & 9.6 \\
\hline CAB-16-98 & 7442048 & 283621 & Itupeva & bt granito róseo & 40.5 & 2.4 & 12.4 & 10.3 \\
\hline CAB-16-98 & 7442048 & 283621 & Itupeva & bt granito róseo & 41.4 & 2.4 & 13.0 & 9.4 \\
\hline CAB-16-98 & 7442048 & 283621 & Itupeva & bt granito róseo & 39.3 & 2.4 & 11.4 & 7.7 \\
\hline CAB-16-98 & 7442048 & 283621 & Itupeva & diorito no pórfiro & 29.7 & 2.0 & 7.9 & 7.9 \\
\hline CAB-16-99 & 7441963 & 283926 & Itupeva & granito róseo grosso & 44.6 & 2.3 & 14.5 & 15.8 \\
\hline CAB-16-99 & 7441963 & 283926 & Itupeva & & 47.8 & 2.5 & 15.4 & 14.1 \\
\hline CAB-16-100 & 7441702 & 284125 & Itupeva & granodiorito & 19.7 & 1.6 & 4.9 & 5.2 \\
\hline CAB-16-100 & 7441702 & 284125 & Itupeva & granodiorito & 18.8 & 1.3 & 4.5 & 5.2 \\
\hline CAB-16-101 & 7441546 & 284370 & Itupeva & granito & 38.7 & 3.0 & 9.4 & 13.0 \\
\hline CAB-16-101 & 7441546 & 284370 & Itupeva & granito & 36.9 & 2.8 & 9.1 & 11.2 \\
\hline CAB-16-101 & 7441546 & 284370 & Itupeva & diorito & 22.0 & 1.3 & 6.7 & 7.9 \\
\hline
\end{tabular}


Tabela A1 - continuação

\begin{tabular}{|c|c|c|c|c|c|c|c|c|}
\hline CAB-16-101 & 7441546 & 284370 & Itupeva & diorito & 28.1 & 2.0 & 7.5 & 7.1 \\
\hline CAB-16-101 & 7441546 & 284370 & Itupeva & granito lajedo & 38.3 & 2.8 & 10.7 & 12.1 \\
\hline CAB-16-102 & 7440870 & 285239 & Itupeva & & 43.7 & 2.9 & 12.7 & 19.5 \\
\hline CAB-16-102 & 7440870 & 285239 & Itupeva & & 53.0 & 3.2 & 14.2 & 26.2 \\
\hline CAB-16-102 & 7440870 & 285239 & Itupeva & milonito granítico & 47.0 & 3.2 & 12.3 & 22.1 \\
\hline IREN-1 & 7431157 & 264714 & Salto & leucogranito & 51.2 & 4.4 & 10.8 & 45.6 \\
\hline IREN-1 & 7431157 & 264714 & Salto & leucogranito & 42.8 & 4.7 & 8.6 & 32.5 \\
\hline IREN-1 & 7431157 & 264714 & Salto & leucogranito & 49.1 & 4.3 & 10.7 & 39.5 \\
\hline IREN-1b & 7431148 & 264777 & Salto & leucogranito & 45.0 & 4.1 & 9.0 & 37.9 \\
\hline IREN-1b & 7431148 & 264777 & Salto & leucogranito & 46.9 & 4.2 & 10.1 & 38.0 \\
\hline IREN-2 & 7430854 & 264660 & Salto & granito pórfiro & 39.4 & 4.4 & 6.5 & 29.1 \\
\hline IREN-2 & 7430854 & 264660 & Salto & granito pórfiro & 39.1 & 4.4 & 6.9 & 27.1 \\
\hline IREN-2b & 7430803 & 264579 & Salto & granito pórfiro & 39.0 & 4.2 & 6.7 & 26.8 \\
\hline IREN-2b & 7430803 & 264579 & Salto & granito pórfiro & 38.8 & 4.3 & 6.4 & 27.2 \\
\hline IREN-3 & 7429674 & 265188 & Salto & granito vermelho & 52.3 & 3.5 & 11.8 & 38.3 \\
\hline IREN-3 & 7429674 & 265188 & Salto & granito vermelho & 45.5 & 3.9 & 9.2 & 26.8 \\
\hline IREN-3 & 7429674 & 265188 & Salto & granito vermelho & 48.5 & 3.7 & 12.0 & 27.4 \\
\hline IREN-3 & 7429674 & 265188 & Salto & granito vermelho & 54.7 & 5.0 & 11.8 & 31.3 \\
\hline IREN-4 & 7428931 & 270918 & Salto & granito vermelho grosso & 34.4 & 3.0 & 7.2 & 14.7 \\
\hline IREN-4 & 7428931 & 270918 & Salto & granito vermelho grosso & 33.1 & 2.8 & 6.9 & 14.7 \\
\hline IREN-4 & 7428931 & 270918 & Salto & granito vermelho grosso & 39.3 & 3.4 & 8.8 & 16.0 \\
\hline IGN22 & 7429670 & 269796 & Salto & granito rapakivi & 36.2 & 3.4 & 8.0 & 16.4 \\
\hline IGN22 & 7429670 & 269796 & Salto & granito rapakivi & 54.7 & 5.3 & 10.4 & 27.9 \\
\hline IGN22 & 7429670 & 269796 & Salto & granito rapakivi & 37.4 & 3.5 & 7.5 & 18.3 \\
\hline IGN22 & 7429670 & 269796 & Salto & granito rapakivi & 49.4 & 4.7 & 9.5 & 25.5 \\
\hline IGN22 & 7429670 & 269796 & Salto & granito rapakivi & 41.5 & 3.7 & 8.6 & 20.4 \\
\hline
\end{tabular}


Tabela A1 - continuação

\begin{tabular}{|c|c|c|c|c|c|c|c|c|}
\hline IREN-6 & 7431390 & 270770 & Salto & granito vermelho & 50.0 & 4.5 & 9.9 & 31.4 \\
\hline IREN-6 & 7431390 & 270770 & Salto & granito vermelho & 54.6 & 4.3 & 12.7 & 34.0 \\
\hline IREN-6 & 7431390 & 270770 & Salto & granito vermelho & 36.8 & 3.3 & 7.0 & 22.8 \\
\hline IREN-7 & 7432164 & 269535 & Salto & granito pórfiro & 38.7 & 4.0 & 7.9 & 23.5 \\
\hline IREN-7 & 7432164 & 269535 & Salto & granito pórfiro & 49.0 & 4.6 & 10.0 & 28.5 \\
\hline IREN-7 & 7432164 & 269535 & Salto & granito pórfiro & 44.5 & 4.3 & 9.4 & 25.2 \\
\hline CAB-17-103 & 7442068 & 286205 & Itupeva & sienogranito inequigranular & 36.1 & 4.8 & 5.3 & 25.2 \\
\hline CAB-17-103 & 7442068 & 286205 & Itupeva & & 49.3 & 6.3 & 8.6 & 35.1 \\
\hline CAB-17-103 & 7442068 & 286205 & Itupeva & & 37.7 & 5.5 & 3.8 & 26.7 \\
\hline CAB-17-103 & 7442068 & 286205 & Itupeva & & 35.7 & 5.1 & 5.0 & 24.3 \\
\hline CAB-17-104 & 7445904 & 285768 & Itupeva & sienogranito inequigranular grosso & 35.6 & 5.5 & 3.8 & 23.0 \\
\hline CAB-17-104 & 7445904 & 285768 & Itupeva & & 30.9 & 4.7 & 3.1 & 20.0 \\
\hline CAB-17-105 & 7447147 & 285609 & Itupeva & leucogranito equigranular médio & 29.7 & 5.9 & 1.9 & 13.0 \\
\hline CAB-17-105 & 7447147 & 285609 & Itupeva & leucogranito equigranular médio & 26.0 & 4.9 & 2.5 & 11.5 \\
\hline CAB-17-106 & 7447033 & 285861 & Itupeva & leucogranito equigranular médio & 25.7 & 4.4 & 2.9 & 13.2 \\
\hline CAB-17-107 & 7446209 & 280388 & Itupeva & $\begin{array}{c}\text { leucogranito equigranular grosso a } \\
\text { médio }\end{array}$ & 28.4 & 4.9 & 3.2 & 14.5 \\
\hline CAB-17-107 & 7446209 & 280388 & Itupeva & & 31.3 & 5.3 & 2.9 & 16.9 \\
\hline CAB-17-108 & 7445389 & 282087 & Itupeva & sienogranito inequigranular & 36.3 & 4.4 & 3.6 & 32.0 \\
\hline CAB-17-108 & 7445389 & 282087 & Itupeva & & 36.5 & 4.8 & 5.6 & 24.7 \\
\hline CAB-17-108 & 7445389 & 282087 & Itupeva & & 40.1 & 4.8 & 4.2 & 36.4 \\
\hline CAB-17-109 & 7444226 & 283529 & Itupeva & sienogranito inequigranular & 56.9 & 6.0 & 8.8 & 50.9 \\
\hline CAB-17-109 & 7444226 & 283529 & Itupeva & & 66.3 & 6.1 & 9.0 & 56.7 \\
\hline CAB-17-110 & 7444631 & 284321 & Itupeva & granodiorito & 25.4 & 2.9 & 5.0 & 18.8 \\
\hline CAB-17-110 & 7444631 & 284321 & Itupeva & & 13.8 & 2.2 & 2.3 & 7.3 \\
\hline CAB-17-110 & 7444631 & 284321 & Itupeva & & 13.8 & 2.1 & 2.1 & 7.3 \\
\hline
\end{tabular}


Tabela A1 - continuação

\begin{tabular}{|c|c|c|c|c|c|c|c|c|}
\hline CAB-17-111 & 7444992 & 284513 & Itupeva & sienogranito inequigranular & 43.2 & 4.8 & 7.1 & 36.1 \\
\hline CAB-17-111 & 7444992 & 284513 & Itupeva & & 41.2 & 4.8 & 5.2 & 35.0 \\
\hline CAB-17-112 & 7445042 & 284804 & Itupeva & & 49.4 & 5.9 & 5.8 & 42.3 \\
\hline CAB-17-112 & 7445042 & 284804 & Itupeva & & 38.2 & 4.7 & 3.2 & 35.4 \\
\hline CAB-17-113 & 7444497 & 285542 & Itupeva & cinza & 44.3 & 5.3 & 6.0 & 37.0 \\
\hline CAB-17-113 & 7444497 & 285542 & Itupeva & róseo & 40.4 & 4.7 & 5.6 & 33.2 \\
\hline CAB-17-113 & 7444497 & 285542 & Itupeva & & & & & \\
\hline CAB-17-114 & 7339784 & 286540 & Encaixante & gnaisse granítico equigranular & 28.3 & 3.7 & 2.8 & 22.4 \\
\hline CAB-17-115 & 7439288 & 285196 & Indaiatuba & granito rapakivi grosso & 33.5 & 5.1 & 2.7 & 23.0 \\
\hline CAB-17-115 & 7439288 & 285196 & Indaiatuba & & 30.2 & 4.9 & 2.8 & 19.0 \\
\hline CAB-17-116 & 7439651 & 284232 & Itupeva & sienogranito inequigranular grosso & 39.4 & 4.5 & 4.9 & 34.4 \\
\hline CAB-17-116 & 7439651 & 284232 & Itupeva & & 44.1 & 5.4 & 5.8 & 35.0 \\
\hline CAB-17-117 & 7442697 & 282033 & Itupeva & & 39.2 & 4.9 & 6.6 & 29.1 \\
\hline CAB-17-117 & 7442697 & 282033 & Itupeva & & 40.6 & 4.5 & 7.8 & 30.1 \\
\hline CAB-17-118 & 7443389 & 281490 & Itupeva & & 50.8 & 6.0 & 9.5 & 35.6 \\
\hline CAB-17-118 & 7443389 & 281490 & Itupeva & & 41.3 & 4.9 & 7.3 & 30.8 \\
\hline CAB-17-119 & 7445091 & 286816 & Itupeva & & 35.1 & 3.8 & 3.9 & 34.9 \\
\hline CAB-17-119 & 7445091 & 286816 & Itupeva & & 26.9 & 3.5 & 4.4 & 19.7 \\
\hline CAB-17-119 & 7445091 & 286816 & Itupeva & & 27.0 & 3.6 & 3.5 & 21.1 \\
\hline CAB-17-119 & 7445091 & 286816 & Itupeva & & 35.2 & 4.0 & 4.0 & 33.5 \\
\hline CAB-17-120 & 7444792 & 287958 & Itupeva & & 35.9 & 4.3 & 3.2 & 33.5 \\
\hline CAB-17-120 & 7444792 & 287958 & Itupeva & & 42.9 & 4.2 & 5.0 & 43.4 \\
\hline CAB-17-120 & 7444792 & 287958 & Itupeva & banda escura & 54.8 & 5.6 & 14.0 & 37.2 \\
\hline CAB-17-120 & 7444792 & 287958 & Itupeva & & 36.9 & 4.1 & 3.2 & 36.2 \\
\hline CAB-17-120 & 7444792 & 287958 & Itupeva & & 44.9 & 6.5 & 3.2 & 35.0 \\
\hline CAB-17-120 & 7444792 & 287958 & Itupeva & & 45.2 & 6.6 & 5.6 & 34.1 \\
\hline
\end{tabular}


Tabela A1 - continuação




Tabela A1 - continuação

\begin{tabular}{|c|c|c|c|c|c|c|c|c|}
\hline CAB-17-129 & 7442260 & 288573 & Encaixante & & 39.2 & 4.0 & 11.4 & 25.4 \\
\hline CAB-17-130 & 7442335 & 288327 & Encaixante & & 33.0 & 5.0 & 3.1 & 22.7 \\
\hline CAB-17-131 & 7442450 & 288280 & Encaixante & & 28.0 & 4.5 & 3.2 & 16.6 \\
\hline CAB-17-131 & 7442450 & 288280 & Encaixante & & 36.2 & 4.3 & 5.7 & 26.6 \\
\hline CAB-17-132 & 7441419 & 287328 & Encaixante & granito fino & 50.6 & 3.7 & 23.9 & 25.0 \\
\hline CAB-17-132 & 7441419 & 287328 & Encaixante & granito fino & 63.6 & 4.8 & 26.7 & 35.1 \\
\hline CAB-17-133 & 7439315 & 286039 & Indaiatuba equi/Cabreúva & & 29.4 & 4.6 & 3.1 & 16.3 \\
\hline CAB-17-133 & 7439315 & 286039 & Indaiatuba equi/Cabreúva & & 31.7 & 4.9 & 2.5 & 22.2 \\
\hline CAB-17-134 & 7439254 & 282297 & Indaiatuba & & 31.4 & 3.6 & 3.2 & 29.2 \\
\hline CAB-17-134 & 7439254 & 282297 & Indaiatuba & & 32.3 & 4.1 & 2.9 & 26.6 \\
\hline CAB-17-135 & 7438770 & 282376 & Indaiatuba & granito inequigranular & 27.9 & 4.3 & 3.1 & 17.5 \\
\hline CAB-17-135 & 7438770 & 282376 & Indaiatuba & & 29.5 & 4.3 & 2.5 & 21.4 \\
\hline CAB-17-135 & 7438770 & 282376 & Indaiatuba & granito fino & 39.3 & 4.9 & 4.4 & 33.4 \\
\hline CAB-17-136 & 7436770 & 283326 & Indaiatuba & granito rapakivi & 38.2 & 4.9 & 3.8 & 33.0 \\
\hline CAB-17-136 & 7436770 & 283326 & Indaiatuba & & 37.5 & 4.6 & 4.2 & 32.3 \\
\hline CAB-17-137 & 7437553 & 288081 & Nhandeara & & 46.7 & 4.4 & 6.0 & 49.3 \\
\hline CAB-17-137 & 7437553 & 288081 & Nhandeara & & 53.1 & 4.8 & 8.3 & 51.2 \\
\hline CAB-17-137 & 7437553 & 288081 & Nhandeara & & 54.1 & 5.2 & 7.0 & 52.3 \\
\hline CAB-17-138 & 7437143 & 287922 & Nhandeara & & 51.6 & 4.3 & 10.4 & 49.2 \\
\hline CAB-17-138 & 7437143 & 287922 & Nhandeara & & 53.5 & 4.8 & 10.0 & 49.1 \\
\hline CAB-17-139 & 7436206 & 285414 & Indaiatuba & & 30.8 & 4.7 & 3.5 & 19.4 \\
\hline CAB-17-139 & 7436206 & 285414 & Indaiatuba & & 35.0 & 5.1 & 3.6 & 24.8 \\
\hline CAB-17-139 & 7436206 & 285414 & Indaiatuba & & 39.2 & 6.2 & 3.4 & 24.4 \\
\hline CAB-17-139 & 7436206 & 285414 & Indaiatuba & & 30.9 & 4.8 & 2.2 & 20.9 \\
\hline CAB-17-139 & 7436206 & 285414 & Indaiatuba & & 16.0 & 2.7 & 1.9 & 8.6 \\
\hline
\end{tabular}


APÊNDICE B - DADOS DE
QUÍMICA MINERAL 
Tabela B1 - Composição química dos plagioclásios do Batólito Itu.

\section{PLÚTON SALTO}

\section{AMOSTRA 2008-ITU-2.1A1}

\begin{tabular}{lccccccccccccccccccc}
\hline & $\mathbf{1}$ & $\mathbf{2}$ & $\mathbf{3}$ & $\mathbf{4}$ & $\mathbf{5}$ & $\mathbf{6}$ & $\mathbf{7}$ & $\mathbf{8}$ & $\mathbf{9}$ & $\mathbf{1 0}$ & $\mathbf{1 1}$ & $\mathbf{1 2}$ & $\mathbf{1 3}$ & $\mathbf{1 4}$ & $\mathbf{1 5}$ & $\mathbf{1 6}$ & $\mathbf{1 7}$ \\
\hline $\mathbf{S i O}_{2}$ & 61.75 & 60.28 & 57.24 & 58.12 & 62.42 & 61.43 & 62.19 & 62.11 & 61.50 & 63.51 & 58.66 & 61.63 & 60.91 & 62.64 & 58.32 & 68.14 & 61.93 \\
\hline $\mathbf{T i O}_{2}$ & 0.02 & 0.00 & 0.08 & 0.12 & 0.00 & 0.03 & 0.01 & 0.03 & 0.00 & 0.00 & 0.00 & 0.00 & 0.00 & 0.00 & 0.03 & 0.00 & 0.00 \\
\hline $\mathbf{A l}_{2} \mathbf{O}_{3}$ & 24.62 & 25.52 & 25.10 & 22.10 & 24.31 & 24.97 & 24.42 & 24.09 & 24.49 & 25.17 & 26.90 & 24.50 & 25.26 & 24.09 & 25.93 & 20.85 & 24.71 \\
\hline $\mathbf{F e O}$ & 0.05 & 0.18 & 1.96 & 3.95 & 0.26 & 0.23 & 0.18 & 0.47 & 0.19 & 0.21 & 0.19 & 0.20 & 0.15 & 0.33 & 0.11 & 0.11 & 0.13 \\
\hline $\mathbf{M n O}$ & 0.01 & 0.00 & 0.04 & 0.12 & 0.01 & 0.01 & 0.00 & 0.01 & 0.00 & 0.00 & 0.02 & 0.01 & 0.00 & 0.00 & 0.00 & 0.02 & 0.00 \\
\hline $\mathbf{M g O}$ & 0.00 & 0.00 & 0.00 & 2.97 & 0.00 & 0.00 & 0.00 & 0.00 & 0.00 & 0.00 & 0.00 & 0.00 & 0.00 & 0.00 & 0.00 & 0.01 & 0.00 \\
\hline $\mathbf{C a O}$ & 5.37 & 6.60 & 8.11 & 3.34 & 5.11 & 5.66 & 5.05 & 4.97 & 5.43 & 5.05 & 7.73 & 5.22 & 6.04 & 4.89 & 8.28 & 0.20 & 5.50 \\
\hline $\mathbf{N a} 2 \mathbf{O}$ & 8.38 & 7.89 & 6.70 & 7.13 & 8.60 & 8.19 & 8.47 & 8.48 & 8.47 & 8.30 & 6.90 & 8.38 & 7.89 & 8.77 & 7.30 & 11.15 & 8.19 \\
\hline $\mathbf{K}_{2} \mathbf{O}$ & 0.10 & 0.09 & 0.48 & 2.06 & 0.10 & 0.12 & 0.16 & 0.16 & 0.13 & 0.14 & 0.11 & 0.18 & 0.20 & 0.13 & 0.08 & 0.36 & 0.12 \\
\hline $\mathbf{S r O}$ & 0.05 & 0.09 & 0.10 & 0.08 & 0.04 & 0.05 & 0.10 & 0.08 & 0.08 & 0.06 & 0.07 & 0.09 & 0.05 & 0.05 & 0.10 & 0.00 & 0.06 \\
\hline $\mathbf{B a O}$ & 0.00 & 0.02 & 0.00 & 0.08 & 0.02 & 0.02 & 0.00 & 0.03 & 0.00 & 0.03 & 0.07 & 0.06 & 0.03 & 0.01 & 0.00 & 0.02 & 0.03 \\
\hline Total & 100.36 & 100.66 & 99.81 & 100.06 & 100.87 & 100.70 & 100.58 & 100.42 & 100.29 & 102.49 & 100.65 & 100.28 & 100.52 & 100.91 & 100.14 & 100.86 & 100.67 \\
\hline
\end{tabular}

\section{Número de cátions calculado na base 8 oxigênios}

\begin{tabular}{llllllllllllllllll}
\hline Si & 2.7282 & 2.6697 & 2.5993 & 2.6541 & 2.7446 & 2.7099 & 2.7415 & 2.7462 & 2.7244 & 2.7422 & 2.6050 & 2.7294 & 2.6940 & 2.7535 & 2.6116 & 2.9542 & 2.7282 \\
\hline $\mathbf{A l}$ & 1.2821 & 1.3322 & 1.3435 & 1.1896 & 1.2599 & 1.2983 & 1.2689 & 1.2555 & 1.2787 & 1.2810 & 1.4080 & 1.2789 & 1.3169 & 1.2482 & 1.3687 & 1.0655 & 1.2831 \\
\hline $\mathbf{T i}$ & 0.0006 & 0.0000 & 0.0026 & 0.0041 & 0.0000 & 0.0009 & 0.0003 & 0.0009 & 0.0000 & 0.0000 & 0.0000 & 0.0001 & 0.0000 & 0.0000 & 0.0009 & 0.0001 & 0.0000 \\
\hline $\mathbf{F e}$ & 0.0019 & 0.0065 & 0.0744 & 0.1507 & 0.0097 & 0.0084 & 0.0067 & 0.0175 & 0.0069 & 0.0075 & 0.0071 & 0.0075 & 0.0054 & 0.0120 & 0.0043 & 0.0039 & 0.0048 \\
\hline Mn & 0.0003 & 0.0000 & 0.0017 & 0.0046 & 0.0004 & 0.0004 & 0.0000 & 0.0002 & 0.0000 & 0.0002 & 0.0006 & 0.0005 & 0.0000 & 0.0000 & 0.0000 & 0.0006 & 0.0000 \\
\hline Mg & 0.0000 & 0.0000 & 0.0001 & 0.2022 & 0.0000 & 0.0000 & 0.0000 & 0.0000 & 0.0000 & 0.0000 & 0.0000 & 0.0000 & 0.0000 & 0.0000 & 0.0000 & 0.0006 & 0.0000 \\
\hline Soma T & 4.0132 & 4.0083 & 4.0215 & 4.2053 & 4.0145 & 4.0179 & 4.0174 & 4.0202 & 4.0099 & 4.0308 & 4.0207 & 4.0163 & 4.0162 & 4.0137 & 3.9854 & 4.0248 & 4.0161 \\
\hline & & & & & & & & & & & & & & \\
\hline Ca & 0.2542 & 0.3132 & 0.3946 & 0.1634 & 0.2407 & 0.2675 & 0.2385 & 0.2355 & 0.2577 & 0.2336 & 0.3678 & 0.2477 & 0.2862 & 0.2303 & 0.3973 & 0.0091 & 0.2596 \\
\hline Na & 0.7179 & 0.6775 & 0.5899 & 0.6313 & 0.7332 & 0.7005 & 0.7240 & 0.7270 & 0.7275 & 0.6949 & 0.5941 & 0.7196 & 0.6767 & 0.7475 & 0.6339 & 0.9373 & 0.6996 \\
\hline
\end{tabular}


Tabela B1 - continuação

\begin{tabular}{llllllllllllllllll}
\hline $\mathbf{K}$ & 0.0059 & 0.0048 & 0.0279 & 0.1200 & 0.0054 & 0.0065 & 0.0088 & 0.0089 & 0.0075 & 0.0080 & 0.0062 & 0.0102 & 0.0112 & 0.0076 & 0.0043 & 0.0201 & 0.0065 \\
\hline Sr & 0.0007 & 0.0012 & 0.0014 & 0.0012 & 0.0006 & 0.0007 & 0.0014 & 0.0011 & 0.0011 & 0.0009 & 0.0010 & 0.0012 & 0.0006 & 0.0006 & 0.0013 & 0.0000 & 0.0009 \\
\hline Ba & 0.0000 & 0.0004 & 0.0000 & 0.0014 & 0.0003 & 0.0003 & 0.0000 & 0.0005 & 0.0000 & 0.0006 & 0.0013 & 0.0011 & 0.0005 & 0.0002 & 0.0000 & 0.0004 & 0.0006 \\
\hline Soma M & 0.9788 & 0.9971 & 1.0138 & 0.9173 & 0.9803 & 0.9756 & 0.9727 & 0.9730 & 0.9939 & 0.9379 & 0.9704 & 0.9798 & 0.9753 & 0.9862 & 1.0368 & 0.9669 & 0.9672 \\
\hline Total & 4.9920 & 5.0054 & 5.0353 & 5.1226 & 4.9948 & 4.9935 & 4.9901 & 4.9932 & 5.0038 & 4.9688 & 4.9912 & 4.9960 & 4.9915 & 4.9999 & 5.0223 & 4.9917 & 4.9833 \\
\hline & & & & & & & & & & & & & \\
\hline Or & 0.604 & 0.485 & 2.753 & 13.117 & 0.555 & 0.669 & 0.909 & 0.918 & 0.751 & 0.849 & 0.639 & 1.041 & 1.149 & 0.766 & 0.416 & 2.080 & 0.673 \\
\hline Ab & 73.403 & 68.056 & 58.270 & 69.017 & 74.863 & 71.880 & 74.534 & 74.842 & 73.286 & 74.202 & 61.369 & 73.618 & 69.465 & 75.860 & 61.215 & 96.977 & 72.443 \\
\hline An & 25.993 & 31.459 & 38.977 & 17.866 & 24.581 & 27.451 & 24.557 & 24.239 & 25.963 & 24.948 & 37.992 & 25.341 & 29.386 & 23.374 & 38.369 & 0.943 & 26.884 \\
\hline
\end{tabular}


Tabela B1 - continuação

\section{PLÚTON SALTO}

\begin{tabular}{|c|c|c|c|c|c|c|c|c|c|c|c|c|c|c|c|c|c|c|}
\hline \multicolumn{19}{|c|}{ AMOSTRA FME3_7* } \\
\hline & PLG1 & PLG1 & PLG1 & PLG1 & PLG1 & PLG1 & PLG1 & PLG1 & PLG1 & PLG1 & PLG1 & PLG1 & PLG1 & PLG1 & PLG1 & PLG1 & PLG1 & PLG1 \\
\hline & pto1 & pto2 & pto3 & pto5 & pto6 & pto7 & pto8 & pto9 & pto10 & pto11 & pto12 & pto13 & pto14 & pto15 & pto16 & pto17 & pto18 & pto19 \\
\hline $\mathrm{SiO}_{2}$ & 57.29 & 57.35 & 55.75 & 62.24 & 61.82 & 64.48 & 61.11 & 68.42 & 60.46 & 59.88 & 61.71 & 60.13 & 60.75 & 61.44 & 61.83 & 61.80 & 62.16 & 61.74 \\
\hline $\mathrm{TiO}_{2}$ & 0.00 & 0.00 & 0.07 & 0.01 & 0.05 & 0.04 & 0.01 & 0.03 & 0.00 & 0.00 & 0.06 & 0.04 & 0.02 & 0.00 & 0.00 & 0.00 & 0.00 & 0.02 \\
\hline $\mathbf{A l}_{2} \mathbf{O}_{3}$ & 21.88 & 26.86 & 27.58 & 23.95 & 24.42 & 22.05 & 24.95 & 20.13 & 25.20 & 25.45 & 24.42 & 25.26 & 25.22 & 24.25 & 23.85 & 24.42 & 24.24 & 24.15 \\
\hline $\mathrm{FeO}$ & 0.13 & 0.50 & 0.18 & 0.26 & 0.20 & 0.28 & 0.18 & 0.15 & 0.26 & 0.12 & 0.19 & 0.14 & 0.18 & 0.19 & 0.32 & 0.19 & 0.15 & 0.19 \\
\hline MnO & 0.00 & 0.00 & 0.00 & 0.01 & 0.00 & 0.02 & 0.02 & 0.00 & 0.00 & 0.00 & 0.01 & 0.03 & 0.01 & 0.00 & 0.01 & 0.02 & 0.01 & 0.00 \\
\hline MgO & 0.00 & 0.07 & 0.02 & 0.00 & 0.01 & 0.10 & 0.00 & 0.03 & 0.06 & 0.00 & 0.00 & 0.00 & 0.00 & 0.00 & 0.04 & 0.00 & 0.00 & 0.00 \\
\hline $\mathrm{CaO}$ & 9.27 & 8.16 & 9.48 & 5.13 & 5.47 & 2.89 & 5.82 & 0.48 & 5.54 & 6.88 & 5.44 & 6.60 & 6.28 & 5.37 & 4.42 & 4.70 & 5.08 & 5.10 \\
\hline $\mathrm{Na}_{2} \mathbf{O}$ & 7.75 & 6.18 & 5.59 & 8.02 & 7.71 & 9.18 & 7.44 & 10.56 & 7.08 & 7.05 & 7.82 & 7.15 & 7.47 & 7.84 & 7.62 & 7.89 & 7.91 & 8.06 \\
\hline $\mathbf{K}_{2} \mathbf{O}$ & 0.12 & 0.07 & 0.19 & 0.18 & 0.08 & 0.09 & 0.15 & 0.06 & 0.64 & 0.10 & 0.12 & 0.11 & 0.08 & 0.09 & 0.65 & 0.44 & 0.12 & 0.08 \\
\hline SrO & 0.29 & 0.19 & 0.29 & 0.29 & 0.20 & 0.13 & 0.21 & 0.06 & 0.21 & 0.21 & 0.20 & 0.23 & 0.24 & 0.22 & 0.21 & 0.22 & 0.20 & 0.24 \\
\hline BaO & 0.03 & 0.04 & 0.00 & 0.01 & 0.01 & 0.05 & 0.00 & 0.00 & 0.02 & 0.02 & 0.02 & 0.00 & 0.01 & 0.11 & 0.00 & 0.06 & 0.04 & 0.05 \\
\hline Total & 96.73 & 99.38 & 99.15 & 100.10 & 99.96 & 99.26 & 99.89 & 99.92 & 99.45 & 99.69 & 99.97 & 99.68 & 100.23 & 99.41 & 98.95 & 99.68 & 99.86 & 99.58 \\
\hline
\end{tabular}

Número de cátions calculado na base 8 oxigênios



\begin{tabular}{lllllllllllllllllll}
\hline Al & 1.2065 & 1.4264 & 1.4748 & 1.2508 & 1.2755 & 1.1517 & 1.3061 & 1.0346 & 1.3270 & 1.3392 & 1.2764 & 1.3287 & 1.3185 & 1.2743 & 1.2580 & 1.2792 & 1.2658 & 1.2666
\end{tabular}

\begin{tabular}{llllllllllllllllllll}
\hline Ti & 0.0000 & 0.0000 & 0.0024 & 0.0002 & 0.0017 & 0.0014 & 0.0004 & 0.0009 & 0.0000 & 0.0000 & 0.0020 & 0.0012 & 0.0005 & 0.0000 & 0.0001 & 0.0000 & 0.0000 & 0.0006
\end{tabular}



\begin{tabular}{lllllllllllllllllllll}
\hline Mn & 0.0002 & 0.0000 & 0.0000 & 0.0006 & 0.0000 & 0.0006 & 0.0006 & 0.0000 & 0.0000 & 0.0000 & 0.0004 & 0.0010 & 0.0003 & 0.0000 & 0.0003 & 0.0006 & 0.0005 & 0.0000
\end{tabular}

\begin{tabular}{llllllllllllllllllll}
\hline Mg & 0.0000 & 0.0047 & 0.0016 & 0.0000 & 0.0008 & 0.0069 & 0.0000 & 0.0022 & 0.0038 & 0.0001 & 0.0001 & 0.0000 & 0.0000 & 0.0002 & 0.0025 & 0.0000 & 0.0000 & 0.0003
\end{tabular}

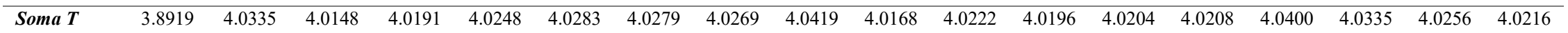

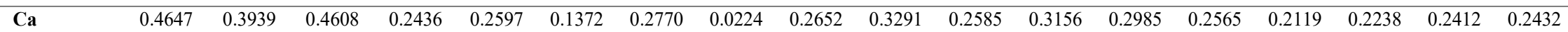


Tabela B1 - continuação

\begin{tabular}{|c|c|c|c|c|c|c|c|c|c|c|c|c|c|c|c|c|c|c|}
\hline $\mathbf{N a}$ & 0.7030 & 0.5399 & 0.4917 & 0.6890 & 0.6625 & 0.7888 & 0.6407 & 0.8929 & 0.6133 & 0.6103 & 0.6724 & 0.6187 & 0.6424 & 0.6777 & 0.6612 & 0.6799 & 0.6795 & 0.6954 \\
\hline K & 0.0073 & 0.0042 & 0.0109 & 0.0103 & 0.0048 & 0.0051 & 0.0087 & 0.0031 & 0.0365 & 0.0058 & 0.0066 & 0.0064 & 0.0044 & 0.0053 & 0.0370 & 0.0251 & 0.0065 & 0.0048 \\
\hline $\mathrm{Sr}$ & 0.0084 & 0.0054 & 0.0082 & 0.0082 & 0.0054 & 0.0037 & 0.0059 & 0.0018 & 0.0058 & 0.0058 & 0.0056 & 0.0063 & 0.0066 & 0.0061 & 0.0059 & 0.0062 & 0.0056 & 0.0066 \\
\hline Ba & 0.0006 & 0.0008 & 0.0000 & 0.0001 & 0.0002 & 0.0010 & 0.0000 & 0.0001 & 0.0004 & 0.0004 & 0.0004 & 0.0000 & 0.0002 & 0.0018 & 0.0000 & 0.0011 & 0.0006 & 0.0008 \\
\hline Soma $M$ & 1840 & 044 & 0.9717 & 0. & 0.9326 & 0.9357 & 0 . & 0 & 0.9212 & 0.9513 & 0.9435 & 0 & 0 & 75 & 0 & $\pi$ & 34 & .9508 \\
\hline Total & 5.0760 & 4.9777 & 4.9865 & 4.9703 & 4.9575 & 4.9041 & 4.9601 & 4.9 & 4.9631 & 81 & 7 & 66 & 24 & 83 & 4.9560 & 4.9695 & 4.9590 & 4.9723 \\
\hline Or & 0.619 & 0.453 & 1.132 & 1.093 & 0.516 & 0.543 & 0.941 & 0.334 & 3.984 & 0.610 & 0.705 & 0.678 & 0.464 & 0.562 & 4.065 & 2.702 & 0.703 & 0.507 \\
\hline $\mathbf{A b}$ & 59.833 & 57.553 & 51.038 & 73.076 & 71.465 & 84.718 & 69.162 & 97.231 & 67.031 & 64.569 & 71.723 & 65.772 & 67.963 & 72.134 & 72.648 & 73.202 & 73.287 & 73.717 \\
\hline An & 39.548 & 41.994 & 47.830 & 25.830 & 28.018 & 14.738 & 29.897 & 2.435 & 28.985 & 34.821 & 27.572 & 33.550 & 31.574 & 27.303 & 23.287 & 24.097 & 26.009 & 25.776 \\
\hline
\end{tabular}


Tabela B1 - continuação

\section{PLÚTON SALTO}

\begin{tabular}{|c|c|c|c|c|c|c|c|c|c|c|c|c|c|c|c|}
\hline \multicolumn{16}{|c|}{ AMOSTRA FME3_7* - cont. } \\
\hline & PLG1 & PLG1 & PLG1 & PLG1 & PLG1 & PLG1 & PLG1 & PLG1 & PLG1 & PLG1 & PLG1 & PLG1 & PLG1 & PLG1 & PLG1 \\
\hline & pto20 & pto21 & pto22 & pto23 & pto24 & pto25 & pto26 & pto27 & pto28 & pto29 & pto30 & pto31 & pto32 & pto33 & pto34 \\
\hline $\mathrm{SiO}_{2}$ & 61.19 & 65.73 & 61.74 & 63.93 & 60.07 & 62.20 & 61.13 & 62.15 & 58.44 & 61.45 & 60.45 & 63.36 & 65.45 & 64.37 & 64.50 \\
\hline $\mathrm{TiO}_{2}$ & 0.02 & 0.03 & 0.01 & 0.00 & 0.01 & 0.00 & 0.00 & 0.02 & 0.00 & 0.03 & 0.02 & 0.02 & 0.01 & 0.02 & 0.03 \\
\hline $\mathbf{A l}_{2} \mathbf{O}_{3}$ & 24.76 & 21.39 & 23.47 & 22.29 & 23.68 & 23.04 & 23.80 & 23.29 & 21.83 & 23.30 & 24.19 & 22.41 & 21.50 & 21.75 & 21.82 \\
\hline $\mathrm{FeO}$ & 0.21 & 0.07 & 0.24 & 0.20 & 0.66 & 0.27 & 0.31 & 0.31 & 0.27 & 0.32 & 0.32 & 0.19 & 0.15 & 0.19 & 0.16 \\
\hline MnO & 0.01 & 0.01 & 0.02 & 0.01 & 0.04 & 0.01 & 0.02 & 0.00 & 0.00 & 0.00 & 0.00 & 0.02 & 0.00 & 0.00 & 0.00 \\
\hline MgO & 0.00 & 0.02 & 0.07 & 0.00 & 0.14 & 0.00 & 0.01 & 0.00 & 0.01 & 0.02 & 0.02 & 0.00 & 0.01 & 0.00 & 0.03 \\
\hline $\mathrm{CaO}$ & 5.94 & 2.00 & 1.72 & 2.68 & 3.07 & 4.60 & 5.31 & 4.77 & 7.63 & 4.96 & 5.72 & 3.53 & 2.47 & 2.76 & 2.05 \\
\hline $\mathrm{Na}_{2} \mathbf{O}$ & 7.64 & 9.61 & 7.30 & 8.74 & 6.88 & 8.01 & 6.96 & 7.63 & 7.12 & 7.76 & 7.45 & 8.74 & 9.18 & 9.06 & 9.17 \\
\hline $\mathbf{K}_{2} \mathbf{O}$ & 0.14 & 0.28 & 1.95 & 0.51 & 1.68 & 0.45 & 1.35 & 0.68 & 1.06 & 0.38 & 0.27 & 0.26 & 0.23 & 0.24 & 0.44 \\
\hline SrO & 0.16 & 0.09 & 0.08 & 0.10 & 0.17 & 0.07 & 0.06 & 0.10 & 0.07 & 0.08 & 0.10 & 0.04 & 0.04 & 0.06 & 0.06 \\
\hline $\mathrm{BaO}$ & 0.01 & 0.00 & 0.03 & 0.04 & 0.00 & 0.02 & 0.00 & 0.00 & 0.06 & 0.03 & 0.02 & 0.04 & 0.00 & 0.05 & 0.09 \\
\hline Total & 100.08 & 99.22 & 96.60 & 98.46 & 96.40 & 98.65 & 98.95 & 98.95 & 96.43 & 98.30 & 98.53 & 98.57 & 99.04 & 98.47 & 98.27 \\
\hline \multicolumn{16}{|c|}{ Número de cátions calculado na base 8 oxigênios } \\
\hline Si & 2.7150 & 2.9039 & 2.8141 & 2.8545 & 2.7634 & 2.7895 & 2.7483 & 2.7817 & 2.7257 & 2.7688 & 2.7236 & 2.8318 & 2.8965 & 2.8715 & 2.8789 \\
\hline Al & 1.2949 & 1.1139 & 1.2609 & 1.1731 & 1.2840 & 1.2179 & 1.2612 & 1.2287 & 1.2001 & 1.2374 & 1.2847 & 1.1805 & 1.1215 & 1.1436 & 1.1479 \\
\hline Ti & 0.0008 & 0.0009 & 0.0003 & 0.0000 & 0.0004 & 0.0000 & 0.0000 & 0.0007 & 0.0000 & 0.0009 & 0.0007 & 0.0006 & 0.0002 & 0.0008 & 0.0010 \\
\hline $\mathrm{Fe}$ & 0.0079 & 0.0025 & 0.0091 & 0.0076 & 0.0254 & 0.0102 & 0.0118 & 0.0116 & 0.0106 & 0.0121 & 0.0119 & 0.0069 & 0.0055 & 0.0072 & 0.0060 \\
\hline Mn & 0.0006 & 0.0005 & 0.0007 & 0.0004 & 0.0016 & 0.0004 & 0.0007 & 0.0000 & 0.0002 & 0.0000 & 0.0000 & 0.0009 & 0.0001 & 0.0000 & 0.0000 \\
\hline Mg & 0.0001 & 0.0010 & 0.0049 & 0.0000 & 0.0093 & 0.0000 & 0.0004 & 0.0000 & 0.0007 & 0.0013 & 0.0015 & 0.0000 & 0.0006 & 0.0003 & 0.0023 \\
\hline Soma $T$ & 4.0193 & 4.0227 & 4.0901 & 4.0357 & 4.0842 & 4.0180 & 4.0224 & 4.0226 & 3.9374 & 4.0205 & 4.0223 & 4.0207 & 4.0244 & 4.0234 & 4.0362 \\
\hline Ca & 0.2824 & 0.0947 & 0.0840 & 0.1282 & 0.1513 & 0.2211 & 0.2558 & 0.2288 & 0.3813 & 0.2395 & 0.2762 & 0.1690 & 0.1171 & 0.1319 & 0.0980 \\
\hline
\end{tabular}


Tabela B1 - continuação

\begin{tabular}{llllllllllllllll}
\hline $\mathbf{N a}$ & 0.6573 & 0.8232 & 0.6452 & 0.7567 & 0.6137 & 0.6966 & 0.6067 & 0.6622 & 0.6439 & 0.6780 & 0.6509 & 0.7574 & 0.7878 & 0.7837 & 0.7936 \\
\hline $\mathbf{K}$ & 0.0079 & 0.0160 & 0.1134 & 0.0292 & 0.0986 & 0.0257 & 0.0774 & 0.0387 & 0.0628 & 0.0220 & 0.0153 & 0.0151 & 0.0131 & 0.0138 & 0.0252 \\
\hline Sr & 0.0045 & 0.0025 & 0.0024 & 0.0027 & 0.0049 & 0.0019 & 0.0018 & 0.0029 & 0.0020 & 0.0022 & 0.0028 & 0.0012 & 0.0012 & 0.0018 & 0.0017 \\
\hline Ba & 0.0002 & 0.0000 & 0.0006 & 0.0007 & 0.0000 & 0.0003 & 0.0000 & 0.0000 & 0.0011 & 0.0005 & 0.0004 & 0.0008 & 0.0000 & 0.0009 & 0.0016 \\
\hline Soma M & 0.9523 & 0.9364 & 0.8455 & 0.9175 & 0.8685 & 0.9456 & 0.9418 & 0.9325 & 1.0912 & 0.9421 & 0.9455 & 0.9435 & 0.9192 & 0.9322 & 0.9202 \\
\hline Total & 4.9716 & 4.9590 & 4.9356 & 4.9532 & 4.9527 & 4.9636 & 4.9641 & 4.9551 & 5.0286 & 4.9627 & 4.9678 & 4.9642 & 4.9436 & 4.9556 & 4.9563 \\
\hline & & & & & & & & & & & & \\
\hline Or & 0.834 & 1.712 & 13.456 & 3.191 & 11.415 & 2.727 & 8.236 & 4.162 & 5.773 & 2.341 & 1.625 & 1.602 & 1.424 & 1.489 & 2.750 \\
\hline Ab & 69.364 & 88.150 & 76.574 & 82.782 & 71.062 & 73.840 & 64.550 & 71.230 & 59.181 & 72.168 & 69.070 & 80.444 & 85.816 & 84.317 & 86.557 \\
\hline An & 29.802 & 10.138 & 9.970 & 14.027 & 17.523 & 23.433 & 27.214 & 24.608 & 35.046 & 25.491 & 29.305 & 17.954 & 12.760 & 14.194 & 10.693 \\
\hline
\end{tabular}

* dados fornecidos por Adriana Alves - não há imagens EDS para esta amostra 
Tabela B1 - continuação

\section{PLÚTON SALTO}

\begin{tabular}{|c|c|c|c|c|c|c|c|c|c|c|c|c|c|c|}
\hline \multicolumn{15}{|c|}{ AMOSTRA ITU-09-11A* } \\
\hline & PLG2 & PLG2 & PLG2 & PLG2 & PLG2 & PLG2 & PLG2 & PLG2 & PLG2 & PLG2 & PLG2 & PLG2 & PLG2 & PLG2 \\
\hline & pto1 & pto2 & pto3 & pto4 & pto5 & pto6 & pto6 & pto7 & pto8 & pto9 & pto10 & pto11 & pto11 & pto12 \\
\hline $\mathrm{TiO}_{2}$ & 0.01 & 0.00 & 0.09 & 0.03 & 0.00 & 0.01 & 0.01 & 0.03 & 0.05 & 0.07 & 0.00 & 0.08 & 0.08 & 0.01 \\
\hline $\mathbf{A l}_{2} \mathbf{O}_{3}$ & 22.84 & 23.47 & 23.03 & 22.98 & 24.03 & 22.83 & 23.12 & 23.02 & 23.20 & 23.27 & 21.77 & 23.26 & 22.98 & 23.36 \\
\hline $\mathrm{FeO}$ & 0.17 & 0.16 & 0.22 & 0.32 & 0.11 & 0.25 & 0.17 & 0.17 & 0.25 & 0.22 & 0.35 & 0.21 & 0.20 & 0.22 \\
\hline MgO & 0.01 & 0.00 & 0.00 & 0.00 & 0.01 & 0.01 & 0.00 & 0.00 & 0.00 & 0.00 & 0.03 & 0.01 & 0.00 & 0.02 \\
\hline $\mathrm{CaO}$ & 4.17 & 4.50 & 4.62 & 4.54 & 5.25 & 4.33 & 4.45 & 4.42 & 4.65 & 4.59 & 2.11 & 4.78 & 4.70 & 4.89 \\
\hline $\mathrm{Na}_{2} \mathrm{O}$ & 9.33 & 8.94 & 8.58 & 8.92 & 8.58 & 8.82 & 8.73 & 8.90 & 9.11 & 8.87 & 8.52 & 8.43 & 8.68 & 8.69 \\
\hline $\mathbf{K}_{2} \mathbf{O}$ & 0.16 & 0.46 & 0.63 & 0.59 & 0.15 & 0.45 & 0.55 & 0.28 & 0.27 & 0.32 & 2.95 & 0.63 & 0.71 & 0.32 \\
\hline SrO & 0.13 & 0.01 & 0.15 & 0.12 & 0.00 & 0.06 & 0.07 & 0.00 & 0.11 & 0.07 & 0.18 & 0.16 & 0.07 & 0.06 \\
\hline
\end{tabular}

Número de cátions calculado na base 8 oxigênios

\begin{tabular}{lllllllllllllll}
\hline Si & 2.7915 & 2.7618 & 2.7799 & 2.7860 & 2.7443 & 2.7920 & 2.7783 & 2.7869 & 2.7719 & 2.7866 & 2.8560 & 2.7723 & 2.7799 & 2.7590 \\
\hline Al & 1.2001 & 1.2363 & 1.2092 & 1.1985 & 1.2551 & 1.2018 & 1.2181 & 1.2084 & 1.2141 & 1.2058 & 1.1428 & 1.2193 & 1.2039 & 1.2318 \\
\hline Ti & 0.0004 & 0.0000 & 0.0031 & 0.0009 & 0.0000 & 0.0002 & 0.0004 & 0.0009 & 0.0015 & 0.0022 & 0.0000 & 0.0026 & 0.0026 & 0.0004 \\
\hline Fe & 0.0063 & 0.0061 & 0.0082 & 0.0120 & 0.0040 & 0.0094 & 0.0062 & 0.0062 & 0.0092 & 0.0081 & 0.0130 & 0.0077 & 0.0072 & 0.0083 \\
\hline Mn & 0.0000 & 0.0000 & 0.0000 & 0.0000 & 0.0000 & 0.0002 & 0.0000 & 0.0000 & 0.0000 & 0.0000 & 0.0000 & 0.0008 & 0.0000 & 0.0007 \\
\hline Mg & 0.0007 & 0.0000 & 0.0000 & 0.0001 & 0.0005 & 0.0009 & 0.0000 & 0.0000 & 0.0001 & 0.0000 & 0.0021 & 0.0008 & 0.0000 & 0.0011 \\
\hline Soma T & 3.9990 & 4.0042 & 4.0004 & 3.9975 & 4.0039 & 4.0045 & 4.0030 & 4.0024 & 3.9969 & 4.0028 & 4.0138 & 4.0036 & 3.9937 & 4.0015 \\
\hline & & & & & & & & & & & & & \\
\hline Ca & 0.1992 & 0.2155 & 0.2203 & 0.2153 & 0.2494 & 0.2072 & 0.2132 & 0.2112 & 0.2212 & 0.2162 & 0.1004 & 0.2275 & 0.2238 & 0.2344 \\
\hline
\end{tabular}


Tabela B1 - continuação

\begin{tabular}{lllllllllllllll}
\hline $\mathbf{N a}$ & 0.8068 & 0.7745 & 0.7413 & 0.7655 & 0.7375 & 0.7634 & 0.7567 & 0.7688 & 0.7845 & 0.7562 & 0.7356 & 0.7271 & 0.7476 & 0.7536 \\
\hline $\mathbf{K}$ & 0.0092 & 0.0260 & 0.0358 & 0.0333 & 0.0083 & 0.0255 & 0.0312 & 0.0157 & 0.0153 & 0.0182 & 0.1673 & 0.0359 & 0.0403 & 0.0183 \\
\hline Sr & 0.0036 & 0.0004 & 0.0042 & 0.0032 & 0.0000 & 0.0017 & 0.0019 & 0.0000 & 0.0029 & 0.0019 & 0.0051 & 0.0044 & 0.0019 & 0.0016 \\
\hline Ba & 0.0000 & 0.0000 & 0.0010 & 0.0000 & 0.0020 & 0.0000 & 0.0011 & 0.0023 & 0.0000 & 0.0012 & 0.0044 & 0.0005 & 0.0031 & 0.0020 \\
\hline Soma M & 1.0189 & 1.0163 & 1.0026 & 1.0173 & 0.9971 & 0.9977 & 1.0041 & 0.9979 & 1.0239 & 0.9937 & 1.0128 & 0.9954 & 1.0167 & 1.0099 \\
\hline Total & 5.0179 & 5.0205 & 5.0031 & 5.0149 & 5.0010 & 5.0022 & 5.0071 & 5.0003 & 5.0208 & 4.9964 & 5.0266 & 4.9990 & 5.0104 & 5.0113 \\
\hline & & & & & & & & & & & & & \\
\hline Or & 0.9075 & 2.5582 & 3.5888 & 3.2833 & 0.8348 & 2.5622 & 3.1155 & 1.5750 & 1.4975 & 1.8342 & 16.6788 & 3.6194 & 3.9786 & 1.8147 \\
\hline Ab & 79.4746 & 76.2344 & 74.3265 & 75.4841 & 74.1052 & 76.6393 & 75.5879 & 77.2169 & 76.8367 & 76.3423 & 73.3099 & 73.4084 & 73.8971 & 74.8896 \\
\hline An & 19.6179 & 21.2074 & 22.0846 & 21.2327 & 25.0600 & 20.7984 & 21.2965 & 21.2081 & 21.6658 & 21.8235 & 10.0113 & 22.9722 & 22.1243 & 23.2956 \\
\hline
\end{tabular}


Tabela B1 - continuação

\section{PLÚTON SALTO}

AMOSTRA ITU-09-11A* - cont

\begin{tabular}{|c|c|c|c|c|c|c|c|c|c|c|c|c|}
\hline & PLG2 & PLG2 & PLG2 & PLG2 & PLG2 & PLG2 & PLG2 & PLG2 & PLG2 & PLG2 & PLG2 & PLG2 \\
\hline & pto13 & pto14 & pto15 & pto16 & pto17 & pto18 & pto19 & pto20 & pto21 & pto22 & pto23 & pto24 \\
\hline $\mathrm{SiO}_{2}$ & 62.62 & 62.08 & 62.14 & 63.63 & 62.59 & 62.40 & 61.99 & 62.11 & 63.12 & 62.62 & 63.08 & 62.44 \\
\hline $\mathrm{TiO}_{2}$ & 0.06 & 0.04 & 0.09 & 0.00 & 0.00 & 0.00 & 0.01 & 0.03 & 0.00 & 0.00 & 0.05 & 0.05 \\
\hline $\mathbf{A l}_{2} \mathbf{O}_{3}$ & 23.15 & 23.64 & 23.35 & 22.25 & 22.79 & 23.35 & 23.05 & 23.47 & 23.21 & 22.93 & 22.77 & 23.48 \\
\hline $\mathrm{FeO}$ & 0.18 & 0.20 & 0.28 & 0.17 & 0.24 & 0.14 & 0.17 & 0.21 & 0.14 & 0.21 & 0.04 & 0.09 \\
\hline MnO & 0.00 & 0.00 & 0.00 & 0.01 & 0.00 & 0.00 & 0.00 & 0.00 & 0.00 & 0.00 & 0.00 & 0.01 \\
\hline MgO & 0.00 & 0.03 & 0.00 & 0.01 & 0.01 & 0.00 & 0.01 & 0.00 & 0.01 & 0.00 & 0.00 & 0.00 \\
\hline $\mathrm{CaO}$ & 4.76 & 5.13 & 4.83 & 2.49 & 4.43 & 4.85 & 5.07 & 5.06 & 4.59 & 4.53 & 4.15 & 4.98 \\
\hline $\mathrm{Na}_{2} \mathrm{O}$ & 8.88 & 8.89 & 8.89 & 9.66 & 8.90 & 8.76 & 8.40 & 8.49 & 8.72 & 8.56 & 9.26 & 8.46 \\
\hline $\mathrm{K}_{2} \mathrm{O}$ & 0.25 & 0.27 & 0.17 & 0.68 & 0.24 & 0.16 & 0.63 & 0.45 & 0.44 & 0.57 & 0.15 & 0.32 \\
\hline SrO & 0.07 & 0.09 & 0.12 & 0.05 & 0.10 & 0.09 & 0.10 & 0.15 & 0.11 & 0.14 & 0.13 & 0.03 \\
\hline $\mathrm{BaO}$ & 0.04 & 0.00 & 0.00 & 0.07 & 0.01 & 0.01 & 0.00 & 0.11 & 0.08 & 0.00 & 0.05 & 0.00 \\
\hline Total & 100.00 & 100.37 & 99.87 & 99.01 & 99.31 & 99.76 & 99.43 & 100.07 & 100.42 & 99.55 & 99.68 & 99.86 \\
\hline
\end{tabular}

Número de cátions calculado na base 8 oxigênios

\begin{tabular}{|c|c|c|c|c|c|c|c|c|c|c|c|c|}
\hline $\mathrm{Si}$ & 2.7784 & 2.7508 & 2.7637 & 2.8397 & 2.7934 & 2.7730 & 2.7717 & 2.7610 & 2.7879 & 2.7907 & 2.8019 & 2.7704 \\
\hline Al & 1.2106 & 1.2347 & 1.2241 & 1.1702 & 1.1989 & 1.2229 & 1.2149 & 1.2299 & 1.2083 & 1.2043 & 1.1923 & 1.2279 \\
\hline Ti & 0.0020 & 0.0013 & 0.0031 & 0.0000 & 0.0000 & 0.0000 & 0.0004 & 0.0009 & 0.0000 & 0.0000 & 0.0015 & 0.0018 \\
\hline $\mathbf{F e}$ & 0.0066 & 0.0073 & 0.0102 & 0.0063 & 0.0088 & 0.0053 & 0.0065 & 0.0079 & 0.0053 & 0.0079 & 0.0014 & 0.0034 \\
\hline Mn & 0.0000 & 0.0000 & 0.0000 & 0.0004 & 0.0000 & 0.0000 & 0.0000 & 0.0000 & 0.0000 & 0.0000 & 0.0000 & 0.0003 \\
\hline Mg & 0.0000 & 0.0018 & 0.0000 & 0.0006 & 0.0007 & 0.0000 & 0.0005 & 0.0000 & 0.0006 & 0.0000 & 0.0000 & 0.0000 \\
\hline Soma $T$ & 3.9976 & 3.9960 & 4.0011 & 4.0172 & 4.0017 & 4.0012 & 3.9940 & 3.9997 & 4.0021 & 4.0029 & 3.9971 & 4.0037 \\
\hline Ca & 0.2262 & 0.2436 & 0.2303 & 0.1190 & 0.2120 & 0.2309 & 0.2430 & 0.2412 & 0.2172 & 0.2164 & 0.1976 & 0.2369 \\
\hline
\end{tabular}


Tabela B1 - continuação

\begin{tabular}{lllllllllllll}
\hline $\mathbf{N a}$ & 0.7635 & 0.7639 & 0.7669 & 0.8355 & 0.7701 & 0.7547 & 0.7284 & 0.7314 & 0.7469 & 0.7394 & 0.7976 & 0.7278 \\
\hline $\mathbf{K}$ & 0.0143 & 0.0152 & 0.0095 & 0.0389 & 0.0136 & 0.0092 & 0.0359 & 0.0255 & 0.0246 & 0.0323 & 0.0086 & 0.0180 \\
\hline $\mathbf{S r}$ & 0.0020 & 0.0026 & 0.0032 & 0.0013 & 0.0027 & 0.0025 & 0.0027 & 0.0042 & 0.0031 & 0.0039 & 0.0037 & 0.0008 \\
\hline Ba & 0.0007 & 0.0000 & 0.0000 & 0.0012 & 0.0002 & 0.0002 & 0.0000 & 0.0018 & 0.0015 & 0.0000 & 0.0008 & 0.0000 \\
\hline Soma M & 1.0066 & 1.0253 & 1.0099 & 0.9958 & 0.9987 & 0.9975 & 1.0099 & 1.0041 & 0.9932 & 0.9920 & 1.0083 & 0.9835 \\
\hline Total & 5.0042 & 5.0213 & 5.0110 & 5.0130 & 5.0004 & 4.9987 & 5.0039 & 5.0037 & 4.9953 & 4.9949 & 5.0054 & 4.9872 \\
\hline & & & & & & & & & & & & \\
\hline Or & 1.4206 & 1.4867 & 0.9411 & 3.9138 & 1.3662 & 0.9231 & 3.5618 & 2.5510 & 2.4846 & 3.2735 & 0.8580 & 1.8313 \\
\hline Ab & 76.0529 & 74.6911 & 76.1805 & 84.1048 & 77.3411 & 75.8653 & 72.3163 & 73.2843 & 75.5477 & 74.8285 & 79.4550 & 74.0623 \\
\hline An & 22.5265 & 23.8222 & 22.8784 & 11.9814 & 21.2926 & 23.2115 & 24.1219 & 24.1647 & 21.9678 & 21.8980 & 19.6871 & 24.1064 \\
\hline
\end{tabular}

* dados fornecidos por Adriana Alves - não há imagens EDS para esta amostra 
Tabela B1 - continuação

\section{PLÚTON SALTO}

AMOSTRA ITU-09-32A*

\begin{tabular}{lcccccccccc}
\hline & PLG1 & PLG1 & PLG1 & PLG1 & PLG1 & PLG1 & PLG1 & PLG1 & PLG1 & PLG1 \\
\hline & pto1 & pto2 & pto3 & pto4 & pto5 & pto6 & pto7 & pto8 & pto9 & pto10 \\
\hline $\mathbf{S i O}_{2}$ & 63.57 & 63.81 & 64.03 & 64.58 & 64.09 & 63.73 & 63.75 & 64.31 & 64.38 & 64.70 \\
\hline $\mathbf{T i O}_{2}$ & 0.03 & 0.00 & 0.04 & 0.06 & 0.01 & 0.00 & 0.00 & 0.01 & 0.03 & 0.05 \\
\hline $\mathbf{A l}_{2} \mathbf{O}_{3}$ & 22.43 & 22.31 & 21.87 & 22.03 & 22.32 & 22.21 & 21.90 & 22.03 & 22.04 & 22.10 \\
\hline $\mathbf{F e O}$ & 0.17 & 0.13 & 0.18 & 0.19 & 0.11 & 0.18 & 0.06 & 0.06 & 0.09 & 0.15 \\
\hline $\mathbf{M n O}$ & 0.00 & 0.00 & 0.00 & 0.00 & 0.00 & 0.00 & 0.00 & 0.00 & 0.00 & 0.02 \\
\hline $\mathbf{M g O}$ & 0.00 & 0.00 & 0.01 & 0.00 & 0.01 & 0.00 & 0.01 & 0.02 & 0.00 & 0.00 \\
\hline $\mathbf{C a O}$ & 3.90 & 4.15 & 3.75 & 3.48 & 3.73 & 3.49 & 3.50 & 3.44 & 3.50 & 3.63 \\
\hline $\mathbf{N a} 2 \mathbf{O}$ & 9.22 & 9.23 & 9.04 & 9.53 & 9.29 & 9.36 & 9.30 & 9.44 & 9.43 & 9.69 \\
\hline $\mathbf{K}_{2} \mathbf{O}$ & 0.25 & 0.25 & 0.26 & 0.23 & 0.35 & 0.44 & 0.43 & 0.37 & 0.27 & 0.20 \\
\hline $\mathbf{S r O}$ & 0.05 & 0.05 & 0.04 & 0.00 & 0.02 & 0.00 & 0.01 & 0.00 & 0.03 & 0.00 \\
\hline $\mathbf{B a O}$ & 0.00 & 0.03 & 0.07 & 0.04 & 0.00 & 0.00 & 0.06 & 0.00 & 0.00 & 0.04 \\
\hline Total & 99.63 & 99.96 & 99.28 & 100.13 & 99.94 & 99.41 & 99.02 & 99.67 & 99.76 & 100.58 \\
\hline & & & & & & & & & & \\
\hline
\end{tabular}

Número de cátions calculado na base 8 oxigênios

\begin{tabular}{lllllllllll}
\hline Si & 2.8208 & 2.8242 & 2.8470 & 2.8467 & 2.8326 & 2.8330 & 2.8437 & 2.8466 & 2.8468 & 2.8420 \\
\hline $\mathbf{A l}$ & 1.1733 & 1.1636 & 1.1461 & 1.1445 & 1.1627 & 1.1635 & 1.1513 & 1.1494 & 1.1487 & 1.1444 \\
\hline $\mathbf{T i}$ & 0.0011 & 0.0000 & 0.0013 & 0.0020 & 0.0004 & 0.0000 & 0.0000 & 0.0002 & 0.0011 & 0.0015 \\
\hline $\mathbf{F e}$ & 0.0064 & 0.0049 & 0.0065 & 0.0068 & 0.0041 & 0.0068 & 0.0023 & 0.0021 & 0.0031 & 0.0055 \\
\hline Mn & 0.0000 & 0.0000 & 0.0000 & 0.0000 & 0.0000 & 0.0000 & 0.0000 & 0.0000 & 0.0000 & 0.0007 \\
\hline Mg & 0.0000 & 0.0002 & 0.0003 & 0.0000 & 0.0008 & 0.0003 & 0.0005 & 0.0015 & 0.0003 & 0.0001 \\
\hline Soma T & 4.0016 & 3.9929 & 4.0012 & 4.0000 & 4.0007 & 4.0034 & 3.9977 & 3.9999 & 4.0000 & 3.9943 \\
\hline
\end{tabular}


Tabela B1 - continuação

\begin{tabular}{lllllllllll}
\hline $\mathbf{N a}$ & 0.7931 & 0.7920 & 0.7792 & 0.8148 & 0.7959 & 0.8067 & 0.8046 & 0.8100 & 0.8082 & 0.8257 \\
\hline $\mathbf{K}$ & 0.0143 & 0.0140 & 0.0145 & 0.0132 & 0.0199 & 0.0248 & 0.0243 & 0.0208 & 0.0150 & 0.0113 \\
\hline Sr & 0.0014 & 0.0013 & 0.0011 & 0.0000 & 0.0006 & 0.0000 & 0.0004 & 0.0000 & 0.0009 & 0.0000 \\
\hline Ba & 0.0000 & 0.0006 & 0.0013 & 0.0007 & 0.0000 & 0.0000 & 0.0011 & 0.0000 & 0.0000 & 0.0007 \\
\hline Soma M & 0.9943 & 1.0048 & 0.9748 & 0.9930 & 0.9932 & 0.9976 & 0.9976 & 0.9940 & 0.9898 & 1.0085 \\
\hline Total & 4.9959 & 4.9977 & 4.9761 & 4.9930 & 4.9939 & 5.0011 & 4.9953 & 4.9938 & 4.9898 & 5.0028 \\
\hline \multirow{2}{*}{ Or } & & & & & & & & & & \\
\hline Ab & 1.437 & 1.396 & 1.487 & 1.326 & 2.005 & 2.489 & 2.439 & 2.090 & 1.517 & 1.123 \\
\hline An & 79.882 & 78.971 & 80.132 & 82.105 & 80.188 & 80.858 & 80.768 & 81.490 & 81.728 & 81.936 \\
\hline
\end{tabular}


Tabela B1 - continuação

\section{PLÚTON SALTO}

AMOSTRA ITU-09-32A* - cont

\begin{tabular}{lccccccccccc}
\hline & PLG1 & PLG1 & PLG1 & PLG1 & PLG1 & PLG1 & PLG1 & PLG1 & PLG1 & PLG1 & PLG1 \\
\hline & pto11 & pto12 & pto13 & pto14 & pto15 & pto16 & pto17 & pto18 & pto19 & pto20 & pto21 \\
\hline $\mathbf{S i O}_{2}$ & 63.98 & 63.90 & 64.08 & 64.04 & 63.80 & 63.94 & 64.41 & 64.46 & 63.73 & 64.52 & 64.32 \\
\hline $\mathbf{T i O}_{2}$ & 0.01 & 0.00 & 0.06 & 0.00 & 0.00 & 0.00 & 0.00 & 0.01 & 0.01 & 0.03 & 0.05 \\
\hline $\mathbf{A l}_{2} \mathbf{O}_{3}$ & 21.93 & 22.06 & 22.30 & 22.03 & 22.12 & 22.17 & 22.15 & 21.61 & 22.40 & 22.24 & 22.08 \\
\hline $\mathbf{F e O}$ & 0.17 & 0.16 & 0.28 & 0.17 & 0.15 & 0.21 & 0.15 & 0.09 & 0.15 & 0.18 & 0.12 \\
\hline $\mathbf{M n O}$ & 0.00 & 0.00 & 0.00 & 0.00 & 0.00 & 0.00 & 0.00 & 0.00 & 0.00 & 0.00 & 0.00 \\
\hline $\mathbf{M g O}$ & 0.00 & 0.01 & 0.00 & 0.00 & 0.00 & 0.00 & 0.00 & 0.00 & 0.00 & 0.00 & 0.00 \\
\hline $\mathbf{C a O}$ & 3.64 & 3.74 & 3.70 & 3.48 & 3.88 & 3.74 & 3.75 & 2.99 & 3.91 & 3.75 & 3.59 \\
\hline $\mathbf{N a} \mathbf{O}_{2} \mathbf{O}$ & 9.41 & 9.30 & 9.19 & 9.48 & 9.23 & 9.42 & 9.41 & 9.72 & 9.15 & 9.54 & 9.42 \\
\hline $\mathbf{K} \mathbf{O}$ & 0.38 & 0.48 & 0.61 & 0.65 & 0.43 & 0.44 & 0.51 & 0.29 & 0.28 & 0.14 & 0.24 \\
\hline $\mathbf{S r O}$ & 0.00 & 0.04 & 0.00 & 0.00 & 0.00 & 0.01 & 0.00 & 0.00 & 0.08 & 0.06 & 0.00 \\
\hline $\mathbf{B a O}$ & 0.02 & 0.04 & 0.13 & 0.07 & 0.04 & 0.00 & 0.00 & 0.03 & 0.00 & 0.00 & 0.00 \\
\hline Total & 99.55 & 99.73 & 100.35 & 99.91 & 99.64 & 99.94 & 100.38 & 99.20 & 99.70 & 100.44 & 99.82 \\
\hline
\end{tabular}

Número de cátions calculado na base 8 oxigênios

\begin{tabular}{llllllllllll}
\hline $\mathbf{S i}$ & 2.8410 & 2.8350 & 2.8287 & 2.8377 & 2.8320 & 2.8311 & 2.8378 & 2.8642 & 2.8252 & 2.8373 & 2.8430 \\
\hline $\mathbf{A l}$ & 1.1479 & 1.1539 & 1.1604 & 1.1507 & 1.1572 & 1.1569 & 1.1503 & 1.1320 & 1.1703 & 1.1529 & 1.1503 \\
\hline $\mathbf{T i}$ & 0.0004 & 0.0000 & 0.0020 & 0.0000 & 0.0000 & 0.0000 & 0.0000 & 0.0002 & 0.0004 & 0.0009 & 0.0018 \\
\hline $\mathbf{F e}$ & 0.0063 & 0.0059 & 0.0102 & 0.0064 & 0.0056 & 0.0079 & 0.0056 & 0.0032 & 0.0057 & 0.0065 & 0.0045 \\
\hline $\mathbf{M n}$ & 0.0000 & 0.0000 & 0.0000 & 0.0000 & 0.0000 & 0.0000 & 0.0000 & 0.0000 & 0.0000 & 0.0000 & 0.0000 \\
\hline $\mathbf{M g}$ & 0.0000 & 0.0005 & 0.0003 & 0.0000 & 0.0000 & 0.0001 & 0.0000 & 0.0000 & 0.0000 & 0.0000 & 0.0000 \\
\hline Soma T & 3.9956 & 3.9952 & 4.0015 & 3.9949 & 3.9948 & 3.9960 & 3.9937 & 3.9996 & 4.0016 & 3.9975 & 3.9995 \\
\hline & & & & & & & & & & & \\
\hline Ca & 0.1730 & 0.1780 & 0.1749 & 0.1651 & 0.1845 & 0.1772 & 0.1772 & 0.1425 & 0.1855 & 0.1765 & 0.1701 \\
\hline
\end{tabular}


Tabela B1 - continuação

\begin{tabular}{llllllllllll}
\hline $\mathbf{N a}$ & 0.8098 & 0.7999 & 0.7867 & 0.8149 & 0.7945 & 0.8090 & 0.8038 & 0.8374 & 0.7864 & 0.8138 & 0.8076 \\
\hline $\mathbf{K}$ & 0.0215 & 0.0274 & 0.0344 & 0.0367 & 0.0241 & 0.0250 & 0.0285 & 0.0164 & 0.0157 & 0.0076 & 0.0133 \\
\hline Sr & 0.0000 & 0.0010 & 0.0000 & 0.0000 & 0.0000 & 0.0004 & 0.0000 & 0.0000 & 0.0023 & 0.0015 & 0.0000 \\
\hline Ba & 0.0004 & 0.0007 & 0.0022 & 0.0011 & 0.0007 & 0.0000 & 0.0000 & 0.0005 & 0.0000 & 0.0000 & 0.0000 \\
\hline Soma M & 1.0047 & 1.0071 & 0.9982 & 1.0178 & 1.0039 & 1.0116 & 1.0095 & 0.9968 & 0.9899 & 0.9994 & 0.9910 \\
\hline Total & 5.0003 & 5.0023 & 4.9997 & 5.0127 & 4.9987 & 5.0076 & 5.0032 & 4.9965 & 4.9914 & 4.9969 & 4.9905 \\
\hline & & & & & & & & & & & \\
\hline Or & 2.143 & 2.725 & 3.454 & 3.608 & 2.399 & 2.474 & 2.823 & 1.644 & 1.592 & 0.759 & 1.343 \\
\hline Ab & 80.633 & 79.570 & 78.986 & 80.152 & 79.204 & 80.002 & 79.625 & 84.050 & 79.625 & 81.557 & 81.490 \\
\hline An & 17.224 & 17.706 & 17.560 & 16.240 & 18.397 & 17.523 & 17.553 & 14.307 & 18.783 & 17.685 & 17.168 \\
\hline
\end{tabular}

* dados fornecidos por Adriana Alves - não há imagens EDS para esta amostra 
Tabela B1 - continuação

\section{PLÚTON INDAIATUBA}

\section{AMOSTRA CAB-14-06B}

\begin{tabular}{|c|c|c|c|c|c|c|c|c|c|c|c|c|c|c|c|}
\hline & 1 & 2 & 3 & 4 & 5 & 6 & 7 & 8 & 9 & 10 & 11 & 12 & 13 & 14 & 15 \\
\hline $\mathrm{SiO}_{2}$ & 63.29 & 64.06 & 65.42 & 65.76 & 64.90 & 63.80 & 64.27 & 64.12 & 63.86 & 63.71 & 64.16 & 65.01 & 64.33 & 65.51 & 65.61 \\
\hline $\mathrm{TiO}_{2}$ & 0.00 & 0.00 & 0.00 & 0.00 & 0.00 & 0.01 & 0.00 & 0.00 & 0.01 & 0.03 & 0.00 & 0.03 & 0.05 & 0.02 & 0.02 \\
\hline $\mathbf{A l}_{2} \mathbf{O}_{3}$ & 23.90 & 23.29 & 22.29 & 21.75 & 22.52 & 23.30 & 23.09 & 22.10 & 23.25 & 22.87 & 23.15 & 22.57 & 22.92 & 22.21 & 22.12 \\
\hline $\mathrm{FeO}$ & 0.18 & 0.16 & 0.18 & 0.17 & 0.28 & 0.19 & 0.21 & 0.24 & 0.46 & 0.42 & 0.19 & 0.18 & 0.24 & 0.10 & 0.19 \\
\hline MnO & 0.01 & 0.00 & 0.00 & 0.00 & 0.02 & 0.01 & 0.00 & 0.01 & 0.02 & 0.01 & 0.00 & 0.00 & 0.00 & 0.00 & 0.00 \\
\hline MgO & 0.00 & 0.01 & 0.00 & 0.00 & 0.00 & 0.00 & 0.00 & 0.00 & 0.08 & 0.05 & 0.00 & 0.00 & 0.00 & 0.00 & 0.00 \\
\hline $\mathrm{CaO}$ & 3.51 & 3.92 & 2.83 & 2.43 & 3.17 & 4.21 & 3.90 & 3.25 & 3.22 & 2.59 & 3.71 & 2.97 & 3.53 & 2.60 & 2.48 \\
\hline $\mathrm{Na}_{2} \mathrm{O}$ & 9.18 & 9.32 & 9.86 & 10.33 & 9.50 & 9.01 & 9.22 & 9.73 & 9.10 & 9.39 & 9.34 & 9.82 & 9.27 & 9.83 & 10.31 \\
\hline $\mathbf{K}_{2} \mathbf{O}$ & 0.55 & 0.32 & 0.32 & 0.24 & 0.46 & 0.59 & 0.50 & 0.52 & 0.45 & 0.83 & 0.31 & 0.36 & 0.46 & 0.41 & 0.17 \\
\hline SrO & 0.02 & 0.06 & 0.01 & 0.05 & 0.06 & 0.06 & 0.04 & 0.01 & 0.09 & 0.05 & 0.04 & 0.06 & 0.03 & 0.05 & 0.03 \\
\hline $\mathrm{BaO}$ & 0.00 & 0.00 & 0.00 & 0.04 & 0.04 & 0.06 & 0.03 & 0.02 & 0.00 & 0.05 & 0.05 & 0.00 & 0.02 & 0.00 & 0.00 \\
\hline Total & 100.65 & 101.14 & 100.90 & 100.76 & 100.95 & 101.25 & 101.27 & 100.00 & 100.54 & 100.00 & 100.96 & 101.00 & 100.84 & 100.73 & 100.94 \\
\hline
\end{tabular}

\section{Número de cátions calculado na base 8 oxigênios}

\begin{tabular}{|c|c|c|c|c|c|c|c|c|c|c|c|c|c|c|c|}
\hline Si & 2.7817 & 2.8020 & 2.8569 & 2.8761 & 2.8402 & 2.7944 & 2.8095 & 2.8375 & 2.8079 & 2.8194 & 2.8098 & 2.8408 & 2.8195 & 2.8640 & 2.8636 \\
\hline Al & 1.2382 & 1.2007 & 1.1473 & 1.1212 & 1.1617 & 1.2029 & 1.1897 & 1.1528 & 1.2050 & 1.1929 & 1.1950 & 1.1625 & 1.1840 & 1.1445 & 1.1380 \\
\hline Ti & 0.0000 & 0.0000 & 0.0000 & 0.0000 & 0.0000 & 0.0004 & 0.0000 & 0.0000 & 0.0003 & 0.0011 & 0.0000 & 0.0010 & 0.0015 & 0.0005 & 0.0006 \\
\hline $\mathbf{F e}$ & 0.0067 & 0.0058 & 0.0065 & 0.0060 & 0.0104 & 0.0069 & 0.0078 & 0.0088 & 0.0169 & 0.0156 & 0.0070 & 0.0067 & 0.0087 & 0.0037 & 0.0070 \\
\hline Mn & 0.0003 & 0.0001 & 0.0000 & 0.0000 & 0.0006 & 0.0005 & 0.0000 & 0.0002 & 0.0006 & 0.0005 & 0.0001 & 0.0001 & 0.0001 & 0.0000 & 0.0000 \\
\hline Mg & 0.0000 & 0.0005 & 0.0000 & 0.0000 & 0.0000 & 0.0000 & 0.0000 & 0.0001 & 0.0052 & 0.0030 & 0.0000 & 0.0000 & 0.0000 & 0.0000 & 0.0000 \\
\hline Soma $T$ & 4.0269 & 4.0091 & 4.0106 & 4.0034 & 4.0129 & 4.0051 & 4.0071 & 3.9993 & 4.0358 & 4.0326 & 4.0119 & 4.0111 & 4.0139 & 4.0126 & 4.0092 \\
\hline Ca & 0.1653 & 0.1837 & 0.1324 & 0.1139 & 0.1486 & 0.1976 & 0.1827 & 0.1541 & 0.1517 & 0.1228 & 0.1741 & 0.1391 & 0.1658 & 0.1218 & 0.1160 \\
\hline $\mathrm{Na}$ & 0.7824 & 0.7904 & 0.8349 & 0.8760 & 0.8061 & 0.7652 & 0.7815 & 0.8349 & 0.7758 & 0.8057 & 0.7931 & 0.8321 & 0.7878 & 0.8333 & 0.8725 \\
\hline
\end{tabular}


Tabela B1 - continuação

\begin{tabular}{llllllllllllllll}
\hline $\mathbf{K}$ & 0.0311 & 0.0176 & 0.0176 & 0.0134 & 0.0256 & 0.0332 & 0.0279 & 0.0293 & 0.0252 & 0.0466 & 0.0174 & 0.0199 & 0.0256 & 0.0231 & 0.0097 \\
\hline Sr & 0.0003 & 0.0008 & 0.0002 & 0.0007 & 0.0008 & 0.0008 & 0.0005 & 0.0002 & 0.0013 & 0.0007 & 0.0006 & 0.0008 & 0.0004 & 0.0007 & 0.0004 \\
\hline Ba & 0.0000 & 0.0000 & 0.0000 & 0.0007 & 0.0007 & 0.0010 & 0.0006 & 0.0003 & 0.0000 & 0.0008 & 0.0009 & 0.0000 & 0.0003 & 0.0000 & 0.0000 \\
\hline Soma M & 0.9790 & 0.9926 & 0.9851 & 1.0046 & 0.9819 & 0.9978 & 0.9932 & 1.0189 & 0.9540 & 0.9767 & 0.9861 & 0.9918 & 0.9798 & 0.9789 & 0.9986 \\
\hline Total & 5.0059 & 5.0017 & 4.9957 & 5.0080 & 4.9948 & 5.0029 & 5.0003 & 5.0182 & 4.9898 & 5.0092 & 4.9980 & 5.0029 & 4.9937 & 4.9915 & 5.0079 \\
\hline \multirow{2}{*}{ Or } & & & & & & & & & & & & & \\
\hline Ab & 3.173 & 1.779 & 1.789 & 1.332 & 2.609 & 3.335 & 2.810 & 2.878 & 2.646 & 4.776 & 1.769 & 2.006 & 2.614 & 2.364 & 0.969 \\
\hline An & 79.937 & 79.698 & 84.767 & 87.317 & 82.228 & 76.828 & 78.776 & 81.988 & 81.431 & 82.629 & 80.550 & 83.962 & 80.455 & 85.185 & 87.412 \\
\hline
\end{tabular}


Tabela B1 - continuação

\section{PLÚTON INDAIATUBA}

\section{AMOSTRA CAB-15-34.1}

\begin{tabular}{|c|c|c|c|}
\hline & 1 & 2 & 3 \\
\hline $\mathrm{SiO}_{2}$ & 63.81 & 65.19 & 68.33 \\
\hline $\mathrm{TiO}_{2}$ & 0.00 & 0.01 & 0.00 \\
\hline $\mathbf{A l}_{2} \mathbf{O}_{3}$ & 23.10 & 22.62 & 20.53 \\
\hline $\mathrm{FeO}$ & 0.14 & 0.13 & 0.06 \\
\hline MnO & 0.00 & 0.00 & 0.00 \\
\hline MgO & 0.00 & 0.00 & 0.01 \\
\hline $\mathrm{CaO}$ & 4.00 & 3.01 & 0.68 \\
\hline $\mathrm{Na}_{2} \mathrm{O}$ & 8.89 & 9.73 & 11.23 \\
\hline $\mathbf{K}_{2} \mathbf{O}$ & 0.77 & 0.17 & 0.09 \\
\hline SrO & 0.04 & 0.02 & 0.00 \\
\hline $\mathrm{BaO}$ & 0.05 & 0.00 & 0.00 \\
\hline Total & 100.80 & 100.88 & 100.92 \\
\hline
\end{tabular}

Número de cátions calculado na base 8 oxigênios

\begin{tabular}{llll}
\hline $\mathbf{S i}$ & 2.8048 & 2.8456 & 2.9598 \\
\hline $\mathbf{A l}$ & 1.1968 & 1.1638 & 1.0482 \\
\hline $\mathbf{T i}$ & 0.0000 & 0.0004 & 0.0000 \\
\hline $\mathbf{F e}$ & 0.0051 & 0.0048 & 0.0020 \\
\hline $\mathbf{M n}$ & 0.0000 & 0.0000 & 0.0001 \\
\hline $\mathbf{M g}$ & 0.0000 & 0.0000 & 0.0004 \\
\hline Soma T & 4.0067 & 4.0146 & 4.0106 \\
\hline $\mathbf{C a}$ & 0.1884 & 0.1408 & 0.0313 \\
\hline $\mathbf{N a}$ & 0.7577 & 0.8235 & 0.9432 \\
\hline
\end{tabular}


Tabela B1 - continuação

\begin{tabular}{lccc}
\hline $\mathbf{K}$ & 0.0431 & 0.0096 & 0.0050 \\
\hline Sr & 0.0005 & 0.0002 & 0.0001 \\
\hline Ba & 0.0009 & 0.0000 & 0.0000 \\
\hline Soma M & 0.9906 & 0.9742 & 0.9796 \\
\hline Total & 4.9972 & 4.9888 & 4.9902 \\
\hline & & & \\
\hline Or & 4.357 & 0.990 & 0.509 \\
\hline Ab & 76.597 & 84.556 & 96.292 \\
\hline An & 19.045 & 14.455 & 3.199 \\
\hline
\end{tabular}


Tabela B1 - continuação

\section{PLÚTON INDAIATUBA}

\begin{tabular}{lccccc}
\hline AMOSTRA CAB-15-34.2 & & & & \\
\hline & $\mathbf{1}$ & $\mathbf{2}$ & $\mathbf{3}$ & $\mathbf{4}$ & $\mathbf{5}$ \\
\hline $\mathrm{SiO}_{2}$ & 65.49 & 65.45 & 59.75 & 60.08 & 65.54 \\
\hline $\mathrm{TiO}_{2}$ & 0.02 & 0.03 & 0.03 & 0.06 & 0.00 \\
\hline $\mathrm{Al}_{2} \mathbf{O}_{3}$ & 22.05 & 22.20 & 25.78 & 25.46 & 22.05 \\
\hline $\mathbf{F e O}$ & 0.09 & 0.33 & 0.39 & 0.28 & 0.16 \\
\hline $\mathrm{MnO}$ & 0.00 & 0.02 & 0.01 & 0.01 & 0.01 \\
\hline $\mathbf{M g O}$ & 0.00 & 0.04 & 0.00 & 0.00 & 0.00 \\
\hline $\mathbf{C a O}$ & 2.48 & 0.76 & 6.82 & 6.39 & 2.48 \\
\hline $\mathbf{N a} 2 \mathbf{O}$ & 10.02 & 9.80 & 7.29 & 7.51 & 10.07 \\
\hline $\mathbf{K} 2 \mathbf{O}$ & 0.24 & 1.17 & 0.42 & 0.35 & 0.22 \\
\hline $\mathbf{S r O}$ & 0.04 & 0.04 & 0.06 & 0.10 & 0.02 \\
\hline $\mathbf{B a O}$ & 0.03 & 0.00 & 0.21 & 0.14 & 0.04 \\
\hline Total & 100.46 & 99.84 & 100.76 & 100.37 & 100.59
\end{tabular}

Número de cátions calculado na base 8 oxigênios

\begin{tabular}{llllll}
\hline $\mathbf{S i}$ & 2.8690 & 2.8829 & 2.6525 & 2.6712 & 2.8684 \\
\hline $\mathbf{A l}$ & 1.1386 & 1.1526 & 1.3490 & 1.3343 & 1.1375 \\
\hline $\mathbf{T i}$ & 0.0006 & 0.0008 & 0.0009 & 0.0018 & 0.0000 \\
\hline $\mathbf{F e}$ & 0.0034 & 0.0123 & 0.0146 & 0.0105 & 0.0058 \\
\hline $\mathbf{M n}$ & 0.0000 & 0.0006 & 0.0005 & 0.0002 & 0.0004 \\
\hline $\mathbf{M g}$ & 0.0000 & 0.0028 & 0.0000 & 0.0000 & 0.0000 \\
\hline Soma T & 4.0115 & 4.0520 & 4.0176 & 4.0180 & 4.0122 \\
\hline & & & & & \\
\hline $\mathbf{C a}$ & 0.1164 & 0.0359 & 0.3244 & 0.3044 & 0.1163 \\
\hline $\mathbf{N a}$ & 0.8511 & 0.8370 & 0.6275 & 0.6474 & 0.8546 \\
\hline
\end{tabular}


Tabela B1 - continuação

\begin{tabular}{lccccc}
\hline K & 0.0133 & 0.0660 & 0.0235 & 0.0197 & 0.0124 \\
\hline Sr & 0.0005 & 0.0005 & 0.0008 & 0.0014 & 0.0003 \\
\hline Ba & 0.0006 & 0.0000 & 0.0037 & 0.0024 & 0.0006 \\
\hline Soma M & 0.9820 & 0.9394 & 0.9800 & 0.9753 & 0.9841 \\
\hline Total & 4.9934 & 4.9915 & 4.9976 & 4.9934 & 4.9963 \\
\hline & & & & & \\
\hline Or & 1.359 & 7.028 & 2.410 & 2.028 & 1.259 \\
\hline Ab & 86.773 & 89.146 & 64.332 & 66.639 & 86.913 \\
\hline An & 11.868 & 3.826 & 33.258 & 31.333 & 11.828 \\
\hline
\end{tabular}


Tabela B1 - continuação

\section{PLÚTON INDAIATUBA}

\section{AMOSTRA CAB-15-57}

\begin{tabular}{lcccccc}
\hline & $\mathbf{1}$ & $\mathbf{2}$ & $\mathbf{3}$ & $\mathbf{4}$ & $\mathbf{5}$ & $\mathbf{6}$ \\
\hline $\mathrm{SiO}_{2}$ & 54.49 & 54.26 & 54.70 & 54.68 & 54.49 & 54.78 \\
\hline $\mathrm{TiO}_{2}$ & 0.12 & 0.06 & 0.07 & 0.09 & 0.11 & 0.05 \\
\hline $\mathrm{Al}_{2} \mathbf{O}_{3}$ & 28.99 & 29.04 & 28.41 & 29.10 & 29.33 & 28.88 \\
\hline $\mathbf{F e O}$ & 0.50 & 0.51 & 0.63 & 0.50 & 0.50 & 0.54 \\
\hline $\mathrm{MnO}$ & 0.00 & 0.00 & 0.01 & 0.01 & 0.02 & 0.00 \\
\hline $\mathrm{MgO}$ & 0.02 & 0.05 & 0.02 & 0.05 & 0.00 & 0.02 \\
\hline $\mathbf{C a O}$ & 11.39 & 11.63 & 11.11 & 11.17 & 11.18 & 10.89 \\
\hline $\mathbf{N a} 2 \mathbf{O}$ & 4.57 & 4.56 & 4.78 & 4.61 & 4.63 & 4.68 \\
\hline $\mathbf{K} 2 \mathbf{O}$ & 0.55 & 0.49 & 0.54 & 0.52 & 0.52 & 0.67 \\
\hline $\mathbf{S r O}$ & 0.08 & 0.04 & 0.07 & 0.05 & 0.05 & 0.04 \\
\hline $\mathbf{B a O}$ & 0.08 & 0.09 & 0.11 & 0.05 & 0.06 & 0.05 \\
\hline Total & 100.79 & 100.73 & 100.46 & 100.82 & 100.89 & 100.60
\end{tabular}

Número de cátions calculado na base 8 oxigênios

\begin{tabular}{lllllll}
\hline $\mathbf{S i}$ & 2.4503 & 2.4428 & 2.4687 & 2.4542 & 2.4452 & 2.4642 \\
\hline $\mathbf{A l}$ & 1.5366 & 1.5410 & 1.5113 & 1.5395 & 1.5514 & 1.5313 \\
\hline $\mathbf{T i}$ & 0.0041 & 0.0020 & 0.0025 & 0.0030 & 0.0037 & 0.0016 \\
\hline $\mathbf{F e}$ & 0.0189 & 0.0192 & 0.0238 & 0.0187 & 0.0186 & 0.0203 \\
\hline $\mathbf{M n}$ & 0.0000 & 0.0000 & 0.0003 & 0.0005 & 0.0007 & 0.0000 \\
\hline $\mathbf{M g}$ & 0.0011 & 0.0032 & 0.0014 & 0.0032 & 0.0001 & 0.0015 \\
\hline Soma T & 4.0110 & 4.0083 & 4.0081 & 4.0190 & 4.0197 & 4.0188 \\
\hline & & & & & & \\
\hline $\mathbf{C a}$ & 0.5488 & 0.5610 & 0.5373 & 0.5372 & 0.5376 & 0.5249 \\
\hline $\mathbf{N a}$ & 0.3985 & 0.3981 & 0.4183 & 0.4012 & 0.4029 & 0.4082 \\
\hline
\end{tabular}


Tabela B1 - continuação

\begin{tabular}{lcccccc}
\hline $\mathbf{K}$ & 0.0317 & 0.0283 & 0.0311 & 0.0295 & 0.0300 & 0.0386 \\
\hline Sr & 0.0011 & 0.0006 & 0.0010 & 0.0007 & 0.0007 & 0.0006 \\
\hline Ba & 0.0014 & 0.0016 & 0.0019 & 0.0009 & 0.0010 & 0.0008 \\
\hline Soma M & 0.9815 & 0.9896 & 0.9897 & 0.9695 & 0.9722 & 0.9731 \\
\hline Total & 4.9924 & 4.9978 & 4.9978 & 4.9885 & 4.9918 & 4.9919 \\
\hline & & & & & & \\
\hline Or & 3.24 & 2.86 & 3.16 & 3.05 & 3.09 & 3.97 \\
\hline Ab & 40.70 & 40.32 & 42.39 & 41.45 & 41.52 & 42.01 \\
\hline An & 56.06 & 56.82 & 54.45 & 55.50 & 55.40 & 54.02 \\
\hline
\end{tabular}


Tabela B1 - continuação

\section{PLÚTON CABREÚVA}

\section{AMOSTRA CAB-14-09}

\begin{tabular}{lccccccc}
\hline & $\mathbf{1}$ & $\mathbf{2}$ & $\mathbf{3}$ & $\mathbf{4}$ & $\mathbf{5}$ & $\mathbf{6}$ & $\mathbf{7}$ \\
\hline $\mathrm{SiO}_{2}$ & 65.17 & 64.38 & 64.00 & 65.32 & 65.11 & 64.38 & 64.72 \\
\hline $\mathbf{T i O}_{2}$ & 0.00 & 0.01 & 0.00 & 0.00 & 0.01 & 0.00 & 0.00 \\
\hline $\mathrm{Al}_{2} \mathbf{O}_{3}$ & 18.88 & 18.87 & 22.77 & 22.67 & 22.46 & 22.87 & 22.65 \\
\hline $\mathbf{F e O}$ & 0.19 & 0.31 & 0.15 & 0.12 & 0.08 & 0.18 & 0.15 \\
\hline $\mathrm{MnO}$ & 0.02 & 0.01 & 0.03 & 0.00 & 0.00 & 0.00 & 0.01 \\
\hline $\mathrm{MgO}$ & 0.01 & 0.13 & 0.00 & 0.00 & 0.00 & 0.00 & 0.00 \\
\hline $\mathbf{C a O}$ & 0.01 & 0.03 & 3.64 & 3.08 & 3.21 & 3.51 & 3.43 \\
\hline $\mathbf{N a} \mathbf{a}_{2} \mathbf{O}$ & 0.32 & 0.43 & 9.12 & 9.57 & 9.58 & 9.32 & 9.50 \\
\hline $\mathbf{K} \mathbf{2} \mathbf{O}$ & 16.06 & 15.74 & 0.43 & 0.41 & 0.44 & 0.41 & 0.41 \\
\hline $\mathbf{S r O}$ & 0.00 & 0.02 & 0.02 & 0.02 & 0.04 & 0.01 & 0.02 \\
\hline $\mathbf{B a O}$ & 0.19 & 0.40 & 0.01 & 0.01 & 0.01 & 0.07 & 0.05 \\
\hline Total & 100.85 & 100.33 & 100.17 & 101.20 & 100.95 & 100.74 & 100.95
\end{tabular}

Número de cátions calculado na base 8 oxigênios

\begin{tabular}{llllllll}
\hline Si & 2.9868 & 2.9728 & 2.8219 & 2.8451 & 2.8457 & 2.8232 & 2.8324 \\
\hline $\mathbf{A l}$ & 1.0199 & 1.0270 & 1.1834 & 1.1639 & 1.1571 & 1.1821 & 1.1684 \\
\hline $\mathbf{T i}$ & 0.0000 & 0.0002 & 0.0000 & 0.0000 & 0.0003 & 0.0000 & 0.0000 \\
\hline $\mathbf{F e}$ & 0.0075 & 0.0120 & 0.0056 & 0.0042 & 0.0028 & 0.0065 & 0.0056 \\
\hline $\mathbf{M n}$ & 0.0009 & 0.0002 & 0.0010 & 0.0000 & 0.0000 & 0.0001 & 0.0005 \\
\hline $\mathbf{M g}$ & 0.0004 & 0.0092 & 0.0000 & 0.0000 & 0.0000 & 0.0000 & 0.0000 \\
\hline Soma T & 4.0155 & 4.0214 & 4.0119 & 4.0132 & 4.0060 & 4.0119 & 4.0069 \\
\hline & & & & & & & \\
\hline $\mathbf{C a}$ & 0.0007 & 0.0015 & 0.1720 & 0.1437 & 0.1503 & 0.1649 & 0.1608 \\
\hline $\mathbf{N a}$ & 0.0284 & 0.0389 & 0.7797 & 0.8083 & 0.8119 & 0.7925 & 0.8061 \\
\hline
\end{tabular}


Tabela B1 - continuação

\begin{tabular}{llllllll}
\hline K & 0.9389 & 0.9271 & 0.0244 & 0.0228 & 0.0246 & 0.0229 & 0.0230 \\
\hline Sr & 0.0000 & 0.0003 & 0.0003 & 0.0003 & 0.0006 & 0.0001 & 0.0003 \\
\hline Ba & 0.0033 & 0.0072 & 0.0002 & 0.0002 & 0.0002 & 0.0011 & 0.0009 \\
\hline Soma M & 0.9713 & 0.9750 & 0.9766 & 0.9753 & 0.9876 & 0.9816 & 0.9912 \\
\hline Total & 4.9868 & 4.9964 & 4.9885 & 4.9885 & 4.9936 & 4.9934 & 4.9980 \\
\hline & & & & & & & \\
\hline Or & 96.992 & 95.828 & 2.498 & 2.342 & 2.495 & 2.335 & 2.323 \\
\hline Ab & 2.933 & 4.017 & 79.883 & 82.912 & 82.272 & 80.840 & 81.430 \\
\hline An & 0.075 & 0.155 & 17.619 & 14.746 & 15.234 & 16.824 & 16.247 \\
\hline
\end{tabular}


Tabela B1 - continuação

\section{PLÚTON CABREÚVA}

\section{AMOSTRA CAB-16-80A}

\begin{tabular}{lccccc}
\hline & $\mathbf{1}$ & $\mathbf{2}$ & $\mathbf{3}$ & $\mathbf{4}$ & $\mathbf{5}$ \\
\hline $\mathrm{SiO}_{2}$ & 66.13 & 68.88 & 65.98 & 65.77 & 65.91 \\
\hline $\mathrm{TiO}_{2}$ & 0.00 & 0.00 & 0.00 & 0.00 & 0.00 \\
\hline $\mathrm{Al}_{2} \mathbf{O}_{3}$ & 21.51 & 19.98 & 21.73 & 22.03 & 22.01 \\
\hline $\mathbf{F e O}$ & 0.16 & 0.02 & 0.14 & 0.10 & 0.12 \\
\hline $\mathrm{MnO}$ & 0.00 & 0.01 & 0.00 & 0.00 & 0.01 \\
\hline $\mathrm{MgO}$ & 0.00 & 0.00 & 0.04 & 0.08 & 0.02 \\
\hline $\mathbf{C a O}$ & 1.92 & 0.20 & 2.19 & 2.11 & 2.41 \\
\hline $\mathbf{N a}{ }_{2} \mathbf{O}$ & 10.44 & 11.50 & 10.22 & 10.18 & 10.13 \\
\hline $\mathbf{K} \mathbf{2} \mathbf{O}$ & 0.30 & 0.18 & 0.22 & 0.20 & 0.31 \\
\hline $\mathbf{S r O}$ & 0.01 & 0.00 & 0.00 & 0.00 & 0.01 \\
\hline $\mathbf{B a O}$ & 0.00 & 0.00 & 0.04 & 0.08 & 0.02 \\
\hline Total & 100.48 & 100.78 & 100.55 & 100.55 & 100.96
\end{tabular}

Número de cátions calculado na base 8 oxigênios

\begin{tabular}{llllll}
\hline $\mathbf{S i}$ & 2.8941 & 2.9851 & 2.8850 & 2.8755 & 2.8736 \\
\hline $\mathbf{A l}$ & 1.1096 & 1.0206 & 1.1199 & 1.1353 & 1.1311 \\
\hline $\mathbf{T i}$ & 0.0000 & 0.0000 & 0.0000 & 0.0000 & 0.0000 \\
\hline $\mathbf{F e}$ & 0.0058 & 0.0008 & 0.0051 & 0.0038 & 0.0044 \\
\hline $\mathbf{M n}$ & 0.0001 & 0.0003 & 0.0001 & 0.0000 & 0.0002 \\
\hline $\mathbf{M g}$ & 0.0000 & 0.0001 & 0.0023 & 0.0051 & 0.0015 \\
\hline Soma T & 4.0095 & 4.0069 & 4.0125 & 4.0196 & 4.0108 \\
\hline & & & & & \\
\hline $\mathbf{C a}$ & 0.0900 & 0.0095 & 0.1026 & 0.0988 & 0.1126 \\
\hline $\mathbf{N a}$ & 0.8859 & 0.9664 & 0.8665 & 0.8630 & 0.8564 \\
\hline
\end{tabular}


Tabela B1 - continuação

\begin{tabular}{lccccc}
\hline $\mathbf{K}$ & 0.0170 & 0.0100 & 0.0121 & 0.0112 & 0.0174 \\
\hline Sr & 0.0001 & 0.0001 & 0.0000 & 0.0001 & 0.0002 \\
\hline Ba & 0.0000 & 0.0000 & 0.0006 & 0.0013 & 0.0004 \\
\hline Soma $\boldsymbol{M}$ & 0.9931 & 0.9860 & 0.9818 & 0.9745 & 0.9869 \\
\hline Total & 5.0026 & 4.9928 & 4.9943 & 4.9940 & 4.9977 \\
\hline & & & & & \\
\hline Or & 1.713 & 1.018 & 1.236 & 1.154 & 1.761 \\
\hline Ab & 89.220 & 98.021 & 88.307 & 88.688 & 86.824 \\
\hline An & 9.067 & 0.960 & 10.457 & 10.158 & 11.415 \\
\hline
\end{tabular}


Tabela B1 - continuação

\section{PLÚTON CABREÚVA}

\begin{tabular}{|c|c|c|c|c|c|c|c|c|c|c|c|c|}
\hline \multicolumn{13}{|c|}{ AMOSTRA CAB-16-90 } \\
\hline & 1 & 2 & 3 & 4 & 5 & 6 & 7 & 8 & 9 & 10 & 11 & 12 \\
\hline $\mathrm{SiO}_{2}$ & 63.97 & 64.15 & 63.45 & 63.86 & 64.63 & 64.04 & 68.53 & 68.40 & 64.18 & 63.76 & 64.47 & 68.27 \\
\hline $\mathrm{TiO}_{2}$ & 0.05 & 0.03 & 0.00 & 0.00 & 0.03 & 0.00 & 0.00 & 0.01 & 0.00 & 0.03 & 0.06 & 0.00 \\
\hline $\mathbf{A l}_{2} \mathbf{O}_{3}$ & 23.06 & 22.97 & 23.63 & 23.19 & 22.64 & 22.63 & 19.94 & 19.94 & 22.68 & 23.01 & 22.47 & 19.95 \\
\hline $\mathrm{FeO}$ & 0.13 & 0.10 & 0.12 & 0.10 & 0.08 & 0.07 & 0.08 & 0.19 & 0.11 & 0.09 & 0.16 & 0.07 \\
\hline MnO & 0.00 & 0.00 & 0.00 & 0.02 & 0.01 & 0.01 & 0.01 & 0.00 & 0.01 & 0.00 & 0.00 & 0.01 \\
\hline MgO & 0.00 & 0.00 & 0.00 & 0.00 & 0.00 & 0.00 & 0.00 & 0.04 & 0.00 & 0.00 & 0.00 & 0.00 \\
\hline $\mathrm{CaO}$ & 3.73 & 3.71 & 4.35 & 3.93 & 3.36 & 3.47 & 0.28 & 0.24 & 3.38 & 3.82 & 3.21 & 0.31 \\
\hline $\mathrm{Na}_{2} \mathrm{O}$ & 9.23 & 9.21 & 8.85 & 9.01 & 9.36 & 9.43 & 11.32 & 11.38 & 9.30 & 9.02 & 9.36 & 11.33 \\
\hline $\mathbf{K}_{2} \mathbf{O}$ & 0.35 & 0.22 & 0.34 & 0.41 & 0.35 & 0.35 & 0.13 & 0.12 & 0.34 & 0.38 & 0.36 & 0.15 \\
\hline SrO & 0.00 & 0.00 & 0.04 & 0.01 & 0.00 & 0.01 & 0.01 & 0.00 & 0.00 & 0.03 & 0.03 & 0.00 \\
\hline $\mathrm{BaO}$ & 0.00 & 0.00 & 0.00 & 0.00 & 0.01 & 0.01 & 0.00 & 0.00 & 0.06 & 0.00 & 0.03 & 0.00 \\
\hline Total & 100.52 & 100.40 & 100.79 & 100.53 & 100.46 & 100.03 & 100.29 & 100.32 & 100.06 & 100.14 & 100.15 & 100.10 \\
\hline
\end{tabular}

\section{Número de cátions calculado na base 8 oxigênios}

\begin{tabular}{lllllllllllll}
\hline Si & 2.8110 & 2.8184 & 2.7851 & 2.8066 & 2.8362 & 2.8265 & 2.9838 & 2.9796 & 2.8298 & 2.8118 & 2.8392 & 2.9796 \\
\hline $\mathbf{A l}$ & 1.1944 & 1.1895 & 1.2226 & 1.2013 & 1.1711 & 1.1773 & 1.0233 & 1.0238 & 1.1787 & 1.1960 & 1.1664 & 1.0263 \\
\hline Ti & 0.0015 & 0.0011 & 0.0000 & 0.0000 & 0.0009 & 0.0000 & 0.0000 & 0.0002 & 0.0000 & 0.0009 & 0.0020 & 0.0000 \\
\hline Fe & 0.0046 & 0.0038 & 0.0045 & 0.0036 & 0.0029 & 0.0027 & 0.0028 & 0.0069 & 0.0042 & 0.0033 & 0.0058 & 0.0026 \\
\hline Mn & 0.0000 & 0.0000 & 0.0000 & 0.0006 & 0.0004 & 0.0004 & 0.0002 & 0.0000 & 0.0005 & 0.0001 & 0.0000 & 0.0003 \\
\hline Mg & 0.0000 & 0.0000 & 0.0000 & 0.0000 & 0.0000 & 0.0000 & 0.0000 & 0.0027 & 0.0000 & 0.0000 & 0.0000 & 0.0000 \\
\hline Soma T & 4.0115 & 4.0127 & 4.0121 & 4.0121 & 4.0114 & 4.0069 & 4.0101 & 4.0132 & 4.0132 & 4.0121 & 4.0135 & 4.0088 \\
\hline & & & & & & & & & & & & \\
\hline Ca & 0.1756 & 0.1746 & 0.2046 & 0.1851 & 0.1580 & 0.1641 & 0.0131 & 0.0110 & 0.1597 & 0.1805 & 0.1515 & 0.0147 \\
\hline Na & 0.7864 & 0.7846 & 0.7532 & 0.7678 & 0.7965 & 0.8070 & 0.9557 & 0.9612 & 0.7951 & 0.7713 & 0.7993 & 0.9588 \\
\hline
\end{tabular}


Tabela B1 - continuação

\begin{tabular}{lllllllllllll}
\hline K & 0.0197 & 0.0124 & 0.0192 & 0.0230 & 0.0193 & 0.0200 & 0.0070 & 0.0069 & 0.0189 & 0.0213 & 0.0200 & 0.0085 \\
\hline Sr & 0.0000 & 0.0000 & 0.0006 & 0.0002 & 0.0000 & 0.0002 & 0.0001 & 0.0000 & 0.0000 & 0.0004 & 0.0004 & 0.0000 \\
\hline Ba & 0.0000 & 0.0000 & 0.0000 & 0.0000 & 0.0001 & 0.0002 & 0.0000 & 0.0000 & 0.0010 & 0.0000 & 0.0005 & 0.0000 \\
\hline Soma M & 0.9819 & 0.9717 & 0.9777 & 0.9760 & 0.9739 & 0.9914 & 0.9759 & 0.9791 & 0.9747 & 0.9735 & 0.9717 & 0.9820 \\
\hline Total & 4.9934 & 4.9843 & 4.9898 & 4.9881 & 4.9853 & 4.9983 & 4.9859 & 4.9923 & 4.9879 & 4.9856 & 4.9852 & 4.9909 \\
\hline \multirow{2}{*}{ Or } & & & & & & & & & & & & \\
\hline Ab & 2.011 & 1.280 & 1.968 & 2.353 & 1.985 & 2.016 & 0.721 & 0.701 & 1.943 & 2.184 & 2.060 & 0.866 \\
\hline An & 80.101 & 80.746 & 77.092 & 78.682 & 81.790 & 81.427 & 97.939 & 98.177 & 81.657 & 79.266 & 82.336 & 97.636 \\
\hline & 17.888 & 17.974 & 20.940 & 18.965 & 16.225 & 16.558 & 1.340 & 1.122 & 16.400 & 18.550 & 15.604 & 1.498 \\
\hline
\end{tabular}


Tabela B1 - continuação

\section{PLÚTON CABREÚVA}

\section{AMOSTRA CAB-16-91B}

\begin{tabular}{|c|c|c|c|c|c|c|c|c|c|c|c|c|c|c|c|c|c|c|}
\hline & & & & & & & & & & & & & \multicolumn{6}{|c|}{ PERFIL BORDA NÚCLEO } \\
\hline & 1 & 2 & 3 & 4 & 5 & 6 & 7 & 8 & 9 & 10 & 11 & 12 & $\underline{13}$ & $\underline{14}$ & $\underline{15}$ & $\underline{16}$ & $\underline{17}$ & $\underline{18}$ \\
\hline $\mathrm{SiO}_{2}$ & 64.73 & 63.34 & 63.61 & 64.99 & 68.31 & 64.09 & 65.06 & 65.08 & 64.54 & 64.41 & 64.61 & 65.03 & 64.41 & 64.17 & 64.75 & 64.19 & 64.39 & 67.82 \\
\hline $\mathrm{TiO}_{2}$ & 0.01 & 0.00 & 0.04 & 0.00 & 0.00 & 0.05 & 0.04 & 0.02 & 0.01 & 0.03 & 0.04 & 0.00 & 0.00 & 0.03 & 0.00 & 0.04 & 0.01 & 0.02 \\
\hline $\mathbf{A l}_{2} \mathbf{O}_{3}$ & 22.53 & 23.23 & 23.31 & 22.60 & 19.91 & 22.74 & 22.46 & 22.34 & 22.41 & 22.85 & 22.35 & 22.42 & 22.83 & 22.82 & 22.67 & 22.66 & 22.80 & 20.67 \\
\hline FeO & 0.14 & 0.14 & 0.16 & 0.13 & 0.00 & 0.10 & 0.10 & 0.12 & 0.13 & 0.14 & 0.13 & 0.14 & 0.09 & 0.19 & 0.13 & 0.16 & 0.15 & 0.03 \\
\hline MnO & 0.00 & 0.00 & 0.00 & 0.00 & 0.01 & 0.02 & 0.00 & 0.00 & 0.00 & 0.00 & 0.01 & 0.00 & 0.00 & 0.00 & 0.00 & 0.00 & 0.00 & 0.00 \\
\hline MgO & 0.00 & 0.00 & 0.00 & 0.00 & 0.01 & 0.00 & 0.00 & 0.00 & 0.00 & 0.00 & 0.00 & 0.00 & 0.00 & 0.00 & 0.00 & 0.00 & 0.00 & 0.00 \\
\hline $\mathrm{CaO}$ & 3.21 & 4.18 & 4.22 & 3.25 & 0.38 & 3.47 & 2.95 & 2.88 & 3.23 & 3.60 & 3.23 & 3.22 & 3.53 & 3.65 & 3.47 & 3.49 & 3.67 & 0.94 \\
\hline $\mathrm{Na}_{2} \mathrm{O}$ & 9.29 & 8.87 & 8.82 & 9.35 & 11.30 & 9.14 & 9.86 & 9.71 & 9.47 & 9.29 & 9.32 & 9.18 & 9.32 & 9.10 & 9.22 & 9.11 & 9.01 & 11.07 \\
\hline $\mathbf{K}_{2} \mathbf{O}$ & 0.56 & 0.55 & 0.44 & 0.47 & 0.03 & 0.41 & 0.25 & 0.49 & 0.57 & 0.52 & 0.60 & 0.67 & 0.35 & 0.49 & 0.54 & 0.54 & 0.39 & 0.04 \\
\hline SrO & 0.02 & 0.03 & 0.00 & 0.04 & 0.03 & 0.00 & 0.04 & 0.00 & 0.02 & 0.02 & 0.03 & 0.00 & 0.00 & 0.07 & 0.02 & 0.02 & 0.02 & 0.01 \\
\hline $\mathrm{BaO}$ & 0.01 & 0.07 & 0.03 & 0.02 & 0.00 & 0.06 & 0.02 & 0.00 & 0.01 & 0.05 & 0.00 & 0.07 & 0.03 & 0.03 & 0.08 & 0.04 & 0.00 & 0.00 \\
\hline Total & 100.50 & 100.41 & 100.63 & 100.84 & 99.99 & 100.08 & 100.78 & 100.64 & 100.40 & 100.90 & 100.31 & 100.74 & 100.57 & 100.55 & 100.89 & 100.24 & 100.45 & 100.59 \\
\hline
\end{tabular}

Número de cátions calculado na base 8 oxigênios

\begin{tabular}{|c|c|c|c|c|c|c|c|c|c|c|c|c|c|c|c|c|c|c|}
\hline $\mathbf{S i}$ & 2.8415 & 2.7944 & 2.7961 & 2.8425 & 2.9822 & 2.8260 & 2.8461 & 2.8513 & 2.8394 & 2.8220 & 2.8432 & 2.8487 & 2.8263 & 2.8211 & 2.8347 & 2.8282 & 2.8278 & 2.9486 \\
\hline Al & 1.1657 & 1.2080 & 1.2077 & 1.1651 & 1.0245 & 1.1819 & 1.1581 & 1.1537 & 1.1621 & 1.1800 & 1.1593 & 1.1576 & 1.1808 & 1.1825 & 1.1698 & 1.1768 & 1.1802 & 1.0592 \\
\hline Ti & 0.0004 & 0.0000 & 0.0015 & 0.0000 & 0.0000 & 0.0018 & 0.0014 & 0.0006 & 0.0002 & 0.0009 & 0.0013 & 0.0000 & 0.0000 & 0.0011 & 0.0000 & 0.0013 & 0.0004 & 0.0007 \\
\hline $\mathrm{Fe}$ & 0.0051 & 0.0053 & 0.0058 & 0.0047 & 0.0000 & 0.0037 & 0.0036 & 0.0043 & 0.0049 & 0.0050 & 0.0046 & 0.0053 & 0.0034 & 0.0069 & 0.0049 & 0.0058 & 0.0055 & 0.0010 \\
\hline Mn & 0.0001 & 0.0000 & 0.0000 & 0.0001 & 0.0005 & 0.0008 & 0.0001 & 0.0000 & 0.0001 & 0.0001 & 0.0003 & 0.0000 & 0.0000 & 0.0000 & 0.0000 & 0.0000 & 0.0001 & 0.0000 \\
\hline Mg & 0.0000 & 0.0000 & 0.0000 & 0.0000 & 0.0008 & 0.0000 & 0.0000 & 0.0000 & 0.0000 & 0.0000 & 0.0000 & 0.0000 & 0.0000 & 0.0000 & 0.0000 & 0.0000 & 0.0000 & 0.0002 \\
\hline Soma $T$ & 4.0128 & 4.0076 & 4.0111 & 4.0124 & 4.0080 & 4.0141 & 4.0093 & 4.0098 & 4.0067 & 4.0080 & 4.0087 & 4.0115 & 4.0105 & 4.0116 & 4.0094 & 4.0121 & 4.0141 & 4.0096 \\
\hline $\mathrm{Ca}$ & 0.1510 & 0.1976 & 0.1988 & 0.1523 & 0.0179 & 0.1639 & 0.1383 & 0.1352 & 0.1523 & 0.1690 & 0.1523 & 0.1511 & 0.1660 & 0.1719 & 0.1628 & 0.1648 & 0.1727 & 0.0436 \\
\hline
\end{tabular}


Tabela B1 - continuação

\begin{tabular}{lllllllllllllllllll}
\hline $\mathbf{N a}$ & 0.7907 & 0.7588 & 0.7518 & 0.7929 & 0.9566 & 0.7815 & 0.8364 & 0.8249 & 0.8078 & 0.7892 & 0.7953 & 0.7797 & 0.7930 & 0.7757 & 0.7827 & 0.7783 & 0.7672 & 0.9332 \\
\hline $\mathbf{K}$ & 0.0314 & 0.0310 & 0.0244 & 0.0260 & 0.0018 & 0.0232 & 0.0139 & 0.0277 & 0.0318 & 0.0290 & 0.0335 & 0.0375 & 0.0193 & 0.0274 & 0.0302 & 0.0304 & 0.0220 & 0.0023 \\
\hline Sr & 0.0003 & 0.0004 & 0.0000 & 0.0005 & 0.0004 & 0.0000 & 0.0005 & 0.0000 & 0.0003 & 0.0003 & 0.0004 & 0.0001 & 0.0000 & 0.0010 & 0.0003 & 0.0003 & 0.0003 & 0.0001 \\
\hline Ba & 0.0001 & 0.0011 & 0.0006 & 0.0003 & 0.0000 & 0.0010 & 0.0003 & 0.0000 & 0.0002 & 0.0008 & 0.0001 & 0.0012 & 0.0006 & 0.0005 & 0.0014 & 0.0006 & 0.0000 & 0.0000 \\
\hline Soma M & 0.9735 & 0.9889 & 0.9755 & 0.9721 & 0.9767 & 0.9696 & 0.9893 & 0.9878 & 0.9925 & 0.9883 & 0.9815 & 0.9696 & 0.9789 & 0.9765 & 0.9774 & 0.9743 & 0.9622 & 0.9792 \\
\hline Total & 4.9863 & 4.9966 & 4.9866 & 4.9845 & 4.9847 & 4.9837 & 4.9986 & 4.9976 & 4.9992 & 4.9963 & 4.9903 & 4.9812 & 4.9894 & 4.9881 & 4.9868 & 4.9864 & 4.9763 & 4.9889 \\
\hline \multirow{2}{*}{ Or } & & & & & & & & & & & & & & & & & & \\
\hline Ab & 3.226 & 3.144 & 2.503 & 2.682 & 0.189 & 2.400 & 1.411 & 2.800 & 3.206 & 2.941 & 3.420 & 3.876 & 1.977 & 2.808 & 3.096 & 3.122 & 2.285 & 0.232 \\
\hline An & 81.259 & 76.845 & 77.109 & 81.637 & 97.975 & 80.675 & 84.602 & 83.512 & 81.443 & 79.940 & 81.057 & 80.518 & 81.058 & 79.558 & 80.220 & 79.952 & 79.761 & 95.311 \\
\hline
\end{tabular}


Tabela B1 - continuação

\section{PLÚTON ITUPEVA}

\section{AMOSTRA CAB-15-36}

\begin{tabular}{|c|c|c|c|c|c|c|c|c|c|c|c|}
\hline & 1 & 2 & 3 & 4 & 5 & 6 & 7 & 8 & 9 & 10 & 11 \\
\hline $\mathrm{SiO}_{2}$ & 63.13 & 64.62 & 68.28 & 62.73 & 60.91 & 69.00 & 63.52 & 63.50 & 70.49 & 64.38 & 63.17 \\
\hline $\mathrm{TiO}_{2}$ & 0.03 & 0.07 & 0.04 & 0.02 & 0.04 & 0.00 & 0.02 & 0.00 & 0.04 & 0.02 & 0.04 \\
\hline $\mathrm{FeO}$ & 0.18 & 0.02 & 0.08 & 0.20 & 0.41 & 0.08 & 0.08 & 0.18 & 0.15 & 0.19 & 0.17 \\
\hline MnO & 0.00 & 0.00 & 0.02 & 0.01 & 0.01 & 0.00 & 0.00 & 0.01 & 0.00 & 0.00 & 0.00 \\
\hline $\mathrm{Na}_{2} \mathrm{O}$ & 8.93 & 9.39 & 11.35 & 8.44 & 7.73 & 11.49 & 9.09 & 9.12 & 10.53 & 9.10 & 9.07 \\
\hline $\mathrm{K}_{2} \mathrm{O}$ & 0.38 & 0.06 & 0.09 & 0.42 & 2.92 & 0.09 & 0.34 & 0.34 & 0.07 & 0.41 & 0.37 \\
\hline SrO & 0.01 & 0.03 & 0.00 & 0.03 & 0.01 & 0.03 & 0.00 & 0.00 & 0.00 & 0.00 & 0.00 \\
\hline $\mathrm{BaO}$ & 0.00 & 0.01 & 0.02 & 0.00 & 0.05 & 0.01 & 0.00 & 0.00 & 0.00 & 0.03 & 0.03 \\
\hline
\end{tabular}

\section{Número de cátions calculado na base 8 oxigênios}

\begin{tabular}{|c|c|c|c|c|c|c|c|c|c|c|c|}
\hline $\mathbf{S i}$ & 2.7829 & 2.8427 & 2.9787 & 2.7786 & 2.7298 & 2.9930 & 2.7964 & 2.7940 & 3.0404 & 2.8193 & 2.7796 \\
\hline Al & 1.2231 & 1.1677 & 1.0263 & 1.2280 & 1.3513 & 1.0128 & 1.2085 & 1.2105 & 0.9680 & 1.1882 & 1.2193 \\
\hline Ti & 0.0009 & 0.0023 & 0.0015 & 0.0007 & 0.0014 & 0.0000 & 0.0006 & 0.0000 & 0.0013 & 0.0006 & 0.0012 \\
\hline Mn & 0.0000 & 0.0000 & 0.0006 & 0.0002 & 0.0006 & 0.0000 & 0.0001 & 0.0004 & 0.0001 & 0.0000 & 0.0002 \\
\hline Mg & 0.0000 & 0.0000 & 0.0013 & 0.0000 & 0.0000 & 0.0000 & 0.0000 & 0.0000 & 0.0001 & 0.0000 & 0.0000 \\
\hline Soma $T$ & 4.0134 & 4.0135 & 4.0113 & 4.0147 & 4.0983 & 4.0086 & 4.0085 & 4.0116 & 4.0153 & 4.0151 & 4.0065 \\
\hline Ca & 0.1989 & 0.1551 & 0.0125 & 0.2174 & 0.0744 & 0.0058 & 0.1925 & 0.1905 & 0.0167 & 0.1727 & 0.2051 \\
\hline $\mathrm{Na}$ & 0.7633 & 0.8010 & 0.9601 & 0.7249 & 0.6717 & 0.9664 & 0.7760 & 0.7781 & 0.8807 & 0.7727 & 0.7739 \\
\hline
\end{tabular}


Tabela B1 - continuação

\begin{tabular}{llllllllllll}
\hline $\mathbf{K}$ & 0.0211 & 0.0033 & 0.0051 & 0.0235 & 0.1669 & 0.0049 & 0.0193 & 0.0192 & 0.0039 & 0.0228 & 0.0209 \\
\hline Sr & 0.0002 & 0.0004 & 0.0000 & 0.0004 & 0.0002 & 0.0004 & 0.0000 & 0.0000 & 0.0000 & 0.0000 & 0.0000 \\
\hline Ba & 0.0000 & 0.0001 & 0.0003 & 0.0000 & 0.0009 & 0.0002 & 0.0001 & 0.0000 & 0.0000 & 0.0006 & 0.0005 \\
\hline Soma $\boldsymbol{M}$ & 0.9834 & 0.9598 & 0.9780 & 0.9662 & 0.9142 & 0.9776 & 0.9878 & 0.9877 & 0.9013 & 0.9687 & 1.0004 \\
\hline Total & 4.9969 & 4.9733 & 4.9893 & 4.9809 & 5.0125 & 4.9862 & 4.9963 & 4.9993 & 4.9166 & 4.9838 & 5.0069 \\
\hline & & & & & & & & & & \\
\hline Or & 2.147 & 0.342 & 0.525 & 2.431 & 18.281 & 0.500 & 1.953 & 1.940 & 0.437 & 2.354 & 2.090 \\
\hline Ab & 77.629 & 83.492 & 98.201 & 75.060 & 73.567 & 98.911 & 78.561 & 78.776 & 97.710 & 79.811 & 77.397 \\
\hline An & 20.224 & 16.166 & 1.275 & 22.508 & 8.152 & 0.589 & 19.486 & 19.284 & 1.853 & 17.835 & 20.513 \\
\hline
\end{tabular}


Tabela B1 - continuação

\section{PLÚTON ITUPEVA}

AMOSTRA CAB-16-98

\begin{tabular}{|c|c|}
\hline & 1 \\
\hline $\mathrm{SiO}_{2}$ & 65.79 \\
\hline $\mathrm{TiO}_{2}$ & 0.12 \\
\hline $\mathbf{A l}_{2} \mathbf{O}_{3}$ & 21.36 \\
\hline $\mathrm{FeO}$ & 1.37 \\
\hline MnO & 0.08 \\
\hline MgO & 0.19 \\
\hline $\mathrm{CaO}$ & 0.75 \\
\hline $\mathrm{Na}_{2} \mathrm{O}$ & 10.27 \\
\hline $\mathbf{K}_{2} \mathbf{O}$ & 0.70 \\
\hline SrO & 0.05 \\
\hline $\mathrm{BaO}$ & 0.02 \\
\hline Total & 100.70 \\
\hline
\end{tabular}

Número de cátions calculado na base 8 oxigênios

$\begin{array}{ll}\mathrm{Si} & 2.8878\end{array}$

Al 1.1051

Ti 0.0039

$\mathrm{Fe} \quad 0.0505$

Mn 0.0030

\begin{tabular}{ll}
\hline Mg & 0.0127 \\
\hline Soma T & 4.0629 \\
\hline
\end{tabular}

\begin{tabular}{ll}
\hline $\mathbf{C a}$ & 0.0351 \\
\hline $\mathbf{N a}$ & 0.8741
\end{tabular}


Tabela B1 - continuação

$$
\text { K }
$$

0.0394

Sr 0.0006

Ba

Soma M

Total 0.9496 5.0125

Or

\begin{tabular}{lr} 
& 4.156 \\
\hline Ab & 92.145
\end{tabular}

An 
Tabela B1 - continuação

\section{PLÚTON ITUPEVA}

\begin{tabular}{|c|c|c|c|c|c|c|c|c|c|c|c|}
\hline \multicolumn{12}{|c|}{ AMOSTRA CAB-16-101 } \\
\hline & 1 & 2 & 3 & 4 & 5 & 6 & 7 & 8 & 9 & 10 & 11 \\
\hline $\mathrm{SiO}_{2}$ & 68.89 & 68.09 & 59.46 & 56.77 & 57.31 & 65.38 & 65.71 & 61.71 & 61.90 & 62.29 & 60.47 \\
\hline $\mathbf{A l}_{2} \mathbf{O}_{3}$ & 20.03 & 20.31 & 26.11 & 28.18 & 27.60 & 21.86 & 22.21 & 24.77 & 24.59 & 24.47 & 25.77 \\
\hline $\mathrm{FeO}$ & 0.09 & 0.06 & 0.14 & 0.15 & 0.13 & 0.65 & 0.06 & 0.14 & 0.13 & 0.13 & 0.09 \\
\hline MnO & 0.01 & 0.01 & 0.02 & 0.01 & 0.00 & 0.01 & 0.03 & 0.01 & 0.02 & 0.00 & 0.01 \\
\hline $\mathrm{CaO}$ & 0.05 & 0.64 & 7.23 & 9.32 & 8.74 & 1.12 & 2.55 & 5.58 & 5.26 & 5.13 & 6.50 \\
\hline $\mathrm{Na}_{2} \mathrm{O}$ & 11.75 & 11.21 & 7.40 & 6.11 & 6.35 & 9.92 & 10.07 & 8.43 & 8.24 & 8.28 & 7.79 \\
\hline $\mathbf{K}_{2} \mathbf{O}$ & 0.02 & 0.17 & 0.21 & 0.18 & 0.10 & 0.83 & 0.07 & 0.15 & 0.10 & 0.13 & 0.09 \\
\hline SrO & 0.05 & 0.01 & 0.03 & 0.03 & 0.04 & 0.02 & 0.00 & 0.05 & 0.02 & 0.06 & 0.03 \\
\hline $\mathrm{BaO}$ & 0.00 & 0.01 & 0.06 & 0.05 & 0.04 & 0.04 & 0.01 & 0.03 & 0.02 & 0.08 & 0.05 \\
\hline $\mathbf{S i}$ & 2.9829 & 2.9634 & 2.6370 & 2.5287 & 2.5592 & 2.8808 & 2.8678 & 2.7179 & 2.7343 & 2.7436 & 2.6701 \\
\hline Al & 1.0222 & 1.0419 & 1.3649 & 1.4795 & 1.4527 & 1.1353 & 1.1425 & 1.2859 & 1.2803 & 1.2704 & 1.3412 \\
\hline Ti & 0.0000 & 0.0000 & 0.0017 & 0.0011 & 0.0002 & 0.0042 & 0.0000 & 0.0007 & 0.0000 & 0.0005 & 0.0000 \\
\hline $\mathrm{Fe}$ & 0.0034 & 0.0023 & 0.0052 & 0.0058 & 0.0050 & 0.0241 & 0.0023 & 0.0053 & 0.0049 & 0.0047 & 0.0032 \\
\hline Mn & 0.0005 & 0.0003 & 0.0008 & 0.0003 & 0.0001 & 0.0004 & 0.0009 & 0.0003 & 0.0008 & 0.0000 & 0.0002 \\
\hline Mg & 0.0001 & 0.0001 & 0.0000 & 0.0000 & 0.0000 & 0.0014 & 0.0000 & 0.0000 & 0.0000 & 0.0000 & 0.0000 \\
\hline Soma T & 4.0091 & 4.0079 & 4.0096 & 4.0153 & 4.0171 & 4.0462 & 4.0136 & 4.0100 & 4.0203 & 4.0192 & 4.0147 \\
\hline $\mathrm{Ca}$ & 0.0025 & 0.0297 & 0.3436 & 0.4448 & 0.4182 & 0.0530 & 0.1192 & 0.2633 & 0.2490 & 0.2421 & 0.3075 \\
\hline
\end{tabular}


Tabela B1 - continuação

\begin{tabular}{|c|c|c|c|c|c|c|c|c|c|c|c|}
\hline $\mathbf{K}$ & 0.0010 & 0.0096 & 0.0119 & 0.0103 & 0.0056 & 0.0469 & 0.0038 & 0.0084 & 0.0057 & 0.0072 & 0.0048 \\
\hline $\mathrm{Sr}$ & 0.0007 & 0.0001 & 0.0004 & 0.0004 & 0.0006 & 0.0002 & 0.0000 & 0.0007 & 0.0003 & 0.0009 & 0.0004 \\
\hline $\mathbf{B a}$ & 0.0000 & 0.0002 & 0.0011 & 0.0009 & 0.0006 & 0.0007 & 0.0001 & 0.0004 & 0.0003 & 0.0014 & 0.0008 \\
\hline Total & 4.9998 & 4.9935 & 5.0030 & 4.9995 & 4.9920 & 4.9945 & 4.9889 & 5.0027 & 4.9812 & 4.9779 & 4.9952 \\
\hline An & 0.253 & 3.016 & 34.641 & 45.259 & 42.952 & 5.592 & 12.227 & 26.556 & 25.923 & 25.313 & 31.402 \\
\hline
\end{tabular}






AMOSTRA 2008-ITU-2.1A1 - SALTO

Prancha B1 - Imagens obtidas por EDS de elétrons retroespalhados dos cristais de plagioclásios analisados com os pontos de análise em vermelho e teores de anortita em azul e branco. 



AMOSTRA CAB-14-06B - INDAIATUBA

Prancha B1 - continuação 


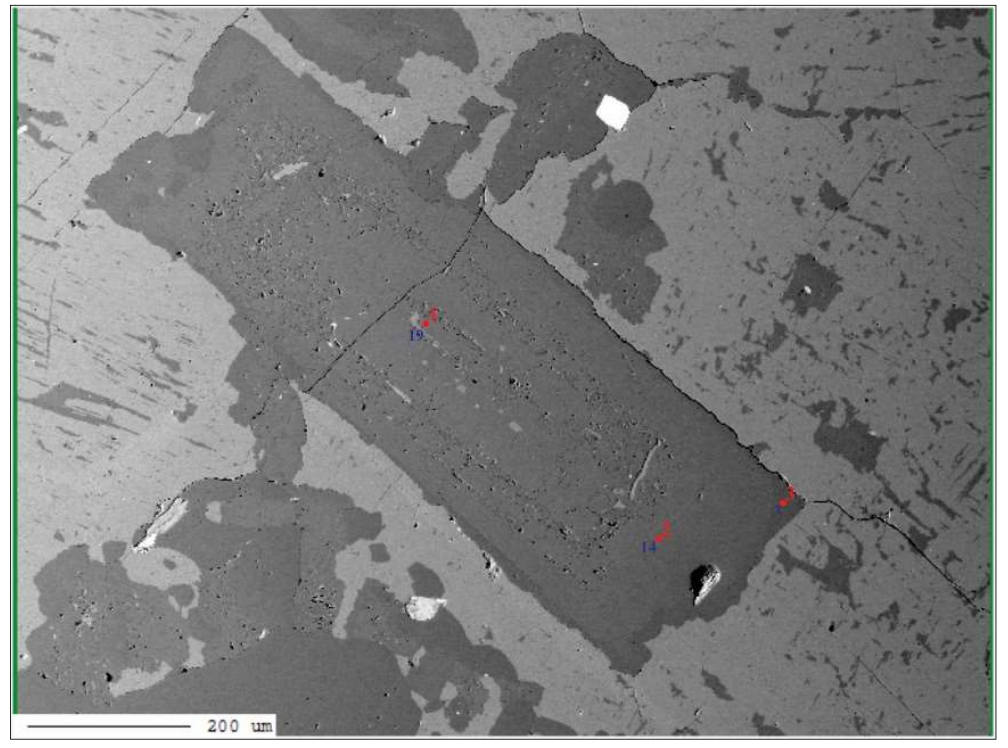

AMOSTRA CAB-15-34.1 - INDAIATUBA

Prancha B1 - continuação



AMOSTRA CAB-15-34.2 - INDAIATUBA

Prancha B1 - continuação 




AMOSTRA CAB-15-57 - INDAIATUBA

Prancha B1 - continuação



AMOSTRA CAB-14-09 - CABREÚVA

Prancha B1 - continuação 



AMOSTRA CAB-16-80A - CABREÚVA

Prancha B1 - continuação

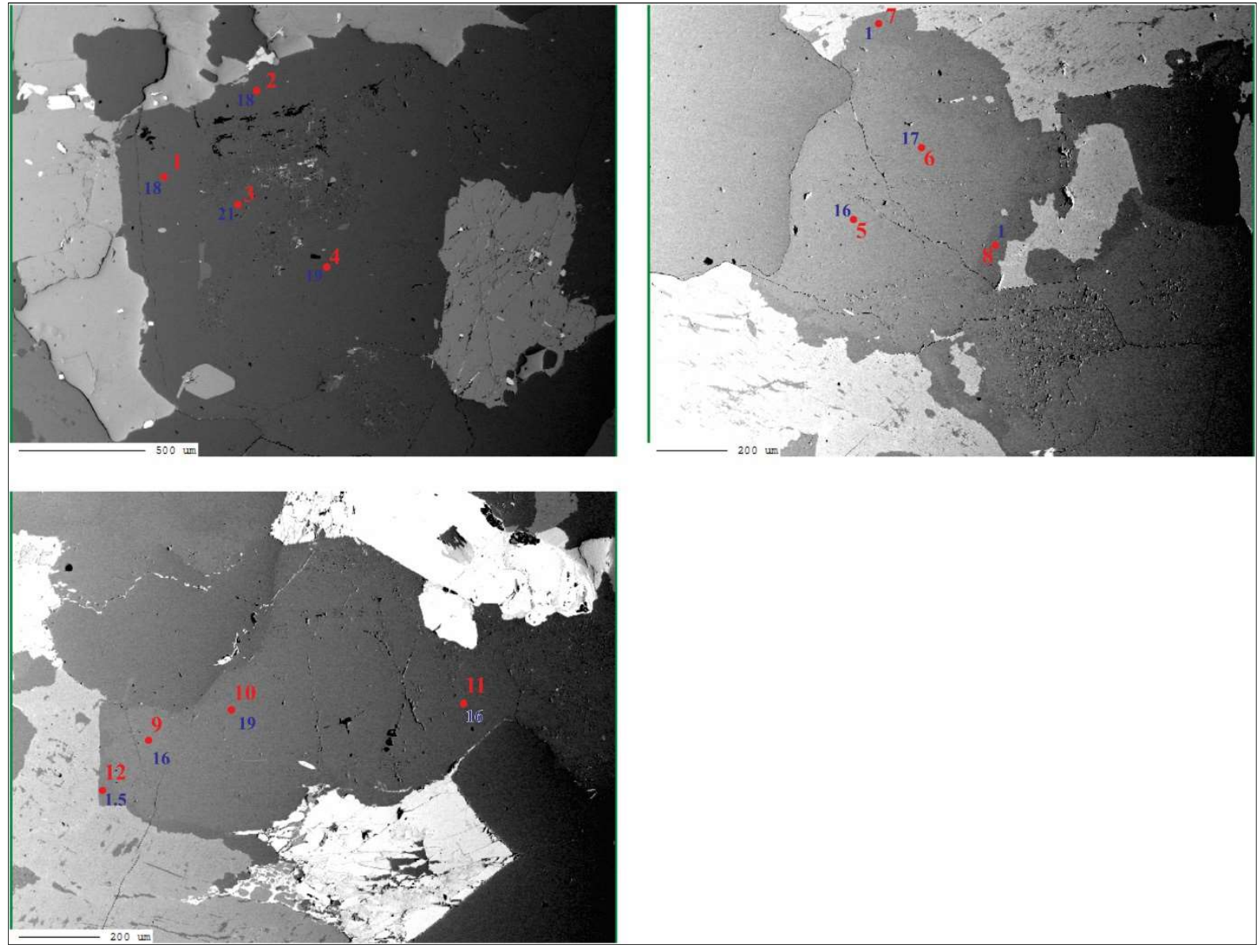

AMOSTRA CAB-16-90 - CABREÚVA

Prancha B1 - continuação 


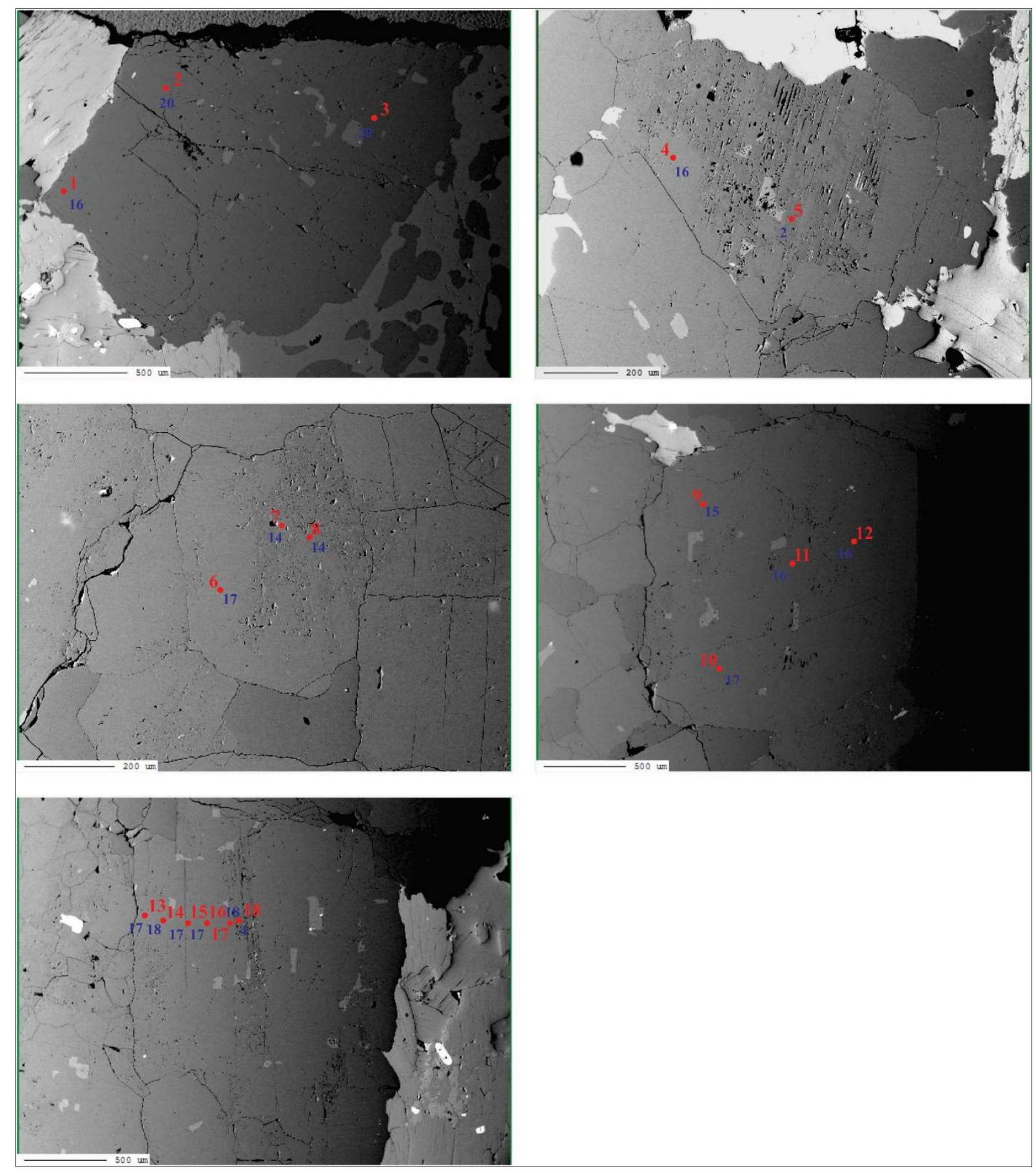

AMOSTRA CAB-16-91B - CABREÚVA

Prancha B1 - continuação 


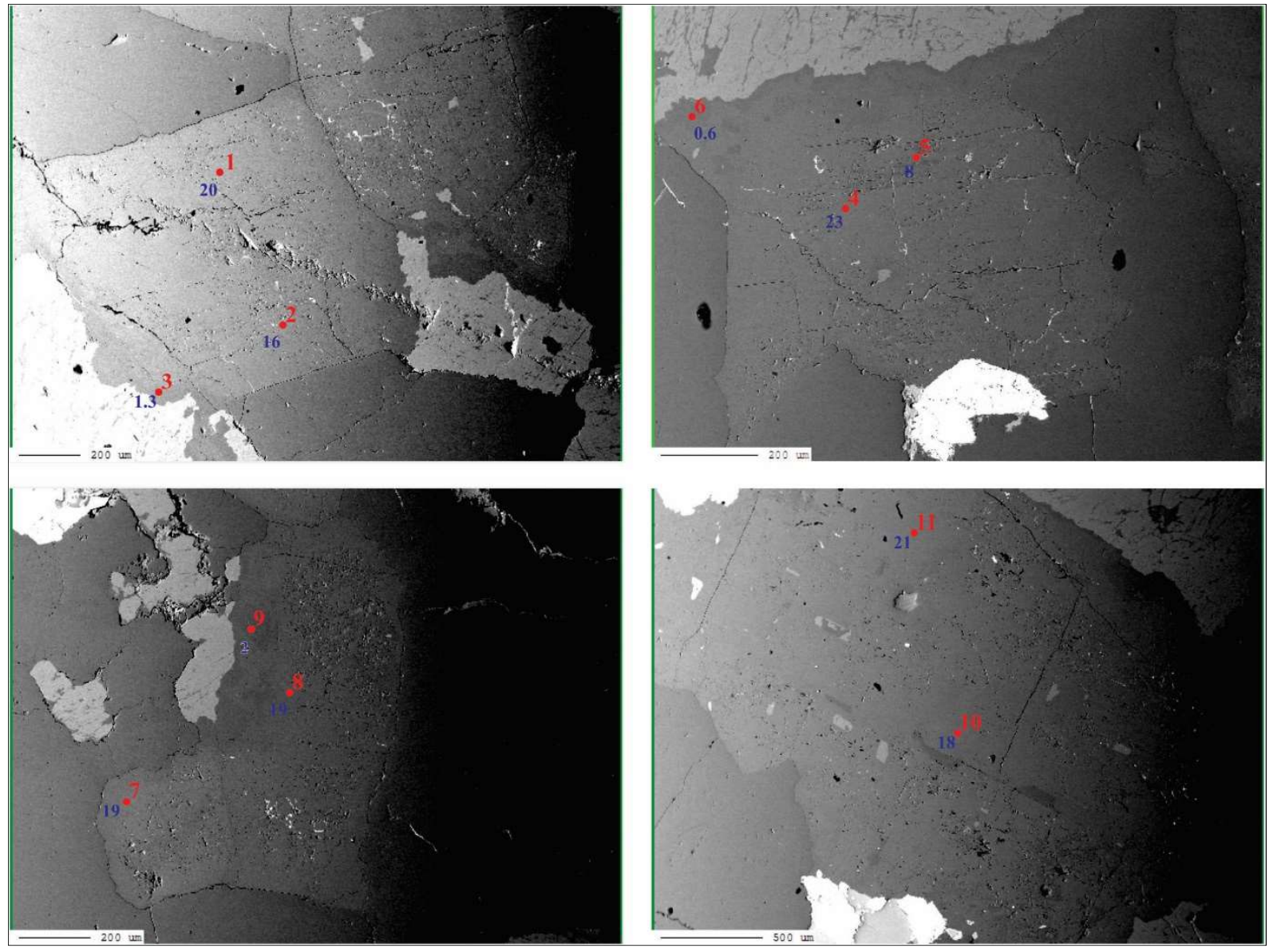

AMOSTRA CAB-15-36 - ITUPEVA

Prancha B1 - continuação

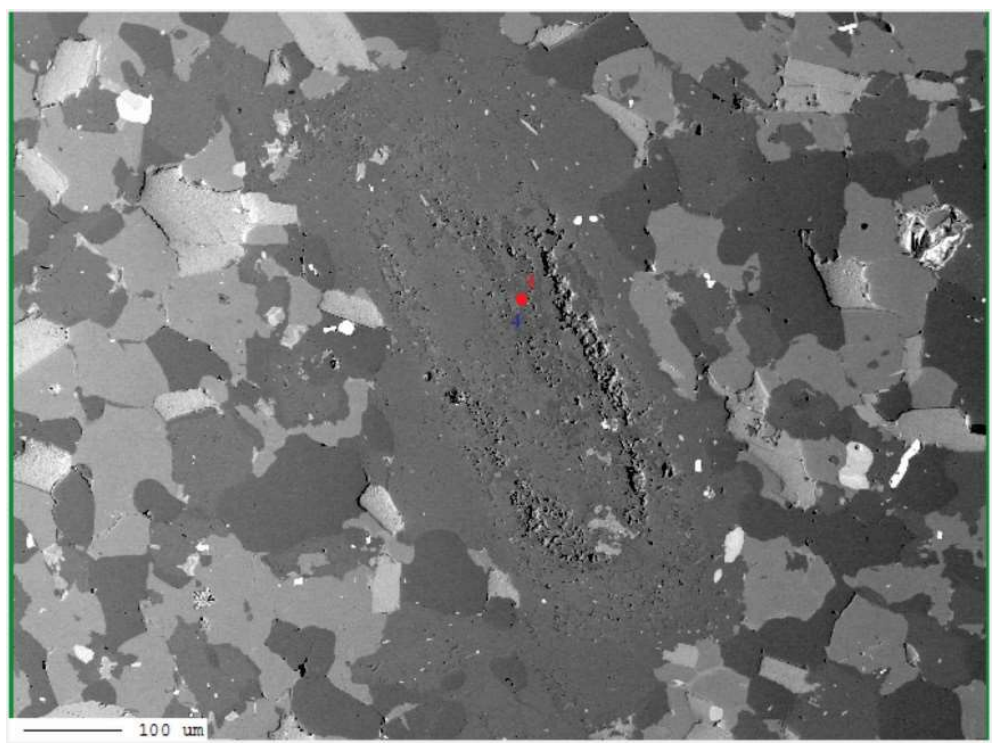

AMOSTRA CAB-16-98 - ITUPEVA

Prancha B1 - continuação 


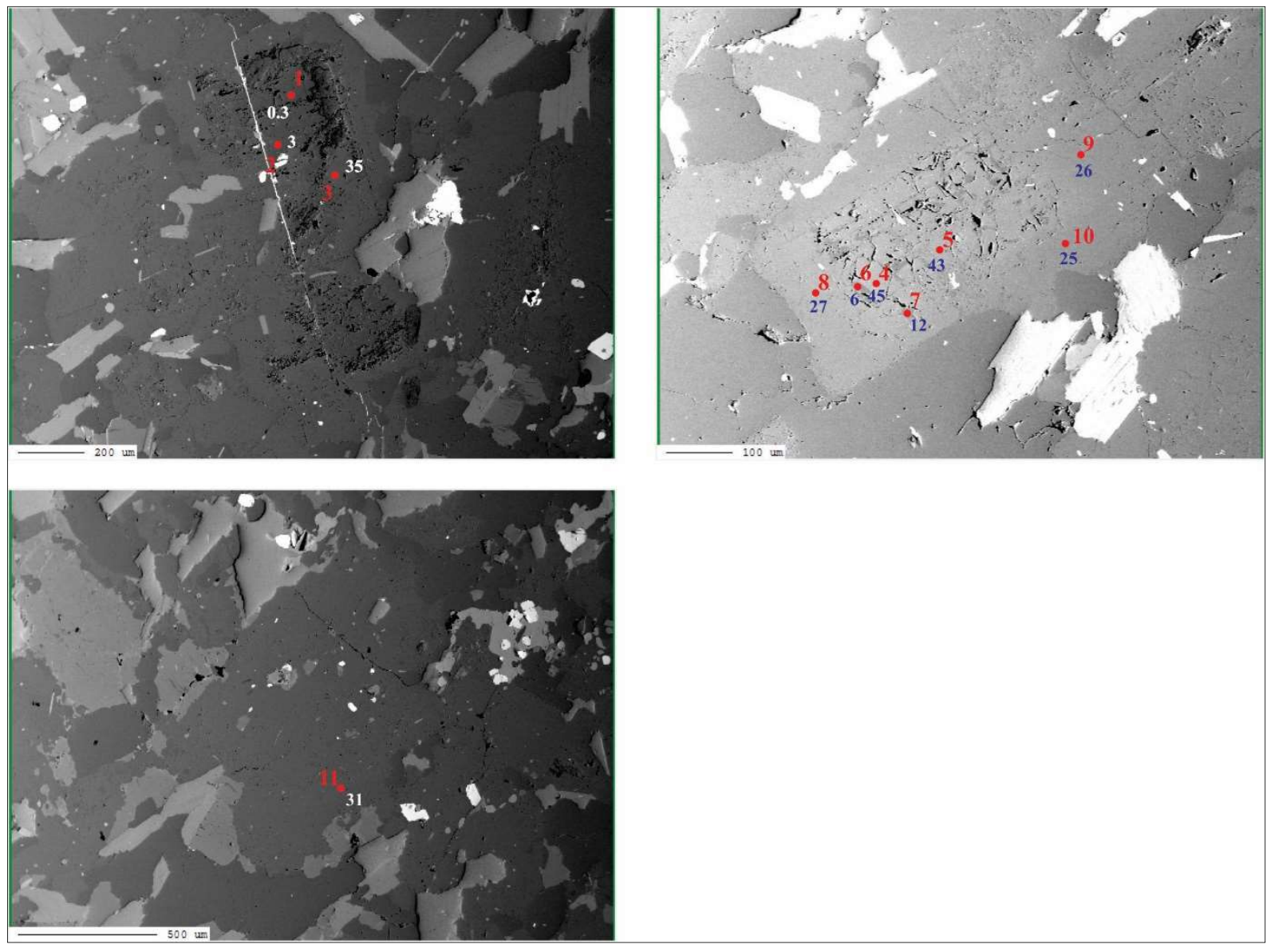

AMOSTRA CAB-16-101 - ITUPEVA

Prancha B1 - continuação 
Tabela B2 - Composição química dos piroxênios da amostra de monzogabro CAB-15-57 do Plúton Indaiatuba.

\section{PLÚTON INDAIATUBA}

\begin{tabular}{lcccccccccccccc}
\hline AMOSTRA CAB-15-57 & $\mathbf{1}$ & $\mathbf{2}$ & $\mathbf{3}$ & $\mathbf{4}$ & $\mathbf{5}$ & $\mathbf{6}$ & $\mathbf{7}$ & $\mathbf{8}$ & $\mathbf{9}$ & $\mathbf{1 0}$ & $\mathbf{1 1}$ & $\mathbf{1 2}$ & $\mathbf{1 3}$ & $\mathbf{1 4}$ \\
\hline $\mathrm{SiO}_{2}$ & 49.70 & 50.30 & 50.57 & 49.91 & 50.23 & 52.23 & 51.77 & 49.99 & 52.24 & 49.94 & 49.67 & 49.50 & 50.95 & 52.26 \\
\hline $\mathbf{A l}_{2} \mathbf{O}_{3}$ & 4.24 & 4.00 & 3.85 & 4.31 & 4.50 & 2.51 & 2.59 & 4.08 & 2.06 & 4.54 & 4.59 & 4.28 & 3.92 & 2.33 \\
\hline $\mathbf{F e O}$ & 10.14 & 9.82 & 9.53 & 9.76 & 8.73 & 9.58 & 9.85 & 10.09 & 10.09 & 9.45 & 9.71 & 10.66 & 8.89 & 9.50 \\
\hline $\mathbf{M n O}$ & 0.25 & 0.22 & 0.21 & 0.22 & 0.14 & 0.25 & 0.28 & 0.25 & 0.29 & 0.20 & 0.19 & 0.25 & 0.18 & 0.26 \\
\hline $\mathbf{C a O}$ & 19.62 & 19.88 & 19.87 & 19.45 & 19.69 & 18.49 & 18.60 & 19.10 & 18.98 & 19.68 & 19.32 & 19.03 & 20.20 & 19.14 \\
\hline $\mathbf{K}_{2} \mathbf{O}$ & 0.00 & 0.00 & 0.00 & 0.00 & 0.08 & 0.01 & 0.02 & 0.00 & 0.00 & 0.00 & 0.00 & 0.02 & 0.00 & 0.00 \\
\hline $\mathbf{T i O}_{2}$ & 1.58 & 1.68 & 1.37 & 1.45 & 1.43 & 0.74 & 0.99 & 1.67 & 0.88 & 1.51 & 1.77 & 1.71 & 1.30 & 0.88 \\
\hline $\mathbf{C r}_{2} \mathbf{O}_{3}$ & 0.12 & 0.06 & 0.06 & 0.12 & 0.48 & 0.13 & 0.00 & 0.06 & 0.00 & 0.20 & 0.22 & 0.06 & 0.19 & 0.00 \\
\hline $\mathbf{N a 2 O}^{2}$ & 0.48 & 0.44 & 0.46 & 0.49 & 0.45 & 0.37 & 0.45 & 0.48 & 0.39 & 0.48 & 0.49 & 0.53 & 0.44 & 0.38 \\
\hline $\mathbf{M g O}_{2}$ & 14.38 & 14.44 & 14.56 & 14.31 & 14.78 & 16.22 & 15.68 & 14.49 & 15.61 & 14.60 & 14.49 & 14.06 & 14.68 & 15.74 \\
\hline Total & 100.50 & 100.84 & 100.48 & 100.02 & 100.50 & 100.53 & 100.22 & 100.20 & 100.54 & 100.59 & 100.46 & 100.11 & 100.75 & 100.48
\end{tabular}

Número de cátions calculado na base 6 oxigênios

\begin{tabular}{lllllllllllllll}
\hline $\mathbf{S i}$ & 1.840 & 1.856 & 1.869 & 1.855 & 1.852 & 1.920 & 1.913 & 1.856 & 1.928 & 1.842 & 1.838 & 1.843 & 1.875 & 1.926 \\
\hline $\mathbf{T i}$ & 0.044 & 0.047 & 0.038 & 0.040 & 0.040 & 0.021 & 0.027 & 0.047 & 0.024 & 0.042 & 0.049 & 0.048 & 0.036 & 0.024 \\
\hline $\mathbf{A l}$ & 0.185 & 0.174 & 0.168 & 0.189 & 0.196 & 0.109 & 0.113 & 0.179 & 0.090 & 0.197 & 0.200 & 0.188 & 0.170 & 0.101 \\
\hline $\mathbf{C r}$ & 0.003 & 0.002 & 0.002 & 0.003 & 0.014 & 0.004 & 0.000 & 0.002 & 0.000 & 0.006 & 0.006 & 0.002 & 0.006 & 0.000 \\
\hline $\mathbf{F e 3 +}$ & 0.078 & 0.051 & 0.049 & 0.053 & 0.044 & 0.033 & 0.039 & 0.049 & 0.033 & 0.063 & 0.055 & 0.067 & 0.033 & 0.025 \\
\hline $\mathbf{F e 2 +}$ & 0.236 & 0.252 & 0.246 & 0.251 & 0.225 & 0.262 & 0.266 & 0.264 & 0.278 & 0.229 & 0.245 & 0.265 & 0.240 & 0.268 \\
\hline $\mathbf{M n}$ & 0.008 & 0.007 & 0.007 & 0.007 & 0.004 & 0.008 & 0.009 & 0.008 & 0.009 & 0.006 & 0.006 & 0.008 & 0.005 & 0.008 \\
\hline $\mathbf{M g}$ & 0.794 & 0.794 & 0.802 & 0.793 & 0.812 & 0.889 & 0.864 & 0.802 & 0.859 & 0.803 & 0.799 & 0.781 & 0.806 & 0.865 \\
\hline $\mathbf{C a}$ & 0.778 & 0.786 & 0.787 & 0.774 & 0.778 & 0.728 & 0.737 & 0.760 & 0.751 & 0.778 & 0.766 & 0.759 & 0.797 & 0.756 \\
\hline $\mathbf{N a}$ & 0.034 & 0.032 & 0.033 & 0.035 & 0.032 & 0.026 & 0.032 & 0.034 & 0.028 & 0.034 & 0.035 & 0.039 & 0.032 & 0.027 \\
\hline $\mathbf{K}$ & 0.000 & 0.000 & 0.000 & 0.000 & 0.004 & 0.000 & 0.001 & 0.000 & 0.000 & 0.000 & 0.000 & 0.001 & 0.000 & 0.000 \\
\hline
\end{tabular}


Tabela B2 - continuação

\begin{tabular}{lllllllllllllll}
\hline Total & 4.000 & 4.000 & 4.000 & 4.000 & 4.000 & 4.000 & 4.000 & 4.000 & 4.000 & 4.000 & 4.000 & 4.000 & 4.000 & 4.000 \\
\hline En & 0.439 & 0.433 & 0.437 & 0.436 & 0.448 & 0.473 & 0.463 & 0.439 & 0.455 & 0.444 & 0.441 & 0.433 & 0.437 & 0.458 \\
\hline Fs & 0.131 & 0.138 & 0.134 & 0.138 & 0.124 & 0.139 & 0.142 & 0.145 & 0.147 & 0.126 & 0.136 & 0.147 & 0.130 & 0.142 \\
\hline Wo & 0.430 & 0.429 & 0.429 & 0.426 & 0.429 & 0.388 & 0.395 & 0.416 & 0.398 & 0.430 & 0.423 & 0.421 & 0.432 & 0.400 \\
\hline
\end{tabular}



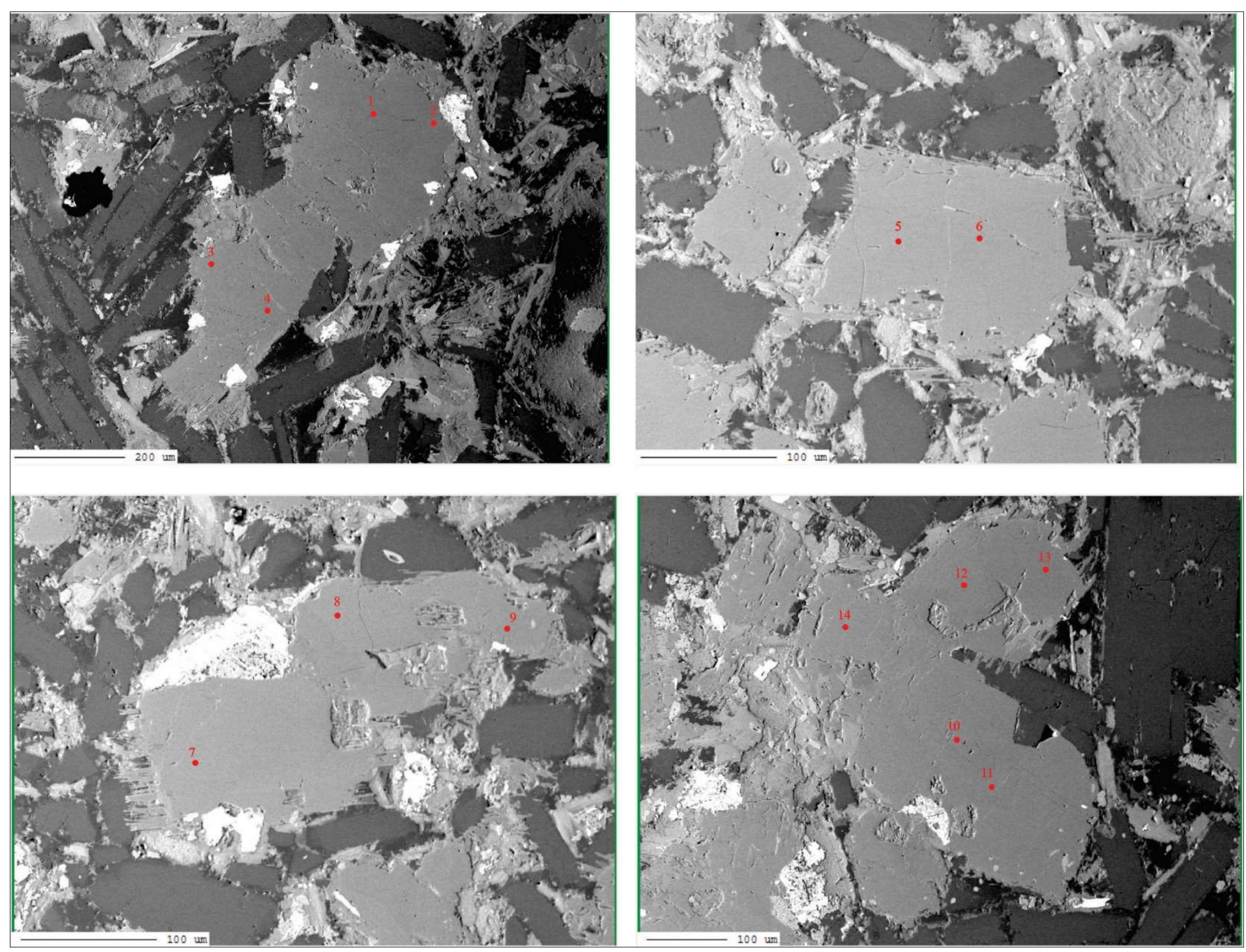

\section{AMOSTRA CAB-15-57 - INDAIATUBA}

Prancha B2 - Imagens obtidas por EDS de elétrons retroespalhados dos cristais de piroxênios analisados com os pontos de análise em vermelho. 
Tabela B3 - Composição química dos anfibólios do Batólito Itu.

\section{PLÚTON SALTO}

\section{AMOSTRA FM3_3}

\begin{tabular}{|c|c|c|c|c|c|c|c|c|c|c|c|c|c|c|c|}
\hline & 1 & 2 & 3 & 4 & 5 & 6 & 7 & 8 & 9 & 10 & 11 & 12 & 13 & 14 & 15 \\
\hline $\mathrm{SiO}_{2}$ & 45.39 & 45.53 & 44.92 & 45.25 & 44.95 & 42.98 & 45.23 & 44.99 & 45.66 & 45.42 & 45.39 & 44.98 & 45.17 & 45.39 & 45.25 \\
\hline $\mathrm{TiO}_{2}$ & 0.86 & 0.72 & 0.62 & 0.74 & 0.66 & 0.96 & 0.88 & 0.83 & 0.77 & 0.65 & 0.63 & 0.63 & 0.73 & 0.75 & 0.90 \\
\hline $\mathbf{A l}_{2} \mathbf{O}_{3}$ & 7.09 & 7.38 & 7.51 & 7.31 & 7.36 & 9.01 & 7.38 & 7.63 & 7.45 & 7.41 & 7.37 & 7.44 & 7.35 & 7.46 & 7.41 \\
\hline $\mathrm{Cr}_{2} \mathrm{O}_{3}$ & 0.00 & 0.01 & 0.02 & 0.02 & 0.00 & 0.01 & 0.00 & 0.02 & 0.00 & 0.00 & 0.00 & 0.03 & 0.00 & 0.01 & 0.02 \\
\hline MnO & 0.83 & 0.82 & 0.82 & 0.81 & 0.89 & 0.87 & 0.91 & 0.90 & 0.94 & 0.82 & 0.89 & 0.90 & 0.90 & 0.85 & 0.90 \\
\hline $\mathrm{FeO}^{\mathrm{T}}$ & 21.25 & 20.49 & 21.59 & 20.99 & 22.07 & 22.43 & 21.75 & 21.73 & 21.73 & 21.01 & 21.00 & 21.01 & 21.35 & 21.39 & 21.31 \\
\hline MgO & 8.48 & 8.34 & 8.11 & 8.38 & 7.35 & 7.05 & 7.71 & 7.78 & 7.64 & 8.17 & 8.20 & 8.31 & 7.94 & 8.23 & 8.20 \\
\hline $\mathrm{CaO}$ & 10.74 & 10.74 & 10.77 & 10.72 & 10.75 & 10.74 & 10.70 & 10.76 & 10.73 & 10.94 & 10.85 & 10.84 & 10.85 & 10.74 & 10.76 \\
\hline $\mathrm{Na}_{2} \mathrm{O}$ & 1.93 & 1.89 & 1.80 & 1.90 & 1.81 & 1.95 & 1.82 & 1.96 & 1.89 & 1.77 & 1.92 & 1.84 & 2.07 & 1.99 & 2.01 \\
\hline $\mathrm{K}_{2} \mathrm{O}$ & 0.90 & 0.98 & 0.99 & 1.00 & 1.01 & 1.18 & 0.99 & 0.96 & 0.95 & 0.97 & 0.96 & 0.98 & 0.85 & 0.96 & 0.96 \\
\hline F & 1.10 & 1.16 & 1.26 & 1.22 & 1.02 & 1.21 & 1.03 & 1.09 & 1.06 & 1.06 & 1.17 & 1.06 & 1.02 & 1.12 & 1.22 \\
\hline Cl & 0.10 & 0.07 & 0.06 & 0.08 & 0.10 & 0.10 & 0.10 & 0.08 & 0.11 & 0.11 & 0.08 & 0.09 & 0.07 & 0.11 & 0.07 \\
\hline $\mathrm{ZnO}$ & 0.00 & 0.00 & 0.00 & 0.00 & 0.00 & 0.00 & 0.00 & 0.00 & 0.00 & 0.00 & 0.00 & 0.00 & 0.00 & 0.00 & 0.00 \\
\hline $\mathrm{ZrO}_{2}$ & 0.00 & 0.00 & 0.00 & 0.00 & 0.00 & 0.00 & 0.00 & 0.00 & 0.00 & 0.00 & 0.00 & 0.00 & 0.00 & 0.00 & 0.00 \\
\hline Soma & 98.66 & 98.13 & 98.48 & 98.42 & 97.97 & 98.50 & 98.50 & 98.73 & 98.92 & 98.34 & 98.46 & 98.11 & 98.30 & 98.99 & 99.01 \\
\hline $\mathbf{O}^{*}=\mathrm{F}, \mathrm{Cl}$ & -0.49 & -0.50 & -0.54 & -0.53 & -0.45 & -0.53 & -0.46 & -0.48 & -0.47 & -0.47 & -0.51 & -0.47 & -0.44 & -0.50 & -0.53 \\
\hline Total & 98.17 & 97.63 & 97.94 & 97.89 & 97.52 & 97.97 & 98.04 & 98.25 & 98.45 & 97.87 & 97.95 & 97.64 & 97.86 & 98.49 & 98.48 \\
\hline
\end{tabular}

Número de cátions calculado na base 13-CNK

\begin{tabular}{|c|c|c|c|c|c|c|c|c|c|c|c|c|c|c|c|}
\hline $\mathbf{S i}$ & 6.901 & 6.960 & 6.862 & 6.906 & 6.933 & 6.625 & 6.914 & 6.868 & 6.953 & 6.939 & 6.935 & 6.882 & 6.922 & 6.891 & 6.881 \\
\hline Al & 1.099 & 1.040 & 1.138 & 1.094 & 1.067 & 1.375 & 1.086 & 1.132 & 1.047 & 1.061 & 1.065 & 1.118 & 1.078 & 1.109 & 1.119 \\
\hline Soma $T$ & 8.000 & 8.000 & 8.000 & 8.000 & 8.000 & 8.000 & 8.000 & 8.000 & 8.000 & 8.000 & 8.000 & 8.000 & 8.000 & 8.000 & 8.000 \\
\hline Ti & 0.098 & 0.083 & 0.071 & 0.085 & 0.076 & 0.112 & 0.101 & 0.096 & 0.088 & 0.075 & 0.072 & 0.072 & 0.084 & 0.086 & 0.103 \\
\hline
\end{tabular}


Tabela B3 - continuação

\begin{tabular}{|c|c|c|c|c|c|c|c|c|c|c|c|c|c|c|c|}
\hline Al & 0.171 & 0.290 & 0.214 & 0.221 & 0.270 & 0.262 & 0.243 & 0.241 & 0.290 & 0.274 & 0.262 & 0.223 & 0.249 & 0.226 & 0.209 \\
\hline $\mathrm{Cr}$ & 0.000 & 0.001 & 0.003 & 0.002 & 0.000 & 0.002 & 0.000 & 0.002 & 0.000 & 0.000 & 0.000 & 0.004 & 0.000 & 0.001 & 0.002 \\
\hline $\mathrm{Fe}^{3+}$ & 0.490 & 0.314 & 0.525 & 0.437 & 0.351 & 0.525 & 0.404 & 0.410 & 0.337 & 0.341 & 0.352 & 0.455 & 0.316 & 0.445 & 0.417 \\
\hline Mn & 0.107 & 0.106 & 0.106 & 0.105 & 0.117 & 0.114 & 0.118 & 0.116 & 0.121 & 0.106 & 0.115 & 0.117 & 0.117 & 0.109 & 0.117 \\
\hline $\mathrm{Fe}^{2+}$ & 2.212 & 2.305 & 2.234 & 2.243 & 2.495 & 2.366 & 2.376 & 2.364 & 2.430 & 2.343 & 2.331 & 2.233 & 2.420 & 2.271 & 2.293 \\
\hline Mg & 1.922 & 1.901 & 1.847 & 1.907 & 1.690 & 1.620 & 1.757 & 1.771 & 1.734 & 1.861 & 1.868 & 1.895 & 1.814 & 1.863 & 1.859 \\
\hline Soma C & 5.000 & 5.000 & 5.000 & 5.000 & 4.999 & 5.001 & 4.999 & 5.000 & 5.000 & 5.000 & 5.000 & 4.999 & 5.000 & 5.001 & 5.000 \\
\hline $\mathrm{Ca}$ & 1.750 & 1.759 & 1.763 & 1.753 & 1.776 & 1.774 & 1.752 & 1.760 & 1.751 & 1.791 & 1.776 & 1.777 & 1.781 & 1.747 & 1.753 \\
\hline $\mathrm{Na}$ & 0.250 & 0.241 & 0.237 & 0.247 & 0.224 & 0.226 & 0.248 & 0.240 & 0.249 & 0.209 & 0.224 & 0.223 & 0.219 & 0.253 & 0.247 \\
\hline Soma B & 2.000 & 2.000 & 2.000 & 2.000 & 2.000 & 2.000 & 2.000 & 2.000 & 2.000 & 2.000 & 2.000 & 2.000 & 2.000 & 2.000 & 2.000 \\
\hline $\mathrm{Na}$ & 0.318 & 0.319 & 0.296 & 0.315 & 0.318 & 0.356 & 0.292 & 0.340 & 0.309 & 0.315 & 0.345 & 0.323 & 0.397 & 0.333 & 0.346 \\
\hline $\mathbf{K}$ & 0.174 & 0.191 & 0.194 & 0.194 & 0.199 & 0.233 & 0.192 & 0.187 & 0.185 & 0.190 & 0.186 & 0.192 & 0.167 & 0.186 & 0.186 \\
\hline Soma $A$ & 0.492 & 0.510 & 0.490 & 0.509 & 0.517 & 0.589 & 0.484 & 0.527 & 0.494 & 0.505 & 0.531 & 0.515 & 0.564 & 0.519 & 0.532 \\
\hline OH & 1.445 & 1.421 & 1.376 & 1.39 & 1.477 & 1.385 & 1.476 & 1.454 & 1.462 & 1.459 & 1.413 & 1.465 & 1.488 & 1.435 & 1.396 \\
\hline F & 0.529 & 0.561 & 0.609 & 0.589 & 0.498 & 0.59 & 0.498 & 0.526 & 0.51 & 0.512 & 0.565 & 0.513 & 0.494 & 0.538 & 0.587 \\
\hline Cl & 0.026 & 0.018 & 0.016 & 0.021 & 0.025 & 0.025 & 0.026 & 0.02 & 0.027 & 0.029 & 0.022 & 0.022 & 0.018 & 0.028 & 0.017 \\
\hline Soma $W$ & 2.000 & 2.000 & 2.001 & 2.000 & 2.000 & 2.000 & 2.000 & 2.000 & 1.999 & 2.000 & 2.000 & 2.000 & 2.000 & 2.001 & 2.000 \\
\hline Total & 15.492 & 15.510 & 15.490 & 15.509 & 15.516 & 15.590 & 15.483 & 15.527 & 15.494 & 15.505 & 15.531 & 15.514 & 15.564 & 15.520 & 15.532 \\
\hline Al total & 1.270 & 1.330 & 1.352 & 1.315 & 1.337 & 1.637 & 1.329 & 1.373 & 1.337 & 1.335 & 1.327 & 1.341 & 1.327 & 1.335 & 1.328 \\
\hline $\mathrm{Mg} /\left(\mathrm{Mg}+\mathrm{Fe}^{2+}\right)$ & 0.465 & 0.452 & 0.453 & 0.460 & 0.404 & 0.406 & 0.425 & 0.428 & 0.416 & 0.443 & 0.445 & 0.459 & 0.428 & 0.451 & 0.448 \\
\hline
\end{tabular}

* dados fornecidos por Adriana Alves 
Tabela B3 - continuação

\section{PLÚTON SALTO}

\section{AMOSTRA 2008-ITU-2.1A1}

\begin{tabular}{|c|c|c|c|c|c|c|c|c|c|c|c|c|c|c|c|c|c|c|c|c|c|c|}
\hline & 1 & 2 & 3 & 4 & 5 & 6 & 7 & 8 & 9 & 10 & 11 & 12 & 13 & 14 & 15 & 16 & 17 & 18 & 19 & 20 & 21 & 22 \\
\hline $\mathrm{SiO}_{2}$ & 45.35 & 45.25 & 46.02 & 45.40 & 45.37 & 44.45 & 45.80 & 45.96 & 45.69 & 45.06 & 46.05 & 45.67 & 45.94 & 45.67 & 45.88 & 45.53 & 46.02 & 45.79 & 45.47 & 46.21 & 46.73 & 45.90 \\
\hline $\mathrm{TiO}_{2}$ & 0.96 & 0.77 & 0.72 & 0.84 & 0.61 & 0.53 & 0.73 & 0.76 & 0.73 & 0.70 & 0.75 & 0.74 & 0.87 & 0.79 & 0.82 & 0.82 & 0.65 & 0.92 & 0.89 & 0.87 & 0.74 & 0.84 \\
\hline $\mathbf{A l}_{2} \mathbf{O}_{3}$ & 7.92 & 7.85 & 7.71 & 7.89 & 7.74 & 8.34 & 7.64 & 7.70 & 7.78 & 8.31 & 7.78 & 7.88 & 7.80 & 7.77 & 7.79 & 7.98 & 7.67 & 7.90 & 7.78 & 7.44 & 7.14 & 7.54 \\
\hline $\mathrm{Cr}_{2} \mathrm{O}_{3}$ & 0.02 & 0.00 & 0.00 & 0.01 & 0.04 & 0.01 & 0.01 & 0.01 & 0.00 & 0.01 & 0.02 & 0.02 & 0.01 & 0.01 & 0.00 & 0.05 & 0.02 & 0.00 & 0.00 & 0.00 & 0.00 & 0.00 \\
\hline MnO & 0.64 & 0.63 & 0.64 & 0.63 & 0.65 & 0.63 & 0.65 & 0.64 & 0.63 & 0.63 & 0.65 & 0.64 & 0.66 & 0.65 & 0.63 & 0.63 & 0.67 & 0.66 & 0.67 & 0.64 & 0.63 & 0.64 \\
\hline $\mathbf{F e O}^{\mathrm{T}}$ & 16.71 & 16.72 & 16.36 & 16.61 & 16.98 & 17.04 & 16.38 & 16.47 & 16.36 & 16.96 & 16.45 & 16.53 & 16.92 & 16.82 & 16.76 & 16.82 & 16.78 & 16.48 & 16.52 & 16.11 & 16.24 & 16.27 \\
\hline MgO & 11.72 & 11.70 & 11.82 & 11.69 & 11.69 & 11.32 & 11.93 & 11.80 & 11.74 & 11.46 & 11.92 & 11.66 & 11.82 & 11.96 & 11.70 & 11.67 & 11.93 & 12.00 & 11.92 & 12.09 & 12.17 & 12.15 \\
\hline $\mathrm{CaO}$ & 11.34 & 11.27 & 11.39 & 11.58 & 11.49 & 11.53 & 11.50 & 11.59 & 11.57 & 11.50 & 11.49 & 11.52 & 11.51 & 11.40 & 11.30 & 11.53 & 11.37 & 11.53 & 11.27 & 11.60 & 11.57 & 11.40 \\
\hline $\mathrm{Na}_{2} \mathrm{O}$ & 1.49 & 1.52 & 1.35 & 1.35 & 1.34 & 1.34 & 1.21 & 1.29 & 1.38 & 1.33 & 1.25 & 1.31 & 1.35 & 1.36 & 1.39 & 1.30 & 1.37 & 1.32 & 1.46 & 1.37 & 1.37 & 1.36 \\
\hline $\mathbf{K}_{2} \mathbf{O}$ & 1.06 & 1.04 & 0.98 & 1.02 & 0.99 & 1.02 & 1.01 & 0.94 & 0.97 & 0.98 & 0.98 & 0.97 & 0.99 & 0.99 & 0.90 & 0.95 & 0.92 & 1.01 & 1.00 & 0.92 & 0.88 & 0.91 \\
\hline F & 0.52 & 0.70 & 0.63 & 0.61 & 0.62 & 0.56 & 0.65 & 0.52 & 0.56 & 0.55 & 0.6 & 0.7 & 0. & 0.62 & 0.66 & 0.59 & 0.60 & 0.66 & 0.65 & 0.73 & 0.43 & 0.76 \\
\hline Cl & 0.06 & 0.06 & 0.02 & 0.09 & 0.07 & 0.06 & 0.07 & 0.07 & 0.07 & 0.05 & 0.05 & 0.06 & 0.04 & 0.05 & 0.04 & 0.05 & 0.05 & 0.04 & 0.06 & 0.03 & 0.04 & 0.06 \\
\hline $\mathrm{ZnO}$ & 0.06 & 0.04 & 0.00 & 0.08 & 0.08 & 0.04 & 0.01 & 0.02 & 0.01 & 0.00 & 0.06 & 0.07 & 0.06 & 0.00 & 0.05 & 0.05 & 0.08 & 0.00 & 0.13 & 0.00 & 0.06 & 0.01 \\
\hline $\mathrm{ZrO}_{2}$ & 0.00 & 0.01 & 0.04 & 0.02 & 0.00 & 0.00 & 0.02 & 0.00 & 0.00 & 0.00 & 0.00 & 0.03 & 0.06 & 0.00 & 0.00 & 0.02 & 0.00 & 0.00 & 0.00 & 0.03 & 0.01 & 0.00 \\
\hline Soma & 97.85 & 97.55 & 97.69 & 97.82 & 97.67 & 96.88 & 97.62 & 97.76 & 97.48 & 97.54 & 98.09 & 97.82 & 98.63 & 98.09 & 97.92 & 97.98 & 98.14 & 98.30 & 97.82 & 98.03 & 98.03 & 97.84 \\
\hline $\mathrm{O}^{*}=\mathrm{F}, \mathrm{Cl}$ & -0.23 & -0.31 & -0.27 & -0.28 & -0.28 & -0.25 & -0.29 & -0.23 & -0.25 & -0.24 & -0.28 & -0.31 & -0.27 & -0.27 & -0.29 & -0.26 & -0.26 & -0.28 & -0.29 & -0.31 & -0.19 & -0.33 \\
\hline Total & 97.62 & 97.24 & 97.42 & 97.54 & 97.39 & 96.63 & 97.33 & 97.53 & 97.23 & 97.30 & 97.81 & 97.51 & 98.36 & 97.82 & 97.63 & 97.72 & 97.88 & 98.02 & 97.53 & 97.72 & 97.84 & 97.51 \\
\hline
\end{tabular}

Número de cátions calculado na base 13-CNK

\begin{tabular}{lllllllllllllllllllllll}
\hline Si & 6.741 & 6.756 & 6.836 & 6.764 & 6.762 & 6.689 & 6.811 & 6.826 & 6.817 & 6.719 & 6.808 & 6.797 & 6.772 & 6.756 & 6.801 & 6.754 & 6.797 & 6.763 & 6.751 & 6.851 & 6.902 & 6.805 \\
\hline Al & 1.259 & 1.244 & 1.164 & 1.236 & 1.238 & 1.311 & 1.189 & 1.174 & 1.183 & 1.281 & 1.192 & 1.203 & 1.228 & 1.244 & 1.199 & 1.246 & 1.203 & 1.237 & 1.249 & 1.149 & 1.098 & 1.195 \\
\hline Ti & 0.000 & 0.000 & 0.000 & 0.000 & 0.000 & 0.000 & 0.000 & 0.000 & 0.000 & 0.000 & 0.000 & 0.000 & 0.000 & 0.000 & 0.000 & 0.000 & 0.000 & 0.000 & 0.000 & 0.000 & 0.000 & 0.000 \\
\hline Soma T & 8.000 & 8.000 & 8.000 & 8.000 & 8.000 & 8.000 & 8.000 & 8.000 & 8.000 & 8.000 & 8.000 & 8.000 & 8.000 & 8.000 & 8.000 & 8.000 & 8.000 & 8.000 & 8.000 & 8.000 & 8.000 & 8.000 \\
\hline
\end{tabular}


Tabela B3 - continuação

\begin{tabular}{|c|c|c|c|c|c|c|c|c|c|c|c|c|c|c|c|c|c|c|c|c|c|c|}
\hline $\mathbf{T i}$ & 0.108 & .086 & 0.081 & 0.094 & 0.068 & 0.060 & 0.082 & 0.085 & 0.082 & 0.078 & 0.084 & 0.083 & 0.096 & 0.088 & 0.091 & 0.092 & 0.073 & 0.102 & 0.100 & 0.097 & 0.082 & 0.094 \\
\hline $\mathbf{Z r}$ & 0.000 & 0.001 & 0.003 & 0.002 & 0.000 & 0.000 & 0.001 & 0.000 & 0.000 & 0.000 & 0.000 & 0.002 & 0.004 & 0.000 & 0.000 & 0.001 & 0.000 & 0.000 & 0.000 & 0.002 & 0.001 & 0.000 \\
\hline Al & 9 & 8 & 0.186 & 19 & 2 & 0.169 & 0.150 & 0.1 & 0.1 & 0.179 & 0.164 & 0.180 & 0.127 & 0.111 & 0.161 & 0.150 & .132 & .138 & 0.112 & 0.151 & .145 & 0.123 \\
\hline $\mathrm{Cr}$ & 03 & 000 & 0.000 & 0.001 & 0.005 & 002 & 1 & 0.001 & 0.000 & 0.001 & 0.003 & 2 & 0.001 & 0.001 & 0.000 & 0.006 & 03 & 00 & 00 & 0.000 & .000 & .000 \\
\hline $\mathrm{Fe}^{3+}$ & 69 & 0.689 & 0.611 & 0.613 & 0.728 & 0.714 & 0.666 & 0.593 & 0.552 & 0.699 & 0.675 & 0.612 & 0.693 & 0.766 & 0.696 & 0.684 & 0.759 & 0.678 & 0.741 & 0.546 & 0.565 & 0.700 \\
\hline $\mathbf{Z n}$ & 006 & 0.004 & 0.000 & 0.009 & 0.008 & 0.005 & 0.001 & 0.002 & 0.001 & 0.000 & 0.007 & 0.007 & 0.007 & 0.000 & 0.005 & 0.005 & 0.009 & 0.000 & 0.014 & 0.000 & 0.007 & 0.001 \\
\hline Mn & 80 & 0.080 & 0.081 & 0.080 & 0.083 & 0.081 & 0.082 & 0.081 & 0.079 & 0.080 & 0.081 & 0.081 & 0.082 & 0.082 & 0.079 & 0.079 & 0.084 & 0.083 & 0.084 & 0.080 & 0.079 & 0.080 \\
\hline $\mathrm{Fe}^{2+}$ & 1.408 & 1.399 & 1.422 & 1.456 & 1.388 & 1.430 & 1.371 & 1.452 & 1.490 & 1.416 & 1.359 & 1.445 & 1.392 & 1.315 & 1.381 & 1.403 & 1.314 & 1.357 & 1.310 & 1.451 & 1.441 & 1.318 \\
\hline Mg & 2.597 & 2.604 & 2.618 & 2.596 & 2.598 & 2.540 & 2.645 & 2.612 & 2.611 & 2.547 & 2.627 & 2.587 & 2.597 & 2.638 & 2.585 & 2.581 & 2.627 & 2.642 & 2.638 & 2.672 & 2.680 & 2.685 \\
\hline Soma C & 00 & 5.001 & 5.00 & 5.000 & 5.000 & 500 & 4.99 & 4.95 & 5. & 0 & 0 & 4.999 & 4.999 & 5.001 & 4.998 & 5.001 & 01 & 00 & 1.999 & 9 & 00 & 5.001 \\
\hline Ca & 806 & 803 & 1.813 & 1.848 & 835 & .859 & 1.832 & 1.844 & 1.850 & 1.837 & 1.820 & 1.837 & 1.818 & 1.807 & 1.795 & 1.833 & 1.199 & 1.825 & 1.793 & 1.843 & 1.831 & 1.811 \\
\hline $\mathbf{N a}$ & 0.194 & 0.197 & 0.187 & 0.152 & 0.165 & 0.141 & 0.168 & 0.156 & 0.150 & 0.163 & 0.180 & 0.163 & 0.182 & 0.193 & 0.205 & 0.167 & 0.201 & 0.175 & 0.207 & 0.157 & 0.169 & 0.189 \\
\hline Soma $B$ & 2.000 & 2.000 & 2.000 & 2.000 & 2.000 & 2.000 & 2.000 & 2.000 & 2.000 & 2.000 & 2.000 & 2.000 & 2.000 & 2.000 & 2.000 & 2.000 & 2.000 & 2.000 & 2.000 & 2.000 & 2.000 & 2.000 \\
\hline $\mathbf{N a}$ & 36 & 243 & 202 & 0.238 & 222 & 250 & 0.181 & 0.216 & 0.249 & 2 & 1 & 0 & 2 & 0.197 & .174 & .201 & 0.192 & 203 & J & .237 & .223 & 0.202 \\
\hline $\mathbf{K}$ & 0.201 & 0.198 & 0.186 & 0.194 & 0.189 & 0.196 & 0.192 & 0.178 & 0.184 & 0.187 & 0.185 & 0.185 & 0.186 & 0.186 & 0.171 & 0.180 & 0.173 & 0.190 & 0.190 & 0.173 & 0.167 & 0.172 \\
\hline Soma $A$ & 0.437 & 0.441 & 0.388 & 0.432 & 0.411 & 0.446 & 0.373 & 0.394 & 0.433 & 0.409 & 0.362 & 0.401 & 0.388 & 0.383 & 0.365 & 0.387 & 0.365 & 0.393 & 0.403 & 0.410 & 0.390 & 0.374 \\
\hline $\mathrm{OH}$ & 740 & 1.654 & 1. & 1.690 & 1.692 & 1 & 1.675 & 1.1 & 1.1 & 1. & 0 & 9 & 6 & 7 & 9 & 1.711 & 1.706 & 1.0 & 0 & 1.651 & 1.786 & 1.628 \\
\hline $\mathbf{F}$ & 0.244 & 0.329 & 0.297 & 0.288 & 0.290 & 0.264 & 0.307 & 0.243 & 0.262 & 0.257 & 0.297 & 0.335 & 0.284 & 0.291 & 0.310 & 0.277 & 0.282 & 0.307 & 0.306 & 0.341 & 0.203 & 0.357 \\
\hline Cl & 0.015 & 0.016 & 0.006 & 0.022 & 0.018 & 0.014 & 0.019 & 0.017 & 0.017 & 0.012 & 0.013 & 0.015 & 0.011 & 0.013 & 0.010 & 0.012 & 0.012 & 0.009 & 0.014 & 0.008 & 0.011 & 0.015 \\
\hline Soma $W$ & 1.999 & 1.999 & 2.000 & 2.000 & 2.000 & 1.999 & 2.001 & 2.000 & 2.000 & 2.000 & 2.000 & 1.999 & 2.001 & 2.001 & 1.999 & 2.000 & 2.000 & 2.000 & 2.000 & 2.000 & 2.000 & 2.000 \\
\hline Total & 15.44 & 15.44 & 15.39 & 15.43 & 15.41 & 15.45 & 15.37 & 15.39 & 15.43 & 15.41 & 15.36 & 15.40 & 15.39 & 15.38 & 15.36 & 15.39 & 15.37 & 15.39 & 15.40 & 15.41 & 15.39 & 15.38 \\
\hline Al total & 1.367 & 1.330 & 1.245 & 1.330 & 1.306 & 1.371 & 1.271 & 1.259 & 1.265 & 1.359 & 1.276 & 1.286 & 1.324 & 1.332 & 1.290 & 1.338 & 1.276 & 1.339 & 1.349 & 1.246 & 1.180 & 1.289 \\
\hline $\mathbf{M g} /\left(\mathbf{M g}+\mathrm{Fe}^{2+}\right)$ & 0.648 & 0.651 & 0.648 & 0.641 & 0.652 & 0.640 & 0.659 & 0.643 & 0.637 & 0.643 & 0.659 & 0.642 & 0.651 & 0.667 & 0.652 & 0.648 & 0.667 & 0.661 & 0.668 & 0.648 & 0.650 & 0.671 \\
\hline
\end{tabular}


Tabela B3 - continuação

\section{PLÚTON INDAIATUBA}

\section{AMOSTRA CAB-14-06A}

\section{PERFIL BORDA-CENTRO}

\begin{tabular}{|c|c|c|c|c|c|c|c|c|c|c|c|c|c|c|c|c|c|c|}
\hline & 1 & 2 & 3 & 4 & 5 & 6 & 7 & 8 & 9 & 10 & 11 & 12 & 13 & 14 & $\underline{15}$ & $\underline{16}$ & $\underline{17}$ & $\underline{18}$ \\
\hline $\mathrm{SiO}_{2}$ & 44.93 & 44.61 & 44.22 & 44.23 & 44.16 & 44.22 & 43.64 & 44.07 & 44.51 & 44.18 & 44.04 & 45.31 & 45.19 & 43.88 & 43.83 & 45.04 & 45.62 & 44.63 \\
\hline $\mathbf{T i O}_{2}$ & 1.37 & 1.29 & 1.30 & 1.19 & 1.42 & 1.28 & 1.64 & 0.79 & 1.59 & 0.85 & 0.73 & 1.68 & 1.64 & 1.57 & 1.36 & 1.48 & 0.80 & 1.24 \\
\hline $\mathbf{A l}_{2} \mathbf{O}_{3}$ & 7.13 & 7.59 & 7.79 & 7.30 & 7.83 & 6.88 & 7.52 & 7.70 & 7.76 & 7.74 & 7.66 & 7.34 & 7.08 & 7.79 & 7.55 & 7.42 & 6.61 & 7.41 \\
\hline $\mathrm{Cr}_{2} \mathrm{O}_{3}$ & 0.03 & 0.00 & 0.01 & 0.03 & 0.00 & 0.02 & 0.02 & 0.00 & 0.02 & 0.01 & 0.00 & 0.02 & 0.02 & 0.02 & 0.00 & 0.00 & 0.02 & 0.00 \\
\hline $\mathrm{FeO}^{\mathrm{T}}$ & 23.06 & 22.97 & 23.56 & 22.34 & 22.67 & 22.38 & 22.54 & 23.14 & 22.04 & 22.51 & 23.47 & 19.09 & 20.25 & 21.42 & 20.17 & 19.18 & 19.69 & 19.42 \\
\hline MnO & 0.84 & 0.86 & 0.92 & 0.87 & 0.84 & 0.84 & 0.78 & 0.79 & 0.72 & 0.81 & 0.83 & 0.56 & 0.63 & 0.68 & 0.62 & 0.60 & 0.62 & 0.56 \\
\hline $\mathrm{CaO}$ & 10.54 & 10.45 & 10.77 & 10.67 & 10.76 & 10.69 & 10.70 & 10.75 & 10.61 & 10.78 & 10.78 & 10.41 & 10.45 & 10.64 & 10.43 & 10.55 & 10.73 & 10.43 \\
\hline $\mathrm{Na}_{2} \mathrm{O}$ & 1.98 & 1.98 & 1.92 & 2.03 & 1.91 & 1.90 & 2.15 & 2.10 & 2.08 & 2.07 & 1.98 & 2.25 & 2.14 & 2.16 & 2.16 & 2.17 & 2.05 & 2.27 \\
\hline $\mathbf{K}_{2} \mathbf{O}$ & 1.00 & 1.12 & 1.11 & 1.06 & 1.10 & 1.02 & 1.05 & 1.18 & 1.07 & 1.22 & 1.10 & 0.95 & 1.05 & 1.21 & 1.04 & 0.94 & 0.69 & 0.91 \\
\hline $\mathbf{F}$ & 0.97 & 0.87 & 1.00 & 1.11 & 1.06 & 1.05 & 1.12 & 1.32 & 1.20 & 1.24 & 1.25 & 1.18 & 1.34 & 1.17 & 1.19 & 1.21 & 1.31 & 1.28 \\
\hline Cl & 0.14 & 0.16 & 0.08 & 0.15 & 0.11 & 0.15 & 0.13 & 0.07 & 0.18 & 0.05 & 0.09 & 0.14 & 0.10 & 0.16 & 0.13 & 0.11 & 0.07 & 0.16 \\
\hline $\mathrm{ZnO}$ & 0.03 & 0.10 & 0.04 & 0.09 & 0.08 & 0.02 & 0.03 & 0.05 & 0.08 & 0.00 & 0.12 & 0.00 & 0.02 & 0.08 & 0.00 & 0.07 & 0.08 & 0.10 \\
\hline $\mathrm{ZrO}_{2}$ & 0.05 & 0.00 & 0.00 & 0.00 & 0.00 & 0.01 & 0.00 & 0.00 & 0.00 & 0.00 & 0.00 & 0.04 & 0.00 & 0.00 & 0.00 & 0.00 & 0.00 & 0.02 \\
\hline $\mathrm{O}^{*}=\mathrm{F}, \mathrm{Cl}$ & -0.44 & -0.40 & -0.44 & -0.50 & -0.47 & -0.48 & -0.50 & -0.57 & -0.54 & -0.53 & -0.55 & -0.53 & -0.59 & -0.53 & -0.53 & -0.53 & -0.57 & -0.57 \\
\hline Total & 99.07 & 98.85 & 99.42 & 98.60 & 99.17 & 98.08 & 98.84 & 99.51 & 99.72 & 99.09 & 99.40 & 98.64 & 98.85 & 99.09 & 97.45 & 98.02 & 97.76 & 97.86 \\
\hline
\end{tabular}

Número de cátions calculado na base 13-CNK

\begin{tabular}{lllllllllllllllllll}
\hline Si & 6.830 & 6.794 & 6.720 & 6.749 & 6.702 & 6.777 & 6.656 & 6.669 & 6.689 & 6.708 & 6.672 & 6.778 & 6.793 & 6.634 & 6.679 & 6.802 & 6.893 & 6.746 \\
\hline Al & 1.170 & 1.206 & 1.280 & 1.251 & 1.298 & 1.223 & 1.344 & 1.331 & 1.311 & 1.292 & 1.328 & 1.222 & 1.207 & 1.366 & 1.321 & 1.198 & 1.107 & 1.254 \\
\hline Soma T & 8.000 & 8.000 & 8.000 & 8.000 & 8.000 & 8.000 & 8.000 & 8.000 & 8.000 & 8.000 & 8.000 & 8.000 & 8.000 & 8.000 & 8.000 & 8.000 & 8.000 & 8.000 \\
\hline
\end{tabular}


Tabela B3 - continuação

\begin{tabular}{|c|c|c|c|c|c|c|c|c|c|c|c|c|c|c|c|c|c|c|}
\hline $\mathbf{T i}$ & 0.157 & 0.148 & 0.148 & 0.137 & 0.162 & 0.147 & 0.188 & 0.090 & 0.180 & 0.097 & 0.083 & 0.189 & 0.186 & 0.178 & 0.156 & 0.169 & 0.091 & 0.141 \\
\hline $\mathbf{Z r}$ & 0.004 & 0.000 & 0.000 & 0.000 & 0.000 & 0.001 & 0.000 & 0.000 & 0.000 & 0.000 & 0.000 & 0.003 & 0.000 & 0.000 & 0.000 & 0.000 & 0.000 & 0.002 \\
\hline Al & 0.107 & 0.156 & 0.115 & 0.061 & 0.102 & 0.019 & 0.007 & 0.043 & 0.063 & 0.093 & 0.039 & 0.072 & 0.048 & 0.022 & 0.035 & 0.123 & 0.070 & 0.066 \\
\hline $\mathrm{Cr}$ & 0.004 & 0.000 & 0.001 & 0.003 & 0.000 & 0.003 & 0.003 & 0.000 & 0.002 & 0.001 & 0.000 & 0.002 & 0.002 & 0.003 & 0.000 & 0.000 & 0.003 & 0.000 \\
\hline $\mathrm{Fe}^{3+}$ & 0.528 & 0.542 & 0.578 & 0.618 & 0.598 & 0.630 & 0.621 & 0.777 & 0.657 & 0.651 & 0.830 & 0.593 & 0.593 & 0.670 & 0.726 & 0.506 & 0.644 & 0.683 \\
\hline $\mathbf{Z n}$ & 0.003 & 0.011 & 0.005 & 0.011 & 0.008 & 0.002 & 0.004 & 0.006 & 0.009 & 0.000 & 0.013 & 0.000 & 0.002 & 0.009 & 0.000 & 0.007 & 0.009 & 0.011 \\
\hline Mn & 0.108 & 0.111 & 0.118 & 0.113 & 0.108 & 0.108 & 0.100 & 0.101 & 0.092 & 0.104 & 0.107 & 0.071 & 0.081 & 0.086 & 0.080 & 0.076 & 0.080 & 0.072 \\
\hline Mg & 1.686 & 1.648 & 1.618 & 1.824 & 1.742 & 1.850 & 1.823 & 1.832 & 1.884 & 1.847 & 1.784 & 2.275 & 2.136 & 1.992 & 2.158 & 2.202 & 2.259 & 2.253 \\
\hline Soma C & 5.001 & 5.000 & 4.999 & 5.000 & 4.999 & 4.998 & 5.000 & 5.000 & 5.000 & 5.000 & 5.000 & 5.001 & 5.001 & 4.999 & 4.999 & 5.000 & 5.000 & 5.000 \\
\hline $\mathrm{Ca}$ & 1.717 & 1.705 & 1.754 & 1.744 & 1.750 & 1.755 & 1.748 & 1.743 & 1.708 & 1.754 & 1.750 & 1.669 & 1.683 & 1.724 & 1.703 & 1.707 & 1.737 & 1.689 \\
\hline $\mathrm{Na}$ & 0.283 & 0.295 & 0.246 & 0.256 & 0.250 & 0.245 & 0.252 & 0.257 & 0.292 & 0.246 & 0.250 & 0.331 & 0.317 & 0.276 & 0.297 & 0.293 & 0.263 & 0.311 \\
\hline Soma $B$ & 2.000 & 2.000 & 2.000 & 2.000 & 2.000 & 2.000 & 2.000 & 2.000 & 2.000 & 2.000 & 2.000 & 2.000 & 2.000 & 2.000 & 2.000 & 2.000 & 2.000 & 2.000 \\
\hline $\mathrm{Na}$ & 0.300 & 0.290 & 0.319 & 0.345 & 0.312 & 0.320 & 0.384 & 0.359 & 0.314 & 0.363 & 0.331 & 0.321 & 0.307 & 0.357 & 0.341 & 0.343 & 0.338 & 0.354 \\
\hline $\mathbf{K}$ & 0.194 & 0.217 & 0.216 & 0.206 & 0.213 & 0.200 & 0.205 & 0.228 & 0.205 & 0.236 & 0.212 & 0.182 & 0.202 & 0.233 & 0.203 & 0.182 & 0.133 & 0.176 \\
\hline Soma $A$ & 0.494 & 0.507 & 0.535 & 0.551 & 0.525 & 0.520 & 0.589 & 0.587 & 0.519 & 0.599 & 0.543 & 0.503 & 0.509 & 0.590 & 0.544 & 0.525 & 0.471 & 0.530 \\
\hline $\mathrm{OH}$ & 1.498 & 1.542 & 1.500 & 1.425 & 1.463 & 1.453 & 1.426 & 1.349 & 1.385 & 1.391 & 1.378 & 1.407 & 1.338 & 1.399 & 1.393 & 1.394 & 1.355 & 1.348 \\
\hline $\mathbf{F}$ & 0.464 & 0.418 & 0.480 & 0.536 & 0.509 & 0.509 & 0.540 & 0.632 & 0.570 & 0.595 & 0.599 & 0.558 & 0.637 & 0.559 & 0.574 & 0.578 & 0.626 & 0.612 \\
\hline $\mathrm{Cl}$ & 0.037 & 0.040 & 0.020 & 0.040 & 0.028 & 0.038 & 0.034 & 0.019 & 0.045 & 0.013 & 0.023 & 0.034 & 0.025 & 0.041 & 0.034 & 0.028 & 0.019 & 0.040 \\
\hline Soma $W$ & 1.999 & 2.000 & 2.000 & 2.001 & 2.000 & 2.000 & 2.000 & 2.000 & 2.000 & 1.999 & 2.000 & 1.999 & 2.000 & 1.999 & 2.001 & 2.000 & 2.000 & 2.000 \\
\hline Total & 15.495 & 15.507 & 15.534 & 15.551 & 15.524 & 15.518 & 15.589 & 15.587 & 15.519 & 15.599 & 15.543 & 15.504 & 15.510 & 15.589 & 15.543 & 15.525 & 15.471 & 15.530 \\
\hline Al total & 1.277 & 1.362 & 1.395 & 1.312 & 1.400 & 1.242 & 1.351 & 1.374 & 1.374 & 1.385 & 1.367 & 1.294 & 1.255 & 1.388 & 1.356 & 1.321 & 1.177 & 1.320 \\
\hline $\mathbf{M g} /\left(\mathbf{M g}+\mathrm{Fe}^{2+}\right)$ & 0.412 & 0.409 & 0.401 & 0.450 & 0.433 & 0.453 & 0.447 & 0.460 & 0.471 & 0.456 & 0.454 & 0.559 & 0.522 & 0.494 & 0.539 & 0.535 & 0.551 & 0.560 \\
\hline
\end{tabular}


Tabela B3 - continuação

\section{PLÚTON INDAIATUBA}

\section{AMOSTRA CAB-15-34.1}

\begin{tabular}{|c|c|c|c|c|c|c|c|c|c|c|c|c|c|c|c|c|c|c|c|}
\hline & 1 & 2 & 3 & 4 & 5 & 6 & 7 & 8 & 9 & 10 & 11 & 12 & 13 & 14 & 15 & 16 & 17 & 18 & 19 \\
\hline $\mathrm{SiO}_{2}$ & 44.06 & 42.64 & 53.73 & 47.53 & 43.53 & 45.92 & 50.57 & 45.85 & 48.06 & 47.18 & 46.69 & 47.73 & 47.52 & 46.21 & 48.55 & 47.25 & 49.04 & 46.62 & 48.95 \\
\hline $\mathrm{TiO}_{2}$ & 1.67 & 1.08 & 0.06 & 0.66 & 0.92 & 0.86 & 0.41 & 1.01 & 0.55 & 0.73 & 0.65 & 0.54 & 0.78 & 0.92 & 0.66 & 0.49 & 0.52 & 0.66 & 0.5277 \\
\hline $\mathbf{A l}_{2} \mathbf{O}_{3}$ & 7.60 & 8.05 & 1.26 & 5.78 & 6.38 & 6.32 & 3.36 & 6.77 & 5.49 & 5.73 & 5.20 & 5.27 & 5.58 & 6.25 & 5.09 & 5.89 & 4.62 & 6.22 & 4.85 \\
\hline $\mathrm{Cr}_{2} \mathrm{O}_{3}$ & 0.00 & 0.00 & 0.00 & 0.00 & 0.00 & 0.00 & 0.01 & 0.02 & 0.00 & 0.02 & 0.03 & 0.01 & 0.03 & 0.00 & 0.00 & 0.00 & 0.00 & 0.03 & 0.00 \\
\hline $\mathrm{FeO}^{\mathrm{T}}$ & 22.59 & 22.49 & 17.89 & 20.07 & 19.78 & 20.20 & 18.26 & 20.67 & 19.97 & 19.88 & 19.23 & 19.73 & 20.08 & 20.29 & 19.66 & 19.61 & 19.40 & 20.35 & 19.67 \\
\hline MnO & 1.15 & 1.16 & 0.88 & 0.55 & 0.52 & 0.60 & 0.57 & 0.56 & 0.54 & 0.56 & 0.51 & 0.52 & 0.56 & 0.55 & 0.61 & 0.57 & 0.62 & 0.62 & 0.64 \\
\hline MgO & 7.34 & 7.00 & 11.46 & 10.04 & 8.98 & 9.54 & 11.82 & 9.19 & 10.11 & 9.97 & 10.32 & 10.15 & 10.29 & 9.77 & 10.52 & 10.18 & 10.75 & 9.53 & 10.86 \\
\hline $\mathrm{CaO}$ & 10.46 & 10.59 & 12.13 & 11.37 & 13.03 & 11.10 & 11.57 & 11.17 & 11.39 & 11.10 & 12.16 & 11.52 & 11.09 & 11.30 & 11.18 & 11.02 & 11.45 & 11.14 & 11.20 \\
\hline $\mathrm{Na}_{2} \mathrm{O}$ & 1.83 & 1.87 & 0.17 & 1.11 & 1.34 & 1.39 & 0.66 & 1.51 & 0.97 & 1.28 & 1.10 & 1.19 & 1.37 & 1.50 & 1.15 & 1.23 & 1.09 & 1.36 & 1.175 \\
\hline $\mathbf{K}_{2} \mathbf{O}$ & 1.02 & 1.16 & 0.06 & 0.67 & 0.78 & 0.73 & 0.40 & 0.83 & 0.66 & 0.70 & 0.64 & 0.62 & 0.66 & 0.78 & 0.63 & 0.65 & 0.56 & 0.79 & 0.62 \\
\hline F & 0.65 & 0.49 & 0.28 & 0.39 & 0.43 & 0.36 & 0.45 & 0.52 & 0.25 & 0.44 & 0.30 & 0.47 & 0.44 & 0.44 & 0.38 & 0.46 & 0.37 & 0.45 & 0.46 \\
\hline Cl & 0.10 & 0.15 & 0.00 & 0.05 & 0.04 & 0.07 & 0.00 & 0.05 & 0.01 & 0.02 & 0.03 & 0.02 & 0.01 & 0.03 & 0.04 & 0.04 & 0.03 & 0.04 & 0.01 \\
\hline $\mathrm{ZnO}$ & 0.08 & 0.08 & 0.00 & 0.01 & 0.03 & 0.00 & 0.03 & 0.00 & 0.02 & 0.00 & 0.02 & 0.00 & 0.07 & 0.12 & 0.04 & 0.06 & 0.11 & 0.07 & 0.06 \\
\hline $\mathrm{ZrO}_{2}$ & 0.04 & 0.03 & 0.02 & 0.00 & 0.00 & 0.03 & 0.06 & 0.00 & 0.01 & 0.00 & 0.00 & 0.00 & 0.06 & 0.01 & 0.00 & 0.07 & 0.00 & 0.0075 & 0.00 \\
\hline Soma & 98.58 & 96.78 & 97.95 & 98.24 & 95.76 & 97.13 & 98.17 & 98.15 & 98.04 & 97.60 & 96.88 & 97.78 & 98.54 & 98.17 & 98.51 & 97.51 & 98.56 & 97.89 & 99.01 \\
\hline $\mathbf{O}^{*}=\mathrm{F}, \mathrm{Cl}$ & -0.30 & -0.24 & -0.12 & -0.18 & -0.19 & -0.17 & -0.19 & -0.23 & -0.11 & -0.19 & -0.13 & -0.20 & -0.19 & -0.19 & -0.17 & -0.20 & -0.16 & -0.20 & -0.20 \\
\hline Total & 98.28 & 96.54 & 97.83 & 98.06 & 95.57 & 96.96 & 97.98 & 97.92 & 97.93 & 97.41 & 96.75 & 97.58 & 98.35 & 97.98 & 98.34 & 97.31 & 98.40 & 97.69 & 98.81 \\
\hline
\end{tabular}

Número de cátions calculado na base 13-CNK

\begin{tabular}{lllllllllllllllllllll}
\hline Si & 6.726 & 6.659 & 7.931 & 7.097 & 6.864 & 6.969 & 7.448 & 6.925 & 7.165 & 7.094 & 7.120 & 7.179 & 7.069 & 6.956 & 7.196 & 7.086 & 7.267 & 7.025 & 7.208 \\
\hline Al & 1.274 & 1.341 & 0.069 & 0.903 & 1.136 & 1.031 & 0.552 & 1.075 & 0.835 & 0.906 & 0.880 & 0.821 & 0.931 & 1.044 & 0.804 & 0.914 & 0.733 & 0.975 & 0.792 \\
\hline Ti & 0.000 & 0.000 & 0.000 & 0.000 & 0.000 & 0.000 & 0.000 & 0.000 & 0.000 & 0.000 & 0.000 & 0.000 & 0.000 & 0.000 & 0.000 & 0.000 & 0.000 & 0.000 & 0.000 \\
\hline Soma T & 8.000 & 8.000 & 8.000 & 8.000 & 8.000 & 8.000 & 8.000 & 8.000 & 8.000 & 8.000 & 8.000 & 8.000 & 8.000 & 8.000 & 8.000 & 8.000 & 8.000 & 8.000 & 8.000 \\
\hline
\end{tabular}


Tabela B3 - continuação

\begin{tabular}{|c|c|c|c|c|c|c|c|c|c|c|c|c|c|c|c|c|c|c|c|}
\hline $\mathrm{Ti}$ & 0.192 & 0.126 & 0.007 & 0.074 & 0.109 & 0.098 & 0.045 & 0.115 & 0.062 & 0.082 & 0.075 & 0.062 & 0.087 & 0.105 & 0.073 & 0.055 & 0.058 & 0.075 & 0.058 \\
\hline $\mathbf{Z r}$ & 0.003 & 0.002 & 0.002 & 0.000 & 0.000 & 0.002 & 0.004 & 0.000 & 0.000 & 0.000 & 0.000 & 0.000 & 0.004 & 0.001 & 0.000 & 0.005 & 0.000 & 0.001 & 0.000 \\
\hline Al & 0.094 & 0.141 & 0.151 & 0.114 & 0.049 & 0.100 & 0.031 & 0.130 & 0.130 & 0.109 & 0.055 & 0.113 & 0.047 & 0.065 & 0.085 & 0.127 & 0.074 & 0.129 & 0.050 \\
\hline $\mathrm{Cr}$ & 0.000 & 0.000 & 0.000 & 0.000 & 0.000 & 0.000 & 0.001 & 0.002 & 0.000 & 0.002 & 0.004 & 0.001 & 0.003 & 0.000 & 0.000 & 0.000 & 0.000 & 0.003 & 0.000 \\
\hline $\mathrm{Fe}^{3+}$ & 0.629 & 0.601 & 0.005 & 0.554 & 0.000 & 0.570 & 0.507 & 0.494 & 0.534 & 0.548 & 0.247 & 0.403 & 0.645 & 0.536 & 0.573 & 0.644 & 0.488 & 0.545 & 0.639 \\
\hline $\mathbf{Z n}$ & 0.009 & 0.009 & 0.000 & 0.001 & 0.004 & 0.000 & 0.004 & 0.000 & 0.002 & 0.000 & 0.002 & 0.000 & 0.008 & 0.013 & 0.004 & 0.006 & 0.012 & 0.008 & 0.006 \\
\hline Mn & 0.148 & 0.154 & 0.111 & 0.070 & 0.069 & 0.077 & 0.071 & 0.072 & 0.068 & 0.071 & 0.066 & 0.066 & 0.071 & 0.071 & 0.077 & 0.072 & 0.077 & 0.079 & 0.079 \\
\hline $\mathrm{Fe}^{2+}$ & 2.255 & 2.337 & 2.204 & 1.952 & 2.608 & 1.994 & 1.742 & 2.117 & 1.956 & 1.952 & 2.205 & 2.079 & 1.853 & 2.018 & 1.864 & 1.815 & 1.917 & 2.019 & 1.784 \\
\hline Mg & 1.670 & 1.630 & 2.522 & 2.235 & 2.111 & 2.158 & 2.595 & 2.069 & 2.247 & 2.235 & 2.346 & 2.276 & 2.282 & 2.192 & 2.324 & 2.276 & 2.375 & 2.141 & 2.384 \\
\hline Soma C & 5.000 & 5.000 & 5.002 & 5.000 & 4.950 & 4.999 & 5.000 & 4.999 & 4.999 & 4.999 & 5.000 & 5.000 & 5.000 & 5.001 & 5.000 & 5.000 & 5.001 & 5.000 & 5.000 \\
\hline $\mathrm{Ca}$ & 1.711 & 1.772 & 1.918 & 1.819 & 2.000 & 1.805 & 1.826 & 1.808 & 1.819 & 1.788 & 1.987 & 1.857 & 1.767 & 1.822 & 1.775 & 1.771 & 1.818 & 1.798 & 1.767 \\
\hline $\mathrm{Na}$ & 0.289 & 0.228 & 0.048 & 0.181 & 0.000 & 0.195 & 0.174 & 0.192 & 0.181 & 0.212 & 0.013 & 0.143 & 0.233 & 0.178 & 0.225 & 0.229 & 0.182 & 0.202 & 0.233 \\
\hline Soma B & 2.000 & 2.000 & 1.966 & 2.000 & 2.000 & 2.000 & 2.000 & 2.000 & 2.000 & 2.000 & 2.000 & 2.000 & 2.000 & 2.000 & 2.000 & 2.000 & 2.000 & 2.000 & 2.000 \\
\hline $\mathrm{Ca}$ & 0.000 & 0.000 & 0.000 & 0.000 & 0.201 & 0.000 & 0.000 & 0.000 & 0.000 & 0.000 & 0.000 & 0.000 & 0.000 & 0.000 & 0.000 & 0.000 & 0.000 & 0.000 & 0.000 \\
\hline $\mathrm{Na}$ & 0.253 & 0.338 & 0.000 & 0.141 & 0.410 & 0.214 & 0.014 & 0.250 & 0.101 & 0.160 & 0.313 & 0.205 & 0.163 & 0.260 & 0.105 & 0.129 & 0.132 & 0.196 & 0.103 \\
\hline $\mathbf{K}$ & 0.198 & 0.231 & 0.011 & 0.128 & 0.157 & 0.141 & 0.076 & 0.161 & 0.126 & 0.134 & 0.125 & 0.119 & 0.124 & 0.150 & 0.120 & 0.124 & 0.106 & 0.153 & 0.117 \\
\hline Soma $A$ & 0.451 & 0.569 & 0.011 & 0.269 & 0.768 & 0.355 & 0.090 & 0.411 & 0.227 & 0.294 & 0.438 & 0.324 & 0.287 & 0.410 & 0.225 & 0.253 & 0.238 & 0.349 & 0.220 \\
\hline $\mathbf{O H}$ & 1.659 & 1.721 & 1.870 & 1.802 & 1.772 & 1.806 & 1.789 & 1.741 & 1.879 & 1.786 & 1.847 & 1.771 & 1.791 & 1.782 & 1.811 & 1.773 & 1.819 & 1.775 & 1.784 \\
\hline $\mathbf{F}$ & 0.315 & 0.240 & 0.130 & 0.186 & 0.217 & 0.175 & 0.211 & 0.246 & 0.118 & 0.209 & 0.144 & 0.224 & 0.206 & 0.210 & 0.179 & 0.216 & 0.175 & 0.216 & 0.213 \\
\hline Cl & 0.026 & 0.039 & 0.000 & 0.013 & 0.011 & 0.019 & 0.000 & 0.012 & 0.003 & 0.005 & 0.008 & 0.005 & 0.003 & 0.007 & 0.010 & 0.011 & 0.006 & 0.010 & 0.003 \\
\hline Soma $W$ & 2.000 & 2.000 & 2.000 & 2.001 & 2.000 & 2.000 & 2.000 & 1.999 & 2.000 & 2.000 & 1.999 & 2.000 & 2.000 & 1.999 & 2.000 & 2.000 & 2.000 & 2.001 & 2.000 \\
\hline Total & 15.451 & 15.569 & 14.979 & 15.269 & 15.718 & 15.354 & 15.090 & 15.410 & 15.226 & 15.293 & 15.438 & 15.324 & 15.287 & 15.411 & 15.225 & 15.253 & 15.239 & 15.349 & 15.220 \\
\hline Al total & 1.368 & 1.482 & 0.220 & 1.017 & 1.185 & 1.131 & 0.583 & 1.205 & 0.965 & 1.015 & 0.935 & 0.934 & 0.978 & 1.109 & 0.889 & 1.041 & 0.807 & 1.104 & 0.842 \\
\hline
\end{tabular}


Tabela B3 - continuação

$\mathbf{M g} /\left(\mathbf{M g}+\mathrm{Fe}^{2+}\right) \quad 0.42$ 
Tabela B3 - continuação

\section{PLÚTON INDAIATUBA}

\section{AMOSTRA CAB-15-34.2}

\begin{tabular}{|c|c|c|c|c|c|c|c|c|c|c|c|c|c|}
\hline & 1 & 2 & 3 & 4 & 5 & 6 & 7 & 8 & 9 & 10 & 11 & 12 & 13 \\
\hline $\mathrm{SiO}_{2}$ & 47.23 & 46.68 & 46.50 & 46.52 & 52.63 & 47.22 & 46.49 & 49.55 & 46.85 & 47.16 & 45.07 & 46.84 & 46.63 \\
\hline $\mathrm{TiO}_{2}$ & 0.63 & 0.73 & 0.71 & 0.74 & 0.15 & 0.69 & 0.66 & 0.44 & 0.78 & 0.64 & 0.67 & 0.65 & 0.83 \\
\hline $\mathbf{A l}_{2} \mathbf{O}_{3}$ & 5.68 & 6.02 & 6.03 & 6.29 & 2.06 & 5.73 & 6.58 & 4.42 & 6.44 & 5.69 & 5.75 & 6.11 & 6.18 \\
\hline $\mathrm{Cr}_{2} \mathrm{O}_{3}$ & 0.00 & 0.00 & 0.00 & 0.01 & 0.00 & 0.00 & 0.00 & 0.00 & 0.00 & 0.00 & 0.00 & 0.02 & 0.00 \\
\hline $\mathbf{F e O}^{\mathrm{T}}$ & 20.29 & 20.19 & 20.00 & 20.82 & 18.01 & 20.29 & 20.84 & 19.51 & 20.64 & 20.45 & 19.82 & 20.51 & 20.20 \\
\hline MnO & 0.61 & 0.58 & 0.61 & 0.58 & 0.63 & 0.60 & 0.51 & 0.54 & 0.63 & 0.62 & 0.55 & 0.52 & 0.53 \\
\hline MgO & 9.79 & 9.74 & 9.53 & 9.48 & 12.15 & 9.83 & 9.47 & 10.82 & 9.19 & 9.93 & 9.41 & 9.65 & 9.61 \\
\hline $\mathrm{CaO}$ & 11.10 & 11.15 & 11.34 & 11.25 & 11.44 & 11.12 & 11.34 & 11.52 & 11.00 & 11.19 & 12.62 & 11.12 & 11.02 \\
\hline $\mathrm{Na}_{2} \mathrm{O}$ & 1.34 & 1.23 & 1.33 & 1.47 & 0.58 & 1.35 & 1.24 & 0.88 & 1.40 & 1.35 & 1.31 & 1.33 & 1.42 \\
\hline $\mathbf{K}_{2} \mathbf{O}$ & 0.72 & 0.73 & 0.74 & 0.81 & 0.29 & 0.78 & 0.83 & 0.50 & 0.85 & 0.70 & 0.72 & 0.77 & 0.76 \\
\hline $\mathbf{F}$ & 0.42 & 0.54 & 0.41 & 0.44 & 0.34 & 0.50 & 0.36 & 0.38 & 0.59 & 0.56 & 0.67 & 0.45 & 0.48 \\
\hline Cl & 0.04 & 0.01 & 0.04 & 0.02 & 0.01 & 0.02 & 0.04 & 0.00 & 0.01 & 0.02 & 0.03 & 0.00 & 0.04 \\
\hline $\mathrm{ZnO}$ & 0.06 & 0.04 & 0.01 & 0.05 & 0.09 & 0.03 & 0.01 & 0.13 & 0.09 & 0.07 & 0.16 & 0.03 & 0.00 \\
\hline $\mathrm{ZrO}_{2}$ & 0.00 & 0.02 & 0.01 & 0.00 & 0.00 & 0.00 & 0.00 & 0.05 & 0.09 & 0.00 & 0.00 & 0.00 & 0.00 \\
\hline Soma & 97.91 & 97.65 & 97.26 & 98.49 & 98.38 & 98.15 & 98.39 & 98.74 & 98.55 & 98.39 & 96.79 & 97.99 & 97.70 \\
\hline $\mathbf{O}^{*}=\mathrm{F}, \mathrm{Cl}$ & -0.19 & -0.23 & -0.18 & -0.19 & -0.14 & -0.21 & -0.16 & -0.16 & -0.25 & -0.24 & -0.29 & -0.19 & -0.21 \\
\hline Total & 97.72 & 97.42 & 97.08 & 98.30 & 98.24 & 97.94 & 98.23 & 98.58 & 98.30 & 98.15 & 96.50 & 97.80 & 97.49 \\
\hline
\end{tabular}

Número de cátions calculado na base 13-CNK

\begin{tabular}{llllllllllllll}
\hline Si & 7.096 & 7.035 & 7.061 & 6.985 & 7.692 & 7.085 & 6.968 & 7.310 & 7.030 & 7.061 & 7.014 & 7.036 & 7.032 \\
\hline Al & 0.904 & 0.965 & 0.939 & 1.015 & 0.308 & 0.915 & 1.032 & 0.690 & 0.970 & 0.939 & 0.986 & 0.964 & 0.968 \\
\hline Soma T & 8.000 & 8.000 & 8.000 & 8.000 & 8.000 & 8.000 & 8.000 & 8.000 & 8.000 & 8.000 & 8.000 & 8.000 & 8.000 \\
\hline & & & & & & & & & & & & & \\
\hline Ti & 0.071 & 0.082 & 0.081 & 0.084 & 0.017 & 0.078 & 0.075 & 0.049 & 0.088 & 0.072 & 0.078 & 0.074 & 0.094 \\
\hline
\end{tabular}


Tabela B3 - continuação

\begin{tabular}{|c|c|c|c|c|c|c|c|c|c|c|c|c|c|}
\hline $\mathbf{Z r}$ & 0.000 & 0.002 & 0.001 & 0.000 & 0.000 & 0.000 & 0.000 & 0.004 & 0.007 & 0.000 & 0.000 & 0.000 & 0.000 \\
\hline Al & 0.102 & 0.104 & 0.141 & 0.098 & 0.047 & 0.098 & 0.130 & 0.079 & 0.169 & 0.065 & 0.069 & 0.118 & 0.130 \\
\hline $\mathrm{Cr}$ & 0.000 & 0.000 & 0.001 & 0.001 & 0.000 & 0.000 & 0.000 & 0.000 & 0.000 & 0.000 & 0.000 & 0.003 & 0.000 \\
\hline $\mathrm{Fe}^{3+}$ & 0.559 & 0.593 & 0.408 & 0.544 & 0.427 & 0.544 & 0.589 & 0.517 & 0.505 & 0.614 & 0.012 & 0.583 & 0.527 \\
\hline $\mathbf{Z n}$ & 0.007 & 0.004 & 0.001 & 0.005 & 0.010 & 0.003 & 0.001 & 0.015 & 0.010 & 0.007 & 0.018 & 0.003 & 0.000 \\
\hline Mn & 0.078 & 0.074 & 0.079 & 0.074 & 0.078 & 0.076 & 0.065 & 0.067 & 0.080 & 0.079 & 0.072 & 0.066 & 0.067 \\
\hline $\mathrm{Fe}^{2+}$ & 1.991 & 1.952 & 2.132 & 2.071 & 1.774 & 2.002 & 2.023 & 1.890 & 2.085 & 1.946 & 2.567 & 1.994 & 2.020 \\
\hline Mg & 2.193 & 2.188 & 2.157 & 2.122 & 2.647 & 2.199 & 2.116 & 2.380 & 2.056 & 2.216 & 2.183 & 2.161 & 2.160 \\
\hline Soma C & 5.001 & 4.999 & 5.001 & 4.999 & 5.000 & 5.000 & 4.999 & 5.001 & 5.000 & 4.999 & 4.999 & 5.002 & 4.998 \\
\hline $\mathrm{Ca}$ & 1.787 & 1.800 & 1.845 & 1.810 & 1.791 & 1.788 & 1.821 & 1.821 & 1.769 & 1.795 & 2.000 & 1.790 & 1.781 \\
\hline $\mathrm{Na}$ & 0.213 & 0.200 & 0.155 & 0.190 & 0.163 & 0.212 & 0.179 & 0.179 & 0.231 & 0.205 & 0.000 & 0.210 & 0.219 \\
\hline Soma B & 2.000 & 2.000 & 2.000 & 2.000 & 1.954 & 2.000 & 2.000 & 2.000 & 2.000 & 2.000 & 2.000 & 2.000 & 2.000 \\
\hline $\mathrm{Ca}$ & 0.000 & 0.000 & 0.000 & 0.000 & 0.000 & 0.000 & 0.000 & 0.000 & 0.000 & 0.000 & 0.104 & 0.000 & 0.000 \\
\hline $\mathbf{N a}$ & 0.178 & 0.159 & 0.237 & 0.238 & 0.000 & 0.180 & 0.183 & 0.073 & 0.176 & 0.187 & 0.396 & 0.177 & 0.196 \\
\hline $\mathbf{K}$ & 0.137 & 0.140 & 0.144 & 0.155 & 0.054 & 0.149 & 0.159 & 0.095 & 0.162 & 0.134 & 0.144 & 0.147 & 0.145 \\
\hline Soma $A$ & 0.315 & 0.299 & 0.381 & 0.393 & 0.054 & 0.329 & 0.342 & 0.168 & 0.338 & 0.321 & 0.644 & 0.324 & 0.341 \\
\hline OH & 1.789 & 1.743 & 1.795 & 1.784 & 1.841 & 1.759 & 1.819 & 1.823 & 1.720 & 1.728 & 1.662 & 1.786 & 1.760 \\
\hline $\mathbf{F}$ & 0.202 & 0.255 & 0.195 & 0.210 & 0.156 & 0.237 & 0.171 & 0.177 & 0.278 & 0.266 & 0.329 & 0.214 & 0.229 \\
\hline Cl & 0.009 & 0.002 & 0.009 & 0.006 & 0.003 & 0.005 & 0.010 & 0.000 & 0.002 & 0.006 & 0.009 & 0.000 & 0.011 \\
\hline Soma $W$ & 2.000 & 2.000 & 1.999 & 2.000 & 2.000 & 2.001 & 2.000 & 2.000 & 2.000 & 2.000 & 2.000 & 2.000 & 2.000 \\
\hline Total & 15.316 & 15.298 & 15.382 & 15.392 & 15.008 & 15.329 & 15.341 & 15.169 & 15.338 & 15.320 & 15.643 & 15.326 & 15.339 \\
\hline Al total & 1.006 & 1.069 & 1.080 & 1.113 & 0.355 & 1.013 & 1.162 & 0.769 & 1.139 & 1.004 & 1.055 & 1.082 & 1.098 \\
\hline $\mathrm{Mg} /\left(\mathbf{M g}+\mathrm{Fe}^{2+}\right)$ & 0.524 & 0.529 & 0.503 & 0.506 & 0.599 & 0.523 & 0.511 & 0.557 & 0.496 & 0.532 & 0.460 & 0.520 & 0.517 \\
\hline
\end{tabular}


Tabela B3 - continuação

\section{PLÚTON CABREÚVA}

\section{AMOSTRA CAB-14-09}

\begin{tabular}{lcccccccccccc}
\hline & $\mathbf{1}$ & $\mathbf{2}$ & $\mathbf{3}$ & $\mathbf{4}$ & $\mathbf{5}$ & $\mathbf{6}$ & $\mathbf{7}$ & $\mathbf{8}$ & $\mathbf{9}$ & $\mathbf{1 0}$ & $\mathbf{1 1}$ & $\mathbf{1 2}$ \\
\hline $\mathbf{S i O}_{2}$ & 43.38 & 44.12 & 43.93 & 43.23 & 43.79 & 42.88 & 43.70 & 43.40 & 42.93 & 44.24 & 43.31 & 43.28 \\
\hline $\mathbf{T i O}_{2}$ & 1.41 & 1.31 & 1.24 & 1.41 & 1.28 & 1.37 & 1.27 & 1.22 & 1.12 & 1.14 & 1.41 & 1.24 \\
\hline $\mathbf{A l}_{2} \mathbf{O}_{3}$ & 7.64 & 7.10 & 7.25 & 7.66 & 7.07 & 7.88 & 7.16 & 7.47 & 7.80 & 7.32 & 7.79 & 8.00 \\
\hline $\mathbf{C r}_{2} \mathbf{O}_{3}$ & 0.00 & 0.01 & 0.03 & 0.00 & 0.00 & 0.00 & 0.00 & 0.02 & 0.00 & 0.00 & 0.00 & 0.02 \\
\hline $\mathbf{F e O}^{\mathbf{T}}$ & 25.33 & 24.79 & 25.25 & 25.67 & 24.81 & 25.53 & 24.92 & 25.37 & 24.79 & 24.67 & 25.10 & 25.37 \\
\hline $\mathbf{M n O}$ & 0.78 & 0.83 & 0.82 & 0.81 & 0.82 & 0.75 & 0.83 & 0.78 & 0.75 & 0.77 & 0.81 & 0.79 \\
\hline $\mathbf{M g O}$ & 6.17 & 6.46 & 6.17 & 5.96 & 6.22 & 6.06 & 6.45 & 6.19 & 6.33 & 6.59 & 6.35 & 6.14 \\
\hline $\mathbf{C a O}$ & 10.60 & 10.48 & 10.41 & 10.57 & 10.37 & 10.77 & 10.55 & 10.65 & 10.77 & 10.85 & 10.74 & 10.87 \\
\hline $\mathbf{N a} \mathbf{O}$ & 1.86 & 1.87 & 1.85 & 1.87 & 1.83 & 1.84 & 1.75 & 1.83 & 1.78 & 1.74 & 1.86 & 1.78 \\
\hline $\mathbf{K}_{2} \mathbf{O}$ & 1.08 & 0.95 & 1.01 & 1.08 & 0.95 & 1.12 & 0.95 & 1.01 & 1.05 & 0.96 & 1.04 & 1.10 \\
\hline $\mathbf{F}$ & 0.51 & 0.61 & 0.55 & 0.67 & 0.58 & 0.68 & 0.62 & 0.68 & 0.70 & 0.76 & 0.56 & 0.66 \\
\hline $\mathbf{C l}$ & 0.16 & 0.06 & 0.13 & 0.10 & 0.13 & 0.15 & 0.11 & 0.16 & 0.07 & 0.05 & 0.08 & 0.07 \\
\hline $\mathbf{Z n O}$ & 0.21 & 0.03 & 0.10 & 0.12 & 0.03 & 0.20 & 0.12 & 0.01 & 0.00 & 0.00 & 0.07 & 0.05 \\
\hline $\mathbf{Z r O} \mathbf{O}_{2}$ & 0.00 & 0.00 & 0.00 & 0.00 & 0.00 & 0.00 & 0.00 & 0.04 & 0.00 & 0.00 & 0.03 & 0.02 \\
\hline Soma & 99.14 & 98.62 & 98.73 & 99.14 & 97.89 & 99.23 & 98.42 & 98.85 & 98.10 & 99.08 & 99.14 & 99.39 \\
\hline $\mathbf{O} *=\mathbf{F}, \mathbf{C l}$ & -0.25 & -0.27 & -0.26 & -0.30 & -0.28 & -0.32 & -0.28 & -0.32 & -0.31 & -0.33 & -0.25 & -0.29 \\
\hline Total & 98.89 & 98.35 & 98.47 & 98.84 & 97.61 & 98.91 & 98.14 & 98.53 & 97.79 & 98.75 & 98.89 & 99.10 \\
\hline & & & & & & & & & & &
\end{tabular}

Número de cátions calculado na base 13-CNK

\begin{tabular}{lllllllllllll}
\hline Si & 6.663 & 6.782 & 6.757 & 6.655 & 6.791 & 6.607 & 6.736 & 6.694 & 6.662 & 6.780 & 6.642 & 6.640 \\
\hline Al & 1.337 & 1.218 & 1.243 & 1.345 & 1.209 & 1.393 & 1.264 & 1.306 & 1.338 & 1.220 & 1.358 & 1.360 \\
\hline Soma T & 8.000 & 8.000 & 8.000 & 8.000 & 8.000 & 8.000 & 8.000 & 8.000 & 8.000 & 8.000 & 8.000 & 8.000
\end{tabular}


Tabela B3 - continuação

\begin{tabular}{|c|c|c|c|c|c|c|c|c|c|c|c|c|}
\hline $\mathbf{T i}$ & 0.163 & 0.152 & 0.144 & 0.164 & 0.150 & 0.159 & 0.147 & 0.142 & 0.131 & 0.131 & 0.163 & 0.143 \\
\hline $\mathbf{Z r}$ & 0.000 & 0.000 & 0.000 & 0.000 & 0.000 & 0.000 & 0.000 & 0.003 & 0.000 & 0.000 & 0.002 & 0.001 \\
\hline Al & 0.046 & 0.068 & 0.071 & 0.045 & 0.083 & 0.038 & 0.037 & 0.052 & 0.088 & 0.102 & 0.051 & 0.086 \\
\hline $\mathrm{Cr}$ & 0.000 & 0.001 & 0.003 & 0.000 & 0.000 & 0.000 & 0.000 & 0.003 & 0.000 & 0.000 & 0.000 & 0.002 \\
\hline $\mathrm{Fe}^{3+}$ & 0.712 & 0.649 & 0.701 & 0.714 & 0.643 & 0.710 & 0.738 & 0.694 & 0.663 & 0.589 & 0.690 & 0.665 \\
\hline $\mathbf{Z n}$ & 0.024 & 0.003 & 0.012 & 0.013 & 0.004 & 0.023 & 0.014 & 0.002 & 0.000 & 0.000 & 0.008 & 0.006 \\
\hline Mn & 0.101 & 0.108 & 0.107 & 0.105 & 0.107 & 0.098 & 0.108 & 0.102 & 0.099 & 0.100 & 0.105 & 0.103 \\
\hline $\mathrm{Fe}^{2+}$ & 2.541 & 2.538 & 2.547 & 2.591 & 2.575 & 2.580 & 2.474 & 2.579 & 2.555 & 2.573 & 2.529 & 2.590 \\
\hline $\mathbf{M g}$ & 1.413 & 1.480 & 1.415 & 1.368 & 1.438 & 1.392 & 1.482 & 1.423 & 1.464 & 1.506 & 1.452 & 1.404 \\
\hline Soma C & 5.000 & 4.999 & 5.000 & 5.000 & 5.000 & 5.000 & 5.000 & 5.000 & 5.000 & 5.001 & 5.000 & 5.000 \\
\hline $\mathrm{Ca}$ & 1.744 & 1.726 & 1.716 & 1.744 & 1.723 & 1.778 & 1.742 & 1.760 & 1.791 & 1.782 & 1.765 & 1.787 \\
\hline $\mathbf{N a}$ & 0.256 & 0.274 & 0.284 & 0.256 & 0.277 & 0.222 & 0.258 & 0.240 & 0.209 & 0.218 & 0.235 & 0.213 \\
\hline Soma B & 2.000 & 2.000 & 2.000 & 2.000 & 2.000 & 2.000 & 2.000 & 2.000 & 2.000 & 2.000 & 2.000 & 2.000 \\
\hline $\mathrm{Na}$ & 0.298 & 0.283 & 0.267 & 0.302 & 0.273 & 0.328 & 0.265 & 0.307 & 0.326 & 0.299 & 0.318 & 0.316 \\
\hline $\mathbf{K}$ & 0.212 & 0.186 & 0.197 & 0.212 & 0.187 & 0.221 & 0.187 & 0.200 & 0.208 & 0.187 & 0.203 & 0.216 \\
\hline Soma A & 0.510 & 0.469 & 0.464 & 0.514 & 0.460 & 0.549 & 0.452 & 0.507 & 0.534 & 0.486 & 0.521 & 0.532 \\
\hline OH & 1.709 & 1.690 & 1.700 & 1.650 & 1.679 & 1.629 & 1.671 & 1.627 & 1.637 & 1.619 & 1.707 & 1.664 \\
\hline $\mathbf{F}$ & 0.248 & 0.295 & 0.266 & 0.324 & 0.286 & 0.332 & 0.301 & 0.330 & 0.344 & 0.367 & 0.272 & 0.318 \\
\hline Cl & 0.043 & 0.016 & 0.034 & 0.026 & 0.035 & 0.039 & 0.028 & 0.043 & 0.019 & 0.014 & 0.021 & 0.019 \\
\hline Soma $W$ & 2.000 & 2.001 & 2.000 & 2.000 & 2.000 & 2.000 & 2.000 & 2.000 & 2.000 & 2.000 & 2.000 & 2.001 \\
\hline Total & 15.510 & 15.468 & 15.464 & 15.514 & 15.460 & 15.549 & 15.452 & 15.507 & 15.534 & 15.487 & 15.521 & 15.532 \\
\hline Al total & 1.383 & 1.286 & 1.314 & 1.390 & 1.292 & 1.431 & 1.301 & 1.358 & 1.426 & 1.322 & 1.409 & 1.446 \\
\hline $\mathbf{M g} /\left(\mathbf{M g}+\mathrm{Fe}^{2+}\right)$ & 0.357 & 0.368 & 0.357 & 0.346 & 0.358 & 0.350 & 0.375 & 0.356 & 0.364 & 0.369 & 0.365 & 0.352 \\
\hline
\end{tabular}


Tabela B3 - continuação

\section{PLÚTON CABREÚVA}

AMOSTRA CAB-16-80A

\begin{tabular}{lccccc}
\hline & $\mathbf{1}$ & $\mathbf{2}$ & $\mathbf{3}$ & $\mathbf{4}$ & $\mathbf{5}$ \\
\hline $\mathrm{SiO}_{2}$ & 41.83 & 41.36 & 41.84 & 41.49 & 41.57 \\
\hline $\mathrm{TiO}_{2}$ & 1.04 & 0.97 & 0.97 & 1.03 & 1.01 \\
\hline $\mathrm{Al}_{2} \mathbf{O}_{3}$ & 7.90 & 8.24 & 7.95 & 7.92 & 8.04 \\
\hline $\mathrm{Cr}_{2} \mathbf{O}_{3}$ & 0.00 & 0.01 & 0.00 & 0.01 & 0.00 \\
\hline $\mathbf{F e O}^{\mathbf{T}}$ & 28.26 & 28.35 & 28.33 & 28.19 & 28.34 \\
\hline $\mathbf{M n O}$ & 1.10 & 1.09 & 1.05 & 1.08 & 1.06 \\
\hline $\mathbf{M g O}$ & 3.89 & 3.68 & 3.91 & 4.01 & 3.75 \\
\hline $\mathbf{C a O}$ & 10.40 & 10.50 & 10.24 & 10.32 & 10.15 \\
\hline $\mathbf{N a} \mathbf{O}_{2} \mathbf{O}$ & 1.67 & 1.81 & 1.67 & 1.75 & 1.73 \\
\hline $\mathrm{K}_{2} \mathbf{O}$ & 1.21 & 1.38 & 1.26 & 1.28 & 1.23 \\
\hline $\mathbf{F}$ & 0.67 & 0.58 & 0.73 & 0.64 & 0.67 \\
\hline $\mathbf{C l}$ & 0.13 & 0.10 & 0.11 & 0.06 & 0.07 \\
\hline $\mathbf{Z n O}$ & 0.16 & 0.05 & 0.05 & 0.10 & 0.12 \\
\hline $\mathbf{Z r O} \mathbf{O}_{2}$ & 0.04 & 0.00 & 0.01 & 0.01 & 0.01 \\
\hline Soma & 98.29 & 98.13 & 98.12 & 97.90 & 97.76 \\
\hline $\mathbf{O} *=\mathbf{F}, \mathbf{C l}$ & -0.31 & -0.27 & -0.33 & -0.28 & -0.30 \\
\hline Total & 97.98 & 97.86 & 97.79 & 97.62 & 97.46 \\
\hline
\end{tabular}

Número de cátions calculado na base 13-CNK

\begin{tabular}{llllll}
\hline $\mathrm{Si}$ & 6.598 & 6.559 & 6.602 & 6.565 & 6.583
\end{tabular}

\begin{tabular}{llllll}
\hline Al & 1.402 & 1.441 & 1.398 & 1.435 & 1.417
\end{tabular}

\begin{tabular}{llllll}
\hline Soma T & 8.000 & 8.000 & 8.000 & 8.000 & 8.000
\end{tabular}

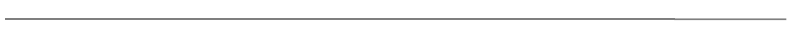


Tabela B3 - continuação

\begin{tabular}{|c|c|c|c|c|c|}
\hline $\mathrm{Ti}$ & 0.123 & 0.116 & 0.115 & 0.123 & 0.121 \\
\hline $\mathbf{Z r}$ & 0.003 & 0.000 & 0.001 & 0.001 & 0.001 \\
\hline Al & 0.067 & 0.100 & 0.080 & 0.042 & 0.084 \\
\hline $\mathrm{Cr}$ & 0.000 & 0.002 & 0.000 & 0.002 & 0.000 \\
\hline $\mathrm{Fe}^{3+}$ & 0.814 & 0.703 & 0.860 & 0.849 & 0.866 \\
\hline Zn & 0.018 & 0.006 & 0.006 & 0.011 & 0.014 \\
\hline $\mathrm{Mn}^{2+}$ & 0.146 & 0.146 & 0.140 & 0.145 & 0.142 \\
\hline $\mathrm{Fe}^{2+}$ & 2.914 & 3.057 & 2.878 & 2.881 & 2.887 \\
\hline $\mathbf{M g}$ & 0.915 & 0.870 & 0.920 & 0.946 & 0.885 \\
\hline Soma C & 5.000 & 5.000 & 5.000 & 5.000 & 5.000 \\
\hline $\mathrm{Ca}$ & 1.758 & 1.784 & 1.731 & 1.750 & 1.722 \\
\hline $\mathrm{Na}$ & 0.242 & 0.216 & 0.269 & 0.250 & 0.278 \\
\hline Soma B & 2.000 & 2.000 & 2.000 & 2.000 & 2.000 \\
\hline $\mathrm{Na}$ & 0.268 & 0.341 & 0.242 & 0.286 & 0.253 \\
\hline $\mathbf{K}$ & 0.243 & 0.279 & 0.254 & 0.258 & 0.248 \\
\hline Soma A & 0.511 & 0.620 & 0.496 & 0.544 & 0.501 \\
\hline OH & 1.629 & 1.682 & 1.607 & 1.663 & 1.642 \\
\hline $\mathbf{F}$ & 0.335 & 0.292 & 0.364 & 0.322 & 0.338 \\
\hline $\mathrm{Cl}$ & 0.035 & 0.026 & 0.029 & 0.016 & 0.020 \\
\hline Soma $W$ & 1.999 & 2.000 & 2.000 & 2.001 & 2.000 \\
\hline Total & 15.511 & 15.620 & 15.496 & 15.544 & 15.501 \\
\hline Al total & 1.469 & 1.541 & 1.478 & 1.477 & 1.501 \\
\hline $\mathbf{M g} /\left(\mathbf{M g}+\mathrm{Fe}^{2+}\right)$ & 0.239 & 0.222 & 0.242 & 0.247 & 0.235 \\
\hline
\end{tabular}


Tabela B3 - continuação

\section{PLÚTON CABREÚVA}

\section{AMOSTRA CAB-16-90}

\begin{tabular}{|c|c|c|c|c|c|c|c|c|c|c|c|c|c|}
\hline & 1 & 2 & 3 & 4 & 5 & 6 & 7 & 8 & 9 & 10 & 11 & 12 & 13 \\
\hline $\mathrm{SiO}_{2}$ & 39.82 & 40.17 & 40.39 & 40.32 & 40.48 & 40.33 & 40.39 & 40.63 & 41.80 & 40.92 & 40.98 & 41.01 & 40.79 \\
\hline $\mathrm{TiO}_{2}$ & 0.90 & 1.37 & 1.41 & 1.51 & 1.29 & 1.50 & 1.66 & 1.39 & 1.03 & 1.31 & 1.50 & 1.36 & 1.28 \\
\hline $\mathbf{A l}_{2} \mathbf{O}_{3}$ & 8.81 & 8.81 & 8.92 & 8.68 & 8.99 & 8.85 & 8.73 & 8.56 & 7.70 & 8.67 & 8.46 & 8.45 & 8.62 \\
\hline $\mathrm{Cr}_{2} \mathrm{O}_{3}$ & 0.02 & 0.00 & 0.00 & 0.00 & 0.02 & 0.00 & 0.02 & 0.00 & 0.00 & 0.00 & 0.03 & 0.00 & 0.00 \\
\hline $\mathrm{FeO}^{\mathrm{T}}$ & 28.93 & 28.55 & 28.52 & 28.61 & 28.65 & 28.42 & 28.17 & 28.55 & 28.75 & 28.78 & 28.87 & 28.75 & 29.29 \\
\hline MnO & 0.72 & 0.67 & 0.64 & 0.73 & 0.67 & 0.68 & 0.73 & 0.68 & 0.75 & 0.63 & 0.69 & 0.72 & 0.70 \\
\hline MgO & 3.06 & 3.41 & 3.50 & 3.49 & 3.31 & 3.39 & 3.49 & 3.37 & 3.60 & 3.55 & 3.44 & 3.46 & 3.34 \\
\hline $\mathrm{CaO}$ & 10.48 & 10.34 & 10.42 & 10.40 & 10.31 & 10.42 & 10.23 & 10.31 & 10.32 & 10.54 & 10.25 & 10.32 & 10.50 \\
\hline $\mathrm{Na}_{2} \mathrm{O}$ & 1.84 & 2.02 & 1.97 & 1.92 & 1.87 & 1.99 & 2.07 & 1.97 & 1.86 & 1.94 & 1.99 & 1.87 & 2.01 \\
\hline $\mathrm{K}_{2} \mathrm{O}$ & 1.37 & 1.32 & 1.38 & 1.33 & 1.31 & 1.33 & 1.22 & 1.20 & 1.10 & 1.36 & 1.20 & 1.18 & 1.25 \\
\hline $\mathbf{F}$ & 0.57 & 0.57 & 0.73 & 0.68 & 0.64 & 0.64 & 0.73 & 0.77 & 0.62 & 0.77 & 0.67 & 0.61 & 0.48 \\
\hline Cl & 0.19 & 0.24 & 0.17 & 0.20 & 0.14 & 0.17 & 0.25 & 0.18 & 0.14 & 0.14 & 0.20 & 0.17 & 0.16 \\
\hline ZnO & 0.08 & 0.00 & 0.00 & 0.12 & 0.11 & 0.15 & 0.02 & 0.09 & 0.04 & 0.03 & 0.11 & 0.02 & 0.10 \\
\hline $\mathrm{ZrO}_{2}$ & 0.01 & 0.03 & 0.01 & 0.02 & 0.03 & 0.05 & 0.01 & 0.02 & 0.00 & 0.00 & 0.00 & 0.00 & 0.01 \\
\hline Soma & 96.79 & 97.49 & 98.05 & 98.00 & 97.80 & 97.92 & 97.71 & 97.72 & 97.70 & 98.65 & 98.40 & 97.93 & 98.53 \\
\hline $\mathrm{O}^{*}=\mathrm{F}, \mathrm{Cl}$ & -0.28 & -0.29 & -0.34 & -0.33 & -0.30 & -0.31 & -0.36 & -0.36 & -0.29 & -0.36 & -0.33 & -0.30 & -0.24 \\
\hline Total & 96.51 & 97.20 & 97.71 & 97.67 & 97.50 & 97.61 & 97.35 & 97.36 & 97.41 & 98.29 & 98.07 & 97.63 & 98.29 \\
\hline
\end{tabular}

Número de cátions calculado na base 13-CNK

\begin{tabular}{llllllllllllll}
\hline Si & 6.444 & 6.437 & 6.437 & 6.429 & 6.448 & 6.439 & 6.455 & 6.495 & 6.649 & 6.484 & 6.493 & 6.516 & 6.462 \\
\hline Al & 1.556 & 1.563 & 1.563 & 1.571 & 1.552 & 1.561 & 1.545 & 1.505 & 1.351 & 1.516 & 1.507 & 1.484 & 1.538 \\
\hline Soma T & 8.000 & 8.000 & 8.000 & 8.000 & 8.000 & 8.000 & 8.000 & 8.000 & 8.000 & 8.000 & 8.000 & 8.000 & 8.000
\end{tabular}


Tabela B3 - continuação

\begin{tabular}{|c|c|c|c|c|c|c|c|c|c|c|c|c|c|}
\hline $\mathbf{T i}$ & 0.109 & 0.165 & 0.168 & 0.181 & 0.154 & 0.180 & 0.200 & 0.167 & 0.124 & 0.156 & 0.179 & 0.163 & 0.153 \\
\hline $\mathbf{Z r}$ & 0.000 & 0.003 & 0.001 & 0.002 & 0.002 & 0.004 & 0.001 & 0.002 & 0.000 & 0.000 & 0.000 & 0.000 & 0.001 \\
\hline Al & 0.125 & 0.101 & 0.112 & 0.060 & 0.135 & 0.105 & 0.099 & 0.108 & 0.092 & 0.103 & 0.073 & 0.098 & 0.071 \\
\hline $\mathrm{Cr}$ & 0.003 & 0.000 & 0.000 & 0.000 & 0.003 & 0.000 & 0.002 & 0.000 & 0.000 & 0.000 & 0.004 & 0.000 & 0.000 \\
\hline $\mathrm{Fe}^{3+}$ & 0.713 & 0.680 & 0.665 & 0.728 & 0.738 & 0.635 & 0.648 & 0.670 & 0.697 & 0.650 & 0.737 & 0.731 & 0.724 \\
\hline $\mathbf{Z n}$ & 0.010 & 0.000 & 0.000 & 0.014 & 0.013 & 0.017 & 0.002 & 0.010 & 0.005 & 0.003 & 0.013 & 0.003 & 0.011 \\
\hline Mn & 0.099 & 0.091 & 0.086 & 0.099 & 0.090 & 0.092 & 0.099 & 0.092 & 0.101 & 0.085 & 0.092 & 0.097 & 0.094 \\
\hline $\mathrm{Fe}^{2+}$ & 3.202 & 3.146 & 3.136 & 3.087 & 3.078 & 3.160 & 3.117 & 3.147 & 3.127 & 3.164 & 3.088 & 3.089 & 3.156 \\
\hline Mg & 0.738 & 0.815 & 0.831 & 0.830 & 0.786 & 0.807 & 0.831 & 0.803 & 0.854 & 0.839 & 0.813 & 0.820 & 0.789 \\
\hline Soma C & 4.999 & 5.001 & 4.999 & 5.001 & 4.999 & 5.000 & 4.999 & 4.999 & 5.000 & 5.000 & 4.999 & 5.001 & 4.999 \\
\hline $\mathrm{Ca}$ & 1.817 & 1.775 & 1.779 & 1.777 & 1.760 & 1.783 & 1.752 & 1.766 & 1.759 & 1.789 & 1.740 & 1.757 & 1.782 \\
\hline $\mathbf{N a}$ & 0.183 & 0.225 & 0.221 & 0.223 & 0.240 & 0.217 & 0.248 & 0.234 & 0.241 & 0.211 & 0.260 & 0.243 & 0.218 \\
\hline Soma B & 2.000 & 2.000 & 2.000 & 2.000 & 2.000 & 2.000 & 2.000 & 2.000 & 2.000 & 2.000 & 2.000 & 2.000 & 2.000 \\
\hline $\mathrm{Na}$ & 0.395 & 0.403 & 0.388 & 0.370 & 0.337 & 0.399 & 0.393 & 0.377 & 0.332 & 0.386 & 0.352 & 0.333 & 0.400 \\
\hline $\mathbf{K}$ & 0.283 & 0.270 & 0.281 & 0.271 & 0.266 & 0.271 & 0.249 & 0.245 & 0.222 & 0.275 & 0.242 & 0.240 & 0.253 \\
\hline Soma $A$ & 0.678 & 0.673 & 0.669 & 0.641 & 0.603 & 0.670 & 0.642 & 0.622 & 0.554 & 0.661 & 0.594 & 0.573 & 0.653 \\
\hline OH & 1.659 & 1.649 & 1.589 & 1.606 & 1.643 & 1.629 & 1.565 & 1.564 & 1.653 & 1.574 & 1.611 & 1.648 & 1.719 \\
\hline F & 0.290 & 0.287 & 0.365 & 0.340 & 0.320 & 0.325 & 0.369 & 0.389 & 0.310 & 0.387 & 0.335 & 0.307 & 0.239 \\
\hline Cl & 0.051 & 0.064 & 0.046 & 0.054 & 0.037 & 0.046 & 0.067 & 0.047 & 0.037 & 0.039 & 0.055 & 0.045 & 0.042 \\
\hline Soma $W$ & 2.000 & 2.000 & 2.000 & 2.000 & 2.000 & 2.000 & 2.001 & 2.000 & 2.000 & 2.000 & 2.001 & 2.000 & 2.000 \\
\hline Total & 15.677 & 15.674 & 15.668 & 15.642 & 15.602 & 15.670 & 15.641 & 15.621 & 15.554 & 15.661 & 15.593 & 15.574 & 15.652 \\
\hline Al total & 1.681 & 1.664 & 1.675 & 1.631 & 1.687 & 1.666 & 1.644 & 1.613 & 1.443 & 1.619 & 1.580 & 1.582 & 1.609 \\
\hline $\mathrm{Mg} /\left(\mathbf{M g}+\mathrm{Fe}^{2+}\right)$ & 0.187 & 0.206 & 0.209 & 0.212 & 0.203 & 0.203 & 0.210 & 0.203 & 0.215 & 0.210 & 0.208 & 0.210 & 0.200 \\
\hline
\end{tabular}


Tabela B3 - continuação

\section{PLÚTON CABREÚVA}

AMOSTRA CAB-16-91B

\begin{tabular}{|c|c|c|c|c|c|c|}
\hline & 1 & 2 & 3 & 4 & 5 & 6 \\
\hline $\mathrm{SiO}_{2}$ & 42.39 & 42.54 & 42.34 & 43.28 & 42.50 & 43.19 \\
\hline $\mathrm{TiO}_{2}$ & 1.24 & 1.34 & 1.13 & 1.34 & 1.26 & 0.93 \\
\hline $\mathbf{A l}_{2} \mathbf{O}_{3}$ & 8.26 & 8.20 & 8.48 & 7.53 & 8.26 & 7.98 \\
\hline $\mathrm{Cr}_{2} \mathrm{O}_{3}$ & 0.00 & 0.04 & 0.04 & 0.00 & 0.02 & 0.03 \\
\hline $\mathrm{FeO}^{\mathrm{T}}$ & 26.72 & 26.21 & 26.38 & 26.55 & 26.89 & 26.45 \\
\hline MnO & 0.69 & 0.72 & 0.70 & 0.74 & 0.71 & 0.71 \\
\hline MgO & 5.50 & 5.57 & 5.32 & 5.58 & 5.38 & 5.64 \\
\hline $\mathrm{CaO}$ & 10.71 & 10.69 & 11.03 & 10.78 & 10.68 & 10.86 \\
\hline $\mathrm{Na}_{2} \mathrm{O}$ & 1.57 & 1.84 & 1.69 & 1.76 & 1.75 & 1.64 \\
\hline $\mathbf{K}_{2} \mathbf{O}$ & 1.30 & 1.25 & 1.31 & 1.03 & 1.33 & 1.16 \\
\hline $\mathbf{F}$ & 1.00 & 0.96 & 0.91 & 0.97 & 1.10 & 1.02 \\
\hline Cl & 0.11 & 0.14 & 0.13 & 0.12 & 0.13 & 0.11 \\
\hline $\mathrm{ZnO}$ & 0.06 & 0.14 & 0.06 & 0.21 & 0.06 & 0.00 \\
\hline $\mathrm{ZrO}_{2}$ & 0.01 & 0.03 & 0.03 & 0.01 & 0.00 & 0.04 \\
\hline Soma & 99.55 & 99.67 & 99.55 & 99.90 & 100.08 & 99.77 \\
\hline $\mathbf{O}^{*}=\mathrm{F}, \mathrm{Cl}$ & -0.44 & -0.44 & -0.41 & -0.43 & -0.49 & -0.45 \\
\hline Total & 99.11 & 99.23 & 99.14 & 99.47 & 99.59 & 99.32 \\
\hline
\end{tabular}

Número de cátions calculado na base 13-CNK

$6.542-6.568-6.564-6.661$

\begin{tabular}{lllllll} 
& & & & & & \\
\hline Al & 1.458 & 1.432 & 1.436 & 1.339 & 1.451 & 1.353
\end{tabular}

\begin{tabular}{llllllll}
\hline Soma T & 8.000 & 8.000 & 8.000 & 8.000 & 8.000 & 8.000
\end{tabular}

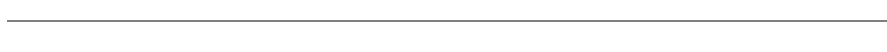


Tabela B3 - continuação

\begin{tabular}{|c|c|c|c|c|c|c|}
\hline $\mathbf{T i}$ & 0.144 & 0.155 & 0.132 & 0.155 & 0.146 & 0.108 \\
\hline $\mathbf{Z r}$ & 0.001 & 0.002 & 0.002 & 0.001 & 0.000 & 0.003 \\
\hline Al & 0.045 & 0.061 & 0.113 & 0.026 & 0.050 & 0.094 \\
\hline $\mathrm{Cr}$ & 0.000 & 0.005 & 0.005 & 0.000 & 0.003 & 0.004 \\
\hline $\mathbf{F e}^{3+}$ & 0.856 & 0.717 & 0.620 & 0.718 & 0.795 & 0.735 \\
\hline $\mathbf{Z n}$ & 0.007 & 0.016 & 0.007 & 0.024 & 0.007 & 0.000 \\
\hline Mn & 0.090 & 0.094 & 0.092 & 0.096 & 0.093 & 0.093 \\
\hline $\mathrm{Fe}^{2+}$ & 2.593 & 2.667 & 2.800 & 2.699 & 2.671 & 2.670 \\
\hline $\mathbf{M g}$ & 1.265 & 1.282 & 1.229 & 1.280 & 1.236 & 1.294 \\
\hline Soma C & 5.001 & 4.999 & 5.000 & 4.999 & 5.001 & 5.001 \\
\hline $\mathrm{Ca}$ & 1.771 & 1.769 & 1.832 & 1.778 & 1.763 & 1.791 \\
\hline $\mathrm{Na}$ & 0.229 & 0.231 & 0.168 & 0.222 & 0.237 & 0.209 \\
\hline Soma B & 2.000 & 2.000 & 2.000 & 2.000 & 2.000 & 2.000 \\
\hline $\mathrm{Na}$ & 0.241 & 0.319 & 0.340 & 0.303 & 0.286 & 0.280 \\
\hline $\mathbf{K}$ & 0.256 & 0.246 & 0.259 & 0.202 & 0.261 & 0.228 \\
\hline Soma A & 0.497 & 0.565 & 0.599 & 0.505 & 0.547 & 0.508 \\
\hline OH & 1.485 & 1.495 & 1.518 & 1.498 & 1.430 & 1.475 \\
\hline $\mathbf{F}$ & 0.486 & 0.469 & 0.446 & 0.470 & 0.536 & 0.496 \\
\hline $\mathrm{Cl}$ & 0.029 & 0.037 & 0.035 & 0.032 & 0.034 & 0.029 \\
\hline Soma $W$ & 2.000 & 2.001 & 1.999 & 2.000 & 2.000 & 2.000 \\
\hline Total & 15.498 & 15.564 & 15.599 & 15.504 & 15.548 & 15.509 \\
\hline Al total & 1.503 & 1.493 & 1.549 & 1.365 & 1.501 & 1.447 \\
\hline $\mathbf{M g} /\left(\mathbf{M g}+\mathrm{Fe}^{2+}\right)$ & 0.328 & 0.325 & 0.305 & 0.322 & 0.316 & 0.326 \\
\hline
\end{tabular}


Tabela B3 - continuação

\section{PLÚTON ITUPEVA}

AMOSTRA CAB-16-98

\begin{tabular}{lccccccccccc}
\hline & $\mathbf{1}$ & $\mathbf{2}$ & $\mathbf{3}$ & $\mathbf{4}$ & $\mathbf{5}$ & $\mathbf{6}$ & $\mathbf{7}$ & $\mathbf{8}$ & $\mathbf{9}$ & $\mathbf{1 0}$ & $\mathbf{1 1}$ \\
\hline $\mathrm{SiO}_{2}$ & 46.73 & 46.07 & 45.95 & 46.75 & 50.14 & 48.22 & 45.86 & 48.52 & 45.82 & 46.89 & 47.22 \\
\hline $\mathbf{T i O}_{2}$ & 0.75 & 0.66 & 0.70 & 0.68 & 0.49 & 0.55 & 0.84 & 0.56 & 0.72 & 0.73 & 0.73 \\
\hline $\mathbf{A l}_{2} \mathbf{O}_{3}$ & 7.07 & 7.62 & 7.80 & 7.31 & 5.01 & 6.43 & 7.64 & 5.82 & 7.77 & 7.22 & 7.27 \\
\hline $\mathbf{C r}_{2} \mathbf{O}_{3}$ & 0.00 & 0.01 & 0.01 & 0.00 & 0.00 & 0.01 & 0.00 & 0.01 & 0.01 & 0.02 & 0.02 \\
\hline $\mathbf{F e O}^{\mathbf{T}}$ & 17.04 & 17.11 & 17.27 & 17.31 & 15.42 & 16.62 & 17.61 & 16.09 & 17.33 & 17.34 & 17.44 \\
\hline $\mathbf{M n O}$ & 0.80 & 0.79 & 0.78 & 0.75 & 0.79 & 0.79 & 0.79 & 0.82 & 0.79 & 0.81 & 0.83 \\
\hline $\mathbf{M g O}$ & 11.74 & 11.34 & 11.41 & 11.61 & 13.37 & 12.25 & 11.22 & 12.92 & 11.35 & 11.73 & 11.47 \\
\hline $\mathbf{C a O}$ & 11.48 & 11.55 & 11.57 & 11.52 & 11.52 & 11.72 & 11.38 & 11.58 & 11.39 & 11.46 & 11.28 \\
\hline $\mathbf{N a} 2 \mathbf{O}$ & 1.25 & 1.08 & 1.14 & 1.35 & 0.98 & 1.03 & 1.35 & 1.03 & 1.47 & 1.28 & 1.42 \\
\hline $\mathbf{K}_{2} \mathbf{O}$ & 0.77 & 0.81 & 0.78 & 0.76 & 0.49 & 0.66 & 0.83 & 0.59 & 0.83 & 0.79 & 0.78 \\
\hline $\mathbf{F}$ & 0.33 & 0.31 & 0.24 & 0.36 & 0.25 & 0.37 & 0.35 & 0.34 & 0.42 & 0.32 & 0.32 \\
\hline $\mathbf{C l}$ & 0.01 & 0.01 & 0.00 & 0.02 & 0.00 & 0.04 & 0.03 & 0.00 & 0.04 & 0.01 & 0.01 \\
\hline $\mathbf{Z n O}$ & 0.01 & 0.00 & 0.09 & 0.06 & 0.00 & 0.05 & 0.02 & 0.00 & 0.07 & 0.00 & 0.00 \\
\hline $\mathbf{Z r O}{ }_{2}$ & 0.04 & 0.00 & 0.04 & 0.00 & 0.01 & 0.01 & 0.02 & 0.05 & 0.00 & 0.01 & 0.00 \\
\hline Soma & 98.02 & 97.37 & 97.79 & 98.47 & 98.47 & 98.75 & 97.94 & 98.32 & 98.00 & 98.62 & 98.79 \\
\hline $\mathbf{O} *=$ F,Cl & -0.14 & -0.13 & -0.10 & -0.16 & -0.11 & -0.17 & -0.16 & -0.14 & -0.18 & -0.14 & -0.14 \\
\hline Total & 97.88 & 97.24 & 97.69 & 98.31 & 98.36 & 98.58 & 97.78 & 98.18 & 97.82 & 98.48 & 98.65 \\
\hline & & & & & & & & & &
\end{tabular}

Número de cátions calculado na base 13-CNK

\begin{tabular}{llllllllllll}
\hline Si & 6.897 & 6.849 & 6.797 & 6.880 & 7.249 & 7.036 & 6.802 & 7.068 & 6.795 & 6.876 & 6.917 \\
\hline Al & 1.103 & 1.151 & 1.203 & 1.120 & 0.751 & 0.964 & 1.198 & 0.932 & 1.205 & 1.124 & 1.083 \\
\hline Soma T & 8.000 & 8.000 & 8.000 & 8.000 & 8.000 & 8.000 & 8.000 & 8.000 & 8.000 & 8.000 & 8.000
\end{tabular}


Tabela B3 - continuação

\begin{tabular}{|c|c|c|c|c|c|c|c|c|c|c|c|}
\hline $\mathbf{T i}$ & 0.084 & 0.074 & 0.078 & 0.075 & 0.054 & 0.060 & 0.094 & 0.062 & 0.081 & 0.080 & 0.081 \\
\hline $\mathbf{Z r}$ & 0.003 & 0.000 & 0.003 & 0.000 & 0.000 & 0.001 & 0.001 & 0.003 & 0.000 & 0.001 & 0.000 \\
\hline Al & 0.127 & 0.184 & 0.157 & 0.148 & 0.103 & 0.142 & 0.138 & 0.067 & 0.153 & 0.124 & 0.172 \\
\hline $\mathrm{Cr}$ & 0.000 & 0.001 & 0.002 & 0.000 & 0.000 & 0.001 & 0.000 & 0.001 & 0.001 & 0.003 & 0.002 \\
\hline $\mathrm{Fe}^{3+}$ & 0.670 & 0.671 & 0.742 & 0.661 & 0.606 & 0.620 & 0.709 & 0.718 & 0.691 & 0.721 & 0.657 \\
\hline $\mathbf{Z n}$ & 0.001 & 0.000 & 0.010 & 0.006 & 0.000 & 0.005 & 0.002 & 0.000 & 0.007 & 0.000 & 0.000 \\
\hline Mn & 0.100 & 0.100 & 0.098 & 0.093 & 0.097 & 0.098 & 0.100 & 0.101 & 0.099 & 0.101 & 0.103 \\
\hline $\mathrm{Fe}^{2+}$ & 1.433 & 1.456 & 1.394 & 1.469 & 1.258 & 1.408 & 1.475 & 1.242 & 1.458 & 1.406 & 1.480 \\
\hline $\mathbf{M g}$ & 2.583 & 2.513 & 2.516 & 2.547 & 2.882 & 2.665 & 2.481 & 2.806 & 2.509 & 2.564 & 2.505 \\
\hline Soma C & 5.001 & 4.999 & 5.000 & 4.999 & 5.000 & 5.000 & 5.000 & 5.000 & 4.999 & 5.000 & 5.000 \\
\hline $\mathrm{Ca}$ & 1.815 & 1.840 & 1.834 & 1.816 & 1.785 & 1.832 & 1.809 & 1.807 & 1.810 & 1.801 & 1.770 \\
\hline $\mathbf{N a}$ & 0.185 & 0.160 & 0.166 & 0.184 & 0.215 & 0.168 & 0.191 & 0.193 & 0.190 & 0.199 & 0.230 \\
\hline Soma B & 2.000 & 2.000 & 2.000 & 2.000 & 2.000 & 2.000 & 2.000 & 2.000 & 2.000 & 2.000 & 2.000 \\
\hline $\mathrm{Na}$ & 0.174 & 0.152 & 0.160 & 0.200 & 0.059 & 0.124 & 0.196 & 0.099 & 0.232 & 0.165 & 0.174 \\
\hline $\mathbf{K}$ & 0.144 & 0.154 & 0.148 & 0.144 & 0.090 & 0.122 & 0.157 & 0.109 & 0.156 & 0.148 & 0.145 \\
\hline Soma A & 0.318 & 0.306 & 0.308 & 0.344 & 0.149 & 0.246 & 0.353 & 0.208 & 0.388 & 0.313 & 0.319 \\
\hline OH & 1.844 & 1.851 & 1.886 & 1.829 & 1.884 & 1.819 & 1.826 & 1.843 & 1.795 & 1.849 & 1.848 \\
\hline $\mathbf{F}$ & 0.155 & 0.146 & 0.114 & 0.167 & 0.116 & 0.170 & 0.166 & 0.157 & 0.196 & 0.149 & 0.150 \\
\hline Cl & 0.002 & 0.003 & 0.000 & 0.004 & 0.000 & 0.010 & 0.008 & 0.000 & 0.009 & 0.002 & 0.002 \\
\hline Soma $W$ & 2.001 & 2.000 & 2.000 & 2.000 & 2.000 & 1.999 & 2.000 & 2.000 & 2.000 & 2.000 & 2.000 \\
\hline Total & 15.319 & 15.305 & 15.308 & 15.343 & 15.149 & 15.246 & 15.353 & 15.208 & 15.387 & 15.313 & 15.319 \\
\hline Al total & 1.230 & 1.335 & 1.360 & 1.268 & 0.854 & 1.106 & 1.336 & 0.999 & 1.358 & 1.248 & 1.255 \\
\hline $\mathbf{M g} /\left(\mathbf{M g}+\mathrm{Fe}^{2+}\right)$ & 0.643 & 0.633 & 0.643 & 0.634 & 0.696 & 0.654 & 0.627 & 0.693 & 0.632 & 0.646 & 0.629 \\
\hline
\end{tabular}



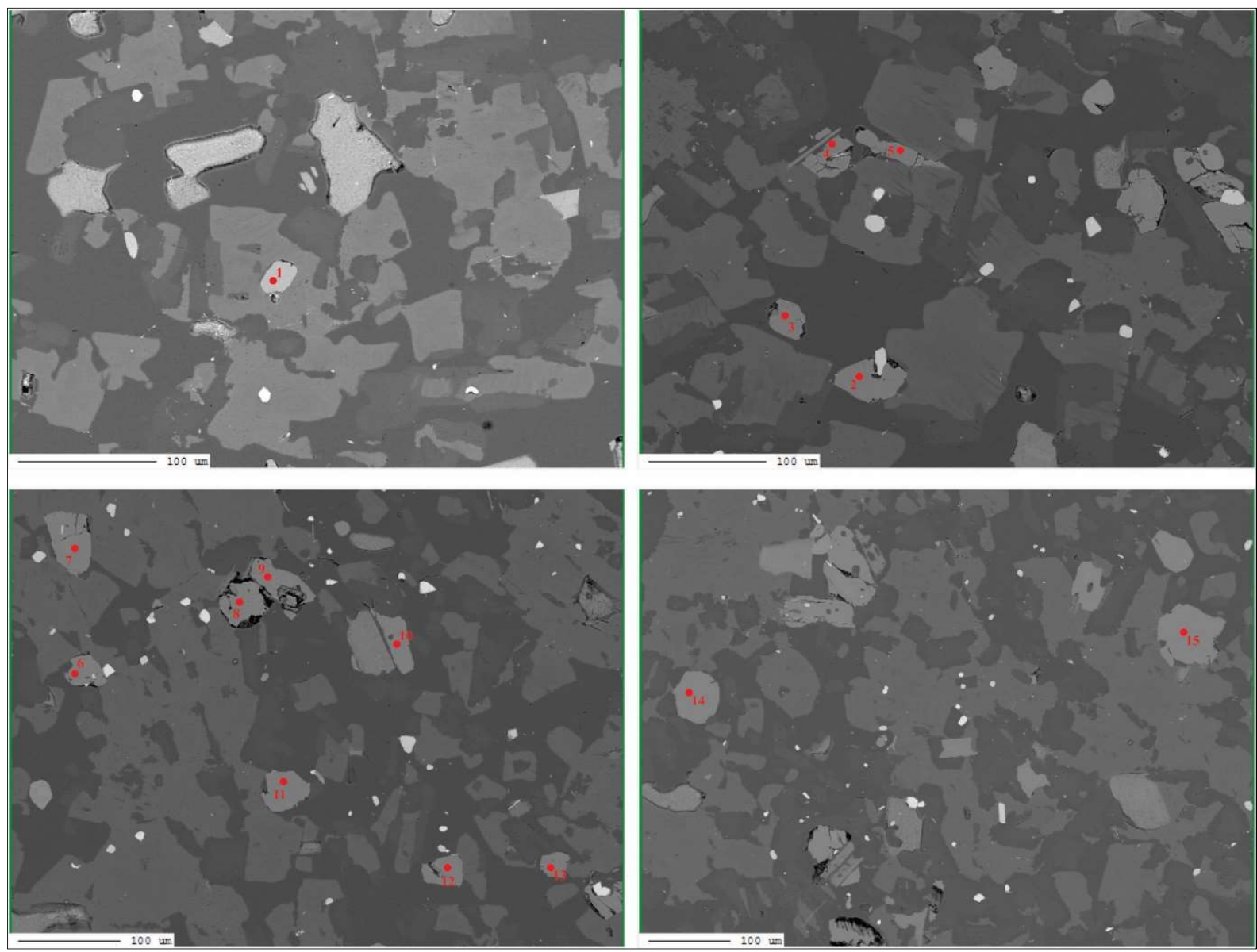

AMOSTRA FM3_3 - SALTO

Prancha B3 - Imagens obtidas por EDS de elétrons retroespalhados dos cristais de anfibólios analisados com os pontos de análise em vermelho. 

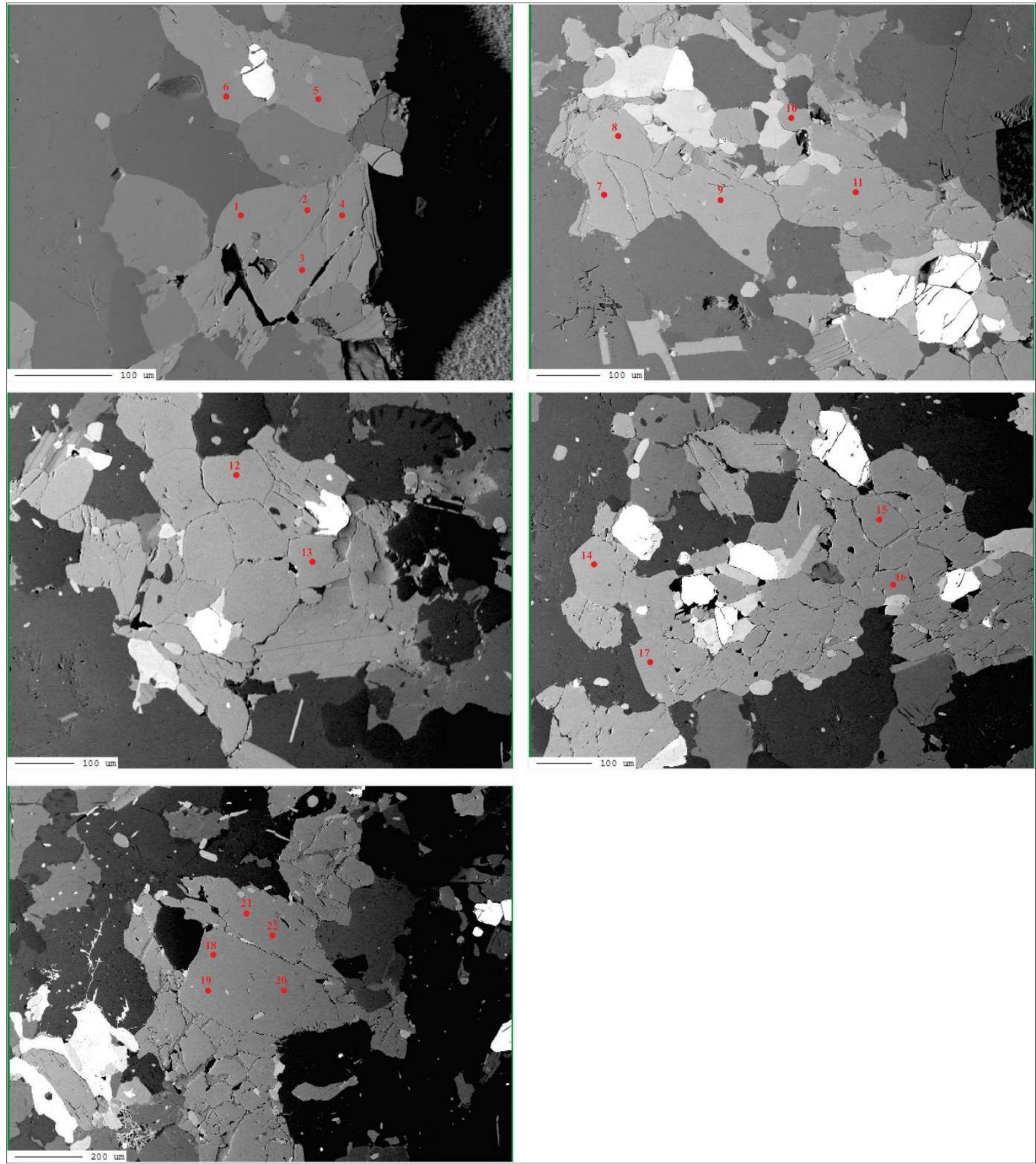

AMOSTRA 2008-ITU-2.1A1 - SALTO

Prancha B3 - continuação 


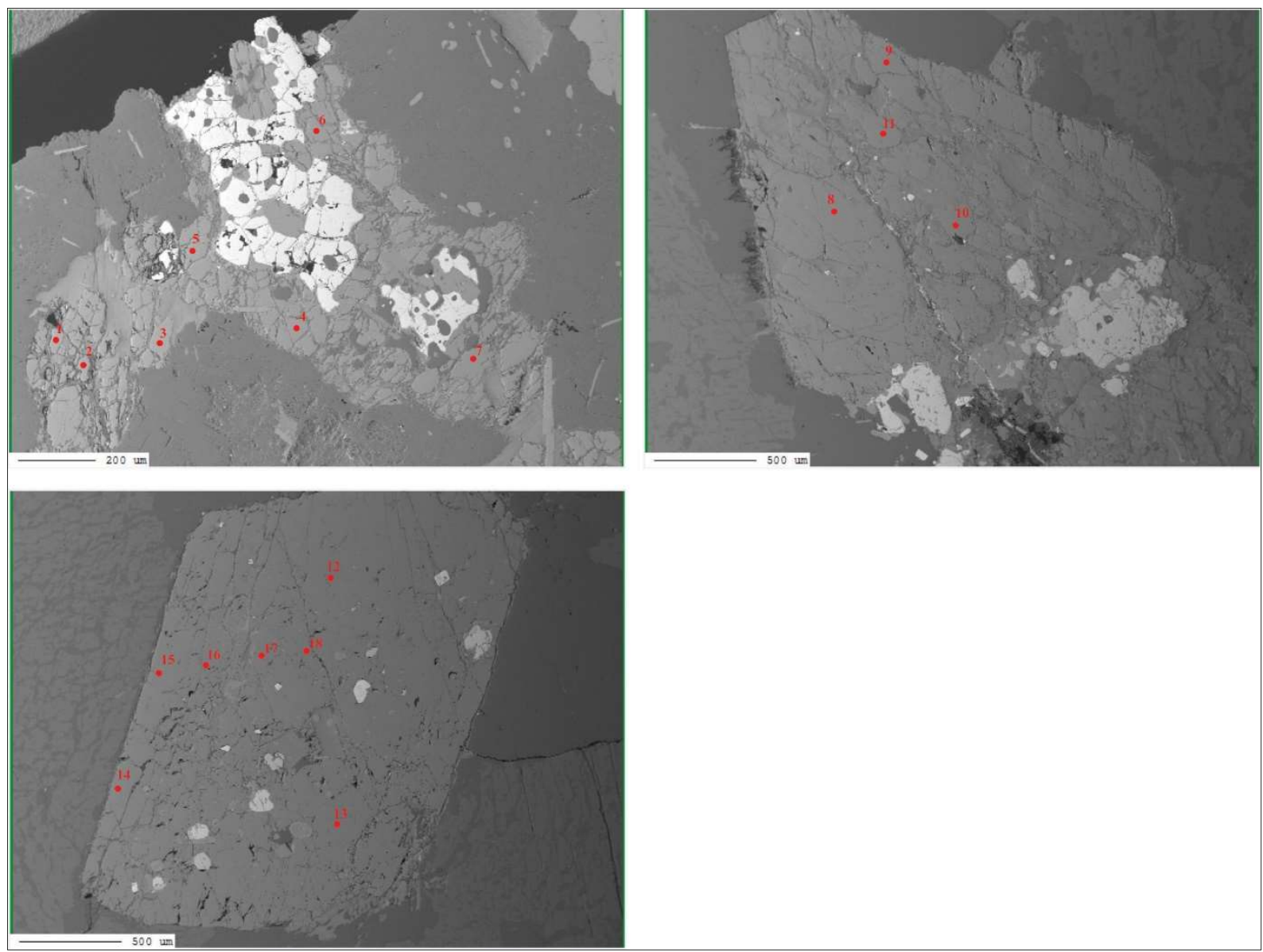

AMOSTRA CAB-14-06A - INDAIATUBA

Prancha B3 - continuação 


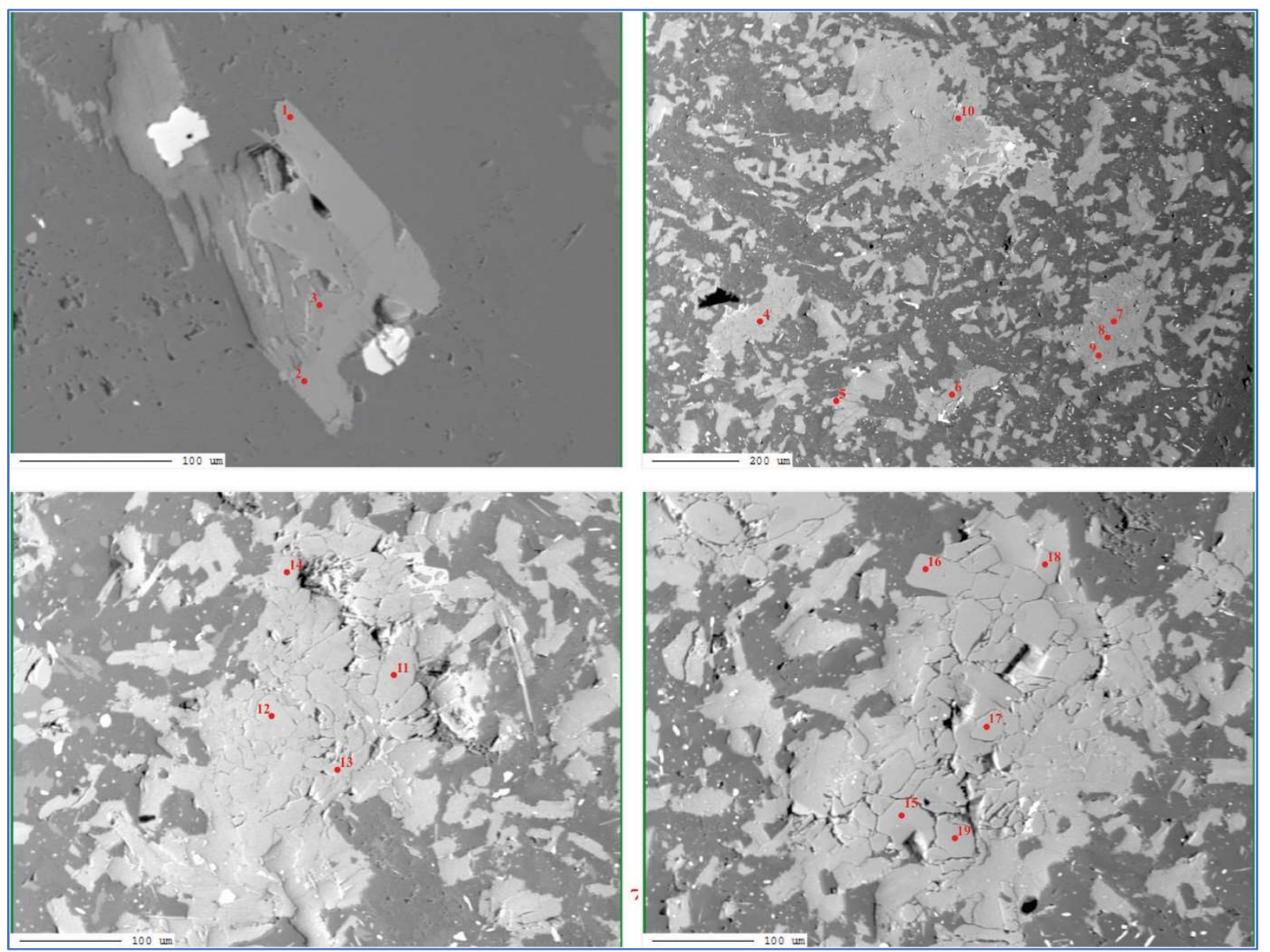

AMOSTRA CAB-15-34.1 - INDAIATUBA

Prancha B3 - continuação 

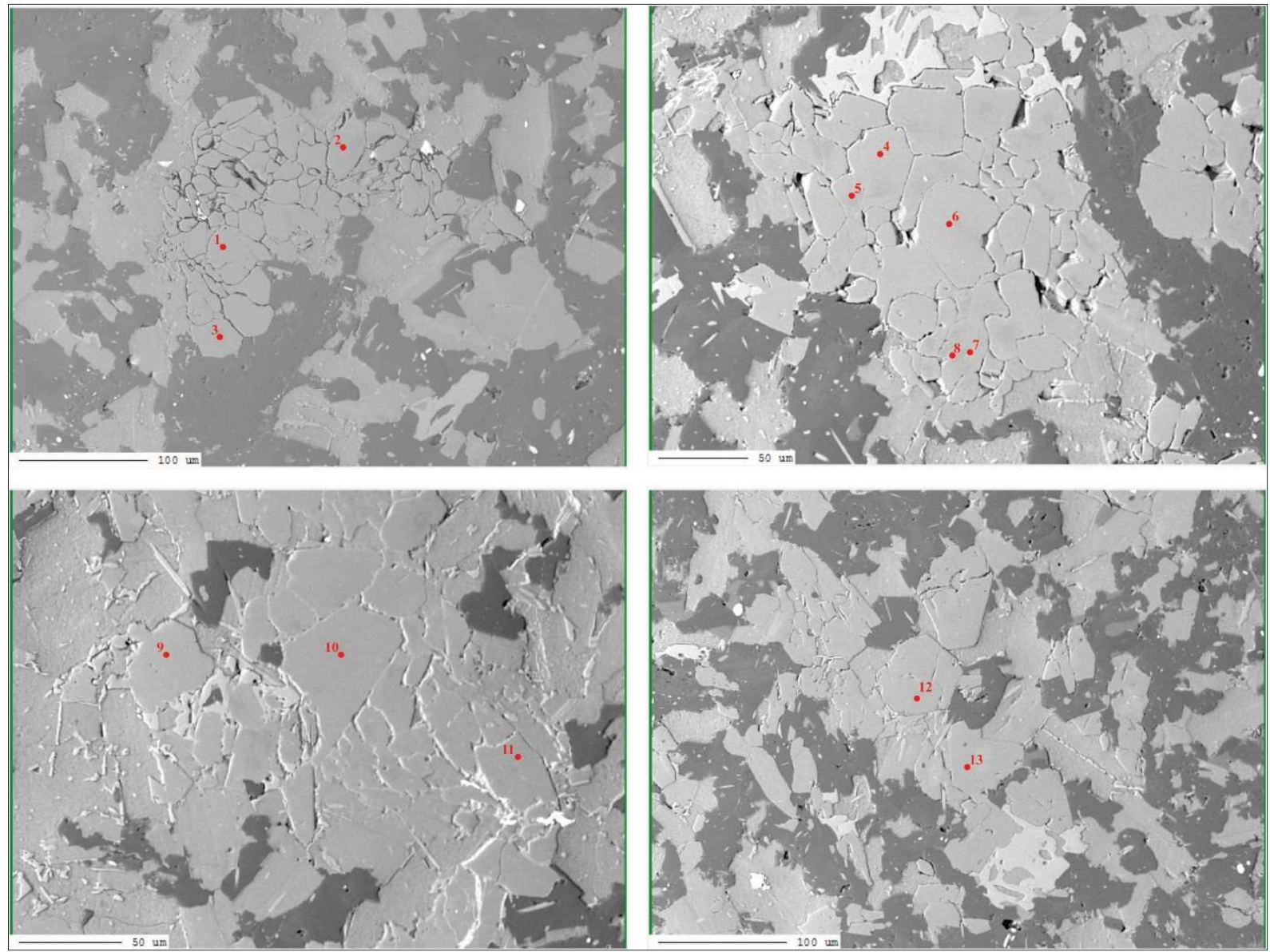

AMOSTRA CAB-15-34.2 - INDAIATUBA

Prancha B3 - continuação

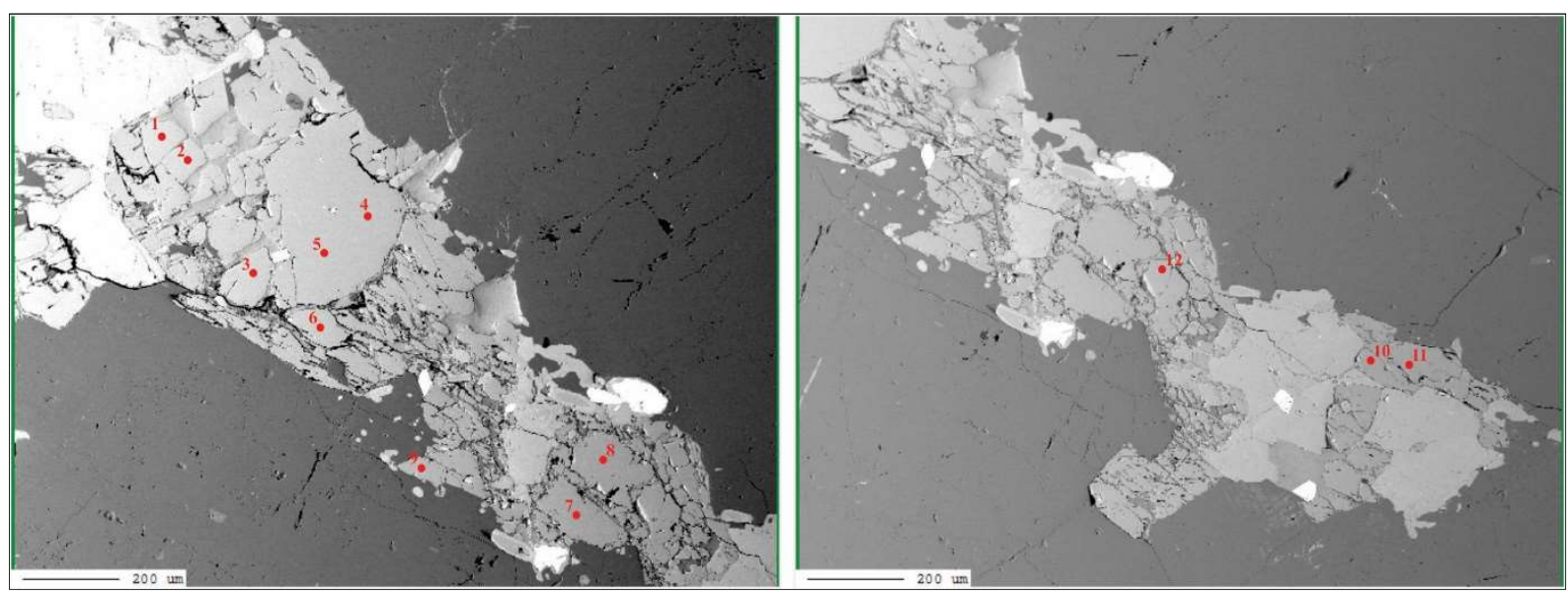

\section{AMOSTRA CAB-14-09 - CABREÚVA}

Prancha B3 - continuação 


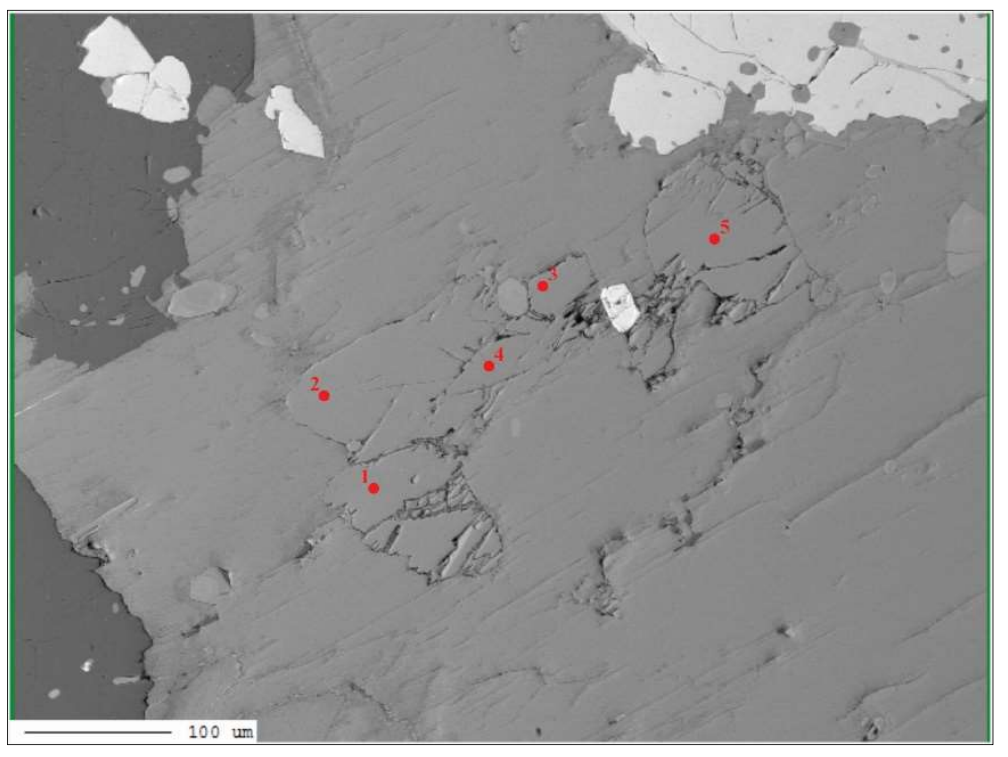

AMOSTRA CAB-16-80A - CABREÚVA

Prancha B3 - continuação 

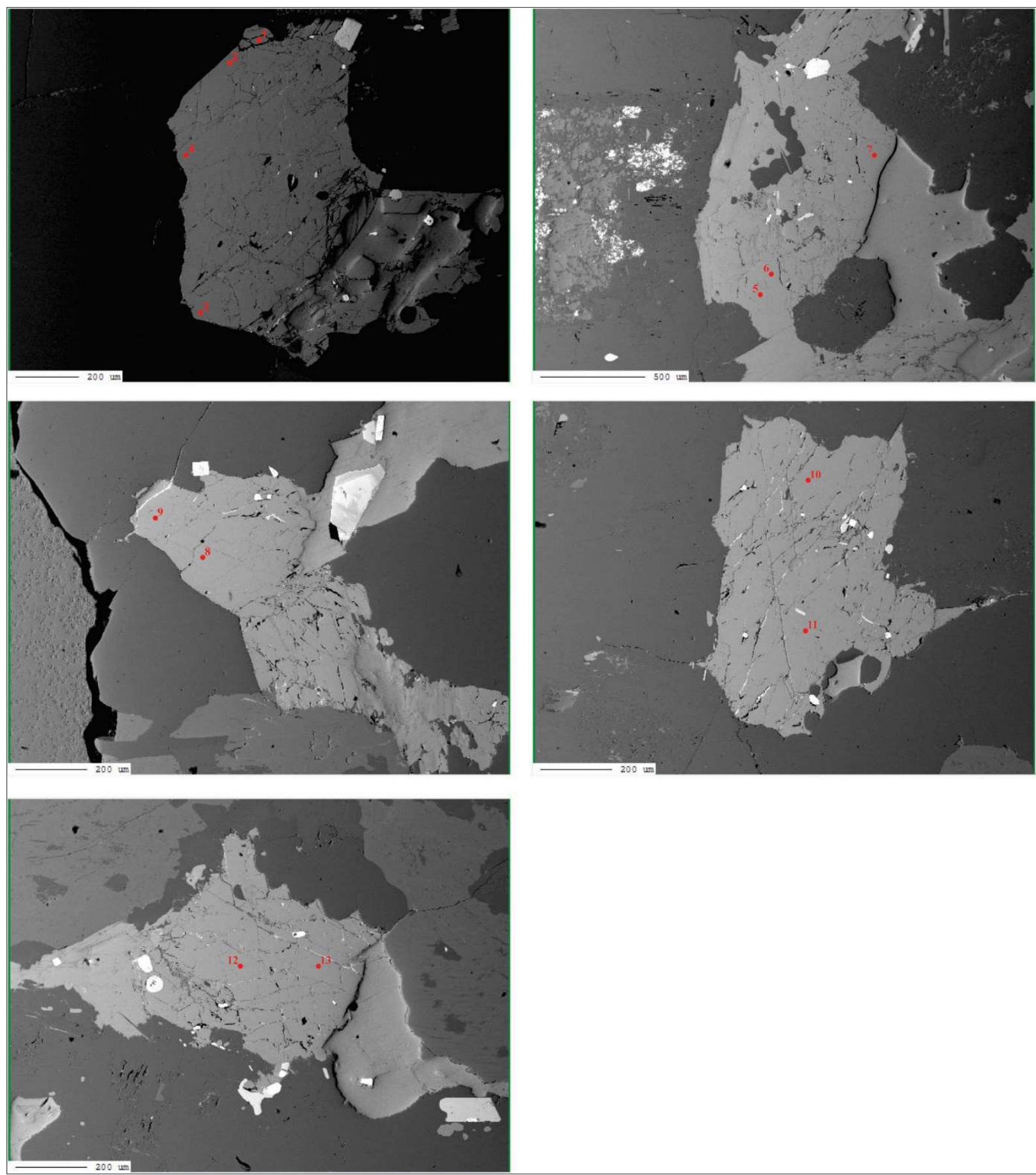

AMOSTRA CAB-16-90 - CABREÚVA

Prancha B3 - continuação 


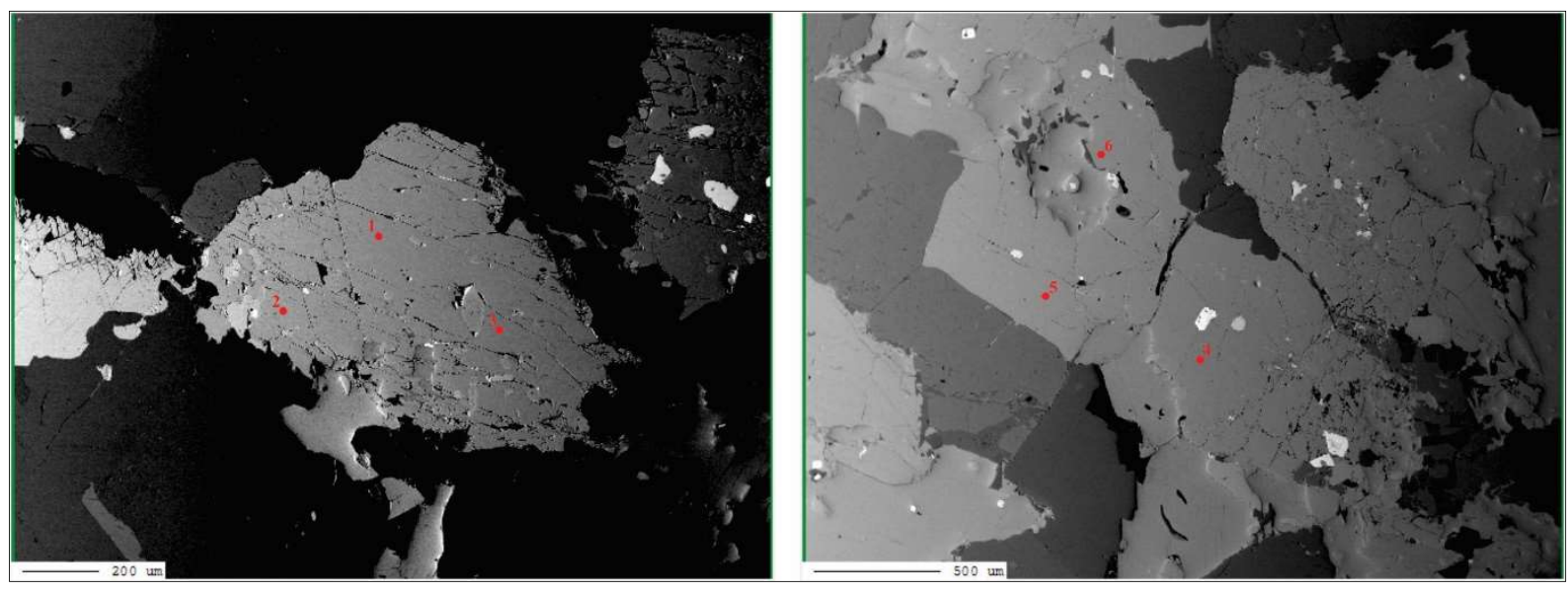

AMOSTRA CAB-16-91B - CABREÚVA

Prancha B3 - continuação 

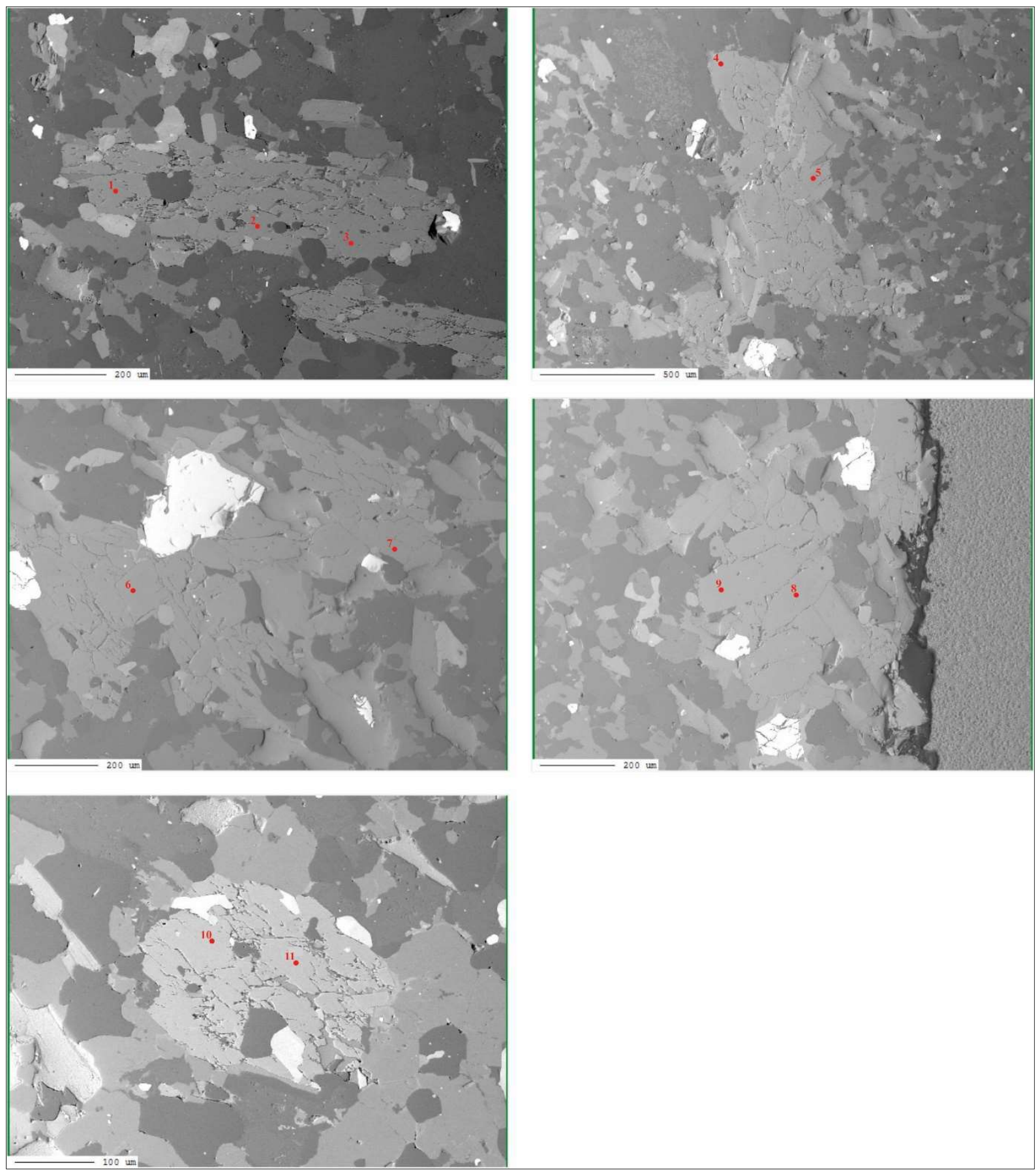

AMOSTRA CAB-16-98 - ITUPEVA

Prancha B3 - continuação 
Tabela B4 - Composição química das biotitas do Batólito Itu.

\section{PLÚTON SALTO}

\section{AMOSTRA FM3_3"}

\begin{tabular}{|c|c|c|c|c|c|c|c|c|c|}
\hline & 1 & 2 & 3 & 4 & 5 & 6 & 7 & 8 & 9 \\
\hline $\mathrm{SiO}_{2}$ & 36.82 & 36.13 & 37.25 & 36.31 & 36.97 & 38.37 & 36.36 & 38.91 & 36.64 \\
\hline $\mathrm{TiO}_{2}$ & 2.77 & 2.81 & 2.72 & 3.07 & 2.77 & 2.93 & 2.93 & 3.26 & 3.04 \\
\hline $\mathbf{A l}_{2} \mathbf{O}_{3}$ & 12.96 & 12.69 & 12.66 & 13.11 & 12.43 & 12.52 & 12.10 & 13.77 & 12.72 \\
\hline $\mathrm{FeO}$ & 22.83 & 23.15 & 22.06 & 23.48 & 22.49 & 21.60 & 22.49 & 22.79 & 21.82 \\
\hline MnO & 0.39 & 0.52 & 0.27 & 0.37 & 0.37 & 0.48 & 0.39 & 0.51 & 0.49 \\
\hline MgO & 10.13 & 9.78 & 10.26 & 10.07 & 11.17 & 10.57 & 10.71 & 8.25 & 9.94 \\
\hline $\mathrm{CaO}$ & 0.00 & 0.02 & 0.01 & 0.00 & 0.07 & 0.01 & 0.00 & 0.03 & 0.04 \\
\hline $\mathrm{Na}_{2} \mathrm{O}$ & 0.04 & 0.89 & 0.07 & 0.07 & 0.02 & 0.04 & 0.07 & 0.07 & 0.07 \\
\hline $\mathbf{K}_{2} \mathbf{O}$ & 9.29 & 9.42 & 9.58 & 8.48 & 8.54 & 9.43 & 9.35 & 9.38 & 9.19 \\
\hline $\mathrm{BaO}$ & 0.11 & 0.19 & 0.15 & 0.12 & 0.09 & 0.00 & 0.01 & 0.25 & 0.10 \\
\hline $\mathrm{ZnO}$ & 0.08 & 0.06 & 0.09 & 0.06 & 0.14 & 0.08 & 0.06 & 0.10 & 0.05 \\
\hline $\mathbf{F}$ & 1.14 & 0.89 & 0.99 & 0.83 & 1.11 & 1.20 & 1.15 & 0.64 & 0.82 \\
\hline Cl & 0.13 & 0.10 & 0.12 & 0.10 & 0.09 & 0.10 & 0.16 & 0.11 & 0.10 \\
\hline $\mathrm{ZrO}_{2}$ & 0.00 & 0.00 & 0.00 & 0.00 & 0.00 & 0.00 & 0.00 & 0.00 & 0.00 \\
\hline $\mathrm{H}_{2} \mathrm{O}^{*}$ & 3.28 & 3.38 & 3.35 & 3.42 & 3.31 & 3.32 & 3.22 & 3.62 & 3.40 \\
\hline Subtotal & 99.96 & 100.03 & 99.59 & 99.49 & 99.57 & 100.66 & 99.00 & 101.70 & 98.43 \\
\hline $\mathrm{O}=\mathrm{F}, \mathrm{Cl}$ & 0.51 & 0.40 & 0.44 & 0.37 & 0.49 & 0.53 & 0.52 & 0.30 & 0.37 \\
\hline Total & 99.46 & 99.63 & 99.15 & 99.12 & 99.08 & 100.13 & 98.48 & 101.40 & 98.06 \\
\hline $\mathbf{S i}$ & 5.732 & 5.665 & 5.801 & 5.668 & 5.746 & 5.877 & 5.726 & 5.899 & 5.763 \\
\hline $\mathrm{Al}^{\mathrm{IV}}$ & 2.268 & 2.335 & 2.199 & 2.332 & 2.254 & 2.123 & 2.246 & 2.101 & 2.237 \\
\hline Soma T & 8.000 & 8.000 & 8.000 & 8.000 & 8.000 & 8.000 & 7.972 & 8.000 & 8.000 \\
\hline $\mathrm{Al}^{\mathrm{VI}}$ & 0.111 & 0.010 & 0.125 & 0.080 & 0.024 & 0.137 & 0.000 & 0.360 & 0.121 \\
\hline
\end{tabular}


Tabela B4 - continuação

\begin{tabular}{|c|c|c|c|c|c|c|c|c|c|}
\hline $\mathbf{T i}$ & 0.324 & 0.331 & 0.319 & 0.360 & 0.324 & 0.338 & 0.347 & 0.372 & 0.360 \\
\hline $\mathbf{F e}$ & 2.973 & 3.036 & 2.873 & 3.065 & 2.924 & 2.767 & 2.962 & 2.890 & 2.870 \\
\hline Mn & 0.051 & 0.070 & 0.036 & 0.048 & 0.049 & 0.062 & 0.053 & 0.066 & 0.066 \\
\hline Mg & 2.351 & 2.286 & 2.382 & 2.343 & 2.588 & 2.413 & 2.514 & 1.865 & 2.331 \\
\hline $\mathbf{Z n}$ & 0.009 & 0.007 & 0.010 & 0.006 & 0.016 & 0.009 & 0.007 & 0.011 & 0.006 \\
\hline Soma X & 5.819 & 5.739 & 5.745 & 5.903 & 5.924 & 5.727 & 5.883 & 5.562 & 5.752 \\
\hline $\mathrm{Ca}$ & 0.000 & 0.004 & 0.002 & 0.000 & 0.011 & 0.001 & 0.000 & 0.005 & 0.007 \\
\hline $\mathbf{N a}$ & 0.013 & 0.271 & 0.021 & 0.022 & 0.006 & 0.012 & 0.020 & 0.019 & 0.023 \\
\hline $\mathbf{K}$ & 1.845 & 1.884 & 1.903 & 1.688 & 1.693 & 1.842 & 1.878 & 1.814 & 1.844 \\
\hline Ba & 0.007 & 0.012 & 0.009 & 0.007 & 0.006 & 0.000 & 0.001 & 0.015 & 0.006 \\
\hline Soma $Y$ & 1.865 & 2.170 & 1.935 & 1.718 & 1.717 & 1.856 & 1.899 & 1.854 & 1.879 \\
\hline $\mathrm{OH}^{*}$ & 3.405 & 3.532 & 3.481 & 3.562 & 3.431 & 3.392 & 3.386 & 3.664 & 3.565 \\
\hline $\mathbf{F}$ & 0.561 & 0.441 & 0.486 & 0.412 & 0.546 & 0.581 & 0.573 & 0.307 & 0.407 \\
\hline Cl & 0.033 & 0.027 & 0.033 & 0.026 & 0.024 & 0.027 & 0.042 & 0.029 & 0.028 \\
\hline Total & 19.683 & 19.909 & 19.681 & 19.621 & 19.641 & 19.583 & 19.753 & 19.416 & 19.632 \\
\hline $\mathbf{A} \mathbf{l}^{\mathrm{T}}$ & 2.378 & 2.345 & 2.324 & 2.412 & 2.277 & 2.260 & 2.246 & 2.461 & 2.358 \\
\hline $\mathrm{Fe} /(\mathbf{F e}+\mathbf{M g})$ & 0.558 & 0.570 & 0.547 & 0.567 & 0.530 & 0.534 & 0.541 & 0.608 & 0.552 \\
\hline $\mathrm{Mg} /(\mathrm{Mg}+\mathrm{Fe})$ & 0.442 & 0.430 & 0.453 & 0.433 & 0.470 & 0.466 & 0.459 & 0.392 & 0.448 \\
\hline $\mathbf{T}(\mathbf{K})$ & 906.3 & 906.4 & 908.1 & 914.7 & 908.0 & 919.1 & 914.3 & 925.9 & 922.5 \\
\hline $\mathbf{T}\left({ }^{\circ} \mathbf{C}\right)$ & 633.2 & 633.2 & 634.9 & 641.6 & 634.8 & 646.0 & 641.2 & 652.7 & 649.3 \\
\hline
\end{tabular}

* dados fornecidos por Adriana Alves 
Tabela B4 - continuação

\section{PLÚTON SALTO}

\section{AMOSTRA 2008-ITU-2.1A1}

\begin{tabular}{|c|c|c|c|c|c|c|c|c|c|c|c|c|c|c|c|c|c|}
\hline & 1 & 2 & 3 & 4 & 5 & 6 & 7 & 8 & 9 & 10 & 11 & 12 & 13 & 14 & 15 & 16 & 17 \\
\hline $\mathrm{SiO}_{2}$ & 37.88 & 37.70 & 37.79 & 37.87 & 37.72 & 37.76 & 37.79 & 37.86 & 38.03 & 37.61 & 37.89 & 37.23 & 37.67 & 37.49 & 37.88 & 37.50 & 37.87 \\
\hline $\mathrm{TiO}_{2}$ & 2.02 & 2.37 & 1.99 & 2.11 & 2.78 & 2.12 & 2.29 & 2.62 & 2.06 & 2.18 & 2.65 & 2.86 & 2.21 & 2.20 & 2.22 & 2.69 & 2.12 \\
\hline $\mathbf{A l}_{2} \mathbf{O}_{3}$ & 14.99 & 14.99 & 14.85 & 15.04 & 14.33 & 14.72 & 14.97 & 14.68 & 14.72 & 15.08 & 14.52 & 14.71 & 14.70 & 14.80 & 14.44 & 14.33 & 14.61 \\
\hline $\mathrm{FeO}$ & 18.20 & 18.40 & 18.17 & 17.47 & 18.06 & 17.95 & 17.78 & 18.16 & 16.94 & 17.83 & 17.89 & 18.34 & 17.50 & 18.06 & 18.01 & 18.42 & 17.76 \\
\hline MnO & 0.51 & 0.49 & 0.48 & 0.44 & 0.43 & 0.52 & 0.45 & 0.45 & 0.46 & 0.52 & 0.43 & 0.48 & 0.44 & 0.48 & 0.46 & 0.46 & 0.50 \\
\hline MgO & 12.42 & 12.18 & 12.60 & 12.53 & 12.19 & 12.29 & 12.31 & 12.35 & 13.36 & 12.52 & 12.79 & 12.01 & 12.88 & 12.72 & 12.83 & 12.34 & 12.68 \\
\hline $\mathrm{CaO}$ & 0.00 & 0.04 & 0.01 & 0.01 & 0.00 & 0.00 & 0.07 & 0.00 & 0.01 & 0.02 & 0.06 & 0.00 & 0.03 & 0.02 & 0.00 & 0.00 & 0.01 \\
\hline $\mathrm{Na}_{2} \mathrm{O}$ & 0.11 & 0.09 & 0.09 & 0.06 & 0.07 & 0.09 & 0.07 & 0.10 & 0.10 & 0.06 & 0.08 & 0.05 & 0.08 & 0.10 & 0.09 & 0.08 & 0.08 \\
\hline $\mathbf{K}_{2} \mathbf{O}$ & 9.77 & 9.58 & 9.63 & 9.68 & 9.60 & 9.66 & 9.60 & 9.61 & 9.62 & 9.81 & 9.70 & 9.40 & 9.88 & 9.60 & 9.46 & 9.69 & 9.47 \\
\hline $\mathrm{BaO}$ & 0.24 & 0.31 & 0.31 & 0.25 & 0.40 & 0.22 & 0.19 & 0.28 & 0.22 & 0.34 & 0.26 & 0.75 & 0.25 & 0.20 & 0.27 & 0.30 & 0.24 \\
\hline $\mathrm{ZnO}$ & 0.12 & 0.15 & 0.10 & 0.07 & 0.06 & 0.01 & 0.06 & 0.10 & 0.00 & 0.07 & 0.01 & 0.00 & 0.00 & 0.14 & 0.09 & 0.10 & 0.04 \\
\hline F & 0.96 & 0.92 & 0.91 & 0.77 & 0.94 & 0.79 & 0.92 & 0.86 & 0.99 & 0.89 & 0.93 & 0.75 & 1.00 & 0.96 & 0.99 & 0.84 & 0.96 \\
\hline $\mathrm{Cl}$ & 0.07 & 0.08 & 0.04 & 0.09 & 0.08 & 0.08 & 0.03 & 0.05 & 0.09 & 0.06 & 0.09 & 0.11 & 0.08 & 0.09 & 0.04 & 0.05 & 0.05 \\
\hline $\mathrm{ZrO}_{2}$ & 0.00 & 0.00 & 0.00 & 0.01 & 0.00 & 0.00 & 0.00 & 0.02 & 0.00 & 0.00 & 0.00 & 0.00 & 0.02 & 0.02 & 0.04 & 0.00 & 0.00 \\
\hline $\mathrm{H}_{2} \mathrm{O}^{*}$ & 3.51 & 3.52 & 3.53 & 3.58 & 3.49 & 3.56 & 3.52 & 3.56 & 3.49 & 3.53 & 3.52 & 3.56 & 3.47 & 3.49 & 3.49 & 3.54 & 3.49 \\
\hline Subtotal & 100.79 & 100.83 & 100.50 & 99.99 & 100.15 & 99.75 & 100.04 & 100.68 & 100.09 & 100.52 & 100.82 & 100.26 & 100.22 & 100.37 & 100.31 & 100.35 & 99.88 \\
\hline $\mathbf{O}=\mathbf{F}, \mathbf{C l}$ & 0.42 & 0.40 & 0.39 & 0.35 & 0.41 & 0.35 & 0.39 & 0.37 & 0.44 & 0.39 & 0.41 & 0.34 & 0.44 & 0.42 & 0.43 & 0.37 & 0.41 \\
\hline Total & 100.37 & 100.42 & 100.10 & 99.64 & 99.74 & 99.41 & 99.65 & 100.31 & 99.65 & 100.13 & 100.40 & 99.92 & 99.78 & 99.95 & 99.88 & 99.98 & 99.46 \\
\hline $\mathbf{S i}$ & 5.708 & 5.684 & 5.708 & 5.723 & 5.723 & 5.735 & 5.715 & 5.704 & 5.731 & 5.679 & 5.699 & 5.658 & 5.700 & 5.673 & 5.726 & 5.689 & 5.738 \\
\hline $\mathrm{Al}^{\mathrm{IV}}$ & 2.292 & 2.316 & 2.292 & 2.277 & 2.277 & 2.265 & 2.285 & 2.296 & 2.269 & 2.321 & 2.301 & 2.342 & 2.300 & 2.327 & 2.274 & 2.311 & 2.262 \\
\hline Soma $T$ & 8.000 & 8.000 & 8.000 & 8.000 & 8.000 & 8.000 & 8.000 & 8.000 & 8.000 & 8.000 & 8.000 & 8.000 & 8.000 & 8.000 & 8.000 & 8.000 & 8.000 \\
\hline $\mathbf{A l}^{\mathrm{VI}}$ & 0.371 & 0.349 & 0.352 & 0.402 & 0.286 & 0.370 & 0.384 & 0.311 & 0.346 & 0.363 & 0.273 & 0.293 & 0.322 & 0.313 & 0.299 & 0.251 & 0.348 \\
\hline
\end{tabular}


Tabela B4 - continuação

\begin{tabular}{|c|c|c|c|c|c|c|c|c|c|c|c|c|c|c|c|c|c|}
\hline Ti & 0.229 & 0.269 & 0.226 & 0.240 & 0.317 & 0.242 & 0.260 & 0.297 & 0.233 & 0.248 & 0.300 & 0.327 & 0.251 & 0.250 & 0.252 & 0.307 & 0.242 \\
\hline $\mathbf{F e}$ & 2.294 & 2.320 & 2.295 & 2.208 & 2.292 & 2.280 & 2.249 & 2.288 & 2.135 & 2.252 & 2.250 & 2.331 & 2.215 & 2.286 & 2.277 & 2.337 & 2.251 \\
\hline Mn & 0.065 & 0.063 & 0.061 & 0.056 & 0.056 & 0.067 & 0.058 & 0.057 & 0.059 & 0.066 & 0.055 & 0.062 & 0.057 & 0.061 & 0.059 & 0.059 & 0.065 \\
\hline $\mathbf{M g}$ & 2.790 & 2.738 & 2.837 & 2.823 & 2.757 & 2.783 & 2.775 & 2.774 & 3.001 & 2.818 & 2.868 & 2.721 & 2.905 & 2.869 & 2.891 & 2.791 & 2.864 \\
\hline $\mathbf{Z n}$ & 0.013 & 0.017 & 0.011 & 0.008 & 0.007 & 0.001 & 0.007 & 0.011 & 0.000 & 0.008 & 0.001 & 0.000 & 0.000 & 0.016 & 0.011 & 0.011 & 0.005 \\
\hline $\mathbf{Z r}$ & 0.000 & 0.000 & 0.000 & 0.001 & 0.000 & 0.000 & 0.000 & 0.001 & 0.000 & 0.000 & 0.000 & 0.000 & 0.001 & 0.002 & 0.003 & 0.000 & 0.000 \\
\hline Soma $X$ & 5.763 & 5.755 & 5.783 & 5.738 & 5.715 & 5.743 & 5.733 & 5.740 & 5.775 & 5.755 & 5.748 & 5.734 & 5.751 & 5.798 & 5.791 & 5.756 & 5.773 \\
\hline $\mathrm{Ca}$ & 0.000 & 0.007 & 0.002 & 0.002 & 0.000 & 0.000 & 0.011 & 0.001 & 0.001 & 0.003 & 0.009 & 0.000 & 0.005 & 0.003 & 0.000 & 0.000 & 0.001 \\
\hline $\mathrm{Na}$ & 0.031 & 0.025 & 0.025 & 0.019 & 0.021 & 0.027 & 0.019 & 0.028 & 0.029 & 0.017 & 0.023 & 0.014 & 0.023 & 0.030 & 0.025 & 0.023 & 0.023 \\
\hline $\mathbf{K}$ & 1.878 & 1.842 & 1.855 & 1.866 & 1.858 & 1.871 & 1.852 & 1.847 & 1.849 & 1.889 & 1.861 & 1.822 & 1.907 & 1.853 & 1.824 & 1.875 & 1.830 \\
\hline $\mathbf{B a}$ & 0.014 & 0.019 & 0.019 & 0.015 & 0.024 & 0.013 & 0.011 & 0.016 & 0.013 & 0.020 & 0.015 & 0.045 & 0.015 & 0.012 & 0.016 & 0.018 & 0.014 \\
\hline Soma $Y$ & 1.923 & 1.893 & 1.901 & 1.902 & 1.903 & 1.911 & 1.893 & 1.892 & 1.893 & 1.929 & 1.908 & 1.881 & 1.950 & 1.899 & 1.866 & 1.916 & 1.869 \\
\hline $\mathrm{OH}^{*}$ & 3.525 & 3.543 & 3.554 & 3.607 & 3.530 & 3.602 & 3.553 & 3.580 & 3.504 & 3.559 & 3.534 & 3.609 & 3.500 & 3.519 & 3.517 & 3.582 & 3.529 \\
\hline $\mathbf{F}$ & 0.456 & 0.437 & 0.434 & 0.370 & 0.450 & 0.378 & 0.440 & 0.408 & 0.473 & 0.427 & 0.444 & 0.362 & 0.479 & 0.458 & 0.473 & 0.404 & 0.460 \\
\hline Cl & 0.019 & 0.020 & 0.011 & 0.024 & 0.020 & 0.020 & 0.007 & 0.012 & 0.023 & 0.014 & 0.022 & 0.029 & 0.021 & 0.023 & 0.010 & 0.013 & 0.012 \\
\hline Total & 19.686 & 19.648 & 19.684 & 19.639 & 19.618 & 19.654 & 19.626 & 19.631 & 19.667 & 19.684 & 19.656 & 19.615 & 19.701 & 19.696 & 19.657 & 19.672 & 19.642 \\
\hline $\mathbf{A \mathbf { T } ^ { \mathrm { T } }}$ & 2.663 & 2.664 & 2.644 & 2.679 & 2.563 & 2.635 & 2.668 & 2.607 & 2.615 & 2.684 & 2.574 & 2.635 & 2.622 & 2.640 & 2.573 & 2.562 & 2.609 \\
\hline $\mathrm{Fe} /(\mathrm{Fe}+\mathrm{Mg})$ & 0.451 & 0.459 & 0.447 & 0.439 & 0.454 & 0.450 & 0.448 & 0.452 & 0.416 & 0.444 & 0.440 & 0.461 & 0.433 & 0.443 & 0.441 & 0.456 & 0.440 \\
\hline $\mathrm{Mg} /(\mathrm{Mg}+\mathrm{Fe})$ & 0.549 & 0.541 & 0.553 & 0.561 & 0.546 & 0.550 & 0.552 & 0.548 & 0.584 & 0.556 & 0.560 & 0.539 & 0.567 & 0.557 & 0.559 & 0.544 & 0.560 \\
\hline $\mathbf{T}(\mathbf{K})$ & 897.3 & 913.0 & 896.1 & 905.9 & 936.0 & 903.5 & 913.0 & 927.0 & 906.6 & 907.2 & 930.6 & 937.9 & 910.7 & 906.8 & 908.1 & 928.7 & 904.6 \\
\hline $\mathrm{T}\left({ }^{\circ} \mathrm{C}\right)$ & 624.2 & 639.8 & 622.9 & 632.7 & 662.9 & 630.4 & 639.8 & 653.9 & 633.4 & 634.0 & 657.4 & 664.8 & 637.6 & 633.6 & 634.9 & 655.5 & 631.5 \\
\hline
\end{tabular}


Tabela B4 - continuação

\section{PLÚTON SALTO}

AMOSTRA 2008-ITU-2.1C

\begin{tabular}{|c|c|c|c|c|c|c|c|c|c|c|}
\hline & 1 & 2 & 3 & 4 & 5 & 6 & 7 & 8 & 9 & 10 \\
\hline $\mathrm{SiO}_{2}$ & 37.06 & 36.97 & 37.28 & 37.33 & 36.98 & 37.67 & 37.15 & 36.75 & 37.71 & 37.38 \\
\hline $\mathrm{TiO}_{2}$ & 3.80 & 3.83 & 3.65 & 3.94 & 3.22 & 2.81 & 3.50 & 2.74 & 2.87 & 3.39 \\
\hline $\mathbf{A l}_{2} \mathbf{O}_{3}$ & 13.07 & 12.49 & 13.74 & 13.38 & 13.40 & 14.22 & 13.35 & 14.60 & 13.79 & 13.15 \\
\hline $\mathrm{FeO}$ & 22.94 & 22.61 & 21.36 & 21.16 & 21.84 & 20.55 & 22.67 & 22.47 & 21.56 & 22.31 \\
\hline MnO & 0.63 & 0.62 & 0.48 & 0.57 & 0.54 & 0.51 & 0.66 & 0.50 & 0.60 & 0.65 \\
\hline MgO & 8.95 & 9.38 & 9.67 & 9.73 & 9.38 & 10.24 & 9.11 & 8.80 & 9.56 & 9.48 \\
\hline $\mathrm{CaO}$ & 0.00 & 0.01 & 0.06 & 0.00 & 0.04 & 0.01 & 0.00 & 0.07 & 0.10 & 0.00 \\
\hline $\mathrm{Na}_{2} \mathrm{O}$ & 0.11 & 0.06 & 0.10 & 0.05 & 0.04 & 0.05 & 0.05 & 0.08 & 0.06 & 0.04 \\
\hline $\mathbf{K}_{2} \mathbf{O}$ & 8.95 & 9.35 & 9.41 & 9.55 & 9.17 & 9.50 & 9.90 & 9.05 & 9.50 & 9.62 \\
\hline BaO & 0.07 & 0.00 & 0.11 & 0.20 & 0.09 & 0.20 & 0.02 & 0.00 & 0.04 & 0.00 \\
\hline $\mathrm{ZnO}$ & 0.08 & 0.11 & 0.10 & 0.07 & 0.07 & 0.08 & 0.05 & 0.05 & 0.10 & 0.03 \\
\hline $\mathbf{F}$ & 0.77 & 0.67 & 0.73 & 0.74 & 0.82 & 0.97 & 0.81 & 0.76 & 0.87 & 0.80 \\
\hline $\mathrm{Cl}$ & 0.10 & 0.05 & 0.06 & 0.10 & 0.08 & 0.04 & 0.12 & 0.06 & 0.06 & 0.11 \\
\hline $\mathrm{ZrO}_{2}$ & 0.00 & 0.00 & 0.00 & 0.00 & 0.00 & 0.00 & 0.00 & 0.00 & 0.00 & 0.00 \\
\hline $\mathrm{H}_{2} \mathrm{O}^{*}$ & 3.48 & 3.52 & 3.55 & 3.53 & 3.44 & 3.45 & 3.47 & 3.49 & 3.48 & 3.48 \\
\hline Subtotal & 100.01 & 99.67 & 100.29 & 100.34 & 99.11 & 100.31 & 100.87 & 99.41 & 100.30 & 100.45 \\
\hline $\mathrm{O}=\mathrm{F}, \mathrm{Cl}$ & 0.35 & 0.29 & 0.32 & 0.33 & 0.37 & 0.42 & 0.37 & 0.33 & 0.38 & 0.36 \\
\hline Total & 99.66 & 99.38 & 99.97 & 100.01 & 98.75 & 99.89 & 100.51 & 99.08 & 99.92 & 100.09 \\
\hline $\mathbf{S i}$ & 5.746 & 5.755 & 5.723 & 5.735 & 5.761 & 5.761 & 5.728 & 5.705 & 5.793 & 5.765 \\
\hline $\mathbf{A I}^{\mathrm{IV}^{\mathrm{V}}}$ & 2.254 & 2.245 & 2.277 & 2.265 & 2.239 & 2.239 & 2.272 & 2.295 & 2.207 & 2.235 \\
\hline Soma T & 8.000 & 8.000 & 8.000 & 8.000 & 8.000 & 8.000 & 8.000 & 8.000 & 8.000 & 8.000 \\
\hline $\mathrm{Al}^{\mathrm{VI}}$ & 0.134 & 0.047 & 0.210 & 0.158 & 0.222 & 0.324 & 0.155 & 0.376 & 0.289 & 0.155 \\
\hline
\end{tabular}


Tabela B4 - continuação

\begin{tabular}{|c|c|c|c|c|c|c|c|c|c|c|}
\hline Ti & 0.443 & 0.448 & 0.421 & 0.455 & 0.377 & 0.323 & 0.406 & 0.320 & 0.332 & 0.393 \\
\hline $\mathrm{Fe}$ & 2.974 & 2.944 & 2.742 & 2.719 & 2.846 & 2.628 & 2.923 & 2.917 & 2.770 & 2.878 \\
\hline Mn & 0.083 & 0.082 & 0.063 & 0.074 & 0.072 & 0.067 & 0.087 & 0.066 & 0.078 & 0.085 \\
\hline Mg & 2.068 & 2.177 & 2.213 & 2.228 & 2.178 & 2.334 & 2.094 & 2.036 & 2.189 & 2.179 \\
\hline $\mathbf{Z n}$ & 0.009 & 0.012 & 0.011 & 0.008 & 0.007 & 0.009 & 0.006 & 0.006 & 0.012 & 0.004 \\
\hline Soma $X$ & 5.712 & 5.711 & 5.661 & 5.643 & 5.702 & 5.686 & 5.670 & 5.720 & 5.669 & 5.694 \\
\hline $\mathrm{Ca}$ & 0.000 & 0.002 & 0.009 & 0.000 & 0.006 & 0.002 & 0.000 & 0.011 & 0.016 & 0.000 \\
\hline $\mathbf{N a}$ & 0.032 & 0.017 & 0.029 & 0.015 & 0.013 & 0.016 & 0.016 & 0.025 & 0.018 & 0.013 \\
\hline $\mathbf{K}$ & 1.770 & 1.857 & 1.843 & 1.872 & 1.822 & 1.853 & 1.947 & 1.792 & 1.861 & 1.892 \\
\hline $\mathbf{B a}$ & 0.005 & 0.000 & 0.006 & 0.012 & 0.006 & 0.012 & 0.001 & 0.000 & 0.003 & 0.000 \\
\hline Soma $Y$ & 1.807 & 1.876 & 1.887 & 1.898 & 1.847 & 1.883 & 1.964 & 1.828 & 1.898 & 1.905 \\
\hline $\mathrm{OH}^{*}$ & 3.597 & 3.656 & 3.631 & 3.615 & 3.572 & 3.521 & 3.574 & 3.610 & 3.561 & 3.582 \\
\hline $\mathbf{F}$ & 0.376 & 0.329 & 0.352 & 0.359 & 0.406 & 0.469 & 0.395 & 0.375 & 0.423 & 0.390 \\
\hline Cl & 0.027 & 0.014 & 0.016 & 0.026 & 0.022 & 0.010 & 0.031 & 0.015 & 0.016 & 0.028 \\
\hline Total & 19.518 & 19.587 & 19.548 & 19.541 & 19.549 & 19.569 & 19.634 & 19.548 & 19.567 & 19.599 \\
\hline $\mathbf{A} \mathbf{I}^{\mathbf{T}}$ & 2.388 & 2.292 & 2.486 & 2.423 & 2.461 & 2.563 & 2.426 & 2.671 & 2.497 & 2.390 \\
\hline $\mathrm{Fe} /(\mathbf{F e}+\mathbf{M g})$ & 0.590 & 0.575 & 0.553 & 0.550 & 0.566 & 0.530 & 0.583 & 0.589 & 0.559 & 0.569 \\
\hline $\mathrm{Mg} /(\mathrm{Mg}+\mathrm{Fe})$ & 0.410 & 0.425 & 0.447 & 0.450 & 0.434 & 0.470 & 0.417 & 0.411 & 0.441 & 0.431 \\
\hline $\mathbf{T}(\mathbf{K})$ & 947.2 & 950.8 & 952.2 & 967.4 & 930.0 & 920.1 & 936.5 & 906.9 & 916.9 & 934.2 \\
\hline $\mathbf{T}\left({ }^{\circ} \mathrm{C}\right)$ & 674.0 & 677.6 & 679.1 & 694.2 & 656.8 & 647.0 & 663.3 & 633.7 & 643.7 & 661.0 \\
\hline
\end{tabular}


Tabela B4 - continuação

\section{PLÚTON INDAIATUBA}

AMOSTRA CAB-14-06A

\begin{tabular}{|c|c|c|c|}
\hline & 1 & 2 & 3 \\
\hline $\mathrm{SiO}_{2}$ & 35.83 & 37.06 & 36.99 \\
\hline $\mathrm{TiO}_{2}$ & 3.48 & 3.54 & 3.26 \\
\hline $\mathbf{A l}_{2} \mathbf{O}_{3}$ & 12.14 & 12.43 & 12.37 \\
\hline $\mathrm{FeO}$ & 23.65 & 24.19 & 24.41 \\
\hline MnO & 0.43 & 0.49 & 0.45 \\
\hline MgO & 9.91 & 8.84 & 9.23 \\
\hline $\mathrm{CaO}$ & 0.02 & 0.00 & 0.00 \\
\hline $\mathrm{Na}_{2} \mathrm{O}$ & 0.11 & 0.11 & 0.12 \\
\hline $\mathrm{K}_{2} \mathrm{O}$ & 9.28 & 9.32 & 9.36 \\
\hline $\mathrm{BaO}$ & 0.06 & 0.11 & 0.08 \\
\hline ZnO & 0.16 & 0.07 & 0.06 \\
\hline $\mathbf{F}$ & 1.06 & 1.04 & 0.84 \\
\hline Cl & 0.09 & 0.14 & 0.08 \\
\hline $\mathrm{ZrO}_{2}$ & 0.00 & 0.00 & 0.04 \\
\hline $\mathbf{H}_{2} \mathbf{O}^{*}$ & 3.27 & 3.32 & 3.44 \\
\hline Subtotal & 99.48 & 100.66 & 100.72 \\
\hline $\mathrm{O}=\mathrm{F}, \mathrm{Cl}$ & 0.47 & 0.47 & 0.37 \\
\hline Total & 99.01 & 100.19 & 100.35 \\
\hline $\mathbf{S i}$ & 5.653 & 5.767 & 5.751 \\
\hline$\overline{\mathbf{A l}^{\mathbf{I V}}}$ & 2.258 & 2.233 & 2.249 \\
\hline Soma $T$ & 7.910 & 8.000 & 8.000 \\
\hline $\mathbf{A l}^{\mathrm{VI}}$ & 0.000 & 0.046 & 0.018 \\
\hline
\end{tabular}


Tabela B4 - continuação

\begin{tabular}{|c|c|c|c|}
\hline Ti & 0.413 & 0.414 & 0.381 \\
\hline $\mathbf{F e}$ & 3.121 & 3.148 & 3.174 \\
\hline Mn & 0.057 & 0.064 & 0.059 \\
\hline $\mathbf{M g}$ & 2.331 & 2.050 & 2.139 \\
\hline $\mathbf{Z n}$ & 0.018 & 0.007 & 0.007 \\
\hline $\mathbf{Z r}$ & 0.000 & 0.000 & 0.003 \\
\hline Soma X & 5.939 & 5.730 & 5.780 \\
\hline $\mathrm{Ca}$ & 0.003 & 0.000 & 0.000 \\
\hline $\mathrm{Na}$ & 0.033 & 0.034 & 0.037 \\
\hline $\mathbf{K}$ & 1.867 & 1.850 & 1.856 \\
\hline $\mathbf{B a}$ & 0.003 & 0.007 & 0.005 \\
\hline Soma $Y$ & 1.906 & 1.891 & 1.898 \\
\hline $\mathrm{OH}^{*}$ & 3.446 & 3.451 & 3.563 \\
\hline $\mathbf{F}$ & 0.529 & 0.512 & 0.415 \\
\hline Cl & 0.025 & 0.038 & 0.022 \\
\hline Total & 19.756 & 19.621 & 19.678 \\
\hline $\mathbf{A l}^{\mathrm{T}}$ & 2.258 & 2.280 & 2.267 \\
\hline $\mathbf{F e} /(\mathbf{F e}+\mathbf{M g})$ & 0.572 & 0.606 & 0.597 \\
\hline $\mathrm{Mg} /(\mathbf{M g}+\mathrm{Fe})$ & 0.428 & 0.394 & 0.403 \\
\hline $\mathbf{T}(\mathbf{K})$ & 929.7 & 928.9 & 917.2 \\
\hline $\mathrm{T}\left({ }^{\circ} \mathrm{C}\right)$ & 656.5 & 655.8 & 644.1 \\
\hline
\end{tabular}


Tabela B4 - continuação

\section{PLÚTON INDAIATUBA}

AMOSTRA CAB-15-34.1

\begin{tabular}{|c|c|c|c|c|c|c|c|c|c|c|}
\hline & 1 & 2 & 3 & 4 & 5 & 6 & 7 & 8 & 9 & 10 \\
\hline $\mathrm{SiO}_{2}$ & 36.90 & 37.09 & 37.27 & 37.53 & 35.35 & 37.07 & 38.16 & 37.00 & 35.71 & 37.12 \\
\hline $\mathrm{TiO}_{2}$ & 3.48 & 3.56 & 3.58 & 2.00 & 3.18 & 2.82 & 3.26 & 3.11 & 3.20 & 3.24 \\
\hline $\mathbf{A l}_{2} \mathbf{O}_{3}$ & 13.31 & 13.61 & 13.72 & 14.00 & 13.32 & 14.02 & 13.29 & 13.93 & 14.14 & 13.89 \\
\hline $\mathrm{FeO}$ & 23.50 & 23.58 & 23.78 & 22.38 & 24.27 & 23.89 & 23.54 & 24.06 & 24.79 & 24.57 \\
\hline MnO & 0.41 & 0.30 & 0.37 & 0.32 & 0.41 & 0.34 & 0.41 & 0.46 & 0.56 & 0.49 \\
\hline MgO & 8.87 & 9.10 & 8.78 & 10.28 & 8.78 & 8.21 & 8.89 & 8.55 & 8.47 & 8.69 \\
\hline $\mathrm{CaO}$ & 0.00 & 0.01 & 0.00 & 0.01 & 0.02 & 0.00 & 0.00 & 0.06 & 0.00 & 0.00 \\
\hline $\mathrm{Na}_{2} \mathrm{O}$ & 0.07 & 0.05 & 0.07 & 0.03 & 0.03 & 0.04 & 0.05 & 0.06 & 0.04 & 0.08 \\
\hline $\mathbf{K}_{2} \mathbf{O}$ & 9.67 & 9.58 & 9.63 & 9.61 & 9.62 & 9.90 & 9.48 & 9.58 & 8.92 & 9.31 \\
\hline $\mathrm{BaO}$ & 0.07 & 0.09 & 0.04 & 0.13 & 0.11 & 0.07 & 0.14 & 0.14 & 0.69 & 0.01 \\
\hline $\mathrm{ZnO}$ & 0.02 & 0.02 & 0.01 & 0.02 & 0.09 & 0.06 & 0.08 & 0.15 & 0.05 & 0.00 \\
\hline $\mathbf{F}$ & 0.54 & 0.66 & 0.63 & 0.78 & 0.46 & 0.58 & 0.56 & 0.51 & 0.45 & 0.53 \\
\hline Cl & 0.07 & 0.05 & 0.04 & 0.01 & 0.05 & 0.04 & 0.06 & 0.07 & 0.08 & 0.08 \\
\hline $\mathrm{ZrO}_{2}$ & 0.00 & 0.00 & 0.01 & 0.01 & 0.01 & 0.00 & 0.01 & 0.00 & 0.00 & 0.00 \\
\hline $\mathrm{H}_{2} \mathrm{O}^{*}$ & 3.60 & 3.58 & 3.61 & 3.54 & 3.56 & 3.59 & 3.65 & 3.64 & 3.61 & 3.64 \\
\hline Subtotal & 100.51 & 101.29 & 101.53 & 100.64 & 99.26 & 100.63 & 101.57 & 101.31 & 100.71 & 101.66 \\
\hline $\mathrm{O}=\mathrm{F}, \mathrm{Cl}$ & 0.24 & 0.29 & 0.27 & 0.33 & 0.21 & 0.26 & 0.25 & 0.23 & 0.21 & 0.24 \\
\hline Total & 100.26 & 101.00 & 101.25 & 100.31 & 99.06 & 100.38 & 101.32 & 101.08 & 100.50 & 101.42 \\
\hline $\mathbf{S i}$ & 5.714 & 5.692 & 5.706 & 5.759 & 5.592 & 5.739 & 5.821 & 5.694 & 5.568 & 5.686 \\
\hline $\mathrm{Al}^{\mathrm{IV}}$ & 2.286 & 2.308 & 2.294 & 2.241 & 2.408 & 2.261 & 2.179 & 2.306 & 2.432 & 2.314 \\
\hline Soma T & 8.000 & 8.000 & 8.000 & 8.000 & 8.000 & 8.000 & 8.000 & 8.000 & 8.000 & 8.000 \\
\hline $\mathbf{A l}^{\mathrm{VI}}$ & 0.144 & 0.153 & 0.182 & 0.291 & 0.076 & 0.297 & 0.211 & 0.221 & 0.166 & 0.195 \\
\hline
\end{tabular}


Tabela B4 - continuação

\begin{tabular}{|c|c|c|c|c|c|c|c|c|c|c|}
\hline $\mathbf{T i}$ & 0.405 & 0.411 & 0.412 & 0.231 & 0.378 & 0.328 & 0.374 & 0.360 & 0.375 & 0.373 \\
\hline $\mathrm{Fe}$ & 3.043 & 3.026 & 3.045 & 2.872 & 3.211 & 3.093 & 3.003 & 3.097 & 3.233 & 3.148 \\
\hline Mn & 0.053 & 0.040 & 0.048 & 0.041 & 0.055 & 0.045 & 0.053 & 0.060 & 0.074 & 0.063 \\
\hline Mg & 2.048 & 2.082 & 2.004 & 2.351 & 2.070 & 1.895 & 2.022 & 1.961 & 1.969 & 1.984 \\
\hline $\mathbf{Z n}$ & 0.003 & 0.003 & 0.001 & 0.002 & 0.011 & 0.007 & 0.009 & 0.017 & 0.006 & 0.000 \\
\hline $\mathbf{Z r}$ & 0.000 & 0.000 & 0.001 & 0.001 & 0.000 & 0.000 & 0.001 & 0.000 & 0.000 & 0.000 \\
\hline Soma X & 5.696 & 5.714 & 5.691 & 5.789 & 5.802 & 5.665 & 5.672 & 5.716 & 5.823 & 5.764 \\
\hline $\mathrm{Ca}$ & 0.000 & 0.002 & 0.000 & 0.002 & 0.003 & 0.000 & 0.000 & 0.009 & 0.000 & 0.000 \\
\hline $\mathrm{Na}$ & 0.020 & 0.013 & 0.019 & 0.009 & 0.010 & 0.013 & 0.014 & 0.018 & 0.012 & 0.025 \\
\hline $\mathbf{K}$ & 1.910 & 1.875 & 1.880 & 1.881 & 1.941 & 1.955 & 1.845 & 1.881 & 1.774 & 1.819 \\
\hline $\mathbf{B a}$ & 0.004 & 0.005 & 0.002 & 0.008 & 0.007 & 0.004 & 0.008 & 0.009 & 0.042 & 0.001 \\
\hline Soma $Y$ & 1.935 & 1.896 & 1.902 & 1.900 & 1.961 & 1.972 & 1.867 & 1.916 & 1.828 & 1.844 \\
\hline $\mathrm{OH}^{*}$ & 3.718 & 3.667 & 3.684 & 3.620 & 3.756 & 3.703 & 3.712 & 3.733 & 3.758 & 3.722 \\
\hline F & 0.264 & 0.321 & 0.305 & 0.378 & 0.230 & 0.286 & 0.271 & 0.250 & 0.222 & 0.257 \\
\hline Cl & 0.018 & 0.012 & 0.011 & 0.002 & 0.015 & 0.011 & 0.017 & 0.017 & 0.020 & 0.022 \\
\hline Total & 19.631 & 19.611 & 19.594 & 19.689 & 19.763 & 19.637 & 19.539 & 19.632 & 19.650 & 19.608 \\
\hline $\mathbf{A \mathbf { l } ^ { \mathrm { T } }}$ & 2.429 & 2.462 & 2.476 & 2.532 & 2.484 & 2.558 & 2.390 & 2.527 & 2.599 & 2.508 \\
\hline $\mathrm{Fe} /(\mathrm{Fe}+\mathrm{Mg})$ & 0.598 & 0.592 & 0.603 & 0.550 & 0.608 & 0.620 & 0.598 & 0.612 & 0.622 & 0.613 \\
\hline $\mathrm{Mg} /(\mathrm{Mg}+\mathrm{Fe})$ & 0.402 & 0.408 & 0.397 & 0.450 & 0.392 & 0.380 & 0.402 & 0.388 & 0.378 & 0.387 \\
\hline $\mathbf{T}(\mathbf{K})$ & 930.6 & 933.3 & 932.9 & 879.0 & 915.0 & 903.5 & 921.7 & 913.4 & 913.2 & 915.7 \\
\hline $\mathrm{T}\left({ }^{\circ} \mathrm{C}\right)$ & 657.4 & 660.1 & 659.7 & 605.9 & 641.8 & 630.3 & 648.6 & 640.2 & 640.1 & 642.6 \\
\hline
\end{tabular}


Tabela B4 - continuação

\section{PLÚTON INDAIATUBA}

\section{AMOSTRA CAB-15-34.2}

\begin{tabular}{|c|c|c|c|c|c|c|c|c|c|c|c|c|}
\hline & 1 & 2 & 3 & 4 & 5 & 6 & 7 & 8 & 9 & 10 & 11 & 12 \\
\hline $\mathrm{SiO}_{2}$ & 36.82 & 36.64 & 36.88 & 36.48 & 36.88 & 36.94 & 36.50 & 37.52 & 37.59 & 36.26 & 37.23 & 35.83 \\
\hline $\mathrm{TiO}_{2}$ & 3.66 & 3.79 & 3.66 & 3.25 & 3.29 & 2.55 & 2.56 & 2.27 & 2.49 & 2.91 & 3.31 & 2.87 \\
\hline $\mathbf{A l}_{2} \mathbf{O}_{3}$ & 13.49 & 13.64 & 13.60 & 13.67 & 13.85 & 14.11 & 14.05 & 14.44 & 14.81 & 14.23 & 13.79 & 14.91 \\
\hline $\mathrm{FeO}$ & 23.61 & 24.07 & 23.81 & 22.82 & 23.45 & 23.56 & 21.76 & 21.47 & 21.43 & 21.84 & 22.30 & 22.73 \\
\hline MnO & 0.34 & 0.35 & 0.31 & 0.36 & 0.35 & 0.37 & 0.25 & 0.23 & 0.22 & 0.27 & 0.28 & 0.27 \\
\hline MgO & 8.97 & 8.57 & 8.94 & 9.31 & 8.71 & 9.22 & 9.09 & 9.76 & 9.54 & 9.20 & 9.15 & 8.77 \\
\hline $\mathrm{CaO}$ & 0.04 & 0.00 & 0.00 & 0.03 & 0.01 & 0.04 & 1.74 & 0.52 & 0.41 & 0.01 & 0.08 & 0.00 \\
\hline $\mathrm{Na}_{2} \mathrm{O}$ & 0.04 & 0.05 & 0.05 & 0.08 & 0.07 & 0.04 & 0.06 & 0.08 & 0.12 & 0.04 & 0.04 & 0.05 \\
\hline $\mathbf{K}_{2} \mathbf{O}$ & 9.77 & 9.34 & 9.48 & 9.48 & 9.62 & 9.60 & 9.22 & 9.44 & 9.39 & 9.55 & 9.79 & 9.27 \\
\hline $\mathrm{BaO}$ & 0.09 & 0.72 & 0.53 & 0.01 & 0.08 & 0.04 & 0.09 & 0.05 & 0.12 & 0.49 & 0.05 & 1.14 \\
\hline $\mathrm{ZnO}$ & 0.06 & 0.04 & 0.05 & 0.04 & 0.14 & 0.00 & 0.02 & 0.10 & 0.00 & 0.01 & 0.11 & 0.09 \\
\hline $\mathbf{F}$ & 0.62 & 0.56 & 0.59 & 0.53 & 0.54 & 0.66 & 0.76 & 0.87 & 0.83 & 0.57 & 0.77 & 0.68 \\
\hline Cl & 0.01 & 0.06 & 0.05 & 0.01 & 0.03 & 0.07 & 0.04 & 0.04 & 0.03 & 0.03 & 0.06 & 0.05 \\
\hline $\mathrm{ZrO}_{2}$ & 0.04 & 0.00 & 0.00 & 0.00 & 0.00 & 0.00 & 0.00 & 0.00 & 0.02 & 0.02 & 0.01 & 0.01 \\
\hline $\mathrm{H}^{2} \mathrm{O}^{*}$ & 3.60 & 3.61 & 3.61 & 3.60 & 3.62 & 3.56 & 3.48 & 3.49 & 3.53 & 3.55 & 3.51 & 3.51 \\
\hline Subtotal & 101.16 & 101.44 & 101.54 & 99.67 & 100.64 & 100.75 & 99.64 & 100.28 & 100.52 & 98.99 & 100.48 & 100.19 \\
\hline $\mathrm{O}=\mathrm{F}, \mathrm{Cl}$ & 0.26 & 0.25 & 0.26 & 0.22 & 0.23 & 0.29 & 0.33 & 0.37 & 0.36 & 0.25 & 0.34 & 0.30 \\
\hline Total & 100.90 & 101.19 & 101.29 & 99.44 & 100.40 & 100.46 & 99.30 & 99.91 & 100.17 & 98.74 & 100.14 & 99.89 \\
\hline $\mathbf{S i}$ & 5.671 & 5.652 & 5.668 & 5.673 & 5.696 & 5.697 & 5.675 & 5.755 & 5.741 & 5.672 & 5.735 & 5.585 \\
\hline $\mathbf{A I}^{\mathrm{IV}}$ & 2.329 & 2.348 & 2.332 & 2.327 & 2.304 & 2.303 & 2.325 & 2.245 & 2.259 & 2.328 & 2.265 & 2.415 \\
\hline Soma $T$ & 8.000 & 8.000 & 8.000 & 8.000 & 8.000 & 8.000 & 8.000 & 8.000 & 8.000 & 8.000 & 8.000 & 8.000 \\
\hline $\mathrm{Al}^{\mathrm{VI}}$ & 0.120 & 0.132 & 0.132 & 0.179 & 0.218 & 0.262 & 0.249 & 0.365 & 0.407 & 0.296 & 0.238 & 0.324 \\
\hline
\end{tabular}


Tabela B4 - continuação

\begin{tabular}{|c|c|c|c|c|c|c|c|c|c|c|c|c|}
\hline $\mathbf{T i}$ & 0.424 & 0.440 & 0.423 & 0.380 & 0.382 & 0.296 & 0.299 & 0.262 & 0.286 & 0.342 & 0.383 & 0.336 \\
\hline $\mathbf{F e}$ & 3.041 & 3.105 & 3.060 & 2.968 & 3.029 & 3.039 & 2.829 & 2.754 & 2.737 & 2.857 & 2.873 & 2.963 \\
\hline Mn & 0.045 & 0.046 & 0.040 & 0.047 & 0.046 & 0.048 & 0.033 & 0.030 & 0.028 & 0.036 & 0.037 & 0.036 \\
\hline Mg & 2.060 & 1.971 & 2.048 & 2.158 & 2.005 & 2.120 & 2.107 & 2.232 & 2.172 & 2.145 & 2.101 & 2.038 \\
\hline $\mathbf{Z n}$ & 0.007 & 0.005 & 0.005 & 0.004 & 0.015 & 0.000 & 0.002 & 0.011 & 0.000 & 0.002 & 0.012 & 0.011 \\
\hline $\mathbf{Z r}$ & 0.003 & 0.000 & 0.000 & 0.000 & 0.000 & 0.000 & 0.000 & 0.000 & 0.002 & 0.002 & 0.001 & 0.001 \\
\hline Soma $X$ & 5.700 & 5.698 & 5.709 & 5.736 & 5.696 & 5.765 & 5.520 & 5.654 & 5.632 & 5.681 & 5.645 & 5.709 \\
\hline $\mathrm{Ca}$ & 0.006 & 0.000 & 0.000 & 0.004 & 0.002 & 0.007 & 0.290 & 0.086 & 0.066 & 0.002 & 0.012 & 0.000 \\
\hline $\mathrm{Na}$ & 0.013 & 0.015 & 0.014 & 0.025 & 0.020 & 0.012 & 0.018 & 0.023 & 0.034 & 0.012 & 0.013 & 0.015 \\
\hline K & 1.919 & 1.838 & 1.858 & 1.880 & 1.895 & 1.889 & 1.828 & 1.847 & 1.829 & 1.906 & 1.923 & 1.843 \\
\hline $\mathbf{B a}$ & 0.005 & 0.044 & 0.032 & 0.001 & 0.005 & 0.002 & 0.006 & 0.003 & 0.007 & 0.030 & 0.003 & 0.070 \\
\hline Soma $Y$ & 1.944 & 1.897 & 1.904 & 1.911 & 1.922 & 1.910 & 2.141 & 1.960 & 1.937 & 1.949 & 1.952 & 1.927 \\
\hline $\mathrm{OH}^{*}$ & 3.695 & 3.710 & 3.701 & 3.739 & 3.728 & 3.660 & 3.612 & 3.569 & 3.592 & 3.708 & 3.609 & 3.649 \\
\hline $\mathbf{F}$ & 0.301 & 0.275 & 0.287 & 0.259 & 0.265 & 0.322 & 0.376 & 0.421 & 0.400 & 0.284 & 0.376 & 0.337 \\
\hline $\mathrm{Cl}$ & 0.004 & 0.015 & 0.012 & 0.002 & 0.007 & 0.017 & 0.012 & 0.010 & 0.008 & 0.008 & 0.016 & 0.014 \\
\hline Total & 19.644 & 19.595 & 19.613 & 19.647 & 19.618 & 19.675 & 19.662 & 19.613 & 19.570 & 19.630 & 19.598 & 19.637 \\
\hline $\mathbf{A \mathbf { l } ^ { \mathrm { T } }}$ & 2.449 & 2.480 & 2.464 & 2.506 & 2.521 & 2.565 & 2.575 & 2.611 & 2.666 & 2.624 & 2.504 & 2.739 \\
\hline $\mathrm{Fe} /(\mathrm{Fe}+\mathrm{Mg})$ & 0.596 & 0.612 & 0.599 & 0.579 & 0.602 & 0.589 & 0.573 & 0.552 & 0.558 & 0.571 & 0.578 & 0.593 \\
\hline $\mathrm{Mg} /(\mathbf{M g}+\mathrm{Fe})$ & 0.404 & 0.388 & 0.401 & 0.421 & 0.398 & 0.411 & 0.427 & 0.448 & 0.442 & 0.429 & 0.422 & 0.407 \\
\hline$T(K)$ & 937.0 & 939.3 & 935.8 & 925.3 & 923.4 & 894.9 & 903.1 & 892.8 & 901.8 & 917.0 & 930.9 & 910.7 \\
\hline $\mathrm{T}\left({ }^{\circ} \mathrm{C}\right)$ & 663.9 & 666.2 & 662.7 & 652.2 & 650.2 & 621.8 & 630.0 & 619.6 & 628.7 & 643.8 & 657.7 & 637.6 \\
\hline
\end{tabular}


Tabela B4 - continuação

PLÚTON CABREÚVA

\section{AMOSTRA CAB-14-09}

\begin{tabular}{|c|c|c|c|c|c|c|c|c|c|c|c|c|}
\hline & 1 & 2 & 3 & 4 & 5 & 6 & 7 & 8 & 9 & 10 & 11 & 12 \\
\hline $\mathrm{SiO}_{2}$ & 36.10 & 36.19 & 35.96 & 36.20 & 36.12 & 36.44 & 36.19 & 36.02 & 36.60 & 36.31 & 35.58 & 35.95 \\
\hline $\mathrm{TiO}_{2}$ & 3.77 & 3.53 & 3.77 & 3.69 & 3.50 & 3.43 & 3.57 & 3.41 & 3.27 & 3.56 & 3.32 & 3.66 \\
\hline $\mathbf{A l}_{2} \mathbf{O}_{3}$ & 12.82 & 12.61 & 12.64 & 12.78 & 12.92 & 12.77 & 12.68 & 12.57 & 12.76 & 12.75 & 12.74 & 12.50 \\
\hline $\mathrm{FeO}$ & 27.27 & 27.08 & 27.14 & 27.12 & 27.06 & 27.60 & 27.61 & 27.78 & 27.47 & 27.46 & 27.18 & 27.69 \\
\hline MnO & 0.46 & 0.38 & 0.41 & 0.37 & 0.45 & 0.49 & 0.45 & 0.44 & 0.46 & 0.48 & 0.41 & 0.44 \\
\hline MgO & 7.67 & 7.55 & 7.48 & 7.69 & 7.62 & 7.57 & 7.39 & 7.44 & 7.47 & 7.72 & 7.16 & 7.52 \\
\hline $\mathrm{CaO}$ & 0.00 & 0.05 & 0.00 & 0.01 & 0.02 & 0.00 & 0.01 & 0.04 & 0.02 & 0.03 & 0.04 & 0.01 \\
\hline $\mathrm{Na}_{2} \mathrm{O}$ & 0.11 & 0.10 & 0.12 & 0.07 & 0.11 & 0.09 & 0.01 & 0.05 & 0.06 & 0.07 & 0.12 & 0.10 \\
\hline $\mathbf{K}_{2} \mathbf{O}$ & 9.09 & 9.05 & 9.13 & 9.28 & 9.15 & 9.26 & 9.22 & 9.18 & 9.15 & 9.10 & 8.91 & 9.07 \\
\hline $\mathrm{BaO}$ & 0.09 & 0.04 & 0.15 & 0.08 & 0.12 & 0.12 & 0.15 & 0.09 & 0.06 & 0.09 & 0.09 & 0.15 \\
\hline $\mathrm{ZnO}$ & 0.01 & 0.12 & 0.05 & 0.01 & 0.13 & 0.13 & 0.03 & 0.14 & 0.01 & 0.11 & 0.08 & 0.12 \\
\hline $\mathbf{F}$ & 0.86 & 0.85 & 0.99 & 0.87 & 0.81 & 0.85 & 0.94 & 0.82 & 0.80 & 0.63 & 0.84 & 0.82 \\
\hline Cl & 0.10 & 0.12 & 0.06 & 0.08 & 0.09 & 0.11 & 0.07 & 0.08 & 0.11 & 0.07 & 0.08 & 0.09 \\
\hline $\mathrm{ZrO}_{2}$ & 0.02 & 0.01 & 0.00 & 0.00 & 0.01 & 0.00 & 0.03 & 0.00 & 0.00 & 0.00 & 0.00 & 0.00 \\
\hline H2O* & 3.41 & 3.39 & 3.33 & 3.41 & 3.43 & 3.42 & 3.37 & 3.41 & 3.44 & 3.54 & 3.35 & 3.41 \\
\hline Subtotal & 101.79 & 101.08 & 101.23 & 101.66 & 101.54 & 102.30 & 101.73 & 101.47 & 101.69 & 101.91 & 99.91 & 101.53 \\
\hline $\mathrm{O}=\mathrm{F}, \mathrm{Cl}$ & 0.38 & 0.39 & 0.43 & 0.38 & 0.36 & 0.39 & 0.41 & 0.36 & 0.36 & 0.28 & 0.37 & 0.36 \\
\hline Total & 101.40 & 100.69 & 100.80 & 101.27 & 101.18 & 101.92 & 101.31 & 101.10 & 101.32 & 101.63 & 99.54 & 101.17 \\
\hline $\mathbf{S i}$ & 5.627 & 5.677 & 5.644 & 5.646 & 5.642 & 5.664 & 5.660 & 5.653 & 5.706 & 5.649 & 5.657 & 5.638 \\
\hline $\mathrm{AI}^{\mathrm{IV}}$ & 2.355 & 2.323 & 2.339 & 2.350 & 2.358 & 2.336 & 2.337 & 2.325 & 2.294 & 2.338 & 2.343 & 2.311 \\
\hline Soma T & 7.983 & 8.000 & 7.983 & 7.996 & 8.000 & 8.000 & 7.997 & 7.979 & 8.000 & 7.987 & 8.000 & 7.948 \\
\hline $\mathrm{AI}^{\mathrm{VI}}$ & 0.000 & 0.008 & 0.000 & 0.000 & 0.021 & 0.003 & 0.000 & 0.000 & 0.050 & 0.000 & 0.044 & 0.000 \\
\hline
\end{tabular}


Tabela B4 - continuação

\begin{tabular}{|c|c|c|c|c|c|c|c|c|c|c|c|c|}
\hline $\mathbf{T i}$ & 0.442 & 0.416 & 0.445 & 0.433 & 0.411 & 0.401 & 0.420 & 0.403 & 0.383 & 0.417 & 0.397 & 0.432 \\
\hline $\mathbf{F e}$ & 3.555 & 3.552 & 3.563 & 3.538 & 3.535 & 3.588 & 3.611 & 3.647 & 3.581 & 3.573 & 3.614 & 3.632 \\
\hline Mn & 0.060 & 0.050 & 0.054 & 0.049 & 0.060 & 0.065 & 0.059 & 0.059 & 0.061 & 0.063 & 0.055 & 0.059 \\
\hline Mg & 1.782 & 1.765 & 1.750 & 1.788 & 1.774 & 1.754 & 1.723 & 1.741 & 1.736 & 1.790 & 1.697 & 1.758 \\
\hline $\mathbf{Z n}$ & 0.001 & 0.014 & 0.005 & 0.001 & 0.015 & 0.015 & 0.004 & 0.016 & 0.002 & 0.012 & 0.010 & 0.014 \\
\hline $\mathbf{Z r}$ & 0.002 & 0.001 & 0.000 & 0.000 & 0.001 & 0.000 & 0.002 & 0.000 & 0.000 & 0.000 & 0.000 & 0.000 \\
\hline Soma $X$ & 5.842 & 5.808 & 5.817 & 5.809 & 5.817 & 5.826 & 5.820 & 5.865 & 5.813 & 5.855 & 5.817 & 5.894 \\
\hline $\mathrm{Ca}$ & 0.000 & 0.009 & 0.000 & 0.002 & 0.004 & 0.000 & 0.002 & 0.006 & 0.004 & 0.004 & 0.008 & 0.002 \\
\hline $\mathrm{Na}$ & 0.033 & 0.031 & 0.035 & 0.022 & 0.033 & 0.028 & 0.004 & 0.014 & 0.018 & 0.021 & 0.037 & 0.030 \\
\hline $\mathbf{K}$ & 1.807 & 1.811 & 1.828 & 1.846 & 1.823 & 1.836 & 1.839 & 1.838 & 1.819 & 1.806 & 1.807 & 1.814 \\
\hline $\mathbf{B a}$ & 0.006 & 0.002 & 0.009 & 0.005 & 0.007 & 0.007 & 0.009 & 0.006 & 0.003 & 0.005 & 0.006 & 0.009 \\
\hline Soma $Y$ & 1.847 & 1.853 & 1.873 & 1.875 & 1.867 & 1.871 & 1.854 & 1.864 & 1.845 & 1.837 & 1.858 & 1.855 \\
\hline $\mathrm{OH}^{*}$ & 3.550 & 3.546 & 3.491 & 3.551 & 3.577 & 3.550 & 3.514 & 3.571 & 3.573 & 3.672 & 3.558 & 3.572 \\
\hline F & 0.423 & 0.423 & 0.493 & 0.429 & 0.399 & 0.420 & 0.467 & 0.407 & 0.397 & 0.310 & 0.421 & 0.405 \\
\hline $\mathrm{Cl}$ & 0.027 & 0.031 & 0.016 & 0.020 & 0.024 & 0.030 & 0.019 & 0.022 & 0.030 & 0.018 & 0.022 & 0.023 \\
\hline Total & 19.671 & 19.661 & 19.673 & 19.680 & 19.684 & 19.697 & 19.671 & 19.707 & 19.658 & 19.679 & 19.675 & 19.698 \\
\hline $\mathbf{A \mathbf { I } ^ { \mathrm { T } }}$ & 2.355 & 2.331 & 2.339 & 2.350 & 2.379 & 2.339 & 2.337 & 2.325 & 2.345 & 2.338 & 2.387 & 2.311 \\
\hline $\mathrm{Fe} /(\mathrm{Fe}+\mathrm{Mg})$ & 0.666 & 0.668 & 0.671 & 0.664 & 0.666 & 0.672 & 0.677 & 0.677 & 0.674 & 0.666 & 0.680 & 0.674 \\
\hline $\mathrm{Mg} /(\mathbf{M g}+\mathrm{Fe})$ & 0.334 & 0.332 & 0.329 & 0.336 & 0.334 & 0.328 & 0.323 & 0.323 & 0.326 & 0.334 & 0.320 & 0.326 \\
\hline $\mathbf{T}(\mathbf{K})$ & 921.5 & 914.4 & 922.1 & 919.5 & 913.5 & 908.9 & 913.4 & 907.6 & 904.3 & 913.7 & 907.1 & 916.0 \\
\hline $\mathrm{T}\left({ }^{\circ} \mathrm{C}\right)$ & 648.4 & 641.2 & 649.0 & 646.4 & 640.3 & 635.8 & 640.3 & 634.4 & 631.2 & 640.6 & 633.9 & 642.9 \\
\hline
\end{tabular}


Tabela B4 - continuação

\section{PLÚTON CABREÚVA}

AMOSTRA CAB-16-80A

\begin{tabular}{|c|c|c|c|c|c|}
\hline & 1 & 2 & 3 & 4 & 5 \\
\hline $\mathrm{SiO}_{2}$ & 35.92 & 35.88 & 35.94 & 36.08 & 36.01 \\
\hline $\mathrm{TiO}_{2}$ & 3.17 & 3.50 & 3.42 & 3.26 & 4.23 \\
\hline $\mathrm{Al}_{2} \mathrm{O}_{3}$ & 12.87 & 12.64 & 12.58 & 12.58 & 12.98 \\
\hline $\mathrm{FeO}$ & 28.77 & 28.90 & 28.78 & 28.97 & 28.18 \\
\hline MnO & 0.46 & 0.48 & 0.60 & 0.46 & 0.47 \\
\hline MgO & 5.69 & 5.65 & 5.91 & 5.88 & 5.39 \\
\hline $\mathrm{CaO}$ & 0.05 & 0.03 & 0.01 & 0.04 & 0.05 \\
\hline $\mathrm{Na}_{2} \mathrm{O}$ & 0.04 & 0.08 & 0.05 & 0.07 & 0.05 \\
\hline $\mathbf{K}_{2} \mathbf{O}$ & 9.13 & 9.23 & 9.19 & 9.17 & 9.06 \\
\hline $\mathrm{BaO}$ & 0.00 & 0.00 & 0.04 & 0.07 & 0.01 \\
\hline $\mathrm{ZnO}$ & 0.09 & 0.07 & 0.08 & 0.08 & 0.02 \\
\hline $\mathbf{F}$ & 0.24 & 0.26 & 0.43 & 0.22 & 0.31 \\
\hline Cl & 0.06 & 0.08 & 0.12 & 0.09 & 0.10 \\
\hline $\mathrm{ZrO}_{2}$ & 0.00 & 0.04 & 0.01 & 0.00 & 0.00 \\
\hline $\mathrm{H}^{2} \mathrm{O}^{*}$ & 3.64 & 3.63 & 3.55 & 3.65 & 3.63 \\
\hline Subtotal & 100.14 & 100.46 & 100.71 & 100.63 & 100.47 \\
\hline $\mathrm{O}=\mathrm{F}, \mathrm{Cl}$ & 0.12 & 0.13 & 0.21 & 0.11 & 0.15 \\
\hline Total & 100.02 & 100.33 & 100.50 & 100.52 & 100.32 \\
\hline $\mathbf{S i}$ & 5.715 & 5.702 & 5.702 & 5.721 & 5.690 \\
\hline $\mathrm{AI}^{\mathrm{IV}}$ & 2.285 & 2.298 & 2.298 & 2.279 & 2.310 \\
\hline Soma T & 8.000 & 8.000 & 8.000 & 8.000 & 8.000 \\
\hline $\mathbf{A l}^{\mathrm{VI}}$ & 0.128 & 0.069 & 0.055 & 0.073 & 0.108 \\
\hline
\end{tabular}


Tabela B4 - continuação

\begin{tabular}{llllll}
\hline $\mathbf{T i}$ & 0.379 & 0.418 & 0.408 & 0.389 & 0.503 \\
\hline $\mathbf{F e}$ & 3.828 & 3.841 & 3.819 & 3.842 & 3.724 \\
\hline $\mathbf{M n}$ & 0.062 & 0.064 & 0.080 & 0.062 & 0.063 \\
\hline $\mathbf{M g}$ & 1.349 & 1.338 & 1.398 & 1.390 & 1.270 \\
\hline $\mathbf{Z n}$ & 0.010 & 0.008 & 0.009 & 0.010 & 0.002 \\
\hline $\mathbf{Z r}$ & 0.000 & 0.003 & 0.001 & 0.000 & 0.000 \\
\hline Soma $\mathbf{X}$ & 5.758 & 5.742 & 5.770 & 5.766 & 5.669 \\
\hline $\mathbf{C a}$ & & & & & \\
\hline $\mathbf{N a}$ & 0.008 & 0.004 & 0.002 & 0.007 & 0.008 \\
\hline $\mathbf{K}$ & 0.012 & 0.023 & 0.016 & 0.021 & 0.015 \\
\hline $\mathbf{B a}$ & 1.853 & 1.871 & 1.860 & 1.855 & 1.826 \\
\hline Soma $\mathbf{Y}$ & 0.000 & 0.000 & 0.003 & 0.004 & 0.000 \\
\hline & 1.874 & 1.898 & 1.880 & 1.886 & 1.850 \\
\hline $\mathbf{O H}{ }^{*}$ & 3.861 & 3.848 & 3.753 & 3.864 & 3.822 \\
\hline $\mathbf{F}$ & 0.121 & 0.131 & 0.214 & 0.113 & 0.153 \\
\hline $\mathbf{C l}$ & 0.017 & 0.021 & 0.033 & 0.024 & 0.026 \\
\hline Total & 19.632 & 19.640 & 19.650 & 19.652 & 19.519 \\
\hline & & & & & \\
\hline $\mathbf{A l}{ }^{\mathbf{T}}$ & 2.413 & 2.368 & 2.353 & 2.351 & 2.418 \\
\hline $\mathbf{F e} /(\mathbf{F e}+\mathbf{M g})$ & 0.739 & 0.742 & 0.732 & 0.734 & 0.746 \\
\hline $\mathbf{M g} /(\mathbf{M g}+\mathbf{F e})$ & 0.261 & 0.258 & 0.268 & 0.266 & 0.254 \\
\hline & & & & & \\
\hline $\mathbf{T}(\mathbf{K})$ & 896.6 & 906.1 & 904.1 & 898.7 & 932.4 \\
\hline $\mathbf{T}\left({ }^{\circ} \mathbf{C}\right)$ & 623.5 & 633.0 & 631.0 & 625.5 & 659.3 \\
\hline & & & & & \\
\hline & & & & & \\
\hline
\end{tabular}


Tabela B4 - continuação

\section{PLÚTON CABREÚVA}

\section{AMOSTRA CAB-16-90}

\begin{tabular}{|c|c|c|c|c|c|c|c|c|c|}
\hline & 1 & 2 & 3 & 4 & 5 & 6 & 7 & 8 & 9 \\
\hline $\mathrm{SiO}_{2}$ & 34.76 & 34.86 & 34.98 & 34.75 & 33.56 & 35.28 & 34.82 & 35.03 & 34.86 \\
\hline $\mathrm{TiO}_{2}$ & 3.36 & 3.38 & 3.62 & 3.56 & 3.38 & 3.55 & 3.28 & 3.58 & 3.66 \\
\hline $\mathbf{A l}_{2} \mathbf{O}_{3}$ & 12.67 & 12.70 & 13.05 & 12.81 & 12.27 & 12.72 & 12.37 & 12.77 & 12.80 \\
\hline $\mathrm{FeO}$ & 31.18 & 30.79 & 30.71 & 31.15 & 32.42 & 31.58 & 31.92 & 31.14 & 31.04 \\
\hline MnO & 0.38 & 0.37 & 0.39 & 0.31 & 0.40 & 0.34 & 0.37 & 0.43 & 0.38 \\
\hline MgO & 4.34 & 4.47 & 4.32 & 4.61 & 4.40 & 4.42 & 4.43 & 4.35 & 4.37 \\
\hline $\mathrm{CaO}$ & 0.02 & 0.00 & 0.00 & 0.00 & 0.03 & 0.01 & 0.01 & 0.01 & 0.01 \\
\hline $\mathrm{Na}_{2} \mathrm{O}$ & 0.06 & 0.03 & 0.06 & 0.09 & 0.05 & 0.07 & 0.09 & 0.07 & 0.07 \\
\hline $\mathbf{K}_{2} \mathbf{O}$ & 8.98 & 9.04 & 8.88 & 8.86 & 8.22 & 8.78 & 8.87 & 8.78 & 9.11 \\
\hline $\mathrm{BaO}$ & 0.16 & 0.17 & 0.15 & 0.06 & 0.15 & 0.15 & 0.13 & 0.11 & 0.17 \\
\hline $\mathrm{ZnO}$ & 0.08 & 0.00 & 0.04 & 0.10 & 0.13 & 0.08 & 0.22 & 0.09 & 0.05 \\
\hline $\mathbf{F}$ & 0.30 & 0.28 & 0.33 & 0.31 & 0.24 & 0.39 & 0.50 & 0.30 & 0.37 \\
\hline Cl & 0.11 & 0.11 & 0.14 & 0.14 & 0.10 & 0.11 & 0.12 & 0.13 & 0.12 \\
\hline $\mathrm{ZrO}_{2}$ & 0.01 & 0.00 & 0.01 & 0.00 & 0.02 & 0.02 & 0.01 & 0.00 & 0.00 \\
\hline H2O* & 3.53 & 3.54 & 3.54 & 3.54 & 3.50 & 3.53 & 3.44 & 3.55 & 3.52 \\
\hline Subtotal & 99.95 & 99.75 & 100.21 & 100.28 & 98.87 & 101.05 & 100.56 & 100.35 & 100.54 \\
\hline $\mathrm{O}=\mathrm{F}, \mathrm{Cl}$ & 0.15 & 0.14 & 0.17 & 0.16 & 0.12 & 0.19 & 0.24 & 0.16 & 0.18 \\
\hline Total & 99.79 & 99.60 & 100.04 & 100.12 & 98.75 & 100.86 & 100.33 & 100.19 & 100.35 \\
\hline $\mathbf{S i}$ & 5.632 & 5.645 & 5.627 & 5.600 & 5.534 & 5.645 & 5.632 & 5.637 & 5.612 \\
\hline $\mathbf{A I}^{I^{\mathbf{V}}}$ & 2.368 & 2.355 & 2.373 & 2.400 & 2.385 & 2.355 & 2.358 & 2.363 & 2.388 \\
\hline Soma $T$ & 8.000 & 8.000 & 8.000 & 8.000 & 7.919 & 8.000 & 7.990 & 8.000 & 8.000 \\
\hline $\mathrm{Al}^{\mathrm{VI}}$ & 0.052 & 0.069 & 0.102 & 0.033 & 0.000 & 0.044 & 0.000 & 0.060 & 0.041 \\
\hline
\end{tabular}


Tabela B4 - continuação

\begin{tabular}{|c|c|c|c|c|c|c|c|c|c|}
\hline $\mathbf{T i}$ & 0.409 & 0.412 & 0.438 & 0.431 & 0.419 & 0.427 & 0.399 & 0.433 & 0.443 \\
\hline $\mathrm{Fe}$ & 4.225 & 4.170 & 4.132 & 4.198 & 4.471 & 4.226 & 4.318 & 4.191 & 4.179 \\
\hline Mn & 0.052 & 0.051 & 0.052 & 0.043 & 0.056 & 0.047 & 0.050 & 0.059 & 0.052 \\
\hline Mg & 1.048 & 1.079 & 1.036 & 1.107 & 1.082 & 1.054 & 1.068 & 1.044 & 1.049 \\
\hline $\mathbf{Z n}$ & 0.010 & 0.000 & 0.005 & 0.011 & 0.016 & 0.010 & 0.026 & 0.011 & 0.006 \\
\hline $\mathbf{Z r}$ & 0.001 & 0.000 & 0.001 & 0.000 & 0.002 & 0.001 & 0.001 & 0.000 & 0.000 \\
\hline Soma X & 5.798 & 5.781 & 5.766 & 5.824 & 6.046 & 5.808 & 5.862 & 5.797 & 5.771 \\
\hline $\mathrm{Ca}$ & 0.003 & 0.000 & 0.000 & 0.000 & 0.005 & 0.002 & 0.001 & 0.003 & 0.002 \\
\hline $\mathrm{Na}$ & 0.018 & 0.011 & 0.020 & 0.027 & 0.016 & 0.022 & 0.027 & 0.022 & 0.023 \\
\hline $\mathbf{K}$ & 1.856 & 1.867 & 1.822 & 1.821 & 1.729 & 1.792 & 1.830 & 1.802 & 1.871 \\
\hline Ba & 0.010 & 0.011 & 0.009 & 0.004 & 0.010 & 0.010 & 0.008 & 0.007 & 0.011 \\
\hline Soma $Y$ & 1.887 & 1.889 & 1.852 & 1.852 & 1.760 & 1.826 & 1.866 & 1.834 & 1.906 \\
\hline $\mathrm{OH}^{*}$ & 3.814 & 3.827 & 3.795 & 3.807 & 3.848 & 3.771 & 3.712 & 3.810 & 3.779 \\
\hline $\mathbf{F}$ & 0.156 & 0.142 & 0.168 & 0.156 & 0.125 & 0.198 & 0.256 & 0.154 & 0.189 \\
\hline Cl & 0.031 & 0.031 & 0.037 & 0.037 & 0.027 & 0.031 & 0.032 & 0.036 & 0.032 \\
\hline Total & 19.685 & 19.670 & 19.618 & 19.676 & 19.725 & 19.634 & 19.718 & 19.630 & 19.677 \\
\hline $\mathbf{A l ^ { \mathrm { T } }}$ & 2.420 & 2.424 & 2.475 & 2.433 & 2.385 & 2.399 & 2.358 & 2.422 & 2.429 \\
\hline $\mathbf{F e} /(\mathbf{F e}+\mathbf{M g})$ & 0.801 & 0.794 & 0.800 & 0.791 & 0.805 & 0.800 & 0.802 & 0.801 & 0.799 \\
\hline $\mathrm{Mg} /(\mathrm{Mg}+\mathrm{Fe})$ & 0.199 & 0.206 & 0.200 & 0.209 & 0.195 & 0.200 & 0.198 & 0.199 & 0.201 \\
\hline $\mathbf{T}(\mathbf{K})$ & 894.5 & 896.3 & 903.3 & 900.2 & 891.5 & 898.6 & 890.3 & 900.8 & 903.3 \\
\hline $\mathrm{T}\left({ }^{\circ} \mathrm{C}\right)$ & 621.4 & 623.1 & 630.2 & 627.0 & 618.4 & 625.4 & 617.1 & 627.6 & 630.2 \\
\hline
\end{tabular}


Tabela B4 - continuação

\section{PLÚTON CABREÚVA}

\section{AMOSTRA CAB-16-91B}

\begin{tabular}{|c|c|c|c|}
\hline & 1 & 2 & 3 \\
\hline $\mathrm{SiO}_{2}$ & 36.36 & 36.69 & 36.16 \\
\hline $\mathrm{TiO}_{2}$ & 3.26 & 2.85 & 3.01 \\
\hline $\mathrm{Al}_{2} \mathrm{O}_{3}$ & 12.46 & 12.67 & 12.52 \\
\hline $\mathrm{FeO}$ & 27.42 & 27.16 & 27.22 \\
\hline MnO & 0.40 & 0.42 & 0.45 \\
\hline MgO & 7.59 & 7.72 & 7.36 \\
\hline $\mathrm{CaO}$ & 0.00 & 0.00 & 0.04 \\
\hline $\mathrm{Na}_{2} \mathrm{O}$ & 0.07 & 0.05 & 0.09 \\
\hline $\mathbf{K}_{2} \mathbf{O}$ & 9.36 & 9.18 & 9.18 \\
\hline $\mathrm{BaO}$ & 0.18 & 0.07 & 0.19 \\
\hline $\mathrm{ZnO}$ & 0.12 & 0.08 & 0.10 \\
\hline $\mathbf{F}$ & 1.37 & 1.35 & 1.39 \\
\hline CI & 0.18 & 0.15 & 0.18 \\
\hline $\mathrm{ZrO}_{2}$ & 0.02 & 0.00 & 0.00 \\
\hline H2O* & 3.13 & 3.16 & 3.09 \\
\hline Subtotal & 101.92 & 101.54 & 100.98 \\
\hline $\mathrm{O}=\mathrm{F}, \mathrm{Cl}$ & 0.62 & 0.60 & 0.63 \\
\hline Total & 101.30 & 100.94 & 100.35 \\
\hline $\mathbf{S i}$ & 5.695 & 5.740 & 5.714 \\
\hline $\mathbf{A l}^{I^{\mathrm{IV}}}$ & 2.300 & 2.260 & 2.286 \\
\hline Soma T & 7.996 & 8.000 & 8.000 \\
\hline $\mathbf{A l}^{\mathrm{VI}}$ & 0.000 & 0.076 & 0.045 \\
\hline
\end{tabular}


Tabela B4 - continuação

\begin{tabular}{llll}
\hline $\mathbf{T i}$ & 0.384 & 0.335 & 0.358 \\
\hline $\mathbf{F e}$ & 3.592 & 3.553 & 3.597 \\
\hline $\mathbf{M n}$ & 0.053 & 0.056 & 0.060 \\
\hline $\mathbf{M g}$ & 1.772 & 1.800 & 1.734 \\
\hline $\mathbf{Z n}$ & 0.014 & 0.009 & 0.011 \\
\hline $\mathbf{Z r}$ & 0.001 & 0.000 & 0.000 \\
\hline Soma $\boldsymbol{X}$ & 5.817 & 5.829 & 5.805 \\
\hline $\mathbf{C a}$ & 0.000 & 0.000 & 0.006 \\
\hline $\mathbf{N a}$ & 0.021 & 0.015 & 0.028 \\
\hline $\mathbf{K}$ & 1.870 & 1.832 & 1.850 \\
\hline Ba & 0.011 & 0.004 & 0.012 \\
\hline Soma $\boldsymbol{Y}$ & 1.902 & 1.851 & 1.896 \\
\hline & & & \\
\hline OH* & 3.274 & 3.293 & 3.257 \\
\hline $\mathbf{F}$ & 0.679 & 0.668 & 0.695 \\
\hline Cl & 0.047 & 0.039 & 0.049 \\
\hline & & &
\end{tabular}

Total

$\begin{array}{lll}19.715 & 19.680 & 19.702\end{array}$

\begin{tabular}{llll}
\hline $\mathbf{A l}^{\mathbf{T}}$ & 2.300 & 2.336 & 2.332 \\
\hline $\mathbf{F e} /(\mathbf{F e}+\mathbf{M g})$ & 0.670 & 0.664 & 0.675 \\
\hline $\mathbf{M g} /(\mathbf{M g}+\mathbf{F e})$ & 0.330 & 0.336 & 0.325
\end{tabular}

\begin{tabular}{llll}
\hline $\mathbf{T}(\mathbf{K})$ & 904.2 & 892.1 & 897.0 \\
\hline $\mathbf{T}\left({ }^{\circ} \mathbf{C}\right)$ & 631.0 & 619.0 & 623.8
\end{tabular}


Tabela B4 - continuação

\section{PLÚTON ITUPEVA}

\section{AMOSTRA CAB-15-36}

\begin{tabular}{|c|c|c|c|c|c|c|c|c|c|c|c|c|}
\hline & 1 & 2 & 3 & 4 & 5 & 6 & 7 & 8 & 9 & 10 & 11 & 12 \\
\hline $\mathrm{SiO}_{2}$ & 37.32 & 37.55 & 37.61 & 37.56 & 37.32 & 37.47 & 37.25 & 37.64 & 37.76 & 37.33 & 37.21 & 37.36 \\
\hline $\mathrm{TiO}_{2}$ & 3.16 & 3.46 & 3.10 & 3.17 & 3.47 & 3.62 & 3.43 & 3.15 & 3.46 & 3.30 & 3.22 & 3.38 \\
\hline $\mathbf{A l}_{2} \mathbf{O}_{3}$ & 13.13 & 13.14 & 13.06 & 13.39 & 13.04 & 12.78 & 12.82 & 13.07 & 12.97 & 12.73 & 12.76 & 12.54 \\
\hline $\mathrm{FeO}$ & 21.88 & 22.08 & 21.64 & 21.58 & 22.25 & 21.93 & 22.58 & 21.76 & 22.18 & 22.02 & 21.58 & 22.19 \\
\hline MnO & 0.58 & 0.67 & 0.58 & 0.62 & 0.59 & 0.56 & 0.73 & 0.65 & 0.70 & 0.54 & 0.58 & 0.58 \\
\hline MgO & 10.43 & 10.27 & 10.73 & 10.52 & 10.29 & 10.20 & 10.19 & 10.38 & 10.12 & 10.34 & 10.37 & 10.48 \\
\hline $\mathrm{CaO}$ & 0.01 & 0.01 & 0.01 & 0.02 & 0.00 & 0.00 & 0.02 & 0.00 & 0.00 & 0.00 & 0.04 & 0.03 \\
\hline $\mathrm{Na}_{2} \mathrm{O}$ & 0.09 & 0.10 & 0.12 & 0.09 & 0.10 & 0.09 & 0.10 & 0.13 & 0.13 & 0.12 & 0.11 & 0.15 \\
\hline $\mathbf{K}_{2} \mathbf{O}$ & 9.60 & 9.46 & 9.57 & 9.58 & 9.52 & 9.50 & 9.36 & 9.52 & 9.30 & 9.43 & 9.18 & 9.46 \\
\hline $\mathrm{BaO}$ & 0.08 & 0.03 & 0.05 & 0.04 & 0.11 & 0.01 & 0.03 & 0.00 & 0.11 & 0.12 & 0.02 & 0.02 \\
\hline $\mathrm{ZnO}$ & 0.18 & 0.08 & 0.07 & 0.12 & 0.15 & 0.05 & 0.07 & 0.12 & 0.14 & 0.12 & 0.14 & 0.06 \\
\hline $\mathbf{F}$ & 0.12 & 0.10 & 0.10 & 0.10 & 0.12 & 0.09 & 0.11 & 0.13 & 0.10 & 0.11 & 0.09 & 0.06 \\
\hline Cl & 1.33 & 1.22 & 1.24 & 1.25 & 1.18 & 1.24 & 1.20 & 1.10 & 0.98 & 1.10 & 1.10 & 1.26 \\
\hline $\mathrm{ZrO}_{2}$ & 0.00 & 0.00 & 0.00 & 0.00 & 0.04 & 0.02 & 0.00 & 0.00 & 0.00 & 0.00 & 0.03 & 0.00 \\
\hline $\mathrm{H}^{2} \mathrm{O}^{*}$ & 3.51 & 3.57 & 3.56 & 3.57 & 3.56 & 3.55 & 3.54 & 3.57 & 3.63 & 3.56 & 3.55 & 3.55 \\
\hline Subtotal & 101.42 & 101.74 & 101.45 & 101.61 & 101.73 & 101.11 & 101.44 & 101.23 & 101.57 & 100.82 & 99.97 & 101.11 \\
\hline $\mathrm{O}=\mathrm{F}, \mathrm{Cl}$ & 0.35 & 0.32 & 0.32 & 0.32 & 0.31 & 0.32 & 0.32 & 0.30 & 0.26 & 0.30 & 0.29 & 0.31 \\
\hline Total & 101.07 & 101.43 & 101.13 & 101.29 & 101.41 & 100.80 & 101.12 & 100.93 & 101.31 & 100.53 & 99.69 & 100.80 \\
\hline $\mathrm{Si}$ & 5.728 & 5.733 & 5.751 & 5.732 & 5.713 & 5.756 & 5.724 & 5.765 & 5.765 & 5.756 & 5.767 & 5.751 \\
\hline $\mathrm{Al}^{\mathrm{IV}}$ & 2.272 & 2.267 & 2.249 & 2.268 & 2.287 & 2.244 & 2.276 & 2.235 & 2.235 & 2.244 & 2.233 & 2.249 \\
\hline Soma T & 8.000 & 8.000 & 8.000 & 8.000 & 8.000 & 8.000 & 8.000 & 8.000 & 8.000 & 8.000 & 8.000 & 8.000 \\
\hline $\mathbf{A l}^{\mathrm{VI}}$ & 0.104 & 0.098 & 0.105 & 0.141 & 0.066 & 0.070 & 0.046 & 0.125 & 0.100 & 0.069 & 0.097 & 0.027 \\
\hline
\end{tabular}


Tabela B4 - continuação

\begin{tabular}{|c|c|c|c|c|c|c|c|c|c|c|c|c|}
\hline Ti & 0.365 & 0.397 & 0.357 & 0.364 & 0.399 & 0.418 & 0.396 & 0.363 & 0.397 & 0.383 & 0.375 & 0.391 \\
\hline $\mathbf{F e}$ & 2.809 & 2.819 & 2.768 & 2.755 & 2.849 & 2.817 & 2.902 & 2.787 & 2.832 & 2.839 & 2.797 & 2.857 \\
\hline Mn & 0.075 & 0.087 & 0.075 & 0.080 & 0.076 & 0.073 & 0.096 & 0.085 & 0.090 & 0.071 & 0.076 & 0.076 \\
\hline Mg & 2.387 & 2.337 & 2.446 & 2.393 & 2.348 & 2.336 & 2.334 & 2.370 & 2.303 & 2.377 & 2.396 & 2.405 \\
\hline $\mathbf{Z n}$ & 0.020 & 0.009 & 0.008 & 0.014 & 0.017 & 0.006 & 0.008 & 0.014 & 0.016 & 0.014 & 0.016 & 0.007 \\
\hline $\mathbf{Z r}$ & 0.000 & 0.000 & 0.000 & 0.000 & 0.003 & 0.001 & 0.000 & 0.000 & 0.000 & 0.000 & 0.002 & 0.000 \\
\hline Soma $X$ & 5.759 & 5.748 & 5.758 & 5.747 & 5.758 & 5.722 & 5.781 & 5.743 & 5.739 & 5.752 & 5.759 & 5.763 \\
\hline $\mathrm{Ca}$ & 0.002 & 0.001 & 0.002 & 0.003 & 0.000 & 0.000 & 0.004 & 0.000 & 0.000 & 0.000 & 0.007 & 0.005 \\
\hline $\mathrm{Na}$ & 0.027 & 0.031 & 0.037 & 0.027 & 0.030 & 0.027 & 0.029 & 0.039 & 0.038 & 0.036 & 0.033 & 0.043 \\
\hline K & 1.880 & 1.842 & 1.867 & 1.865 & 1.859 & 1.861 & 1.835 & 1.860 & 1.811 & 1.855 & 1.815 & 1.858 \\
\hline $\mathbf{B a}$ & 0.005 & 0.002 & 0.003 & 0.003 & 0.006 & 0.001 & 0.002 & 0.000 & 0.006 & 0.007 & 0.001 & 0.001 \\
\hline Soma $Y$ & 1.913 & 1.876 & 1.908 & 1.898 & 1.895 & 1.890 & 1.869 & 1.898 & 1.856 & 1.898 & 1.855 & 1.907 \\
\hline $\mathrm{OH}^{*}$ & 3.597 & 3.637 & 3.629 & 3.630 & 3.638 & 3.634 & 3.634 & 3.651 & 3.699 & 3.658 & 3.665 & 3.644 \\
\hline $\mathbf{F}$ & 0.057 & 0.047 & 0.050 & 0.047 & 0.056 & 0.043 & 0.054 & 0.063 & 0.049 & 0.055 & 0.046 & 0.027 \\
\hline $\mathrm{Cl}$ & 0.346 & 0.316 & 0.321 & 0.323 & 0.306 & 0.323 & 0.313 & 0.286 & 0.253 & 0.287 & 0.289 & 0.329 \\
\hline Total & 19.672 & 19.624 & 19.667 & 19.645 & 19.653 & 19.612 & 19.651 & 19.642 & 19.595 & 19.650 & 19.614 & 19.670 \\
\hline $\mathbf{A \mathbf { l } ^ { \mathrm { T } }}$ & 2.376 & 2.365 & 2.354 & 2.409 & 2.353 & 2.314 & 2.322 & 2.360 & 2.334 & 2.313 & 2.331 & 2.275 \\
\hline $\mathrm{Fe} /(\mathrm{Fe}+\mathrm{Mg})$ & 0.541 & 0.547 & 0.531 & 0.535 & 0.548 & 0.547 & 0.554 & 0.540 & 0.551 & 0.544 & 0.539 & 0.543 \\
\hline $\mathrm{Mg} /(\mathbf{M g}+\mathrm{Fe})$ & 0.459 & 0.453 & 0.469 & 0.465 & 0.452 & 0.453 & 0.446 & 0.460 & 0.449 & 0.456 & 0.461 & 0.457 \\
\hline $\mathbf{T}(\mathbf{K})$ & 927.2 & 938.6 & 926.1 & 929.5 & 937.9 & 946.6 & 934.1 & 927.5 & 938.0 & 932.2 & 931.6 & 934.5 \\
\hline $\mathrm{T}\left({ }^{\circ} \mathrm{C}\right)$ & 654.0 & 665.5 & 652.9 & 656.3 & 664.8 & 673.5 & 661.0 & 654.3 & 664.8 & 659.1 & 658.5 & 661.4 \\
\hline
\end{tabular}


Tabela B4 - continuação

\section{PLÚTON ITUPEVA}

\begin{tabular}{|c|c|c|c|c|c|c|c|c|c|}
\hline \multicolumn{10}{|c|}{ AMOSTRA CAB-16-98 } \\
\hline & 1 & 2 & 3 & 4 & 5 & 6 & 7 & 8 & 9 \\
\hline $\mathrm{SiO}_{2}$ & 37.68 & 36.97 & 37.82 & 37.44 & 37.55 & 36.75 & 36.24 & 37.12 & 37.55 \\
\hline $\mathrm{TiO}_{2}$ & 1.97 & 1.98 & 2.00 & 2.00 & 1.82 & 1.37 & 1.71 & 2.49 & 2.37 \\
\hline $\mathbf{A l}_{2} \mathbf{O}_{3}$ & 15.06 & 15.15 & 15.38 & 15.30 & 15.45 & 15.84 & 14.80 & 15.04 & 15.37 \\
\hline $\mathrm{FeO}$ & 20.32 & 19.48 & 19.65 & 19.60 & 19.42 & 19.81 & 20.63 & 20.64 & 19.86 \\
\hline MnO & 0.55 & 0.57 & 0.54 & 0.60 & 0.53 & 0.60 & 0.57 & 0.60 & 0.58 \\
\hline MgO & 11.21 & 11.77 & 11.21 & 11.49 & 11.43 & 11.82 & 11.51 & 10.41 & 11.04 \\
\hline $\mathrm{CaO}$ & 0.09 & 0.02 & 0.00 & 0.04 & 0.04 & 0.06 & 0.09 & 0.06 & 0.02 \\
\hline $\mathrm{Na}_{2} \mathrm{O}$ & 0.10 & 0.05 & 0.08 & 0.06 & 0.08 & 0.04 & 0.06 & 0.08 & 0.03 \\
\hline $\mathbf{K}_{2} \mathbf{O}$ & 9.19 & 9.61 & 9.65 & 9.68 & 9.52 & 9.21 & 9.44 & 9.36 & 9.61 \\
\hline $\mathrm{BaO}$ & 0.21 & 0.19 & 0.27 & 0.23 & 0.22 & 0.12 & 0.17 & 0.20 & 0.26 \\
\hline $\mathrm{ZnO}$ & 0.05 & 0.04 & 0.06 & 0.08 & 0.04 & 0.07 & 0.16 & 0.01 & 0.08 \\
\hline $\mathbf{F}$ & 0.46 & 0.61 & 0.48 & 0.53 & 0.64 & 0.55 & 0.56 & 0.60 & 0.43 \\
\hline $\mathrm{Cl}$ & 0.01 & 0.02 & 0.00 & 0.04 & 0.02 & 0.00 & 0.00 & 0.04 & 0.01 \\
\hline $\mathrm{ZrO}_{2}$ & 0.01 & 0.03 & 0.03 & 0.00 & 0.00 & 0.00 & 0.00 & 0.02 & 0.00 \\
\hline $\mathrm{H}^{2} \mathrm{O}^{*}$ & 3.74 & 3.64 & 3.75 & 3.70 & 3.65 & 3.68 & 3.62 & 3.63 & 3.77 \\
\hline Subtotal & 100.65 & 100.12 & 100.92 & 100.79 & 100.41 & 99.91 & 99.55 & 100.30 & 100.97 \\
\hline $\mathrm{O}=\mathrm{F}, \mathrm{Cl}$ & 0.20 & 0.26 & 0.20 & 0.23 & 0.28 & 0.23 & 0.24 & 0.26 & 0.18 \\
\hline Total & 100.45 & 99.86 & 100.72 & 100.56 & 100.13 & 99.68 & 99.31 & 100.04 & 100.78 \\
\hline $\mathbf{S i}$ & 5.705 & 5.635 & 5.704 & 5.665 & 5.690 & 5.601 & 5.596 & 5.668 & 5.669 \\
\hline $\mathrm{Al}^{\mathrm{IV}^{\mathrm{V}}}$ & 2.295 & 2.365 & 2.296 & 2.335 & 2.310 & 2.399 & 2.404 & 2.332 & 2.331 \\
\hline Soma T & 8.000 & 8.000 & 8.000 & 8.000 & 8.000 & 8.000 & 8.000 & 8.000 & 8.000 \\
\hline $\mathbf{A l}^{\mathrm{VI}}$ & 0.393 & 0.356 & 0.439 & 0.394 & 0.449 & 0.447 & 0.290 & 0.375 & 0.404 \\
\hline
\end{tabular}


Tabela B4 - continuação

\begin{tabular}{|c|c|c|c|c|c|c|c|c|c|}
\hline $\mathbf{T i}$ & 0.224 & 0.227 & 0.227 & 0.228 & 0.207 & 0.158 & 0.199 & 0.286 & 0.269 \\
\hline $\mathrm{Fe}$ & 2.573 & 2.483 & 2.479 & 2.480 & 2.461 & 2.525 & 2.664 & 2.636 & 2.507 \\
\hline Mn & 0.071 & 0.073 & 0.069 & 0.076 & 0.068 & 0.078 & 0.074 & 0.077 & 0.074 \\
\hline Mg & 2.530 & 2.674 & 2.521 & 2.592 & 2.582 & 2.686 & 2.650 & 2.370 & 2.484 \\
\hline $\mathbf{Z n}$ & 0.005 & 0.004 & 0.007 & 0.009 & 0.004 & 0.008 & 0.018 & 0.001 & 0.009 \\
\hline $\mathbf{Z r}$ & 0.001 & 0.002 & 0.002 & 0.000 & 0.000 & 0.000 & 0.000 & 0.002 & 0.000 \\
\hline Soma X & 5.797 & 5.820 & 5.743 & 5.780 & 5.772 & 5.901 & 5.895 & 5.746 & 5.747 \\
\hline $\mathrm{Ca}$ & 0.014 & 0.003 & 0.000 & 0.006 & 0.006 & 0.010 & 0.015 & 0.010 & 0.003 \\
\hline $\mathbf{N a}$ & 0.031 & 0.016 & 0.023 & 0.019 & 0.023 & 0.011 & 0.018 & 0.023 & 0.009 \\
\hline $\mathbf{K}$ & 1.775 & 1.868 & 1.857 & 1.868 & 1.840 & 1.791 & 1.859 & 1.823 & 1.850 \\
\hline $\mathbf{B a}$ & 0.012 & 0.011 & 0.016 & 0.013 & 0.013 & 0.007 & 0.010 & 0.012 & 0.015 \\
\hline Soma $Y$ & 1.832 & 1.898 & 1.896 & 1.907 & 1.883 & 1.818 & 1.902 & 1.867 & 1.877 \\
\hline OH* & 3.778 & 3.702 & 3.773 & 3.735 & 3.687 & 3.737 & 3.724 & 3.702 & 3.792 \\
\hline $\mathbf{F}$ & 0.220 & 0.293 & 0.227 & 0.256 & 0.309 & 0.263 & 0.276 & 0.288 & 0.204 \\
\hline Cl & 0.002 & 0.006 & 0.000 & 0.010 & 0.005 & 0.000 & 0.000 & 0.010 & 0.004 \\
\hline Total & 19.629 & 19.718 & 19.639 & 19.686 & 19.654 & 19.719 & 19.797 & 19.614 & 19.624 \\
\hline $\mathbf{A l ^ { \mathrm { T } }}$ & 2.688 & 2.722 & 2.734 & 2.729 & 2.759 & 2.846 & 2.694 & 2.707 & 2.735 \\
\hline $\mathbf{F e} /(\mathbf{F e}+\mathbf{M g})$ & 0.504 & 0.481 & 0.496 & 0.489 & 0.488 & 0.485 & 0.501 & 0.527 & 0.502 \\
\hline $\mathrm{Mg} /(\mathrm{Mg}+\mathrm{Fe})$ & 0.496 & 0.519 & 0.504 & 0.511 & 0.512 & 0.515 & 0.499 & 0.473 & 0.498 \\
\hline $\mathbf{T}(\mathbf{K})$ & 885.3 & 889.3 & 889.4 & 889.7 & 882.6 & 862.7 & 873.7 & 905.7 & 904.6 \\
\hline $\mathrm{T}\left({ }^{\circ} \mathrm{C}\right)$ & 612.2 & 616.2 & 616.3 & 616.5 & 609.5 & 589.6 & 600.5 & 632.6 & 631.4 \\
\hline
\end{tabular}


Tabela B4 - continuação

\section{PLÚTON ITUPEVA}

\section{AMOSTRA CAB-16-101}

\begin{tabular}{|c|c|c|c|c|c|c|c|c|}
\hline & 1 & 2 & 3 & 4 & 5 & 6 & 7 & 8 \\
\hline $\mathrm{SiO}_{2}$ & 37.59 & 37.10 & 37.79 & 37.53 & 37.97 & 37.88 & 37.44 & 37.77 \\
\hline $\mathrm{TiO}_{2}$ & 2.55 & 2.85 & 2.46 & 3.00 & 2.77 & 2.69 & 2.91 & 2.64 \\
\hline $\mathbf{A l}_{2} \mathbf{O}_{3}$ & 14.67 & 14.40 & 14.81 & 14.55 & 15.06 & 14.74 & 14.50 & 14.88 \\
\hline $\mathrm{FeO}$ & 18.79 & 18.58 & 18.50 & 18.71 & 17.91 & 19.01 & 19.14 & 18.01 \\
\hline MnO & 0.57 & 0.58 & 0.55 & 0.51 & 0.53 & 0.60 & 0.61 & 0.59 \\
\hline MgO & 11.46 & 11.29 & 11.76 & 11.67 & 11.51 & 11.38 & 11.40 & 11.68 \\
\hline $\mathrm{CaO}$ & 0.05 & 0.03 & 0.00 & 0.01 & 0.04 & 0.01 & 0.00 & 0.02 \\
\hline $\mathrm{Na}_{2} \mathrm{O}$ & 0.06 & 0.07 & 0.10 & 0.09 & 0.08 & 0.07 & 0.07 & 0.07 \\
\hline $\mathbf{K}_{2} \mathbf{O}$ & 9.54 & 9.62 & 9.63 & 9.66 & 9.46 & 9.49 & 9.60 & 9.70 \\
\hline $\mathrm{BaO}$ & 0.29 & 0.29 & 0.28 & 0.25 & 0.26 & 0.23 & 0.20 & 0.29 \\
\hline $\mathrm{ZnO}$ & 0.00 & 0.08 & 0.04 & 0.12 & 0.00 & 0.16 & 0.00 & 0.10 \\
\hline $\mathbf{F}$ & 0.99 & 1.04 & 1.11 & 1.07 & 1.02 & 1.10 & 1.11 & 1.06 \\
\hline Cl & 0.07 & 0.07 & 0.06 & 0.08 & 0.05 & 0.06 & 0.06 & 0.09 \\
\hline $\mathrm{ZrO}_{2}$ & 0.00 & 0.01 & 0.00 & 0.00 & 0.00 & 0.02 & 0.00 & 0.00 \\
\hline $\mathrm{H}^{2} \mathrm{O}^{*}$ & 3.45 & 3.39 & 3.42 & 3.43 & 3.47 & 3.43 & 3.40 & 3.43 \\
\hline Subtotal & 100.09 & 99.41 & 100.51 & 100.68 & 100.13 & 100.87 & 100.44 & 100.33 \\
\hline $\mathrm{O}=\mathrm{F}, \mathrm{Cl}$ & 0.43 & 0.45 & 0.48 & 0.47 & 0.44 & 0.48 & 0.48 & 0.47 \\
\hline Total & 99.65 & 98.95 & 100.03 & 100.22 & 99.69 & 100.39 & 99.96 & 99.86 \\
\hline $\mathbf{S i}$ & 5.721 & 5.699 & 5.721 & 5.685 & 5.738 & 5.724 & 5.693 & 5.721 \\
\hline $\mathbf{A l}^{\mathbf{I V}}$ & 2.279 & 2.301 & 2.279 & 2.315 & 2.262 & 2.276 & 2.307 & 2.279 \\
\hline Soma $T$ & 8.000 & 8.000 & 8.000 & 8.000 & 8.000 & 8.000 & 8.000 & 8.000 \\
\hline $\mathbf{A l}^{\mathrm{VI}}$ & 0.353 & 0.306 & 0.364 & 0.284 & 0.421 & 0.350 & 0.292 & 0.377 \\
\hline
\end{tabular}


Tabela B4 - continuação

\begin{tabular}{|c|c|c|c|c|c|c|c|c|}
\hline $\mathbf{T i}$ & 0.292 & 0.329 & 0.280 & 0.342 & 0.315 & 0.306 & 0.333 & 0.301 \\
\hline $\mathbf{F e}$ & 2.392 & 2.387 & 2.342 & 2.370 & 2.264 & 2.402 & 2.434 & 2.281 \\
\hline Mn & 0.073 & 0.075 & 0.070 & 0.066 & 0.068 & 0.077 & 0.078 & 0.076 \\
\hline Mg & 2.600 & 2.585 & 2.654 & 2.635 & 2.593 & 2.563 & 2.584 & 2.637 \\
\hline $\mathbf{Z n}$ & 0.001 & 0.009 & 0.004 & 0.014 & 0.000 & 0.018 & 0.000 & 0.011 \\
\hline $\mathbf{Z r}$ & 0.000 & 0.001 & 0.000 & 0.000 & 0.000 & 0.001 & 0.000 & 0.000 \\
\hline Soma $X$ & 5.710 & 5.692 & 5.716 & 5.711 & 5.660 & 5.717 & 5.721 & 5.682 \\
\hline $\mathrm{Ca}$ & 0.008 & 0.005 & 0.000 & 0.002 & 0.006 & 0.001 & 0.000 & 0.004 \\
\hline $\mathrm{Na}$ & 0.018 & 0.022 & 0.030 & 0.026 & 0.024 & 0.020 & 0.021 & 0.020 \\
\hline $\mathbf{K}$ & 1.852 & 1.885 & 1.860 & 1.867 & 1.824 & 1.829 & 1.862 & 1.874 \\
\hline $\mathbf{B a}$ & 0.017 & 0.018 & 0.016 & 0.015 & 0.015 & 0.014 & 0.012 & 0.017 \\
\hline Soma $Y$ & 1.896 & 1.929 & 1.906 & 1.909 & 1.869 & 1.864 & 1.895 & 1.915 \\
\hline $\mathrm{OH}^{*}$ & 3.506 & 3.476 & 3.452 & 3.467 & 3.500 & 3.459 & 3.451 & 3.470 \\
\hline $\mathbf{F}$ & 0.476 & 0.505 & 0.531 & 0.513 & 0.488 & 0.526 & 0.534 & 0.508 \\
\hline $\mathrm{Cl}$ & 0.018 & 0.018 & 0.016 & 0.021 & 0.012 & 0.016 & 0.015 & 0.022 \\
\hline Total & 19.606 & 19.621 & 19.622 & 19.620 & 19.529 & 19.581 & 19.616 & 19.597 \\
\hline $\mathbf{A \mathbf { l } ^ { \mathrm { T } }}$ & 2.632 & 2.607 & 2.643 & 2.598 & 2.683 & 2.625 & 2.599 & 2.656 \\
\hline $\mathrm{Fe} /(\mathrm{Fe}+\mathrm{Mg})$ & 0.479 & 0.480 & 0.469 & 0.474 & 0.466 & 0.484 & 0.485 & 0.464 \\
\hline $\mathrm{Mg} /(\mathrm{Mg}+\mathrm{Fe})$ & 0.521 & 0.520 & 0.531 & 0.526 & 0.534 & 0.516 & 0.515 & 0.536 \\
\hline $\mathbf{T}(\mathbf{K})$ & 919.2 & 935.5 & 916.7 & 942.1 & 936.7 & 924.5 & 934.2 & 929.2 \\
\hline $\mathrm{T}\left({ }^{\circ} \mathrm{C}\right)$ & 646.0 & 662.4 & 643.6 & 668.9 & 663.6 & 651.3 & 661.1 & 656.0 \\
\hline
\end{tabular}



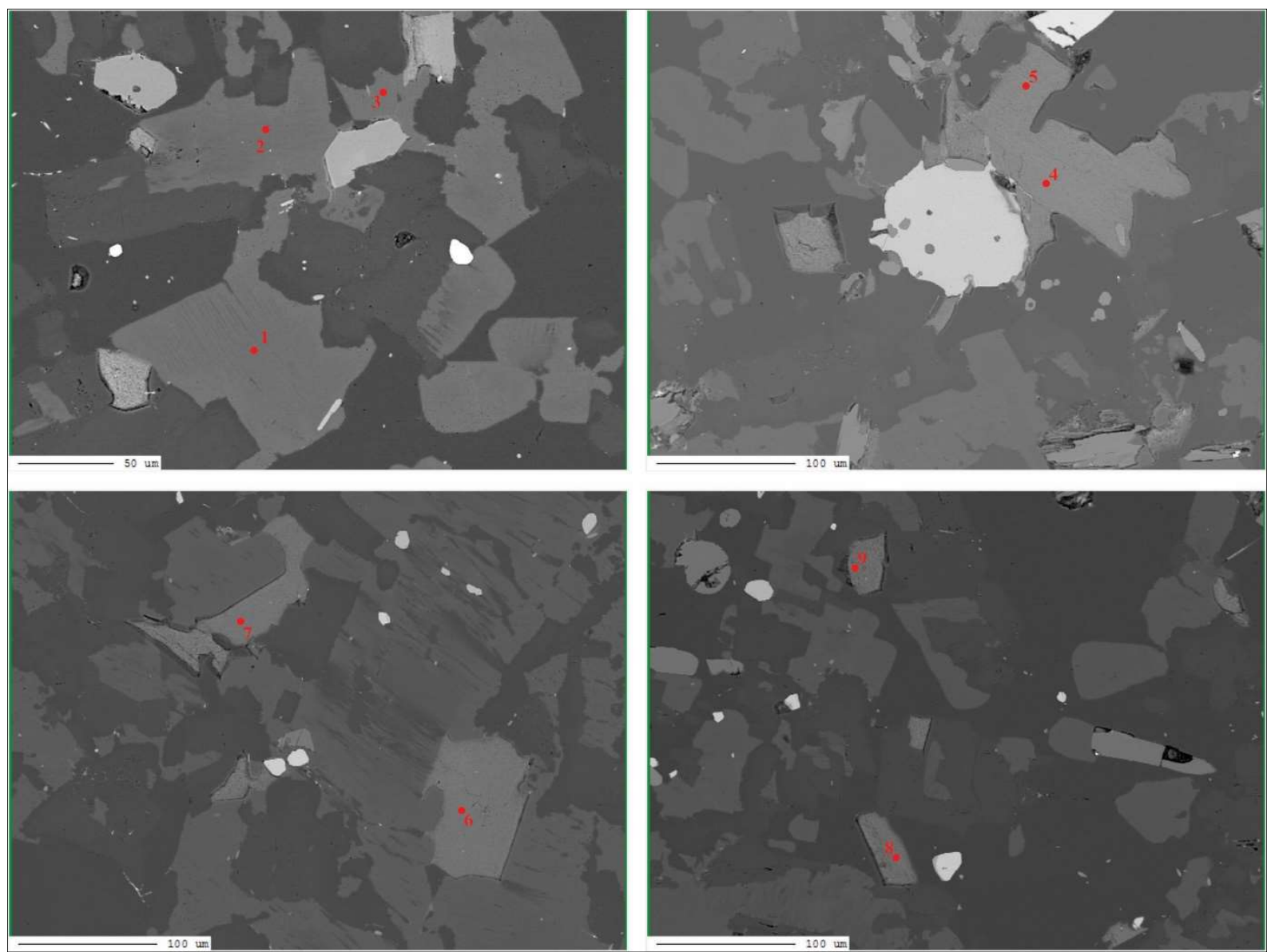

AMOSTRA FM3_3 - SALTO

Prancha B4 - Imagens obtidas por EDS de elétrons retroespalhados dos cristais de biotitas analisados com os pontos de análise em vermelho. 

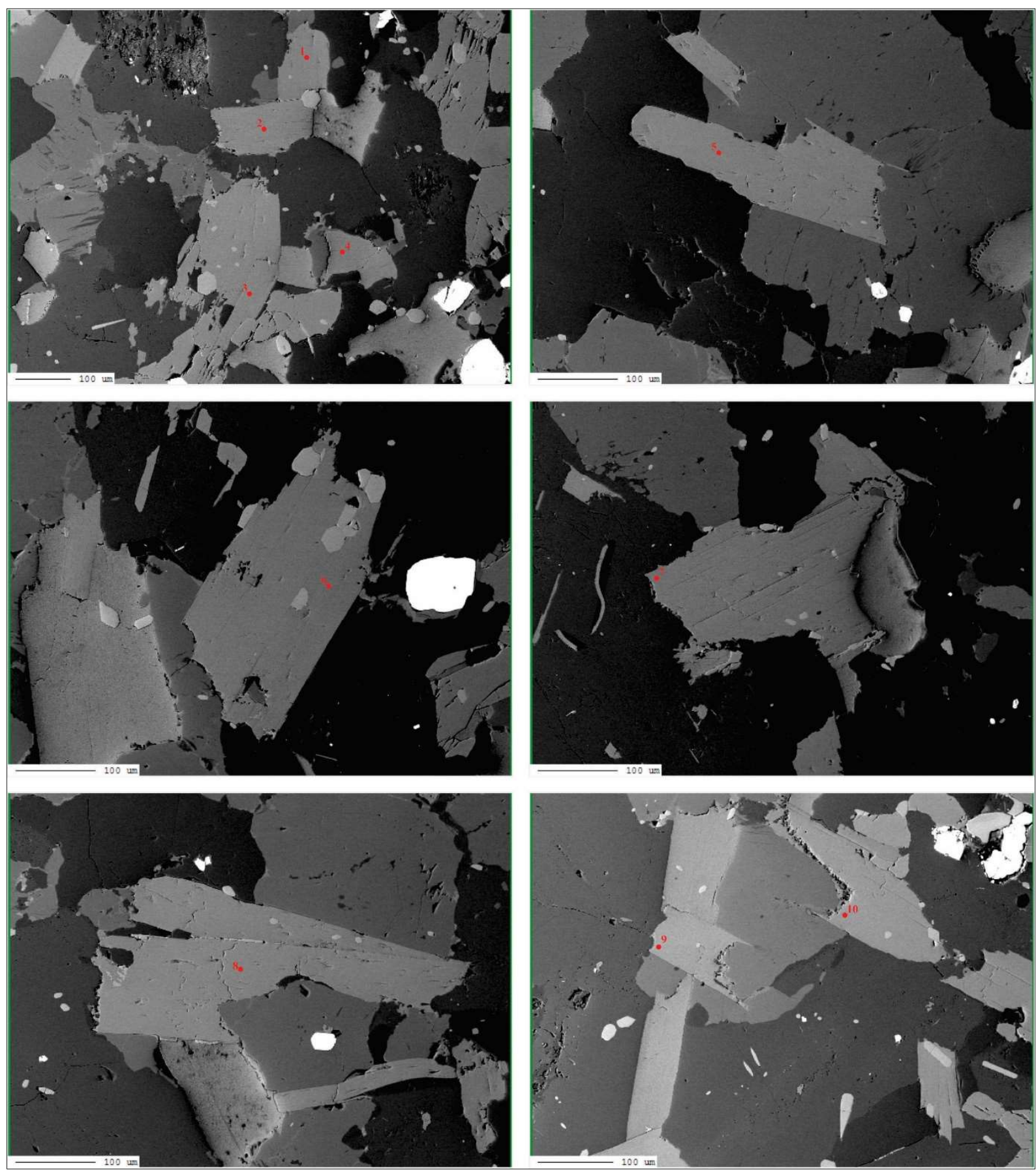

AMOSTRA 2008-ITU-2.1A1(1) - SALTO

Prancha B4 - continuação 

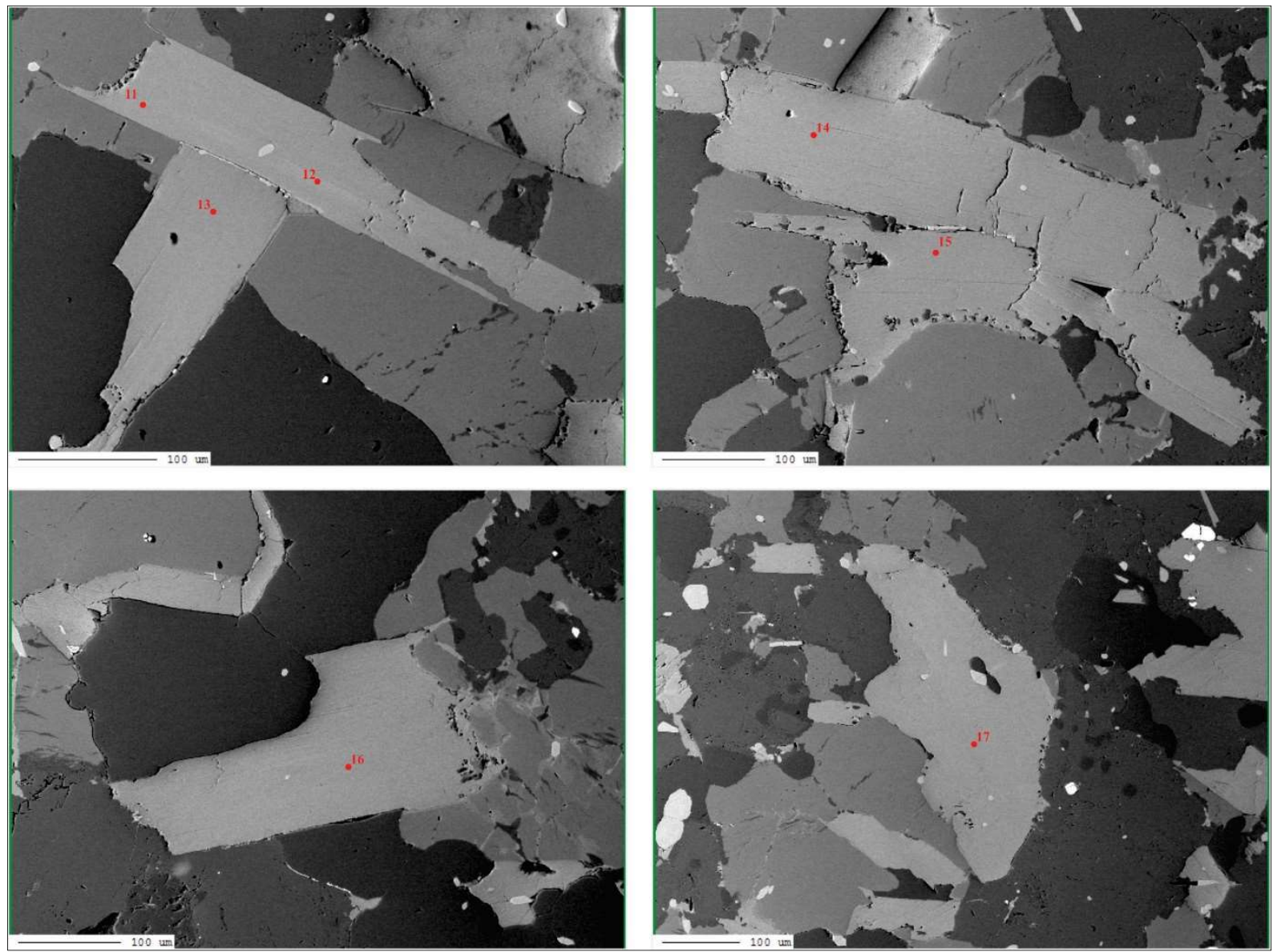

AMOSTRA 2008-ITU-2.1A1(2) - SALTO

Prancha B4 - continuação 

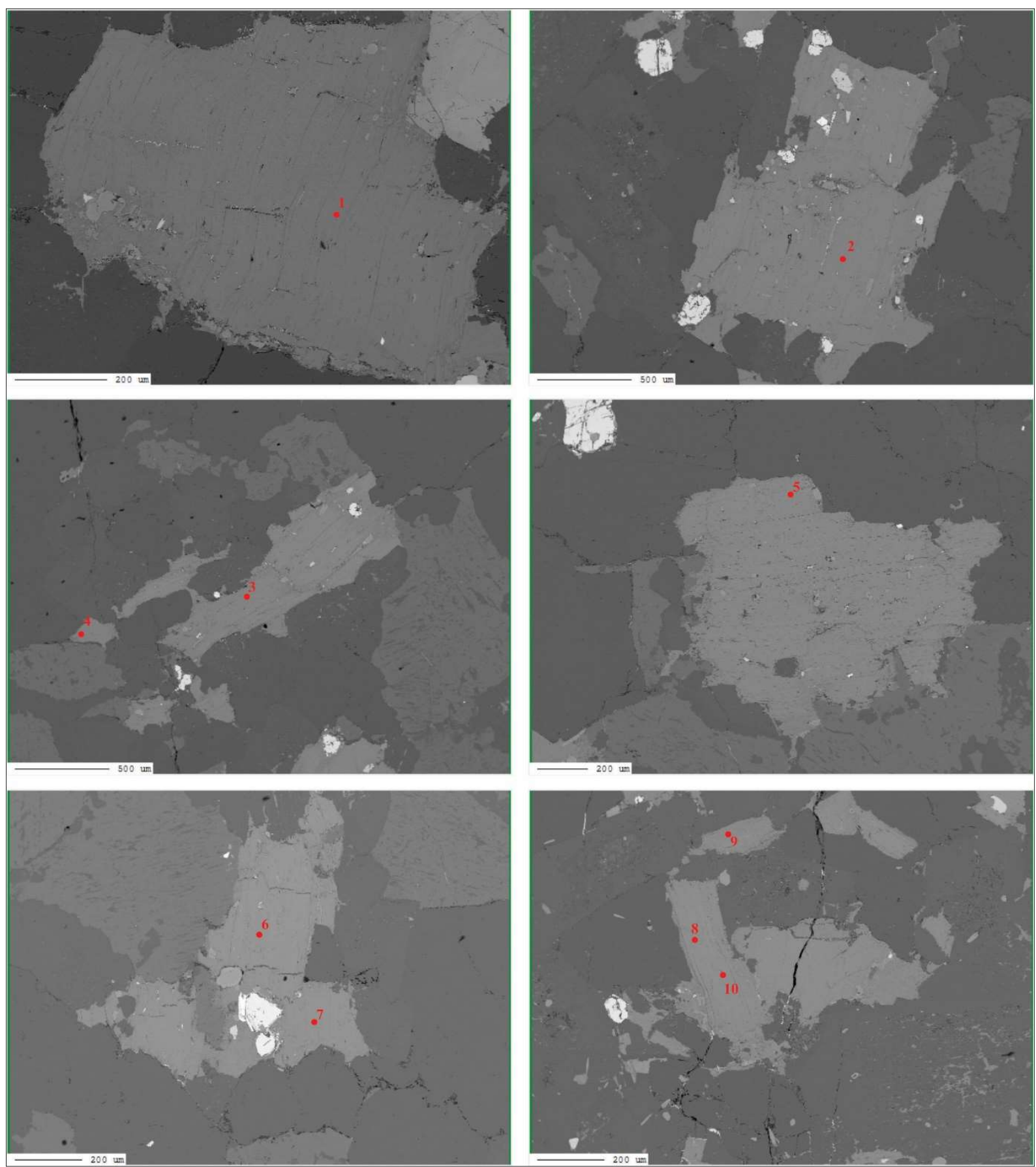

AMOSTRA 2008-ITU-2.1C - SALTO

Prancha B4 - continuação 


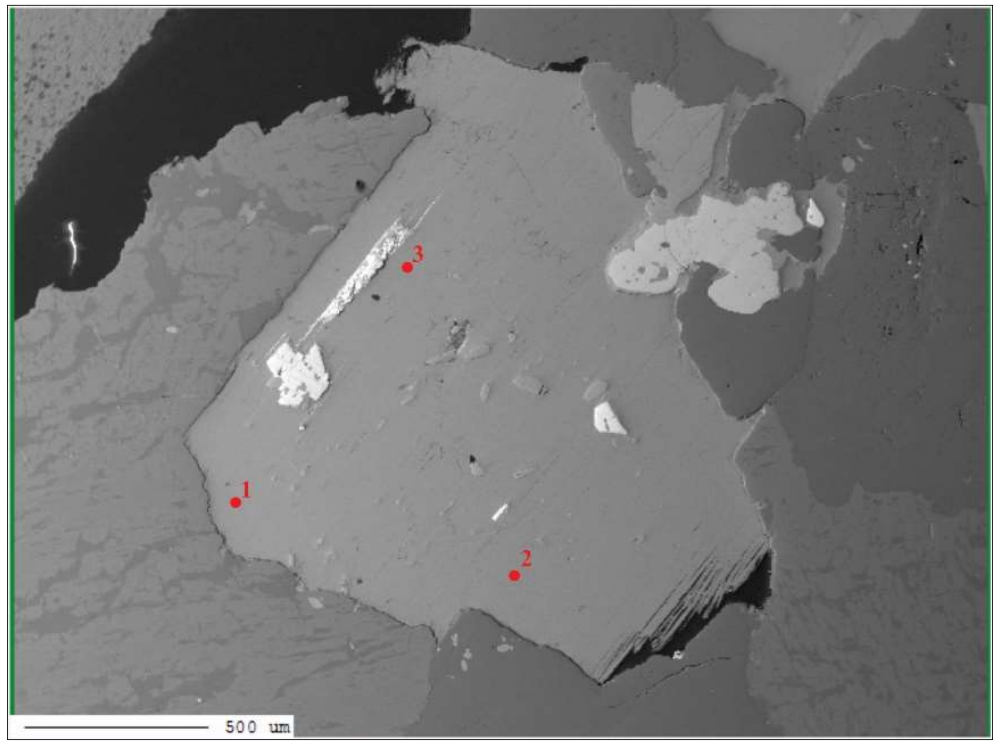

AMOSTRA CAB-14-06A - INDAIATUBA

Prancha B4 - continuação
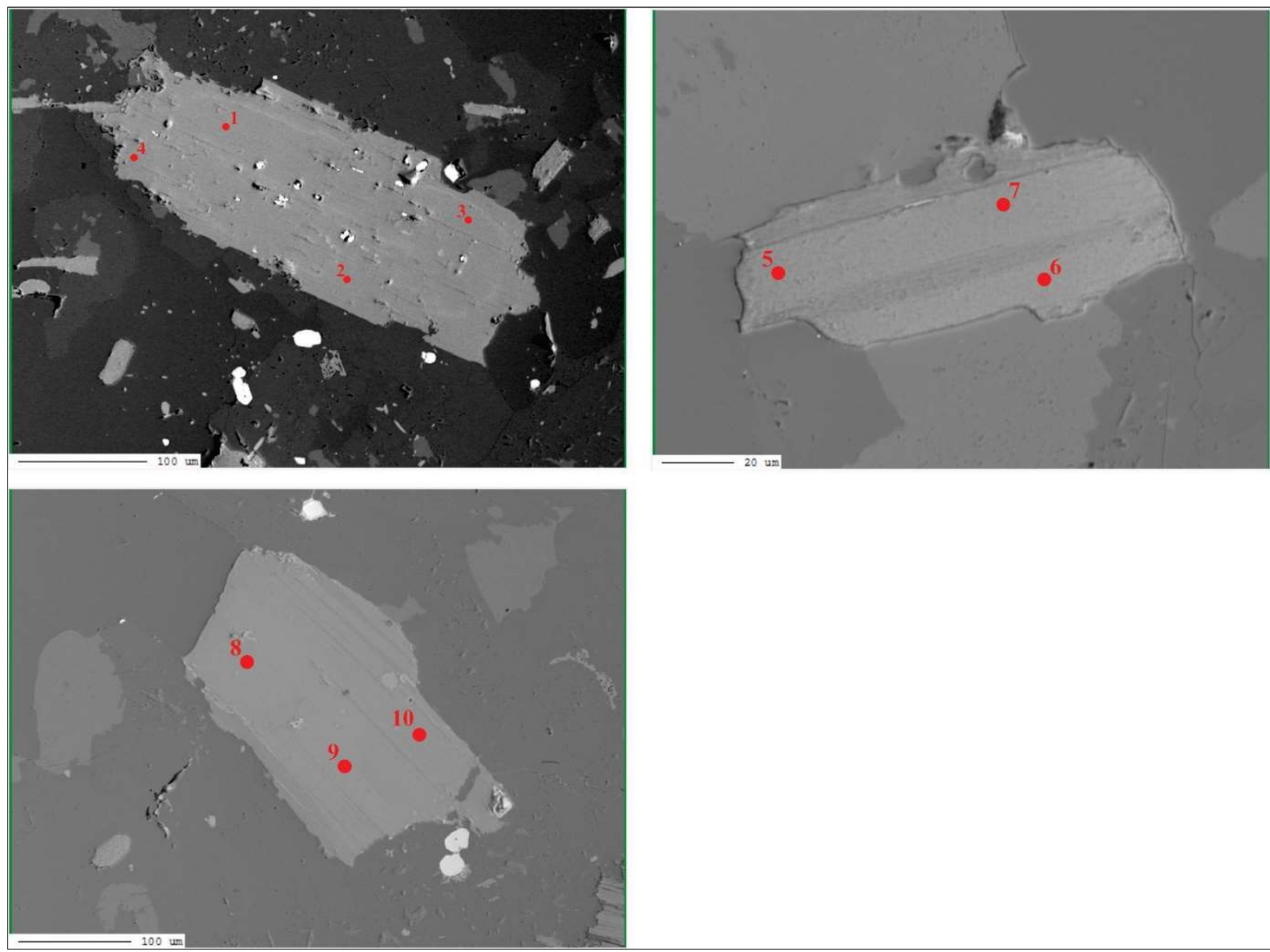

AMOSTRA CAB-15-34.1 - INDAIATUBA

Prancha B4 - continuação 


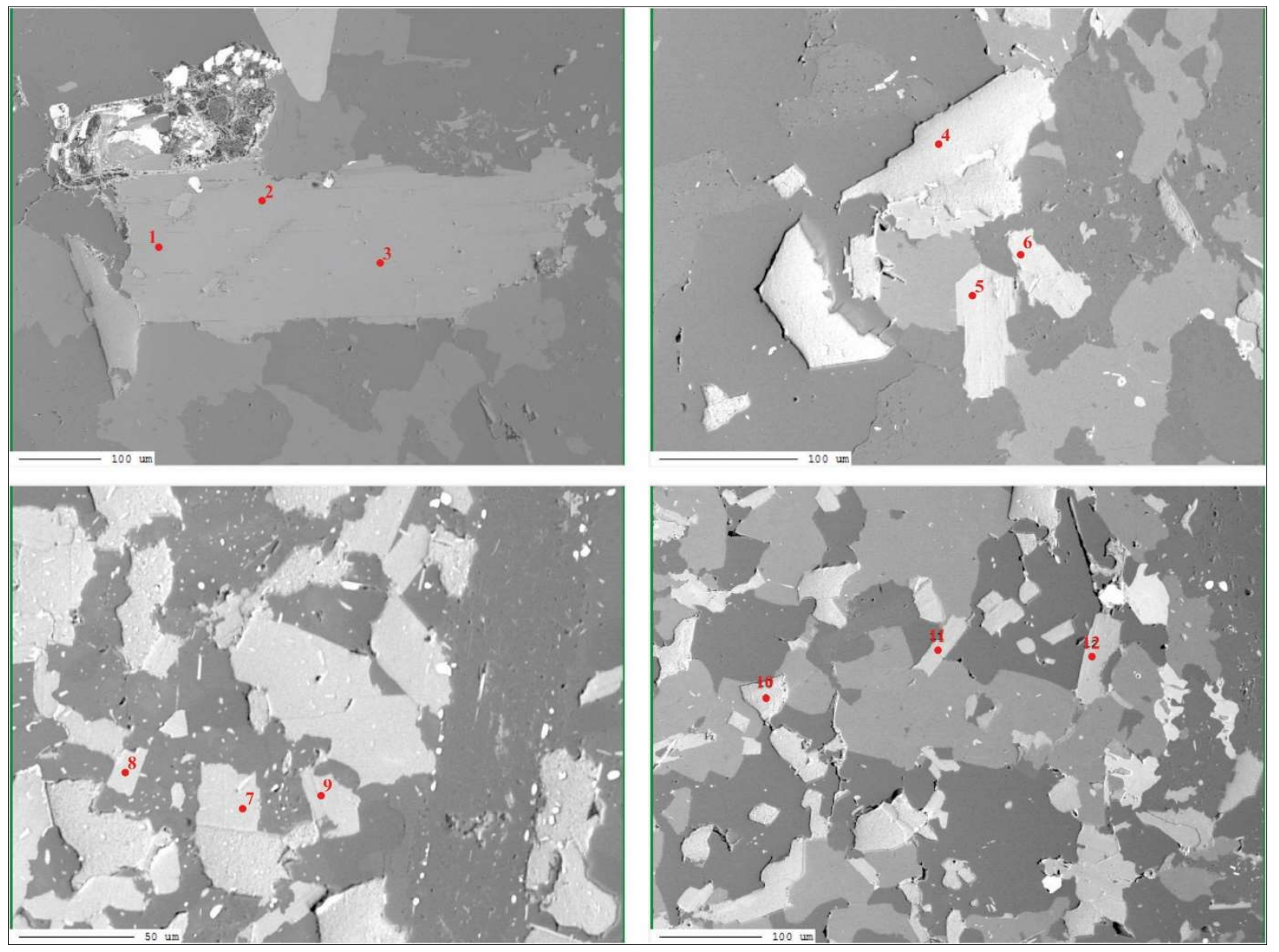

AMOSTRA CAB-15-34.2 - INDAIATUBA

Prancha B4 - continuação 

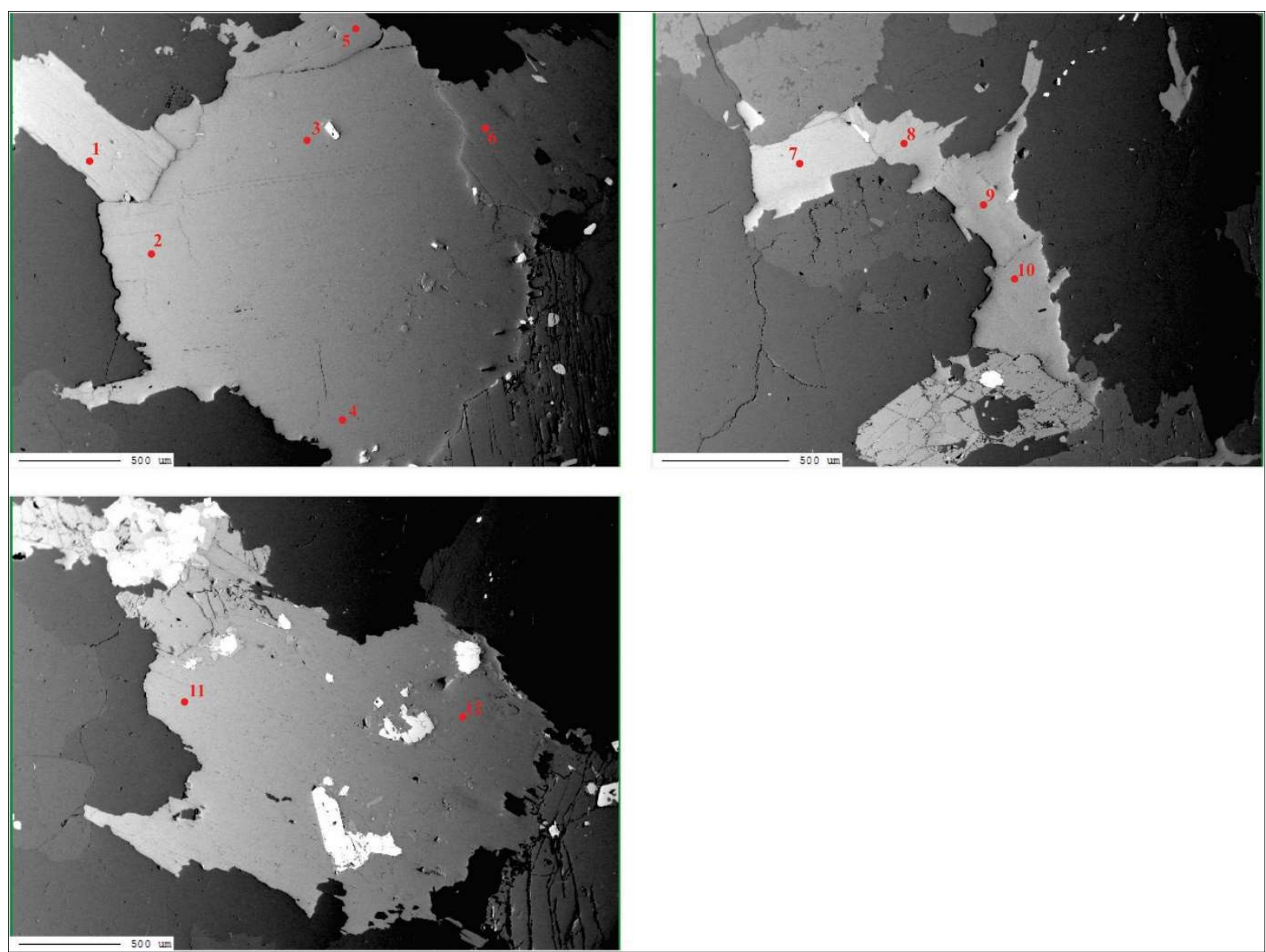

AMOSTRA CAB-14-09 - CABREÚVA

Prancha B4 - continuação

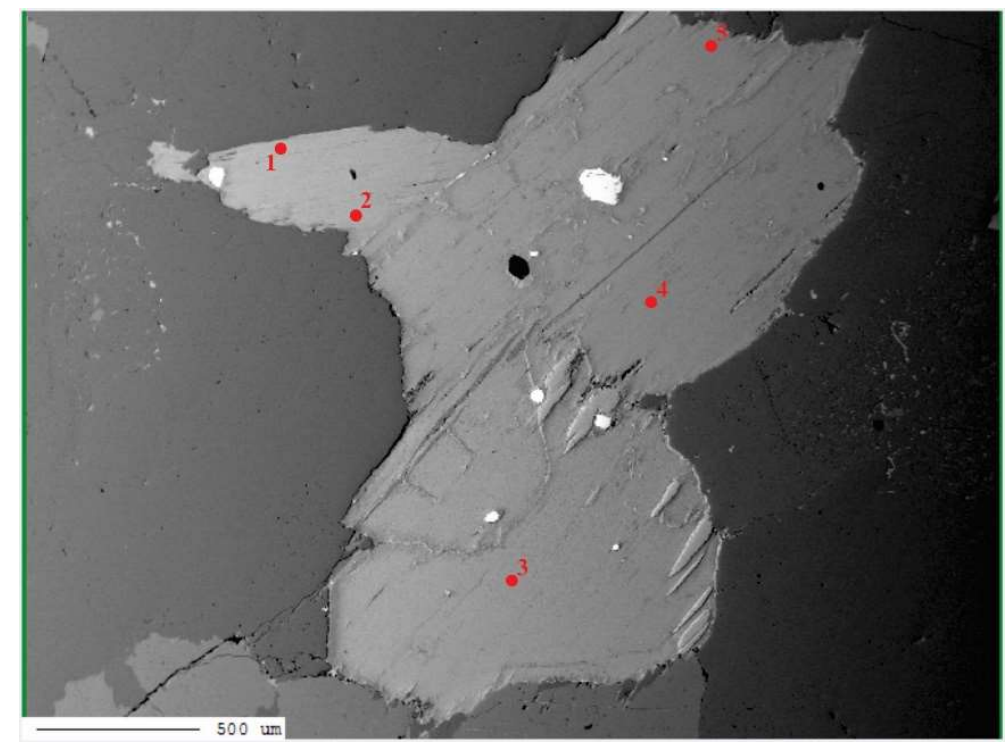

AMOSTRA CAB-16-80A - INDAIATUBA

Prancha B4 - continuação 

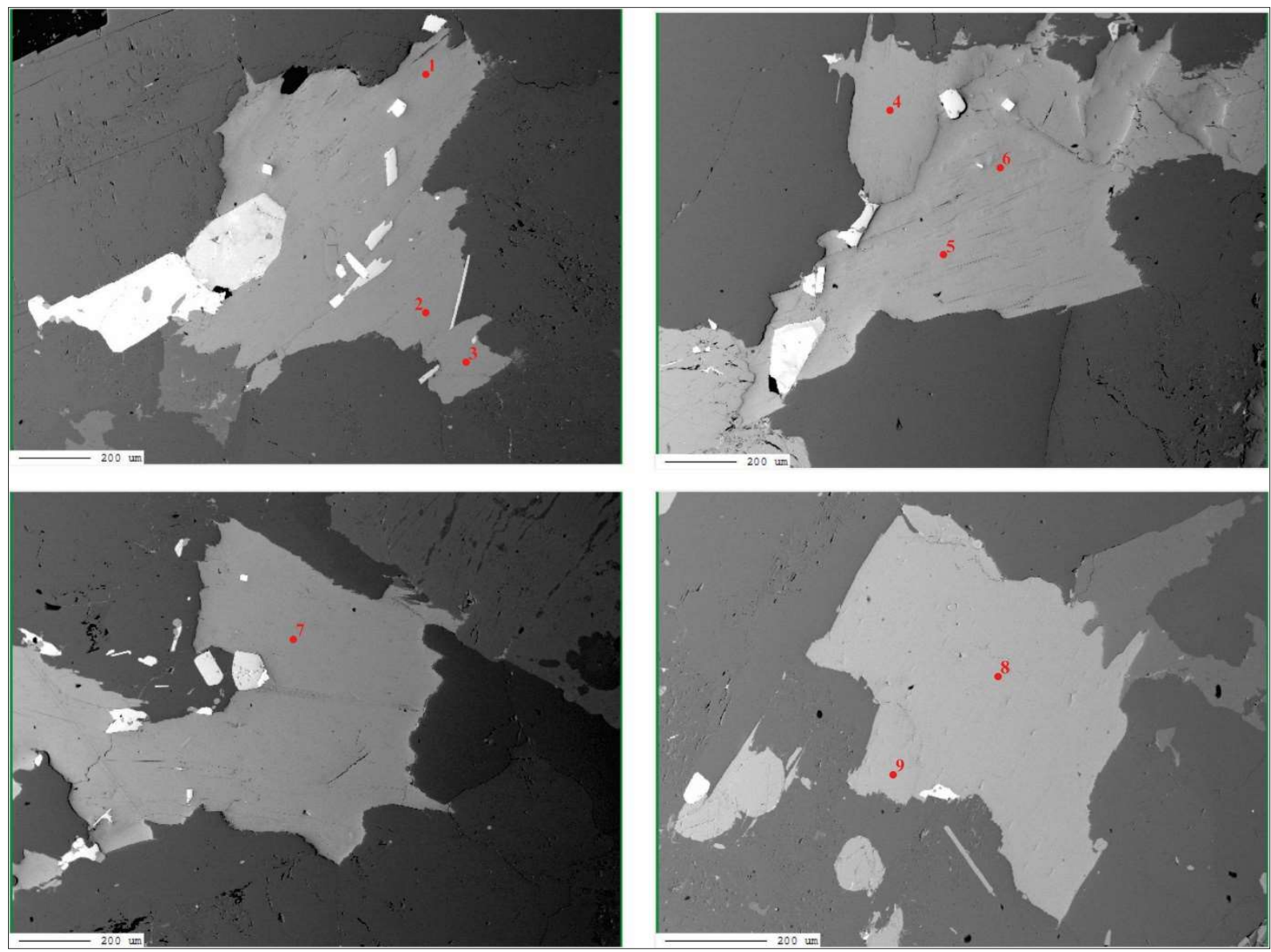

AMOSTRA CAB-16-90 - CABREÚVA

Prancha B4 - continuação

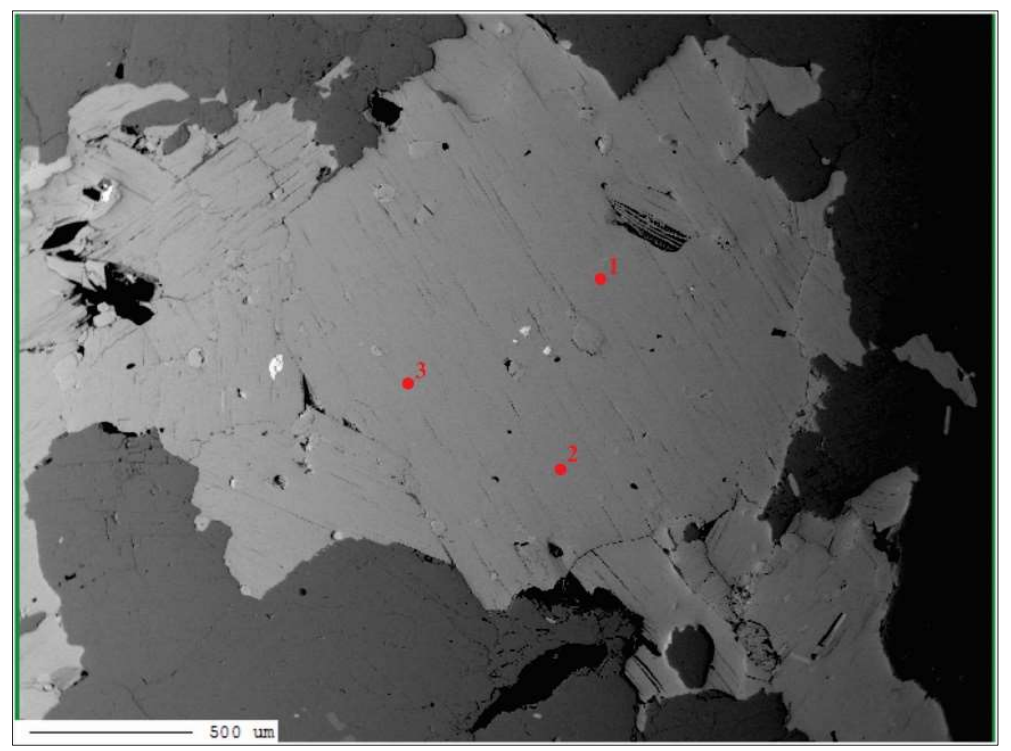

AMOSTRA CAB-16-91B - CABREÚVA

Prancha B4 - continuação 

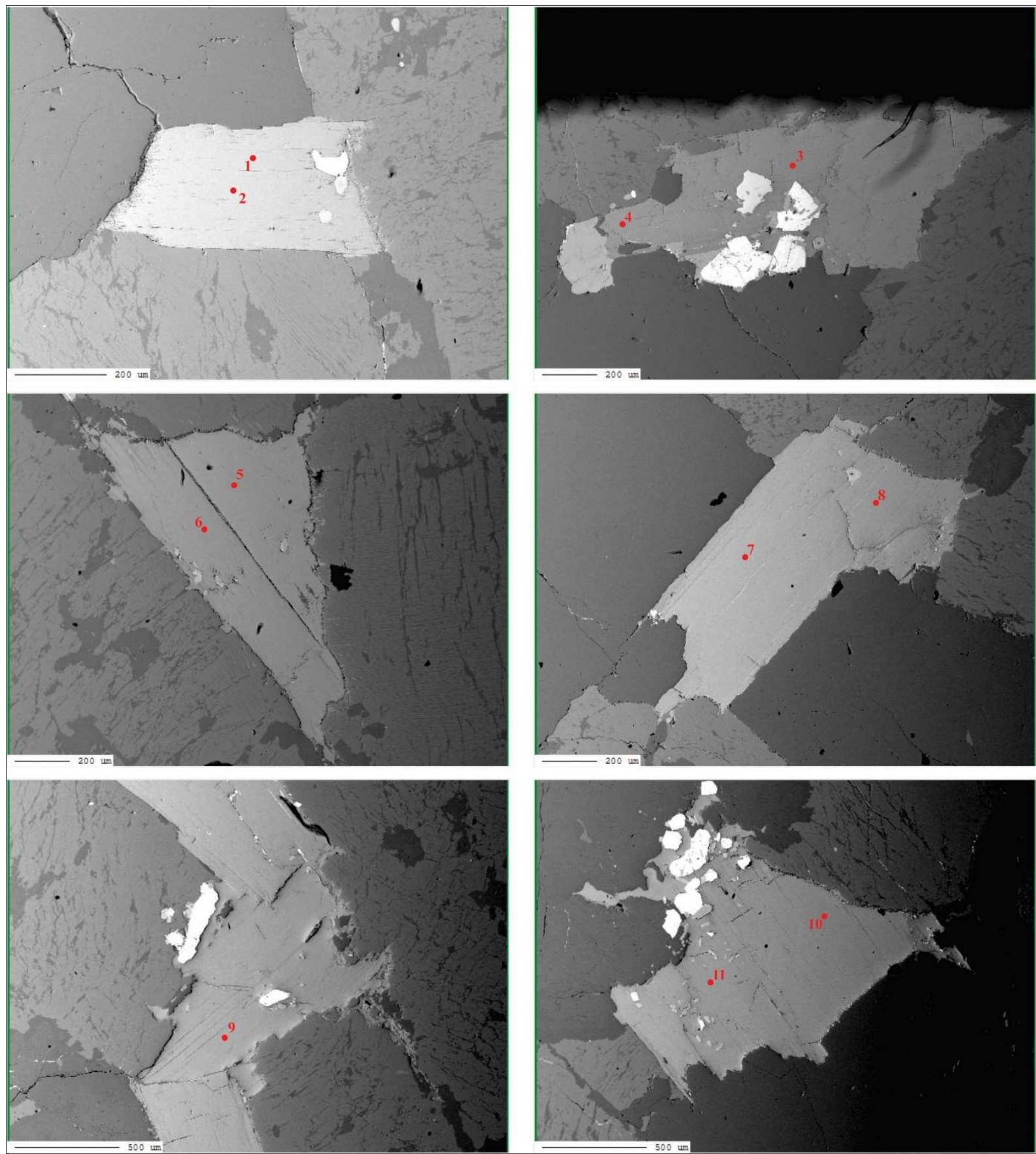

AMOSTRA CAB-15-36(1) - ITUPEVA

Prancha B4 - continuação 


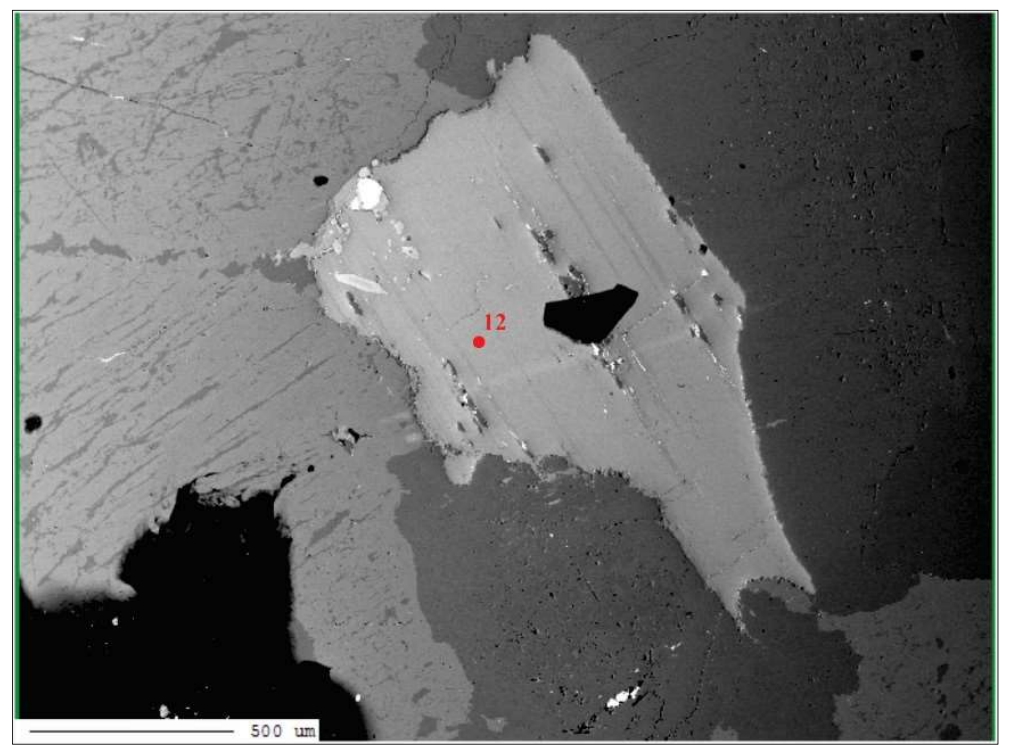

AMOSTRA CAB-15-36(2) - ITUPEVA

Prancha B4 - continuação

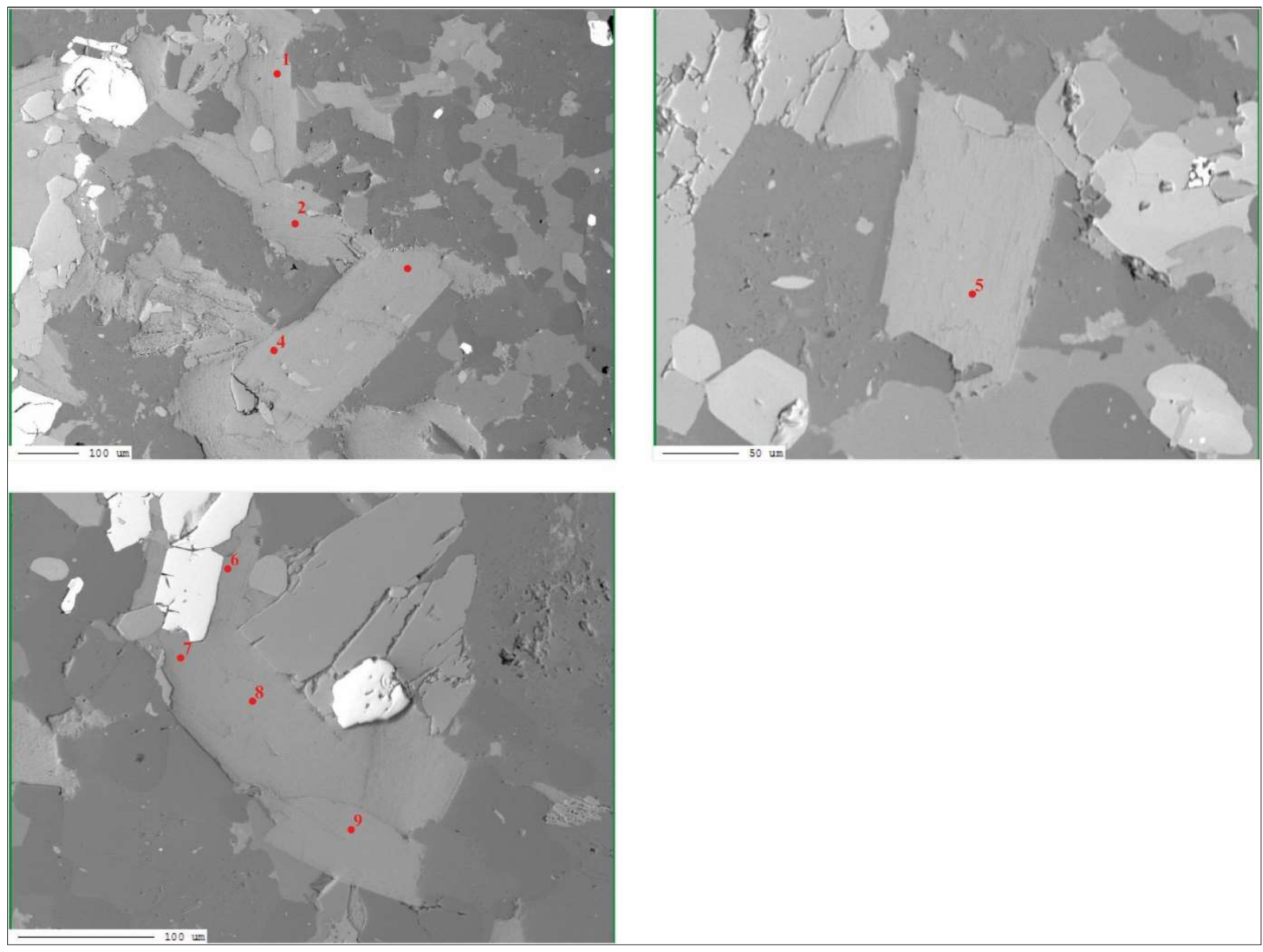

AMOSTRA CAB-16-98 - ITUPEVA

Prancha B4 - continuação 


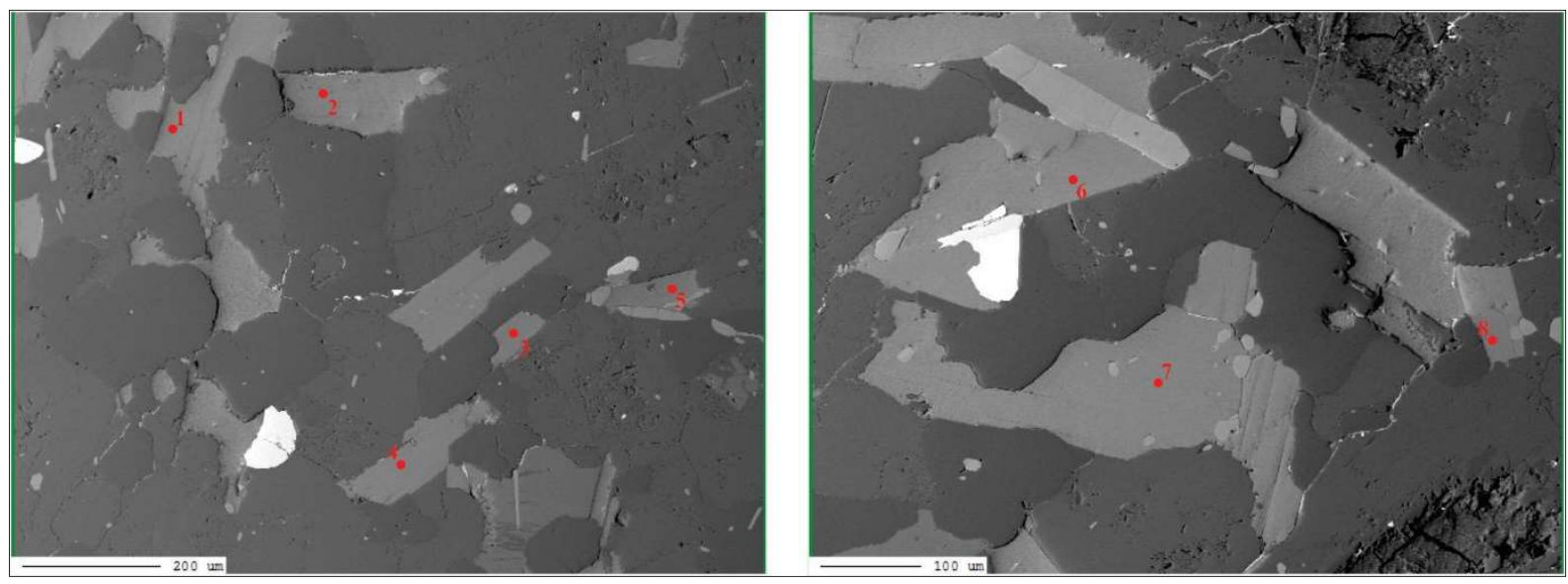

AMOSTRA CAB-16-101 - ITUPEVA

Prancha B4 - continuação 


\section{APÊNDICE C - DADOS DE GEOQUÍMICA DE ROCHA TOTAL}



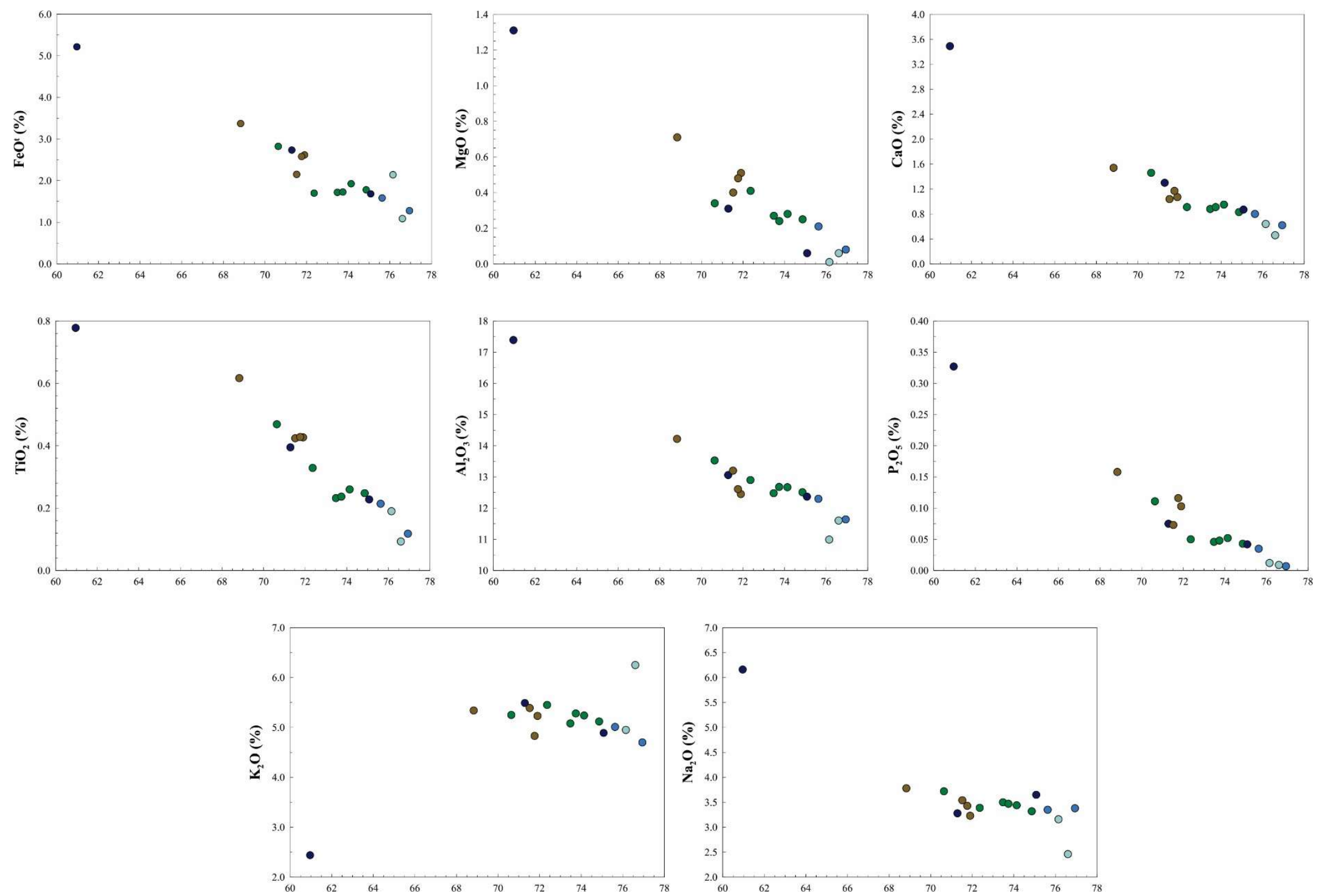

Diagramas $\mathbf{C 1}$ - Diagramas de variação utilizando o teor de $\mathbf{S i O}_{2}$ como índice de diferenciação para as amostras do Plúton Cabreúva. Simbologia conforme a legenda da Figura 114 do Capítulo 7 no corpo do texto. 

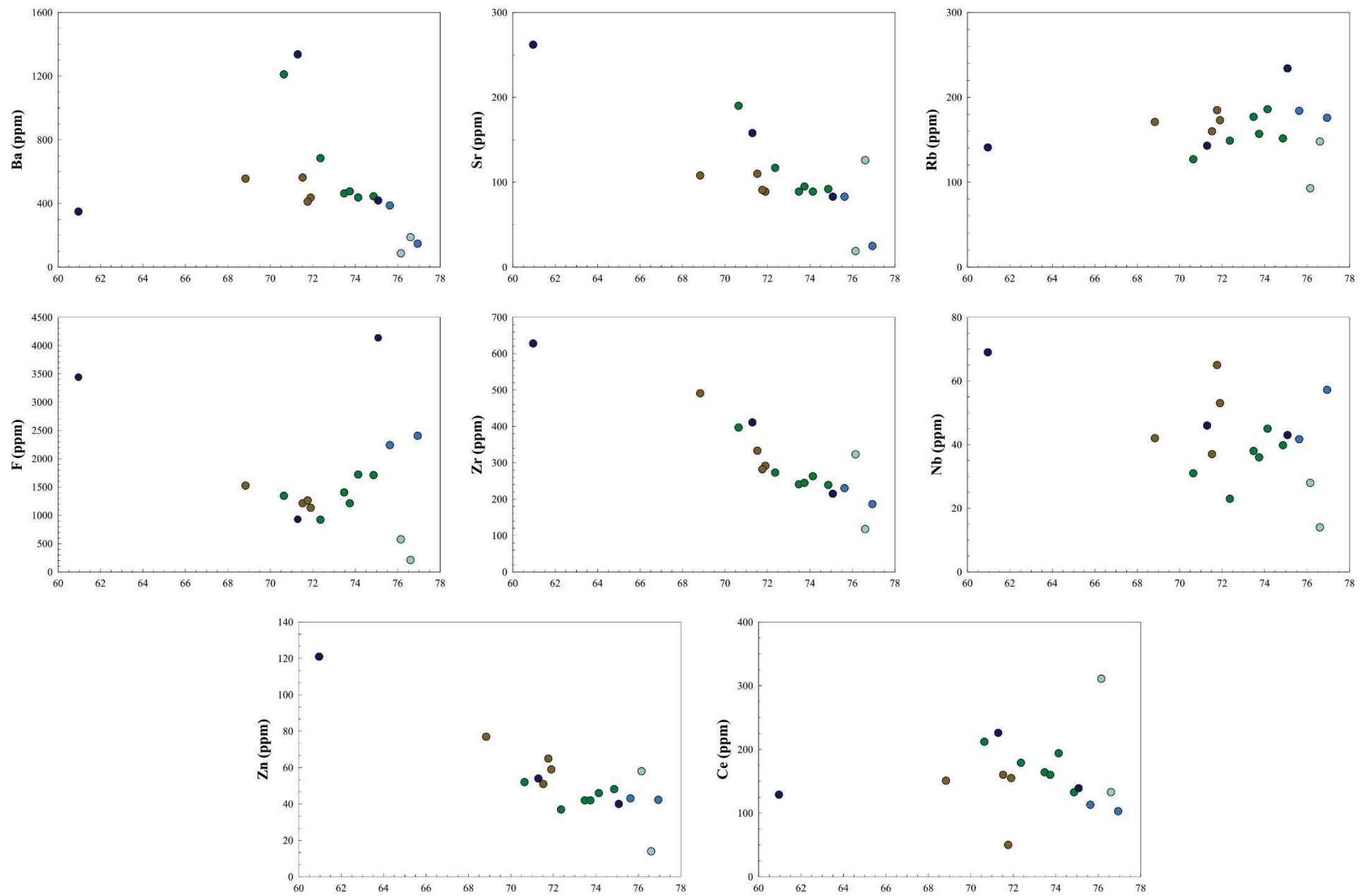

Diagramas C2 - Diagramas de variação utilizando o teor de $\mathbf{S i O}_{2}$ como índice de diferenciação para as amostras do Plúton Cabreúva. Simbologia conforme a legenda da Figura 114 do Capítulo 7 no corpo do texto. 

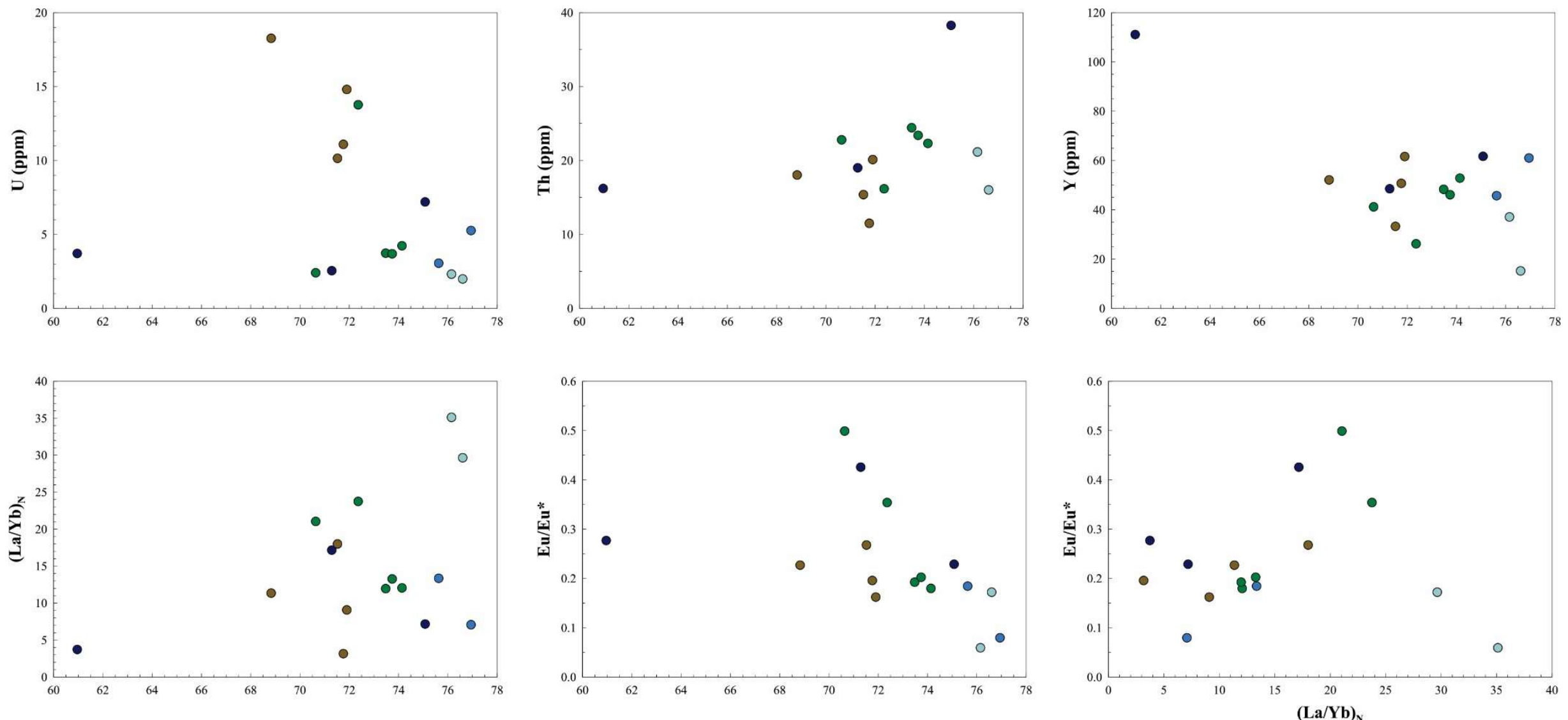

Diagramas $\mathbf{C 3}$ - Diagramas de variação utilizando o teor de $\mathbf{S i O}_{2}$ como índice de diferenciação para as amostras do Plúton Cabreúva, com exceção do diagrama $\mathbf{E u / E u * ~} \mathbf{x}(\mathbf{L a} / \mathbf{Y b})_{\mathbf{N}}$. Simbologia conforme a legenda da Figura 114 do Capítulo 7 no corpo do texto. 

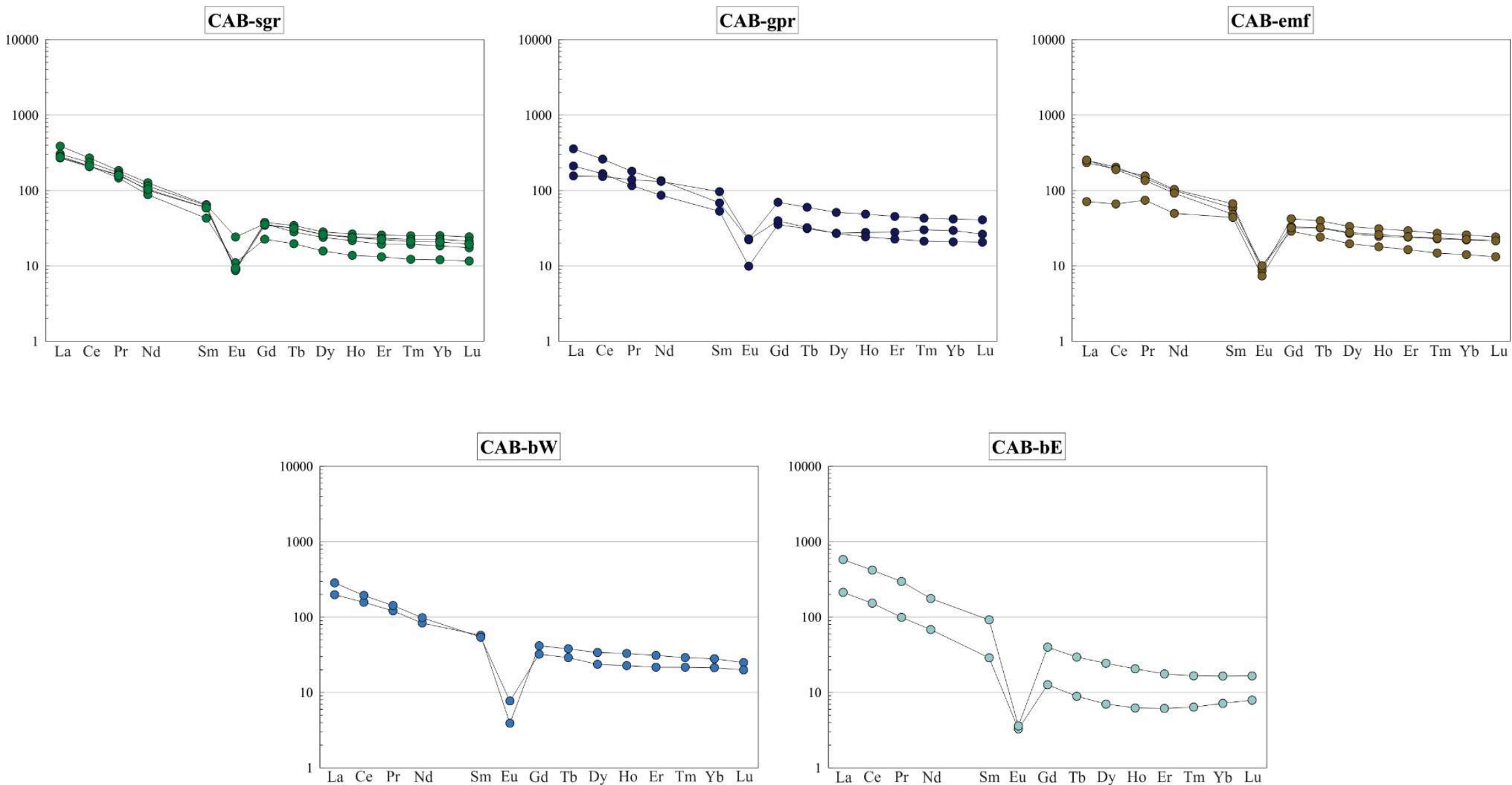

Diagramas C4 - Padrões de fracionamento dos elementos terras raras das amostras do Plúton Cabreúva, normalizados segundo Boynton (1984); dados em escala logarítmica. 

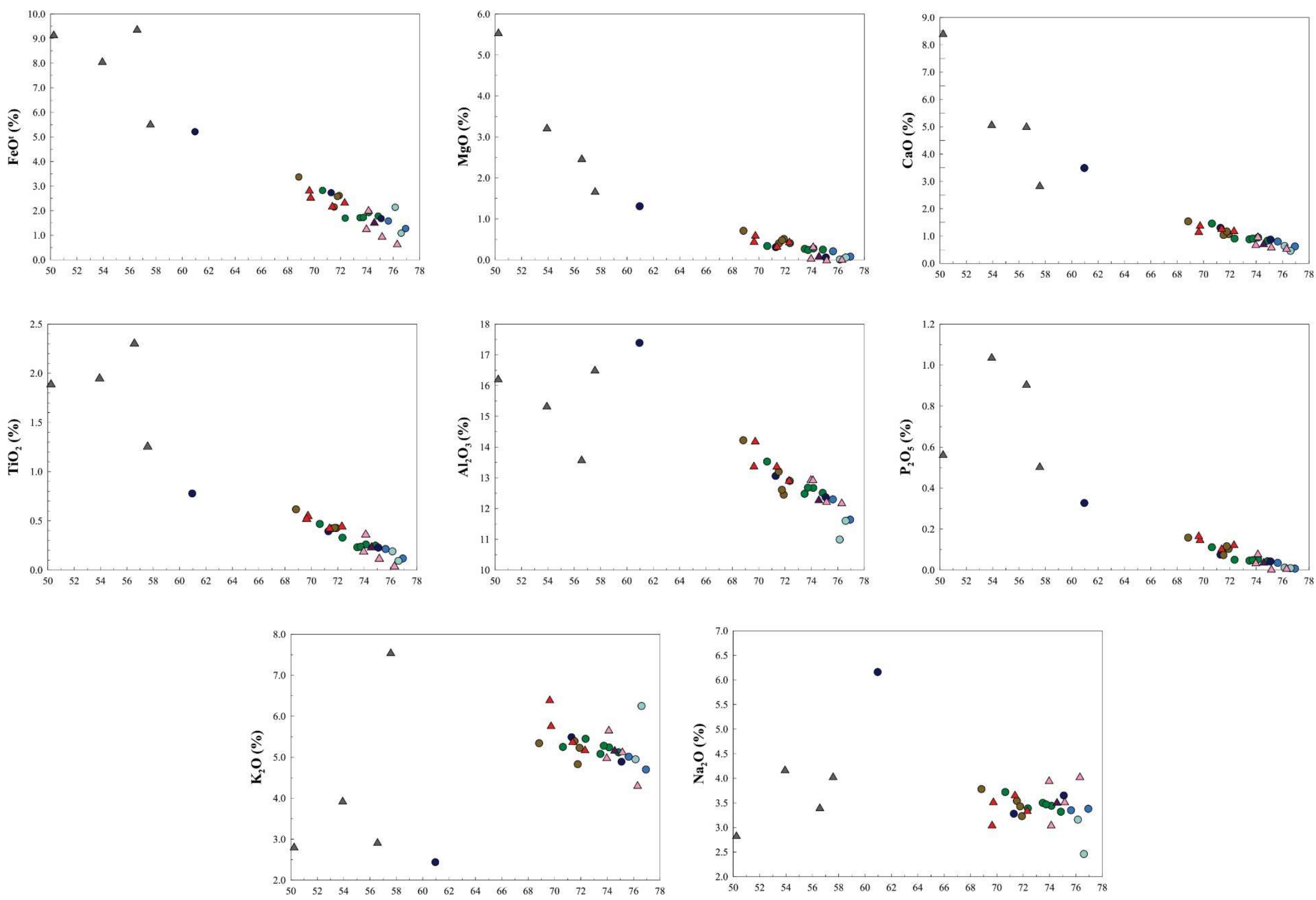

Diagramas $\mathbf{C 5}$ - Diagramas de variação utilizando o teor de $\mathbf{S i O}_{2}$ como índice de diferenciação para as amostras do Plúton Indaiatuba em comparação com as do Plúton Cabreúva. Simbologia conforme a legenda das Figuras 114 e 115 do Capítulo 7 no corpo do texto. 

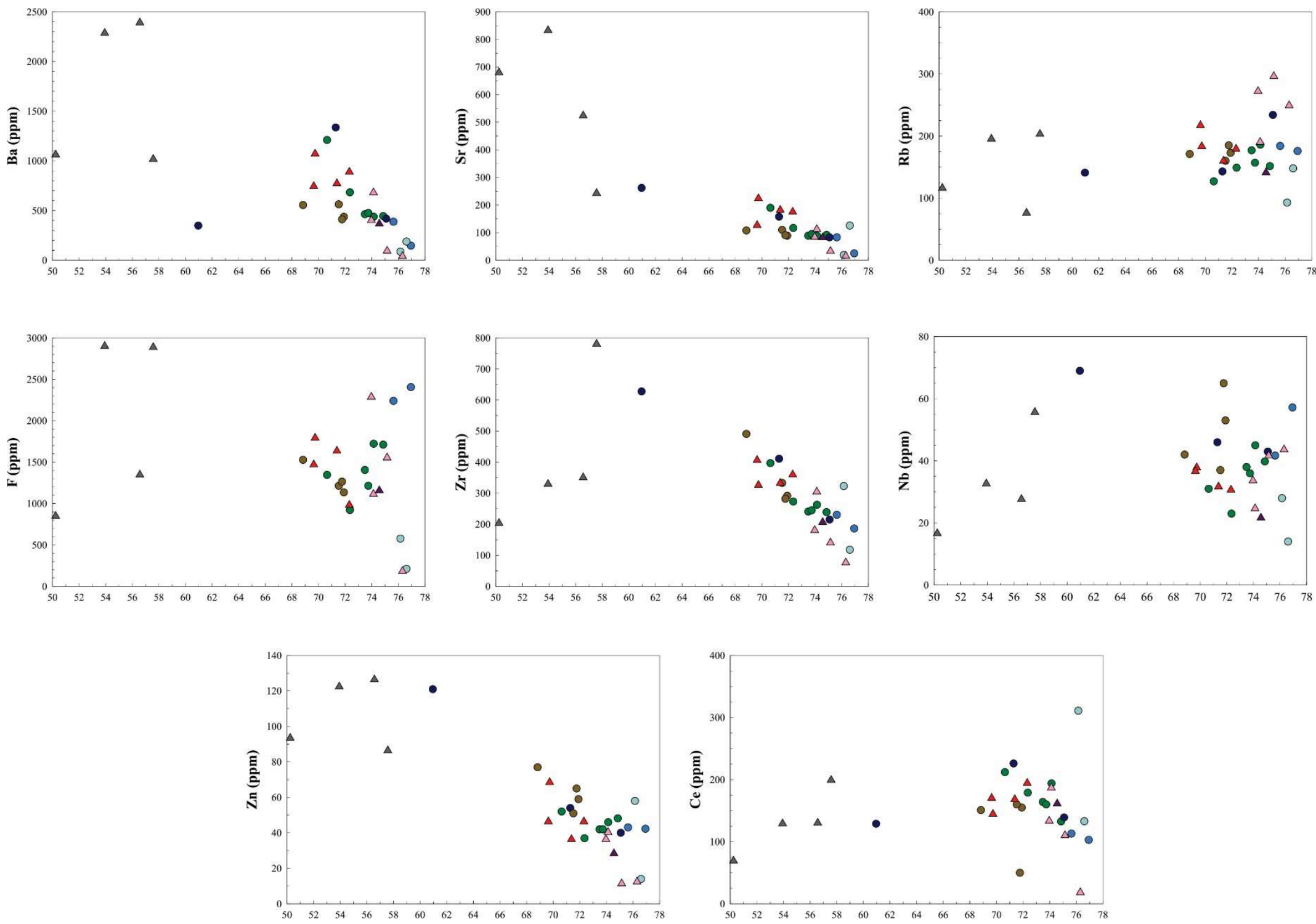

Diagramas $\mathbf{C 6}$ - Diagramas de variação utilizando o teor de $\mathbf{S i O}_{2}$ como índice de diferenciação para as amostras do Plúton Indaiatuba em comparação com as do Plúton Cabreúva. Simbologia conforme a legenda das Figuras 114 e 115 do Capítulo 7 no corpo do texto. 

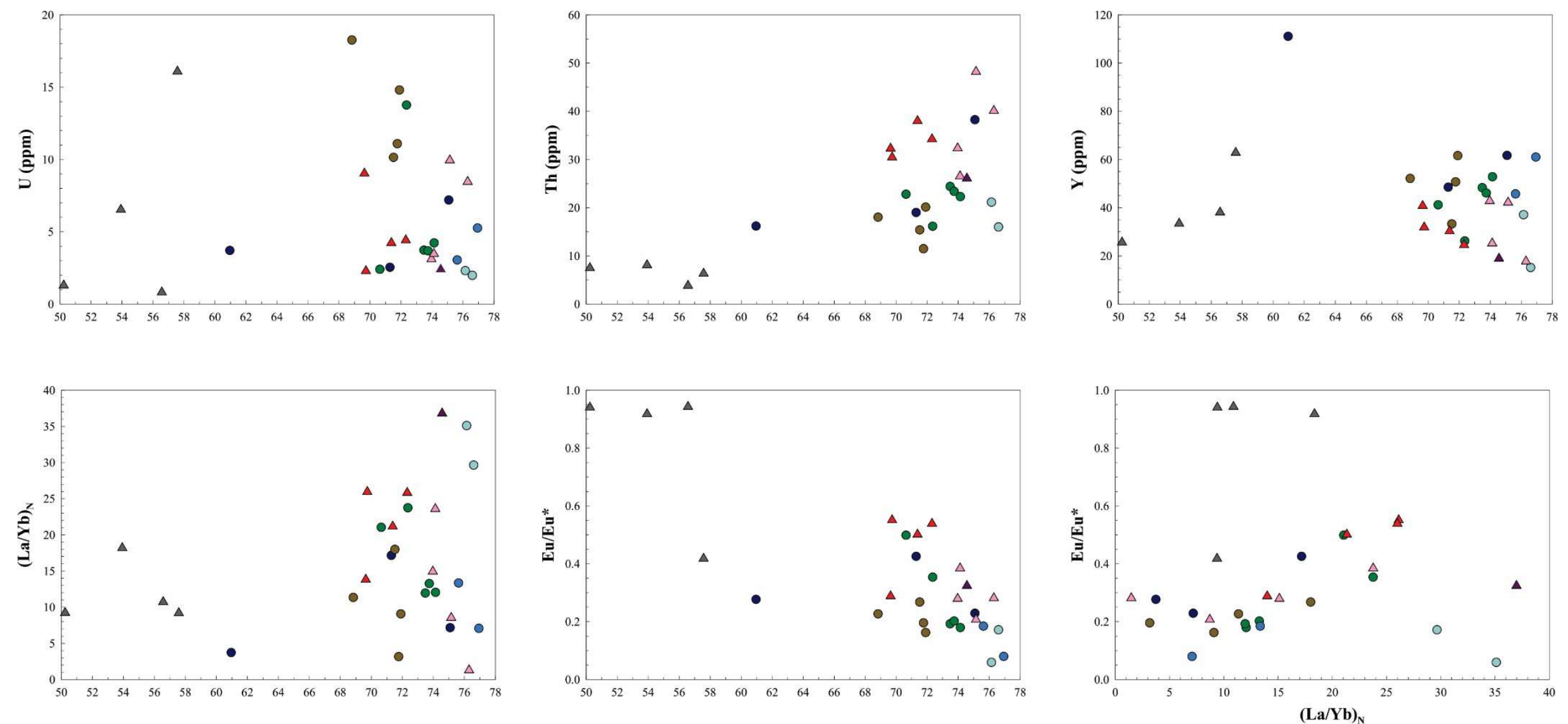

Diagramas $\mathbf{C 7}$ - Diagramas de variação utilizando o teor de $\mathbf{S i O}_{2}$ como índice de diferenciação para as amostras do Plúton Indaiatuba em comparação com as do Plúton Cabreúva, com exceção do diagrama $\mathbf{E u / E u * ~} \mathbf{x}$ $(\mathbf{L a} / \mathbf{Y b})_{\mathbf{N}}$. Simbologia conforme a legenda das Figura 114 e 115 do Capítulo 7 no corpo do texto. 

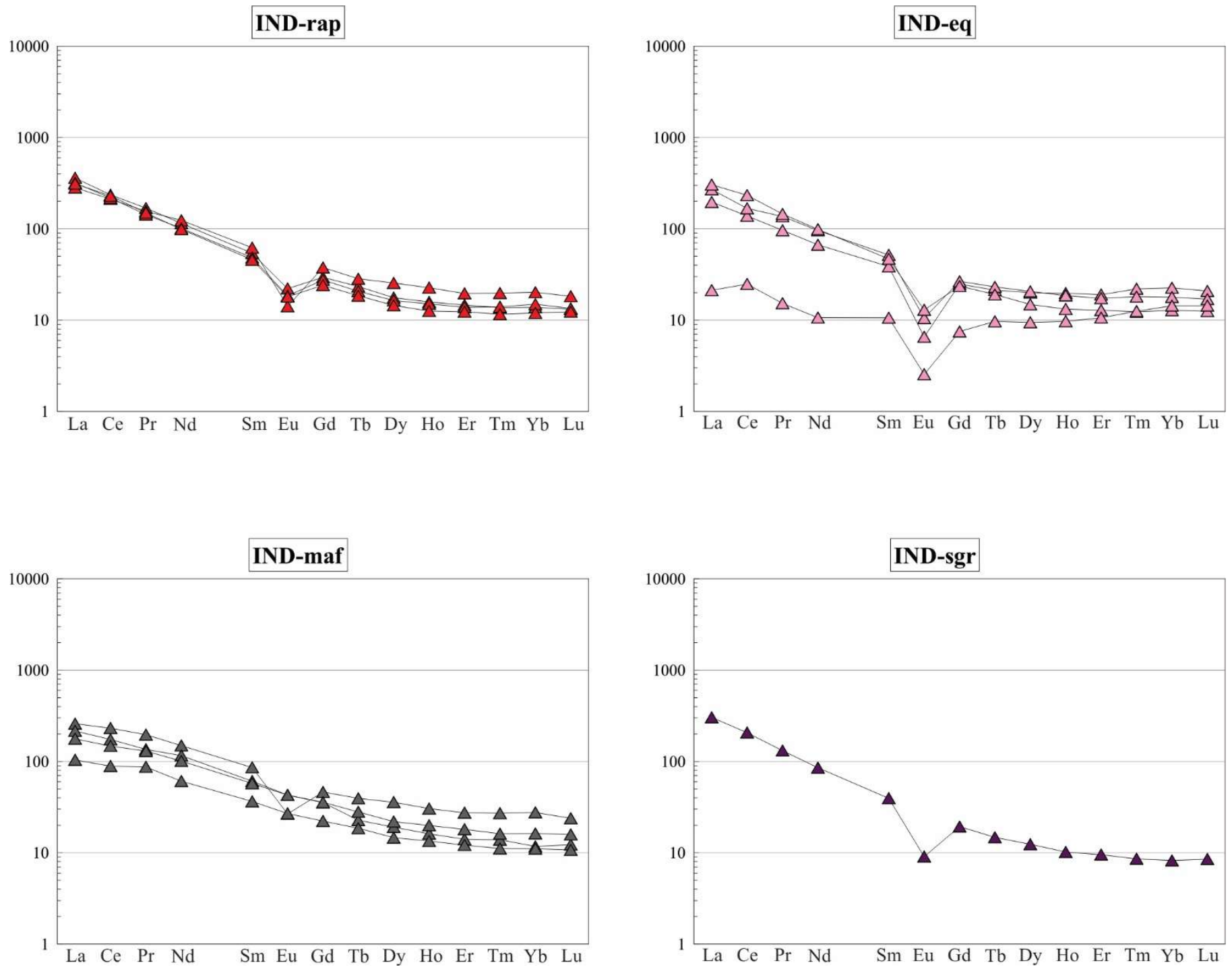

Diagramas C8 - Padrões de fracionamento dos elementos terras raras das amostras do Plúton Indaiatuba, normalizados segundo Boynton (1984); dados em escala logarítmica. 
Tabela C1 - Análises químicas pelo método de FRX de amostras do Plúton Cabreúva.

\begin{tabular}{|c|c|c|c|c|c|c|c|c|c|c|c|c|c|}
\hline & $\begin{array}{l}\text { IGN- } \\
29\end{array}$ & $\begin{array}{c}\text { CAB-14- } \\
13\end{array}$ & CAB-16-76A & CAB-16-76D & CAB-16-79 & CAB-16-80A & $\begin{array}{c}\text { CAB-14- } \\
15\end{array}$ & $\begin{array}{l}\text { CAB-16- } \\
90\end{array}$ & CAB-16-91B & CAB-16-76B & CAB-16-76E & CAB-16-80B & CAB-16-76C \\
\hline & \multicolumn{6}{|c|}{ CAB-gsr } & \multicolumn{3}{|c|}{ CAB-gpr } & \multicolumn{4}{|c|}{ CAB-emf } \\
\hline $\mathrm{SiO}_{2}$ & 74.86 & 70.64 & 74.14 & 73.48 & 72.36 & 73.74 & 75.08 & 71.29 & 60.96 & 68.83 & 71.90 & 71.52 & 71.76 \\
\hline $\mathrm{TiO}_{2}$ & 0.25 & 0.47 & 0.26 & 0.23 & 0.33 & 0.24 & 0.23 & 0.40 & 0.78 & 0.62 & 0.43 & 0.42 & 0.43 \\
\hline $\mathbf{A l}_{2} \mathbf{O}_{3}$ & 12.51 & 13.53 & 12.67 & 12.48 & 12.90 & 12.68 & 12.37 & 13.06 & 17.39 & 14.22 & 12.45 & 13.20 & 12.61 \\
\hline $\mathrm{Fe}_{2} \mathrm{O}_{3}$ & 1.98 & 3.14 & 2.14 & 1.91 & 1.89 & 1.92 & 1.87 & 3.04 & 5.80 & 3.75 & 2.91 & 2.39 & 2.87 \\
\hline FeOt & 1.78 & 2.82 & 1.92 & 1.72 & 1.70 & 1.73 & 1.68 & 2.73 & 5.21 & 3.37 & 2.62 & 2.15 & 2.58 \\
\hline MnO & 0.046 & 0.060 & 0.044 & 0.038 & 0.037 & 0.033 & 0.046 & 0.049 & 0.100 & 0.077 & 0.062 & 0.043 & 0.060 \\
\hline MgO & 0.25 & 0.34 & 0.28 & 0.27 & 0.41 & 0.24 & 0.06 & 0.31 & 1.31 & 0.71 & 0.51 & 0.40 & 0.48 \\
\hline $\mathrm{CaO}$ & 0.83 & 1.46 & 0.95 & 0.88 & 0.91 & 0.91 & 0.87 & 1.30 & 3.49 & 1.54 & 1.07 & 1.04 & 1.17 \\
\hline $\mathrm{Na}_{2} \mathrm{O}$ & 3.32 & 3.72 & 3.44 & 3.50 & 3.39 & 3.47 & 3.65 & 3.28 & 6.16 & 3.78 & 3.23 & 3.54 & 3.43 \\
\hline $\mathbf{K}_{2} \mathbf{O}$ & 5.12 & 5.25 & 5.24 & 5.08 & 5.45 & 5.28 & 4.89 & 5.49 & 2.44 & 5.34 & 5.23 & 5.39 & 4.83 \\
\hline $\mathbf{P}_{2} \mathbf{O}_{5}$ & 0.043 & 0.111 & 0.052 & 0.046 & 0.050 & 0.048 & 0.042 & 0.075 & 0.327 & 0.158 & 0.103 & 0.073 & 0.116 \\
\hline $\mathbf{P F}$ & 0.42 & 0.38 & 0.57 & 0.72 & 0.75 & 0.46 & 0.41 & 0.42 & 0.49 & 0.82 & 0.78 & 0.88 & 0.80 \\
\hline Total & 99.63 & 99.10 & 99.79 & 98.63 & 98.48 & 99.02 & 99.52 & 98.71 & 99.24 & 99.84 & 98.67 & 98.90 & 98.55 \\
\hline $\mathbf{B a}$ & 445 & 1211 & 438 & 463 & 684 & 476 & 419 & 1336 & 349 & 556 & 437 & 563 & 412 \\
\hline $\mathrm{Ce}$ & 133 & 212 & 194 & 164 & 179 & 160 & 139 & 226 & 129 & 151 & 155 & 160 & 50 \\
\hline Co & $<6$ & $<6$ & $<6$ & $<6$ & $<6$ & $<6$ & $<6$ & $<6$ & 10 & $<6$ & $<6$ & $<6$ & $<6$ \\
\hline $\mathrm{Cr}$ & $<13$ & $<13$ & $<13$ & $<13$ & $<13$ & $<13$ & $<13$ & $<13$ & 16 & $<13$ & $<13$ & $<13$ & $<13$ \\
\hline $\mathrm{Cu}$ & 5 & $<5$ & $<5$ & $<5$ & $<5$ & $<5$ & $<5$ & $<5$ & 6 & $<5$ & $<5$ & 6 & $<5$ \\
\hline Ga & 19 & 18 & 20 & 20 & 16 & 19 & 20 & 20 & 29 & 20 & 19 & 19 & 21 \\
\hline La & 102 & 132 & 108 & 105 & 109 & 95 & 68 & 136 & 43 & 97 & 88 & 76 & $<28$ \\
\hline $\mathrm{Nb}$ & 40 & 31 & 45 & 38 & 23 & 36 & 43 & 46 & 69 & 42 & 53 & 37 & 65 \\
\hline Nd & 60 & 64 & 72 & 61 & 56 & 58 & 44 & 89 & 77 & 62 & 66 & 56 & 30 \\
\hline $\mathbf{N i}$ & $<5$ & $<5$ & $<5$ & $<5$ & $<5$ & $<5$ & $<5$ & $<5$ & 6 & $<5$ & $<5$ & $<5$ & $<5$ \\
\hline $\mathbf{P b}$ & 24 & 19 & 13 & 12 & 13 & 13 & 19 & 12 & 14 & 18 & 16 & 19 & 18 \\
\hline $\mathbf{R b}$ & 152 & 127 & 186 & 177 & 149 & 157 & 234 & 143 & 141 & 171 & 173 & 160 & 185 \\
\hline Sc & $<14$ & $<14$ & $<14$ & $<14$ & $<14$ & $<14$ & $<14$ & $<14$ & $<14$ & $<14$ & $<14$ & $<14$ & \\
\hline
\end{tabular}


Tabela C1 - continuação

\begin{tabular}{|c|c|c|c|c|c|c|c|c|c|c|c|c|c|}
\hline $\mathbf{S r}$ & 92 & 190 & 89 & 89 & 117 & 95 & 83 & 158 & 262 & 108 & 89 & 110 & 91 \\
\hline Th & 26 & 22 & 17 & 18 & 8 & 17 & 44 & 15 & 14 & 12 & 11 & $<7$ & $<7$ \\
\hline $\mathbf{U}$ & 14 & 3 & $<3$ & $<3$ & 7 & $<3$ & 7 & $<3$ & 4 & 16 & 8 & 6 & 6 \\
\hline $\mathbf{V}$ & $<9$ & 14 & $<9$ & $<9$ & 15 & 10 & $<9$ & 11 & 39 & 27 & 17 & 17 & 17 \\
\hline $\mathbf{Y}$ & 53 & 42 & 57 & 51 & 29 & 47 & 61 & 47 & 111 & 56 & 65 & 35 & 52 \\
\hline $\mathbf{Z n}$ & 48 & 52 & 46 & 42 & 37 & 42 & 40 & 54 & 121 & 77 & 59 & 51 & 65 \\
\hline $\mathbf{Z r}$ & 239 & 397 & 263 & 241 & 273 & 245 & 215 & 411 & 628 & 487 & 291 & 380 & 294 \\
\hline $\mathbf{F}$ & 1712 & 1346 & 1722 & 1406 & 923 & 1214 & 4136 & 931 & 3442 & 1527 & 1135 & 1214 & 1265 \\
\hline Cl & $<50$ & $<500$ & $<500$ & $<500$ & $<500$ & $<500$ & $<500$ & $<500$ & $<500$ & $<500$ & $<500$ & $<500$ & $<500$ \\
\hline $\mathbf{S}$ & $<300$ & $<550$ & $<550$ & $<550$ & $<550$ & $<550$ & $<550$ & $<550$ & $<550$ & $<550$ & $<550$ & $<550$ & $<550$ \\
\hline
\end{tabular}


Tabela C1 - continuação

\begin{tabular}{|c|c|c|c|c|}
\hline & $\begin{array}{l}\text { IGN- } \\
24 \mathrm{~A}\end{array}$ & $\begin{array}{c}\text { IGN- } \\
28\end{array}$ & $\begin{array}{c}\text { CAB-14- } \\
18\end{array}$ & $\begin{array}{c}\text { CAB-16- } \\
82\end{array}$ \\
\hline & \multicolumn{2}{|c|}{ CAB-bW } & \multicolumn{2}{|c|}{ CAB-bE } \\
\hline $\mathrm{SiO}_{2}$ & 76.94 & 75.63 & 76.15 & 76.60 \\
\hline $\mathrm{TiO}_{2}$ & 0.12 & 0.21 & 0.19 & 0.09 \\
\hline $\mathbf{A l}_{2} \mathbf{O}_{3}$ & 11.64 & 12.30 & 10.99 & 11.60 \\
\hline $\mathrm{Fe}_{2} \mathrm{O}_{3}$ & 1.42 & 1.76 & 2.38 & 1.21 \\
\hline $\mathrm{FeOt}$ & 1.28 & 1.58 & 2.14 & 1.09 \\
\hline MnO & 0.047 & 0.042 & 0.072 & 0.011 \\
\hline MgO & 0.08 & 0.21 & 0.01 & 0.06 \\
\hline $\mathrm{CaO}$ & 0.62 & 0.80 & 0.64 & 0.46 \\
\hline $\mathrm{Na}_{2} \mathrm{O}$ & 3.38 & 3.35 & 3.16 & 2.46 \\
\hline $\mathbf{K}_{2} \mathbf{O}$ & 4.70 & 5.01 & 4.95 & 6.25 \\
\hline $\mathbf{P}_{2} \mathbf{O}_{5}$ & 0.007 & 0.035 & 0.012 & 0.009 \\
\hline $\mathbf{P F}$ & 0.52 & 0.46 & 0.10 & 0.26 \\
\hline Total & 99.47 & 99.81 & 98.65 & 99.01 \\
\hline Ba & 147 & 388 & 87 & 188 \\
\hline $\mathrm{Ce}$ & 103 & 113 & 311 & 133 \\
\hline Co & $<6$ & $<6$ & $<6$ & $<6$ \\
\hline $\mathrm{Cr}$ & $<13$ & $<13$ & $<13$ & $<13$ \\
\hline $\mathrm{Cu}$ & 12 & $<5$ & $<5$ & $<5$ \\
\hline Ga & 19 & 20 & 16 & 16 \\
\hline La & 65 & 83 & 167 & 77 \\
\hline Nb & 57 & 42 & 28 & 14 \\
\hline Nd & 59 & 50 & 97 & 40 \\
\hline $\mathbf{N i}$ & $<5$ & $<5$ & $<5$ & $<5$ \\
\hline $\mathbf{P b}$ & 24 & 24 & 22 & 17 \\
\hline $\mathbf{R b}$ & 176 & 184 & 93 & 148 \\
\hline Sc & $<14$ & $<14$ & $<14$ & $<14$ \\
\hline
\end{tabular}


Tabela C1 - continuação

\begin{tabular}{lcccc}
\hline $\mathbf{S r}$ & 25 & 83 & 19 & 126 \\
\hline $\mathbf{T h}$ & 34 & 30 & 25 & 7 \\
\hline $\mathbf{U}$ & 14 & 13 & 4 & $<3$ \\
\hline $\mathbf{V}$ & $<9$ & $<9$ & $<9$ & $<9$ \\
\hline $\mathbf{Y}$ & 66 & 57 & 37 & 13 \\
\hline $\mathbf{Z n}$ & 42 & 43 & 58 & 14 \\
\hline $\mathbf{Z r}$ & 187 & 230 & 323 & 118 \\
\hline & & & & \\
\hline $\mathbf{F}$ & 2406 & 2240 & 577 & 212 \\
\hline $\mathbf{C l}$ & $<50$ & $<50$ & $<500$ & $<500$ \\
\hline $\mathbf{S}$ & $<300$ & $<300$ & $<550$ & $<550$ \\
\hline
\end{tabular}


Tabela C2 - Análises químicas pelo método de ICP-MS de amostras do Plúton Cabreúva.

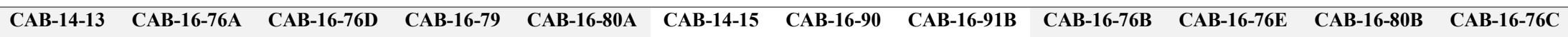

\begin{tabular}{|c|c|c|c|c|c|c|c|c|c|c|c|c|}
\hline & & 皮 & & & & 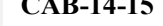 & ences & CAB-16-91B & 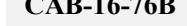 & של & & We 10 \\
\hline & & & CAB-sgr & & & & CAB-gpr & & & CAl & 3-emf & \\
\hline $\mathbf{R b}$ & 124 & 184 & 176 & 150 & 158 & 236 & 140 & 138 & 170 & 176 & 160 & 185 \\
\hline $\mathrm{Sr}$ & 191 & 90 & 90 & 121 & 96 & 80 & 168 & 270 & 111 & 92 & 111 & 91 \\
\hline $\mathrm{Zr}$ & 436 & 252 & 238 & 256 & 255 & 223 & 410 & 643 & 491 & 292 & 333 & 282 \\
\hline $\mathbf{N b}$ & 44.2 & 51.6 & 44.5 & 33.2 & 41.9 & 57.2 & 57.5 & 88.7 & 52.4 & 64.6 & 45.7 & 77.6 \\
\hline Cs & 1.39 & 1.53 & 0.83 & 0.20 & 1.03 & 2.30 & 0.96 & 2.38 & 0.60 & 0.51 & 0.46 & 0.83 \\
\hline Ba & 1394 & 474 & 480 & 722 & 515 & 519 & 1407 & 356 & 568 & 455 & 580 & 428 \\
\hline La & 120.25 & 94.29 & 83.55 & 88.60 & 85.45 & 65.43 & 110.80 & 48.37 & 77.71 & 72.57 & 78.66 & 22.07 \\
\hline Ce & 218.21 & 190.26 & 166.89 & 170.91 & 170.60 & 134.92 & 210.33 & 123.65 & 164.76 & 155.30 & 153.17 & 53.60 \\
\hline Pr & 22.43 & 20.87 & 19.90 & 17.88 & 19.30 & 14.16 & 21.96 & 16.95 & 17.76 & 19.01 & 16.56 & 9.07 \\
\hline Nd & 76.10 & 68.68 & 60.28 & 52.72 & 62.41 & 51.83 & 81.31 & 79.00 & 59.95 & 61.85 & 55.26 & 29.75 \\
\hline Sm & 12.62 & 12.38 & 11.47 & 8.36 & 11.52 & 10.34 & 13.36 & 18.84 & 11.45 & 13.00 & 9.42 & 8.57 \\
\hline Eu & 1.77 & 0.65 & 0.64 & 0.81 & 0.68 & 0.73 & 1.63 & 1.67 & 0.74 & 0.63 & 0.73 & 0.54 \\
\hline Tb & 1.34 & 1.62 & 1.51 & 0.93 & 1.50 & 1.48 & 1.53 & 2.84 & 1.51 & 1.88 & 1.14 & 1.52 \\
\hline Dy & 7.69 & 9.07 & 8.40 & 5.06 & 8.34 & 8.75 & 8.66 & 16.50 & 8.66 & 10.74 & 6.32 & 8.94 \\
\hline Ho & 1.55 & 1.90 & 1.74 & 0.99 & 1.70 & 2.00 & 1.74 & 3.48 & 1.77 & 2.23 & 1.29 & 1.86 \\
\hline Er & 4.07 & 5.39 & 4.90 & 2.77 & 4.73 & 5.87 & 4.76 & 9.51 & 5.04 & 6.15 & 3.45 & 5.13 \\
\hline Tm & 0.63 & 0.81 & 0.73 & 0.40 & 0.68 & 0.97 & 0.69 & 1.39 & 0.74 & 0.88 & 0.48 & 0.76 \\
\hline $\mathbf{Y b}$ & 3.85 & 5.27 & 4.71 & 2.51 & 4.34 & 6.15 & 4.35 & 8.74 & 4.61 & 5.38 & 2.95 & 4.70 \\
\hline Lu & 0.56 & 0.78 & 0.68 & 0.37 & 0.63 & 0.85 & 0.66 & 1.31 & 0.70 & 0.78 & 0.43 & 0.69 \\
\hline Hf & 10.79 & 9.33 & 8.56 & 7.72 & 9.20 & 7.36 & 10.26 & 15.61 & 13.51 & 9.08 & 9.58 & 8.62 \\
\hline $\mathbf{P b}$ & 22.09 & 26.43 & 26.34 & 26.09 & 26.24 & 25.88 & 23.22 & 19.19 & 26.73 & 28.11 & 27.22 & 28.38 \\
\hline Th & 22.80 & 22.31 & 24.43 & 16.17 & 23.40 & 38.27 & 19.02 & 16.21 & 18.04 & 20.13 & 15.39 & 11.51 \\
\hline $\mathbf{U}$ & 2.41 & 4.24 & 3.74 & 13.77 & 3.69 & 7.20 & 2.55 & 3.71 & 18.26 & 14.81 & 10.15 & 11.09 \\
\hline
\end{tabular}


Tabela C2 - continuação

IGN-24A IGN-28 $\quad$ CAB-14-18 $\quad$ CAB-16-82

\begin{tabular}{lcccc}
\hline \multicolumn{2}{c}{ CAB-bW } & \multicolumn{2}{c}{ CAB-bE } \\
\hline Rb & 171 & 182 & 93 & 146 \\
\hline Sr & 27 & 69 & 16 & 131 \\
\hline Y & 61.0 & 45.7 & 37.1 & 15.2 \\
\hline Zr & 196 & 216 & 342 & 115 \\
\hline Nb & 82.2 & 39.2 & 34.8 & 18.2 \\
\hline Cs & 0.81 & 1.53 & 1.36 & 1.77 \\
\hline Ba & 127 & 387 & 97 & 217 \\
\hline La & 61.49 & 88.34 & 179.91 & 65.86 \\
\hline Ce & 127.16 & 156.69 & 338.87 & 123.38 \\
\hline Pr & 14.77 & 17.40 & 36.21 & 12.15 \\
\hline Nd & 49.97 & 58.93 & 106.04 & 40.97 \\
\hline Sm & 11.19 & 10.54 & 17.91 & 5.61 \\
\hline Eu & 0.29 & 0.57 & 0.26 & 0.24 \\
\hline Gd & 10.79 & 8.34 & 10.36 & 3.28 \\
\hline Tb & 1.80 & 1.38 & 1.40 & 0.42 \\
\hline Dy & 10.93 & 7.60 & 7.86 & 2.26 \\
\hline Ho & 2.37 & 1.63 & 1.48 & 0.45 \\
\hline Er & 6.51 & 4.54 & 3.70 & 1.29 \\
\hline Tm & 0.94 & 0.70 & 0.54 & 0.21 \\
\hline Yb & 5.86 & 4.46 & 3.45 & 1.50 \\
\hline Lu & 0.80 & 0.64 & 0.53 & 0.25 \\
\hline Hf & 6.65 & 6.90 & 9.09 & 4.15 \\
\hline Pb & 22.24 & 21.68 & 17.59 & 28.39 \\
\hline Th & 32.52 & 28.00 & 21.16 & 16.02 \\
\hline U & 5.27 & 3.06 & 2.31 & 1.99 \\
\hline & & & & \\
\hline
\end{tabular}


Tabela C3 - Análises químicas pelo método de FRX de amostras do Plúton Indaiatuba.

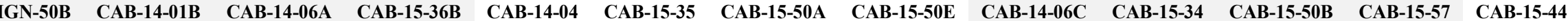

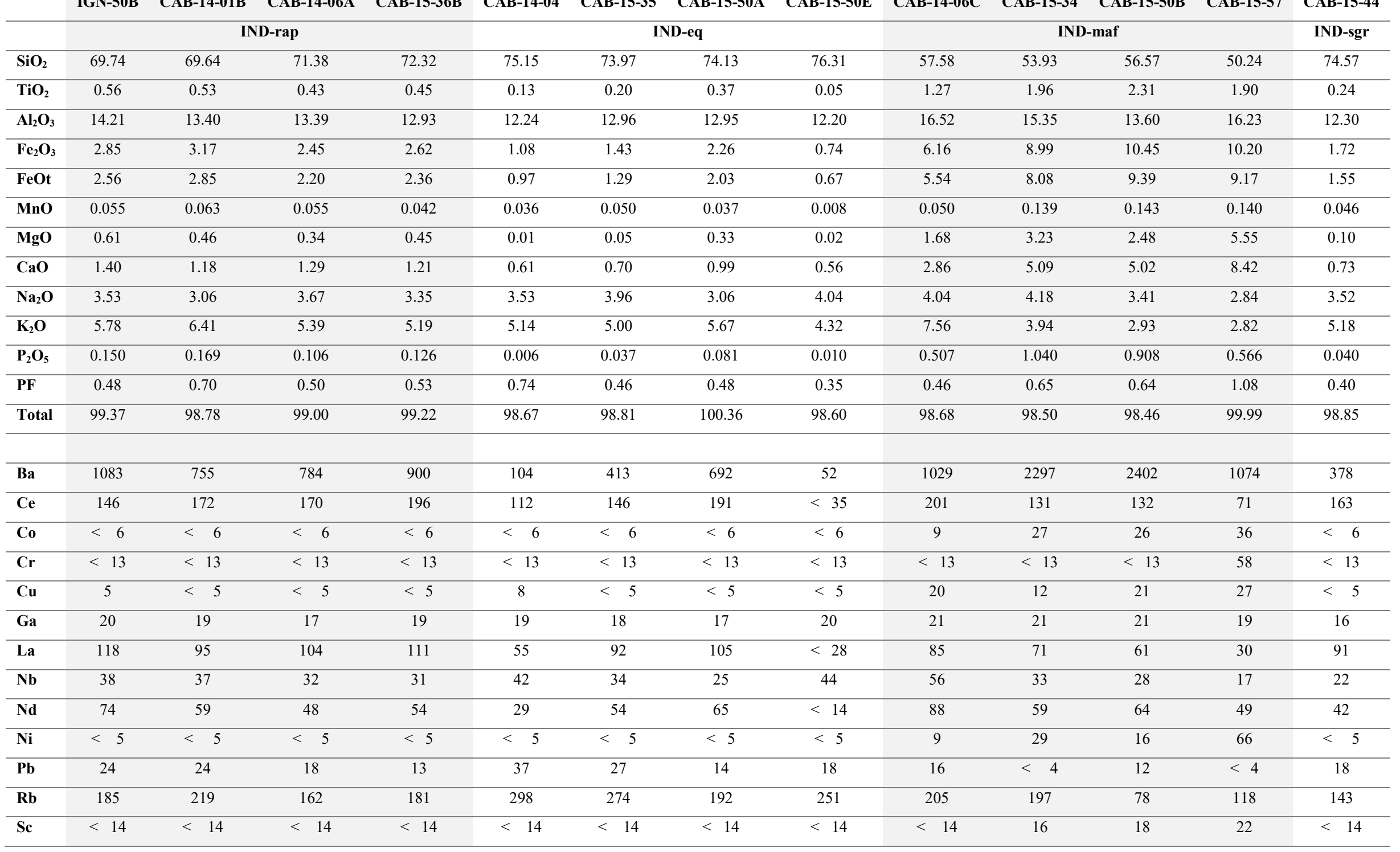


Tabela C3 - continuação

\begin{tabular}{|c|c|c|c|c|c|c|c|c|c|c|c|c|c|}
\hline $\mathbf{S r}$ & 228 & 131 & 186 & 179 & 37 & 88 & 116 & 19 & 247 & 837 & 528 & 684 & 86 \\
\hline Th & 36 & 36 & 44 & 31 & 53 & 37 & 23 & 31 & & & $<7$ & 9 & 29 \\
\hline $\mathbf{U}$ & 13 & 9 & 4 & 3 & 10 & 3 & $<3$ & $<3$ & 19 & 4 & 6 & 9 & 3 \\
\hline $\mathbf{V}$ & 26 & 24 & 19 & 20 & $<9$ & $<9$ & 12 & $<9$ & 60 & 139 & 175 & 177 & 6 \\
\hline $\mathbf{Y}$ & 40 & 42 & 31 & 27 & 42 & 45 & 28 & 17 & 63 & 35 & 41 & 29 & 20 \\
\hline $\mathbf{Z n}$ & 69 & 47 & 37 & 47 & 12 & 37 & 41 & 13 & 87 & 123 & 127 & 94 & 29 \\
\hline $\mathbf{Z r}$ & 329 & 410 & 336 & 363 & 144 & 184 & 308 & 80 & 784 & 333 & 354 & 207 & 210 \\
\hline F & 1806 & 1484 & 1648 & 996 & 1567 & 2301 & 1128 & 195 & 2901 & 2914 & 1360 & 862 & 1171 \\
\hline Cl & $<50$ & $<500$ & $<500$ & $<500$ & $<500$ & $<500$ & $<500$ & $<500$ & $<500$ & $<500$ & $<500$ & $<500$ & $<500$ \\
\hline $\mathbf{S}$ & $<300$ & $<550$ & $<550$ & $<550$ & $<550$ & $<550$ & $<550$ & $<550$ & $<550$ & $<550$ & $<550$ & $<550$ & $<550$ \\
\hline
\end{tabular}


Tabela C4 - Análises químicas pelo método de ICP-MS de amostras do Plúton Indaiatuba.

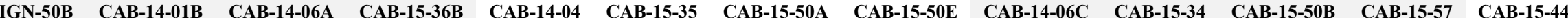

\begin{tabular}{|c|c|c|c|c|c|c|c|c|c|c|c|c|c|}
\hline & & & & & & & -eq & & & & - maf & & IND-sgr \\
\hline $\mathbf{R b}$ & 172 & 212 & 156 & 181 & 293 & 259 & 191 & 250 & 193 & 186 & 77 & 118 & 140 \\
\hline $\mathbf{S r}$ & 212 & 139 & 194 & 182 & 35 & 86 & 117 & 21 & 253 & 843 & 544 & 693 & 88 \\
\hline $\mathbf{Y}$ & 32.4 & 41.3 & 30.8 & 25.1 & 42.7 & 43.3 & 25.8 & 18.3 & 63.4 & 34.0 & 38.6 & 26.1 & 19.4 \\
\hline $\mathbf{Z r}$ & 320 & 419 & 346 & 349 & 155 & 185 & 279 & 73 & 907 & 315 & 340 & 190 & 214 \\
\hline Nb & 37.2 & 47.8 & 39.8 & 44.2 & 56.9 & 44.2 & 36.1 & 43.5 & 84.6 & 47.7 & 40.1 & 23.1 & 26.6 \\
\hline Cs & 3.18 & 1.73 & 3.14 & 2.70 & 4.09 & 4.51 & 2.70 & 4.85 & 1.08 & 2.97 & 2.49 & 7.38 & 1.22 \\
\hline $\mathbf{B a}$ & 1240 & 851 & 901 & 966 & 126 & 437 & 757 & 53 & 1050 & 2416 & 2484 & 1085 & 418 \\
\hline La & 111.86 & 87.65 & 98.71 & 96.62 & 60.94 & 83.65 & 94.33 & 6.59 & 80.22 & 66.83 & 54.86 & 32.26 & 94.26 \\
\hline $\mathrm{Ce}$ & 190.06 & 171.26 & 175.85 & 185.39 & 112.02 & 135.33 & 188.69 & 20.06 & 186.96 & 140.64 & 119.48 & 71.79 & 167.12 \\
\hline $\mathrm{Pr}$ & 20.55 & 19.01 & 17.41 & 18.24 & 11.75 & 16.65 & 17.70 & 1.86 & 23.98 & 16.56 & 15.82 & 10.62 & 16.05 \\
\hline Nd & 68.77 & 74.35 & 60.72 & 59.35 & 40.10 & 57.70 & 59.27 & 6.39 & 89.55 & 69.56 & 60.55 & 36.53 & 51.21 \\
\hline Sm & 10.55 & 12.09 & 9.44 & 8.92 & 7.54 & 10.07 & 9.13 & 2.07 & 16.76 & 11.87 & 11.19 & 7.12 & 7.71 \\
\hline $\mathbf{E u}$ & 1.63 & 1.04 & 1.36 & 1.33 & 0.48 & 0.77 & 0.95 & 0.19 & 1.96 & 3.15 & 3.15 & 1.98 & 0.67 \\
\hline Gd & 7.62 & 9.74 & 7.14 & 6.25 & 6.42 & 6.89 & 6.11 & 1.94 & 11.99 & 9.19 & 9.23 & 5.77 & 5.01 \\
\hline $\mathbf{T b}$ & 1.10 & 1.35 & 0.98 & 0.88 & 1.01 & 1.09 & 0.90 & 0.46 & 1.87 & 1.08 & 1.33 & 0.88 & 0.70 \\
\hline Dy & 5.68 & 8.21 & 5.28 & 4.66 & 6.45 & 6.64 & 4.79 & 3.03 & 11.52 & 6.15 & 7.06 & 4.71 & 3.99 \\
\hline Ho & 1.14 & 1.62 & 1.08 & 0.90 & 1.41 & 1.33 & 0.95 & 0.70 & 2.18 & 1.16 & 1.43 & 0.96 & 0.73 \\
\hline Er & 3.07 & 4.11 & 2.90 & 2.59 & 3.99 & 3.64 & 2.70 & 2.24 & 5.75 & 2.95 & 3.78 & 2.55 & 2.00 \\
\hline $\mathbf{T m}$ & 0.44 & 0.64 & 0.45 & 0.38 & 0.71 & 0.59 & 0.40 & 0.41 & 0.88 & 0.45 & 0.52 & 0.36 & 0.28 \\
\hline $\mathbf{Y b}$ & 2.89 & 4.22 & 3.12 & 2.51 & 4.71 & 3.73 & 2.68 & 3.01 & 5.77 & 2.45 & 3.39 & 2.31 & 1.72 \\
\hline Lu & 0.42 & 0.59 & 0.43 & 0.40 & 0.67 & 0.55 & 0.40 & 0.46 & 0.77 & 0.39 & 0.51 & 0.35 & 0.27 \\
\hline Hf & 7.60 & 10.50 & 9.38 & 9.81 & 6.17 & 6.03 & 8.63 & 4.04 & 19.47 & 7.13 & 8.63 & 4.96 & 6.80 \\
\hline $\mathbf{P b}$ & 21.22 & 28.17 & 21.10 & 24.83 & 39.56 & 29.09 & 25.10 & 36.20 & 24.21 & 15.18 & 11.17 & 4.14 & 21.90 \\
\hline Th & 30.72 & 32.54 & 38.25 & 34.49 & 48.49 & 32.61 & 26.82 & 40.38 & 6.60 & 8.37 & 4.09 & 7.77 & 26.34 \\
\hline $\mathbf{U}$ & 2.38 & 9.12 & 4.32 & 4.51 & 10.03 & 3.20 & 3.56 & 8.55 & 16.18 & 6.62 & 0.91 & 1.38 & 2.49 \\
\hline
\end{tabular}


Tabela C5 - Análises químicas pelo método de FRX de amostras do Plúton Itupeva.

\begin{tabular}{|c|c|c|c|c|c|c|c|c|c|c|c|c|c|}
\hline & IGN-63 & IGN-65B & IGN-66C & IGN-66D & CAB-15-62A & CAB-15-62B & CAB-15-68A & CAB-15-68B & CAB-15-68C & CAB-15-21 & CAB-15-27 & CAB-15-36 & IGN-51 \\
\hline $\mathrm{SiO}_{2}$ & 71.78 & 71.86 & 72.30 & 72.85 & 69.90 & 71.94 & 73.08 & 71.51 & 73.37 & 72.04 & 72.92 & 70.56 & 74.06 \\
\hline $\mathrm{TiO}_{2}$ & 0.42 & 0.39 & 0.40 & 0.38 & 0.57 & 0.36 & 0.33 & 0.33 & 0.33 & 0.35 & 0.24 & 0.46 & 0.27 \\
\hline $\mathrm{Al}_{2} \mathrm{O}_{3}$ & 13.61 & 13.59 & 13.40 & 13.12 & 14.38 & 13.36 & 13.37 & 13.74 & 13.40 & 13.92 & 13.41 & 13.96 & 13.17 \\
\hline $\mathrm{Fe}_{2} \mathrm{O}_{3}$ & 2.47 & 2.50 & 2.50 & 2.37 & 3.14 & 2.08 & 2.06 & 2.13 & 2.17 & 2.12 & 1.70 & 2.33 & 1.73 \\
\hline FeOt & 2.22 & 2.25 & 2.25 & 2.13 & 2.82 & 1.87 & 1.85 & 1.91 & 1.95 & 1.91 & 1.53 & 2.09 & 1.56 \\
\hline MnO & 0.065 & 0.080 & 0.054 & 0.047 & 0.080 & 0.040 & 0.050 & 0.050 & 0.050 & 0.062 & 0.067 & 0.070 & 0.078 \\
\hline MgO & 0.58 & 0.52 & 0.65 & 0.57 & 0.60 & 0.38 & 0.31 & 0.34 & 0.26 & 0.27 & 0.19 & 0.25 & 0.36 \\
\hline $\mathrm{CaO}$ & 1.41 & 1.35 & 1.53 & 1.49 & 1.67 & 1.34 & 1.17 & 1.29 & 1.10 & 0.86 & 0.75 & 1.15 & 0.97 \\
\hline $\mathrm{Na}_{2} \mathrm{O}$ & 3.35 & 3.31 & 3.41 & 3.31 & 3.55 & 3.32 & 3.46 & 3.55 & 3.47 & 3.62 & 3.46 & 3.58 & 3.54 \\
\hline $\mathbf{K}_{2} \mathrm{O}$ & 5.27 & 5.33 & 4.72 & 4.72 & 5.53 & 5.20 & 5.20 & 5.40 & 5.26 & 5.45 & 5.47 & 6.04 & 4.98 \\
\hline $\mathbf{P}_{2} \mathbf{O}_{5}$ & 0.134 & 0.125 & 0.153 & 0.127 & 0.180 & 0.110 & 0.100 & 0.100 & 0.060 & 0.083 & 0.069 & 0.075 & 0.074 \\
\hline PF & 0.52 & 0.36 & 0.34 & 0.28 & 0.46 & 0.40 & 0.36 & 0.43 & 0.42 & 0.52 & 0.36 & 2.02 & 0.30 \\
\hline Total & 99.61 & 99.41 & 99.45 & 99.27 & 100.06 & 98.53 & 99.49 & 98.87 & 99.89 & 99.29 & 98.64 & 100.50 & 99.53 \\
\hline $\mathbf{B a}$ & 1580 & 1456 & 1752 & 1792 & 1406 & 1389 & 1438 & 1512 & 927 & 1015 & 995 & 646 & 962 \\
\hline $\mathrm{Ce}$ & 104 & 113 & 108 & 119 & 243 & 144 & 181 & 178 & 177 & 123 & 221 & 177 & 90 \\
\hline Co & $<6$ & $<6$ & $<6$ & $<6$ & $<6$ & $<6$ & $<6$ & $<6$ & $<6$ & $<6$ & $<6$ & $<6$ & $<6$ \\
\hline $\mathrm{Cr}$ & $<13$ & 17 & $<13$ & 45 & 20 & 24 & 30 & 29 & 16 & $<13$ & $<13$ & 14 & $<13$ \\
\hline $\mathrm{Cu}$ & 14 & 9 & 10 & 6 & 6 & 5 & $<5$ & 5 & $<5$ & $<5$ & $<5$ & 7 & 7 \\
\hline Ga & 19 & 19 & 17 & 17 & 18 & 17 & 17 & 17 & 18 & 19 & 17 & 18 & 19 \\
\hline La & 78 & 85 & 63 & 74 & 159 & 196 & 132 & 103 & 106 & 62 & 409 & 105 & 63 \\
\hline $\mathbf{N b}$ & 44 & 47 & 38 & 39 & 36 & 22 & 34 & 33 & 23 & 53 & 36 & 37 & 46 \\
\hline Nd & 48 & 47 & 27 & 31 & 85 & 96 & 63 & 56 & 51 & 39 & 294 & 44 & 37 \\
\hline $\mathbf{N i}$ & $<5$ & $<5$ & $<5$ & 5 & 24 & 24 & 19 & 17 & 26 & $<5$ & 5 & $<5$ & $<5$ \\
\hline $\mathbf{P b}$ & 27 & 33 & 26 & 24 & 6 & 5 & $<5$ & $<5$ & $<5$ & 27 & 32 & 28 & 34 \\
\hline $\mathbf{R b}$ & 207 & 230 & 168 & 154 & 206 & 192 & 188 & 187 & 178 & 310 & 265 & 177 & 266 \\
\hline Sc & $<14$ & $<14$ & $<14$ & $<14$ & $<14$ & $<14$ & $<14$ & $<14$ & $<14$ & $<14$ & $<14$ & $<14$ & $<14$ \\
\hline $\mathrm{Sr}$ & 268 & 249 & 358 & 362 & 326 & 310 & 270 & 280 & 200 & 149 & 181 & 151 & 194 \\
\hline
\end{tabular}


Tabela C5 - continuação

\begin{tabular}{|c|c|c|c|c|c|c|c|c|c|c|c|c|c|}
\hline Th & 41 & 45 & 45 & 50 & 45 & 27 & 33 & 30 & 41 & 26 & 38 & 33 & 43 \\
\hline $\mathbf{U}$ & 12 & 13 & 5 & 7 & 4 & 3 & 3 & & 8 & 15 & 6 & 5 & 14 \\
\hline $\mathbf{V}$ & 33 & 35 & 28 & 31 & 33 & 24 & 23 & 20 & 20 & 19 & 14 & 13 & $<9$ \\
\hline $\mathbf{Y}$ & 40 & 41 & 34 & 37 & 76 & 134 & 48 & 36 & 58 & 46 & 195 & 22 & 34 \\
\hline Zn & 46 & 52 & 41 & 37 & 60 & 42 & 43 & 40 & 39 & 50 & 32 & 38 & 33 \\
\hline $\mathrm{Zr}$ & 239 & 231 & 197 & 207 & 292 & 207 & 228 & 231 & 231 & 306 & 162 & 384 & 179 \\
\hline F & 1344 & 1660 & - & - & - & - & - & - & - & 889 & 972 & 1159 & 1452 \\
\hline Cl & $<50$ & $<50$ & - & - & - & - & - & - & - & $<500$ & $<500$ & $<500$ & $<50$ \\
\hline $\mathbf{S}$ & $<300$ & $<300$ & - & - & - & - & - & - & - & $<550$ & $<550$ & $<550$ & $<300$ \\
\hline
\end{tabular}


Tabela C5 - continuação

\begin{tabular}{|c|c|c|c|}
\hline & IGN-52 & CAB-15-41 & CAB-15-30 \\
\hline $\mathrm{SiO}_{2}$ & 74.20 & 75.95 & 75.89 \\
\hline $\mathrm{TiO}_{2}$ & 0.27 & 0.14 & 0.04 \\
\hline $\mathbf{A l}_{2} \mathbf{O}_{3}$ & 12.96 & 11.98 & 12.80 \\
\hline $\mathrm{Fe}_{2} \mathrm{O}_{3}$ & 1.84 & 1.23 & 0.67 \\
\hline FeOt & 1.65 & 1.11 & 0.60 \\
\hline MnO & 0.076 & 0.086 & 0.008 \\
\hline MgO & 0.38 & 0.01 & 0.01 \\
\hline $\mathrm{CaO}$ & 1.03 & 0.62 & 0.36 \\
\hline $\mathrm{Na}_{2} \mathrm{O}$ & 3.32 & 3.66 & 2.79 \\
\hline $\mathbf{K}_{2} \mathbf{O}$ & 5.10 & 4.75 & 6.17 \\
\hline $\mathbf{P}_{2} \mathbf{O}_{5}$ & 0.082 & 0.011 & 0.000 \\
\hline PF & 0.36 & 0.44 & 0.60 \\
\hline Total & 99.62 & 98.88 & 99.34 \\
\hline
\end{tabular}

\begin{tabular}{lccc}
\hline Ba & 896 & 84 & 293 \\
\hline $\mathbf{C e}$ & 85 & 64 & - \\
\hline $\mathbf{C o}$ & $<6$ & $<6$ & $<6$ \\
\hline $\mathbf{C r}$ & $<13$ & 15 & $<13$ \\
\hline $\mathbf{C u}$ & 5 & $<5$ & $<5$ \\
\hline $\mathbf{G a}$ & 19 & 18 & 20 \\
\hline $\mathbf{L a}$ & 64 & 31 & \\
\hline $\mathbf{N b}$ & 40 & 65 & \\
\hline $\mathbf{N d}$ & 36 & 15 & $<14$ \\
\hline $\mathbf{N i}$ & 5 & $<5$ & $<5$ \\
\hline $\mathbf{P b}$ & 33 & 32 & 23 \\
\hline $\mathbf{R b}$ & 256 & 358 & 256 \\
\hline Sc & $<14$ & $<14$ & $<14$ \\
\hline Sr & 179 & 27 & 119 \\
\hline & & &
\end{tabular}


Tabela C5 - continuação

\begin{tabular}{lccc}
\hline Th & 46 & 73 & 41 \\
\hline $\mathbf{U}$ & 13 & 21 & 8 \\
\hline $\mathbf{V}$ & 19 & $<9$ & $<9$ \\
\hline $\mathbf{Y}$ & 34 & 31 & 3 \\
\hline $\mathbf{Z n}$ & 49 & 19 & 8 \\
\hline $\mathbf{Z r}$ & 182 & 131 & 130 \\
\hline
\end{tabular}

\begin{tabular}{lccc}
\hline $\mathbf{F}$ & 1287 & 2073 & 277 \\
\hline $\mathbf{C l}$ & $<50$ & $<500$ & $<500$ \\
\hline $\mathbf{S}$ & $<300$ & $<550$ & $<550$ \\
\hline
\end{tabular}


Tabela C6 - Análises químicas pelo método de FRX de amostras do Plúton Salto.

\begin{tabular}{|c|c|c|c|c|c|c|c|c|c|c|c|c|}
\hline & ITU-06-03A & ITU-06-03B & ITU-06-04B & ITU-06-11A & ITU-06-13C & 2008-ITU-2.1D & ITU-06-11A & ITU-06-13C & IGN-21 & ITU-09-27D(E) & ITU-09-32 & ITU-11-76B \\
\hline $\mathrm{SiO}_{2}$ & 70.30 & 70.27 & 70.37 & 70.14 & 72.18 & 71.82 & 69.92 & 72.01 & 72.81 & 73.82 & 72.05 & 75.45 \\
\hline $\mathrm{TiO}_{2}$ & 0.50 & 0.52 & 0.46 & 0.55 & 0.41 & 0.38 & 0.55 & 0.42 & 0.36 & 0.33 & 0.36 & 0.29 \\
\hline $\mathrm{Al}_{2} \mathrm{O}_{3}$ & 13.69 & 13.67 & 14.06 & 14.02 & 13.62 & 13.68 & 13.97 & 13.63 & 13.39 & 13.17 & 13.56 & 12.24 \\
\hline $\mathrm{Fe}_{2} \mathrm{O}_{3}$ & 2.68 & 2.80 & 2.46 & 3.01 & 2.24 & 2.19 & 3.01 & 2.26 & 1.88 & 1.76 & 1.97 & 1.77 \\
\hline FeOt & 2.41 & 2.52 & 2.21 & 2.71 & 2.02 & 1.97 & 2.71 & 2.03 & 1.69 & 1.58 & 1.77 & 1.59 \\
\hline MnO & 0.059 & 0.068 & 0.072 & 0.074 & 0.050 & 0.055 & 0.067 & 0.049 & 0.042 & 0.037 & 0.041 & 0.030 \\
\hline MgO & 0.60 & 0.62 & 0.58 & 0.70 & 0.44 & 0.42 & 0.67 & 0.44 & 0.40 & 0.35 & 0.38 & 0.35 \\
\hline $\mathrm{CaO}$ & 1.30 & 1.30 & 1.04 & 1.25 & 1.11 & 0.94 & 1.28 & 1.12 & 1.01 & 0.99 & 1.11 & 0.71 \\
\hline $\mathrm{Na}_{2} \mathrm{O}$ & 3.61 & 3.52 & 3.82 & 3.38 & 3.86 & 3.66 & 3.47 & 3.81 & 3.40 & 3.43 & 3.52 & 2.82 \\
\hline $\mathbf{K}_{2} \mathbf{O}$ & 5.48 & 5.35 & 5.45 & 5.92 & 5.02 & 5.62 & 5.75 & 5.09 & 5.56 & 5.36 & 5.48 & 5.71 \\
\hline $\mathbf{P}_{2} \mathbf{O}_{5}$ & 0.149 & 0.150 & 0.102 & 0.150 & 0.090 & 0.084 & 0.147 & 0.091 & 0.080 & 0.071 & 0.084 & 0.069 \\
\hline PF & 0.84 & 0.83 & 0.72 & 0.65 & 0.80 & 0.52 & 0.54 & 0.68 & 0.72 & 0.58 & 0.80 & 0.64 \\
\hline Total & 99.21 & 99.10 & 99.13 & 99.85 & 99.82 & 99.37 & 99.37 & 99.60 & 99.65 & 99.90 & 99.36 & 100.08 \\
\hline $\mathbf{B a}$ & 1008 & 938 & 707 & 1028 & 1120 & 463 & 996 & 1098 & 973 & 863 & 1036 & 555 \\
\hline $\mathrm{Ce}$ & 143 & 127 & 103 & 162 & 134 & 133 & 145 & 144 & 113 & 113 & 141 & 167 \\
\hline Co & $<6$ & $<6$ & $<6$ & $<6$ & $<6$ & $<6$ & $<6$ & $<6$ & $<6$ & $<6$ & $<6$ & $<6$ \\
\hline $\mathrm{Cr}$ & $<13$ & $<13$ & $<13$ & $<13$ & $<13$ & $<13$ & $<13$ & $<13$ & $<13$ & 16 & 29 & $<13$ \\
\hline $\mathrm{Cu}$ & 8 & $<5$ & $<5$ & $<5$ & $<5$ & $<5$ & 6 & $<5$ & $<5$ & $<5$ & $<5$ & $<5$ \\
\hline Ga & 19 & 19 & 20 & 20 & 18 & 19 & 19 & 18 & 17 & 16 & 17 & 13 \\
\hline La & 72 & 79 & 67 & 81 & 94 & 83 & 77 & 93 & 86 & 68 & 89 & 73 \\
\hline $\mathbf{N b}$ & 33 & 32 & 35 & 34 & 32 & 31 & 37 & 32 & 32 & 30 & 29 & 28 \\
\hline Nd & 33 & 41 & 35 & 38 & 35 & 37 & 48 & 39 & 46 & 39 & 42 & 40 \\
\hline $\mathbf{N i}$ & $<5$ & $<5$ & $<5$ & $<5$ & $<5$ & $<5$ & $<5$ & $<5$ & $<5$ & $<5$ & $<5$ & $<5$ \\
\hline $\mathbf{P b}$ & 37 & 44 & 45 & 39 & 35 & 43 & 38 & 33 & 29 & 11 & 13 & 10 \\
\hline $\mathbf{R b}$ & 258 & 258 & 264 & 288 & 256 & 301 & 278 & 259 & 201 & 194 & 199 & 202 \\
\hline Sc & $<14$ & $<14$ & $<14$ & $<14$ & $<14$ & $<14$ & $<14$ & $<14$ & $<14$ & $<14$ & $<14$ & $<14$ \\
\hline $\mathrm{Sr}$ & 166 & 159 & 118 & 157 & 170 & 90 & 161 & 172 & 182 & 171 & 196 & 113 \\
\hline
\end{tabular}


Tabela C6 - continuação

\begin{tabular}{|c|c|c|c|c|c|c|c|c|c|c|c|c|}
\hline Th & 30 & 31 & 28 & 30 & 31 & 30 & 29 & 29 & 37 & 35 & 33 & 38 \\
\hline $\mathbf{U}$ & 24 & 27 & 31 & 20 & 7 & 28 & 22 & 8 & 14 & 8 & 7 & 4 \\
\hline V & 32 & 33 & 22 & 20 & 17 & 11 & 25 & 10 & 10 & 9 & 21 & 19 \\
\hline $\mathbf{Y}$ & 38 & 38 & 37 & 37 & 36 & 32 & 41 & 38 & 36 & 33 & 26 & 31 \\
\hline $\mathbf{Z n}$ & 60 & 61 & 47 & 54 & 49 & 39 & 49 & 46 & 38 & 28 & 33 & 31 \\
\hline $\mathbf{Z r}$ & 320 & 321 & 395 & 410 & 321 & 319 & 405 & 316 & 249 & 223 & 252 & 217 \\
\hline $\mathbf{F}$ & - & - & - & - & - & - & - & - & - & 1618 & 1525 & 719 \\
\hline Cl & - & - & - & - & - & - & - & - & - & - & - & $<50$ \\
\hline $\mathbf{S}$ & - & - & - & - & - & - & - & - & - & - & - & $<550$ \\
\hline
\end{tabular}


Tabela C6 - continuação

\begin{tabular}{|c|c|c|c|c|c|c|c|c|c|c|c|}
\hline & IGN-2.2.4 & ITU-06-04A & ITU-09-24 & ITU-09-29 A & ITU 11-131 & ITU-14X & IGN-22 & ITU-10-67 & ITU-11-67B & ITU-11-115 & ITU-11-127 \\
\hline $\mathrm{SiO}_{2}$ & 74.80 & 72.89 & 74.26 & 74.94 & 72.36 & 73.60 & 72.54 & 72.10 & 74.80 & 74.16 & 72.11 \\
\hline $\mathrm{TiO}_{2}$ & 0.32 & 0.36 & 0.34 & 0.32 & 0.41 & 0.37 & 0.39 & 0.41 & 0.31 & 0.39 & 0.39 \\
\hline $\mathbf{A l}_{2} \mathbf{O}_{3}$ & 12.51 & 12.94 & 12.43 & 12.66 & 13.71 & 12.41 & 13.64 & 13.55 & 12.55 & 12.59 & 13.76 \\
\hline $\mathrm{Fe}_{2} \mathrm{O}_{3}$ & 1.73 & 2.02 & 1.91 & 1.71 & 2.23 & 2.18 & 2.05 & 2.36 & 1.74 & 2.18 & 1.97 \\
\hline FeOt & 1.56 & 1.82 & 1.72 & 1.54 & 2.00 & 2.06 & 1.84 & 2.12 & 1.56 & 1.96 & 1.77 \\
\hline MnO & 0.050 & 0.050 & 0.044 & 0.028 & 0.060 & 0.068 & 0.040 & 0.049 & 0.050 & 0.058 & 0.037 \\
\hline MgO & 0.39 & 0.50 & 0.36 & 0.38 & 0.47 & 0.41 & 0.42 & 0.41 & 0.28 & 0.36 & 0.29 \\
\hline $\mathrm{CaO}$ & 0.86 & 1.01 & 0.90 & 0.79 & 1.13 & 0.99 & 1.20 & 1.23 & 1.00 & 0.94 & 0.96 \\
\hline $\mathrm{Na}_{2} \mathrm{O}$ & 3.18 & 3.47 & 3.25 & 3.29 & 3.47 & 3.29 & 3.58 & 3.61 & 3.29 & 3.37 & 3.69 \\
\hline $\mathbf{K}_{2} \mathbf{O}$ & 5.10 & 5.03 & 5.21 & 5.23 & 5.54 & 5.15 & 5.39 & 5.24 & 5.15 & 5.05 & 5.65 \\
\hline $\mathbf{P}_{2} \mathbf{O}_{5}$ & 0.060 & 0.083 & 0.080 & 0.069 & 0.098 & 0.092 & 0.097 & 0.089 & 0.065 & 0.089 & 0.055 \\
\hline PF & 0.64 & 0.50 & 0.52 & 0.60 & 0.60 & 0.48 & 0.38 & 0.58 & 0.59 & 0.60 & 0.68 \\
\hline Total & 99.64 & 98.85 & 99.31 & 100.02 & 100.07 & 99.04 & 99.73 & 99.63 & 99.83 & 99.79 & 99.59 \\
\hline
\end{tabular}

\begin{tabular}{|c|c|c|c|c|c|c|c|c|c|c|c|}
\hline $\mathbf{B a}$ & 698 & 755 & 721 & 705 & 1096 & - & 943 & 1122 & 726 & 680 & 1102 \\
\hline $\mathrm{Ce}$ & 103 & 130 & 140 & 128 & 162 & - & 119 & 159 & 129 & 201 & 151 \\
\hline Co & $<6$ & $<6$ & $<6$ & $<6$ & $<6$ & - & & $<6$ & $<6$ & $<6$ & $<6$ \\
\hline $\mathrm{Cr}$ & $<13$ & $<13$ & $<13$ & $<13$ & $<13$ & - & 16 & $<13$ & $<13$ & $<13$ & $<13$ \\
\hline $\mathbf{C u}$ & 5 & 8 & $<5$ & $<5$ & $<5$ & - & & $<5$ & $<5$ & $<5$ & $<5$ \\
\hline Ga & 17 & 18 & 17 & 17 & 16 & - & 17 & 16 & 15 & 16 & 16 \\
\hline La & 83 & 78 & 81 & 75 & 83 & - & 79 & 70 & 68 & 104 & 69 \\
\hline $\mathbf{N b}$ & 33 & 32 & 32 & 32 & 31 & - & 29 & 30 & 29 & 39 & 36 \\
\hline Nd & 51 & 26 & 41 & 40 & 52 & - & 33 & 45 & 39 & 56 & 35 \\
\hline $\mathbf{N i}$ & $<5$ & $<5$ & $<5$ & $<5$ & $<5$ & - & & $<5$ & $<5$ & $<5$ & $<5$ \\
\hline $\mathbf{P b}$ & 26 & 29 & 25 & 9 & 11 & - & 13 & 14 & 7 & 10 & 14 \\
\hline $\mathbf{R b}$ & 199 & 195 & 206 & 186 & 196 & - & 191 & 225 & 209 & 215 & 250 \\
\hline Sc & $<14$ & $<14$ & $<14$ & $<14$ & $<14$ & - & & $<14$ & $<14$ & $<14$ & $<14$ \\
\hline $\mathrm{Sr}$ & 145 & 158 & 150 & 127 & 212 & - & 204 & 180 & 157 & 143 & 166 \\
\hline
\end{tabular}


Tabela C6 - continuação

\begin{tabular}{lccccccccccc}
\hline Th & 40 & 36 & 37 & 40 & 29 & - & 32 & 31 & 31 & 46 & 27 \\
\hline $\mathbf{U}$ & 14 & 6 & 7 & 9 & 4 & - & 9 & 9 & 6 & 8 \\
\hline $\mathbf{V}$ & 16 & $<9$ & $<9$ & 16 & 18 & - & 16 & 21 & 15 & 13 \\
\hline $\mathbf{Y}$ & 37 & 37 & 34 & 38 & 33 & - & 33 & 35 & 33 & 53 \\
\hline $\mathbf{Z n}$ & 34 & 39 & 33 & 26 & 41 & - & 30 & 37 & 25 & 39 \\
\hline $\mathbf{Z r}$ & 210 & 235 & 229 & 223 & 244 & - & 229 & 324 & 196 & 270 \\
\hline & & & - & - & 1559 & 1251 & - & - & 1330 & 1431 & 1744 \\
\hline $\mathbf{F}$ & - & - & - & $<49$ & $<50$ & - & - & $<50$ & $<50$ & $<50$ \\
\hline $\mathbf{C l}$ & - & - & - & $<300$ & $<550$ & - & - & $<550$ & $<550$ & $<550$ \\
\hline $\mathbf{S}$ & - & - & - & & $<50$ & $<50$ \\
\hline
\end{tabular}




\section{APÊNDICE D - DADOS DE QUÍMICA DE ZIRCÃO E GEOCRONOLOGIA}




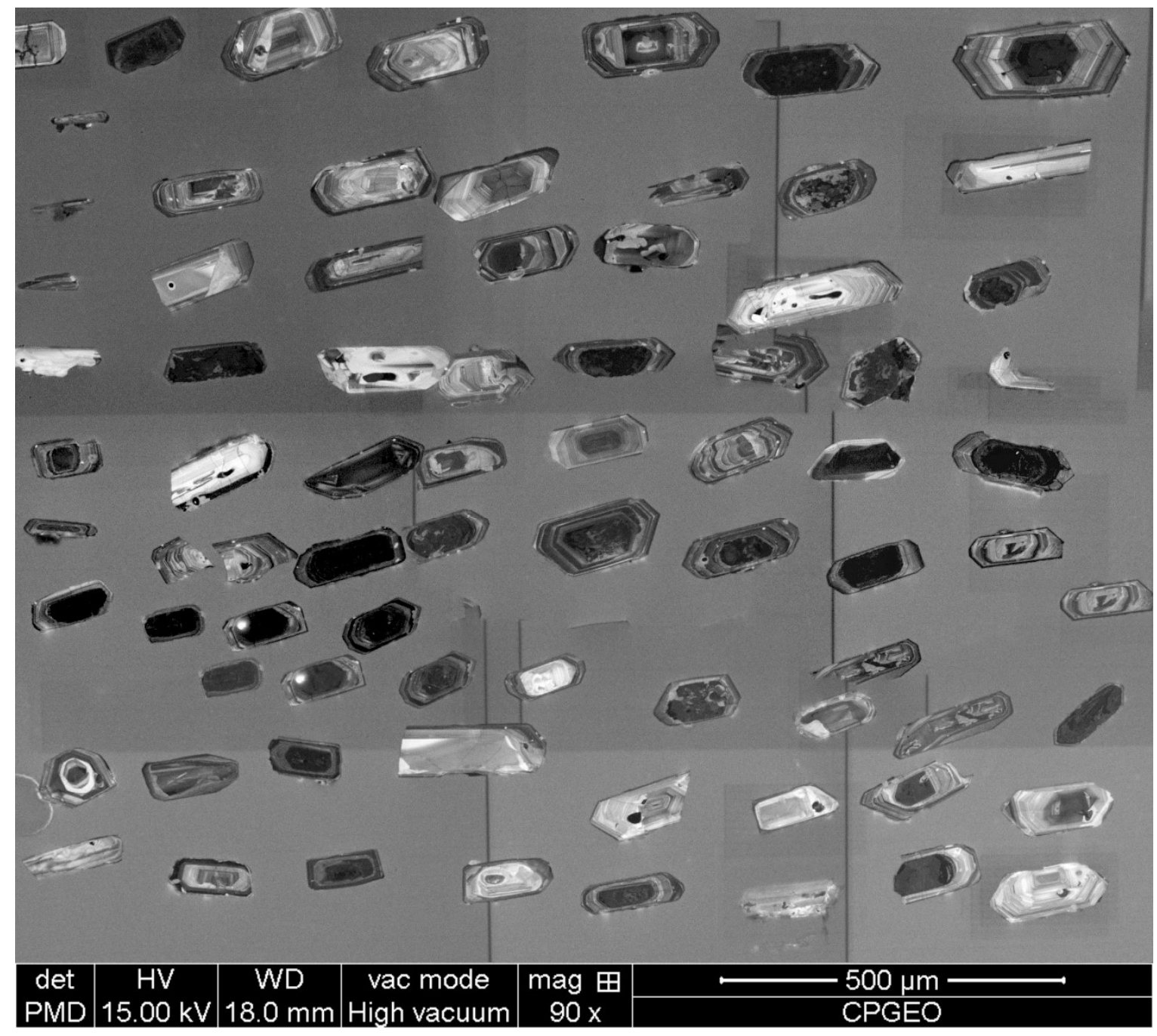
AMOSTRA CAB-16-80A - CABREÚVA

Imagem de catodoluminescência de cristais de zircão analisados pelo método SHRIMP e via LA-Q-ICPMS 

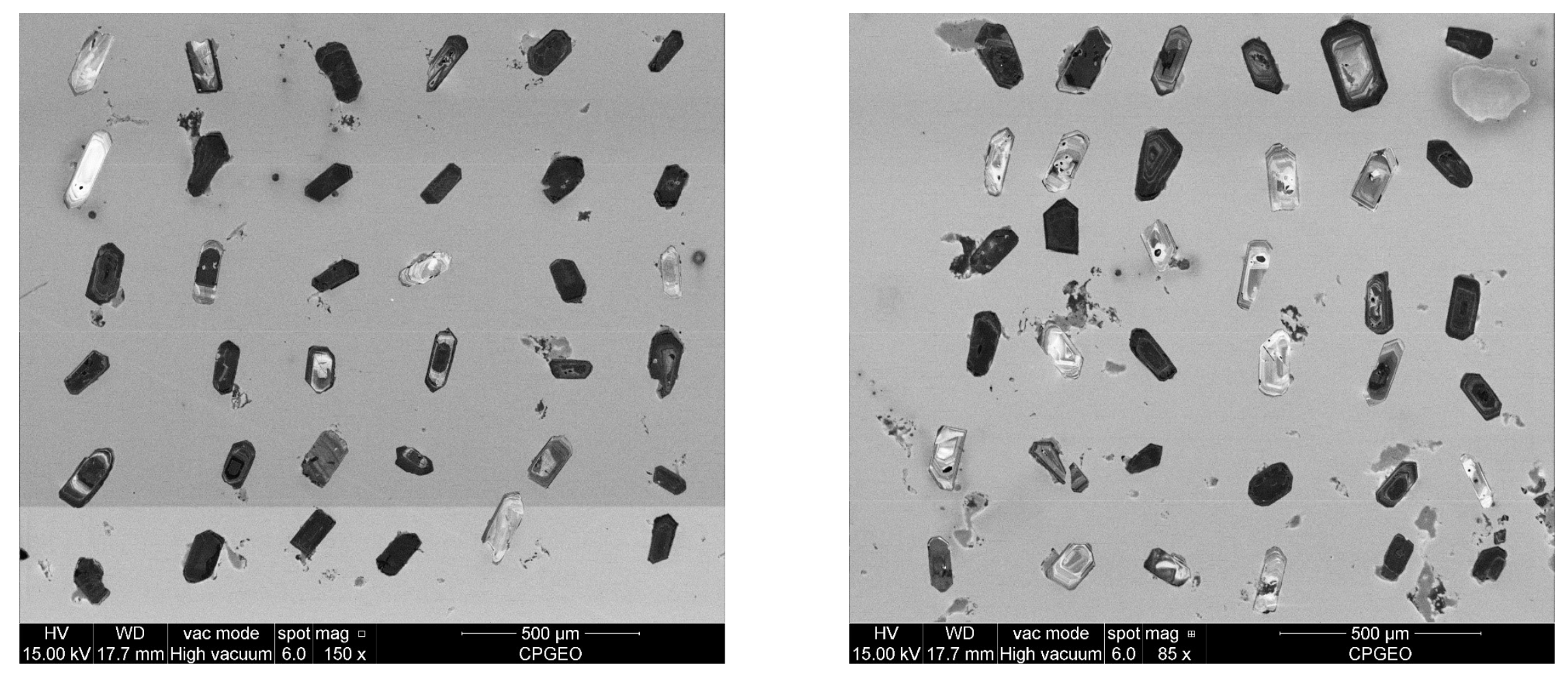

AMOSTRA IGN24A - CABREÚVA

Imagens de catodoluminescência de cristais de zircão analisados pelo método SHRIMP e via LA-Q-ICPMS. 

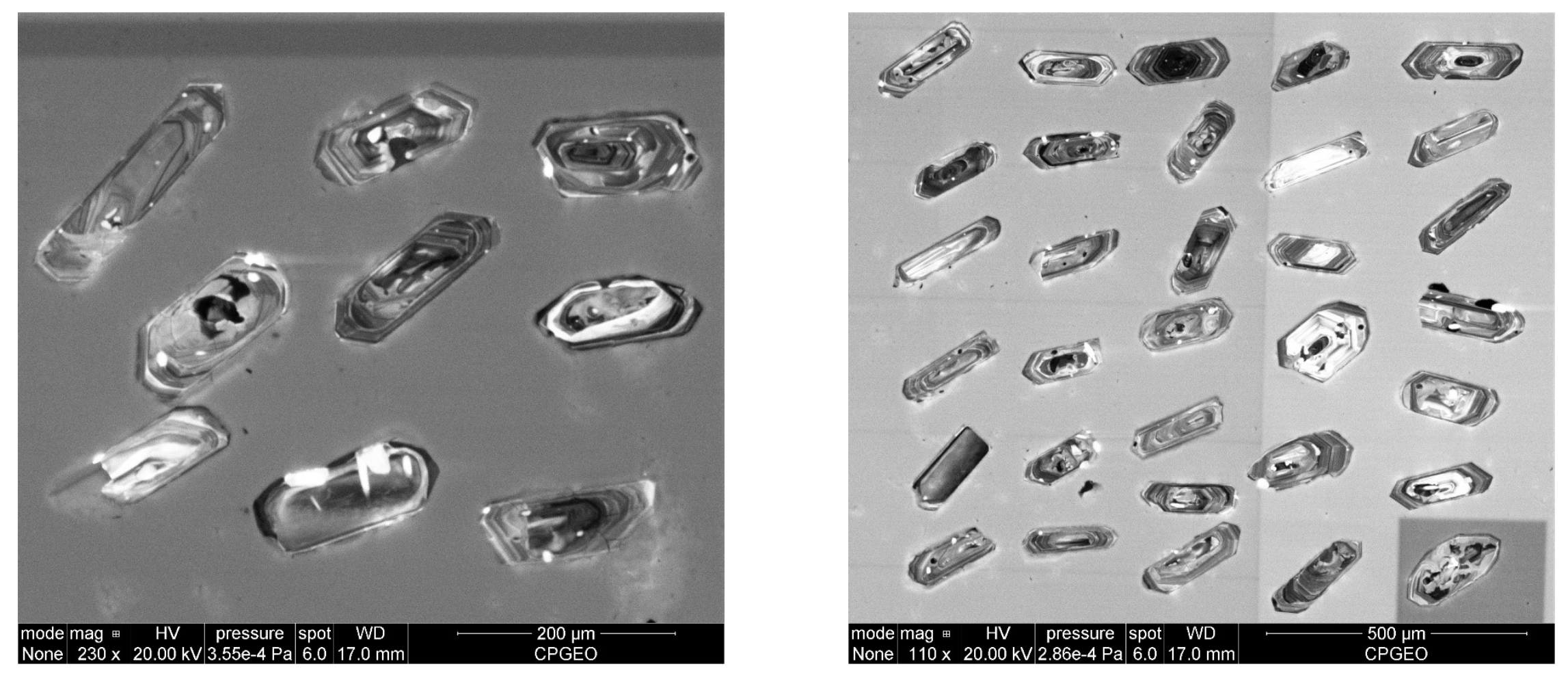

\section{AMOSTRA IGN50B - INDAIATUBA}

Imagens de catodoluminescência de cristais de zircão analisados pelo método SHRIMP e via LA-Q-ICPMS. 

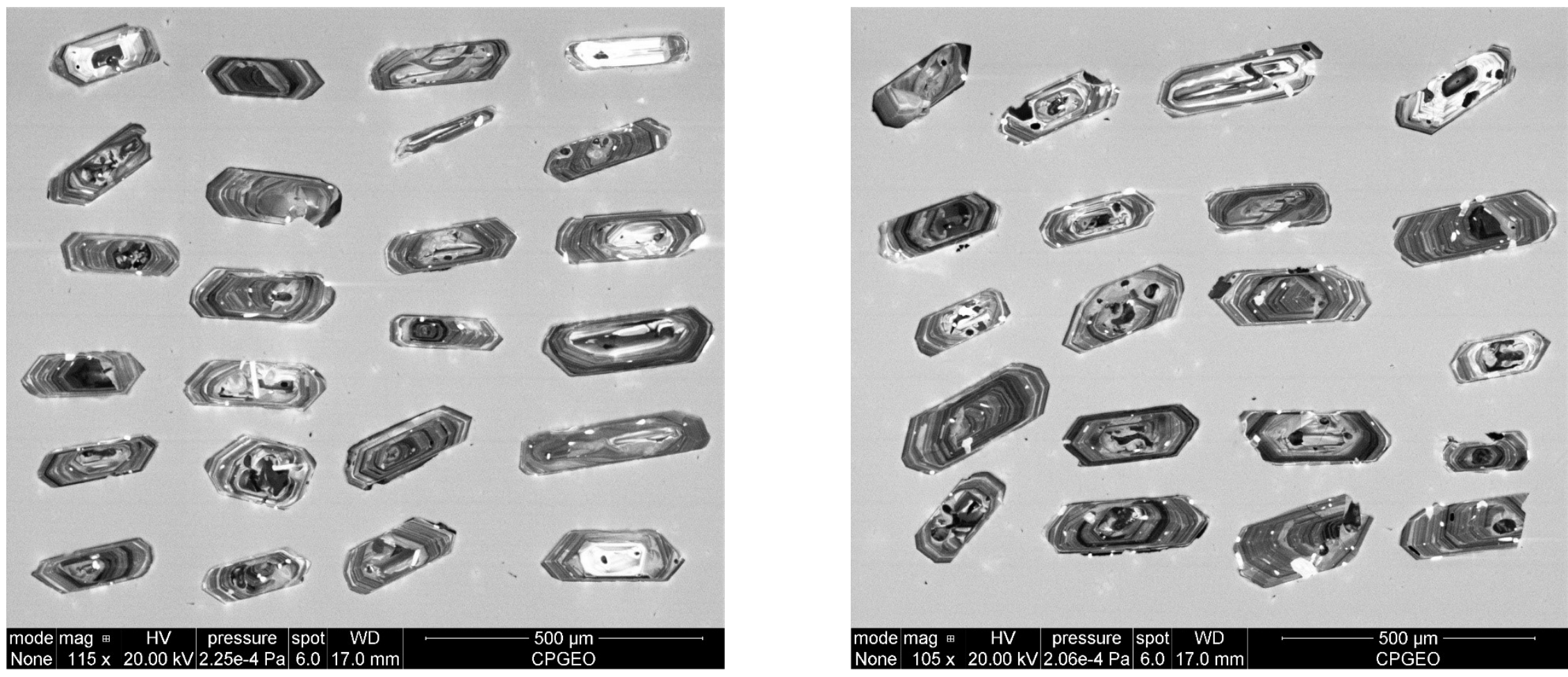

\section{AMOSTRA IGN50B - INDAIATUBA (continuação)}

Imagens de catodoluminescência de cristais de zircão analisados pelo método SHRIMP e via LA-Q-ICPMS. 


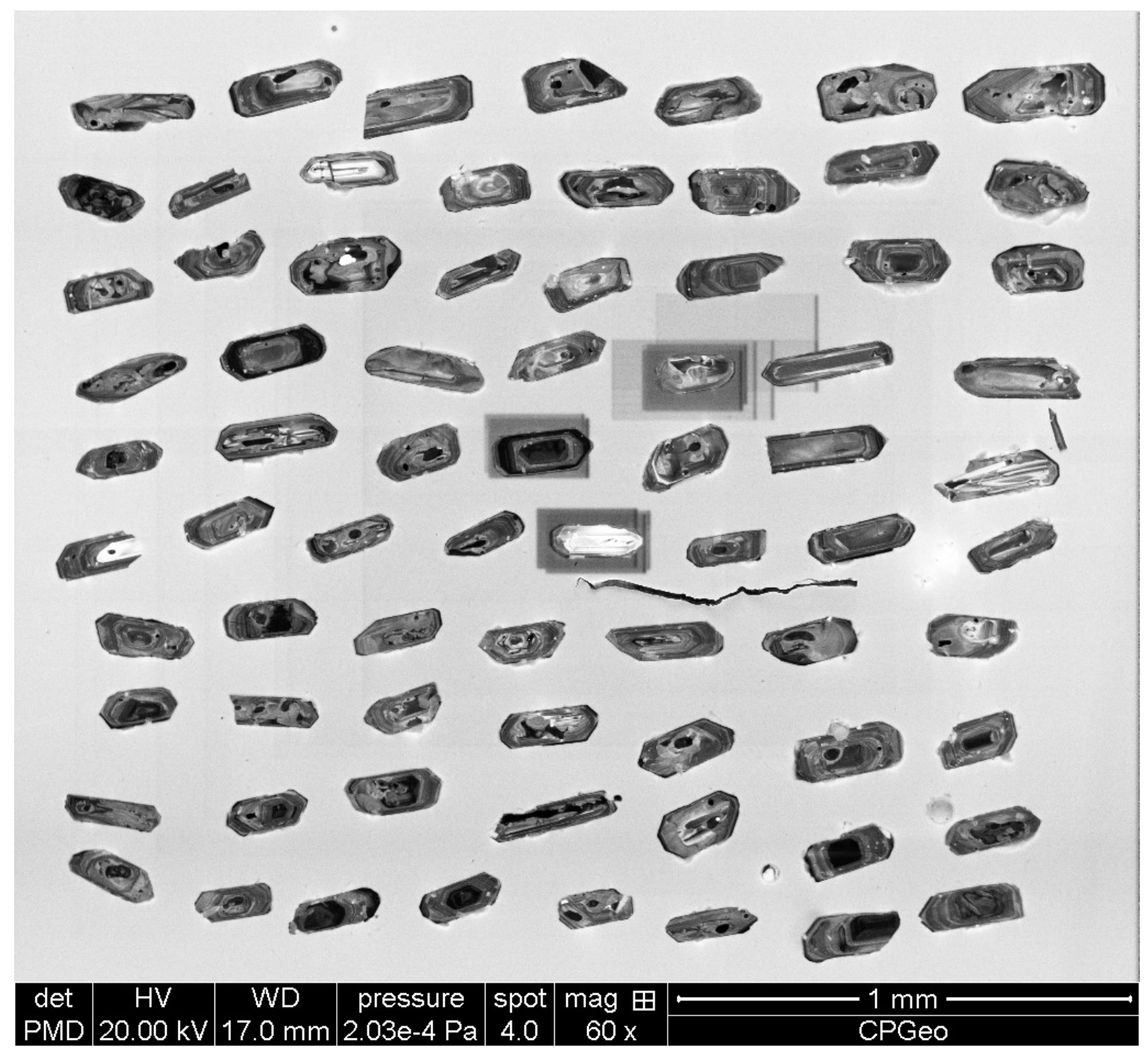

AMOSTRA CAB-15-36A - ITUPEVA

Imagem de catodoluminescência de cristais de zircão analisados pelo método SHRIMP e via LA-Q-ICPMS. 


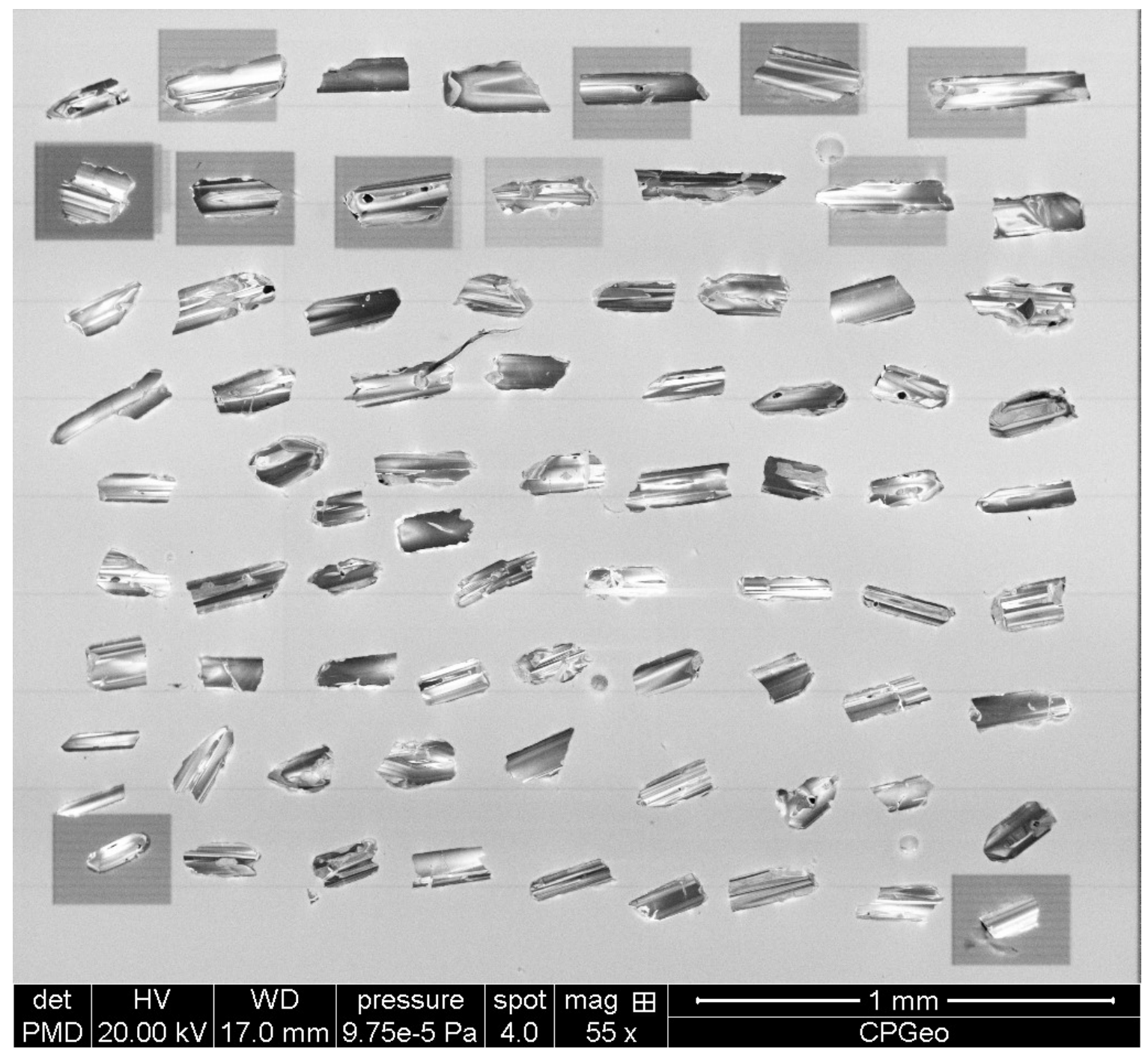

AMOSTRA IGN56 - ITUPEVA

Imagem de catodoluminescência de cristais de zircão analisados pelo método SHRIMP e via LA-Q-ICPMS. 

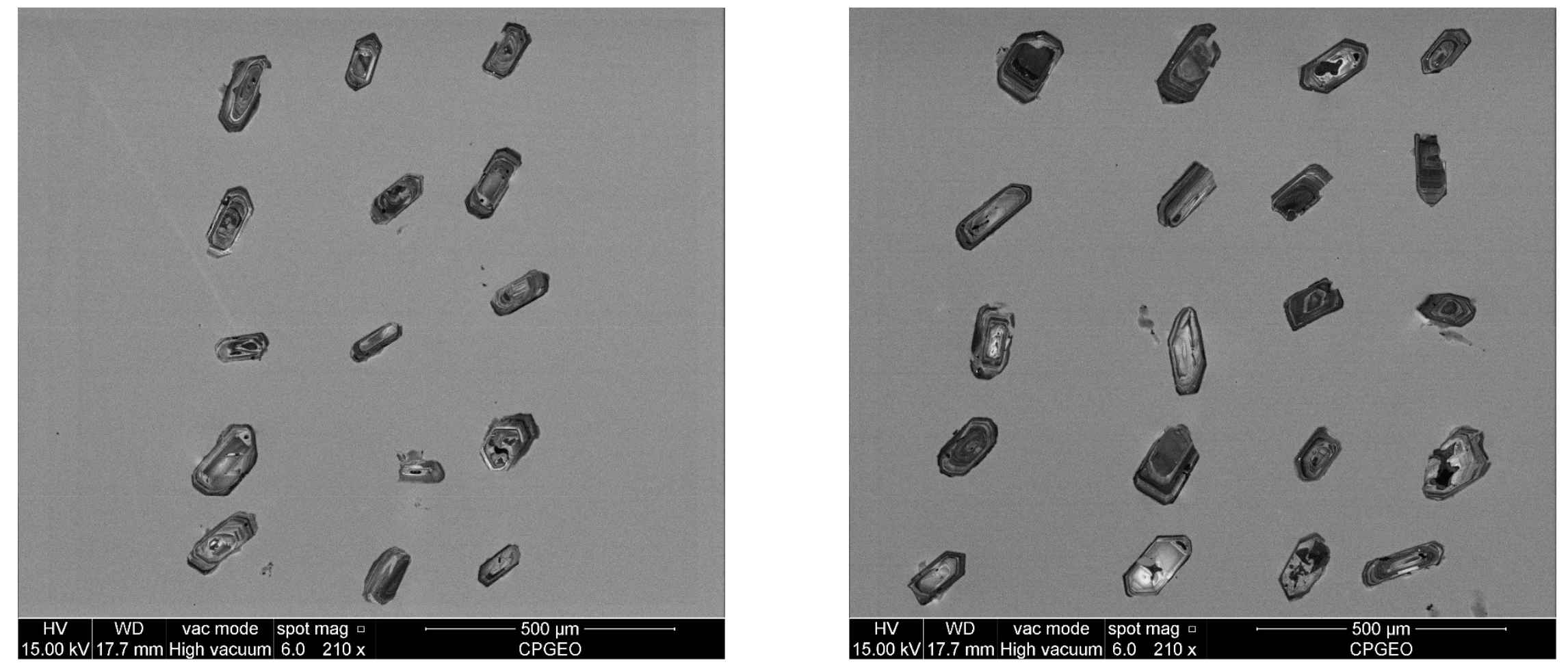

\section{AMOSTRA IGN2.2.4 - SALTO}

Imagens de catodoluminescência de cristais de zircão analisados pelo método SHRIMP e via LA-Q-ICPMS. 

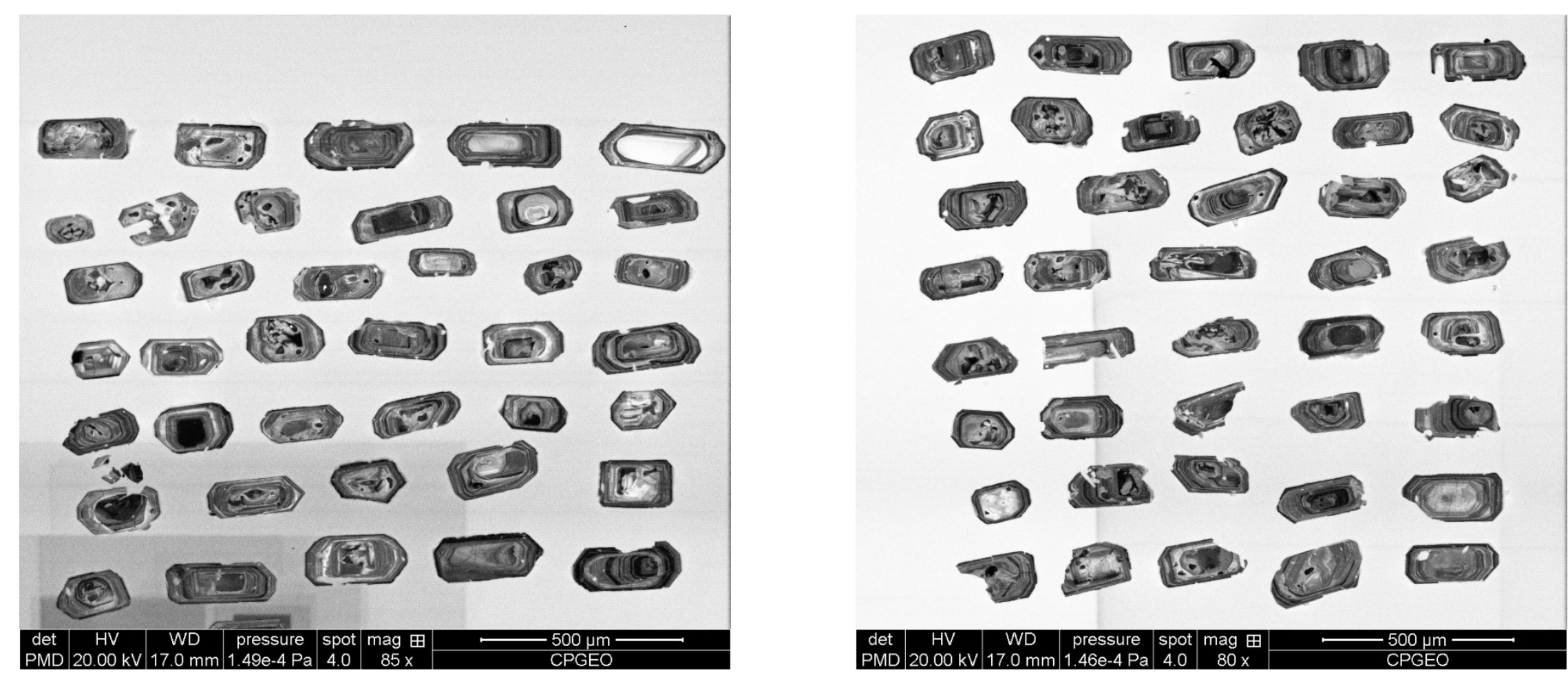

AMOSTRA ITU-14X - SALTO

Imagens de catodoluminescência de cristais de zircão analisados pelo método SHRIMP e via LA-Q-ICPMS. 

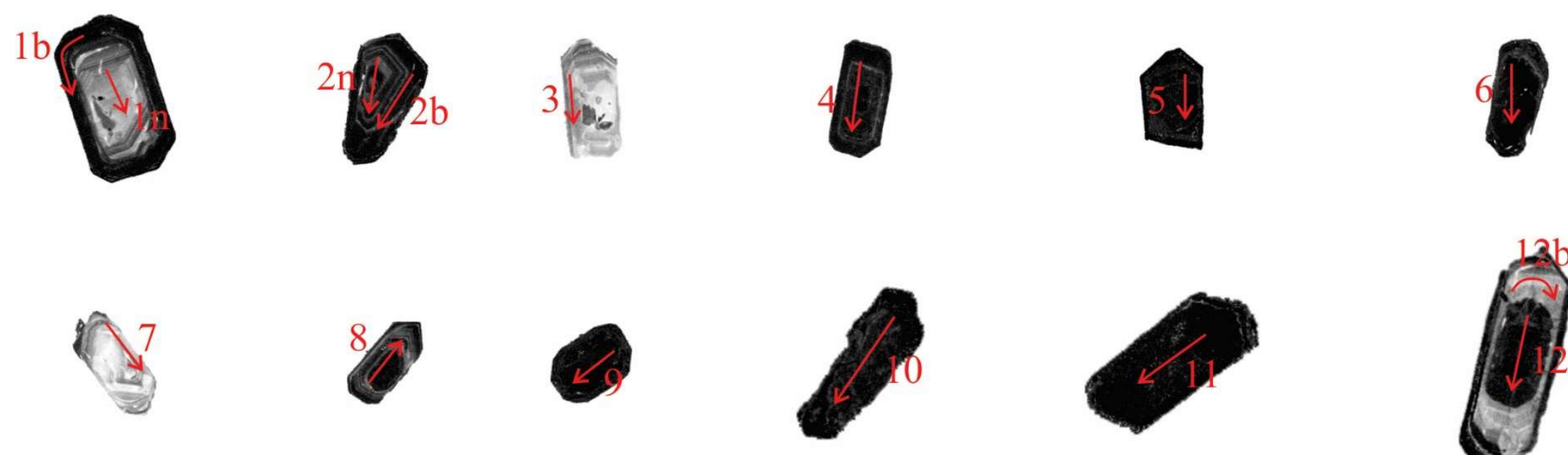

$-250 \mu \mathrm{m} \longrightarrow$

\section{AMOSTRA IGN24A - CABREÚVA}

Localização de rasters das análises químicas por LA-Q-ICPMS em cristais de zircão selecionados. 

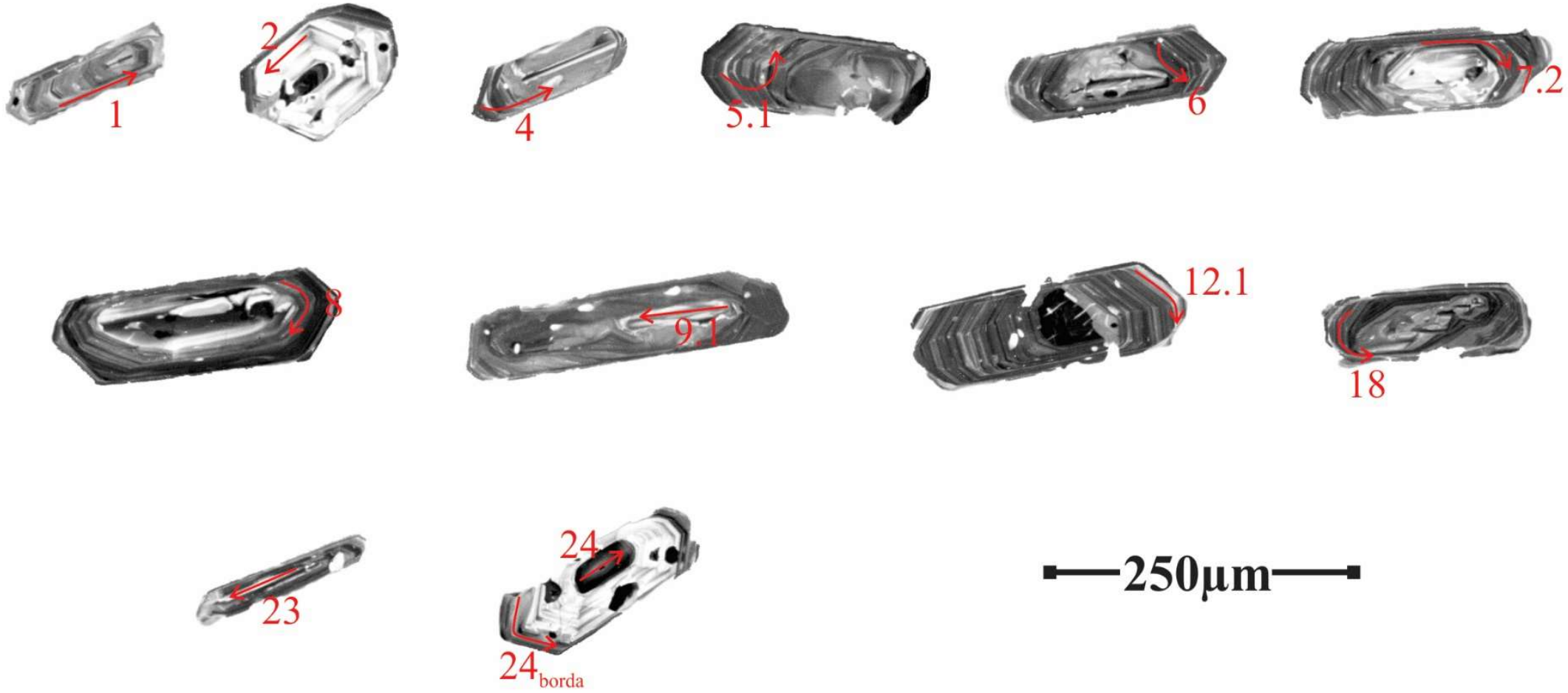

$-250 \mu \mathrm{m} \longrightarrow$

AMOSTRA IGN-50B - INDAIATUBA

Localização de rasters das análises químicas por LA-Q-ICPMS em cristais de zircão selecionados. 

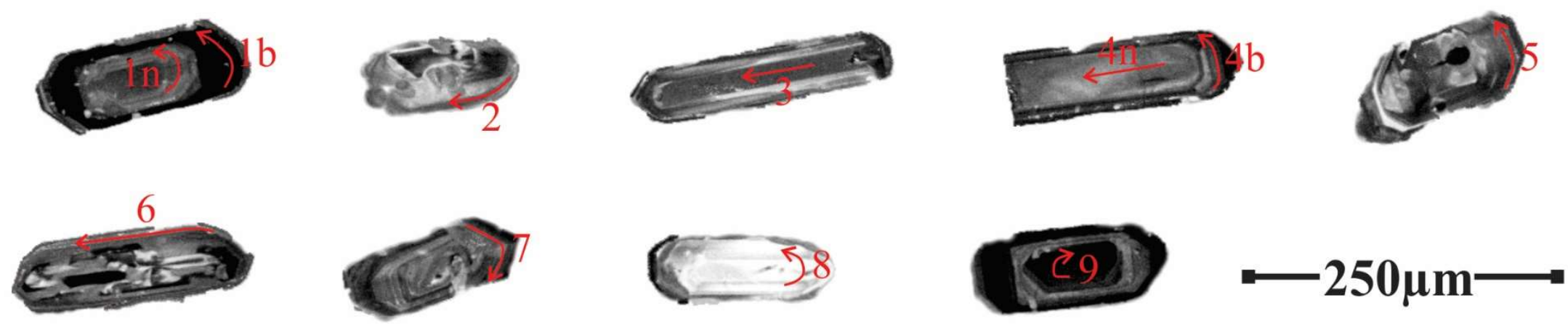

AMOSTRA CAB-15-36A - ITUPEVA

Localização de rasters das análises químicas por LA-Q-ICPMS em cristais de zircão selecionados. 

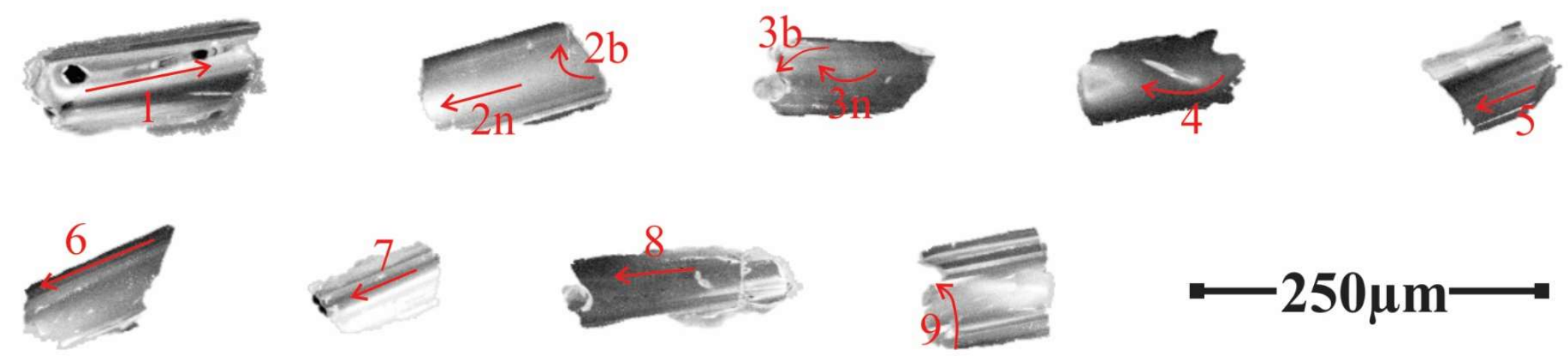

$-250 \mu \mathrm{m}$

\section{AMOSTRA IGN56 - ITUPEVA}

Localização de rasters das análises químicas por LA-Q-ICPMS em cristais de zircão selecionados. 


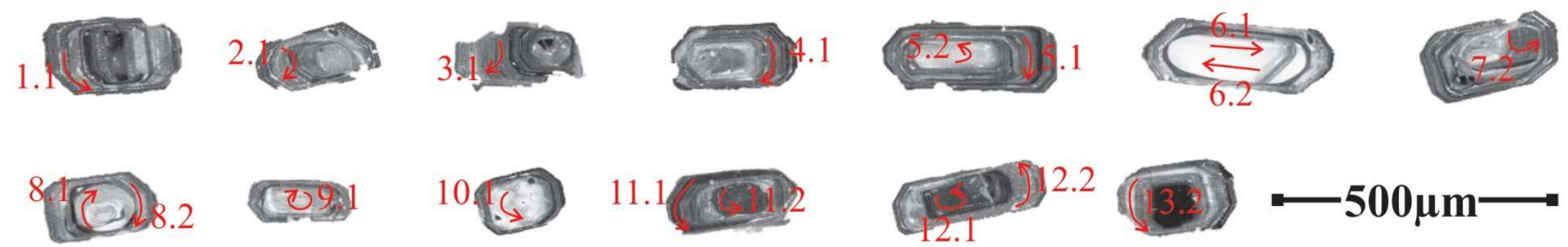

\section{AMOSTRA ITU-14X - SALTO}

Localização de rasters das análises químicas por LA-Q-ICPMS em cristais de zircão selecionados. 
Tabela D1 - Análises químicas de cristais de zircão por LA-Q-ICPMS

\begin{tabular}{|c|c|c|c|c|c|c|c|c|c|c|c|c|c|c|}
\hline \multicolumn{15}{|c|}{ PLÚTON CABREÚVA } \\
\hline \multicolumn{15}{|c|}{ AMOSTRA CAB-16-80A } \\
\hline RASTER & 1b & 1n & 2 & 3 & 4 & 5 & 6 & $7 \mathrm{~b}$ & $7 n$ & 8 & $9 b$ & $9 n$ & 10 & 11 \\
\hline \multicolumn{15}{|c|}{ [ ] de elementos traço em ppm } \\
\hline $\mathbf{L i} 7$ & 4.46 & 5.30 & 3.12 & 11.27 & 12.63 & 8.03 & 107.06 & 13.52 & 2.41 & 6.05 & 2.35 & 5.63 & 5.83 & 2.21 \\
\hline Mg24 & 1.04 & 2.75 & 72.43 & 61.01 & 145.58 & 18.10 & 158.07 & 7.00 & 1.43 & 17.37 & 9.85 & 13.52 & 10.44 & $<0.25$ \\
\hline $\mathbf{A l 2 7}$ & 2.73 & 29.91 & 233.94 & 1089.94 & 637.32 & 236.39 & 329.96 & 76.03 & 8.04 & 214.85 & 750.49 & 354.94 & 133.28 & $<1.59$ \\
\hline Si29 & 191158.64 & 200339.09 & 168129.11 & 204908.36 & 218162.39 & 190325.53 & 195287.52 & 169812.58 & 194673.09 & 206638.31 & 191115.08 & 192830.86 & 204476.94 & 191097.56 \\
\hline P31 & 391.60 & 279.32 & 257.29 & 447.39 & 927.95 & 311.12 & 156.22 & 290.07 & 207.79 & 292.42 & $<109.79$ & 266.64 & 329.61 & 363.99 \\
\hline Ca42 & $<1000.00$ & $<952.56$ & $<1107.97$ & 2468.44 & $<1219.21$ & $<1044.71$ & $<1893.45$ & $<993.31$ & $<933.58$ & $<1052.78$ & $<2772.16$ & 2531.13 & $<971.01$ & 1835.41 \\
\hline Ca44 & $<121.08$ & $<115.53$ & 535.18 & 1945.46 & 1928.25 & $<128.21$ & 1403.68 & 288.62 & $<114.96$ & 260.86 & $<342.27$ & $<273.18$ & $<119.96$ & $<112.21$ \\
\hline Sc45 & 169.17 & 169.77 & 149.70 & 217.76 & 163.45 & 158.20 & 166.52 & 155.14 & 160.54 & 179.06 & 172.41 & 154.06 & 174.92 & 167.17 \\
\hline Ti49 & $<1.19$ & 7.69 & 147.26 & 281.78 & 51.67 & 9.83 & 113.41 & 9.87 & 4.05 & 38.47 & $<4.26$ & 10.81 & 22.71 & 7.31 \\
\hline Mn55 & $<0.91$ & $<0.91$ & 15.21 & 54.53 & 45.01 & 16.46 & 184.42 & 7.66 & $<0.93$ & 12.84 & 4.69 & 3.45 & 5.36 & $<0.91$ \\
\hline Fe56 & $<10.01$ & $<9.50$ & 587.59 & 873.81 & 1229.29 & 195.69 & 2303.89 & 134.63 & $<9.12$ & 104.75 & 40.47 & 101.66 & 82.72 & $<8.71$ \\
\hline Co59 & $<0.098$ & $<0.086$ & 0.34 & $<0.126$ & 0.28 & $<0.118$ & 0.18 & $<0.129$ & $<0.087$ & 0.20 & $<0.26$ & $<0.31$ & $<0.102$ & $<0.068$ \\
\hline Rb85 & 0.26 & $<0.158$ & $<0.184$ & 0.46 & 0.56 & 0.47 & 1.12 & 0.83 & 0.50 & 0.80 & 0.59 & $<0.39$ & $<0.19$ & $<0.17$ \\
\hline Sr88 & 0.22 & 0.49 & 1.77 & 23.40 & 15.97 & 0.85 & 7.61 & 2.79 & 0.50 & 7.12 & 0.99 & 1.13 & 2.29 & 0.14 \\
\hline Y89 & 2188.33 & 1147.63 & 2130.88 & 3560.34 & 4604.01 & 1432.08 & 2241.94 & 1658.61 & 3500.00 & 2914.40 & 1754.89 & 2072.66 & 2118.14 & 972.41 \\
\hline Zr91 & 496007.06 & 496007.16 & 496007.13 & 496007.13 & 496007.13 & 496007.13 & 496007.16 & 496007.13 & 496007.13 & 496007.19 & 496007.16 & 496007.16 & 496007.16 & 496007.19 \\
\hline Nb93 & 14.61 & 12.84 & 12.59 & 74.72 & 47.63 & 24.25 & 51.05 & 21.76 & 19.12 & 53.15 & 9.24 & 17.06 & 16.64 & 8.22 \\
\hline Mo95 & 5.63 & 7.12 & 6.31 & 5.56 & 6.50 & 4.73 & 11.45 & 6.09 & 4.71 & 108.24 & 4.63 & 5.84 & 5.52 & 4.21 \\
\hline Sn118 & $<1.11$ & $<1.06$ & $<1.34$ & 3.04 & $<1.44$ & 2.60 & $<2.30$ & $<1.32$ & $<1.24$ & $<1.41$ & $<3.43$ & $<3.02$ & $<1.28$ & 1.33 \\
\hline Sb121 & $<0.34$ & $<0.37$ & $<0.38$ & $<0.35$ & $<0.49$ & $<0.41$ & $<0.69$ & $<0.36$ & $<0.32$ & $<0.43$ & $<1.02$ & $<0.81$ & $<0.39$ & $<0.33$ \\
\hline Ba137 & $<0.48$ & 0.40 & 3.50 & 14.44 & 4.94 & $<0.59$ & 5.12 & 2.47 & 0.34 & 5.29 & 0.79 & $<1.14$ & 1.03 & $<0.40$ \\
\hline La139 & 0.06 & 3.52 & 13.43 & 149.41 & 38.82 & 41.39 & 41.49 & 6.32 & 0.40 & 13.64 & 1.49 & 5.68 & 5.50 & 0.35 \\
\hline Ce140 & 19.06 & 40.93 & 85.05 & 721.33 & 329.87 & 86.95 & 190.94 & 40.02 & 26.00 & 135.14 & 34.66 & 44.56 & 66.70 & 24.03 \\
\hline Pr141 & 0.13 & 4.79 & 9.56 & 126.12 & 56.73 & 5.27 & 26.75 & 3.91 & 0.50 & 22.15 & 2.49 & 3.07 & 9.03 & 0.40 \\
\hline Nd143 & 4.95 & 39.04 & 63.04 & 799.82 & 336.45 & 38.60 & 123.86 & 22.05 & 8.70 & 141.20 & 19.61 & 26.60 & 62.46 & 3.98 \\
\hline
\end{tabular}


Tabela D1 - continuação

\begin{tabular}{|c|c|c|c|c|c|c|c|c|c|c|c|c|c|c|}
\hline Sm147 & 8.23 & 17.09 & 34.51 & 377.10 & 172.07 & 8.50 & 34.56 & 12.16 & 16.18 & 83.34 & 15.88 & 19.25 & 28.06 & 5.34 \\
\hline Eu151 & $<0.086$ & 0.35 & 0.64 & 7.04 & 4.12 & $<0.068$ & 0.54 & 0.21 & $<0.097$ & 1.01 & 0.29 & 0.65 & 1.12 & 0.22 \\
\hline Gd157 & 41.86 & 33.15 & 62.60 & 421.08 & 226.38 & 24.00 & 54.27 & 35.23 & 79.03 & 136.10 & 57.80 & 51.56 & 65.21 & 23.92 \\
\hline Tb159 & 17.20 & 9.52 & 17.95 & 74.09 & 50.20 & 10.03 & 17.49 & 12.71 & 29.21 & 33.44 & 17.06 & 16.94 & 19.94 & 9.21 \\
\hline Dy161 & 209.56 & 106.95 & 187.02 & 505.32 & 440.35 & 121.22 & 189.31 & 152.39 & 345.14 & 309.72 & 177.39 & 194.16 & 213.00 & 99.70 \\
\hline Ho165 & 76.90 & 41.53 & 64.62 & 129.61 & 152.99 & 50.26 & 75.54 & 57.55 & 133.04 & 104.63 & 59.15 & 72.15 & 78.98 & 34.86 \\
\hline Er166 & 342.06 & 178.85 & 283.46 & 476.32 & 666.32 & 231.84 & 381.92 & 260.39 & 577.54 & 422.43 & 260.02 & 319.44 & 350.71 & 158.89 \\
\hline Tm169 & 68.40 & 38.35 & 53.69 & 91.33 & 133.33 & 48.12 & 87.92 & 55.34 & 114.57 & 83.69 & 50.41 & 63.75 & 68.07 & 33.60 \\
\hline Yb173 & 633.11 & 361.72 & 508.26 & 768.68 & 1274.70 & 492.49 & 961.18 & 524.42 & 999.38 & 765.65 & 481.54 & 604.39 & 634.99 & 321.64 \\
\hline Lu175 & 118.43 & 68.24 & 93.35 & 136.50 & 225.66 & 88.84 & 221.14 & 104.84 & 185.80 & 147.79 & 90.95 & 116.04 & 122.76 & 62.79 \\
\hline Hf179 & 13025.29 & 13568.88 & 11401.88 & 14349.52 & 14562.29 & 14303.65 & 21809.06 & 14323.33 & 14250.86 & 13094.01 & 11966.24 & 12651.47 & 13006.46 & 11584.70 \\
\hline Ta181 & 3.32 & 3.42 & 2.08 & 7.17 & 8.95 & 5.52 & 7.30 & 4.63 & 5.65 & 3.42 & 2.37 & 3.60 & 4.20 & 1.93 \\
\hline Pb206 & 127.45 & 99.05 & 95.88 & 190.50 & 564.62 & 153.30 & 540.94 & 183.03 & 269.97 & 211.34 & 83.57 & 138.78 & 136.78 & 43.51 \\
\hline Pb207 & 6.35 & 18.99 & 5.37 & 14.14 & 30.01 & 13.06 & 36.23 & 30.74 & 21.73 & 14.27 & 7.01 & 11.98 & 40.25 & 3.53 \\
\hline Pb208 & 10.42 & 22.32 & 11.28 & 20.27 & 55.18 & 14.83 & 17.19 & 29.57 & 30.61 & 25.82 & 12.23 & 18.14 & 51.17 & 5.21 \\
\hline Th232 & 194.56 & 126.21 & 220.18 & 678.72 & 1287.24 & 210.73 & 486.90 & 175.62 & 432.21 & 442.71 & 177.17 & 271.48 & 298.45 & 96.64 \\
\hline U238 & 348.18 & 250.62 & 293.91 & 686.07 & 1288.53 & 372.65 & 2069.57 & 486.25 & 658.34 & 606.67 & 234.64 & 416.54 & 347.75 & 116.67 \\
\hline
\end{tabular}


Tabela D1 - continuação

\section{PLÚTON CABREÚVA}

\begin{tabular}{|c|c|c|c|c|c|c|c|c|c|c|c|c|c|c|c|}
\hline \multicolumn{16}{|c|}{ AMOSTRA IGN24A } \\
\hline RASTER & 1n & 1b & $2 n$ & $2 \mathbf{b}$ & 3 & 4 & 5 & 6 & 7 & 8 & 9 & 10 & 11 & $12 n$ & $12 \mathrm{~b}$ \\
\hline Tipo & osc & black & black & black & osc & black & black & black & osc & black & black & black & black & black & osc \\
\hline \multicolumn{16}{|c|}{ [ ] de elementos traço em ppm } \\
\hline Li7 & 9.56 & 16.10 & 33.39 & 28.71 & 3.85 & 31.29 & 45.03 & 59.50 & 2.73 & 8.00 & 37.04 & 28.03 & 61.34 & 70.87 & 5.13 \\
\hline Mg24 & 0.52 & $<0.60$ & 97.82 & 19.02 & 3.86 & 28.14 & 0.54 & 4.89 & 5.79 & 563.53 & 10.45 & 6.52 & 3.21 & 0.94 & $<0.89$ \\
\hline Al27 & 0.69 & $<2.62$ & 492.95 & 191.05 & 35.82 & 350.15 & 57.38 & 65.63 & 32.75 & 1347.28 & 167.58 & 81.39 & 19.76 & 15.03 & $<3.28$ \\
\hline Si29 & 245880.52 & 243811.30 & 213924.77 & 211936.47 & 206823.88 & 241749.16 & 237962.16 & 211009.30 & 228487.89 & 274119.31 & 212496.45 & 232616.59 & 230828.88 & 245057.47 & 223469.56 \\
\hline P31 & 343.87 & 846.36 & 983.97 & 821.04 & 648.43 & 1042.96 & 993.26 & 987.96 & 377.71 & 22435.76 & 938.23 & 835.65 & 1147.82 & 1487.18 & 344.88 \\
\hline Ca42 & $<188.10$ & 2396.77 & 1000.65 & 845.91 & 550.72 & 1375.94 & 466.48 & $<186.05$ & $<203.52$ & 40799.77 & $<191.87$ & 625.50 & 421.54 & $<1105.99$ & $<1163.40$ \\
\hline Ca44 & $<92.62$ & $<375.57$ & 746.78 & 493.83 & $<93.88$ & 797.60 & 181.01 & 226.34 & $<87.43$ & 50255.00 & 513.69 & 380.35 & 313.91 & $<468.20$ & $<479.59$ \\
\hline Sc45 & 320.93 & 288.73 & 290.65 & 287.46 & 314.34 & 292.10 & 289.28 & 285.66 & 341.41 & 398.36 & 247.78 & 264.06 & 249.74 & 275.61 & 281.53 \\
\hline Ti49 & 6.17 & 2.81 & 95.91 & 25.44 & 26.28 & 95.80 & 3.28 & 11.83 & 24.07 & 19.83 & 31.42 & 12.90 & 8.70 & 9.60 & $<2.27$ \\
\hline Mn55 & $<0.24$ & 5.17 & 107.10 & 93.11 & 44.85 & 83.41 & 6.04 & 55.02 & 7.77 & 285.33 & 109.19 & 31.80 & 60.06 & 15.00 & 3.31 \\
\hline Fe56 & 3.31 & 80.96 & 1350.71 & 513.75 & 149.18 & 1521.37 & 55.40 & 153.34 & 238.74 & 19327.33 & 722.89 & 125.14 & 273.10 & 82.71 & $<16.94$ \\
\hline Co59 & $<0.059$ & $<0.253$ & 0.08 & $<0.076$ & $<0.070$ & 0.30 & $<0.082$ & $<0.065$ & $<0.072$ & $<0.15$ & $<0.074$ & $<0.077$ & $<0.073$ & 0.58 & 1.41 \\
\hline Rb85 & 0.34 & 2.42 & 1.91 & 1.67 & 0.18 & 2.65 & 1.34 & 1.97 & 0.46 & 2.35 & 2.00 & 1.28 & 2.31 & 2.57 & 0.45 \\
\hline Sr88 & 0.41 & 2.52 & 34.17 & 30.23 & 0.80 & 59.65 & 1.86 & 16.73 & 0.87 & 8.37 & 25.06 & 13.23 & 17.14 & 5.67 & 1.03 \\
\hline Y89 & 1753.02 & 8679.07 & 6485.10 & 7041.40 & 2411.73 & 10426.30 & 7208.27 & 6920.48 & 1665.10 & 7553.17 & 6455.01 & 5651.11 & 6782.56 & 11501.54 & 1422.13 \\
\hline Zr91 & 496007.25 & 496007.16 & 496007.28 & 496007.25 & 496007.28 & 496007.25 & 496007.22 & 496007.25 & 496007.19 & 496007.22 & 496007.19 & 496007.16 & 496007.13 & 496007.13 & 496007.16 \\
\hline Nb93 & 29.87 & 134.87 & 918.92 & 284.30 & 38.20 & 620.52 & 124.83 & 603.68 & 21.95 & $<17.12$ & 453.87 & 189.72 & 456.22 & 603.68 & 17.80 \\
\hline Mo95 & 2.49 & $<0.60$ & 2.23 & 3.20 & 2.87 & 3.00 & 1.78 & 1.60 & 2.46 & $<1.25$ & 1.49 & 1.36 & 1.44 & 0.63 & $<0.35$ \\
\hline Sn118 & 0.45 & $<1.74$ & 5.08 & 2.98 & 2.66 & 16.52 & 0.59 & 1.21 & 0.97 & 8.86 & 2.83 & 1.51 & 0.49 & $<2.25$ & $<2.37$ \\
\hline Sb121 & $<0.090$ & $<0.243$ & $<0.101$ & $<0.068$ & 0.21 & 0.19 & $<0.110$ & 0.15 & $<0.088$ & $<0.21$ & $<0.087$ & $<0.10$ & $<0.089$ & $<0.64$ & $<0.64$ \\
\hline Ba137 & $<0.00$ & 3.30 & 10.62 & 9.52 & 1.27 & 7.40 & 0.40 & 5.87 & 0.18 & $<2.64$ & 6.19 & 4.12 & 7.00 & $<0.84$ & $<0.99$ \\
\hline La139 & $<0.0135$ & 0.21 & 12.66 & 4.92 & 2.27 & 35.16 & 0.68 & 1.57 & 0.27 & 385.51 & 4.10 & 2.92 & 0.58 & 1.03 & 0.11 \\
\hline Ce140 & 31.76 & 37.08 & 140.07 & 61.03 & 30.63 & 142.83 & 49.53 & 103.98 & 28.64 & 1083.71 & 68.03 & 68.84 & 89.13 & 92.10 & 25.88 \\
\hline Pr141 & 0.07 & 0.16 & 15.81 & 5.48 & 1.03 & 16.45 & 0.56 & 1.89 & 0.91 & 132.92 & 3.95 & 2.07 & 1.03 & 0.08 & $<0.064$ \\
\hline
\end{tabular}


Tabela D1 - continuação

\begin{tabular}{|c|c|c|c|c|c|c|c|c|c|c|c|c|c|c|c|}
\hline Nd143 & 2.40 & 2.40 & 81.66 & 30.06 & 10.59 & 75.06 & 6.87 & 9.91 & 8.42 & 611.77 & 24.67 & 12.82 & 6.23 & 2.78 & 5.35 \\
\hline Sm147 & 8.08 & 11.92 & 58.20 & 28.47 & 15.20 & 60.18 & 21.70 & 18.78 & 16.36 & $<12.08$ & 30.22 & 18.98 & 18.63 & 16.91 & 7.10 \\
\hline Eu151 & 0.09 & $<0.127$ & 0.92 & 0.46 & 0.31 & 1.07 & 0.16 & 0.14 & 1.12 & 3.17 & 0.34 & 0.18 & 0.13 & $<0.163$ & 0.34 \\
\hline Gd157 & 40.02 & 132.21 & 164.69 & 118.74 & 56.74 & 225.32 & 134.45 & 98.82 & 52.55 & $<13.65$ & 129.24 & 96.80 & 141.92 & 170.45 & 29.46 \\
\hline Tb159 & 15.02 & 63.69 & 63.86 & 50.30 & 20.60 & 92.34 & 59.38 & 47.71 & 16.22 & $<2.73$ & 58.10 & 41.43 & 60.88 & 84.94 & 13.33 \\
\hline Dy161 & 183.63 & 846.59 & 746.93 & 641.21 & 232.08 & 1150.73 & 779.25 & 652.28 & 168.92 & $<18.25$ & 745.08 & 528.51 & 809.26 & 1095.47 & 129.10 \\
\hline Ho165 & 69.04 & 326.28 & 282.22 & 261.98 & 84.57 & 435.46 & 304.42 & 261.31 & 58.91 & 103.01 & 289.09 & 207.25 & 340.97 & 398.68 & 51.84 \\
\hline Er166 & 296.33 & 1597.20 & 1254.28 & 1170.42 & 344.85 & 1925.50 & 1330.38 & 1283.77 & 237.29 & 788.97 & 1297.75 & 917.85 & 1493.25 & 1886.85 & 249.38 \\
\hline Tm169 & 62.26 & 309.17 & 256.09 & 243.00 & 68.87 & 366.74 & 287.50 & 318.01 & 50.28 & 137.15 & 271.95 & 195.82 & 291.02 & 390.40 & 48.72 \\
\hline Yb173 & 606.87 & 2935.11 & 2371.30 & 2167.11 & 647.10 & 3064.14 & 2601.77 & 3280.92 & 477.62 & 1116.45 & 2518.07 & 1950.58 & 2928.70 & 3701.05 & 429.56 \\
\hline Lu175 & 98.94 & 510.97 & 361.94 & 375.64 & 119.41 & 550.36 & 401.19 & 463.96 & 81.65 & 234.38 & 396.54 & 281.67 & 431.07 & 607.20 & 87.81 \\
\hline Hf179 & 15427.79 & 19969.00 & 16326.32 & 19140.96 & 14314.77 & 17558.91 & 17918.80 & 22003.13 & 10757.14 & 16345.10 & 17046.64 & 15933.32 & 17797.32 & 20769.89 & 14484.02 \\
\hline Ta181 & 6.65 & 20.84 & 63.72 & 28.73 & 2.85 & 37.44 & 21.29 & 117.03 & 1.86 & $<2.24$ & 37.89 & 22.24 & 62.61 & 105.67 & 3.53 \\
\hline Pb206 & 177.26 & 1665.91 & 1547.63 & 1148.83 & 111.42 & 1220.74 & 1427.62 & 2160.10 & 49.30 & 468.90 & 1479.83 & 898.24 & 2470.82 & 3986.54 & 139.97 \\
\hline Pb207 & 12.05 & 102.75 & 114.57 & 77.07 & 9.87 & 97.33 & 93.05 & 136.75 & 4.16 & 42.74 & 96.15 & 52.83 & 175.78 & 222.83 & 7.42 \\
\hline Pb208 & 15.71 & 157.16 & 151.87 & 93.55 & 14.09 & 133.07 & 138.60 & 213.56 & 9.97 & 39.39 & 146.30 & 97.50 & 319.86 & 433.04 & 10.91 \\
\hline Th232 & 271.91 & 2563.77 & 2494.06 & 1831.14 & 229.62 & 2181.79 & 2364.86 & 3662.31 & 177.87 & 703.84 & 2469.93 & 1529.99 & 5652.57 & 7938.76 & 199.03 \\
\hline U238 & 466.69 & 3974.79 & 4030.75 & 3015.00 & 309.88 & 2795.89 & 3675.88 & 5088.66 & 124.60 & 606.91 & 3406.89 & 2071.09 & 6502.82 & 9971.55 & 300.98 \\
\hline
\end{tabular}


Tabela D1 - continuação

\section{PLÚTON INDAIATUBA}

\begin{tabular}{|c|c|c|c|c|c|c|c|c|c|c|c|c|c|}
\hline \multicolumn{14}{|c|}{ AMOSTRA IGN50B } \\
\hline RASTER & 1 & 2 & 4 & 5.1 & 6 & 7.2 & 8 & 9.1 & 12.1 & 18 & 23 & 24 & 24borda \\
\hline Tipo & osc b & white b & osc & osc & osc & osc & osc & core & osc & osc & core & osc & $\begin{array}{l}\text { black } \\
\text { core }\end{array}$ \\
\hline \multicolumn{14}{|c|}{ [ ] de elementos traço em ppm } \\
\hline Li7 & 6.73 & 1.11 & 7.73 & 9.27 & 10.33 & 6.06 & 8.79 & 4.70 & 8.23 & 8.87 & 4.05 & 14.07 & 7.04 \\
\hline Mg24 & 13.59 & 0.60 & 7.89 & 12.68 & 4.40 & 79.01 & 33.86 & 12.24 & $<0,67$ & 32.69 & 99.00 & 151.73 & 0.90 \\
\hline Al27 & 328.17 & 2.83 & 12.97 & 90.34 & 35.29 & 633.29 & 776.74 & 48.43 & $<2,77$ & 75.27 & 214.28 & 2186.47 & 16.71 \\
\hline Si29 & 221117.23 & 186673.94 & 164936.45 & 153375.36 & 186052.88 & 147650.66 & 198998.81 & 169489.88 & 179163.20 & 168916.69 & 151624.98 & 186204.66 & 152157.58 \\
\hline P31 & 420.41 & 239.34 & 182.04 & 199.87 & 373.78 & 297.77 & 763.99 & 149.38 & 192.96 & 240.76 & 239.70 & 590.47 & 151.22 \\
\hline Ca44 & 320.44 & $<212,86$ & $<335,84$ & $<371,20$ & 505.29 & 510.03 & 2036.35 & $<373,33$ & $<273,86$ & $<644,34$ & 1028.93 & 1477.96 & 258.18 \\
\hline Sc45 & 267.87 & 254.72 & 219.14 & 235.65 & 241.78 & 268.81 & 307.80 & 228.02 & 210.49 & 225.53 & 255.67 & 574.17 & 179.35 \\
\hline Ti49 & 21.60 & 18.90 & 8.47 & 11.43 & 5.91 & 14.39 & 40.60 & 5.81 & 5.49 & 12.17 & 9.51 & 300.50 & 113.81 \\
\hline Mn55 & 1.57 & $<0,73$ & $<1,09$ & 4.64 & 1.06 & 9.60 & 49.05 & $<1,35$ & $<0,96$ & 6.44 & 11.73 & 93.91 & 8.55 \\
\hline Fe56 & 258.79 & $<11,08$ & 49.09 & 101.14 & 12.20 & 199.68 & 758.43 & 44.35 & $<13,61$ & 148.35 & 338.14 & 4030.58 & 527.31 \\
\hline Rb85 & 0.63 & 0.43 & 0.42 & 0.44 & 0.45 & 1.98 & 0.66 & $<0,25$ & $<0,20$ & 0.63 & $<0,57$ & 2.17 & $<0,16$ \\
\hline Sr88 & 0.63 & 0.48 & 0.67 & 0.92 & 1.42 & 2.05 & 11.58 & 0.98 & 0.43 & 1.89 & 3.61 & 33.69 & 0.55 \\
\hline Y89 & 1074.50 & 1649.12 & 1259.28 & 1151.26 & 809.68 & 1526.31 & 2623.74 & 1240.39 & 813.88 & 1539.77 & 2216.78 & 4948.49 & 719.88 \\
\hline Zr91 & 496007.09 & 496007.09 & 496007.09 & 496007.09 & 496007.09 & 496007.09 & 496007.09 & 496007.09 & 496007.09 & 496007.09 & 496007.09 & 496007.09 & 496007.09 \\
\hline Nb93 & 16.11 & 11.90 & 20.66 & 18.17 & 16.06 & 17.25 & 32.07 & 15.91 & 16.09 & 16.76 & 16.43 & 35.97 & 17.22 \\
\hline Mo95 & 7.70 & 9.18 & 11.64 & 12.99 & 10.15 & 11.10 & 9.89 & 9.55 & 8.31 & 11.73 & 8.52 & 26.29 & 10.78 \\
\hline Ba137 & 0.92 & $<0,27$ & 0.53 & 0.93 & 0.30 & 5.12 & 10.05 & 0.75 & $<0,26$ & 0.75 & 6.54 & 23.76 & $<0,34$ \\
\hline La139 & 5.74 & 0.21 & 0.79 & 5.33 & 16.04 & 6.02 & 98.26 & 2.98 & 0.11 & 6.49 & 76.45 & 184.19 & 2.33 \\
\hline Ce140 & 45.05 & 34.71 & 39.91 & 48.65 & 61.89 & 58.73 & 418.20 & 41.00 & 30.42 & 45.24 & 168.84 & 1057.79 & 31.15 \\
\hline Pr141 & 1.38 & 0.83 & 0.30 & 2.43 & 6.81 & 4.41 & 53.92 & 1.15 & 0.11 & 2.63 & 17.83 & 132.24 & 0.85 \\
\hline Nd143 & 7.30 & 9.91 & 2.81 & 15.20 & 36.97 & 25.03 & 254.54 & 8.36 & 1.53 & 17.21 & 73.64 & 611.66 & 4.62 \\
\hline Sm147 & 3.84 & 13.54 & 4.81 & 10.32 & 15.71 & 11.28 & 123.56 & 5.45 & 2.42 & 10.21 & 34.85 & 339.38 & 2.56 \\
\hline Eu151 & 0.33 & 2.75 & 0.50 & 1.11 & 1.31 & 1.43 & 18.61 & 0.79 & 0.24 & 1.26 & 2.73 & 43.11 & 0.38 \\
\hline Gd157 & 17.47 & 53.88 & 25.92 & 26.67 & 27.31 & 32.92 & 162.73 & 21.98 & 11.55 & 27.66 & 67.93 & 443.89 & 12.76 \\
\hline
\end{tabular}


Tabela D1 - continuação

\begin{tabular}{lcccccccccccccc}
\hline Tb159 & 7.64 & 16.21 & 9.86 & 9.59 & 6.77 & 11.62 & 43.91 & 8.76 & 4.83 & 11.89 & 21.70 & 110.32 & 3.99 \\
\hline Dy163 & 93.84 & 178.48 & 97.54 & 99.53 & 74.73 & 123.31 & 374.82 & 103.67 & 61.21 & 125.77 & 226.21 & 806.30 & 50.25 \\
\hline Ho165 & 36.08 & 59.71 & 36.57 & 36.65 & 27.96 & 49.02 & 103.56 & 41.49 & 25.85 & 47.39 & 74.44 & 194.01 & 18.71 \\
\hline Er166 & 178.38 & 248.27 & 189.20 & 168.95 & 125.58 & 250.85 & 374.28 & 182.21 & 117.32 & 208.84 & 297.95 & 628.08 & 86.59 \\
\hline Tm169 & 39.03 & 51.66 & 40.85 & 37.20 & 30.27 & 50.74 & 72.62 & 39.98 & 26.48 & 48.12 & 63.11 & 109.10 & 20.59 \\
\hline Yb173 & 400.38 & 499.45 & 453.06 & 436.96 & 291.28 & 470.69 & 691.87 & 395.45 & 271.10 & 432.99 & 649.05 & 948.76 & 207.82 \\
\hline Lu175 & 83.19 & 91.50 & 74.27 & 73.37 & 55.25 & 92.41 & 123.00 & 76.55 & 55.81 & 85.25 & 115.30 & 158.11 & 41.91 \\
\hline Hf179 & 12831.08 & 9207.51 & 9246.38 & 10045.04 & 11442.79 & 9773.20 & 10514.94 & 11517.13 & 11153.67 & 11905.48 & 10195.60 & 11653.16 & 9595.16 \\
\hline Ta181 & 3.72 & 0.91 & 3.99 & 2.98 & 3.78 & 2.80 & 4.51 & 2.92 & 2.81 & 3.17 & 2.06 & 4.88 & 2.08 \\
\hline Pb207 & 8.21 & 3.68 & 10.39 & 9.47 & 9.26 & 14.34 & 21.73 & 8.80 & 8.05 & 12.28 & 20.45 & 40.56 & 7.13 \\
\hline Pb208 & 16.70 & 11.32 & 16.28 & 17.58 & 15.70 & 27.64 & 39.16 & 12.28 & 15.10 & 22.33 & 41.13 & 50.58 & 10.18 \\
\hline Th232 & 336.06 & 211.32 & 304.38 & 359.45 & 216.78 & 442.10 & 683.27 & 212.96 & 269.39 & 298.15 & 566.22 & 1267.47 & 197.98 \\
\hline U238 & 401.48 & 151.98 & 314.59 & 412.52 & 358.16 & 343.42 & 797.20 & 347.35 & 344.65 & 499.56 & 452.95 & 603.37 & 270.20
\end{tabular}


Tabela D1 - continuação

\begin{tabular}{|c|c|c|c|c|c|c|c|c|c|c|c|}
\hline \multicolumn{12}{|c|}{ PLÚTON ITUPEVA } \\
\hline \multicolumn{12}{|c|}{ AMOSTRA CAB-15-36A } \\
\hline RASTER & 1n & 1b & 2 & 3 & $4 n$ & $4 b$ & 5 & 6 & 7 & 8 & 9 \\
\hline Tipo & osc & black & white rim & core & core & black rim & osc rim & osc b & osc & white & $\begin{array}{l}\text { black } \\
\text { core }\end{array}$ \\
\hline \multicolumn{12}{|c|}{ [] de elementos traço em ppm } \\
\hline Li7 & 7.16 & 15.48 & 5.51 & $<1.37$ & 9.67 & 11.32 & 5.12 & 7.89 & 9.61 & $<1.40$ & 3.49 \\
\hline Mg24 & 1.22 & 392.37 & 2.53 & 1.09 & 68.78 & 14.05 & 2.77 & $<0.95$ & 1.61 & 1.19 & 7.59 \\
\hline Al27 & 9.05 & 5001.82 & 16.55 & $<2.57$ & 259.33 & 164.40 & 30.40 & 4.27 & 5.01 & 4.99 & 86.66 \\
\hline Si29 & 193008.00 & 217631.48 & 187770.47 & 193285.61 & 191622.39 & 188846.38 & 196759.72 & 190217.72 & 189922.86 & 192507.63 & 190605.03 \\
\hline P31 & 454.96 & 785.69 & 314.21 & 879.46 & 719.22 & 2023.28 & 493.18 & 225.73 & 183.91 & 503.71 & 337.48 \\
\hline Ca42 & $<885.54$ & 11382.24 & 1278.30 & 1213.09 & $<760.69$ & 7055.00 & $<904.16$ & $<979.16$ & $<881.33$ & $<954.01$ & $<863.09$ \\
\hline Ca44 & $<298.36$ & 10503.26 & $<352.19$ & $<319.08$ & $<256.58$ & 5012.24 & $<303.29$ & $<331.81$ & 405.82 & 413.69 & 322.14 \\
\hline Se45 & 293.33 & 2290.68 & 261.98 & 289.50 & 305.44 & 288.09 & 296.33 & 257.43 & 246.59 & 300.54 & 289.29 \\
\hline Ti49 & 3.39 & 1213.97 & 3.66 & 23.69 & 28.77 & 34.56 & 13.40 & 3.01 & 4.94 & 29.84 & 9.60 \\
\hline Mn55 & 1.18 & 705.76 & $<1.34$ & $<1.25$ & 10.10 & 20.81 & 1.15 & $<1.25$ & $<1.17$ & 2.47 & 4.09 \\
\hline Fe56 & $<13.26$ & 6224.88 & 20.16 & 28.76 & 808.16 & 226.78 & $<13.18$ & $<14.56$ & $<13.10$ & 29.91 & 82.35 \\
\hline Co59 & $<0.60$ & 3.03 & 1.03 & $<0.64$ & $<0.45$ & $<0.56$ & $<0.52$ & $<0.56$ & $<0.58$ & $<0.57$ & $<0.45$ \\
\hline Rb85 & $<0.46$ & 3.80 & $<0.57$ & 1.10 & $<0.40$ & 0.54 & $<0.50$ & $<0.42$ & $<0.47$ & $<0.53$ & 0.46 \\
\hline Sr88 & 0.62 & 177.42 & 0.34 & 0.72 & 3.40 & 5.53 & 1.40 & 0.38 & 0.47 & 0.21 & 1.23 \\
\hline Y89 & 1099.96 & 20235.43 & 881.98 & 7684.86 & 1626.65 & 1440.77 & 2394.17 & 784.61 & 704.87 & 1725.52 & 2735.94 \\
\hline Zr91 & 496007.03 & 496007.09 & 496007.09 & 496007.06 & 496007.13 & 496007.09 & 496007.09 & 496007.06 & 496007.06 & 496007.06 & 496007.06 \\
\hline Nb93 & 10.98 & 525.99 & 9.84 & 14.51 & 16.45 & 16.75 & 17.51 & 13.91 & 10.76 & 1.70 & 12.77 \\
\hline Mo95 & $<0.50$ & 10.26 & $<0.54$ & $<0.62$ & 0.50 & 0.83 & 1.10 & 1.81 & 1.55 & 1.54 & 1.82 \\
\hline Sn118 & $<2.47$ & 37.25 & $<2.36$ & $<2.44$ & $<1.84$ & $<2.39$ & $<2.31$ & $<2.57$ & $<2.28$ & $<2.31$ & $<1.85$ \\
\hline Sb121 & $<0.58$ & 3.52 & $<0.62$ & $<0.47$ & $<0.46$ & $<0.57$ & $<0.64$ & $<0.82$ & $<0.50$ & $<0.52$ & 1.15 \\
\hline Ba137 & 1.64 & 552.31 & 0.61 & $<0.44$ & 8.85 & 14.56 & $<0.82$ & 0.63 & $<0.72$ & $<0.65$ & 9.91 \\
\hline La139 & 4.42 & 294.36 & 0.97 & 0.24 & 9.67 & 81.35 & 0.82 & 0.34 & 0.12 & 0.68 & 5.11 \\
\hline Ce140 & 35.62 & 3058.80 & 25.08 & 49.96 & 94.79 & 266.91 & 71.06 & 20.41 & 22.23 & 29.21 & 80.70 \\
\hline Pr141 & 2.37 & 469.68 & 0.74 & 2.44 & 13.50 & 38.07 & 2.50 & 0.61 & 0.15 & 0.77 & 6.09 \\
\hline
\end{tabular}


Tabela D1 - continuação

\begin{tabular}{lccccccccccc}
\hline Nd143 & 10.80 & 2622.83 & 2.28 & 45.57 & 73.58 & 155.22 & 18.20 & 2.96 & 1.65 & 24.44 & 42.74 \\
\hline Sm147 & 4.60 & 1930.04 & 4.70 & 80.57 & 54.45 & 57.94 & 20.22 & 2.20 & 1.78 & 12.14 & 45.03 \\
\hline Eu151 & 0.17 & 142.43 & $<0.18$ & 11.39 & 2.83 & 3.85 & 1.15 & $<0.23$ & 0.24 & 4.58 & 3.03 \\
\hline Gd157 & 18.56 & 2259.82 & 15.17 & 296.85 & 84.19 & 65.92 & 62.36 & 11.20 & 9.64 & 57.61 & 92.07 \\
\hline Tb159 & 6.21 & 508.56 & 5.12 & 88.13 & 21.58 & 16.07 & 20.37 & 4.52 & 4.16 & 18.37 & 29.24 \\
\hline Dy161 & 82.89 & 3642.36 & 73.55 & 873.19 & 167.92 & 154.82 & 228.80 & 62.93 & 53.97 & 172.47 & 290.11 \\
\hline Ho165 & 35.16 & 842.41 & 32.04 & 288.77 & 57.65 & 49.69 & 82.69 & 24.66 & 23.14 & 62.96 & 98.82 \\
\hline Er166 & 164.89 & 2748.08 & 137.07 & 1128.83 & 244.76 & 216.99 & 376.57 & 130.09 & 112.91 & 263.46 & 410.09 \\
\hline Tm169 & 39.79 & 503.48 & 32.31 & 206.21 & 56.19 & 51.53 & 76.85 & 30.17 & 27.14 & 49.21 & 84.62 \\
\hline Yb173 & 387.60 & 4063.33 & 361.73 & 1722.29 & 512.34 & 482.44 & 757.95 & 313.29 & 272.85 & 466.80 & 753.72 \\
\hline Lu175 & 79.75 & 684.57 & 60.06 & 303.71 & 95.10 & 88.25 & 131.35 & 64.43 & 56.07 & 84.61 & 145.01 \\
\hline Hf179 & 14865.28 & 19050.65 & 16271.82 & 9152.04 & 13828.28 & 15647.32 & 11917.31 & 17354.90 & 16172.85 & 10114.66 & 14034.15 \\
\hline Ta181 & 3.31 & 40.44 & 2.59 & 2.20 & 3.59 & 4.30 & 4.29 & 5.40 & 4.37 & 0.69 & 3.76 \\
\hline Pb206 & 118.91 & 589.80 & 101.13 & 96.28 & 131.88 & 190.83 & 194.47 & 140.28 & 145.13 & 31.69 & 194.65 \\
\hline Pb207 & 12.67 & 202.75 & 8.41 & 5.64 & 28.19 & 25.52 & 16.71 & 12.32 & 10.10 & 3.59 & 18.28 \\
\hline Pb208 & 10.60 & 234.95 & 7.30 & 38.20 & 29.60 & 39.35 & 49.76 & 10.63 & 10.38 & 11.36 & 43.52 \\
\hline Th232 & 223.31 & 2385.63 & 145.41 & 700.64 & 237.97 & 349.65 & 742.66 & 144.00 & 165.29 & 154.32 & 653.71 \\
\hline U238 & 349.21 & 4328.42 & 280.71 & 261.45 & 380.49 & 508.28 & 523.68 & 364.36 & 373.06 & 92.10 & 540.79 \\
\hline & & & & & & & & &
\end{tabular}


Tabela D1 - continuação

\begin{tabular}{|c|c|c|c|c|c|c|c|c|c|c|c|}
\hline \multicolumn{12}{|c|}{ PLÚTON ITUPEVA } \\
\hline \multicolumn{12}{|c|}{ AMOSTRA IGN56 } \\
\hline RASTER & 1 & $2 n$ & $2 \mathbf{b}$ & $3 n$ & $3 \mathbf{b}$ & 4 & 5 & 6 & 7 & 8 & 9 \\
\hline Tipo & $\begin{array}{l}\text { white } \\
\text { core }\end{array}$ & $\begin{array}{l}\text { white } \\
\text { core }\end{array}$ & $\begin{array}{l}\text { white } \\
\text { core }\end{array}$ & $\begin{array}{l}\text { white } \\
\text { core }\end{array}$ & $\begin{array}{l}\text { white } \\
\text { core }\end{array}$ & rim & $\begin{array}{l}\text { medium } \\
\text { core }\end{array}$ & black rim & $\begin{array}{l}\text { white } \\
\text { core }\end{array}$ & $\begin{array}{c}\text { medium } \\
\text { core }\end{array}$ & $\begin{array}{c}\text { medium } \\
\text { core }\end{array}$ \\
\hline \multicolumn{12}{|c|}{ [ ] de elementos traço em ppm } \\
\hline Li7 & 2.65 & $<1.63$ & $<1.54$ & $<1.74$ & 4.30 & 2.43 & 1.55 & 1.99 & $<1.50$ & $<1.61$ & $<1.58$ \\
\hline Mg24 & $<0.65$ & 1.36 & 1.46 & $<0.92$ & 0.92 & 35.38 & $<0.93$ & $<0.98$ & $<0.79$ & 1.53 & 2.72 \\
\hline A127 & $<2.25$ & 3.93 & 4.86 & 4.05 & $<2.88$ & 34.01 & $<2.69$ & $<2.81$ & 2.91 & 9.55 & 4.10 \\
\hline Si29 & 195309.81 & 216480.61 & 220510.84 & 216981.05 & 206309.86 & 206612.73 & 209991.64 & 206025.22 & 206231.61 & 205895.16 & 199820.73 \\
\hline P31 & 378.12 & 541.46 & 389.44 & 1142.88 & 187.12 & 439.95 & 375.58 & 489.84 & 369.61 & 1076.97 & 240.32 \\
\hline Ca42 & $<806.67$ & $<1083.45$ & $<1046.77$ & 1547.91 & $<1079.87$ & $<1061.85$ & $<997.40$ & $<1040.52$ & $<989.94$ & 1111.38 & $<1028.22$ \\
\hline Ca44 & $<313.37$ & $<415.61$ & 769.47 & 777.57 & $<397.07$ & $<396.57$ & $<367.94$ & $<380.37$ & $<363.23$ & 641.85 & $<368.81$ \\
\hline Sc45 & 342.73 & 381.38 & 387.89 & 376.09 & 328.77 & 368.76 & 361.76 & 357.66 & 358.14 & 356.95 & 334.73 \\
\hline Ti49 & 24.92 & 29.46 & 21.87 & 18.84 & 14.20 & $<1.93$ & 12.40 & 20.33 & 21.35 & 20.64 & 18.67 \\
\hline Mn55 & $<1.04$ & $<1.41$ & $<1.32$ & 1.63 & $<1.38$ & $<1.35$ & $<1.23$ & $<1.33$ & $<1.26$ & $<1.26$ & $<1.21$ \\
\hline Fe56 & 11.84 & $<15.13$ & 16.30 & 22.51 & $<14.90$ & 37.72 & 18.28 & $<14.43$ & $<13.72$ & 26.08 & $<14.10$ \\
\hline Co59 & $<0.49$ & $<0.59$ & $<0.50$ & 0.58 & $<0.60$ & $<0.63$ & $<0.50$ & $<0.52$ & $<0.59$ & $<0.62$ & $<0.62$ \\
\hline Rb85 & $<0.44$ & $<0.61$ & $<0.52$ & 1.29 & $<0.43$ & 0.87 & 0.66 & 0.52 & 0.47 & 0.89 & $<0.53$ \\
\hline Sr88 & 0.52 & 0.40 & 0.66 & 0.97 & 0.30 & 1.04 & 0.65 & 0.48 & 0.48 & 1.21 & 0.31 \\
\hline Y89 & 1779.33 & 2944.30 & 2508.71 & 4028.82 & 575.94 & 2607.86 & 2304.63 & 2741.51 & 1744.35 & 3547.14 & 1100.60 \\
\hline Zr91 & 496006.97 & 496007.03 & 496007.06 & 496007.06 & 496007.06 & 496007.06 & 496007.09 & 496007.09 & 496007.16 & 496007.16 & 496007.13 \\
\hline Nb93 & 4.49 & 5.20 & 5.09 & 11.67 & 1.99 & 12.77 & 7.28 & 6.46 & 3.76 & 8.24 & 3.50 \\
\hline Mo95 & 0.52 & $<0.78$ & $<0.75$ & 1.13 & $<0.97$ & $<1.02$ & 1.07 & 0.93 & 0.92 & 1.38 & $<0.60$ \\
\hline Sn118 & 1.79 & $<2.28$ & $<2.19$ & $<2.50$ & $<2.23$ & $<2.29$ & $<2.21$ & $<2.14$ & $<2.05$ & $<2.37$ & $<2.35$ \\
\hline Sb121 & $<0.59$ & $<0.76$ & $<0.66$ & $<0.51$ & 0.72 & $<0.66$ & $<0.70$ & $<0.59$ & $<0.56$ & $<0.55$ & $<0.60$ \\
\hline Ba137 & $<0.79$ & $<0.47$ & 0.81 & 0.55 & $<0.77$ & 1.73 & $<0.63$ & 0.17 & 0.63 & $<0.90$ & $<0.61$ \\
\hline La139 & $<0.00$ & 0.34 & 0.27 & 1.10 & 0.14 & $<0.084$ & 0.14 & $<0.128$ & 0.16 & 1.35 & $<0.075$ \\
\hline Ce140 & 48.37 & 51.47 & 50.16 & 83.16 & 13.69 & 83.73 & 76.68 & 57.91 & 39.50 & 66.35 & 32.38 \\
\hline Pr141 & 0.44 & 1.09 & 0.95 & 1.32 & 0.56 & 0.62 & 0.66 & 1.13 & 0.72 & 1.28 & 0.43 \\
\hline
\end{tabular}


Tabela D1 - continuação

\begin{tabular}{lccccccccccc}
\hline Nd143 & 5.61 & 14.87 & 15.55 & 19.53 & 0.77 & 11.42 & 13.06 & 15.14 & 11.04 & 19.31 & 3.91 \\
\hline Sm147 & 11.91 & 25.91 & 20.61 & 30.93 & 5.12 & 21.47 & 18.78 & 26.11 & 13.31 & 23.48 & 7.63 \\
\hline Eu151 & 4.40 & 8.38 & 7.55 & 8.62 & 2.31 & 6.19 & 4.25 & 6.96 & 5.70 & 9.74 & 3.27 \\
\hline Gd157 & 48.80 & 94.13 & 75.29 & 117.87 & 12.95 & 78.08 & 64.88 & 84.87 & 51.19 & 110.49 & 36.46 \\
\hline Tb159 & 15.82 & 29.33 & 23.50 & 33.54 & 5.45 & 24.18 & 21.61 & 28.16 & 17.00 & 34.84 & 11.21 \\
\hline Dy161 & 154.16 & 301.79 & 259.46 & 399.91 & 58.33 & 304.04 & 224.23 & 280.20 & 174.17 & 358.60 & 111.26 \\
\hline Ho165 & 56.75 & 102.55 & 85.60 & 144.04 & 19.45 & 91.27 & 79.32 & 96.15 & 62.11 & 121.70 & 39.02 \\
\hline Er166 & 242.19 & 426.72 & 367.67 & 613.88 & 80.71 & 415.81 & 344.35 & 404.06 & 259.45 & 530.62 & 167.88 \\
\hline Tm169 & 52.34 & 84.50 & 75.00 & 123.73 & 17.35 & 82.66 & 75.47 & 84.09 & 55.14 & 109.14 & 36.44 \\
\hline Yb173 & 475.67 & 811.22 & 709.72 & 1191.91 & 187.63 & 824.74 & 712.08 & 788.23 & 517.53 & 1026.33 & 342.99 \\
\hline Lu175 & 89.92 & 154.82 & 131.78 & 211.60 & 39.27 & 159.11 & 130.22 & 144.61 & 98.54 & 198.10 & 64.31 \\
\hline Hf179 & 11662.21 & 11225.56 & 11374.32 & 12029.68 & 14436.83 & 13745.23 & 14157.80 & 11845.09 & 11120.06 & 10803.47 & 11204.81 \\
\hline Ta181 & 1.60 & 2.14 & 1.48 & 3.03 & $<0.062$ & 2.16 & 2.56 & 1.61 & 1.26 & 2.58 & 1.14 \\
\hline Pb206 & 41.32 & 62.15 & 52.99 & 114.70 & 44.80 & 129.28 & 80.80 & 66.13 & 34.75 & 85.68 & 34.15 \\
\hline Pb207 & 2.80 & 3.63 & 3.68 & 7.83 & 3.02 & 8.57 & 6.31 & 3.78 & 2.58 & 7.03 & 3.12 \\
\hline Pb208 & 8.04 & 14.43 & 13.54 & 28.61 & 1.74 & 28.63 & 14.08 & 15.52 & 8.15 & 20.67 & 6.14 \\
\hline Th232 & 155.96 & 262.84 & 223.94 & 514.65 & 62.57 & 478.41 & 290.30 & 271.32 & 137.62 & 397.13 & 88.87 \\
\hline U238 & 118.06 & 149.87 & 140.11 & 306.16 & 116.74 & 275.99 & 217.43 & 168.42 & 92.13 & 222.64 & 86.16 \\
\hline
\end{tabular}


Tabela D1 - continuação

\begin{tabular}{|c|c|c|c|c|c|c|c|c|c|c|c|c|c|c|}
\hline \multicolumn{15}{|c|}{ PLÚTON SALTO } \\
\hline \multicolumn{15}{|c|}{ AMOSTRA ITU-14X } \\
\hline RASTER & 1.1 & 2.1 & 3.1 & 4.1 & 5.1 & 5.2 & 6.1 & 6.2 & 7.2 & 8.1 & 8.2 & 9.1 & 10.1 & 11.1 \\
\hline Tipo & rim & interm & interm & interm & rim & $\begin{array}{l}\text { white } \\
\text { core }\end{array}$ & $\begin{array}{l}\text { white } \\
\text { core }\end{array}$ & $\begin{array}{l}\text { white } \\
\text { core }\end{array}$ & interm & $\begin{array}{c}\text { white } \\
\text { core }\end{array}$ & rim & $\begin{array}{c}\text { white } \\
\text { core }\end{array}$ & $\begin{array}{c}\text { white } \\
\text { core }\end{array}$ & rim \\
\hline & \multicolumn{14}{|c|}{ [ ] de elementos traço em ppm } \\
\hline Li7 & 14.01 & 8.66 & 14.38 & 8.17 & 6.54 & 3.76 & 1.50 & $<1.33$ & 3.98 & 2.24 & 3.77 & 4.40 & $<1.36$ & 12.34 \\
\hline Mg24 & 8.28 & 76.60 & 10.89 & 76.02 & 7.37 & 78.69 & $<0.64$ & 0.70 & 17.06 & 6.17 & $<0.99$ & 35.33 & $<0.70$ & 10.20 \\
\hline Al27 & 154.00 & 708.13 & 167.47 & 436.28 & 101.86 & 1370.36 & 3.47 & $<1.86$ & 3566.18 & 25.21 & 41.29 & 196.50 & 85.33 & 661.71 \\
\hline Si29 & 205501.20 & 178523.72 & 199211.38 & 184379.89 & 145449.05 & 219212.34 & 192347.44 & 150613.91 & 200863.30 & 175490.97 & 173929.09 & 172750.09 & 164956.86 & 192129.47 \\
\hline P31 & 472.62 & 4571.07 & 1501.72 & 2410.14 & 586.26 & 937.87 & 232.62 & 202.80 & 1142.15 & 276.04 & 413.40 & 426.89 & 433.67 & 463.29 \\
\hline Ca44 & $<354.85$ & 5334.50 & 2807.93 & 2521.83 & 431.34 & 477.85 & $<260.38$ & $<216.86$ & 644.19 & $<226.77$ & 350.22 & $<254.69$ & $<246.75$ & $<305.21$ \\
\hline Sc45 & 335.42 & 329.06 & 301.36 & 315.23 & 246.18 & 379.70 & 308.34 & 246.82 & 326.91 & 280.81 & 265.04 & 268.80 & 287.98 & 275.35 \\
\hline Ti49 & 91.46 & 484.63 & 83.99 & 143.84 & 53.82 & 264.29 & 17.48 & 12.94 & 54.82 & 17.63 & 23.76 & 105.69 & 20.51 & 74.87 \\
\hline Mn55 & 18.45 & 62.37 & 33.95 & 45.36 & 6.26 & 27.67 & $<1.06$ & $<0.83$ & 24.30 & 2.31 & 2.64 & 25.37 & $<0.99$ & 13.34 \\
\hline Fe56 & 397.26 & 1420.91 & 436.95 & 1366.45 & 770.72 & 1731.91 & 63.45 & $<15.80$ & 809.34 & 82.89 & $<22.40$ & 643.05 & $<21.18$ & 530.06 \\
\hline Rb85 & 0.62 & 1.54 & 0.43 & 0.60 & 0.89 & 12.82 & 0.45 & 0.22 & 28.42 & $<0.174$ & 0.24 & 0.42 & 0.47 & 2.60 \\
\hline Sr88 & 1.32 & 8.05 & 16.09 & 4.26 & 1.19 & 2.99 & 0.31 & 0.21 & 3.31 & 0.25 & 0.55 & 1.18 & 0.98 & 2.86 \\
\hline Y89 & 1116.64 & 2140.15 & 1358.27 & 1934.56 & 1415.11 & 3833.64 & 1110.33 & 878.11 & 1369.34 & 799.98 & 1073.29 & 1674.26 & 1223.85 & 1194.69 \\
\hline Zr91 & 496007.09 & 496007.13 & 496007.09 & 496007.09 & 496007.09 & 496007.06 & 496007.09 & 496007.09 & 496007.09 & 496007.09 & 496007.09 & 496007.09 & 496007.09 & 496007.09 \\
\hline Nb93 & 33.33 & 91.32 & 45.88 & 75.65 & 51.49 & 69.98 & 3.71 & 3.11 & 20.96 & 8.98 & 16.88 & 40.49 & 4.61 & 36.06 \\
\hline Mo95 & 3.75 & 1.96 & 1.60 & 2.36 & 2.64 & 3.39 & 2.97 & 1.71 & 2.32 & 2.67 & 1.99 & 1.85 & 2.21 & 2.71 \\
\hline Ba137 & 3.87 & 13.05 & 10.58 & 6.45 & 0.85 & 9.47 & $<0.40$ & $<0.30$ & 22.89 & $<0.36$ & 0.61 & 1.97 & 1.39 & 4.33 \\
\hline La139 & 18.90 & 90.22 & 145.87 & 61.58 & 11.96 & 29.75 & 0.06 & 0.06 & 19.80 & 3.30 & 7.31 & 15.68 & 2.18 & 29.90 \\
\hline Ce140 & 122.50 & 563.70 & 723.52 & 375.35 & 126.93 & 452.62 & 34.59 & 24.49 & 151.23 & 49.98 & 78.93 & 281.70 & 34.23 & 244.28 \\
\hline Pr141 & 17.89 & 101.49 & 112.41 & 57.50 & 15.13 & 73.24 & 0.23 & 0.33 & 20.33 & 3.86 & 5.34 & 45.15 & 1.12 & 37.79 \\
\hline Nd143 & 110.07 & 624.64 & 606.14 & 342.88 & 86.84 & 451.29 & 4.20 & 4.64 & 132.92 & 24.38 & 34.35 & 297.10 & 11.28 & 230.26 \\
\hline Sm147 & 48.10 & 254.10 & 178.31 & 167.15 & 43.88 & 232.97 & 8.53 & 6.04 & 59.05 & 20.48 & 21.63 & 154.05 & 9.55 & 87.43 \\
\hline Eu151 & 5.78 & 30.60 & 23.55 & 28.14 & 6.62 & 47.89 & 1.91 & 1.71 & 8.20 & 2.96 & 3.00 & 17.26 & 2.29 & 11.99 \\
\hline Gd157 & 42.25 & 206.59 & 138.78 & 159.49 & 58.01 & 267.38 & 30.98 & 22.53 & 69.63 & 26.30 & 39.23 & 156.17 & 38.27 & 79.21 \\
\hline
\end{tabular}


Tabela D1 - continuação

\begin{tabular}{|c|c|c|c|c|c|c|c|c|c|c|c|c|c|c|}
\hline Tb159 & 12.82 & 34.17 & 25.66 & 31.11 & 13.75 & 65.61 & 10.03 & 7.88 & 16.23 & 7.81 & 10.57 & 31.33 & 12.75 & 16.14 \\
\hline Dy163 & 118.40 & 247.97 & 188.60 & 257.09 & 137.58 & 563.14 & 114.62 & 81.98 & 140.61 & 77.20 & 105.96 & 239.45 & 141.67 & 142.57 \\
\hline Ho165 & 43.11 & 74.12 & 56.17 & 75.37 & 47.00 & 164.02 & 41.97 & 30.19 & 48.62 & 27.65 & 36.24 & 65.99 & 48.52 & 47.00 \\
\hline Er166 & 201.78 & 306.23 & 233.19 & 330.70 & 216.03 & 601.72 & 170.70 & 126.06 & 211.53 & 127.00 & 174.77 & 253.79 & 209.78 & 206.53 \\
\hline Tm169 & 46.13 & 62.79 & 54.00 & 70.55 & 49.67 & 108.07 & 34.83 & 26.50 & 41.84 & 26.49 & 38.22 & 48.67 & 41.98 & 44.38 \\
\hline Yb173 & 477.24 & 583.57 & 509.03 & 688.92 & 462.52 & 964.16 & 310.76 & 238.70 & 395.93 & 267.25 & 394.27 & 460.39 & 377.75 & 420.66 \\
\hline Lu175 & 95.06 & 106.67 & 96.04 & 126.57 & 83.72 & 175.54 & 66.14 & 48.45 & 76.69 & 49.76 & 73.65 & 85.48 & 68.84 & 81.34 \\
\hline Hf179 & 14391.71 & 10376.06 & 12601.83 & 13097.28 & 10744.67 & 9090.08 & 10199.13 & 8698.71 & 10197.48 & 8838.52 & 10569.52 & 9563.28 & 8478.64 & 12146.85 \\
\hline Ta181 & 5.12 & 5.90 & 5.27 & 7.96 & 4.65 & 3.66 & 1.24 & 0.51 & 2.31 & 1.62 & 3.00 & 4.27 & 0.97 & 8.28 \\
\hline Pb207 & 46.97 & 13.07 & 16.72 & 18.15 & 11.77 & 14.14 & 3.29 & 1.64 & 7.76 & 4.55 & 7.89 & 4.87 & 2.00 & 14.37 \\
\hline Pb208 & 51.68 & 27.73 & 34.83 & 38.15 & 31.83 & 42.20 & 8.98 & 5.44 & 17.95 & 10.65 & 16.28 & 15.71 & 7.48 & 25.50 \\
\hline Th232 & 510.09 & 1134.40 & 969.34 & 1118.02 & 862.70 & 1866.84 & 150.10 & 90.60 & 570.61 & 184.95 & 329.63 & 751.63 & 145.95 & 581.09 \\
\hline U238 & 517.76 & 641.49 & 713.12 & 683.01 & 508.04 & 639.16 & 137.78 & 69.63 & 330.14 & 140.00 & 301.94 & 480.71 & 89.95 & 590.05 \\
\hline
\end{tabular}


Tabela D1 - continuação

\begin{tabular}{|c|c|c|c|c|}
\hline \multicolumn{5}{|c|}{ PLÚTON SALTO } \\
\hline \multicolumn{5}{|c|}{ AMOSTRA ITU-14X - cont. } \\
\hline RASTER & 11.2 & 12.1 & 12.2 & 13.2 \\
\hline \multirow[t]{2}{*}{ Tipo } & black core & black core & rim & white rim \\
\hline & \multicolumn{4}{|c|}{ [ ] de elementos traço em ppm } \\
\hline $\mathbf{L i 7}$ & 11.85 & 10.46 & 9.70 & 7.11 \\
\hline Mg24 & 78.00 & 15.38 & $<0.93$ & 20.35 \\
\hline $\mathbf{A l 2 7}$ & 486.58 & 402.85 & $<2.35$ & 403.94 \\
\hline Si29 & 161531.53 & 175714.17 & 167342.73 & 180996.66 \\
\hline P31 & 810.65 & 771.75 & 207.04 & 538.62 \\
\hline Ca44 & 313.41 & $<326.69$ & $<290.22$ & $<232.42$ \\
\hline Sc45 & 277.00 & 292.40 & 242.79 & 295.42 \\
\hline Ti49 & 309.81 & 305.71 & 4.37 & 186.51 \\
\hline Mn55 & 50.17 & 47.30 & $<1.18$ & 19.99 \\
\hline Fe56 & 1438.90 & 657.06 & $<24.07$ & 622.97 \\
\hline Rb85 & 1.89 & 0.95 & 0.30 & 0.50 \\
\hline Sr88 & 5.46 & 2.32 & 0.36 & 2.18 \\
\hline Y89 & 3072.01 & 2220.61 & 949.96 & 2076.83 \\
\hline Zr91 & 496007.09 & 496007.13 & 496007.09 & 496007.09 \\
\hline Nb93 & 109.41 & 53.96 & 10.95 & 59.31 \\
\hline Mo95 & 3.04 & 1.68 & $<0.91$ & 3.46 \\
\hline Ba137 & 28.43 & 4.87 & $<0.39$ & 5.50 \\
\hline La139 & 41.57 & 26.02 & $<0.066$ & 54.42 \\
\hline Ce140 & 516.82 & 350.94 & 31.81 & 588.01 \\
\hline Pr141 & 85.77 & 64.23 & 0.26 & 104.44 \\
\hline Nd143 & 508.84 & 410.69 & 2.47 & 647.03 \\
\hline Sm147 & 236.34 & 212.79 & 3.68 & 248.08 \\
\hline Eu151 & 31.03 & 25.24 & 0.56 & 43.19 \\
\hline Gd157 & 235.10 & 195.66 & 14.51 & 202.26 \\
\hline
\end{tabular}


Tabela D1 - continuação

\begin{tabular}{lcccc}
\hline Tb159 & 48.30 & 37.30 & 4.97 & 38.09 \\
\hline Dy163 & 376.89 & 289.99 & 67.76 & 305.15 \\
\hline Ho165 & 111.01 & 88.81 & 28.14 & 87.07 \\
\hline Er166 & 461.54 & 352.19 & 139.23 & 337.92 \\
\hline Tm169 & 95.84 & 69.72 & 32.55 & 70.73 \\
\hline Yb173 & 891.80 & 632.24 & 302.91 & 656.04 \\
\hline Lu175 & 151.72 & 127.77 & 65.42 & 118.87 \\
\hline Hf179 & 9767.00 & 12317.58 & 10735.66 & 11366.87 \\
\hline Ta181 & 14.52 & 4.57 & 3.60 & 4.79 \\
\hline Pb207 & 21.58 & 16.14 & 8.23 & 13.16 \\
\hline Pb208 & 89.42 & 34.81 & 16.77 & 28.89 \\
\hline Th232 & 1672.02 & 859.56 & 325.69 & 1649.02 \\
\hline U238 & 1043.42 & 640.17 & 343.77 & 962.06
\end{tabular}


Tabela D2 - Dados geocronológicos U-Pb obtidos para cristais de zircão (dados calculados pelo laboratório CPGeo para o método SHRIMP e pelo Laboratório de Química e ICP-AES/MS do NAP Geoanalítica para o método LA-MC-ICPMS)

PLÚTON ITUPEVA

AMOSTRA IGN56 (método SHRIMP)

\begin{tabular}{|c|c|c|c|c|c|c|c|c|c|c|c|c|c|c|c|c|c|c|}
\hline Spot & $\begin{array}{c}\text { Total } \\
204 \\
\text { cts } \\
\text { /sec }\end{array}$ & $\begin{array}{c}\text { 7-corr } \\
\% \text { com } \\
206\end{array}$ & $\underset{(\mathbf{p p m})}{\mathbf{U}}$ & $\begin{array}{c}\text { Th } \\
(\mathbf{p p m})\end{array}$ & $\begin{array}{l}\text { 232Th } \\
/ 238 \mathrm{U}\end{array}$ & $\begin{array}{c}\text { 204corr } \\
206 \mathrm{~Pb} \\
/ 238 \mathrm{U} \\
\text { Age }\end{array}$ & $\begin{array}{c}1 \mathrm{~s} \\
\text { err }\end{array}$ & $\begin{array}{c}\text { 204corr } \\
207 \mathrm{~Pb} \\
/ 206 \mathrm{~Pb} \\
\text { Age }\end{array}$ & $\begin{array}{c}1 \mathrm{~s} \\
\text { err }\end{array}$ & $\begin{array}{c}\text { 204corr } \\
208 P b \\
\text { /232Th } \\
\text { Age }\end{array}$ & $\begin{array}{c}1 \mathrm{~s} \\
\text { err }\end{array}$ & $\begin{array}{c}\% \\
\text { Discordant }\end{array}$ & $\begin{array}{l}\text { 4corr } \\
208^{*} \\
/ 232\end{array}$ & $\begin{array}{c}\% \\
\text { err }\end{array}$ & $\begin{array}{l}7 \text { corr } \\
206^{*} \\
/ 238\end{array}$ & $\begin{array}{c}\% \\
\text { err }\end{array}$ & $\begin{array}{c}\text { 8corr } \\
206^{*} \\
/ 238\end{array}$ & $\begin{array}{c}\% \\
\text { err }\end{array}$ \\
\hline 1.1 & 0.03 & 0.07 & 191 & 307 & 1.66 & 584.7 & 7.4 & 547 & 40 & 600 & 11 & +18 & .0301 & 1.8 & .0951 & .0013 & .0941 & .0017 \\
\hline 2.1 & -0.04 & -0.16 & 112 & 70 & 0.64 & 574.1 & 8.1 & 622 & 60 & 560 & 36 & -2 & .0281 & 6.4 & .0930 & .0014 & .0934 & .0016 \\
\hline 3.1 & -0.04 & -0.14 & 116 & 154 & 1.38 & 605.6 & 9.2 & 639 & 44 & 604 & 14 & +5 & .0303 & 2.3 & .0984 & .0016 & .0986 & .0021 \\
\hline 4.1 & 0.06 & 0.12 & 193 & 32 & 0.17 & 584.2 & 7.4 & 570 & 43 & 574 & 33 & -8 & .0288 & 5.6 & .0949 & .0013 & .0949 & .0013 \\
\hline 5.1 & -0.02 & -0.09 & 104 & 147 & 1.46 & 602.7 & 8.3 & 539 & 68 & 619 & 15 & +6 & .0311 & 2.3 & .0982 & .0014 & .0973 & .0019 \\
\hline 6.1 & 0.08 & 0.20 & 145 & 191 & 1.36 & 592.8 & 7.7 & 584 & 38 & 597 & 13 & -5 & .0300 & 2.1 & .0964 & .0013 & .0961 & .0017 \\
\hline 7.1 & 0.39 & 0.71 & 209 & 324 & 1.60 & 562.6 & 7.3 & 549 & 101 & 568 & 12 & +1 & .0285 & 2.1 & .0913 & .0012 & .0910 & .0017 \\
\hline 8.1 & 0.06 & 0.19 & 127 & 239 & 1.94 & 580.0 & 7.7 & 577 & 63 & 585 & 14 & +8 & .0294 & 2.4 & .0942 & .0013 & .0938 & .0020 \\
\hline 9.1 & 0.04 & 0.08 & 222 & 373 & 1.74 & 590.3 & 7.4 & 554 & 32 & 595 & 10 & -5 & .0299 & 1.7 & .0960 & .0013 & .0956 & .0018 \\
\hline 10.1 & 0.04 & 0.21 & 79 & 102 & 1.33 & 575.7 & 8.4 & 579 & 98 & 595 & 17 & +8 & .0299 & 2.9 & .0934 & .0014 & .0926 & .0018 \\
\hline 11.1 & 0.02 & 0.06 & 147 & 244 & 1.72 & 588.1 & 7.9 & 574 & 45 & 585 & 12 & +1 & .0294 & 2.0 & .0956 & .0014 & .0957 & .0019 \\
\hline 12.1 & 0.03 & 0.05 & 230 & 477 & 2.15 & 590.0 & 8.2 & 600 & 33 & 587 & 11 & +6 & .0295 & 1.9 & .0958 & .0014 & .0961 & .0022 \\
\hline
\end{tabular}

Tabela D2 - continuação

204 corrected

\begin{tabular}{|c|c|c|c|c|c|c|c|c|c|}
\hline Spot & $\begin{array}{c}\text { 4corr } \\
238 \\
1206^{*}\end{array}$ & $\begin{array}{c}\% \\
\text { err }\end{array}$ & $\begin{array}{c}\text { 4corr } \\
207^{*} \\
1206^{*}\end{array}$ & $\begin{array}{c}\% \\
\text { err }\end{array}$ & $\begin{array}{l}4 \text { corr } \\
207^{*} \\
/ 235\end{array}$ & $\begin{array}{c}\% \\
\text { err }\end{array}$ & $\begin{array}{l}\text { 4corr } \\
206^{*} \\
/ 238\end{array}$ & $\begin{array}{c}\% \\
\text { err }\end{array}$ & $\begin{array}{l}\text { err } \\
\text { corr }\end{array}$ \\
\hline 1.1 & 10.53 & 1.3 & .0585 & 1.8 & 0.77 & 2.3 & .0949 & 1.3 & .588 \\
\hline 2.1 & 10.74 & 1.5 & .0605 & 2.8 & 0.78 & 3.1 & .0931 & 1.5 & .471 \\
\hline
\end{tabular}




\begin{tabular}{llllllllll}
\hline $\mathbf{3 . 1}$ & 10.15 & 1.6 & .0610 & 2.1 & 0.83 & 2.6 & .0985 & 1.6 & .612 \\
\hline $\mathbf{4 . 1}$ & 10.54 & 1.3 & .0591 & 2.0 & 0.77 & 2.4 & .0949 & 1.3 & .551 \\
\hline $\mathbf{5 . 1}$ & 10.20 & 1.4 & .0582 & 3.1 & 0.79 & 3.4 & .0980 & 1.4 & .422 \\
\hline $\mathbf{6 . 1}$ & 10.38 & 1.4 & .0594 & 1.7 & 0.79 & 2.2 & .0963 & 1.4 & .617 \\
\hline $\mathbf{7 . 1}$ & 10.96 & 1.4 & .0585 & 4.6 & 0.74 & 4.8 & .0912 & 1.4 & .283 \\
\hline $\mathbf{8 . 1}$ & 10.62 & 1.4 & .0593 & 2.9 & 0.77 & 3.2 & .0941 & 1.4 & .436 \\
\hline $\mathbf{9 . 1}$ & 10.43 & 1.3 & .0587 & 1.5 & 0.78 & 2.0 & .0959 & 1.3 & .661 \\
\hline $\mathbf{1 0 . 1}$ & 10.70 & 1.5 & .0593 & 4.5 & 0.76 & 4.7 & .0934 & 1.5 & .321 \\
\hline $\mathbf{1 1 . 1}$ & 10.47 & 1.4 & .0592 & 2.1 & 0.78 & 2.5 & .0955 & 1.4 & .560 \\
\hline $\mathbf{1 2 . 1}$ & 10.43 & 1.5 & .0599 & 1.5 & 0.79 & 2.1 & .0958 & 1.5 & .698 \\
\hline
\end{tabular}

Tabela D2 - continuação

PLUTON ITUPEVA

AMOSTRA CAB-15-36A (método SHRIMP)

\begin{tabular}{|c|c|c|c|c|c|c|c|c|c|c|c|c|c|c|c|c|c|}
\hline Spot & $\begin{array}{c}\text { Total } \\
204 \\
\text { cts } \\
/ \text { sec }\end{array}$ & $\begin{array}{c}\text { 7-corr } \\
\% \text { com } \\
206\end{array}$ & $\underset{(\mathbf{p p m})}{\mathbf{U}}$ & $\begin{array}{c}\text { Th } \\
\text { (ppm) }\end{array}$ & $\begin{array}{l}\text { 232Th } \\
\text { /238U }\end{array}$ & $\begin{array}{c}\text { 204corr } \\
206 \mathrm{~Pb} \\
/ 238 \mathrm{U} \\
\text { Age }\end{array}$ & $\begin{array}{c}1 \mathrm{~s} \\
\text { err }\end{array}$ & $\begin{array}{c}204 \text { corr } \\
207 \mathrm{~Pb} \\
/ 206 \mathrm{~Pb} \\
\text { Age }\end{array}$ & $\begin{array}{c}1 \mathrm{~s} \\
\text { err }\end{array}$ & $\begin{array}{c}\text { 204corr } \\
208 \mathrm{~Pb} \\
\text { /232Th } \\
\text { Age }\end{array}$ & $\begin{array}{c}1 \mathrm{~s} \\
\text { err }\end{array}$ & $\begin{array}{c}\% \\
\text { Discordant }\end{array}$ & $\begin{array}{l}\text { 4corr } \\
208^{*} \\
/ 232\end{array}$ & $\begin{array}{c}\% \\
\text { err }\end{array}$ & $\begin{array}{l}\text { 7corr } \\
206^{*} \\
/ 238\end{array}$ & $\begin{array}{c}\% \\
\text { err }\end{array}$ & $\begin{array}{l}\text { 8corr } \\
206^{*} \\
/ 238\end{array}$ \\
\hline 1.1 & 0.12 & 0.18 & 297 & 212 & 0.74 & 569.0 & 7.0 & 553 & 54 & 577 & 14 & -3 & .0290 & 2.4 & .0923 & .0012 & .0921 \\
\hline 2.1 & 0.05 & 0.07 & 281 & 138 & 0.51 & 583.3 & 7.2 & 560 & 48 & 590 & 16 & -4 & .0296 & 2.8 & .0948 & .0012 & .0946 \\
\hline 3.1 & 0.04 & 0.07 & 247 & 236 & 0.99 & 589.1 & 7.5 & 559 & 32 & 594 & 11 & -5 & .0298 & 1.9 & .0958 & .0013 & .0956 \\
\hline 4.1 & 0.00 & 0.00 & 90 & 110 & 1.26 & 583.2 & 8.2 & 606 & 54 & 598 & 15 & 4 & .0300 & 2.5 & .0946 & .0014 & .0942 \\
\hline 5.1 & 0.40 & 0.76 & 233 & 152 & 0.67 & 577.1 & 7.4 & 579 & 91 & 587 & 21 & 0 & .0295 & 3.4 & .0937 & .0013 & .0935 \\
\hline 7.1 & 4.01 & 4.64 & 429 & 394 & 0.95 & 425.0 & 6.2 & 577 & 237 & 544 & 21 & 36 & .0274 & 3.8 & .0679 & .0011 & .0651 \\
\hline 8.1 & 0.50 & 0.80 & 264 & 269 & 1.05 & 563.4 & 7.0 & 564 & 70 & 566 & 12 & 0 & .0284 & 2.2 & .0914 & .0012 & .0913 \\
\hline 9.1 & -0.02 & -0.03 & 226 & 93 & 0.43 & 578.2 & 8.3 & 632 & 28 & 623 & 16 & 9 & .0313 & 2.5 & .0937 & .0014 & .0934 \\
\hline 10.1 & 0.07 & 0.09 & 389 & 284 & 0.75 & 561.7 & 7.6 & 602 & 23 & 580 & 11 & 7 & .0291 & 1.9 & .0909 & .0013 & .0907 \\
\hline 11.1 & 11.31 & 9.43 & 603 & 399 & 0.68 & 446.2 & 6.3 & 728 & 458 & 487 & 53 & 63 & .0249 & 10.3 & .0713 & .0015 & .0711 \\
\hline
\end{tabular}




\begin{tabular}{|c|c|c|c|c|c|c|c|c|c|c|c|c|c|c|c|c|c|}
\hline 12.1 & 0.08 & 0.09 & 394 & 281 & 0.74 & 573.4 & 6.9 & 538 & 33 & 551 & 11 & -6 & .0276 & 1.9 & .0931 & .0012 & .0935 \\
\hline 13.1 & 5.65 & 6.11 & 407 & 253 & 0.64 & 543.0 & 7.2 & 556 & 403 & 522 & 52 & 2 & .0267 & 9.6 & .0881 & .0015 & .0884 \\
\hline 6.1 & 0.25 & 0.16 & 135 & 88 & 0.68 & 2152.3 & 27.3 & 2189 & 12 & 2125 & 42 & 2 & .1111 & 1.9 & .3950 & .0070 & .3969 \\
\hline
\end{tabular}

Tabela D2 - continuação

204 corrected

\begin{tabular}{|c|c|c|c|c|c|c|c|c|c|}
\hline Spot & $\begin{array}{c}4 \text { corr } \\
238 \\
/ 206^{*}\end{array}$ & $\begin{array}{c}\% \\
\text { err }\end{array}$ & $\begin{array}{l}4 \operatorname{corr} \\
207^{*} \\
1206^{*}\end{array}$ & $\begin{array}{c}\% \\
\text { err }\end{array}$ & $\begin{array}{l}4 \operatorname{corr} \\
207^{*} \\
/ 235\end{array}$ & $\begin{array}{c}\% \\
\text { err }\end{array}$ & $\begin{array}{l}\text { 4corr } \\
206^{*} \\
/ 238\end{array}$ & $\begin{array}{c}\% \\
\text { err }\end{array}$ & $\begin{array}{l}\text { err } \\
\text { corr }\end{array}$ \\
\hline 1.1 & 10.84 & 1.3 & .0586 & 2.5 & 0.75 & 2.8 & .0923 & 1.3 & .464 \\
\hline 2.1 & 10.56 & 1.3 & .0588 & 2.2 & 0.77 & 2.6 & .0947 & 1.3 & .504 \\
\hline 3.1 & 10.45 & 1.3 & .0588 & 1.4 & 0.78 & 2.0 & .0957 & 1.3 & .675 \\
\hline 4.1 & 10.56 & 1.5 & .0601 & 2.5 & 0.78 & 2.9 & .0947 & 1.5 & .505 \\
\hline 5.1 & 10.67 & 1.3 & .0593 & 4.2 & 0.77 & 4.4 & .0937 & 1.3 & .302 \\
\hline 7.1 & 14.65 & 1.5 & .0593 & 10.7 & 0.56 & 11.0 & .0682 & 1.5 & .136 \\
\hline 8.1 & 10.94 & 1.3 & .0589 & 3.2 & 0.74 & 3.5 & .0913 & 1.3 & .375 \\
\hline 9.1 & 10.66 & 1.5 & .0608 & 1.3 & 0.79 & 2.0 & .0938 & 1.5 & .755 \\
\hline 10.1 & 10.98 & 1.4 & .0600 & 1.1 & 0.75 & 1.8 & .0910 & 1.4 & .803 \\
\hline 11.1 & 13.90 & 1.5 & .0636 & 21.1 & 0.63 & 21.7 & .0717 & 1.5 & .068 \\
\hline 12.1 & 10.75 & 1.3 & .0582 & 1.5 & 0.75 & 2.0 & .0930 & 1.3 & .646 \\
\hline 13.1 & 11.34 & 1.4 & .0587 & 18.1 & 0.71 & 18.5 & .0879 & 1.4 & .075 \\
\hline 6.1 & 2.52 & 1.5 & 1369 & $\theta .7$ & 7.48 & 1.6 & .3964 & 1.5 & .911 \\
\hline
\end{tabular}


Tabela D2 - continuação

PLUTON SALTO

AMOSTRA ITU-2.2.4 (método SHRIMP)

\begin{tabular}{|c|c|c|c|c|c|c|c|c|c|c|c|c|c|c|c|c|c|c|}
\hline Spot & $\begin{array}{c}\text { Total } \\
204 \\
\text { cts } \\
/ \text { sec }\end{array}$ & $\begin{array}{c}\text { 7-corr } \\
\text { \%com } \\
206\end{array}$ & $\begin{array}{c}\mathbf{U} \\
(\mathbf{p p m})\end{array}$ & $\begin{array}{c}\text { Th } \\
(\mathbf{p p m})\end{array}$ & $\begin{array}{l}\text { 232Th } \\
/ 238 \mathrm{U}\end{array}$ & $\begin{array}{c}\text { 204corr } \\
206 \mathrm{~Pb} \\
/ 238 \mathrm{U} \\
\text { Age }\end{array}$ & $\begin{array}{c}1 \mathrm{~s} \\
\text { err }\end{array}$ & $\begin{array}{c}204 \text { corr } \\
207 \mathrm{~Pb} \\
/ 206 \mathrm{~Pb} \\
\text { Age }\end{array}$ & $\begin{array}{c}1 s \\
\text { err }\end{array}$ & $\begin{array}{c}\text { 204corr } \\
208 P b \\
\text { /232Th } \\
\text { Age }\end{array}$ & $\begin{array}{c}1 s \\
\text { err }\end{array}$ & $\begin{array}{c}\% \\
\text { Discordant }\end{array}$ & $\begin{array}{l}\text { 4corr } \\
208^{*} \\
\text { /232 }\end{array}$ & $\begin{array}{c}\% \\
\text { err }\end{array}$ & $\begin{array}{l}\text { 7corr } \\
206^{*} \\
/ 238\end{array}$ & $\begin{array}{c}\% \\
\text { err }\end{array}$ & $\begin{array}{l}\text { 8corr } \\
206^{*} \\
/ 238\end{array}$ & $\begin{array}{l}\% \\
\text { err }\end{array}$ \\
\hline 1.1 & 1.70 & 1.47 & 2567 & 1299 & 0.52 & 220.9 & 3.8 & 614 & 88 & 307 & 10 & 178 & .0153 & 3.3 & .0344 & .0006 & .0337 & .0007 \\
\hline 2.1 & 1.53 & 4.56 & 1038 & 1066 & 1.06 & 420.2 & 7.8 & 587 & 290 & 310 & 24 & 40 & .0156 & 7.5 & .0671 & .0013 & .0707 & .0016 \\
\hline 3.1 & 0.17 & 0.48 & 285 & 366 & 1.33 & 546.5 & 9.5 & 581 & 86 & 554 & 15 & 6 & .0278 & 2.7 & .0884 & .0016 & .0882 & .0021 \\
\hline 4.1 & 0.08 & 0.22 & 276 & 244 & 0.92 & 589.5 & 10.2 & 588 & 66 & 559 & 16 & 0 & .0280 & 2.9 & .0958 & .0018 & .0966 & .0020 \\
\hline 5.1 & 1.83 & 2.73 & 424 & 559 & 1.36 & 571.1 & 9.9 & 706 & 162 & 558 & 19 & 24 & .0281 & 3.4 & .0923 & .0017 & .0932 & .0022 \\
\hline 6.1 & 0.25 & 0.30 & 616 & 1062 & 1.78 & 519.0 & 8.8 & 614 & 47 & 475 & 10 & 18 & .0238 & 2.0 & .0836 & .0015 & .0864 & .0021 \\
\hline 7.1 & 0.57 & 0.58 & 635 & 743 & 1.21 & 561.7 & 9.4 & 545 & 64 & 544 & 12 & -3 & .0273 & 2.2 & .0911 & .0016 & .0917 & .0020 \\
\hline 8.1 & 0.58 & 0.91 & 710 & 568 & 0.83 & 398.5 & 7.2 & 492 & 88 & 447 & 13 & 23 & .0224 & 2.9 & .0636 & .0012 & .0627 & .0014 \\
\hline 9.1 & 0.22 & 2.18 & 103 & 578 & 5.82 & 468.2 & 10.2 & 433 & 381 & 213 & 9 & -8 & .0106 & 4.3 & .0755 & .0017 & .2507 & .0724 \\
\hline 10.1 & 0.33 & 0.48 & 735 & 679 & 0.95 & 454.9 & 7.7 & 644 & 56 & 493 & 12 & 42 & .0247 & 2.4 & .0727 & .0013 & .0721 & .0015 \\
\hline 11.1 & 0.12 & 0.22 & 442 & 414 & 0.97 & 553.1 & 9.4 & 608 & 46 & 520 & 14 & 10 & .0261 & 2.8 & .0894 & .0016 & .0905 & .0019 \\
\hline 12.1 & 0.58 & 1.16 & 740 & 827 & 1.15 & 343.8 & 6.4 & 825 & 89 & 252 & 8 & 140 & .0126 & 3.3 & .0539 & .0011 & .0579 & .0013 \\
\hline 13.1 & 0.39 & 0.51 & 716 & 897 & 1.29 & 536.8 & 9.5 & 584 & 58 & 429 & 11 & 9 & .0215 & 2.4 & .0867 & .0016 & .0910 & .0020 \\
\hline 14.1 & 4.01 & 6.25 & 3881 & 2041 & 0.54 & 110.1 & 2.0 & 731 & 285 & 137 & 12 & 564 & .0068 & 8.5 & .0169 & .0004 & .0169 & .0004 \\
\hline 15.1 & 0.38 & 0.94 & 506 & 532 & 1.09 & 419.5 & 7.3 & 463 & 104 & 423 & 12 & 10 & .0212 & 2.9 & .0672 & .0012 & .0671 & .0015 \\
\hline 11.2 & 7.85 & 6.35 & 6748 & 6385 & 0.98 & 99.7 & 1.9 & 1153 & 251 & 100 & 7 & 1057 & .0050 & 6.5 & .0150 & .0003 & .0156 & .0004 \\
\hline
\end{tabular}


Tabela D2 - continuação

204 corrected

\begin{tabular}{lccccccccc}
\hline Spot & $\begin{array}{c}\mathbf{4 c o r r} \\
\mathbf{2 3 8}\end{array}$ & $\begin{array}{c}\mathbf{\%} \\
\text { err }\end{array}$ & $\begin{array}{c}\text { 4corr } \\
\mathbf{2 0 7}\end{array}$ & $\begin{array}{c}\text { \% } \\
\text { err }\end{array}$ & $\begin{array}{c}\text { 4corr } \\
\mathbf{2 0 6}\end{array}$ & $\begin{array}{c}\text { \% } \\
\text { err }\end{array}$ & $\begin{array}{c}\text { 4corr } \\
\mathbf{2 0 6} \\
\text { /235 }\end{array}$ & $\begin{array}{c}\text { \% } \\
\text { err }\end{array}$ & $\begin{array}{c}\text { err } \\
\text { corr }\end{array}$ \\
\hline $\mathbf{1 . 1}$ & 28.67 & 1.8 & .0603 & 4.1 & 0.29 & 4.5 & .0349 & 1.8 & .394 \\
\hline $\mathbf{2 . 1}$ & 14.82 & 1.9 & .0595 & 13.2 & 0.55 & 13.5 & .0674 & 1.9 & .143 \\
\hline $\mathbf{3 . 1}$ & 11.30 & 1.8 & .0594 & 3.9 & 0.72 & 4.3 & .0885 & 1.8 & .420 \\
\hline $\mathbf{4 . 1}$ & 10.44 & 1.8 & .0596 & 3.0 & 0.79 & 3.5 & .0958 & 1.8 & .515 \\
\hline $\mathbf{5 . 1}$ & 10.78 & 1.8 & .0629 & 7.5 & 0.80 & 7.8 & .0926 & 1.8 & .231 \\
\hline $\mathbf{6 . 1}$ & 11.92 & 1.8 & .0603 & 2.2 & 0.70 & 2.8 & .0838 & 1.8 & .634 \\
\hline $\mathbf{7 . 1}$ & 10.98 & 1.8 & .0584 & 2.9 & 0.73 & 3.4 & .0911 & 1.8 & .512 \\
\hline $\mathbf{8 . 1}$ & 15.68 & 1.9 & .0570 & 3.9 & 0.50 & 4.4 & .0638 & 1.9 & .425 \\
\hline $\mathbf{9 . 1}$ & 13.26 & 2.3 & .0555 & 17.0 & 0.58 & 17.2 & .0753 & 2.3 & .132 \\
\hline $\mathbf{1 0 . 1}$ & 13.68 & 1.8 & .0611 & 2.6 & 0.62 & 3.2 & .0731 & 1.8 & .557 \\
\hline $\mathbf{1 1 . 1}$ & 11.16 & 1.8 & .0601 & 2.1 & 0.74 & 2.8 & .0896 & 1.8 & .639 \\
\hline $\mathbf{1 2 . 1}$ & 18.25 & 1.9 & .0666 & 4.2 & 0.50 & 4.7 & .0548 & 1.9 & .412 \\
\hline $\mathbf{1 3 . 1}$ & 11.51 & 1.8 & .0595 & 2.6 & 0.71 & 3.2 & .0868 & 1.8 & .570 \\
\hline $\mathbf{1 4 . 1}$ & 58.01 & 1.9 & .0637 & 13.4 & 0.15 & 13.6 & .0172 & 1.9 & .138 \\
\hline $\mathbf{1 5 . 1}$ & 14.87 & 1.8 & .0563 & 4.7 & 0.52 & 5.0 & .0672 & 1.8 & .358 \\
\hline $\mathbf{1 1 . 2}$ & 64.15 & 1.9 & .0783 & 12.6 & 0.17 & 12.8 & .0156 & 1.9 & .149 \\
\hline & & & & & & & & & \\
\hline
\end{tabular}


Tabela D2 - continuação

PLUTON SALTO

AMOSTRA ITU-14X (método SHRIMP)

\begin{tabular}{|c|c|c|c|c|c|c|c|c|c|c|c|c|c|c|c|c|c|c|}
\hline Spot & $\begin{array}{c}\text { Total } \\
204 \\
\text { cts } \\
\text { /sec }\end{array}$ & $\begin{array}{c}\text { 7-corr } \\
\% \text { com } \\
206\end{array}$ & $\begin{array}{c}\mathbf{U} \\
(\mathbf{p p m})\end{array}$ & $\begin{array}{c}\text { Th } \\
(\mathbf{p p m})\end{array}$ & $\begin{array}{l}\text { 232Th } \\
/ 238 \mathrm{U}\end{array}$ & $\begin{array}{c}\text { 204corr } \\
206 \mathrm{~Pb} \\
\text { /238U } \\
\text { Age }\end{array}$ & $\begin{array}{c}1 s \\
\text { err }\end{array}$ & $\begin{array}{c}\text { 204corr } \\
207 \mathrm{~Pb} \\
\text { /206Pb } \\
\text { Age }\end{array}$ & $\begin{array}{c}1 \mathrm{~s} \\
\text { err }\end{array}$ & $\begin{array}{c}\text { 204corr } \\
208 P b \\
\text { /232Th } \\
\text { Age }\end{array}$ & $\begin{array}{c}1 \mathrm{~s} \\
\text { err }\end{array}$ & $\begin{array}{c}\% \\
\text { Discordant }\end{array}$ & $\begin{array}{c}\text { 4corr } \\
208^{*} \\
/ 232\end{array}$ & $\begin{array}{c}\% \\
\text { err }\end{array}$ & $\begin{array}{l}\text { 7corr } \\
206^{*} \\
/ 238\end{array}$ & $\begin{array}{c}\% \\
\text { err }\end{array}$ & $\begin{array}{l}\text { 8corr } \\
206 * \\
/ 238\end{array}$ & $\begin{array}{c}\% \\
\text { err }\end{array}$ \\
\hline 9.1 & 0.71 & 1.61 & 191 & 422 & 2.28 & 488.7 & 6.6 & 629 & 121 & 315 & 11 & 29 & .0157 & 3.4 & .0784 & .0011 & .0929 & .0027 \\
\hline 10.1 & 1.20 & 1.94 & 331 & 251 & 0.78 & 463.9 & 5.9 & 570 & 129 & 389 & 19 & 23 & .0195 & 4.7 & .0744 & .0010 & .0762 & .0011 \\
\hline 11.1 & 2.43 & 2.05 & 523 & 447 & 0.88 & 540.4 & 6.6 & 596 & 113 & 514 & 16 & 10 & .0259 & 2.9 & .0874 & .0011 & .0881 & .0013 \\
\hline 12.1 & 1.00 & 1.37 & 360 & 337 & 0.97 & 479.1 & 6.6 & 596 & 97 & 462 & 12 & 24 & .0232 & 2.6 & .0769 & .0011 & .0776 & .0013 \\
\hline 13.1 & 0.05 & 0.08 & 328 & 350 & 1.10 & 573.4 & 7.0 & 553 & 30 & 606 & 10 & -4 & .0304 & 1.7 & .0931 & .0012 & .0920 & .0015 \\
\hline 14.1 & 0.11 & 0.14 & 384 & 435 & 1.17 & 583.4 & 17.9 & 565 & 32 & 589 & 21 & -3 & .0296 & 3.5 & .0948 & .0031 & .0945 & .0037 \\
\hline 15.1 & 0.52 & 0.60 & 381 & 414 & 1.12 & 529.4 & 6.6 & 535 & 60 & 431 & 9 & 1 & .0216 & 2.1 & .0856 & .0011 & .0887 & .0015 \\
\hline 16.1 & 0.82 & 1.20 & 359 & 607 & 1.75 & 437.3 & 5.5 & 426 & 102 & 300 & 10 & -3 & .0150 & 3.2 & .0703 & .0009 & .0779 & .0016 \\
\hline 18.1 & 0.13 & 0.27 & 206 & 147 & 0.74 & 579.8 & 7.4 & 599 & 65 & 599 & 17 & 3 & .0301 & 2.7 & .0941 & .0013 & .0937 & .0014 \\
\hline 19.1 & 0.01 & 0.08 & 66 & 58 & 0.90 & 586.7 & 11.1 & 561 & 72 & 592 & 21 & -4 & .0297 & 3.5 & .0954 & .0019 & .0952 & .0022 \\
\hline 20.1 & 1.23 & 1.40 & 436 & 862 & 2.04 & 451.9 & 5.6 & 603 & 89 & 231 & 5 & 34 & .0115 & 2.3 & .0723 & .0009 & .0880 & .0024 \\
\hline 21.1 & 0.09 & 0.21 & 198 & 144 & 0.75 & 574.0 & 7.5 & 559 & 38 & 584 & 13 & -3 & .0294 & 2.2 & .0932 & .0013 & .0929 & .0014 \\
\hline
\end{tabular}

Tabela D2 - continuação

\section{4 corrected}

\begin{tabular}{|c|c|c|c|c|c|c|c|c|c|}
\hline Spot & $\begin{array}{c}\text { 4corr } \\
238 \\
1206^{*}\end{array}$ & $\begin{array}{c}\% \\
\text { err }\end{array}$ & $\begin{array}{c}\text { 4corr } \\
207^{*} \\
1206^{*}\end{array}$ & $\begin{array}{c}\% \\
\text { err }\end{array}$ & $\begin{array}{l}\text { 4corr } \\
207^{*} \\
/ 235\end{array}$ & $\begin{array}{c}\% \\
\text { err }\end{array}$ & $\begin{array}{l}\text { 4corr } \\
206^{*} \\
/ 238\end{array}$ & $\begin{array}{c}\% \\
\text { err }\end{array}$ & $\begin{array}{c}\text { err } \\
\text { corr }\end{array}$ \\
\hline 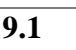 & 12.69 & 1.4 & .0607 & 5.6 & 0.66 & 5.8 & .0788 & 1.4 & .242 \\
\hline 10.1 & 13.39 & 1.3 & .0591 & 5.9 & 0.61 & 6.1 & .0746 & 1.3 & .219 \\
\hline 11.1 & 11.42 & 1.3 & .0598 & 5.1 & 0.72 & 5.4 & .0875 & 1.3 & .237 \\
\hline
\end{tabular}




\begin{tabular}{llllllllll}
\hline $\mathbf{1 2 . 1}$ & 12.95 & 1.4 & .0598 & 4.5 & 0.64 & 4.7 & .0772 & 1.4 & .302 \\
\hline $\mathbf{1 3 . 1}$ & 10.75 & 1.3 & .0586 & 1.4 & 0.75 & 1.9 & .0930 & 1.3 & .686 \\
\hline $\mathbf{1 4 . 1}$ & 10.56 & 3.2 & .0589 & 1.5 & 0.77 & 3.5 & .0947 & 3.2 & .910 \\
\hline $\mathbf{1 5 . 1}$ & 11.68 & 1.3 & .0581 & 2.7 & 0.69 & 3.0 & .0856 & 1.3 & .428 \\
\hline $\mathbf{1 6 . 1}$ & 14.24 & 1.3 & .0553 & 4.5 & 0.54 & 4.8 & .0702 & 1.3 & .275 \\
\hline $\mathbf{1 8 . 1}$ & 10.62 & 1.3 & .0599 & 3.0 & 0.78 & 3.3 & .0941 & 1.3 & .405 \\
\hline $\mathbf{1 9 . 1}$ & 10.49 & 2.0 & .0588 & 3.3 & 0.77 & 3.9 & .0953 & 2.0 & .515 \\
\hline $\mathbf{2 0 . 1}$ & 13.76 & 1.3 & .0600 & 4.1 & 0.60 & 4.3 & .0726 & 1.3 & .296 \\
\hline $\mathbf{2 1 . 1}$ & 10.74 & 1.4 & .0588 & 1.7 & 0.75 & 2.2 & .0931 & 1.4 & .619
\end{tabular}

Tabela D2 - continuação

PLUTON CABREÚVA

AMOSTRA CAB-16-80A (método SHRIMP)

\begin{tabular}{|c|c|c|c|c|c|c|c|c|c|c|c|c|c|c|c|c|c|c|}
\hline Spot & $\begin{array}{c}\text { Total } \\
204 \\
\text { cts } \\
/ \text { sec }\end{array}$ & $\begin{array}{c}\text { 7-corr } \\
\text { \%com } \\
206\end{array}$ & $\begin{array}{c}\mathbf{U} \\
(\mathbf{p p m})\end{array}$ & $\begin{array}{c}\text { Th } \\
(\mathbf{p p m})\end{array}$ & $\begin{array}{l}\text { 232Th } \\
/ 238 \mathrm{U}\end{array}$ & $\begin{array}{c}\text { 204corr } \\
206 \mathrm{~Pb} \\
\text { /238U } \\
\text { Age }\end{array}$ & $\begin{array}{c}1 s \\
\text { err }\end{array}$ & $\begin{array}{c}204 \text { corr } \\
207 \mathrm{~Pb} \\
/ 206 \mathrm{~Pb} \\
\text { Age }\end{array}$ & $\begin{array}{c}1 \mathrm{~s} \\
\text { err }\end{array}$ & $\begin{array}{c}\text { 204corr } \\
208 P b \\
/ 232 T h \\
\text { Age }\end{array}$ & $\begin{array}{c}1 s \\
\text { err }\end{array}$ & $\begin{array}{c}\% \\
\text { Discordant }\end{array}$ & $\begin{array}{l}\text { 4corr } \\
208^{*} \\
/ 232\end{array}$ & $\begin{array}{l}\% \\
\text { err }\end{array}$ & $\begin{array}{l}\text { 7corr } \\
208^{*} \\
/ 232\end{array}$ & $\begin{array}{l}\% \\
\text { err }\end{array}$ & $\begin{array}{l}\text { 8corr } \\
206^{*} \\
/ 238\end{array}$ & $\begin{array}{l}\% \\
\text { err }\end{array}$ \\
\hline 1.1 & 0.23 & 0.72 & 299 & 753 & 2.60 & 499 & 9 & 607 & 35 & 418 & 10 & +18 & 0.0209 & 2.3 & 0.0207 & 2.3 & .0805 & 1.9 \\
\hline 2.1 & 0.86 & 1.01 & 303 & 175 & 0.60 & 605 & 9 & 596 & 57 & 596 & 17 & -2 & 0.0299 & 2.9 & 0.0301 & 2.2 & .0984 & 1.5 \\
\hline 2.2 & 1.39 & 1.79 & 276 & 158 & 0.59 & 570 & 8 & 599 & 73 & 570 & 24 & +5 & 0.0286 & 4.2 & 0.0283 & 3.4 & .0924 & 1.5 \\
\hline 3.1 & 0.22 & -0.09 & 415 & 207 & 0.52 & 610 & 9 & 564 & 24 & 628 & 13 & -8 & 0.0315 & 2.1 & 0.0322 & 2.2 & .0992 & 1.5 \\
\hline 3.2 & 0.12 & 0.28 & 111 & 100 & 0.93 & 573 & 9 & 606 & 80 & 548 & 13 & +6 & 0.0275 & 2.4 & 0.0272 & 3.1 & .0929 & 1.6 \\
\hline 4.1 & 0.26 & -0.07 & 1821 & 1466 & 0.83 & 591 & 8 & 563 & 9 & 549 & 8 & -5 & 0.0275 & 1.5 & 0.0278 & 1.6 & .0961 & 1.4 \\
\hline 4.2 & 0.46 & 0.22 & 762 & 874 & 1.18 & 546 & 8 & 552 & 19 & 422 & 9 & +1 & 0.0211 & 2.1 & 0.0211 & 2.1 & .0884 & 1.5 \\
\hline 5.1 & 0.51 & 0.70 & 221 & 122 & 0.57 & 580 & 8 & 629 & 43 & 566 & 15 & +8 & 0.0284 & 2.6 & 0.0278 & 2.4 & .0941 & 1.5 \\
\hline 6.1 & 0.14 & 0.14 & 141 & 165 & 1.22 & 567 & 9 & 540 & 44 & 539 & 12 & -5 & 0.0270 & 2.3 & 0.0272 & 2.3 & .0919 & 1.6 \\
\hline 7.1 & 0.12 & 0.28 & 103 & 84 & 0.84 & 575 & 9 & 619 & 42 & 540 & 14 & +8 & 0.0271 & 2.6 & 0.0267 & 2.7 & .0933 & 1.6 \\
\hline 8.1 & 0.46 & 1.24 & 105 & 91 & 0.90 & 575 & 9 & 581 & 90 & 555 & 18 & +1 & 0.0278 & 3.2 & 0.0278 & 2.6 & .0932 & 1.6 \\
\hline
\end{tabular}


Tabela D2 - continuação

\begin{tabular}{|c|c|c|c|c|c|c|c|c|c|}
\hline & \multicolumn{9}{|c|}{204 corrected } \\
\hline Spot & $\begin{array}{c}\text { 4corr } \\
238 \\
/ 206^{*}\end{array}$ & $\begin{array}{c}\% \\
\text { err }\end{array}$ & $\begin{array}{l}\text { 4corr } \\
207^{*} \\
1206^{*}\end{array}$ & $\begin{array}{c}\% \\
\text { err }\end{array}$ & $\begin{array}{c}\text { 4corr } \\
207 * \\
/ 235\end{array}$ & $\begin{array}{c}\% \\
\text { err }\end{array}$ & $\begin{array}{l}\text { 4corr } \\
206^{*} \\
/ 238\end{array}$ & $\begin{array}{c}\% \\
\text { err }\end{array}$ & $\begin{array}{c}\text { err } \\
\text { corr }\end{array}$ \\
\hline 1.1 & 12.43 & 1.9 & 0.06009 & 1.6 & 0.667 & 2.5 & 0.0805 & 1.9 & 0.8 \\
\hline 2.1 & 10.16 & 1.5 & 0.05979 & 2.6 & 0.811 & 3.1 & 0.0984 & 1.5 & 0.5 \\
\hline 2.2 & 10.82 & 1.5 & 0.05987 & 3.4 & 0.763 & 3.7 & 0.0924 & 1.5 & 0.4 \\
\hline 3.1 & 10.08 & 1.5 & 0.05892 & 1.1 & 0.806 & 1.8 & 0.0992 & 1.5 & 0.8 \\
\hline 3.2 & 10.76 & 1.6 & 0.06008 & 3.7 & 0.770 & 4.0 & 0.0929 & 1.6 & 0.4 \\
\hline 4.1 & 10.41 & 1.4 & 0.05888 & 0.4 & 0.780 & 1.5 & 0.0961 & 1.4 & 1.0 \\
\hline 4.2 & 11.31 & 1.5 & 0.05860 & 0.9 & 0.715 & 1.7 & 0.0884 & 1.5 & 0.9 \\
\hline 5.1 & 10.62 & 1.5 & 0.06071 & 2.0 & 0.788 & 2.5 & 0.0941 & 1.5 & 0.6 \\
\hline 6.1 & 10.88 & 1.6 & 0.05826 & 2.0 & 0.738 & 2.6 & 0.0919 & 1.6 & 0.6 \\
\hline 7.1 & 10.72 & 1.6 & 0.06044 & 2.0 & 0.777 & 2.5 & 0.0933 & 1.6 & 0.6 \\
\hline 8.1 & 10.73 & 1.6 & 0.05937 & 4.1 & 0.763 & 4.5 & 0.0932 & 1.6 & 0.4 \\
\hline 9.1 & 11.00 & 1.7 & 0.05981 & 5.2 & 0.749 & 5.4 & 0.0909 & 1.7 & 0.3 \\
\hline
\end{tabular}


Tabela D2 - continuação

\section{PLUTON CABREÚVA}

\section{AMOSTRA IGN24A (método SHRIMP)}

\begin{tabular}{|c|c|c|c|c|c|c|c|c|c|c|c|c|c|c|c|c|c|c|}
\hline Spot & $\begin{array}{c}\text { Total } \\
204 \\
\text { cts } \\
\text { /sec }\end{array}$ & $\begin{array}{c}\text { 7-corr } \\
\% \text { com } \\
206\end{array}$ & $\begin{array}{c}\mathbf{U} \\
(\mathbf{p p m})\end{array}$ & $\begin{array}{c}\text { Th } \\
(\mathbf{p p m})\end{array}$ & $\begin{array}{l}\text { 232Th } \\
\text { /238U }\end{array}$ & $\begin{array}{c}\text { 204corr } \\
206 \mathrm{~Pb} \\
/ 238 \mathrm{U} \\
\text { Age }\end{array}$ & $\begin{array}{l}1 s \\
\text { err }\end{array}$ & $\begin{array}{c}\text { 204corr } \\
207 \mathrm{~Pb} \\
/ 206 \mathrm{~Pb} \\
\text { Age }\end{array}$ & $\begin{array}{c}1 \mathrm{~s} \\
\text { err }\end{array}$ & $\begin{array}{c}\text { 204corr } \\
208 \mathrm{~Pb} \\
/ 232 \mathrm{Th} \\
\text { Age }\end{array}$ & $\begin{array}{c}1 \mathrm{~s} \\
\text { err }\end{array}$ & $\begin{array}{c}\% \\
\text { Discordant }\end{array}$ & $\begin{array}{l}\text { 4corr } \\
208^{*} \\
/ 232\end{array}$ & $\begin{array}{c}\% \\
\text { err }\end{array}$ & $\begin{array}{l}\text { 7corr } \\
206^{*} \\
/ 238\end{array}$ & $\begin{array}{c}\% \\
\text { err }\end{array}$ & $\begin{array}{l}\text { 8corr } \\
206^{*} \\
/ 238\end{array}$ & $\begin{array}{c}\% \\
\text { err }\end{array}$ \\
\hline 1.1 & 0.20 & 0.48 & 332 & 210 & 0.65 & 563.9 & 9.7 & 576 & 70 & 542 & 19 & 2 & .0272 & 3.4 & .0914 & .0017 & .0918 & .0018 \\
\hline 2.1 & 0.22 & 0.57 & 299 & 223 & 0.77 & 551.2 & 9.6 & 584 & 83 & 464 & 18 & 6 & .0233 & 3.8 & .0892 & .0016 & .0911 & .0018 \\
\hline 3.1 & 0.19 & 0.81 & 182 & 112 & 0.64 & 561.8 & 10.2 & 646 & 221 & 575 & 31 & 15 & .0289 & 5.3 & .0908 & .0018 & .0909 & .0019 \\
\hline 4.1 & 0.06 & 0.59 & 82 & 93 & 1.18 & 549.9 & 11.2 & 552 & 139 & 494 & 20 & 0 & .0248 & 4.1 & .0891 & .0019 & .0910 & .0024 \\
\hline 5.1 & 0.14 & 0.69 & 167 & 152 & 0.94 & 565.5 & 10.5 & 608 & 158 & 534 & 22 & 8 & .0268 & 4.0 & .0916 & .0018 & .0925 & .0021 \\
\hline 6.1 & 2.34 & 0.91 & 2309 & 2323 & 1.04 & 530.5 & 8.8 & 566 & 52 & 386 & 9 & 7 & .0193 & 2.3 & .0857 & .0015 & .0900 & .0018 \\
\hline 7.1 & 0.40 & 1.56 & 208 & 377 & 1.87 & 557.5 & 10.1 & 738 & 207 & 544 & 16 & 32 & .0273 & 2.9 & .0898 & .0018 & .0912 & .0025 \\
\hline 8.1 & 0.17 & 0.84 & 167 & 110 & 0.68 & 558.7 & 11.9 & 548 & 141 & 482 & 31 & -2 & .0242 & 6.2 & .0906 & .0020 & .0919 & .0022 \\
\hline 9.1 & 0.72 & 2.03 & 409 & 558 & 1.41 & 446.3 & 8.2 & 698 & 191 & 318 & 16 & 56 & .0159 & 5.0 & .0711 & .0013 & .0772 & .0018 \\
\hline 10.1 & -0.03 & 0.00 & 5549 & 3752 & 0.70 & 599.2 & 10.0 & 566 & 10 & 551 & 10 & -5 & .0276 & 1.8 & .0975 & .0017 & .0983 & .0019 \\
\hline 11.1 & 0.03 & 0.01 & 3844 & 2141 & 0.58 & 575.5 & 9.5 & 565 & 9 & 545 & 10 & -2 & .0273 & 1.9 & .0934 & .0016 & .0938 & .0018 \\
\hline 12.1 & 0.22 & 0.05 & 3517 & 2231 & 0.66 & 551.1 & 9.2 & 574 & 17 & 498 & 10 & 4 & .0250 & 1.9 & .0892 & .0016 & .0902 & .0017 \\
\hline
\end{tabular}

Tabela D2 - continuação

\section{4 corrected}

\begin{tabular}{|c|c|c|c|c|c|c|c|c|c|}
\hline Spot & $\begin{array}{c}\text { 4corr } \\
238 \\
1206^{*}\end{array}$ & $\begin{array}{c}\% \\
\text { err }\end{array}$ & $\begin{array}{l}\text { 4corr } \\
207^{*} \\
1206^{*}\end{array}$ & $\begin{array}{c}\% \\
\text { err }\end{array}$ & $\begin{array}{c}\text { 4corr } \\
207^{*} \\
/ 235\end{array}$ & $\begin{array}{c}\% \\
\text { err }\end{array}$ & $\begin{array}{l}\text { 4corr } \\
206^{*} \\
/ 238\end{array}$ & $\begin{array}{c}\% \\
\text { err }\end{array}$ & $\begin{array}{l}\text { err } \\
\text { corr }\end{array}$ \\
\hline 1.1 & 10.94 & 1.8 & .0592 & 3.2 & 0.75 & 3.7 & .0914 & 1.8 & .490 \\
\hline 2.1 & 11.20 & 1.8 & .0595 & 3.8 & 0.73 & 4.2 & .0893 & 1.8 & .431 \\
\hline
\end{tabular}




\begin{tabular}{llllllllll}
\hline $\mathbf{3 . 1}$ & 10.98 & 1.9 & .0612 & 10.3 & 0.77 & 10.5 & .0911 & 1.9 & .181 \\
\hline $\mathbf{4 . 1}$ & 11.23 & 2.1 & .0586 & 6.4 & 0.72 & 6.7 & .0890 & 2.1 & .316 \\
\hline $\mathbf{5 . 1}$ & 10.90 & 1.9 & .0601 & 7.3 & 0.76 & 7.6 & .0917 & 1.9 & .256 \\
\hline $\mathbf{6 . 1}$ & 11.65 & 1.7 & .0590 & 2.4 & 0.70 & 3.0 & .0858 & 1.7 & .584 \\
\hline $\mathbf{7 . 1}$ & 11.06 & 1.9 & .0639 & 9.7 & 0.80 & 9.9 & .0903 & 1.9 & .191 \\
\hline $\mathbf{8 . 1}$ & 11.04 & 2.2 & .0585 & 6.4 & 0.73 & 6.8 & .0905 & 2.2 & .326 \\
\hline $\mathbf{9 . 1}$ & 13.94 & 1.9 & .0627 & 8.9 & 0.62 & 9.2 & .0717 & 1.9 & .209 \\
\hline $\mathbf{1 0 . 1}$ & 10.27 & 1.8 & .0590 & 0.5 & 0.79 & 1.8 & .0974 & 1.8 & .965 \\
\hline $\mathbf{1 1 . 1}$ & 10.71 & 1.7 & .0590 & 0.4 & 0.76 & 1.8 & .0934 & 1.7 & .970 \\
\hline $\mathbf{1 2 . 1}$ & 11.20 & 1.7 & .0592 & 0.8 & 0.73 & 1.9 & .0892 & 1.7 & .913 \\
\hline
\end{tabular}

Tabela D2 - continuação

\section{PLUTON INDAIATUBA}

\section{AMOSTRA IGN50B (método LA-MC-ICPMS)}

\begin{tabular}{|c|c|c|c|c|c|c|c|c|c|c|c|c|c|c|c|c|}
\hline & & & & & & & & & & & Razões & & & & & \\
\hline Spot & $\begin{array}{l}\text { Pb total } \\
\text { comum } \%\end{array}$ & $\begin{array}{l}\text { Pb rad } \\
\text { ppm \% }\end{array}$ & Th ppm & U ppm & Th/U & $\begin{array}{c}207 \mathrm{~Pb} / \\
235 \mathrm{U}\end{array}$ & $1 \sigma$ & $\begin{array}{c}206 \mathrm{~Pb} / \\
238 \mathrm{U}\end{array}$ & $1 \sigma$ & $\rho$ & $\begin{array}{l}238 \mathrm{U} / \\
206 \mathrm{~Pb}\end{array}$ & $1 \sigma$ & $\begin{array}{l}207 \mathrm{~Pb} / \\
206 \mathrm{~Pb}\end{array}$ & $1 \sigma$ & $\begin{array}{l}208 \mathrm{~Pb} / \\
206 \mathrm{~Pb}\end{array}$ & $1 \sigma$ \\
\hline 1.1 & 0.6 & 73 & 436 & 656 & 0.7 & 0.7832 & 0.0401 & 0.0959 & 0.0015 & 0.39 & 10.43 & 0.16 & 0.0593 & 0.0031 & 0.2169 & 0.0084 \\
\hline 2.1 & 2.7 & 28 & 332 & 203 & 1.6 & 0.8653 & 0.1190 & 0.0970 & 0.0033 & 0.26 & 10.31 & 0.35 & 0.0647 & 0.0098 & 0.4406 & 0.0586 \\
\hline 3.1 & 0.7 & 58 & 439 & 489 & 0.9 & 0.7893 & 0.0549 & 0.0984 & 0.0018 & 0.09 & 10.16 & 0.19 & 0.0582 & 0.0041 & 0.3174 & 0.0156 \\
\hline 3.2 & 1.3 & 77 & 628 & 649 & 1.0 & 0.7267 & 0.0481 & 0.0895 & 0.0014 & 0.14 & 11.17 & 0.18 & 0.0589 & 0.0042 & 0.3051 & 0.0114 \\
\hline 4.1 & 1.9 & 45 & 238 & 422 & 0.6 & 0.7111 & 0.0591 & 0.0944 & 0.0019 & 0.26 & 10.60 & 0.21 & 0.0546 & 0.0049 & 0.2389 & 0.0504 \\
\hline 5.1 & 0.6 & 107 & 856 & 911 & 0.9 & 0.8214 & 0.0395 & 0.1016 & 0.0015 & 0.54 & 9.84 & 0.15 & 0.0586 & 0.0029 & 0.3058 & 0.0110 \\
\hline 5.2 & 0.3 & 109 & 1194 & 829 & 1.4 & 0.7719 & 0.0356 & 0.0952 & 0.0014 & 0.55 & 10.50 & 0.15 & 0.0588 & 0.0028 & 0.3235 & 0.0539 \\
\hline 6.1 & 0.0 & 142 & 943 & 1149 & 0.8 & 0.7429 & 0.0318 & 0.0937 & 0.0013 & 0.87 & 10.67 & 0.15 & 0.0575 & 0.0025 & 0.2693 & 0.0061 \\
\hline 7.1 & 0.2 & 121 & 898 & 1056 & 0.9 & 0.7786 & 0.0340 & 0.0953 & 0.0013 & 0.72 & 10.50 & 0.15 & 0.0593 & 0.0026 & 0.2722 & 0.0057 \\
\hline 7.2 & 2.5 & 40 & 432 & 288 & 1.5 & 0.7585 & 0.0415 & 0.0947 & 0.0015 & 0.89 & 10.56 & 0.17 & 0.0581 & 0.0033 & 0.4222 & 0.0564 \\
\hline
\end{tabular}




\begin{tabular}{|c|c|c|c|c|c|c|c|c|c|c|c|c|c|c|c|c|}
\hline 8.1 & 0.7 & 188 & 1540 & 1529 & 1.0 & 0.8064 & 0.0295 & 0.0986 & 0.0012 & 0.29 & 10.14 & 0.13 & 0.0593 & 0.0021 & 0.2827 & 0.0159 \\
\hline 9.1 & 0.4 & 120 & 686 & 1106 & 0.6 & 0.7746 & 0.0331 & 0.0958 & 0.0013 & 0.47 & 10.44 & 0.14 & 0.0586 & 0.0025 & 0.1815 & 0.0111 \\
\hline 10.1 & 1.4 & 133 & 1084 & 1146 & 0.9 & 0.7684 & 0.0340 & 0.0946 & 0.0013 & 0.43 & 10.57 & 0.15 & 0.0589 & 0.0026 & 0.2932 & 0.0095 \\
\hline 11.1 & 0.1 & 113 & 733 & 970 & 0.8 & 0.7950 & 0.0361 & 0.0969 & 0.0014 & 0.62 & 10.32 & 0.15 & 0.0595 & 0.0028 & 0.2376 & 0.0087 \\
\hline 12.1 & 0.0 & 120 & 805 & 1025 & 0.8 & 0.7663 & 0.0382 & 0.0924 & 0.0012 & 0.21 & 10.83 & 0.15 & 0.0602 & 0.0031 & 0.2728 & 0.0076 \\
\hline 12.2 & 2.2 & 134 & 922 & 1162 & 0.8 & 0.7719 & 0.0367 & 0.0934 & 0.0012 & 0.68 & 10.71 & 0.14 & 0.0600 & 0.0030 & 0.2943 & 0.0147 \\
\hline 13.1 & 0.0 & 110 & 875 & 904 & 1.0 & 0.7444 & 0.0415 & 0.0936 & 0.0013 & 0.52 & 10.68 & 0.15 & 0.0577 & 0.0034 & 0.2934 & 0.0269 \\
\hline 14.1 & 0.2 & 105 & 692 & 913 & 0.8 & 0.7699 & 0.0457 & 0.0928 & 0.0014 & 0.27 & 10.77 & 0.16 & 0.0601 & 0.0037 & 0.2469 & 0.0136 \\
\hline 15.1 & 1.0 & 61 & 367 & 569 & 0.6 & 0.7032 & 0.0515 & 0.0895 & 0.0015 & 0.53 & 11.17 & 0.18 & 0.0570 & 0.0044 & 0.2119 & 0.0111 \\
\hline 15.2 & 2.8 & 129 & 806 & 1188 & 0.7 & 0.7667 & 0.0388 & 0.0936 & 0.0012 & 0.47 & 10.68 & 0.14 & 0.0594 & 0.0032 & 0.2413 & 0.0088 \\
\hline 16.1 & 0.5 & 140 & 876 & 1226 & 0.7 & 0.7536 & 0.0381 & 0.0923 & 0.0012 & 0.33 & 10.83 & 0.14 & 0.0592 & 0.0031 & 0.2504 & 0.0105 \\
\hline 17.1 & 0.3 & 204 & 1326 & 1827 & 0.7 & 0.7323 & 0.0288 & 0.0899 & 0.0011 & 0.77 & 11.12 & 0.13 & 0.0591 & 0.0024 & 0.2448 & 0.0053 \\
\hline 18.1 & 0.1 & 119 & 746 & 1016 & 0.7 & 0.7832 & 0.0412 & 0.0935 & 0.0013 & 0.85 & 10.70 & 0.15 & 0.0608 & 0.0034 & 0.2569 & 0.0499 \\
\hline 19.1 & 12.0 & 98 & 767 & 872 & 0.9 & 0.7108 & 0.0425 & 0.0898 & 0.0013 & 0.76 & 11.14 & 0.17 & 0.0574 & 0.0035 & 0.2607 & 0.0114 \\
\hline 20.1 & 0.1 & 123 & 952 & 1050 & 0.9 & 0.7409 & 0.0372 & 0.0910 & 0.0012 & 0.79 & 10.99 & 0.15 & 0.0591 & 0.0031 & 0.3166 & 0.0098 \\
\hline 21.1 & 0.5 & 85 & 769 & 698 & 1.1 & 0.7069 & 0.0550 & 0.0903 & 0.0016 & 0.49 & 11.08 & 0.19 & 0.0568 & 0.0046 & 0.3247 & 0.0227 \\
\hline
\end{tabular}

Tabela D2 - continuação

\begin{tabular}{|c|c|c|c|c|c|}
\hline & \multicolumn{4}{|c|}{ Idades (Ga) } & Conc. \\
\hline Spot & $\begin{array}{l}206 \mathrm{~Pb} / \\
238 \mathrm{~Pb}\end{array}$ & $1 \sigma$ & $\begin{array}{l}207 \mathrm{~Pb} / \\
206 \mathrm{~Pb}\end{array}$ & $1 \sigma$ & $\begin{array}{l}206 / 238 \\
207 / 206\end{array}$ \\
\hline 1.1 & 0.590 & 0.009 & 0.576 & 0.117 & 102 \\
\hline 2.1 & 0.597 & 0.019 & 0.764 & 0.303 & 78 \\
\hline 3.1 & 0.605 & 0.011 & 0.536 & 0.151 & 112 \\
\hline 3.2 & 0.553 & 0.008 & 0.563 & 0.153 & 98 \\
\hline 4.1 & 0.581 & 0.011 & 0.398 & 0.173 & 146 \\
\hline 5.1 & 0.624 & 0.009 & 0.553 & 0.108 & 112 \\
\hline
\end{tabular}




\begin{tabular}{llllll}
\hline $\mathbf{5 . 2}$ & 0.586 & 0.008 & 0.560 & 0.107 & 104 \\
\hline $\mathbf{6 . 1}$ & 0.577 & 0.007 & 0.511 & 0.096 & 113 \\
\hline $\mathbf{7 . 1}$ & 0.587 & 0.008 & 0.577 & 0.095 & 101 \\
\hline $\mathbf{7 . 2}$ & 0.584 & 0.009 & 0.532 & 0.122 & 109 \\
\hline $\mathbf{8 . 1}$ & 0.606 & 0.007 & 0.578 & 0.080 & 104 \\
\hline $\mathbf{9 . 1}$ & 0.590 & 0.008 & 0.554 & 0.093 & 106 \\
\hline $\mathbf{1 0 . 1}$ & 0.582 & 0.008 & 0.565 & 0.096 & 103 \\
\hline $\mathbf{1 1 . 1}$ & 0.596 & 0.008 & 0.585 & 0.108 & 101 \\
\hline $\mathbf{1 2 . 1}$ & 0.569 & 0.007 & 0.610 & 0.117 & 93 \\
\hline $\mathbf{1 2 . 2}$ & 0.575 & 0.007 & 0.602 & 0.112 & 95 \\
\hline $\mathbf{1 3 . 1}$ & 0.577 & 0.008 & 0.517 & 0.129 & 111 \\
\hline $\mathbf{1 4 . 1}$ & 0.572 & 0.008 & 0.609 & 0.136 & 94 \\
\hline $\mathbf{1 5 . 1}$ & 0.553 & 0.009 & 0.491 & 0.171 & 112 \\
\hline $\mathbf{1 5 . 2}$ & 0.577 & 0.007 & 0.582 & 0.117 & 99 \\
\hline $\mathbf{1 6 . 1}$ & 0.569 & 0.007 & 0.574 & 0.114 & 99 \\
\hline $\mathbf{1 7 . 1}$ & 0.555 & 0.006 & 0.570 & 0.086 & 97 \\
\hline $\mathbf{1 8 . 1}$ & 0.576 & 0.008 & 0.631 & 0.129 & 91 \\
\hline $\mathbf{1 9 . 1}$ & 0.554 & 0.008 & 0.508 & 0.129 & 108 \\
\hline $\mathbf{2 0 . 1}$ & 0.561 & 0.007 & 0.569 & 0.114 & 98 \\
\hline $\mathbf{2 1 . 1}$ & 0.557 & 0.009 & 0.483 & 0.167 & 115 \\
\hline & & & & & \\
\hline
\end{tabular}




\section{APÊNDICE E - DADOS ISÓTOPICOS EM ROCHA TOTAL}


Tabela E1 - Dados isotópicos obtidos para o sistema Sm-Nd

\begin{tabular}{|c|c|c|c|c|c|c|c|c|c|c|}
\hline PLÚTON & AMOSTRA & Sm (ppm) & Nd (ppm) & ${ }^{147} \mathrm{Sm} /{ }^{144} \mathrm{Nd}$ & ${ }^{143} \mathrm{Nd} /{ }^{144} \mathrm{Nd}$ & $2 \sigma$ & ENdo & ENdT & TDM(Ma) & TDM(Ga) \\
\hline Itupeva & CAB-15-27 & 52.53 & 291.95 & 0.11 & 0.511696 & $3.617315 \mathrm{E}-06$ & -18.4 & -11.9 & 1958 & 2.0 \\
\hline Itupeva & CAB-15-36A & 6.98 & 53.60 & 0.08 & 0.511619 & $5.916208 \mathrm{E}-06$ & -19.9 & -11.2 & 1608 & 1.6 \\
\hline Itupeva & IGN56 & 9.72 & 59.62 & 0.10 & 0.511731 & $1.098555 \mathrm{E}-05$ & -17.7 & -10.5 & 1745 & 1.7 \\
\hline Itupeva & IGN66D & 8.33 & 49.80 & 0.10 & 0.511654 & 8.999099E-06 & -19.2 & -12.2 & 1891 & 1.9 \\
\hline Itupeva & IGN66G & 14.23 & 90.42 & 0.10 & 0.511718 & $1.035253 \mathrm{E}-05$ & -18.0 & -10.5 & 1711 & 1.7 \\
\hline Itupeva & CAB-16-101 & 10.61 & 62.11 & 0.10 & 0.511754 & 4.828454E-06 & -17.2 & -10.3 & 1778 & 1.8 \\
\hline Salto & 2008-ITU-2.1C & 11.08 & 52.90 & 0.13 & 0.511831 & $1.094381 \mathrm{E}-05$ & -15.7 & -10.6 & 2144 & 2.1 \\
\hline Salto & ITU-06-11A & 7.94 & 49.79 & 0.10 & 0.511747 & $9.316724 \mathrm{E}-06$ & -17.4 & -10.0 & 1691 & 1.7 \\
\hline Salto & 2008-ITU-2.1D & 7.06 & 44.85 & 0.10 & 0.511726 & $1.150431 \mathrm{E}-05$ & -17.8 & -10.3 & 1701 & 1.7 \\
\hline Salto & IGN2.2.4 & 7.51 & 46.99 & 0.10 & 0.511730 & $6.295424 \mathrm{E}-06$ & -17.7 & -10.3 & 1716 & 1.7 \\
\hline Salto & IGN22A & 7.39 & 45.95 & 0.10 & 0.511727 & $1.108670 \mathrm{E}-05$ & -17.8 & -10.5 & 1731 & 1.7 \\
\hline Salto & ITU-14X & 7.36 & 43.98 & 0.10 & 0.511758 & $4.763856 \mathrm{E}-06$ & -17.2 & -10.1 & 1740 & 1.7 \\
\hline Indaiatuba & IGN50B & 10.55 & 68.77 & 0.09 & 0.511608 & $1.098167 \mathrm{E}-05$ & -20.1 & -12.4 & 1816 & 1.8 \\
\hline Indaiatuba & CAB-14-06A & 9.44 & 60.72 & 0.09 & 0.511651 & $4.515078 \mathrm{E}-06$ & -19.3 & -11.7 & 1772 & 1.8 \\
\hline Indaiatuba & CAB-15-34 & 11.87 & 69.56 & 0.10 & 0.511718 & $5.573487 \mathrm{E}-06$ & -17.9 & -11.0 & 1827 & 1.8 \\
\hline Cabreúva & CAB-14-18 & 17.91 & 106.04 & 0.10 & 0.511677 & $4.754140 \mathrm{E}-06$ & -18.7 & -11.7 & 1865 & 1.9 \\
\hline Cabreúva & IGN28A & 10.54 & 58.93 & 0.11 & 0.511707 & $9.836700 \mathrm{E}-06$ & -18.2 & -11.6 & 1934 & 1.9 \\
\hline Cabreúva & CAB-16-80A & 11.52 & 62.41 & 0.11 & 0.511721 & $5.407711 \mathrm{E}-06$ & -17.9 & -11.6 & 1974 & 2.0 \\
\hline Cabreúva & CAB-16-90 & 13.36 & 81.31 & 0.10 & 0.511647 & 4.779192E-06 & -19.3 & -12.1 & 1861 & 1.9 \\
\hline Cabreúva & CAB-16-91A & 18.84 & 79.00 & 0.14 & 0.511835 & $4.875965 \mathrm{E}-06$ & -15.7 & -11.8 & 2674 & 2.7 \\
\hline Nhandeara & CAB-15-42 & 8.80 & 50.43 & 0.11 & 0.511620 & $5.565566 \mathrm{E}-06$ & -19.9 & -13.1 & 2006 & 2.0 \\
\hline
\end{tabular}


Tabela E2 - Dados isotópicos obtidos para o sistema $\mathrm{Rb}-\mathrm{Sr}$

\begin{tabular}{llccccccc}
\hline PLÚTON & AMOSTRA & $\mathbf{R b}(\mathbf{p p m})$ & $\mathbf{S r}(\mathbf{p p m})$ & ${ }^{\mathbf{8 7}} \mathbf{R b} /{ }^{\mathbf{8 6}} \mathbf{S r}$ & ${ }^{\mathbf{8 7}} \mathbf{S r} /{ }^{\mathbf{8 6}} \mathbf{S r}$ & $\mathbf{2 \sigma}$ & $\mathbf{S r}$ & $\mathbf{T}(\mathbf{M a})$ \\
\hline Itupeva & CAB-15-27 & 265 & 181 & 4.25 & 0.73949 & $2.21648 \mathrm{E}-05$ & 0.70434 & 580 \\
\hline Itupeva & CAB-15-36A & 177 & 151 & 3.40 & 0.73474 & $1.75523 \mathrm{E}-05$ & 0.70661 & 580 \\
\hline Itupeva & IGN56 & 111 & 825 & 0.39 & 0.70944 & $5.29558 \mathrm{E}-05$ & 0.70622 & 580 \\
\hline Itupeva & IGN66D & 154 & 362 & 1.23 & 0.71616 & $5.71001 \mathrm{E}-05$ & 0.70598 & 580 \\
\hline Itupeva & IGN66G & 225 & 642 & 1.01 & 0.71379 & $5.02043 \mathrm{E}-05$ & 0.70541 & 580 \\
\hline Itupeva & CAB-16-101 & 167 & 657 & 0.74 & 0.71190 & $1.94231 \mathrm{E}-05$ & 0.70582 & 580 \\
\hline Salto & $\mathbf{2 0 0 8 - I T U - 2 . 1 C}$ & 227 & 141 & 4.66 & 0.74588 & $4.28998 \mathrm{E}-05$ & 0.70736 & 580 \\
\hline Salto & ITU-06-11A & 288 & 157 & 5.31 & 0.75059 & $6.12011 \mathrm{E}-05$ & 0.70670 & 580 \\
\hline Salto & $\mathbf{2 0 0 8 - I T U - 2 . 1 D}$ & 301 & 90 & 9.68 & 0.78957 & $6.71750 \mathrm{E}-05$ & 0.70954 & 580 \\
\hline Salto & IGN2.2.4 & 199 & 145 & 3.97 & 0.73912 & $5.88960 \mathrm{E}-05$ & 0.70628 & 580 \\
\hline Salto & IGN22A & 191 & 204 & 2.71 & 0.72820 & $1.19284 \mathrm{E}-05$ & 0.70580 & 580 \\
\hline Salto & ITU-14X & 201 & 155 & 3.76 & 0.73560 & $1.85689 \mathrm{E}-05$ & 0.70448 & 580 \\
\hline Indaiatuba & IGN50B & 185 & 228 & 2.35 & 0.72655 & $3.32895 \mathrm{E}-05$ & 0.70713 & 580 \\
\hline Indaiatuba & CAB-14-06A & 162 & 186 & 2.53 & 0.72699 & $3.85893 \mathrm{E}-05$ & 0.70610 & 580 \\
\hline Indaiatuba & CAB-15-34 & 197 & 837 & 0.68 & 0.71125 & $2.00202 \mathrm{E}-05$ & 0.70562 & 580 \\
\hline Cabreúva & CAB-14-18 & 93 & 19 & 14.34 & 0.82936 & $1.86953 \mathrm{E}-05$ & 0.71080 & 580 \\
\hline Cabreúva & IGN28A & 184 & 83 & 6.41 & 0.76391 & $4.55483 \mathrm{E}-05$ & 0.71086 & 580 \\
\hline Cabreúva & CAB-16-80A & 157 & 95 & 4.80 & 0.74816 & $2.06397 \mathrm{E}-05$ & 0.70844 & 580 \\
\hline Cabreúva & CAB-16-90 & 143 & 158 & 2.63 & 0.72957 & $1.71401 \mathrm{E}-05$ & 0.70786 & 580 \\
\hline Cabreúva & CAB-16-91A & 141 & 261 & 1.57 & 0.72081 & $1.85274 \mathrm{E}-05$ & 0.70786 & 580 \\
\hline Nhandeara & $\mathbf{C A B - 1 5 - 4 2}$ & 365 & 46 & 23.39 & 0.89626 & $2.31462 \mathrm{E}-05$ & 0.70281 & 580 \\
\hline & & & & & & &
\end{tabular}

